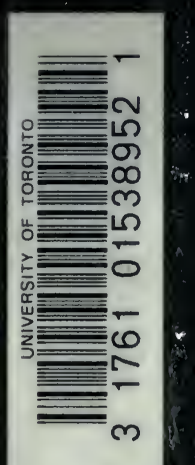

SCHLICH'S

Manual of Forestry

\title{
VOL.IV.
}

FOREST PROTECTION

$$
\text { W. R. FISHER }
$$





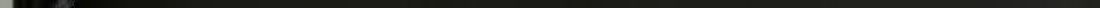





\title{
SCHLICH'S
}

\section{MANUAL OF FORESTRY.}

\author{
FOREST PROFECTION.
}



Digitized by the Internet Archive in 2007 with funding from Microsoft Corporation 


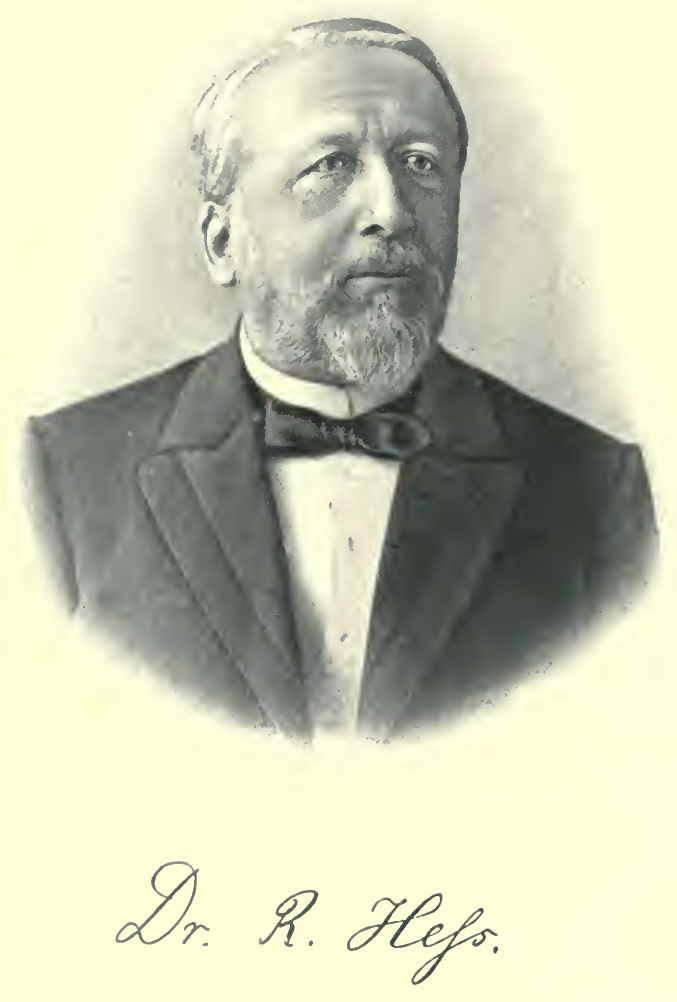




\section{DR. SCHLICH'S}

\section{MANUAL OF FORESTRY.}

VOLUME IV.

\section{FOREST PROTECTION,}

BY

W. R. Fisher, M.A. Cantab. et Oxon.,

PAST PRESIDENT, ROYAL ENGLISH ARBORICULTURAL SOCIETY; FORMERLY CONSERVATOR OF FORESTS TO THE GOVERNMENT OF INDIA.

WITH 300 ILLUSTRATIONS

BEING

AN ENGLISH ADAPTATION OF

"DER FORSTSCHUTZ," вy DR. RICHARD HESS,

PROFESSOR OF FORFSTRY AT THE UNIVERSITY OF GIESSEN.

LIBRARY

FACULTY OF FORESTRY

SECOND EDITION. UNIVERSITY OF TORONTO

'LONDON :

BRADBURY, AGNEW, \& CO. 'LD., 10, BOUVERIE STREET. 1907. 


$$
\begin{aligned}
& 50 \\
& 371 \\
& 533 \\
& 1906 \\
& v .4
\end{aligned}
$$




\section{PREFACE TO THE SECOND EDITION.}

The first edition of my translation of Dr. Hess' FonstschuTz, published in 1895, is now exhausted. I have therefore revised it and have increased the number of pages from 593 to 712 , and the number of plates from 259 to 300 . I have also added a portrait and short biography of Dr. Hess, both of which are taken from a biographical sketch written by Forstmeister F. Kraetzl, and published in 1902, in the 53rd annual volume of "Verhandlungen der Forstwirte von Mähren und Schlesien." I have also added an index, although the table of contents appeared to me, when publishing the first edition, as a sufficient substitute.

The French have never produced an independent work on forest protection, but have included the subject in works on silviculture, entomology, mycology, \&c.; the rapid sale, however, of my first edition has shown that English-speaking foresters require a separate treatise, while such a treatise is part of the scheme of Schlich's MandaL of Forestry, of which this book forms Volume IV. I have been asked why I do not write an original book on the subject. It would have been impossible to do so without borrowing largely from German authors, and it therefore appears preferable to continue my former plan of translating the best German work on the subject.

Most of the additional matter contained in the present volume, as compared with the former edition, is due to additions made by Dr. Hess, in the fourth edition of his Forstschutz, published in 1900 . He has also revised the scientific nomenclature of insects and fungi, and has corrected 
his earlier editions wherever the advance of knowledge rendered such correction necessary. The present volume is not, however, merely a translation of Hess' book; I have added matter that I considered important for British and Indian foresters, and have omitted other matter as being only of local interest. Several of the new plates are not in Hess' book, but have been inserted as illustrations of the subject-matter, and also to fill otherwise unsightly gaps at the ends of the chapters.

This second edition of Forest Protection is uniform with the third edition of Volumes I., II. and III. of the MANUAL of Forestry, which are written by Dr. Schlich. It will very shortly be necessary for me to publish a second edition of Volume V., Forest Utilization, as that book is also nearly out of print.

\section{W. R. FISHER.}

6, Linton RoAd, Oxford,

January 1st, 1907. 


\section{PREFACE TO FIRST EDITION.}

Dr. W. Schlich, C.I.E., has allowed the present book to form Volume IV. of his Manual of Forestry. For this favour I have therefore to thank him, as well as for the kind advice and assistance he has always readily afforded me during the progress of the work. This treatise on Forest Protection, the full scope of which is explained in the Introduction, is an adaptation for English readers of the well-known German Forstschutz, by Dr. Richard Hess, Professor of Forestry at the University of Giessen, in Hesse Darmstadt, to whom I am most grateful for permission to utilize his book and its illustrative plates. I have found it at times necessary to deviate from the original, especially in the chapters on Forest Offences and Rights and Forest Insects, so as to render them more serviceable for English readers. I have also, wherever practicable, exemplified the subject-matter from Britain and India, so that the book might be specially useful to British and Indian foresters.

Mr. B. H. Baden Powell, C.I.E., Instructor in Forest Law at the Royal Indian Engineering College, and late Judge of the Chief Court of the Punjab, has very kindly revised Chapters III. and IV. of Part I., which deal with Forest Offences and Rights, and has rewritten the pages on forest property and the general account of forests rights, so as to make them concordant with English law. My own knowledge of insects is too inadequate to enable me to deal properly with Part II., Chapters IV. to VIII., which treat of Forest Insects; I have therefore submitted my translation of this portion of the Fonstschutz to Mr. W. F. H. Blandford, F.Z.S., lecturer on Entomology at the Royal Indian Engineering College, and I here express my great obligation to 
him for revising these chapters and rewriting many pages of them, so as to make them more distinctly applicable to British insects. While those portions of the work of Dr. Hess which deal with insects unknown in the British Isles have been largely abridged or entirely omitted, it has not been found possible or advisable to remodel the chapters on insects from an entirely British point of view. The scientific names of the insects referred to have been altered, wherever this was required, so as to conform with the nomenclature adopted in the best modern systematic works on British entomology.

Dr. H. Marshall Ward, F.R.S., has very kindly looked over Part III., which deals with forest weeds and fungi, in which he has made some corrections. The scientific names of the forest weeds follow Hooker's and Bentham's British Flora, 1892, and those of the fungi, R. Hartig's LeHrbuch DER BaumKRANKHEITEN, being nearly all the same as those adopted by Dr. Hess.

My colleague Dr. F. E. Matthews, F.I.C., has very kindly assisted me wherever any special knowledge of chemistry was required, as in the last chapter dealing with the effects of acid fumes on trees, and also in correcting proofs of the whole book. I have to thank Mr. J. W. Sowerby, of the Botanic Gardens, Regent's Park, for information supplied regarding the effects of London smoke on the growth of trees.

Due reference will be found in the footnotes to the authors whose works I have consulted.

W. R. FISHER.

Coopers hill College.

May 1st, 1895. 


\section{SHORT BIOGRAPHICAL NOTICE OF DR. RICHARD HESS.}

Richard Alexander Hess was born on the 23rd of June, 1835, in Gotha. His father, Karl August Hess, was Privy Councillor and Member of the Board of Revenue at Coburg, where Hess passed his early youth. In 1849, his father became President of the Board of Revenue at Gotha, and Hess continued his studies there. After leaving school, he was at first inclined to a military career, but in 1854 decided to become a forester and studied practical forestry and at the same time entomology and botany in the Georgental Revier, under Oberförster, afterwards Forstrat, Kellner, and Forstmeister Schrödter, both distinguished men. In 1855-56, he attended the Bavarian forest school at Aschaffenburg out of which he passed first among thirty-four candidates. From 1856 till 1858, he attended classes in Law, Finance, and Natural Science at Göttingen.

$\mathrm{He}$ entered the State forest service of Saxe-Coburg-Gotha in 1858 , and was appointed, in 1859, to the charge of the forest range Gehlberg, in the Thüringer Wald. The reigning Duke was extremely fond of the chase, so that forestry was then subordinate to game-preserving in the State forests. This v) subordination of forestry to game induced Hess to write on the subject to the Forst-und-Jagdzeitung, of which Dr. Gustav - Fess, Professor of Forestry at Giessen, was then editor. This paper was not published, but it led to his visiting Heyer at Giessen, and he thus formed a friendship with one of the most distinguished of German foresters.

Heyer made him French correspondent to the Forst-und Jagdzeitung, and he translated a number of French forest 
pamphlets ("Annales forestières," "Revue des eaux et forêts," sc.), and reviewed several important French works on forestry. In 1868, Heyer was appointed Director of the newly-established forest school at Münden, and Hess succeeded him as Director of the Giessen forest school and Professor of Forestry there. This post he has held ever since, although he was nominated Professor of Forestry at Vienna in 1877, and to a similar post at Munich in 1884, but he preferred to remain at Giessen.

Hess was made a Privy Councillor in Hesse Darmstadt in 1890 , and in thesame year, his portrait and a sketch of his career appeared in the Golden Book of the German people among the eleven most distinguished German foresters. $\mathrm{He}$ has published several works, which give a true picture of his mind, intelligent, clear and true. The best-known among these are: "Forstschutz," the 4th edition of which was published in 1900 , of which the present book is chiefly a translation; "Eigenschaften und forstiches Verhalten der wigtigeren in Deutschland einheimischen und eingefuhrten Holzarten"; "Encyclopädie und Methodologie der Forstwissenschaft"'; a revision of the 4th edition of Heyer's "Waldban" ; and "Die Forstbenutzung," a second edition of which was published in 1901.

Hess has travelled all over Germany in order to observe the various aspects of local forestry, also in Austria, Bosnia and Herzogovina. $\mathrm{He}$ is one of the most popular and widest known of German foresters, and English-speaking people are greatly indebted to him for the permission he has so generously accorded for a translation into English of the results of his long experience and studies. 


\section{TABLE OF CONTENTS.}

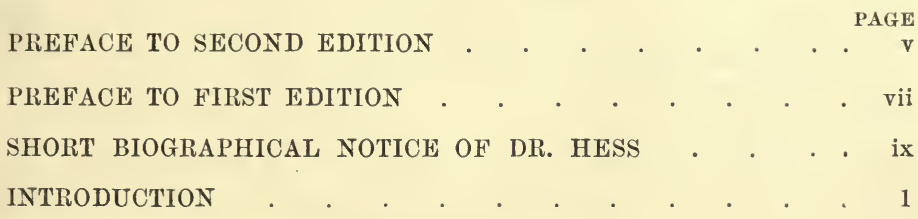

PART I.

PROTECTION OF FORESTS AGAINST MAN.

CHAPTER I.

FOREST BOUNDARIES.

1. The various kinds . . . . . . . . . . . 10

2. Settlement . . . . . . . . . . . . 11

3. Demarcation . . . . . . . . . 12

4. Survey . . . . . . . . . . . . 19

5. Description . . . . . . . . . 19

6. Legalisation . . . . . . . . . . 20

7. Upkeep . . . . . . . . . . . 20

8. Cost . . . . . . . . . . . . . 21

9. Improvement . . . . . . . . . . . 21

CHAPTER II.

PROTECTION OF FORESTS AGAINST IRREGULARITIES IN UTILIZING FOREST PRODUCE.

Section I.-Principal Produce.

1. General account . . . . . . . . . . 23

2. Overfelling . . . . . . . . . 23

3. Bad felling . . . . . . . . . . . 24

4. Careless conversion . . . . . . . . . . . 25

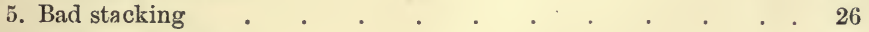

6. Careless transport . . . . . . . . . . . . 26 
Section II.-Minor Produce.

PAGE

1. General account . . . . . . . . . . . 27

2. Bark . . . . . . . . . . . 27

3. Turpentine, resin, and gums . . . . . . . . 28

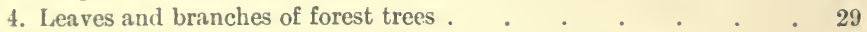

5. Fruits of forest trees (collection) . . . . . . . . $\quad 30$

" . (pannage) . . . . . . . 31

6. Grass and herbage (grass-cutting) . . . . . . . 33

" $"$ (pasture) . . . . . . 35

7. Forest litter. . . . . . . . . . . . . . 49

8. Dead branch-wood . . . . . . . . . . 51

9. Stones, gravel, sand, sc. . . . . . . . . . . . 52

10. Other produce . . . . . . . . . . . 53

11. Game and fisheries . . . . . . . . . 53

\section{CHAPTER III.}

PROTECTION OF THE FOREST AGAINST OHFENCES.

1. General account . . . . . . . . . . 55

2. Definition of a forest offence . . . . . . . . 5 5

3. Classification of forest offences . . . . . . . 56

4. Protective rules . . . . . . . . . 59

\section{CHAP'TER IV.}

PROTECTION AGAINST FOREST RIGHTS.

Section I.-General View of forests as "Estates" or Pieces of Property. . . . . . . . . 64

$" \quad$ II.-General Account of Forest Rights _ . . . 67

$" \quad$ III.-SPecial Account of Forest Rights . . . . 78 
PART II.

PROTECTION OF THE FOREST AGAINST ANIMAIS.

PAGE

Introductory remarks . 95

\section{CHAPTER I.}

PROTECTION AGAINST DEER AND WILD PIGS.

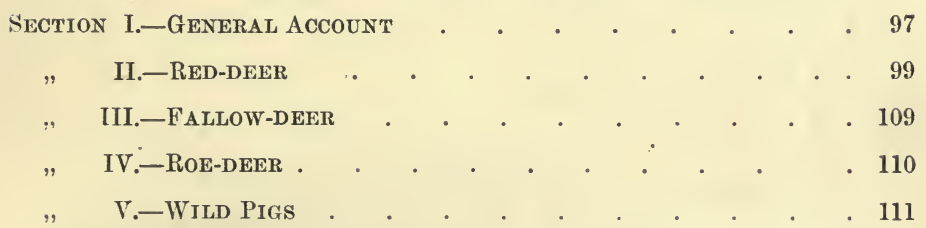

\section{CHAPTER II.}

PROTECIION AGAINST RODENTS.

SECTion I.-General Account

II.-HARES

, III.-RABBITS

, IV.--SQUIRRELS.

, V.-DORMICE

,$\quad$ VI.-MICE.

$"$ VIII.-Beavers aNd Porcupines

\section{CHAPTER III.}

\section{PROTECTION AGAINST BIRDS.}

$$
\begin{aligned}
& \text { Section I.-General Account . . . . . . . . . . . } 136 \\
& \text { II.-CAPERCAilzie AND Grouse . . . . . . . } 138 \\
& \text { " III.-Pigeons AND Doves . . . . . . . . . . } 139
\end{aligned}
$$

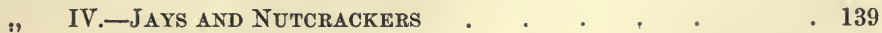

$$
\begin{aligned}
& \text {, V.-Finches and other Small Birds . . . . . . } 140 \\
& " \text { VI,-WOODPECKERS . . . . . . . . . . } 142
\end{aligned}
$$




\section{CHAPTER IV.}

\section{FOREST INSECTS (GENERAL ACCOUNT).}

Section I.-Classification . . . . . . . . . 149

" II.-Distribution . ‘. . . . . . . . . . 153

" III.-LIFE-HistoRY . . . . . . . . . 155

" IV.-NUMBER . . . । . . . . . . . . 159

$"$ V.--Useful Forest Insects . . . . . . . 160

VI.-INJURIOUS ForEst INSECTS . . . . . . . . 161

1. Damagc done . . . . . . . . . 161

2. Preventive rules (Protection of insectivorous birds, sc.) . . . 164

3. Remedial measures . . . . . . . . . . 173

4. Treatment of injured woods . . . . . . . . 178

\section{CHAPTER V.}

INSECTS USEFUI, TO FORESTS (SPECIAI، ACCOUNT).

\begin{tabular}{|c|c|c|c|c|c|c|c|c|c|c|c|c|c|c|}
\hline RDER & I.-COLEOPTERA & · & . & . & & · & & & & & & & & \\
\hline • & II.-HYMENOPTERA . & · & & . & - & - & & & & & & & & \\
\hline$"$ & III.-DIPTERA & . & · & - & & • & . & & & & & & & \\
\hline$"$ & IV.-NEUROPTERA & - & & & . & . & & & & & & & & . \\
\hline : & V.-ORThopterA (Psi & & & J ROI & & RA) & & & & & & & & \\
\hline
\end{tabular}

\section{CHAPTER VI.}

INJURIOUS FOREST INSECTS (SPECIAL ACCOUNT OF COLEOPTERA).

FAMILY I. - SCARABAEIDAE.

1. Melolontha rulgaris (Common cockchafer) . . . . 199

2. M. hippocastani . . . . . . . . . . 209

3. Rhizotrogus solstitialis (June chafer) . . . . . . 210

FAMILY II.-BUPRESTIDAE.

1. Agrilus viridis . . . . . . . . . . . 211

2. Other species . . . . . . . . . . 213

FAMILY III.-FLATERIDAE (Click-beetles) . . . . . . . 214

"IV.-IXMEXYLONIDAE.

Lymerylon narule . 
FAMILY V.-ANOBIIDAE.

Xestobium tesselatum

2. Rhynchites betulae . . . . . . . . . . 219

3. Strophosomus coryli . . . . . . . . . . 220

4. Balaninus nucum (Nut-weevil) . . . . . . . . 221

5. Orchestes fagi . . . . . . . . . . . . 221

6. O. quercus. . . . . . . . . . . 223

7. Cryptorrhynchus lapathi . . . . . . . . . 223

8. Hylobius abietis (Pine-weevil) . . . . . . . . 225

9. Pissodes notatus . . . . . . . . . . 233

10. Other species . . . . . . . . . . . . 235

FAMily VII.-ScolytidaE (Bark-beetles).

(a) Subfamily Tomicini.

1. Tomicus typographus . . . . . . . . . 238

2. T. амitinus . . . . . . . . . . . 246

3. T. chalcographus . . . . . . . . . . 248

4. T. stenographus. . . . . . . . . . . 250

5. T. laricis . . . . . . . . . . . 251

6. T. bidentatus . . . . . . . . . . . 253

7. T. acuminatus . . . . . . . . . 255

8. T. lineatus . . . . . . . . . . 255

9. T. domesticus . . . . . . . . . . . 258

10. T. dispar . . . . . . . . . . . . . . 259

(b) Subfamily Hylesinini.

1. Hylastes palliatus . . . . . . . . . . 262

2. H. ater . . . . . . . . . . . . 263

3. Myelophilus piniperda (Pine-beetle) . . . . . . 26 .

4. M. minor . . . . . . . . . . . . 271

5. Hylesinus fraxini (Ash-bark beetle) . . . . . . 273

6. H. vittatus . . . . . . . . . . . . 275

7. $H$. crenatus . . . . . . . . . . . 275

(c) Subfamily Scolytini.

1. Scolytus Geoffrogi (Elm-bark beetle) . . . . . . . 277

2. S. intricatus . . . . . . . . . . . 278

FAMILY VIII.-Cerambycidae (Longicorns).

1. Saperda carcharias (Large poplar longicorn) . . . . 280

2. S. populnea (Small poplar longicorn) . . . . . . 282

FAMILY IX.-Chrysomelidae (Leaf-beetles).

1. Chrysomela populi (Red poplar-leaf beetle) . . . . . 284

2. C. vulgatissima (Willow-beetle) . . . . . . . 285 


\section{CHAPTER VII.}

LEPIDOPTERA (Heterocern, Moths).

FAMILY I.-SESIIDAE.

PAGE

1. Sesia a piformis (Hornet clearwing-moth) . . . . . . . . 289

FAMILY II.-COSSIDAE.

1. Cussus ligniperda (Goat-moth) . . . . . . . 291

2. C. aesculi (Wood leopard-moth) . . . . . . . . 293

FAMILY III.-BOMBYCIDAE.

1. Gastropacha pini (Pine-moth) . . . . . . . 294

2. Bomby.x neustria (Lackey-moth) . . . . . . . 302

3. B. pudibunda (Pale tussock moth) . . . . . . 304

4. B. chrysorrhoea (Brown-tail moth) . . . . . . . 308

5. Liparis monacha (Black-arches or Nun moth) . . . . 310

FAMILY IV.-NOCTUIDAE (Night-moths).

1. Noctua piniperla (Pine noctua) . . . . . . . 320

2. N. restigialis . . . . . . . . . . . 322

3. N. segetum (Turnip dart-moth) . . . . . . . . 325

FAMily V.-Geometridae (Loopers).

1. Geometra piniaria (Pine looper-moth) . . . . . . 326

2. G. brumata (Winter-moth) . . . . . . . . . 329

FAMily VI.-ToRTRicidae (Leaf-roller moths).

1. IIalias chlorana (Green willow leaf-roller) . . . . . 332

2. Tortrix viridana (Oak-leaf roller) . . . . . . . . 333

3. T. buoliana (Pine-shoot tortrix) . . . . . . . 335

4. T.turionana . . . . . . . . . . . 338

5. T. resinella . . . . . . . . . . . . 339

6. T. rufimitrana . . . . . . . . . . 340

7. T. pinicolana . . . . . . . . . . . . . 341

FAMILY VII.-TINEIDAE.

1. Tinea rariabilis. . . . . . . . . . . 343

2. T. curtisella (Ash-twig moths). . . . . . . . 344

3. Coleophora laricella (Larch-miner moth) . . . . . 346

\section{CHAPTER VIII.}

OTHER ORDERS OF DESTRUCTIVE INSECTS.

\section{(A) Hymenoptera.}

Family I.-Tenthredinidae (Sawflies).

1. Lophyrus pini (Pine sawfly). 
FAMILY II.-UROCERIDAE (Wood-wasps).

PAGE

1. Sirex juvencus (Steel-blue wood-wasp) . . . . . . 355

2. S. gigas (Yellow wood-wasp). . . . 357

FAMily III.-Cxxipidae (Gall-wasps) . . . . . . 358

(B.) Diptera.

FAMiLY I.-CeCidomyiddae (Gall-gnats).

1. Cecidomyia saliciperda (Willow gall-gnat) . . . . . 360

(C.) Hemiptera.

FAMiLY I.-APHididae (Plant-lice).

1. Chermes abietis (Spruce-gall Aphis) . . . . . . 361

2. C. coccineus . . . . . . . . 364

3. C. strobilobius (Larch Aphis) .. . . . . . . . 364

4. C. sibiricus . . . . . . . . . . . . 365

FAMiLY II.-CoccidaE (Scale-insects).

1. Coccus fagi . . . . . . . . . . 366

1. Lecanium hemicryphum . . . . . . . . . 367

(D.) Orthoptera.

FAMiLY I.-GryLlidae (Crickets).

1. Gryllotalpa rulgaris (Mole-cricket) . . . . . . . 368

FAMILY II.-ACRIDIIDAE (Locusts).

1. Pachytylus migratorius (Migratory locust) . . . . . 372

List of Trees with the Insects which attack them . . 373

PART III.

PROTECTION AGAINST PLANTS.

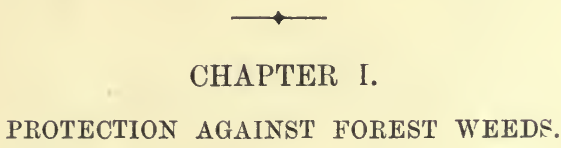

Section I.-General Account.

1. Definition . . . . . . . . . . . 386

2. Classification . . . . . . . . . . . 386

3. Utility of certain weeds . . . . . . . . . . 390

4. Damage done by forest weeds . . . . . . . 390

5. Preventive measures . . . . . . . . . . . 395

6. Remedial measures . . . . . . . . . 397

F.P. 
Section II.-SPecial Account.

PAGE

1. Lightdemanding weeds .

2. Half-shadebearers

3. Shadebearing weeds

4. Weeds of wet peaty soil

5. Lianes

6. Parasitic phanerogams

7. Weeds acting as hosts to injurious fungi

8. Classification of weeds in order of injuriousness
399

403

410

412

420

\section{CHAPTER II.}

\section{PROTECTION AGAINST FUNGI.}

\section{Section I.-General Account.}

1. Position of fungi in vegetable kingdom . . . . . . 421

2. Classification and importance . . . . . . . . . 422

3. Mode of life . . . . . . . . . . . . 423

4. Distribution . . . . . . . . . . . 427

Section II.-Fungi AtTACKing Conifers.

1. Armillarea mellea (Honey fungus).

2. Fomes annosus

3. Rhizina inflata . . . . . . . . . . . . 437

4. Trametes Pini . . . . . . . . . . . 438

5. Peridermium Pini (corticola) (Pine-blister) . . . . . 441

6. P. Strobi . . . . . . . . . . . . 443

7. Melampsora Pinitorqua (Pinc branch-twist) . . . . 444

8. Melampsorella Caryophyllaccarum (Silver-fir canker) . . . 448

9. Nectria Cucurbitula . . . . . . . . . . 452

10. Dasyscypha calycina (Larch-blister). . . . . . . 454

11. Cenangium Abietis (Pine-shoot fungus). . . . . . 459

12. Pestalozzia Hartigii . . . . . . . . . . 460

13. Septoria parasitica . . . . . . . . 460

14. Botritis Douglassii . . . . . . . . . . 461

15. Peridermium Pini (acicola) . . . . . . . 461

16. Aecidium abietinum . . . . . . . . . . . 462

17. A. columnare . . . . . . . . . . 462

18. ('hrysomyxa Abietis . . . . . . . . . . 463

19. Luphodermium Pinastri (Pıne needle-cast) . . . . . 465

20. L. macrospurium . . . . . . . . . . 467

21. L. nervisequium . . . . . . . . . 468

22. Sphaerella laricina . . . . . . . . . . . . . . . . . . . 469

23. Trichsphaeria parasiticu . . . . . . . 470

24. Herpotrichia nigra . . . . . . . . . . 472

25. Aecidium strobilinum . . . . . . . . . 472 
Section 1II.-Fungi attacking Broad-Leaved Trees.

PAGE

1. Rosellinia quercina . . . . . . . . . . . . 473

2. Polyporus sulphureus . . . . . . . . . 475

3. Nectria ditissima (Beech-canker) . . . . . . . 477

4. N. cinnabarina (Coral-spot disease) . . . . . . 479

5. Aglaospora taleola . . . . . . . . . . . . 481

6. Phytophthora Fagi (Beach seedling mildew) . . . . . 482

7. Rhytisma acerinum . . . . . . . . . . 483

8. Melampsora Hartigii . . . . . . . . . 485

\section{PART IV.}

PROTECTION AGAINST ATMOSPHERIC INELUENCES.

\section{CHAPTER I.}

PROTECTION AGAINST FROST.

Section I.-Frozen Plant-Organs.

1. Exterual appearance . . . . . . . . . 492

2. Explanation of the action of frost on plants . . . . . 492

3. Damage done. . . . . . . . . . . 494

4. Register of severe frosts . . . . . . . . . 502

5. Protective measures . . . . . . . . . 502

Section II.-FrostCrack . . . . . . . . . 505

"III.--FROST-CANKER . . . . . . . . . 510

IV.-Uprooting of SeedLings by Frost . . . . . 510

\section{CHAPTER II.}

\section{PRO'TECTION AGAINST INSOLATION.}

SECTION I.-DROUGHT.

1. Appearance and cause of injury . . . . . . . 514

2. Damage done . . . . . . . . . . 514

3. Register of dry years . . . . . . . . . . . . . . . . . 518

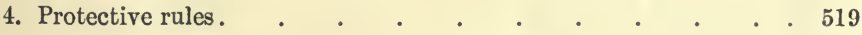

SECTION II.-BARK-SCORCHING . . . . . . . . . 522

" III.-HEAT-CRACK . . . . . . . . . . .526 


\section{CHAPTER III.}

\section{PROTECTION AGAINST WIND.}

PAGE

SECTION I. - P'REVALENT WINDS.

1. Damage done

2. Protective rules.

SECTION 1I.-STORMS.

1. Origin . . . . . . . . 531

2. Damage done . . . . . . . . . . . . 533

3. Register of storms . . . . . . . . . . 540

4. Protective rules . . . . . . . . . 542

5. Treatment of windfalls . . . . . . . . . 550

6. Treatment of injured woods . . . . . . . . . 551

CHAPTER IV.

PROTECTION AGAINST VIOLENT RAIN.

1. Damage done . . . . . . . . . . . 554

2. Protective rules . . . . . . . . . . 555

\section{CHAP'TER V.}

PROTECTION AGAINST HAIL.

1. Damage done . . . . . . . . . . 557

2. Prevalence of hail-storms . . . . . . . . . . 558

3. Protective measures . . . . . . . . . . 560

CHAPTER VI.

PROTECTION AGAINST SNOW.

1. Damage done . . . . . . . . . . . 561

2. Record of bad years . . . . . . . . . . . . 569

3. Protective rules . . . . . . . . . . 570

4. Treatment of injured woods $\quad . \quad$. $\quad . \quad$. $\quad . \quad 572$

CHAPTER VII.

PROTECTION AGAINST RIME.

1. Damage done . . . . . . . . . . 574

2. Record of bad years . . . . . . . . 576

3. Protective rules . . . . . . . . . . 578

4. Treatment of injured woods . . . . . . . . 578 


\section{PART V. \\ PROTECTION AGAINST NON-ATMOSPHERIC NATURAL PHENOMENA.}

CHAPTER I.

PROTECTION AGAINST DAMAGE BY WATER.

Section I-Soll-Denudation

$"$ II.-InUndations . . . . . . . . . . 586

$"$ III.-SWAMPS.

1. Formation. . . . . . . . . . . . 596

2. Damage done . . . . . . . . . . . 597

3. Protective rules. . . . . . . . . . . 601

Section IV.-Drainage.

1. Vertical drainage . . . . . . . . . . . 604

2. Surface drainage . . . . . . . . . . 604

3. Covered drains . . . . . . . . . . . 612

CHAPTER II.

PROTECTION AGAINST AVALANCHES . . . . 616

CHAPTER III.

PROTECTION AGAINST SHIFTING SAND.

SECTION I.-SAND DUNES.

1. Description . . . . . . . . . . . . 621

2. Construction of littoral dune . . . . . . . . 623

3. Material for fixing the sand. . . . . . . . . 624

4. Maintenance of the littoral dune . . . . . . . . 625

5. Protective coast forest zone . . . . . . . . . 626

SECTION II.-INLAND SAND.

1. Description . . . . . . . . . . . 630

2. Protective rules . . . . . . . . . . 630

3. Fixation of the sand . . . . . . . . . . . . 631

4. Stocking the area . . . . . . . . . . . . 634 


\section{CHAPTER IV. \\ PROTECTION AGAINST FOREST FIRES.}

Section 1.-Forest Fires caused by Human Agency. Page

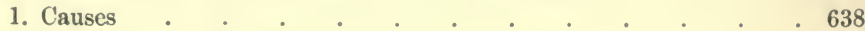

2. Kinds of forest fires . . . . . . . . . 639

3. Damage done . . . . . . . . . . 640

4. Register of fires . . . . . . . . . . . . . 645

5. Protective measures . . . . . . . . 647

6. Rules for extinguishing forest fires . . . . . . . 654

7. Watching site of fire. . . . . . . . . . . . 656

8. Treatment of injured woods . . . . . . . . . . 65i

9. Insurance against forest fires . . . . . . . . 6557

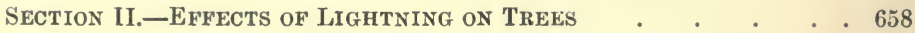

PART VI.

PROTECTION AGAINST CERTAIN DISEASES.

\section{CHAPTER I.}

\section{CHAPTER II.}

RED ROT.

1. Description . . . . . . . . . 673

2. Modifying factors. . . . . . . . . . . 674

3. Causes . . . . . . . . . . 675

4. Damage done . . . . . . . . . . 677

5. Treatment. . . . . . . . . . 677

\section{CHAPTER III.}

CHAPTER IV.

STAG-HEADEDNESS. 
CHAPTER V.

ABNORMAL NEEDLE-CAST.

PAGE

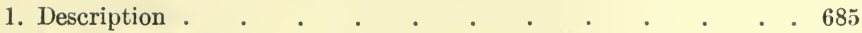

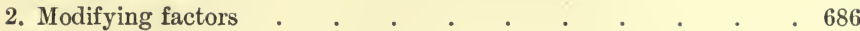

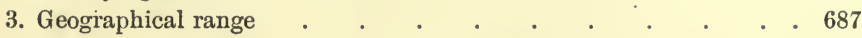

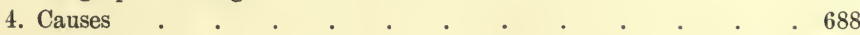

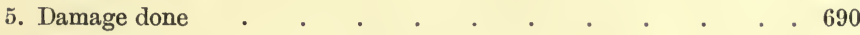

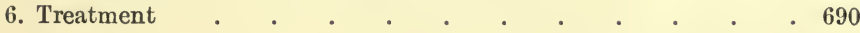

\section{CHAPTER VI.}

DAMAGE BY ACID FUMES FROM FURNACES, dc.

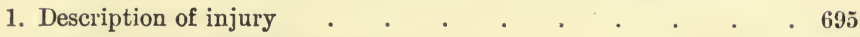

2. Injurious components of smoke . . . . . . . . . 696

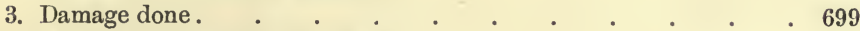

4. Methods of recognizing damage . . . . . . 705

5. Protective measures . . . . . . . . . . 707

6. Estimation of damage . . . . . . . . . . 707 



\section{FOREST PROTECTION.}

\section{INTRODUCTION.}

1. Definition of the Term Forest Protection.

Forests may be protected by two agencies:-

By the State, through laws and regulations made for the general welfare of the country and forming the subject of Forest Law.

By the Owner of the forest, in his private capacity; only this part of the subject comes under the term Forest Protection, which may therefore be defined as follows:-

Forest Protection has for its object, the security of forests, as far as lies within the power of their owner's, against unfavourable external influences.

The measures to be taken in order to protect a forest may be :-

Preventive or remedial, according as their object is to ward off certain dangers, or to remedy evils which the forest has already incurred.

The essential conditions of successful Forest Protection are :-

Knowledge of the phenomena and causes of all damage which may threaten forests.

Knowledge of the available preventive and remedial measures.

A proper application of the above knowledge to any special case of damage which may arise.

2. Position of Forest Protection in Forestry.

'I'he position of Forest Protection in the science of forestry will be seen from the following considerations:-

Sylviculture teaches us how to form, tend, and regenerate 
forests ; Forest Protection, how to guard them against injurious external influences, and is followed by Forest Utilisation, which shows how to utilise a forest in the most suitable manner. These three branches of Forestry are also included in the term Forest Production, while the remaining branches are comprised under Forest Management, which includes Mensuration and Valuation of Forests, Working-Plans, and Political Economy applied to forests, which may be termed Forest Policy.

\section{Historical Notice.}

The first trace in history of forest protection consists in that afforded to sacred groves and trees. We read of such groves in the Bible and in Tacitus, and they still exist in India, especially in the hill-tracts south of Assam. In Europe, the oak and lime appear to have been the trees looked upon as most sacred, and in the Himalayas, the deodar (God's tree).

The Ban forests of the middle ages, established by the Emperors of Germany and other royal or noble personages who wished to secure sufficient tracts of forest for the preservation of deer and other game, formed the next stage. The Windsor, Epping, and Dean forests, the New Forest, and some other smaller forest areas are the relics of former extensive tracts reserved as hunting-grounds by the Norman kings of England.

The forest laws of the middle ages, besides being chiefly concerned in the preservation of game, contain many provisions regarding boundaries, forest fires, mast, forest pasture, damage to trees, etc. In the Salzburg Forest Ordinance* of 1524, for instance, directions are given regarding boundary marks. In a Bavarian forest ordinance of 1568 , the influence of the west wind on the natural regeneration of forests is referred to, and directions are given to leave a protective belt of trees to the west of a felling-area.

In 1665, the famous Ordonnance des forêts proposed by Colbert was sanctioned by Louis XIV, and, amongst other improvements, put an end to the grazing of sheep and goats in the French Crown forests.

- H. Eding, "Die Rechtsverhältnisse des Waldes." Berlin, 1874, p. 36. 
Hans von Carlowitz in 1713, in his classical work Sylvicultura Economica, which is chiefly devoted to sylviculture, describes several measures of forest protection, including a regulation made in 1680 against caterpillars.

As regards damage by game, Burgsdorf wrote in 1796 concerning the peeling of bark by deer. At the commencement of the nineteenth century, the damage done to forests by game was very considerable; in a battue held by King Frederick of Würtemberg in 1812 in the beech forests near Tübingen, 823 deer and wild pigs were killed in two hours. Only since the eventful year 1848 has damage by game to forests in Germany considerably diminished, and become more localised by the constitution of special parks for game. Such was the forest of Compiègne under Napoleon III., where all the forest revenues were absorbed by the cost of fencing and planting the young woods, and where, in 1870, several hundred red-deer and thousands of roes, besides much smaller game, were killed.

In England, James the First was the first monarch who considered forest trees of more importance than game; he obtained much unpopularity by enclosing part of Windsor Forest, and put an end to the pollarding of maiden oak-trees, which were lopped in winter to enable the deer to browse off the bark of the lopped branches. None but pollard oak have been lopped in this way since 1608, and the hollow old oak pollards now in the Windsor Forest were in existence before that date. That king's fondness* for knocking rabbits on the head with a stick would, however, be amply satisfied were he now at Windsor, as rabbits have increased in the most alarming manner during the last 20 years, and have destroyed the valuable undergrowth over large areas of the forest. They render the reproduction of the trees exceedingly difficult and expensive, and altogether nullify the proper management of the large area of oak forest planted for the nation in 1816-25. Such wholesale destruction of valuable woods by rabbits would not be allowed in any other European Crown forest.

Forest grazing was regulated in 1585 by the ordinance of Mansfeld, which prescribed a 5-years close season for all

* Hepworth Dixon, "Royal Windsor." 
coppice woods with 12-years rotation. Forest pasture, and pannage, or the eating of mast by pigs, have greatly fallen off in importance of late years, but in earlier times these forest usages vied in importance with that of hunting.

The great damage done to forests by insects was first noted in Germany in 1780, and between that date and 1830 several works on Forest Entomology appeared. That by Ratzeburg was published in 1837, and another by Altum in 1872. Ratzeburg's book was revised and enlarged by Judeich and Nitche in 1885 and in 1895.

The engineer Brémontier undertook the fixing of the shifting sands on the west coast of France in 1800, on lines already proposed by Baron de Charlevoix Villers in 1786. A French law on that subject was passed in 1810 . Oberforster von Kropf did a similar service for Germany at about the same time.

The great damage done in 1856 , by floods in the Rhone Valley, induced the French to pass in 1860 a law for "reboisement des montagnes."

Forest fires were formerly of frequent occurrence in France and Germany, but are now regarded as national calamities, and rarely allowed to extend over considerable areas. A special law against forest fires in Dauphiny was passed in 1872, and revised in 1893. They are still prevalent on a large scale in Russia and Greece, and in North America. In British India, for the last 30 years, a steadily increasing success has been attained by the Government in its efforts to reduce the area of State forests burned annually, and measures for protecting 36,651 square miles of State forest from fire were taken in 1903.

The preservation of birds useful in forestry and agriculture has been furthered by the naturalists of different European countries and by the enactment of special laws. At the same time, the British gamekeeper by indiscriminately destroying birds-of-prey and the smaller carnivora, has allowed rabbits and wood-pigeons to increase so enormously, as to become a veritable scourge to forestry and agriculture, to say nothing of even greater danger from mice and voles.

Lastly, the researches of Willkomm in 1866, and of Robert Hartig in 1874, have brought to light the causes of many diseases of forest trees which are due to fungi. 


\section{Arrangement of Material.}

The measures to be taken by the owner for the protection of his forests may be arranged under the following heads :-

Protection of forests against man, animals, plants, atmospheric influences (frost, heat, wind, rain, hail, snow and rime) ; against extraordinary natural phenomena (inundations, avalanches, shifting sand and forest fires); and against certain diseases the causes of which are doubtful, stagheadedness, and factory fumes.

A detailed list of the headings are given at the commencement of this book.

It will be noticed that some of the protective measures suggested in certain cases are conflicting; thus woods should be cut from west to east, in order to protect them against cutting east winds, but from east to west, when liable to be thrown by strong westerly gales. Stumps must be extracted to prevent the breeding of certain insects, but should be left on hill-sides, when there is danger of erosion. The forester will, however, have little difficulty in deciding, for any case, which is the greater danger, and will bear that chiefly in mind in protecting his woods.

5. List of Sciences on which Forest Protection is based.

Jurisprudence, chiefly as regards landed property and servitudes.

Zoology, chiefly of game and forest insects.

Botany and Mycology.

Physiography and Meteorology.

Other branches of Forestry (Sylviculture, Forest Utilisation, and Forest Policy).

A knowledge of forest legislation and of game laws is also useful. 



\section{PART I.}

PROTECTION OF FORESTS AGAINST MAN. 



\section{PROTECTION OF FORESTS AGAINST MAN.}

THE damage which may be caused to forests by our fellowcreatures may be classified as follows :-

Injuries to forest boundaries.

Irregularities in utilising forest produce.

Theft of forest produce and damage to forests, or forest offences.

Excesses by holders of forest servitudes.

It is the duty of the forester to maintain the boundaries of the forest entrusted to his care, to counteract irregularities in utilising it, to prevent theft of forest produce and damage to the forest, and also excesses in the exercise of forest servitudes. 


\section{CHAPTER I.}

\section{PROTECTION OF FOREST BOUNDARIES.*}

A Clearly defined and permanent demarcation of a forest stands in the first rank of the protective measures for forest property. It protects the forest against fraud and damage, - and affords security for all the details of forest management.

The different points which require consideration under this heading are :-

The various kinds of forest boundaries.

Settlement of do.

Demarcation of do.

Survey of do.

Description of do.

Legalisation of do.

Upkeep of do.

Cost of do.

Improvement of do.

1. The Various Kinds of Forest Boundaries.

Boundaries are of two principal kinds, property and administrative boundaries.

By the term property boundaries is meant those that separate estates, or portions of the same estate subject to servitudes.

Property boundaries may be either external or internal surrounding enclosures. Boundaries of servitudes separate those parts of an estate that are affected by rights of third parties from those which are not so affected. Parts of a forest may be leased for sporting or other purposes, and their boundaries must be clearly defined.

Administrative boundaries may indicate:-

Administrative units, such as beats, ranges, divisions, etc., or,

Working units, as compartments, periodic blocks, workingsections, working-circles, etc.

"Eding, H., "Die Rechtsverhältnisse des Waldes." Berlin, 1874. Kalk, R., "Die Sicherung der Forstgrenzen." Eberswalde, 1879. 


\section{Settlement of Boundaries.}

All forests must be properly demarcated by boundaries.

The procedure for settling boundaries differs according as they are property or administrative boundaries. Administrative boundaries depend merely on the will and pleasure of the owner of the estate, and the details regarding them are dealt with under Working-Plans.

- Property boundaries must be accurately defined. This is of the greatest importance to the owner and also to the public, so as to prevent uncertainty and unnecessary work for the executive and legal machinery of the State. Hence in all

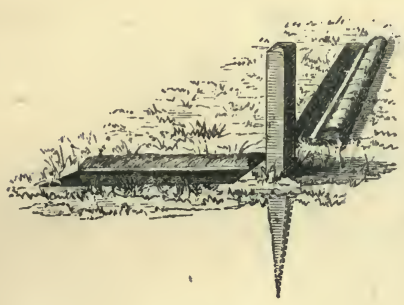

Fig. 1.

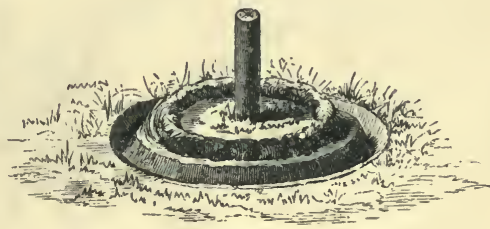

Fig. 2.

civilised countries the procedure for settling property boundaries is laid down by law. Evidence as to the correct boundary consists in existing boundary pillars or traces of where they have been, statements of old people who know the boundaries, and boundary maps. The settlement is best done by a public surveyor, who may be either chosen by the parties concerned, the adjacent owners, or by the executive State or local authority.

During the boundary settlement the adjacent proprietors should be present personally, or by their legally appointed agents, and boundaries which may be regulated in their absence after a formal summons to be present will be held to have been duly accepted by them. The surveyor should endeavour to lay down the boundary on the ground by friendly agreement between the parties; if he should not succeed, the competent law-courts or officials must decide disputed points.

The surveyor should fix the boundary lines as long and 
straight as possible, in order to render the estates more valuable, and to keep down the cost of demarcating and maintaining the boundary. This maxim should not, however, be carried too far, when by so doing, boundary points would be situated in impassable places, such as swamps, etc.

All boundary points which have been finally settled should at once be marked by durable posts, and by digging narrow trenches in the direction of the boundary lines (Fig. 1), or in a circle round each post (Fig. 2). During the progress of the boundary settlement, the surveyor should make a rough plan of the boundary line, and keep notes of the evidence brought before him.

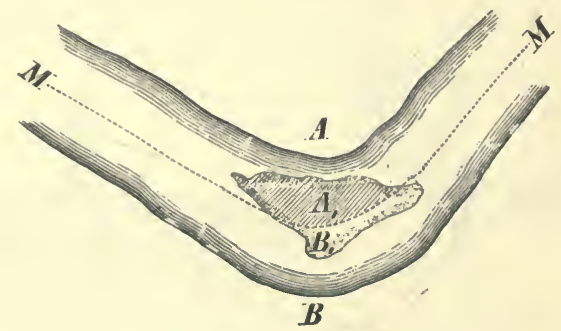

Fig. 3.- Partition of an island by the line $M \Gamma$, mid-stream, between two adjacent owners, A. and B., into two parts $A, B$,

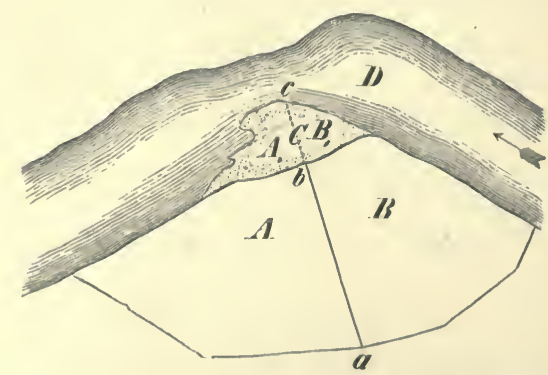

Fig. 4.-Partition of a river-side accretion $C$, by the line $a b c$.

\section{Demarcation of Boundaries.}

The demarcation of boundaries is effected by natural, artificial, or mixed boundaries.

Property boundaries require to be more permanently marked than administrative boundaries. 
a. Natural Boundaries.

Natural boundaries are :-

Water-partings,

Water-courses,

Marked trees, etc.

With the exception of water-partings no natural boundarios are very permanent. Streams frequently alter their course, and trees are liable to die or be blown over or cut down.* At the same time, wherever the course of a stream is fairly well fixed, as in a deep valley, such a natural feature forms a good and economical boundary between two properties. In the case of water-courses, mid-stream is generally considered the boundary as in Fig. 5. Where deposits of new land occur, they belong as a rule to the proprietor who owns the shore along which they occur. If several owners participate in the

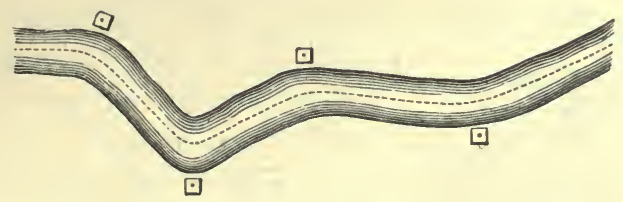

Fig. 5.-Water-course with boundary marks.

shore, the new boundaries are indicated by producing the original boundary line through the new accretion to the waterside as shown in Fig. 4. In the case of erosion and re-deposit, laws differ; in some cases, the owners can claim the area thus lost and re-deposited. In other cases, as in certain parts of British India, new islands formed in the middle of a river belong to the State. Owners are allowed to prevent erosion by artificial works, fixing the banks, etc. It is not, however, permissible to induce deposits by artificial means.

For greater security natural boundary lines may be marked by numbered marks similar to those described below for artificial boundaries. If the centre of a stream is the boundary,

* Pollarded trees often serve as boundary marks in private forests near the river Rhine. They are thus easily distinguished from the other trees, that are not pollarded. Slips of poplars or willows may be planted on favourable soil to serve as boundary marks. 'These may be subsequently pollarded. In India, species of Ficus may be used. 
the boundary marks are placed alternately on either side of it, as in Fig. 5, but only on one side of it if the bank be the boundary.

\section{b. Artificial" Boundaries.}

Artificial boundary lines consist of :-

Roads, or lines of boundary marks.

The line of a road may have to be changed, especially at certain points to reduce too steep a gradient, and this may be an objection in some cases to a road as a permanent boundary, but a well aligned road forms an excellent and economical forest boundary, and facilitates the export of produce from the forests on either side of it.

Lines of boundary marks may be demarcated by mounds of earth or stones; by wooden or iron posts, masonry pillars, or cut stone blocks. All boundary

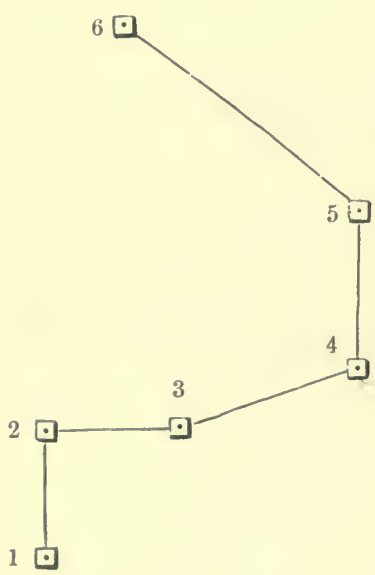

Fig. 6.-Artificial boundary line. marks should be numbered consecutively, and the numbers on them painted black or white according to the colour of the marks. The marks for each separate forest property are usually numbered from north to west and by south to east, and on property boundary marks the initial letter of the owner's name may be added. Every enclosure in a forest belonging to another owner than that of the forest should be surrounded by similarly numbered boundary marks.

In case of any addition to a forest involving fresh boundary marks being interposed between two formerly existing marks, letters $\mathrm{A}, \mathrm{B}$, etc., may be added to the earlier number to denote their position.

Fig. 6 shows the usual mode of representing a line of boundary marks, on a map.

The nature of the boundary will differ according as the adjoining estate is woodland, or cleared for agriculture. In the 
former case, a strip of a certain breadth inside the boundary may have to be kept clear of forest growth. The choice of the kind of boundary mark depends on circumstances, but stone or masonry pillars are generally to be preferred. In cases where a rapid demarcation is necessary, and cut stones or even bricks are not easily procurable, as in certain districts in India, conical mounds of earth or of stones, with posts in the centre, are sometimes used, at any

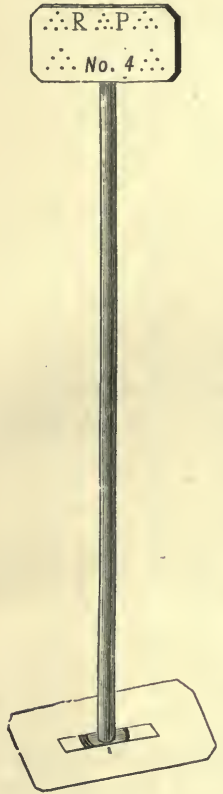

Fig. 7. rate until more permanent marks can be supplied.

In constructing such mounds, the post, made of heartwood only and of the most durable timber available, is first planted in the soil, the portion in the ground having been charred, or the whole post creosoted or tarred so as to ensure greater durability. Round the post two circles are then traced in the ground, and earth to be heaped up must be dug from beyond the outer circle and placed within the inner one. Otherwise the heap would soon settle down into the trench. The mounds may be made of stones

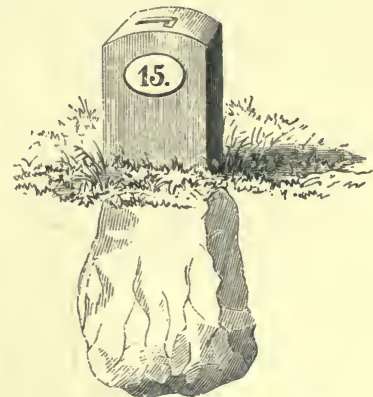

Fig. 8.-Boundary stone.

if available. The slope of the mounds will correspond with the natural angle of repose for the class of material employed, and their height should be about four feet. Earthen mounds should be carefully protected by placing sods on their surface. Wooden posts without mounds may also be used as boundary marks, but they are then more liable to be thrown down by cattle, or wild animals, or to be removed. In either case the posts should bear current numbers, a very durable form being a cast-iron plate, in which the number is embossed or the numbers may be painted on the posts. 
Hess gives a useful kind of iron boundary mark as shown in Fig. 7. The lower and upper plates can be removed to facilitate transport. Stones are heaped on the lower plate after it has been put into the ground to the required depth.

The best of all boundary marks are generally hewn stones (Fig. 8), or masonry pillars. The former may be prismatic, triangular, or rectangular in section, with a rounded top on which lines are cut showing the directions of the two adjacent pillars. Serial numbers should be cut on one of the faces of pillar. The lower portion to be placed in the ground should be left rough and be of larger bulk than the cut portion, so as to ensure stability.

Care should be taken to select durable material such as granite, basalt or quartzite for these stones.

Where hewn stones are not available, pillars of brick and mortar or rubble masonry may be erected, a sufficient foundation being of course provided. The current number is carved on a small flat piece of stone or slate inserted in the sloping top of the pillar. This is greatly preferable to inserting the number on a prismatic piece of stone let into the apex of the pillar, as is sometimes done. Such pieces are easily loosened by boys engaged in tending cattle or sheep near the forest boundary. These pillars should be formed of cubes with a side of $2 \frac{1}{2}$ to 3 feet, surmounted by a pyramid 6 to 9 inches high.

It is customary in India to bury a quantity of charcoal under boundary pillars, so as to assist detection of any fraudulent change in their position.

In all lines of boundary marks, one mark should be placed at each angle, and whenever two angular points of the boundary are too distant to be seen from one another, a sufficient number of intermediate pillars should be erected. The intermediate pillars need not be so substantial as the corner pillars.

If the boundary is merely a line, the pillars are placed along its centre, but if pillars are placed along a road, the middle of which forms the boundary, they sbould be alternately on either side of it.

After boundary lines have been laid out, their exact position 
may be more clearly defined by rows of trees, hedges, fences, walls, forest rides, or ditches.

Rows of trees are injurious to neighbouring fields by their shade and the spread of their roots. Hedges are difficult to keep in order, and rarely answer their purpose in keeping out cattle along a lengthy forest boundary. Fences are expensive, but their use is sometimes unavoidable where browsing by game or grazing is to be feared. Details regarding fences are given in Schlich's Sylviculture, Vol. II., 3rd edition, page 122.

Walls may be erected when stones can be collected on the spot, or where, on account of the sloping nature of the ground,

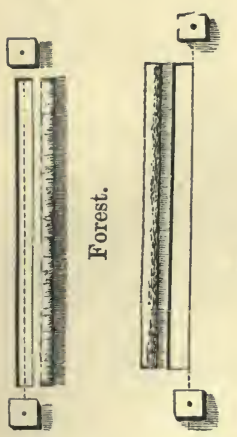

Fig. 9.

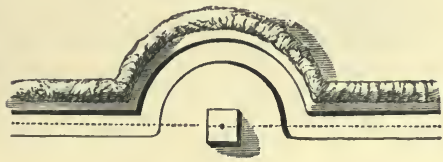

Fig. 10.-Boundary-ditches.

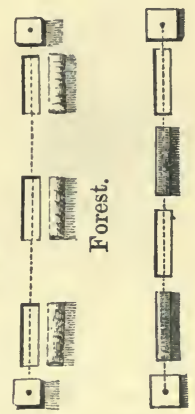

Fig. 11. Fig. 12.

ditches are not practicable. Such walls should be 1 yard broad at the base and from a height of 18 inches should gradually taper off to the top. The stones should be placed with the thick end outside.

Forest boundary rides as well as boundary marks are necessary where two forests adjoin. Unless the ride is also to be used as a road, a breadth of 4 to 8 feet will suffice, 16 feet being the least admissible breadth for a road, so that two carts may pass one another. Along boundary rides it may be advisable to dig out all stumps in order to prevent the growth of coppiceshoots, and the ground may be roughly levelled and drained, and even narrow bridges erected, so as to convert the ride into a bridle-path to facilitate inspection.

Boundary ditches (Figs. 9 to 12) give a clearly cut line and prevent encroachment by ploughing or grazing when the forest 
boundary runs along a field or meadow. Such ditches can usually be dug except on very stony or steep ground ; they run either along the entire boundary line from point to point, or
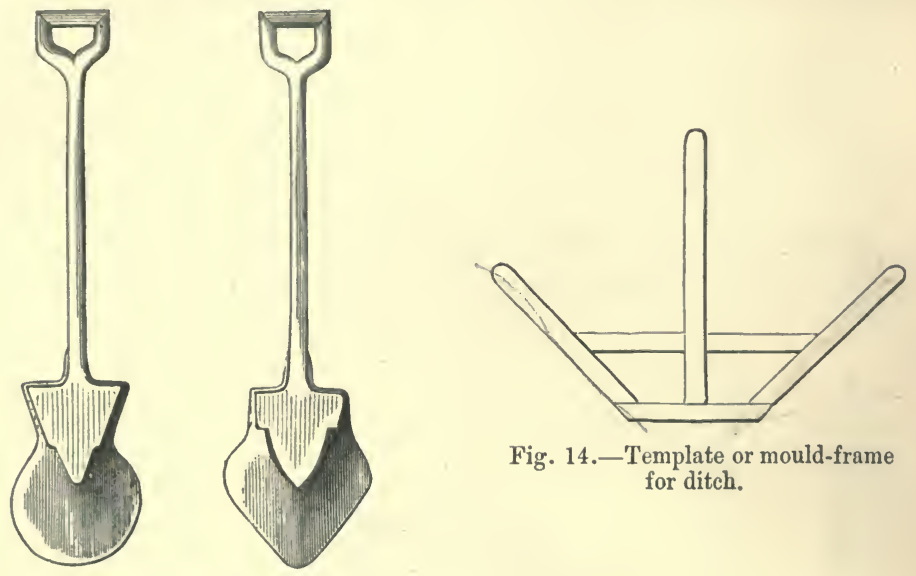

Fig. 14.-Template or mould-frame for ditch.

Fig. 13.-Ditching-

spades.

are intermittent. In either case they should stop a few feet from the boundary marks.

The earth dug out of the ditches should be placed on the forest side of the ditch and a few feet from it (Fig. 9), or in
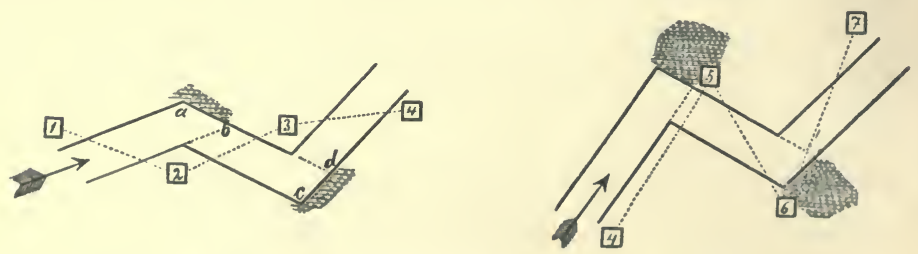

Figs. 15 and 16.-Boundary-ditch serving as a drain.

the case of intermittent ditches it may be placed between them as shown in Fig. 12.

Intermittent ditches (Figs. 11 and 12) are usual on sloping ground to prevent the formation of ravines.

The section of the ditches depends on the nature of the soil, but is generally $2-2 \frac{1}{2}$ feet wide at the top and $8-10$ inches 
at the bottom and the same depth. The boundary line may be the centre of the ditch, or one of its sides; in the latter case the ditch belongs to the proprietor on whose land the earth from it is thrown, which is generally towards the forest. Special kinds of spades are used for ditching, as shown in Fig. 13.

A wooden model of the ditch-profile is also useful (Fig. 14), and is termed template or mould-frame.

In case the ditches are also used as drains, care must be taken not to allow the boundary marks to be undermined. Thus the arrangement shown in Fig. 15 should be followed to protect the boundary marks from erosion, and not that shown in Fig. 16.

\section{Survey of Boundaries.}

The best survey is that carried out by the theodolite and a chain, or measuring staff, but for preliminary work a less accurate instrument, such as the plane-table or prismatic compass, will suffice. From the survey a boundary map should be drawn up, the usual scale of such maps being 40 or 50 inches to the mile in Germany. No larger scale than 25 inches to the mile is usual for British woodlands.

These maps should show:-

All boundary marks with their numbers.

The course of the boundary lines.

The names of adjoining properties, and the nature of their cultivation, or otherwise.

\section{Description of Boundaries.}

This should be prepared in a tabular form, and should show : Name of forest and of proprietor.

Names of adjoining estates and of their proprietors. Current number and nature of boundary marks. Angle at each corner in degrees, minutes and seconds. Distance from one mark to the next, both horizontally and along the surface of the ground.

Direction of boundary line from mark to mark, with reference either to that of the magnetic needle or true north. 
Other remarks worth recording should be added, such as crossing-points of streams, roads and rights-of-way, or reference to any permanent objects near the line, such as trigonometrical pillars, etc.

\section{Legalisation of Boundaries.}

It is desirable to cause the boundary map and description to be recognised by the proper State authority, according to the law in force. The original documents should be deposited in the State Registry Office and certificated copies given to the owners of the two adjoining estates.

\section{Upkeep of Boundaries.}

Forest boundary lines and marks are liable to various injuries by men and animals, and by the weather. When once laid down they must be maintained in good order; the following measures being specially necessary:-

(a) Periodic clearing of the boundary line, so that one mark may be visible from the next. In case the boundary line be a road, bridle-path or ditch, repairs to these become necessary from time to time. Any vegetation that is removed should be shared between the adjacent owners.

(b) Periodic inspection of the lines by the forest officials, to whose charge definite lengths of boundary should be allotted, according to their rank, and each official should from time to time submit reports to his superiors on the condition of the boundaries.

(c) Wherever woodlands border on agricultural land, the trees must not overshade the latter with their foliage, nor their roots grow into the fields. Drip from the branches should not go beyond the actual boundary line, and a space should be kept free from woody growth, the actual breadth of which varies according to local law. As a rule, the neighbour can lop an overhanging tree only if the owner of the woodland has neglected to do so; the loppings belong to the latter. Intrusive roots may usually be cut by the neighbour. Lawbooks should be consulted on this question. 
(d) Immediate repair of all defects in the marks, repainting fading numbers, etc., before any point becomes doubtful. Marks which may have been removed can be replaced only with the consent of both owners or by order of a Court of Law. Any uncertainty about the position of forest boundary marks, that are also boundary marks of adjoining States, gives rise to much difficulty.

(e) Immediate report of all tampering with established boundaries and prosecution of the offenders.

\section{Cost.}

The cost of erecting and maintaining forest boundaries should be divided between the adjacent owners, unless there is any legal provision to the contrary.

These costs vary so much according to circumstances, that it is difficult to lay down any general estimates; the following figures may be considered approximate. One man can erect in one day an earth boundary mound 4 to 5 feet in diameter and 3 to 4 feet high, and can sod about 3 to 6 such mounds, and repair from 6 to 9 of them.

Hewn limestone boundary stones cost 2 to 3 shillings each, and 20 such stones can be carted by two horses. Iron boundary posts cost from $1 s .6 d$. to $2 s$. $6 d$. each.

In loam, a man can dig in one day 30 to 40 yards of boundary trench, 10 inches wide at the base, and of the same depth. In light soils, the labour is from 10 to 15 per cent. heavier.

Boundary works are generally done by contract, and on the continent of Europe repairs to forest ditches are frequently executed by petty offenders in lieu of fines.

\section{Improvement of Boundaries.}

Advantage should be taken of every opportunity to consolidate forest property and thereby to improve its boundaries. This can be done by purchase, disposal or exchange of land, so as to cut off inconvenient corners or narrow strips, to alienate detached pieces, or to acquire enclosures belonging to other proprietors. 
Some of the advantages of consolidation are:-

(a) Greater facility for keeping the boundary line in order, and at a reduced cost.

(b) Saving in protection expenses, in work of staff, and less liability to cases of misappropriation and damage by outsiders, especially in the case of danger from fire.

(c) Increase in the productiveness of the forest. Fewer roads are required; damage is reduced, whether it is caused to the forest by frost, storms, etc., or to adjoining farm-land, by overhanging trees or by game sheltering in the forest. Small private estates enclosed in a forest frequently encourage poaching, or unfair destruction of game.

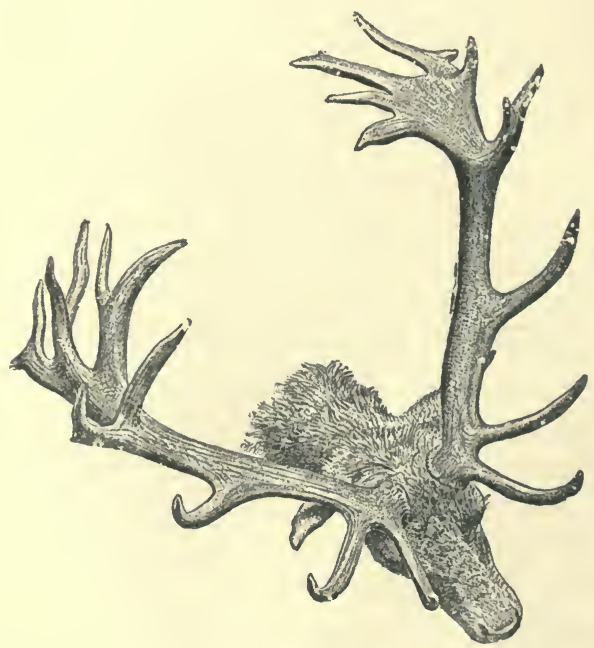

Fig. 17. - Head of Stoke Jark Red Deer from Mr. Rowland Ward's "Records of . Big Game." 


\section{CHAPTER II.}

\section{PROTECTION OF THE FOREST AGAINST IRREGU- LARITIES IN THE UTILISATION OF FOREST PRODUCE.}

\section{Section I.-Principal Produce.}

1. General Account of Damage done.

THE standing-crop or soil of a forest may be endangered during fellings and in the conversion and transport of timber in the following ways:-By overfelling, bad felling, careless conversion or bad stacking of timber and firewood, and careless transport.

The methods for fixing the annual yield of a forest are explained under Forest Management, and how timber should be felled and converted, under Forest Utilisation; here, only the preventive measures necessary to obviate irregularities will be considered.

Irregularities of wood-cutters, cartmen, etc., may be dealt with, either by regulations made by the forest owner, or by the forest laws of the country.

In a general way, it should be noted that some damage must be done during fellings, conversion and transport, and it is only by experience that a forester learns how much damage is unavoidable. Too stringent conditions should not be enforced on woodcutters or timber purchasers.

\section{Overfelling.}

All forest operations must be carefully watched, and their results recorded, so that only the fixed yield prescribed by the working-plan is cut annually. At the same time, at least in private forests, it may be advisable to cut more than the fixed yield in seasons when the price of timber is exceptionally high, and reduce the fellings when it is low. 
In order to keep within the limits of the fixed annual yield, trees to be felled should be properly marked in accordance with administrative rules, and after the fellings, the stumps of felled trees should be examined and counted in order to detect possible irregularities. In some cases, as in Coppice-withStandards, the trees to be reserved are marked instead of those to be felled. The practice in France of marking such trees by cutting off a portion of the bark and stamping on them with a steel hammer may give rise to attacks of fungi and defects in the wood at the base of the tree.

In the case of large felling-areas, it may be necessary to employ an extra forest guard, in addition to the guard of the beat, to supervise the woodmen, and when trees are sold standing, the purchaser may be allowed to appoint a special guard with temporary police powers and a badge of office. This necessity for special supervision applies to all the succeeding sections, referring both to the removal of principal and minor produce.

\section{Bad Felling.}

Measures for the prevention of mischief are :-

(a) Employment of competent and trustworthy woodcutters, and careful instruction in, and supervision of, their work. It is generally advisable to employ the same men year after year, and withdraw from the gang all those who fell badly, also to encourage the best men by instruction and higher wages. The best available implements should be used.

(b) Only such trees should be felled, as are so designated by the manager of the forest. Should any other tree be accidentally thrown, owing to a falling tree coming against it, a neighbouring tree of similar dimensions and species should be left to replace it.

(c) Trees should be uprooted, whenever this is possible, and felling so conducted as to facilitate the transport of the timber.

(d) Cessation of the work during unfavourable seasons or weather ; for instance, when the trees are in sap, except where bark is being harvested; during absence of snow on the ground to break the fall of the trees and spare natural regeneration; 
during seasons of hard frost, when the stems may be broken, or during strong winds, when the direction of the fall of the trees is uncertain. In northern India, fellings are frequently stopped during the hot dry months of May and June, from fear of forest fires which may be caused by the workmen.

(e) Avoidance of damage to seedbearing trees in regeneration fellings, and to standards.

( $f$ ) Throwing trees on to bare spots and not amongst young growth.

(g) Removal of branches and crowns of trees before felling, to prevent the trees from crushing valuable undergrowth.

(h) Preservation of young growth during the removal of stumps, and putting earth into holes thus caused to prevent their being filled with water.

(i) Careful felling of coppice with sharp instruments and with a clean and sloping cut.

( $j$ ) Leaving stools on steep slopes where erosion is to be feared, and also on shifting sands.

(k) Avoidance of throwing felled trees on to rocks, stones or other stems; felling uphill or sideways so that there may be a minimum of breakage.

(l) Tropical woody climbers should be cut two years before a felling is to take place, as otherwise they bind trees together, and the fall of any tree may involve that of a group of surrounding ones. The softwooded climbers rot in about two years' time.

$(m)$ Trees are sometimes, as in the case of teak in Burma, girdled two or three years before being felled, so that the wood may dry and lose weight, and become floatable. Care must be taken that this is not done to trees liable after girdling to be bored by insects.

\section{Careless Conversion.}

Here may be mentioned:-

(a) Quick conversion and removal of felled trees, especially in the case of natural regeneration and of coppice; protection of young growth in both cases.

(b) Use of the saw instead of the axe in order to prevent waste.

(c) Quick removal of bark to prevent insect-attacks. 
(d) Repairs of any damage done to young plants, which, if of broadleaved species, may, when injured, be cut back close to the ground so as to get a strong regrowth. Otherwise, replanting must be effected with strong transplants after the felling-area has been cleared.

\section{Bad Stacking of Timber and Firewood.}

Employ specially trained men for stacking firewood, as ordinary woodcutters generally stack loosely.

Stacking should be done on blanks, or along the edges of felling-areas, on roadsides, etc. The stacks should not lean against trees.

Withes for binding faggots should be cut from suppressed stems, or taken from cleanings or special plantations.

\section{Careless Transport of Timber and Firewood.}

Attend to the timely construction and repairs of the necessary roads, slides, etc., which should be ready when the fellings commence. This is specially requisite in mountain forests.

Remove material from the felling-area at favourable seasons, when snow is on the ground; not in hard frosts, nor when the trees are in sap and the bark of standing trees is easily abraded by the wheels of the carts, etc.

Avoid damaging methods, such as rolling, etc., among young growth. Use the best methods of transport: slides, tramways, etc. Make good roads.

Fix a period during which the material must be removed, say from November of one year to the end of winter in the next, so that the ground may be cleared in time for the springgrowth of the second year. At the end of this period, all injured broadleaved plants should be cut back, blanks planted up, and all ruts on temporary cart-tracks filled in.

Certain rules should be made for the protection of roads and other means of transport. For instance, new roads should not be used until the earth has settled, and they have, if possible, been macadamised. Notices closing roads under construction or repair should be posted up, and bars put 
across such roads. Dragging along ordinary roads should be disallowed.

All transport should be carefully supervised, if necessary, by extra forest guards.

\section{Section II.-Irregularities in utilising Minor Forest} Produce.

1. General Account of Damage done.

Whenever the minor produce is less important than the principal produce of a forest, it should be harvested in such a way as not to endanger or diminish the supply of the latter. The following are the chief items of minor forest produce :Bark, turpentine, resin and gums, leaves, fruits of forest trees, dead branch-wood, grass and herbage, litter, stones, gravel, sand and earth, peat, forest cultivation of cereals, berries, edible fungi, game, fish, wild honey and wax, etc., etc.

\section{Bark.}

Bark is chiefly used for tanning, or for dyes, but the bark of certain species, such as the paper-mulberry (Broussonetia papyrifera), may be made into paper-pulp, or, as in the case of Betula Bhojpatra in India, into hats and umbrellas. The inner bark of the lime and of many tropical trees is used for rope-making or mats.

In the case of oak-bark used for tanning, the following rules should be observed :

(a) Secure a clean and slanting cut of the stems in order to protect the stools against moisture, and produce good coppice shoots.

(b) Prevent any tearing of bark from the stool, by making a clean cut round the shoot near the ground before the bark is peeled from standing poles.

(c) Avoid beating the bark in peeling, as this causes loss of tannin.

(d) Remove peeled stems expeditiously, so that the new shoots may harden before early frosts occur.

(e) Carefully stack and quickly dry the bark, so as to avoid 
loss of tannin by rain, and ensure rapid clearance of the felling-area.

Wherever bark is used for any of the other purposes above referred to, similar rules, modified for the species in question, should be observed.

\section{Turpentine, Resin and Gums.}

The present chief sources of the supply of turpentine and resin are the pitch pine (P. palustris, Mill.) and other pine-trees in the Southern States of North America, and the cluster pine (Pinus Pinaster, Aitm.) forests in the west of France. Tappings for turpentine and resin on a moderate scale have, however, been started in the forests of the long-needled pine of the Himalayas (P. longifolia, Roxb.). Some turpentine is still obtained from the spruce in Germany and the north of Europe, but as this tree only yields it in small quantities and the process of tapping it is extremely injurious to spruce timber, its tapping should be absolutely prohibited.

The following remarks, therefore, apply only to species of pine which yield turpentine abundantly, and to the extraction of gums and caoutchouc from several species of trees in hot countriẹs.

(a) Lessees of turpentine or gum should be held pecuniarily responsible for all damage done in forests by their workmen.

(b) Tapping should generally be confined either to trees like the Ficus elastica, Blume., that are hardly of any value except for the gum they yield, or to trees too remote from means of transport for their timber to be of any marketable value as compared with the value of the turpentine or gum which may be extracted from them. In other cases, it should be confined to trees which will be felled for timber within a period of from ten to twenty years, as when young trees are tapped no considerable increment of growth may be expected. For the same reason the best shaped and most promising trees should not be tapped.

In seeding-fellings, a certain number of the seed-bearers should remain untapped, as tapping is prejudicial to both the quantity and quality of the seed. In the cluster pine forests of the Landes, in France, regeneration is effected by seed 
from untapped woods adjoining the felling-area on which all trees are tapped.

(c) Pules regarding the size and number of cuts and the depth of cut to be made in each tree will vary with the species, and are given in detail in Vol. V. on Forest Utilisation. In tapping pines for resin, there should not be more than two points of attack, unless it is intended to kill the tree, when as many as six may be opened. There should be from 8 to 12 inches between each cut, and the cuts should not be more than 2 inches broad and in one year only about 3 feet long.

(d) Tapping must be intermittent, so as to allow recovery of the trees before a fresh tapping is allowed, unless it is intended to tap the tree to death before felling it. The interval between successive tappings will of course vary with the species in question. In Europe, all tapping should cease with the first early frost in August or September, and not be resumed till the spring.

(e) Tapping should rarely be attempted on poor soils.

\section{Leares and Branches of Forest Trees.}

Leaves of forest trees are used for fodder, manure, thatching, tanning, dyes, etc. Leaf-fodder is extensively used for cattle in countries where sufficient grass is not available, as in the centre and south of France, where hedge-row oaks are annually pollarded for this purpose. A similar practice prevails in the Himalayan districts of India during winter, evergreen oaks, elms and species of Celtis, Prunus, etc., being thus utilised. During the season of rest, leaves of evergreen trees are rich in reserve nutrient material, and afford valuable fodder. In seasons of drought in Central and Western Europe, as in 1893, leaf-fodder from hornbeam and other deciduous trees is álso extensively used instead of grass.

In the north of India, camels, buffaloes and elephants are chiefly fed on branches and leaves of trees during the cold and dry seasons. Oaks and other forest trees were formerly extensively pollarded in European deer-forests to afford fodder for the deer, which ate the bark of these branches when the ground was covered with snow. 
Wherever the use of leaf-fodder prevails, the important points are: to allow trees to be lopped only after the principal growth of the year is over; to restrict lopping, as much as possible, to inferior species of little or no value as timber trees, and to prevent the lopping of trees until they have attained a certain size. Wherever the restriction is practicable, only side-shoots should be lopped and the leaders spared, and the trees lopped only every third year. In timber forests, lopping should, if possible, be restricted to compartments which will shortly be cut over.

Where the demands for leaf-fodder are large and cannot otherwise be met, a regular system of pollarding should be introduced, with a fixed rotation, the length of which will be decided by local experience.

In India and other hot countries, the foliage of woody climbers may be used for leaf-fodder to the actual benefit of the forests. In certain parts of India, green branches and leaves of trees are used to manure the rice-fields, under the term of $r a b$; this subject will be referred to again under the heading Forest Servitudes. In hot countries, leaves of various forest species are used for tanning, dyes, drugs, hat- and umbrella-making, plates, and for feeding silkworms. The last is a very important and valuable industry, and the trees utilised are generally of much less value for timber than for their leaves, and therefore rules should be made which will afford the greatest possible quantity of leaves at the time required, and in a way most easily accessible to the silk producers. Thus pure coppice is adopted with very short rotations, even of one year in the case of the mulberry in Bengal. As regards the other demands for leaves, forest officers would do well not to be pedantic in stopping industries dependent on their forests which can be supplied without serious injury to the trees by the exercise of a little ingenuity and suitable control.

\section{Fruits of Forest Trees.}

Fruits of forest trees are collected for sowing; for the food of men or animals; for extracting oil, dyes, tannin, etc.: or 
they may be eaten on the ground in the forest by swine (pannage), or by deer. The rules for the protection of the forest are as follows :-

\section{A. Collection by Hand.}

Where regeneration by seed is expected, or where swine or deer are to be fed in a forest, fruits should not be collected for other purposes. Acorns when eaten in large quantities are poisonous to young cattle. Beasts over three years old are seldom thus affected. Hence, the collection of acorns in forests open to pasture is most beneficial, and they may be used advantageously for feeding domestic pigs.

Forest guards must watch most assiduously during the fruit-collecting season.

All injuries to the trees during the collection of the seed must be strictly forbidden. These are: beating trees with axes; dragging down fruit-laden branches; use of climbingirons, etc. The bad effects of the latter on the quality of the wood may be seen from Fig. 18, each wound made by the iron introducing decay into the timber. Smooth-barked species such as beech and Weymouth pine suffer most in this way; so does the sweet chestnut.

The work must be stopped during frost, when the branches are easily broken.

\section{B. Pannage.}

Pannage, or the feeding of swine on the mast of a forest, consisting of fallen acorns, beech-nuts, chestnuts, etc., was formerly a very important industry, but is now becoming less frequent in the forests of Europe. It still prevails in the New Forest, where about 5,000 pigs are turned into the woods in good mast-years, from the 14th Sept. to the 8th Nov.

Swine damage forests in the following ways:-

(a) Eating-up mast in seeding-fellings.

(b) Uprooting young plants, breaking off weak stems, abrading the bark off poles, and exposing and gnawing roots of valuable forest species. All these injuries are chiefly felt in natural regeneration-fellings, and in thinnings in young woods, on loose sandy or shallow soils, on steep slopes, etc. 
Swine are useful to forests in the preparation of the soil for seed, by removing the covering of dead leaves and exposing the mineral soil, and by burying acorns and other fruits; also by trampling dead leaves into the soil, which is of importance in places exposed to winds, and by destroying mice and certain insects hibernating or moving in the soil-covering.

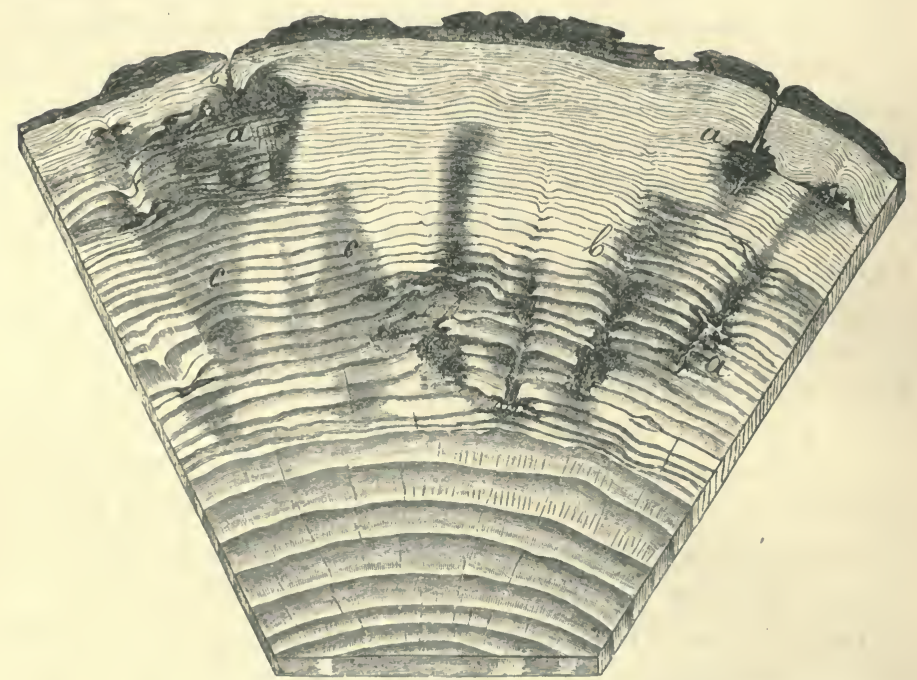

Fig. 18.-Section of a Scots pine injured by climbing-irons.

(a) Points of injury.

(b) Concave annual rings of wood occluding wounds.

(c) Brown-coloured wood below the wounds, showing consequent decay.

The protective rules for pannage are:-

(a) Exclusion from the following places: Seeding-fellings, except when seed is very abundant; dry loose soils in the case of swine driven in to feed exclusively on fungi, worms, insects, etc.; places where the mast is reserved for deer or wild pigs.

(b) Compartments opened for pannage should as nearly as possible adjoin one another, so that the swine may not wander uselessly through the forest. They should not be allowed to remain long in compartments without mast, as they then proceed to bark the trees. 
(c) The place where the swine pass the night should be carefully selected. In such places scarcely a root escapes injury.

(d) The number of swine to be allowed in a forest must depend on the quantity of mast available. Each full-grown animal requires from two-and-a-half to seven-and-a-half acres of forest.

(e) Limitation of pannage to the period of the year from the middle of October till the end of January. It should not commence till sufficient mast has fallen, as otherwise the swine become thin from much wandering about, are not easily kept together, and do much mischief. On the other hand, it must cease when the mast is no longer sufficiently plentiful, and it is in the spring that the greatest damage is done by peeling the bark and roots. During the aftermast, after Christmas, the acorns become more digestible, and are specially suitable for breeding-animals.

$(f)$ The admission of swine into a forest should be granted only on condition that they are perfectly healthy, and guarded by trustworthy swineherds; two hundred swine for each man, and an assistant for every hundred additional swine.

(g) The owners of the swine should be made collectively responsible for all damage which may be done to the forest. In Epping Forest all swine admitted to pannage are ringed.

\section{Grass and Herbage.}

Grass and herbage, dry ferns, heather, etc., may either be cut and removed from the forest and used for fodder or litter for cattle, or, with the exception of the ferns, may be utilised on the spot as pasture by grazing animals.

\section{A. Grass-cutting.}

Grass and herbage may be cut for fodder, or to form thatching material, paper-pulp, etc. Dead ferns, especially bracken, are largely used for litter, and heather for litter or thatching. 
The protective rules are:-

(1) Limitation to persons who have obtained a formal permit from the forest manager, and, as a general rule, on certain fixed days, when the forest guards can supervise the cutting.

When a number of people are together cutting herbage in the forest, they should be held collectively responsible for any damage which may be done.

(2) Restriction of cutting to places with a moist fertile soil, which can bear the removal of the mineral constituents of the grass, etc. In such places, planting in lines between which grass can easily be cut is more suitable than natural regeneration. In some cases, heather and broom protect young plants from frost and insolation and should be left intact. High grass, on the contrary, as will be seen further on, greatly increases radiation, the intensity of frost and the drying-up of the soil by the sun, so that it is frequently more advantageous to have it removed. Its removal also furnishes additional security against forest fires.

(3) The use of scythes should not be permitted amongst young growth, where grass should be cut with sickles or pulled up by hand. In India, a flat cutting-instrument called a khurpa is frequently used by grass-cutters to scrape out the rhizomes of the grass, which are highly nutritious; this practice should not be allowed in forests. Scythes may be used in older plantations, but on the condition of leaving a narrow zone of grass round each plant. On rides, extensive blanks, road-sides, etc., there need be no restriction as regards the instruments used for grass-cutting.

(4) In hot countries, grass which springs up after forests have been burned furnishes better thatch or paper-material than when cut from unburned forest containing much dead and decayed grass, dead leaves, etc. Hence, in forests under fire protection, grass can be used with advantage only from off roads, fire-traces or blanks which are cut every year.

(5) Grass-cutting must be carefully supervised by forestguards, and offenders against the rules reported and punished. 


\section{B. Forest Pasture.*}

\section{(1) General Account.}

Forest pasture, except in mountainous districts, where the area of cultivable land is very limited, is no longer so important as was formerly the case; cultivators object to their cattle becoming thin and wiry in roaming about the forests, to their cows yielding less milk than when kept at home, to the loss of valuable manure, and to the increased danger from disease.

In backward countries, however, forest pasture is still prevalent, and it is therefore necessary to draw up rules for its exercise with the least possible amount of injury to forests, as, when unrestricted, it is incompatible with the existence of forests. To a certain extent, however, some good may be done to forests by cattle, by keeping down a rank growth of grass and herbage, which interferes with reproduction, and by breaking through and scattering the dense layer of needles in coniferous forests, and thus exposing the mineral soil for the rooting of seedlings. Browsing on advance-growth of subsidiary species or softwoods, which it is desirable to keep in check in favour of more valuable species, may also be sometimes useful. $\dagger$

The damage done to forests by the grazing and browsing of domestic animals extends to the soil, especially on slopes, and standing-crop; to the roads and other means of communication, and the boundaries, ditches, fences, etc.

The soil of a forest suffers chemically, becoming impoverished in potash, phosphorus, and nitrogen by the removal of the grass; and physically, becoming hardened owing to the tread of the grazing animals, and the consequent insufficient aeration of the humus in process of formation. The dung left by the animals on the ground is a quite inadequate compensation for the reduction in fertility of the soil consequent on their admission to the forest. The woods are injured in

* Hundeshagen, J. C., "Die Waldweide u. Waldstreu." Tübingen, 1830.

† In "Forest Utilisation," p. 137, Fernandez states that goats are useful to regeneration in mature Acacia arabica (babul) forests. When the pods are falling, the seeds swallowed by the goats and excreted germinate without delay, whilst other seeds require at least a whole year to sprout, during which they are exposed to destruction, chiefly by insects. 
the following ways: by the animals browsing on young plants ; biting-off buds, leaves, and shoots; breaking-off coppice-shoots and gnawing the bark of trees; trampling on, bending down and breaking young growth; exposing and destroying roots, etc. The damage done by biting the plants is twofold; they lose organs that are necessary for their nourishment, while the normal development of their stems and branches is prevented. Both forms of injury occur chiefly in their youth, until their leading shoots have grown beyond the reach of the animals.

Roads, ditches, slopes, hedges, and fences, are especially liable to injury by grazing animals.

The extent of the damage done by grazing depends on a number of factors. Among the chief of these are :-Species of tree, age of tree; system of management, nature of locality, density of crop, species of grazing animal, number of animals, season of the year, state of the weather. The amount of damage varies greatly according to circumstances. Hundeshagen* estimates the ordinary loss of increment due to cattlegrazing at one-tenth. In Carinthia it has been observed that goats in 15- to 35-years-old spruce, Scotch pines and hornbeams prevent almost any growth from taking place.

(2) According to Species of Tree.

Broadleaved species are more exposed than conifers, but recover more readily from browsing than the latter. Most exposed to damage are : ash, maples, hornbeam, beech. Next to them: lime, sallow, and poplars. Less still: oaks, elms, Pyrus sp. Least of all : birch, alder, horse-chestuut and robinia.

Of conifers, the silver-fir suffers most, then larch, the different species of pine and the spruce. If the spruce appears to suffer more than pines, this is due to its abundance in mountain regions, where there is most forest pasture.

The above scale is drawn up chiefly as regards horned cattle, but if we consider the preferences shown by other

" "Encyclopädie der Forstwissenschaft." I. Forstliche Productionslehre, 3 Aufl. Tübingen, 1835, p. 512. 
grazing animals, it should be noted, that:-horses prefer oakfoliage and avoid that of the lime; sheep appear to prefer light-demanding species, even the birch and Scots pine; young lambs, the leaves of robinia; goats are not particular, and even browse on the poisonous yew without injury, in India, however, they succumb to the foliage of Rhododendron campanulatum.

Another peculiarity of horned cattle is to prefer plants introduced into pure woods, such as ash or hornbeam in beech forests, or exotics planted among native woods.

The vegetable monstrosities resulting from browsing are very striking to the eye; rounded bushes, which sometimes broaden out till some leading shoots in their centre escape and grow into trees, are frequent eyesores wherever forest pasture is practised.

Shallow-rooted plants such as the spruce, in spring, suffer most from the tread of the animals.

(3) Age of Trees.

Young plants suffer most. In older woods, without undergrowth, the chief injury is done by the hardening of the soil owing to the tread of the animals. The trees suffer from browsing until the foliage is beyond the reach of the animals, and the age at which this happens depends on the rate of growth, the conditions of the locality and the kind of animal.

\section{(4) System of Management.}

In the case of the Selection system, grazing is most dangerous; then come in descending order of danger: Group system, Coppice-with-Standards, Coppice, Shelterwood Compartment and Clear-cutting systems. Pollarding is the most favourable system to adopt on land open to grazing, as young pollardshoots are out of the reach of the cattle; pollards are regenerated by planting taller transplants, or cuttings, than in other systems, and the plants should at first be securely fenced against cattle, which might injure them by rubbing against them, or gnawing their bark. The uneven-aged systems of High Forest, such as the Selection and Group 
systems, suffer most of all, as in the former, young growth is scattered all over the forest, and in the latter, it is scattered in patches over very large areas. If grazing be allowed under the Selection system, regeneration can usually be effected only by fencing-in patches of ground where large trees have been felled, and planting them with strong transplants, which will be out of the reach of the cattle by the time the fences are no longer effectual.

Coppice-with-standards suffers more than pure coppice, on account of the necessity for preserving numerous seedling plants, both natural and transplanted, to replace the standards as they are felled. Coppice suffers more than even-aged High Forest, because stool-shoots branch out lower, and are less firmly rooted than High Forest poles; in the even-aged systems of High Forest all pole-woods can be opened to cattle without much danger. - In regular plantations, damage done by grazing is less than in irregular artificial, or natural reproduction, and planting in lines somewhat far apart in one direction is most favourable, as the cattle can readily graze between the rows. It has also been observed in grazed forests in hill-tracts, that mound-planting gives better results than pit-planting.

Gayer holds an opinion differing from that of Hess regarding the comparative immunity of Selection Forest and even-aged High Forest from grazing. He maintains, that even-aged densely stocked woods are destitute of herbage, which is found only on the reproduction areas closed against cattle. It is a matter of everyday experience that no amount of care in fencing will always protect such areas. In a Selection Forest, not only is far more fodder produced, but damage by cattle is less concentrated than in even-aged woods.*

\section{(5) Locality.}

On moist and fertile soil, the damage done by grazing is minimised, because a strong growth of herbage generally springs up on such localities, and the cattle have less inclination to attack woody growth; moreover the trees grow faster, 
and are sooner out of their reach. Binding or heavy soil becomes all the more compact by the tread of the animals, and less susceptible to the entrance of air and water, and the roots lying immediately below the soil-covering are exposed to damage. Very loose soil becomes still looser from the tread of cattle, as they destroy the herbage which binds the soil together. The greatest damage by grazing animals is on shifting sands.

On level ground, damage is less than among hills, where it is increased if the soil be loose, or the slopes steep ; very wet slopes are also endangered by the sliding of the feet of the cattle. The steeper a slope, up to a certain point, the more erosion is caused; larger plants are also reached by cattle from above, on slopes, than on level ground, and the damage by browsing, bending and breaking is greater.

Scantily wooded, dry, hot aspects are obviously unsuited for grazing.

(6) Density of Foreign Growth.

In dense woods, little or no grass is to be found, so that more damage is done to woody growth than in more open forests, where herbage grows under the trees.

(7) Species of Grazing Animal.

Among European animals, goats show the greatest preference for woody plants, and their mode of feeding is most injurious. They even devour woody plants when there is plenty of herbage available, and beat down saplings with their forelegs till they can reach the leading shoots, on which they browse; they can thus reach plants 12 feet in height. They also peel the bark from stems in spring. Their constant movement on the steepest slopes is another great source of damage. To take some of many instances of the destruction of forests by goats:-In the Tyrol and Southern Switzerland, and in the Himalayas, fine forests have been completely destroyed by them, and in Ajmere and Merwara, whole hillsides where vegetation once flourished have been laid almost bare, with nothing left but deformed, thorny shrubs. In 
France, since 1665, goats have been excluded from all forests managed by the State Forest Department, and no legal right can be enforced to graze goats in private forests, as the grazing of these animals is considered incompatible with the maintenance of underwood.

The sheep is less. injurious than the goat, holding its head low, and preferring grass, but sheep browse freely on woody plants, and injure forest soil and the roots of shallow-rooted species by their short tread and sharp feet.

Horned cattle generally confine themselves to grass and herbage, and attack woody plants only in the absence or scarcity of the former. The buffalo in India is frequently fed during the cold season on loppings of evergreen or wintergreen trees. Cattle do much injury to forest soil, slopes, roads, and ditches owing to their weight and size, and also break down seedlings and saplings; these injuries are aggravated in the case of the buffalo, which is a heavier animal than common cattle. Oxen are more destructive than cows, and young beasts are worse than older ones, as they gnaw woody growth, partly out of pure mischief and partly to develop the formation of their teeth, and are much more active.

Horses can reach higher, and are fonder of leaf-fodder than cattle, and do much damage to roots by their tread. Foals occasionally peel the bark from trees. I have seen a clump of old beech trees in Cambridgeshire killed by the trampling of horses, which sheltered there in the heat of the day. The trees had originally been fenced, but when the fence had been broken the trees were soon killed.

Camels eat almost everything that grows within their reach, to a considerable height, and can feed readily on thorny species owing to their hard mouths. Much damage has been done to forest growth by camels in Northern and Central India and in Central Asia.

Elephants are fed chiefly by loppings from species of Ficus and other trees, as well as on grass and herbage, but the number of tame elephants admitted to a forest is limited, and their browsing can be easily controlled. Wild elephants are very destructive in bamboo forests, and also bark trees with their tusks. 
The relative damage done to forests by European grazing animals has been estimated as follows by Hundeshagen :-

\begin{tabular}{|c|c|}
\hline Horse's foal & \\
\hline Horse & • \\
\hline Young cattle & • \\
\hline Old cattle & • \\
\hline Goat . & \\
\hline Sheep & . \\
\hline
\end{tabular}

This list is drawn up on the understanding that the animals are freely grazing in forests where the crowns of the trees have grown beyond their reach. The fact that the goat is only estimated to do a quarter the damage of the horse does not controvert the former statement of its being relatively to its size the most harmful beast, for its weight is only about 1-14th of that of the horse.

\section{(8) Number of Cattle admitted to the Forest.}

The number of cattle admitted to graze in a forest must be regulated by the species and amount of herbage available; it should be so fixed that the latter is sufficient to nourish the cattle, or else they are certain to attack the trees.

Hundeshagen has calculated for the complete nourishment of large milch cattle for the whole summer, night and day, that 10 to $12 \frac{1}{2}$ acres of good pasture is required; for merely rrazing by day, $2 \frac{1}{2}-5$ acres, and he reckons 2 to 3 young cattle or 10 sheep as equivalent to one head of full-grown cattle. He estimates for their daily requirements, 18-20 lbs. of hay for a cow weighing four hundredweight, 10 to $12 \frac{1}{2} \mathrm{lbs}$. per head of young cattle, and $1 \frac{1}{2}-2 \mathrm{lbs}$. for a sheep. In Switzerland, one cow is usually reckoned to eat as much as seven sheep.

\section{(9) Season of the Year.}

In Europe the greatest amount of damage is done to forests by grazing in the spring, when the young leaves and shoots are most tempting and the herbage scanty. The strong appetite and restlessness of the beasts after the long winter stalling has also to be considered. The least damage is done 
in the autumn, but as the grass at that season is hard and unnutritious, forest-pasture is chiefly used when the herbage is best and most plentiful, from the end of May till the middle of July.

In the plains and lower hills of extra-tropical India, forest grazing is chiefly confined to the cold and dry seasons, but varies with localities.

In the Himalayas, grazing is carried on in the upper forests from 8,000 to 10,000 feet above sea-level, between May and September, the animals coming down in the cold season below the snow-level.

\section{(10) State of the Weather.}

During very dry or very wet weather, or in the morning, while heavy dew is on the ground, cattle prefer the leaves of trees to herbage. The damage done to the roots of trees by the tread of cattle is also greatest in wet weather.

\section{(11) Other Considerations.}

Milch cattle require the best grazing grounds, and those nearest to the villages; then come young cattle. Beasts of draught can go further and put up with inferior pasture. Sheep can be pastured in places that are more remote from the farmsteads than those used for cattle pasture.

Horned cattle and especially buffaloes like moist pastures, and the latter will eat very coarse herbage. Horses prefer short grass on old roads to that grown on loose forest soil. Sheep prefer even drier herbage, in elevated lands exposed to full light, such as heather-land, and are very liable to disease if fed on moister lands.

Horned cattle will not graze readily after sheep, and attack woody growth in preference to grass where sheep have been grazing.

Cattle accustomed from their youth to forest grazing do more damage than others which seldom come into the forest. Less damage is done when the herds are kept well together, and this is most difficult to secure in the case of goats and easiest with sheep.

When one considers all the various circumstances which 
affect the damage done by grazing, it is not surprising that practical foresters should differ greatly in their estimates of its amount in different cases. Whilst a forester having coppice-with-standards to deal with may consider the amount of damage done as very considerable, another in charge of spruce forest under the clear-cutting system may look upon it as quite trifling.

It is, however, clear from the experience of grazing in so many mountain forests in the Harz, Black Forest, etc., where thousands of head of cattle have grazed for centuries, and the forests are still flourishing, that well-regulated forest grazing may be admitted wherever its necessity for the welfare of the people is very pressing; a great resource in times of drought may also be secured to the people by opening portions of State and other forests for pasture at such seasons.

Under certain circumstances, where the ground under a seeding-felling is covered with tall herbage, or a dense mass of dead leaves and moss, temporary driving-in of cattle may prove useful, and also in the case of a plague of mice, or of insects, when their larvæ or pupæ are on the ground.

\section{(12) Protective Measures.}

The regulation of forest pasture may be considered under the headings :-close-time, arrangement of grazing areas, season for grazing, species of animal, number of animals, control and protective staff.

\section{a. Close-time.}

Close-time is the period during which a wood should not be opened to grazing. It commences with the regeneration of the wood, and terminates when the young trees can no longer be reached by the animals, in the pole stage. The length of the close-time depends on the species of tree, the system of management, the circumstances of the locality, and the kind of grazing animal.

Broadleaved species, especially slow-growing ones, require a longer close-time than conifers ; high forests, a longer closetime than coppice. In the case of mixed woods, the length of the close-time will depend on the most endangered species. 
On poor soil, in exposed places, longer close-periods are required than for good soils, sheltered positions, and mild climates, since trees then grow faster. Sheep can be driven earlier than cattle or horses into a forest.

The calculation of the open area in a forest is given in the following formula :-

$$
\text { Let } \begin{aligned}
\mathrm{F} & =\text { area of forest, } \\
f & =\text { closed area, } \\
f_{1} & =\mathrm{F}-f=\text { open area, } \\
s & =\text { close-time } \\
r & =\text { rotation of forest. }
\end{aligned}
$$

$$
\text { Then, } \begin{aligned}
f & =\mathrm{F} \frac{s}{r} \\
f_{1} & =\mathrm{F}-f=\mathrm{F}\left(1-\frac{s}{r}\right)=\mathrm{F}\left(\frac{r-s}{r}\right) \ldots \mathrm{II} .
\end{aligned}
$$

For example, a forest of 1,000 acres area, with a rotation of 100 years, and a close-time of 25 years :

$$
\begin{aligned}
\text { The closed area } & =1,000 \frac{25}{100}=250 \text { acres. } \\
\text { The open area } & =1,000 \frac{75}{100}=750 \text { acres. }
\end{aligned}
$$

Speaking generally, according to G. L. Hartig, the following areas should be closed :-

Broadleaved forest . . . $\frac{1}{4}$ to $\frac{1}{3}$ of the whole area.

Coniferous do. . . . $\frac{1}{6}$ to $\frac{1}{4}$,"

Coppice do. . . . $\frac{1}{3}$ to $\frac{2}{3}$,"

According to Hundeshagen, the close-time should be as follows :-

System of Management.

\begin{tabular}{|c|c|c|c|c|}
\hline $\begin{array}{c}\text { Species } \\
\text { of } \\
\text { Cattle. }\end{array}$ & $\begin{array}{c}\text { Broadleaved } \\
\text { High Forest. }\end{array}$ & $\begin{array}{c}\text { Coniferous } \\
\text { Forest. }\end{array}$ & $\begin{array}{c}\text { Coppice } \\
\text { with } \\
\text { Standards. }\end{array}$ & Coppice. \\
\hline $\begin{array}{c}\text { Horses and } \\
\text { horned cattle }\end{array}$ & $\begin{array}{c}\text { Years. } \\
18-24\end{array}$ & $\begin{array}{c}\text { Years. } \\
12-20\end{array}$ & $\begin{array}{c}\text { Years. } \\
\text { Sheep-18 }\end{array}$ & $\begin{array}{c}\text { Years. } \\
\mathbf{6}-14\end{array}$ \\
\hline
\end{tabular}


In this table the minima are for good localities, and for species not much endangered by grazing, and the maxima for inferior localities, and for species preferred by the animals.

When the animals are simply driven through a forest, much younger woods can be opened, but in such cases the gradient of the slopes and the consistency of the soil should be considered. Thus, in the Harz, 3-to-5-years-old plantations of spruce with appetising grass are opened to cattle and suffer less than older woods, where the grass is hard and unnutritious.

\section{b. Location of Grazing Areas.}

Every year a new tabular form showing the areas opened to grazing should be drawn up and publicly advertised amongst the grazing villages that use the forest. In preparing such a form, the open compartments should be arranged so as to make it possible for the animals to pass through old woods from one grazing ground to the next, or drift-roads should be laid-out between them wherever young woods intervene, and sufficient time allowed for the grass to grow in a grazed area before its turn for opening recurs. Marshy places, loose soil and steep slopes are to be excluded. Localities with undergrowth that is valued for regeneration must not be opened to sheep. Where trampling is to be dreaded, horned cattle must also be excluded. Attention to the requirements of the animals when drawing up the plan of grazing will also tend to restrict damage.

The closed areas must be marked on the ground with notice boards, or protected with fences or ditches, the latter to be 3 feet wide and $1 \frac{1}{2}$ feet deep, with the earth thrown up on the side of the closed area.

If drift-roads are required from one part of the forest to another, they should be from 15 to 24 feet wide, according to the number and species of grazing animals. Wherever these roads pass through very young growth, ditches, earth or stone walls, or dry thorn hedges, should be placed on either side. The earth from the ditches should be thrown up towards the closed area to assist in keeping out the cattle.

Wherever such protective works are not made along a drift 
road, the nearest rows of young plants should bo protected, as in Fig. 20, each with three rough stakes with the jagged sides pointing outwards. When for the removal of a strong growth of herbage, or other reasons,

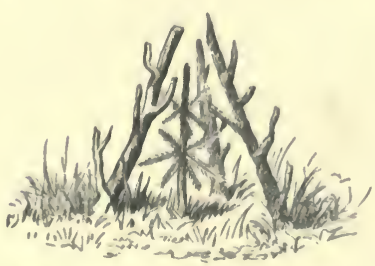

Fig. 19.-Protection for young plants. pasture in young growth is considered advisable, this should be allowed only from the 1st of July after the year's shoots have commonced hardoning, and in dry weather. By multiple-planting at each spot, in threes or more, there is moro chance of success in grazed forests, than when single plants aro used. In grazed selection forests, the only certain system of reproduction is to plant in groups whore old troes havo been removed, and fenco-in each group until the plants roquire no further protection.

\section{c. Duration of Pasture.}

The usual duration of pasture in Europe is from May till Soptembor. 'T'he period for grazing varies in differont countries, boing, however, much the same in the mountainous parts of Northern India as in Europe. In hot countries great danger arises from the custom of firing the dry grass in forests for spring-grazing, in order to got fresh young shoots from the rhizomes of the grass, as the dead cold-weather grass is unnutritious. In certain forests, however, some of the grasses remain green, long after the grass outside the forests has dried up, especially when the forests are at a certain altitude and on northern aspects.

Owing to unsuitability of the unburned grass for pasture, certain inferior areas of forest and blanks may have to be given up as grazing-grounds, and burned anmually for this purpose. It is found by experience, that, owing to constant grazing, conrse grasses gradually disappear from these arens, so that eventually they need not be burned, the non-inflammability of the finer grasses then assists in the protection of the valuable parts of the forest from fire. It is, however, always proferable to try and induce the people to cut and 
remove the grass before it has become dried-up, and preserve it as hay or ensilage for use during the dry season. This plan has had great success in Ajmir, in India.

In the Alps, forest pasture lasts only for ten or twelve weeks, and sheep-grazing on the high forest pastures of the Himalayas is of a similar nature, these pastures not being burned. The winter pastures in the N.-W. Himalayas, in forests of Pinus longifolia, Roxb., are generally burned, both in order to destroy the dead needles, and to produce a fresh crop of grass. Forests so treated must eventually disappear, but the magnificent reproduction of Pinus excelsa, Wall., in the middle altitudes of the Himalayas between 6,000 and 8,000 feet, since fire protection has been introduced into the forests, is most remarkable.

In wet weather, forest grazing must be stopped, or carried on in old woods only. The usual daily grazing should commence only after the sun has dried the dew, and night-grazing is not generally allowable. If cattle are to be driven through young growth, this should be in the afternoon, after they have already had a good meal.

\section{d. Species of Grazing Animals.}

Goats, horses, and camels must not be allowed to browse in valuable forests; their fodder should be cut and brought to them. The French laws exclude sheep as well as goats from all forests managed by the State Forest Department, but sheep may be admitted to graze in forests in certain localities under special sanction. Elephants may be admitted into forests with their keeper, and their fodder cut and brought in by them. A list of climbers and inferior forest trees and shrubs suitable for the fodder of goats, camels, elephants and buffaloes should be drawn up and circulated amongst all keepers of these animals who obtain fodder from a forest, and the fodder, as far as it consists of woody plants, should be restricted to these species.

As regards other grazing animals, the number to be admitted into forests must be carefully controlled. This number will be determined by considering the amount of their requirements and the available quantity and quality of the herbage 
in the forest. Wherever tender grasses are available, these are exclusively grazed on.

No diseased or sick cattle should be admitted, and from onetenth to one-fifteenth of the animals should be provided with bells, those inclined to wander from the herd being chosen.

The animals should be driven into the forest only in flocks or herds under the care of trustworthy herdsmen, who must see that they do not crowd together, nor stray too far apart. A few horses may be attached to a herd of cattle, but cattle and sheep should never be kept together to graze. The herds must not be too great, not above 100 to 150 head. All crowding and fast driving, and especially driving cattle with dogs through young growth, must be forbidden.

On slopes grazing animals are driven straight up from below, and very slowly, in order, as much as possible, to avoid damage by their tread.

Shady places in old woods without undergrowth should be selected for rest in the middle of the day, and must be near water for the animals to drink.

\section{e. Herdsmen.}

Well-reputed, trustworthy people must be selected as herdsmen, and the owners of the cattle held responsible for damage or breach of regulations, any failing in this respect being at once reported and seriously dealt with.

The forest manager should secure for himself a certain influence in the appointment of the herdsmen, and endeavour to get them to take interest in the welfare of the forest, by rewards for good behaviour, and discouragement if they are careless. If the herdsman chooses the proper moment, when the beasts show an inclination to attack woody plants, to drive them on to another pasture, and when to graze in young woods, and selects old woods in wet weather-in fact, if he has the necessary power of observation and will use it for the benefit of the forest, the damage done by grazing may become quite inconsiderable.

(13) Geese, etc.

As regards domestic birds; geese, fowls and pigeons may damage a forest, the former spoiling the pasturage, and the 
latter devouring forest seeds; but certain blanks may be found suitable for geese, and the damage done by fowls and pigeons is inconsiderable.

\section{Forest Litter.**}

As the removal of litter consisting either of the soil-covering of dead leaves, needles, humus, moss, etc., or of branches of forest trees in full foliage, is the most hurtful form of utilisation of minor forest produce, its permission must be looked upon as altogether exceptional, and only to be granted under most pressing necessity (scarcity of straw, etc.).

The then requisite protective measures are:-

Limitation of the quantity of litter to be removed to what is absolutely required by local farmers and peasants. Not a word should be heard in favour of selling the litter to others.

If the rides, roads, ditches, places from which the wind would inevitably blow away the litter, and hollow places where it becomes heaped-up unnecessarily deep do not suffice for the requisite supply of litter, then felling-areas with high herbage should be opened, but growing woods only as a last resort.

Only places with fertile, deep and fresh soil can bear a limited deprivation of litter. On poor, shallow, easily dried, hot soils and on sunny aspects, the collection of litter must be unconditionally refused. So also in woods that are insufficiently stocked, or in badly growing woods, of quality under 0.7 .

Woods which have not yet attained their maximum heightgrowth must be closed against the removal of litter. The necessary close-time depends on the species, the locality, and the length of rotation $(r)$; it should be at least $\frac{1}{3} r$ for High Forest and Coppice-with-Standards, $\frac{1}{2} r$ for Coppice, but for exacting species, such as the beech, we must wait up to $\frac{1}{2} r$ even in high forest.

The repetition of the utilisation of litter is allowable only after a certain close-time, which varies from 5 to 10 years according to species of wood, quality of locality, rate of growth, etc.

* For an account of the value of humus in the soil of a forest, see Vol. II., 3rd edition, p. 41, et seq., and Vol. V., part II., chap. VII.

F.P. 
Removal of leaves should not be permitted two years before or after a thinning, and in the case of natural regeneration there must be a close-time for litter $4-8$ years before and after a seeding-felling. This, however, implies such a state of decomposition of the soil-covering, that seedlings can strike their tap-roots into the mineral soil. Wherever deep layer's of undecomposed humus prevent this, they must be removed so as to expose the mineral soil.

The most suitable time in Europe for removing litter is on sunny dry days in September and October, shortly before the fall of the leaf. This rule will require modifying where, as in hot countries, some of the trees lose their leaves in the spring.

Iron rakes must not be used for collecting litter, as they go in too deep and may injure the roots of the trees; brooms also remove too much litter. Only the uppermost undecomposed layer of litter should be removed. Cutting and removal of sods of grass with the roots must be forbidden.

As regards moss, species of Hypnum should be removed only in strips during the spring, so that the regeneration of the moss on the bare places may be facilitated from the strips left untouched; this happens, when the soil is fertile and moist, in about six years. Then the old strips of moss may be removed, and another six years left for the bare places to recover, and so on. Species of Polytrichum and Sphagnum, which generally grow in patches on wet soil, cause swamps and are hurtful rather than useful, and can therefore always be removed.

Branch loppings for litter, best from silver-fir, should be conceded only from felled trees or from those just about to be felled. Sometimes it may be uséful to allow grass, heather, broom, bracken, etc., to be cut in young plantations, for use as litter. The kind of implement to be used will depend on circumstances.

During removal of the litter, the forest must be carefully watched, and wherever annual permission for litter is given, a scheme should be drawn up, allotting the open areas for successive years.

By careful economy in the preservation and use of all 
manures, and by the use of straw and provision of foddercrops for stock, the demand for forest litter may be reduced; it is the duty of the State to impart public instruction in this respect, and as to the extreme impoverishment of forest soil by the constant removal of litter. The worst possible instances of damage to the soil by the removal of litter are exhibited by the State forests near Nuremberg in Bavaria, where even Scots pine, in some parts of the forest, can now grow only as a dwarfed scrubby tree almost useless except for fuel. Litter from coppice-with-standards in Kent, Sussex and Hampshire is regularly used for manuring hop-fields, to the impoverishment of the soil of those woodlands.

\section{Dead Branch-wood.}

Wherever the removal of dead branch-wood is not a right of usage, but is permitted under certain conditions by the forest manager, the following rules apply :-

Written or printed permits for the removal of the dead wood must be held by each person so engaged in order to prevent the concession from becoming a right, and generally, people too poor to purchase fuel should be favoured in this respect, but they should not be allowed to sell the wood.

Very poor or exposed localities in the forest should be excluded from the use of this concession, as the dead branches increase the humus of the soil.

As a rule, no tools should be used, but where removal of dead branches from standing trees is allowed, they should be sawn off close to the stem.

In order to facilitate control, the removal of dead wood should be allowed only on certain days, and not between sunset and sunrise, and the forest carefully watched on those days.

Wherever game is of importance, the privilege must be suspended during the breeding season.

It may be necessary to prescribe the removal by certain roads in order to facilitate control.

The removal of fallen dead wood is not so harmless as many people think, as a considerable amount of humus is formed 
from it. Thus sapwood, of which young branches are chiefly composed, contains far more potash than heartwood.

In the Crown forests of Hesse the privilege of collecting dead wood gratis is subject to the following rules:-

All dry fallen wood, which in the opinion of the forest manager is unsuitable for sale, may be taken. Also dead branches, which can be broken off by hand by one person without climbing the trees, provided it be not over $6 \mathrm{~cm}$.

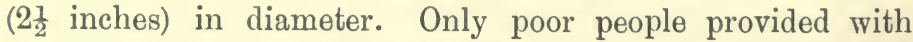
formal permits are admitted between sunrise and sunset to this privilege. All tools are excluded, and no sale of the wood allowed. Transport is by head-loads, or in hand-sledges. The privilege is stopped during May and June.

In North-West Indian State-forests, the privilege of removal of dead fuel is frequently leased annually; it is also granted free to villages paying grazing dues, and to travellers on high roads passing through the forests.

\section{Removal of Stones, Gravel, Sand, etc.}

The following rules should be enforced:-

All quarries, sand, clay and gravel pits must be properly demarcated, and the boundaries strongly walled or fenced to prevent accidents. Proper precautions must be taken that neither roads, nor streams, nor the forest outside the quarry are imperilled by quarrying.

In agreements made with lessees of stone-quarries, etc., they may have to pay for repairs to forest roads leading from the quarry; they should also be held responsible for any damage done by their employees. In French State-forests, where coal-mines are worked below the forests and subsidences occur, the coal companies have either to restore the ground to its original level and replant it, or to dig out fish-tanks, which are valuable in France.

Stones lying about on the ground should be collected only where their removal is not prejudicial to the forest, and when removed, the ground where they were lying should be levelled. Removal of loose stones should not generally be allowed on the sites of fellings, especially on loose sandy or calcareous soils 
that dry up easily; stones retain moisture in the soil. Places must be assigned where the stones may be stored and roads designated for their removal.

Pits of sand, clay and gravel, that have been abandoned, should be levelled or sloped-off to prevent accidents, and if possible planted. This rule is specially applicable to experimental pits abandoned as not sufficiently profitable.

\section{Collection of other Items of Minor Produce.}

Collecting berries, such as bilberries, wild strawberries, raspberries, etc.; edible fungi; empty cones lying on the ground; grass-seeds; medicinal herbs or fruits, and other such produce, the collection of which is not worth the trouble of the forest owner, must be so regulated that only persons provided with formally written or printed permits should be admitted, and the period of collection fixed. In hot countries, some of those products attain a much greater importance than in temperate regions, and certain special rules may be necessary, as in the collection of wild honey and wax in India, where care must be taken to prevent the collectors from firing the forest, so that it may be necessary to prohibit the collection altogether except during seasons when the grass or other soilcovering in the forest will not burn.

\section{Game and Fisheries.}

Leases in forests of the right to hunt or shoot game, and of fisheries, frequently produce considerable annual revenues, but whilst little or no damage is done by pheasants and other birds, deer and ground-game (hares and rabbits) may do a great amount of harm to a forest. The measures to protect forests against these animals will be given further on.

The protection of game and fisheries is dealt with in special treatises, and would take up too much space in the present book. In most civilised countries there are special laws relating to game, and these should be so framed as not only to prevent wholesale destruction of useful wild animals, especially during their breeding season, but also to afford 
compensation to owners or tenants of land bordering on a forest, for damage done to their crops by any excessive head of game which may be preserved in the forest. They should also fix a minimum limit to the area on which a man may claim the exclusive right of shooting on his own land; this is especially required in countries where landed property is much subdivided.

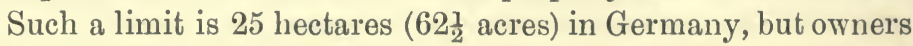
of such small areas may combine with others to form shooting syndicates. In French State-forests, sporting leases generally run for nine years, the lessee having to pay for any wire-fences that may be required to protect the young growth.

Fisheries are also regulated by laws. In France, since 1897, the preservation and control of fisheries in all State non-tidal waters, have been placed under the State Forest Department, which is styled "Administration des Eaux et Forêts."

Their plan of operations over 342 miles of canals and canalised rivers, and 210 miles of other rivers that belong to the State, is :-

1. 'To form reserved waters where fish can freely propagate. On other streams, private fishing rights prevent State interference.

2. Rewards are offered to fishery guards and to forest guards for protecting natural breeding-places of fish and for establishing new ones, for killing otters and other fish-enemies, for protecting streams against netting by driving stakes into river-beds.

3. Fish-ladders are erected.

4. Live fish are bred in special piscicultural establishments and are placed in State streams, lakes, and grounds. They are also distributed to private fishery owners.

5. Crayfish have died out to a large extent in France from disease, and fresh crayfish are imported and placed in the rivers.

6. Pisciculture is taught at the National Forest School, at Nancy, where a special piscicultural laboratory and breeding establishment is maintained, the latter in the adjoining forest of Haye. 


\section{CHAPTER III.}

\section{PROTECTION OF THE FOREST AGAINST OFFENCES.}

\section{General Account of the Subject.}

The theory of forest legislation and the law of forest police is dealt with under Forest Law.*

There are, of course, a number of acts in a forest constituting an infringement of the rights of the owner, which may be remediable only by a civil court:-either by a suit for an injunction to the offender not to repeat his act, or for damages. Of such cases it is not necessary to speak in detail; but a word may be said about "trespass." Ordinarily an entry on a man's property which is not lawfully warrantable gives rise to an action for damages; but under the English law (and so in India) trespass cannot be prosecuted criminally, unless there is proof that the entry was with intention to do "mischief" or commit a legal offence of some kind. When, therefore, in forests, it is desirable (owing to the special circumstances) to make penal the mere act of climbing a fence and aimlessly wandering (off regular paths) in a compartment, or a young plantation, it can be done only by an express enactment of a suitable prohibition and (light) penalty.

\section{Definition of a F'orest Offence.}

Under the term "forest offence" is here included any act done in a forest which is punishable under an existing forest or other law. Offences which affect or threaten forests (or the produce of them when converted and stored, or in transit) or which interfere with control, are naturally sometimes of a

* Reference may be made to "Forest Law," by B. H. Baden-Powell, C.I.E., I.ondon (Bradbury, Agnew, \& Co. Ld.), 1893, which also refers to the principal works on the subject. 
lind which might occur in respect of any property, and sometimes of a special character: i.e. they happen only in forests and are not attempted elsewhere; or else are exceptionally dangerous or injurious when done in a forest (or with regard to forest property generally). Hence in most systems of law, "offences" are partly punishable under the provisions of a forest law, and partly under the ordinary "Penal Code" or the statute and common law of the country.

In INDIA, for example, such offences will sometimes come under the Forest Acts; sometimes under the Penal Code; sometimes under either. And it is a matter for the law manuals to tell us when one law or the other should be had recourse to. In the British IsLes there is no special forest law; accordingly all "offences" that are punishable (as distinguished from acts which give rise to a claim for damages) are so under the ordinary (Criminal) Common and Statute Law.

\section{Classification of Forest Offences.}

Forest offences may, therefore, be classified as follows:-

(a) Damage :

Unintentional.

Wilful.

(b) Misappropriation :

Simple.

Accompanied by damage.

(c) Contraventions of forest police.

The subjects of forest offences are sometimes the forest soil, or its covering; the stock of wood or minor produce, whether standing or converted; houses, roads and other works and appliances used in forest business.

\section{a. Damage.}

Unintentional damage occurs in a variety of ways, as for instance:-damage to standing trees through clumsy felling of other trees, to young growth during fellings or removal of material; cutting up valuable timber into firewood in ignorance of its value; cutting seedlings during grass-cutting; 
driving carts over boundary marks, through ditches, down embankments, etc. The number of cases which may occur is so great, that to draw up a complete list here is impossible. In many cases no legal offence is committed which is punishable criminally; but the doer of the damage is liable to make reparation.

In the case of wilful damage, the motives may be wantonness, revenge, selfishness, even superstition.*

Damage of this kind includes:-peeling the bark from standing trees, girdling, cutting-off leading shoots, lopping branches or exposed roots; lopping branches from trees yielding mast, or from cone-bearing trees in order to facilitate the removal of their fruit; wilful damage to boundary marks, fences, forest nurseries, or other forest appurtenances.

\section{万. Misappropriation.}

Under this heading is understood illegal appropriation of forest property still belonging to the forest owner.

In most systems of law "theft" and "larceny" refer to "personal" or "moveable" property : such as a watch, ftrewood in a stack, a log, or a beam; and there is (or may be) a difficulty about prosecuting cases of lopping, or the offence of cutting a standing or growing tree, bush, or sapling; generally, therefore, the forest law (if there is one) will specially provide for these cases, and will leave "theft" of forest produce (stored), cut timber, etc., to the ordinary law. $t$ Where there is no special forest law, the cutting of standing trees would at any rate constitute "wilful damage" or " mischief."

Simple misappropriation (in the general sense of the term) is unaccompanied by any damage to the forest, so that no loss of increment, no impoverishment of the soil, results from the offence, but merely the loss of the property illegally taken

* About thirty years ago a depdar forest in Jaunsar, in the N.-W. Himalayas, was deliberately burned to propitiate the goddess of small-pox.

† In India, a technical distinction is drawn between "theft" and misappropriation," for which see "Forest Law" (pp. 118, 426). It is provided, however, in the Indian law, that though "theft" can only be of "moveable" property,and a standing tree is not such,-still the act of cutting and severing the tree from the suil may make the object moveable and also effect the moving with dishonest intention that is necessary to constitute "theft." 
away. In this is included the illegal removal of dead standing trees (provided no damage is thus done to living trees); of dead branches or windfalls ; of fruits not required for natural reproduction; of grass from rides, or roads; of stones lying on the ground, berries, edible fungi, etc.

Misappropriation accompanied by damage is committed when the forest owner, in addition to the loss of the articles abstracted, suffers physical damage to his property, which may differ greatly in degree according to circumstances (species, age of wood, system of management, density of growth, locality, etc.).

To offences of this class belong, as regards principal produce :-cutting and removal of standing timber, or parts of standing trees, involving loss of increment and irregularity of management, or introducing decay into the wood; removal of mother-trees in regeneration-fellings, or of standards in stored coppice, resulting in delay in the reproduction of the wood, deprivation of shelter against atmospheric influences for the young growth, exposure of the soil, etc. Some of the most harmful of these offences are digging up green stools from coppice, and removal of young plants from plantations, as thus the care taken to restock a wood is frustrated. Another very harmful offence in Germany is the breaking off of the leaders and side-shoots of young pines by children for sale to apothecaries, who grind them up and export them, chiefly to America, as medicine, under the name I'uriones pini.

As regards minor produce :- peeling bark, tapping for turpentine or gum, lopping branches for fodder, grazing, rakingup litter, cutting sods, and appropriation of the resulting produce, are common offences. When tall herbage is pulled up round seedling plants, or excessive layers of humus are removed from felling areas, the owner of the forest may actually profit by the offence. Such nominal offences may be prevented by permits to remove noxious material.

In many of these cases, as for instance in the removal of litter, the damage done to the forest far exceeds the value of the material abstracted. 


\section{c. Contravention of Forest Police Regulations.}

The offences comprised under the above heading are infractions of police regulations made for the public welfare, or in the interests of forest conservancy. No damage need result from such offences, as for instance from kindling a fire in a forest which may become extinguished without causing a forest fire, although there is an imminent probability that such a calamity will happen, and this probability necessitates the stringent prohibition of such an act. Offences of this nature may be placed in the following groups :-

(i) Offences against forest control.-Examples: removal of wood without permission, at a forbidden time, or by a closed road; collection of dead fallen wood without a permit, on forbidden days, or with prohibited tools, etc.

(ii) Offences endangering the forest.-Examples: lighting a fire; leaving unextinguished a fire lighted with permission of the forest manager ; carelessness in burning charcoal or lime; smoking pipes without covers; going into a forest with torches, etc.

(iii) Acts preparatory to a forest offence, which are consequently prohibited:-Examples: trespass by climbing over fences, carrying axes or saws in a forest without permission, injury to notices, etc. Forest trespass (in closed places, off regular paths, etc.) where this is made penal by law.

Many forest offences comprise damage or misappropriation, as well as contravention of regulations; as for instance injury to growing trees by transport on a prohibited road, kindling a fire in a forest with misappropriated wood, etc.

Such complications may involve several heads of charge in the prosecution case, or call for severer punishment than offences of a simpler nature.

\section{Protective Measures.}

Protective measures against forest offences may be either direct or indirect. The latter chiefly involve removal of the cause of offences, and the former are directed against the offence itself ; it is, however, difficult to draw the line between them. 
Unfortunately, forest offences are always considered by country people less culpable than those against the penal code, as many German proverbs show. This results from the former communal possession of many forests, and the small value of forest produce in earlier times. Even now, the appropriation of Christmas trees, birches for Whitsuntide and sallow branches in bloom for Palm Sunday, are frequently considered justifiable. The forester should not be too exacting regarding certain innocent practices ingrained in the popular mind, and he should endeavour to become acquainted with all local customs which prevail near his forests.

The following are the protective measures against forest offences :-

\section{a. Removal of Causes of Offence.}

Want of occupation and consequent poverty often leads to an increase of forest offences. As a population increases, without more opportunities for employment arising, and as the clearance of communal and private forests causes a rise in the price of forest produce, the temptation to commit offences is increased. They are also more frequent near populous towns than elsewhere, as the trade in stolen forest produce is thus facilitated. At Hardwar in N.-W. India, in 1882, unmarked forest produce brought into the town was regularly priced lower than properly certificated produce, as the former was suspected of having been misappropriated and might get the purchaser into trouble. Insufficient education, careless watching of a forest, bad forest legislation, and a feeble execution of justice on the part of magistrates, may all combine to increase forest offences.

The subject of Forest Policy comprises a study of the above factors, and only the energetic action of the State can ensure thorough protection to forests against forest offences. Under Forest Protection, we can rely only on means within the power of the private forest owner, which are as follows:-

(i) Careful utilisation of all forest products, so that all local wants may as far as possible be supplied. Frequent sales of produce, and in small lots, and credit given for a certain part 
of the purchase-money until the purchaser can begin to realise the value of his purchase, are useful measures.

(ii) Provision should also be made for the sale, by printed or written permit, of kinds of principal forest produce which frequently form the object of misappropriation, such as hoppoles, props for fruit-trees, cart-axles, wood for ploughs, peasticks, thorny bushes or stakes for fences, bast for ropemaking, Christmas trees, faggots, stumps and roots of felled trees, etc.*

(iii) Permits, if necessary without payment, to remove certain minor forest produce as far as is consistent with the safety of the forest, should also be obtainable throughout the year. For instance, to cut grass; for dead fallen fuel; to collect berries, edible fungi, cones; to utilise some kinds of litter the removal of which is not harmful; in certain cases for the temporary cultivation of crops. Tall coarse grasses may frequently be removed to the advantage of a forest, and thus may be secured less danger from frost and fire, more heat and moisture in the soil, and loosening of the surface, all of which are important for plantations. In the case of temporary cultivation, potatoes are to be preferred to cereal crops, as they impoverish the soil less.

(iv) Supplying work in the forest during winter or at other seasons when employment is scarce. When a village near a State forest has been burned, building and thatching material may be supplied free, or, at a low price, in order to prevent dealers in such material from charging excessive prices to the distressed villagers. Roads, drainage, ditching and removal of stumps, will furnish employment, in addition to the ordinary felling and planting work in a forest.

(v) In the case of communal forests we have moreover to secure economy in the use of firewood by introducing the use of improved stoves, ovens, etc. The firewood store-depôts should be centrally situated, so as to facilitate removal of the material by the householders. The wood should be delivered dry and in the smallest quantities in demand.

* In "Rev. des E. et F.," 1905 , p. 688 , it is stated that sales of small felling areas of coppice in Algeria have resulted in a considerable reduction of offences. The people living near the forests formerly gained their livelihood partly by illicit fellings or thefts of forest produce. 
(vi) Improvement of agricultural methods, so that agriculture may depend as little as possible on the forest. Common-land should be used to the best advantage; technical instruction in agriculture should be afforded, etc.

(vii) Much may be done by the exercise of tact and kindness in the administration of a forest, to prevent the ignorant peasantry from feeling the forest to be a hostile institution in their neighbourhood. This need not impair the effectiveness with which important rules are enforced and the safety of the forest ensured. It is possible so to act as to make the people not dislike the control, by using discretion in enforcing particular prohibitions. Ignorant peasantry will always dislike forest conservancy ; but they need not feel it a grievance: there is an irritating kind of exactness which tends to provoke a spirit of malice and a desire to injure the forest; whereas, a judicious management will in time disseminate the idea that the forest is after all a benefit, and that the forester is not the enemy of the people.*

\section{b. Direct Dealing with Forest Offences.}

(i) The forest should be subdivided into beats of suitable size and shape for patrolling and keeping watch against trespassers, or against the causes or origin of fire; in Germany, the area of a beat ranges between 500 and 1,800 acres, the latter in Würtemberg, the mean area being 1,150 acres. Trustworthy forest guards should be appointed, who should be allowed sufficient pay and houses well situated as regards their beat, also allotments for a garden and potato-field, and pasture for one or two cows on forest rides and blanks. Proper control of the guards, and promotion and reward of good men must be seen to by the forest managers. Friendly-societies of the guards should be encouraged.

(ii) Wood-cutters and contractors employed on work should be induced to participate in the protection of the forest.

The forest should be constantly inspected, and all workmen

* In the Jaunsar district in India, the wages paid annually by the Forest Department were in 1888 sufficient to cover the rent paid to Government by the peasants. 
employed in it supervised. Proper rules regarding forest fires must be duly made known and strictly enforced.

(iii) All forest offences must be promptly reported, and the offenders prosecuted. There are some particular offences against which special remedies may be adopted. Where tappings for turpentine have been illegally effected, they may be smeared with lime-water, which stops the flow of turpentine. Where removal of litter is to be feared, stumps may be left somewhat high at the thinnings, or stakes driven into the ground to impede progress. All stumps of stolen trees should, on discovery, be marked with a special hammer to facilitate control.

(iv) Wherever it is possible to free forests from rights-ofcommon, this should be done, as abuses almost always accompany them. A comparison between open and closed forest is shown in Fig. 20.

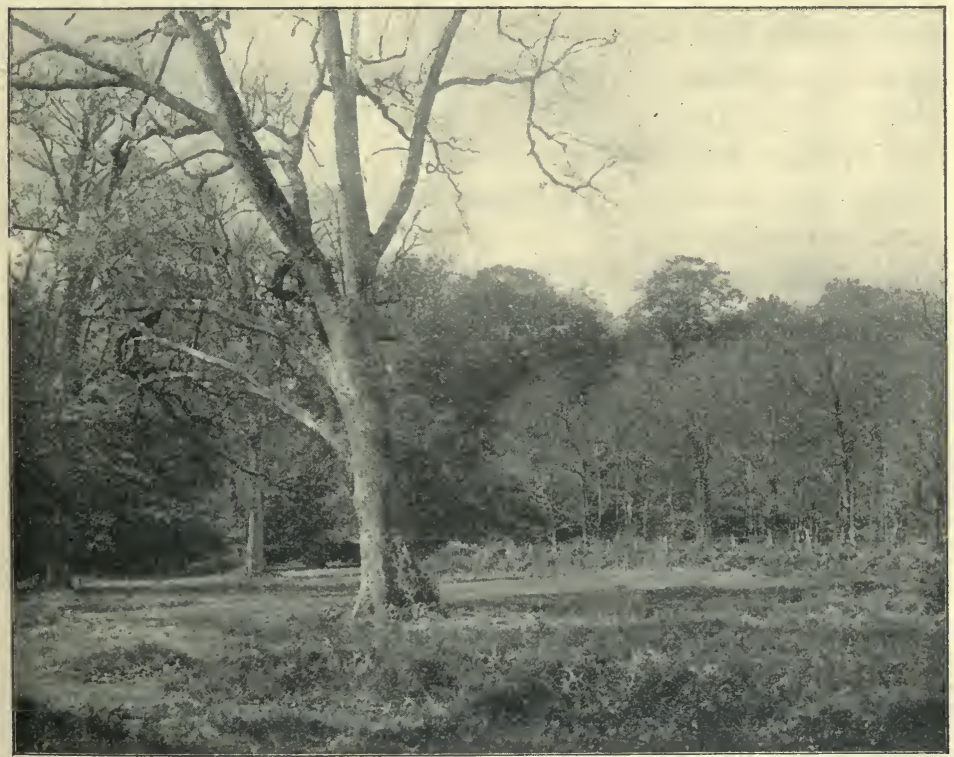

Fig. 20.-New Forest, 1900. Comparison between closed and open forest. Kindly supplied by Commissioners of Woods and Forests. 


\title{
CHAPTER IV.
}

\section{PROTECTION AGAINST DANGER FROM FOREST RIGHTS.}

\author{
Section I.-General View of Foregts as "Estates" or \\ Pieces of Property.
}

\section{What is Property?}

A Discussion cannot here be attempted of the legal definitions of property, or the questions involved in legal possession, and so forth, with which the whole subject is bound up. We commence with the practical consideration, that in modern times most things that are available for use have, or are presumed to have, an owner. In particular all land (in countries where there is a civilised government) has come to be recognised as the "property" of someone: even an open moor or waste is owned by someone. This ownership implies the following elements:-

(a) That within certain limits or boundaries,

(b) the "owner" has certain positive rights : which other people have not.

(c) $\mathrm{He}$ has also the negative right, that other persons are bound not to interfere with his rights.

In either case there is a legal remedy, which the owner can invoke in the case of an infringement of his right.

(d) It is possible that some other persons (without actually infringing the owner's right) may have certain rights of their own which limit the enjoyment of the owner; if so, these rights must be known and certain.

Where these conditions are not yet legally existing there cannot be, for any practical purposes of management or control, an estate or property.

Where the owner's right ( $a$ and $b$ above) is not limited by the existence of other rights under $(d)$, the lawyers shortly 
express the sum of his rights as ouner, by saying that he has the use (every possible advantage from the estate); the abuse (the right to destroy and make it a waste, unless some express law prevents him); the fruits, i.e. all produce and accessories; and lastly, the right to let, hire, alienate, and maintain any kind of legal action necessary to defend his property.

\section{Of the Persons who are Owners.}

Forest property may belong to an individual owner, or to a partnership or body of co-owners, or to the State; or to what is called an artificial or legal person, namely, some body of men, or individual holding a peculiar position, or even an official trust, or some institution, which the law regards as if it were one single person, taking (as regards the property owned) no thought of the individual member or members composing it.

The corporation, as a legal person is called, is exemplified by the "Crown," the "rector of a parish," a town corporation, a college, charitable or other body, which is by law, or by a Royal Charter declared to be corporate. In such cases the law or charter specifies the officer (chairman, secretary, etc.) who is to represent the corporation : the act of the whole body is signified by a common seal.* The individual members of a corporation have no interest in or liability for the property whatever, nor can they take any action regarding it. Thus corporate property differs from property where the owner is a company (not being a corporation), or a partnership, or a set of two or more joint owners: for all these have separate rights and individual interest, although until partition, no one of them alone can deal with any portion of the estate.

\section{Limitation of Owner's Right.}

In the short enumeration of the characteristics of property it was noted that sometimes, though there was an owner to

* This has nothing to do with the departmental official seal used by a forest department or government secretariat, etc. The "State" or "the government" as owner of forests and so forth, is not exactly a corporation-but it is anulogous. State property is always provided to be managed and held by someone-e.g. the Secretary of State for India in Council, in the case of public property in India. 
the estate, whose right extended over the whole, within its proper boundaries, there might be third persons, having rights within the boundaries also. When this is the case it is often popularly (but inaccurately) said that the ownership is linited. Ownership in itself is an ultimate and indivisible right; if a person is owner at all, he is simply owner, he cannot be something more or less, so long as he retains the legal title at all. But around the right of ownership cluster also a number of subsidiary rights and enjoyments, some of which can be broken off, so to speak, and come into the hands of other persons. Hence, though the ownership remains, the enjoyment of it may be either absolute and unfettered or may be limited. One obvious way in which such limitation arises, is by some contract-such as a lease, pledge, or mortgage, or loan of the estate; with that kind, however, the present work is not concerned. There is another class of rights of third parties which do not arise out of any lease or temporary contract, and their existence often causes a very considerable limitation of a forest owner's enjoyment and control of his property.

\section{Rules of Protecting Forest Property.}

Before discussing the nature of these rights, some brief rules may be given, which apply to the protection of the forest property or estate as such; to secure the area, general title, and legal position of the property.

(a) See that the forest is regularly and permanently demarcated, both as to its general outer boundaries and as to all inner boundaries-which mark the limits to which certain rights extend, or in which there are no rights other than the owner's.

(b) Provide convenient means of entrance to and exit from the forest and its various compartments.

(c) Exercise the rights of ownership in the forest, especially near its outer boundaries; let no one have an excuse for saying it could not be known that any one was in possession, or was owner of the place. The mere fact of possession renders the assertion of ownership much stronger before the courts of law, in cases of disputed ownership. 
(d) Carefully prevent damage to the estate, its roads, fences, works, etc., especially if caused by the removal of forest produce.

(e) Carefully watch against encroachments, and all kinds of forest offences, injury to boundary pillars and other marks.

$(f)$ When any licences or concessions are allowed, see that this is always done by written or printed permission so worded as to make it clear that no right of a prescriptive character can arise.

(g) Exercise any rights the forest estate may possess over other estates, and all claims to labour, or payments, all rights of receiving help in case of forest fire or other calamity, or receiving information (which may be imposed by the forest or other law).

\section{Section II.-General Account of Forest Rights on Servitudes.}

\section{Nature and Origin of Forest Rights.}

As already stated, it frequently happens that persons (sometimes individuals, sometimes legal persons or corporations) possess rights over a forest (or other) property which belongs to someone else. These are permanent rights, which have nothing to do with a contract, or temporary lease, mortgage, etc. In that case the forest or other estate over which the limited right exists is called the servient estate-it is burdened with the right. These rights are called by various names. The Roman lawyers called them servitudes (because the burdened property was made to serve the purpose of the holder of the right). In English some were called easements (i.e. one kind of them were so, of which presently), others rights-of-common. In India, the Legislature (abandoning this distinction) has called them all "easements." * Such rights depend partly on grants, or some form of written title,

* Origin of forest rights.-In Germany these rights often arose out of the old agricultural communities whose territory or Mark had a portion or borderland of waste and forest which (in some sense, at any rate) belonged to the inhabitants. From the time of Charlemagne these border-forests were appropriated by the empire or by powerful landowners and town corporations, and the original owners became mere right-holders. Waste lands attached to villages in India have also 
perhaps a judgment of some Court, and partly on what is called prescription. By this latter term we mean, that though the exact origin is not known, yet as a matter of fact the right has been exercised for a long time-the term of years (usually 20 or 30 ) is fixed by the law of each country -and also has been exercised openly (not by fraud and unknown to the owner), peaceably (not by violence), and as of right (not by mere leave or sufferance, acknowledging that the owner could put a stop to the practice). When these conditions concur, there is a full legal right by prescription. It is also possible the rights may be regarded as (in a way) prescriptive, by reason of their being admittedly matters of ancient local custom or on other equitable grounds, even when the precise terms of a legal prescription, as above stated, are not established.

\section{Rights or Servitudes classified into Kinds.}

The lawyers in various countries have classified these rights in different ways in consequence of particular legal distinctions. For example, such rights are said to be negative when the estate which bears the right is merely under the continuous obligation not to do something-i.e. not to dig a hole so as to endanger the right-holder's foundations, not to stop the flow of water, etc.; and positive, when it is obliged to allow the right-holder to do or take something, as to drive his cattle across a field, take wood, or drive-in pigs to feed on acorns, etc. Rights are also said to be continuous or discontinuous (intermittent); the former in their nature are continually in operation at every moment (as a right to light and air by ancient windows*); the latter are used from time had something of the same history ; but under the effeets of the land settlements such areas have mostly been freely given over to the villages. In the Garo Hills (Assam), where tribal settlements in the ancient model still can be observed, it is only within the last 40 years that fighting has ceased when one village group tried to eneroach on the border-forest of the next. Forest rights also arose by grant of the baron or lord: and still more grow up by loeal eustom, and long user of the neighbours, partly because the modes of agriculture then known suggested forest grazing, pannage, etc., as the most desirable, and wood fuel was required before coal was obtainable. In those times, too, forests were abundant in com. parison with the number of the population : and no one eared to interfere with people habitually taking what was so abundant and had so little value.

* And in general all negutive servitudes are neessarily continuous. 
to time, either at fixed intervals (e.g. a right to have 10 beams for repairs once every 5 years), or on occasion (as to cut brushwood for fuel when wanted). This latter feature (discontinuity) may give rise to a further question, which will be noticed presently.

On the subject of classification of rights of user, only two points have a practical bearing on protection. One concerns the nature of the right, the other concerns the nature of the right-holder.

As regards the nature of the right, there is an obvious distinction between rights which (whether negative or positive) imply only some use of the servient estate (as walking over it, letting water flow across it, having the support of soil for foundations, having a beam resting on a (servient) neighbouring wall, etc.,-in all which cases nothing is taken out of or from the servient estate; and those rights which do take something ; e.g. rights of pasture, wood rights, rights to dig sand, litter, etc.). [It is the former only that the English lawyers call easements; the latter are rights-of-common, or profits à prendre in older books.] And then as to the holder of the right: this may be a person A. B. and his heirs; it is always understood that the person cannot alienate the right or servitude. Such rights are said to be personal rights: or as English lawyers say, rights in gross. But very often the right is held not by a person (natural or artificial) as such, but by a certain house, farm, or other building or estate; so that the right is exercised by the person who happens to be the holder of the estate or farm, etc., for the time being. Should the present holder go away and sell the farm, etc., he would cease to have any right; but the right must pass with the farm by sale. Rights of this kind are called real rights (real in a technical sense), and the estate, house, farm, etc., to which they are attached is called the dominant estate, just as the estate which bears the right is called the servient estate.

Different systems of law have different ideas regarding these rights. For instance, in France and Germany forest rights (to pasture, wood, etc.) are always real rights-they are always attached to some farm, building, etc., for the benefit of which the right exists. But this is not always the case in 
Britain or in India (except in some few cases which in their nature imply some (dominant) house or building or land to which the right is attached); it is quite possible for an individual to have a prescriptive right as such individual.* It is not necessary then to pursue this classification further, except to be sure that when a right is so attached, the record of it makes it quite clear exactly where, what and of what extent, is the house, farm, or estate, which is the dominant or right-holding property.

It need only be mentioned that personal rights may be granted or become prescriptive to a person and his heirs for ever, or may be (granted) for life or lives only.

\section{Forest Rights which are Undefined.}

Returning for. one moment to the prescriptive origin of rights, one very important matter has to be noticed. Such rights are nearly always undefined or indefinite-indeed, it is possible that some rights by the terms of a grant are also left undefined; but most commonly it is prescriptive rights that are so.

The custom is that the right-holder may graze " his cattle" in forest A. (how many and of what kind, and at what season is not stated); or that he may have power to build and repair "his house" ; or he has "common of estovers"- $\mathrm{a}$ right to fuel-but of what kind (brushwood or billets) and for what purposes, does not expressly appear.

In all systems of law there are rules for determining how such undefined rights can either be brought formally to record in a definite shape (e.g. the Indian Forest Act), $\dagger$ or at least

* A brief note may be useful as to village rights in India : it cannot be said, or can only be true in particular cases, that a rillage is in any sense a corporation, or that it, regarded as a single (artificial) person, can hold rights of user or common; nor can it in general be regarded as a single dominant estate possessing rights. If (though not warranted by the Indian forest law) a right is set down in a public record as existing in favour of "village C." - this merely means that all inhabitants (or perhaps only all landholders) of village C., for the time being, can exercise the right in question.

f In all fully-constituted State forests in India, the law requires every right claimed to be brought before a public officer appointed for that purpose and not only recorded, but made as definite in number, extent, kind, etc., as circumstances allow. 
there are provisions for fixing the number of cattle, quantity of timber or firewood, etc., to be claimed under the right. These principles are detailed in law manuals.* No system of law allows such a thing as an unlimited right-for that might swallow up the entire ownership - a thing contrary to the very nature of a right of this kind which, it should be always remembered, is a permanent right (not arising out of contract) of one person or estate, which exists over the property of another person, to have some use, or take some part of the produce of the other property.

It is true that sometimes a number of separate rights may exist, the aggregate demands of which form a serious burden on the forest property; but there is no infringement of the principle. It is also to be mentioned in passing, that sometimes there is a kind of right over property of a special nature, called the usufruct, which implies that the whole of the normal produce and the general enjoyment of the property passes for life to the usufructuary; but even then, the holder of such a right is not owner, nor can he do anything that alters or injures the property in its substance, or affects the ownership rightt-à fortiori, therefore, a mere holder of a right-of-common is bound to respect the estate on which his right subsists, and treat it civiliter et modeste according to Roman Law, or en bon père de famille, in French Law, and cannot demand an unlimited, or abusive enjoyment of it.

\section{How Forest Rights may Terminate.}

As we have considered how such rights may grow up, so a few words will be appropriate as to how they came to an end.

* For instance, in Danckelmann's "Ablösung und Regelung," 3 vols., Berlin, 1880. Baden-Powell, "Forest Law," p. 318, .f.

† The usufruct is always for life (see Broillard, "Le Traitement des Bois en France." Paris : Berger, Levrault et Cie.-i.e. 1894, pp. 627-654). If there is a prescribed working-plan the usufructuary must carry it out and only take such produce as comes within its directions, and he must carry out all works, such as new planting, sowing, keeping forest works and roads in order. Such a usufruct arises in the case of entailed forests, or those comprised in a family settlement; also it may be that part of the glebe lands in a rectory in which the parson has a life-interest, is stocked with trees, and may come under this head. By English law, a rector may cut underwood on his glebe land in accordance with the usual rotation, but may fell timber trees only when they are mature. 
(a) It may be naturally: as where the dominant estate disappears (e.g. river diluvion), or where the personal right-holder dies without heirs.

(b) It may be that the forest is unable to satisfy the requirements of the right; here the right must remain in abeyance, till the forest has recovered from the calamity which caused the inability. Where the rights are permanently in excess of the yield-power of a normal forest, then the law usually provides express terms for dealing with the difficulty.*

(c) When the right-holder becomes (by will, purchase, etc.) owner of the servient estate, or where the dominant estate is acquired by the servient estate, the lesser right merges into the greater.

(d) Where the right-holder submits to an interruption, or acquiesces in an act on the part of the servient owner who prevents the exercise (of course having notice of the interruption), the right will be lost if no action is taken for one year.t It may be that the right-holder himself discontinues or intermits the exercise of his right. In England, it is a question of fact for the jury, whether the discontinuance was long enough or under such circumstances, as to give rise to a conclusion that the right was abandoned. In India, the matter has been settled by legislation (Act XV. of 1877, sect. 26 Exp.). Two years' intermission (under the conditions stated in the Act) will cause the right to terminate.

Of course in all cases, as a right can be gained by prescription so it can be lost by complete non-user for the whole legal period of prescription.

(e) Lastly, the right may terminate when, either by friendly agreement, or (if the law prescribes) by compulsory process, the right is commuted or bought-out on paying compensation. $\ddagger$

* See Baden-Powell, "Forest Law," pp. 293, 369, 378.

† For England, see $2 \& 3$ Will. 4, c. 71 . The Indian law is sinilar: see sect. 26, Act XV. of 1877 .

‡ Explained in Danckelmann's " Die Ablösung und Regelung der Waldgrundgerechtigkeiten." Cooke's "Wingrove on Enclosures," 1864 (referring to the multitudinous and complicated Enclosure Acts). Baden-Powell, "Forest Law," pp. $367-393$ (where an abstract of the German law is given). Meaume, "Usage Forestier" (reprinted from the "Répertoire de Législation," Nancy, 1861). 
5. Practical Principles of Law regarding Forest Rights.

The following short statement of legal principles, all of which are based on broad rules recognised in all systems of civilised law, will be found useful :-

(a) There can be no such thing as a right to destroy the estate or do wanton mischief (e.g. burn a forest).

(b) The right-holder is in no sense a part-owner of the forest. When a part of the forest is separated and given over to him, such a proceeding is at the option of the owner, - as a means of compensating for and getting rid of the right.

(c) The right is always a limited one; it can be exercised so only if while fully and fairly enjoyed it does not attack the substance of the forest: it can never exceed the normal regular yield of the forest nor its capacity to bear the right without deterioration in the case of grazing, soil-litter, etc. etc.

(d) When a right is undefined in its character, and has not been reduced to definite terms, it is always understood to be limited to the actual needs of the person, or the dominant estate (as the case may be), in his or its normal condition as it was when the right originated. If a peasant has a right to wood for "building his house," it means such a house as is usual in the locality, not a large villa or whole range of farmbuildings. *

(e) The right must be exercised so as to interfere as little as possible with the regular management proper to forests of the normally existing class or kind; it cannot prevent the restoration of an ill-used forest, or the proper planting operations and production of young growth.

(f) On the other hand, the forest owner cannot claim to alter the character of the forest, or its general destination so as to affect rights; and where one mode of proper working would provide for the rights while another would not, the owner must make his working-plan so as to provide for the rights. $\dagger$

* See Baden-Powell, " Forest Law," p. $290 . f f, 328$.

† See "Forest Law," p. 294 ff. In England we have a recent example which illustrates the rule that a forest owner cannot alter the entire destination and character of his estate to the prejudice of right-holders ; and at the same time is a rare instance of forest rights being beneficial (from a forest point of view). In the case of Epping Forest, the right possessed by the commoners to lop the trees 


\section{The Disadrantages Arising from Forest Servitudes.}

The chief disadvantages to forests, from the existence of rights-of-common are :-

(a) Limitation of the owner's power of managing the forest in the best possible manner, or of converting it, and so forth. An insuperable obstacle to systematic management in English woodlands subject to rights-of-common, is, that they cannot be enclosed, or fenced. Such woodlands pay no rates, and thus, the general public has to pay for the privileges of the right-holders, often a few neighbouring land-owners, who obtain a higher rental, than they would otherwise, from the farmers, or cottagers, who exercise the rights.

Some servitudes affect the control more than others, and it is noteworthy, that it is generally not any one right that is objectionable; the difficulty arises from the aggregate demand for a number of right-holders, both as to the quantity of produce, area of grazing, etc., which they require, and also the number of persons introduced, to graze flocks, gather wood, etc.

(b) Even rights-of-way and other rights which take nothing from the forest, give occasion to accidental trespass, to forest fires, and perhaps to wilful offences.

(c) The forest owner is tempted to be less careful of his forest, and is deterred from expending capital on its improvement.

(d) Both the labour and cost of protection are considerably increased when forest rights are numerous.

was enforeed when the lords of the manors wished to enelose the forest areas, ineluded in their manors, and had even proceeded so far as to elear a thousand aeres of forest and subdivide it into building allotments. They claimed the power to purehase the right of lopping from the right-holders within their own manors. The right-holders, on the other hand, claimed that their right extended over the whole forest, and not over any particular manor, and this view of the matter was eventually aeeepted by the High Court of Justice after a protracted judieial inquiry. Thus it was deeided that the lords of the manors could not free their respeetive manors from the rights without satisfying all the rightholders, in whatever manor they might reside. This deeision saved Epping Forest from being eonverted into building-sites, and the City of London erentually purchased all the manorial and lopping rights in the forest, the latter for $£ 7,000$, and now only rights of pasture and pannage are exereised by the commoners. 
(e) And so are the risks of offences, and forest fires.

(f) Control of the right-holders involves much otherwise unnecessary work both in the office and forest.

(g) The revenue from a forest is reduced, not only by loss of produce, but also by degradation of the soil owing to pasture or removal of litter.

(h) Disputes arise, and risk of litigation, and of ill-feeling culminating in revengeful attempts to burn or otherwise injure the forest. Forest right-holders are also tempted to presume on their position and encroach on the rights of the owners.*

Looking at the question from the broad point of view of political economy, forest servitudes encourage extravagance in the use of wood, and establish a backward style of agriculture, as regards the use of litter for manure, loppings for fodder, and forest grazing, which may in the end overtax the forest and result in serious forest destruction and consequent injuries to the country, from floods, landslips and other physical evils against which forests are a natural and often effective protection.

The degree of danger incurred, irrespectively of the character of the servitude, depends on the conditions of the locality and the density of the standing crop. A completely stocked wood, on favourable site (as regards slope, exposure, etc.), and with a mild climate, suffers (proportionately) least of all.

\section{Equitable Principles in Dealing with Rights.}

Where forest laws exist, there is usually provision for the record of all forest rights, and for the definition of those which

* In the New Forest, the present tendency is for commoners to exaggerate their rights at the expense of those of the Crown; and in 1894 they attempted to prevent the Crown from erecting a saw-mill and exercising other rights of ownership in the forest. In the Forest of Dean, since 1857, grazing by sheep is largely practised ; and it remains to be seen whether the Commissioners of Woods and Forests will be able to stop this practice, which is fast ruining the Forest of Dean, for centuries the most productive oak forest in Britain. Sheep are not beasts-ofcommon by English law (see "Williams on Rights of Common," 1880, p. 232), and no prescriptive right to sheep-grazing can arise in England; the question is whether local feeling in favour of the commoners will be allowed to override the national interest in this matter. 
are claimed in indefinite terms. It is hardly necessary to remark, that every claim must be proved: the natural presumption is that the owner's enjoyment is not limited-it is for the person who asserts a right to any use or produce limiting the enjoyment, to prove it.

The forest estate should always possess the means of referring to documents conferring rights, and if there is a serious doubt about terms, the sooner a judicial decision is obtained the better. Nothing is gained by "letting sleeping dogs lie"-for in this case uncertain rights are not "sleeping"; they always tend to grow more difficult to settle, and are ultimately fixed in a form that perhaps was never contemplated.

It may be confidently stated that where indefinite rights exist all rational management is impossible until they are properly defined.

The forest'owner has, in general, a right to share in the produce of the forest, along with the right-holders.*

Attention should be paid (p. 64) to the legal principles stated, especially as regards the limitation of undefined rights to the actual needs of the person or dominant estate, and to there being no right (in general) to a surplus which may be sold or turned to an extra profit. Also to the limit that cannot be exceeded, when the yield-power (possibilité) of the forest is in question.

On the other hand it must be borne in mind that while the forest right-holder has his obligations and must submit to those reasonable restrictions which are necessitated by proper conservative management, the forest owner has a duty on his side. He cannot adopt special methods of management (however desirable in themselves) that would destroy the rights; and the working-plans should be prepared with the express object of providing for such rights as exist, and which (especially in certain localities) are almost indispensable to the welfare of the present population. $t$

New rights ought never to be allowed (by neglect, etc.) to

* See Baden-Powell, "Forest Law," p. 397.

† See "Forest Law," p. $294 \not f$, where the correlative right and duties of the right-holder and forest-holder are discussed. 
grow up in forests even when there is no forest law which expressly forbids such growths. Nor can the State or other owner grant new forest rights to the prejudice of old and existing ones.

\section{Protective Measures.}

From the point of view of the forest owner, the following measures are desirable :-

(a) Clear demarcation of the portions of the forest burdened with rights, and those free from them or closed against them; and maintenance of distinct boundary lines; also indication by ditches or sign-posts, etc., of lines of right-ofway for cattle, etc.

(b) Careful record of rights-of-way, etc., use of water, as well as those to produce. Where there is a forest law, it is probably provided how this is to be done. Besides which all working-plans of the forest must contain a schedule of the rights showing:-

(i) Title-deed, or other origin of the right.

(ii) Exact description of personal holder or dominant estate; and the exact name, etc., of the servient estate or part of it affected.

(iii) The extent of the right, kind, number, quantity, quality, season of exercise, etc., etc.

(iv) The mode and conditions of exercise, and whether any particular duty is laid on either side (e.g. providing a competent herdsman for the cattle, providing cattle-bells, or the forest-owner maintaining culverts, etc., for a roadway).

(v) Any payments, or returns in labour, due to the forestowner for the exercise of the right.

(vi) A notice of any obscure or disputed points.

(c) Careful watching of the exercise of forest rights by the forest guards and inspecting officers. But the caution already given about irritating and vexatious interference should be borne in mind.

It is only necessary to add that where the rights are such that the forest is seriously threatened, then efforts must be made to get rid of them by commutation or cantonment. The rights should either be purchased from the right-holders 
(commutation), or a portion of the forest set apart in perpetuity as a common for their exercise and handed over as property to the body of right-holders (cantonment), and the remainder of the forest declared free of all rights. Such commutation, or cantonment of rights in a State-forest require the sanction of an Act of the Legislature.

Section III.-Special Account of the several Forest Rights.

This section is concerned with some rules applicable to each particular kind of right, for which purpose the following list of "forest-rights" is given :-

\section{Wood-Rights.}

(a.) Building-timber.

(b.) Wood for industrial purposes and agricultural implements.

(c.) Firewood.

(d.) Softwoods.

(e.) Dead, or fallen wood.

(f.) Lop and top.

(g.) Stumps and roots.

(h.) Windfalls and broken trees.

(i.) Dead standing trees.

2. Rights to Minor Produce.

(a.) Bark.

(b.) Turpentine and tar.

(c.) Leaf-fodder.

(d.) Grass (cutting or gathering).

(e.) Pasture.

(f.) Collecting acorns and beech-mast.

(g.) Pannage.

(h.) Litter.

(i.) Quarrying or digging pits for sand, gravel, turf, etc.

(j.) Gathering berries, wild fruit, hazel-nuts, fungi, etc.

(k.) Shooting and fishing. 


\section{Sundry Rights (Easements).}

(a.) Rights-of-way.

(b.) Rights to water, water-channels, use of springs or wells, to water cattle at streams, etc.

(c.) Rights to float timber.

(d.) Right to burn charcoal, to stack wood, etc.

\section{Wood-Rights.}

Under the above term is understood either a right to claim from a forest a certain fixed quantity of wood, or as much as may be necessary for certain purposes. Such rights may, or may not, be subject to certain payments to the owner of the forest. It is generally stated what kind of wood is the subject of the right, thus, it may be building-timber, timber for implements, or firewood. Sometimes the title-deed merely mentions "necessary wood," under which term firewood is generally understood. The forest manager has the right of delivering the wood, and certain days may be fixed for its removal:

A defined right to wood is fixed as regards quantity and form, and sometimes as regards species.

When the species is not mentioned, the right-holder must be satisfied with wood of the prevailing species, provided it is suitable for the purpose required.

An undefined right to wood is limited to the requirements of the right-holder or the dominant estate; for instance, the actual house of the right-holder, not his sheds and farm-buildings (unless those are equitably included).

The owner of the burdened forest must manage it so that the wood which is the subject of the right may continue to be produced. For instance, where there is a right to buildingtimber, the forest cannot be converted to coppice.

The right-holder may not sell his wood, but must use it for the purpose for which it has been granted to him.

\section{a. Building-Timber.}

The supply of building timber to right-holders should be fairly proportional to the number and size of the buildings 
which existed at the time of the acquisition of the right. Often the right applies only to wood for the exterior of the house, but may include wood for wainscots, windows and doors.

When repairs to a building become necessary, a regular estimate of the requisite amount of timber should be drawn up ; and the wood must be used within a fixed period. When a new house is being built, all still serviceable wood from the old house must be deducted from the estimate. It is usual for the right-holder to pay the cost of extraction of the wood, even though he pays nothing for the wood itself. In the Himalayan forests, right-holders usually fell the trees and convert the timber for themselves; in some cases the rightholder is allotted annually a certain number of trees for houserepairs or building; in other cases the right-holder is put down as being entitled to what is needed on application, for the particular work. Account has here to be taken of the ignorance of the people, and their ancient but wasteful habit of preparing beams with the axe or adze-chipping away a whole stem for one beam. By loan of saws, and by issuing suitable beams ready prepared, it may be possible to overcome this defect, which leads of course to much waste of material.

The work of the forest staff is considerably burdened by rights to building-timber, as the correctness of the estimates has to be tested, and the amount of wood granted to be entered on special registers. It is clearly the duty of forest officers who manage large areas of State or municipal forests subject to rights for building-timber, to know thoroughly the customary forms of building of the locality and the proper dimensions of beams and other timbers used in the construction of houses, or they may be called upon to grant much larger quantities of timber than is necessary in particular cases.

\section{b. Wood for Industrial Purposes.}

This right (as claimed) may be defined, or not, in its nature and extent. In general, it comprises timber required for ordinary agricultural and domestic objects, such as wood for carts, ploughs, hop-poles, vine-props, etc. Wherever the right is undefined, the quantity should be fixed, so as to correspond to the amount required at the time of acquisition of the right, 
extent of hop-garden, vineyard, etc. This right, if indefinite, interferes greatly with the development of the revenue of a forest.

\section{c. Firewood.}

Rights to firewood (as claimed) may be either defined or indefinite, and in the latter case the amount granted would be only what is required for the household of the right-holder, including such ordinary household requirements as heating, cooking, washing, baking, drying fruit, etc. Requirement for industrial purposes such as distilling, etc., is not included. As a rule, the wood is prepared by order of the owner of the forest, and must be taken from all classes of firewood in due proportion, split and round wood, dead wood, stump-wood and faggots. Occasionally the right-holder is permitted to cut and remove the wood, especially where it is brushwood or small coppice stuff.

In case a forest burdened with this right should be damaged by some calamity (storm, insects, etc.), which causes an excessive yield in any particular year, then several years' supply of firewood may be granted to the right-holder, in advance, but the latter cannot claim this as a right.

\section{d. Softwoods.}

Where the right is to "softwoods," termed in France bois blancs, in Germany, Weichholz, the question is to decide on the meaning of the term. It may be interpreted as including inferior softwood species which are not the object of the management of the forest, and therefore only appear in trifling quantity, and can never get the upper hand under a proper treatment. The following species are generally included under this head:-Aspen and other poplars, the sallow and other willows, limes, hazel, thorns and other shrubs, sometimes also alder and birch, even Scots pine: mostly trees which spring up amongst young growth, and are removed in the cleanings.

\section{e. Fallen Dead Wood.}

All dead branches and twigs lying on the ground, and refuse from fellings which the owner does not require, are F.P. 
generally included under this heading. In some cases also are included dead branches, which can be broken off by hand from standing trees. In many forests, dead standing stems up to a certain girth are also included, and stump-wood as well. The meaning of the term fallen dead wood must therefore be decided locally, but it is rarely taken to include saleable fallen timber. This distinction is thoroughly recognised in North-Western India. Cutting tools must generally be prohibited, but a wooden rake may be allowed for collecting the fallen dead wood on the ground. If there is only a small quantity of dead wood available in a forest, the right-holder cannot claim other wood to make up a full supply. The sale of such wood is not usually permissible, as the servitude is for household requirements.

Within properly regulated limits this usage is only slightly hurtful to a forest, though all dead wood eventually becomes humus.

\section{f. Lop and 'T'op.}

This right is generally to the crown of a felled tree from the place where the stem is cut off by the woodman, at a certain fixed girth, and to the lower branches lopped off the stem. The right-holder cannot take possession of the wood until the stem has been severed from the crown. The only serious disadvantage caused by this right to the owner is that he cannot well manage his forest as Coppice, or Coppice-withStandards, as the greater part of his produce would then go to the right-holder.

If, however, the right-holder has the right of lopping the crown from standing trees, great injury will accrue to the forest. In such a case the right must not be exercised during the growing season, and only in compartments where the trees are ripe for the axe, and at a certain height from the ground. A particular form of this servitude is the right existing in certain forests to lop birch-trees for brooms.

\section{g. Stumps and Roots.}

This right is admissible only in High Forest, and the owner cannot then convert his forest into Coppice, or Coppice-withStandards. 
Unless it is distinctly laid down to the contrary, the owner can fell his trees as low as he likes. The right must be suspended wherever its exercise would damage the forest, as for instance in regeneration-fellings well stocked with young seedlings, on steep slopes where landslips or erosion are to be feared, or on shifting sands. Sometimes the right-holder is under the obligation to fill up the holes made in extracting the stumps, and to sow or plant-up the ground. The right may also be limited to certain months, days, or hours.

\section{h. Windfalls and Broken Trees.}

The right may be to all or merely to certain categories of this material, wood broken by wind, by snow, or rime. Trees which are bent down, but may recover themselves, are not included, nor are portions of trees still rooted in the ground. The right. can extend only to single trees broken here and there, not to whole woods broken down and uprooted, as occasionally happens by an exceptional storm or calamity which is not in the contemplation (naturally) either of custom or a grant. The right-holders may use implements to convert the timber. This servitude is not of sylvicultural importance.

\section{i. Dead Standing Trees.}

Poles and trees which have died naturally are included in this class, and care must be taken to exclude all those which may have been killed intentionally by damage, girdling, etc. This usage gives rise to trouble between the right-holder and the owner, as the latter will endeavour to remove dying trees before they are actually dead, and the former to claim trees not yet quite dead. To prevent such contentions it is better to fix definitely the period at which thinnings of dead wood can be commenced.

As in the former case, when a large extent of wood is killed by injuries from storms, etc., the produce is not the property of the right-holder. 


\section{Rights to Minor Produce.}

a. Bark.

In Europe this right is generally restricted to the bark of trees yielding tannin, such as oak, spruce, larch and birch.

The bark can be claimed by the right-holders only from felled trees in regular fellings. The right may be either by quantity or by number of trees, or commensurate with the requirements of the right-holder. The owner must fell during the growing season when the bark can be easily removed.

Lime-bark, or bast, for cordage and matting is sometimes the subject of a right, and then similar rules must be followed. In India, bark of Betula Bhojpatra is used for making umbrellas and paper, and the bark of many species of trees for ropes and cords; all these may be subject to rights.

\section{b. Turpentine.}

Rights to tap the spruce or the Austrian pine for turpentine frequently exist. The number and size of the trees to be tapped, as well as of the cuts to be made in each, may be defined, or not. In any case the usage must be restricted to nearly mature woods, and there should be a close-time between successive tappings of the same tree, the season during which the usage is permissible must also be fixed. As turpentine is usually an article of commerce, it may be in the nature of the right that there is no restriction to household requirements, nor as to the sale of the produce.

This is a most hurtful servitude, as tapping for turpentine, especially in the case of the spruce, results in a loss of increment, and lessens the quantity of timber in the base of the tree, and also introduces spores of fungi and insects into the wood, causing disease.

\section{c. Leaves for Fodder, etc.}

This is the right to pluck leaves from trees, especially for feeding cattle in stored and simple coppice. Implements may not be used, nor can twigs be broken off. If the demand for leaves cannot be supplied from the regular fellings, then 
certain compartments may be opened for plucking leaves as far from the ground as the hands can reach, but only after late summer.

In various parts of India leaves of forest species are used for cattle-fodder, for thatching, for wrapping up goods at a market, as plates, for making umbrellas, cigarettes, etc., or for manure, and sometimes these customs may have become prescriptive rights. In such cases protective rules similar to the above should be enforced.

Where foliage and branches are lopped for litter or fodder, as in the Himalayas and in other parts of India, where, owing to the absence during winter of fodder-crops or natural herbage, leaf-fodder is wanted, and a prescriptive right has been acquired, it is by custom limited to certain species, and certain protective measures can be adopted. These are:-

(i) No lopping to take place till after the principal growth of the year is over.

(ii) To restrict the usage, as much as possible, to woody climbers and species of little value as timber-trees.

(iii) To forbid the lopping of the leading shoots of the trees, and to restrict the lopping of side-shoots till they have attained certain dimensions and only to a certain height up to the stem.

(iv) To give the trees a rest so that the same tree is not lopped in two consecutive years.

(v) Should the right apply to more valuable timber trees it should be restricted to compartments which will shortly be cut over. The use of leafy twigs and branches of trees felled in the ordinary course cannot harm the forest.

(vi) Where the demands for this kind of fodder or cattlelitter are large, and cannot otherwise be met, a regular system of pollarding should be introduced, with a fixed rotation giving the trees time to recover between successive cuttings. Such a system prevailed in Epping Forest prior to 1878, when the right was commuted. The loppings of hornbeam-pollards, of which this forest is chiefly composed, were not, however, used for litter only, but also for making fences, hurdles, etc., and then a rotation of ten years was fixed; in the former case, the trees were lopped annually. 
Another case in Western India is the use of green branches, termed $r a b$, as manure in rice-fields. Here similar rules should be adopted as long as this practice is allowed.

(vii) In every case where leaf-fodder is used by rightholders, the people should be induced, as far as possible, to cut and preserve hay or ensilage, or to grow root-crops for the winter-fodder of their animals. Leaf-fodder from forests will always prove a valuable resource when other fodder fails, as was the case in France and Germany during the drought of 1893 .

\section{d. Grass for Fodder, Thatch, etc.}

Rights of cutting grass are also of very common occurrence under the coppice systems, and they should be limited according to locality, time, and mode of exercise, the limitations which prevail varying according to local law or custom. They can commence only at a certain age of the wood, and the closetime must be regulated according to species, and to specified days, when the forest guard can supervise the grass-cutting. Sometimes the grass must be plucked by hand, or sickles or scythes may be used; the latter instrument is evidently not admissible amongst young plants. If properly regulated and supervised, this usage does little or no harm on moist fertile soil, and may even assist in fire-conservancy by removing a great source of danger, and also prove useful during the reproduction of the forest. It is also often usefully allowed as a compromise for grazing when that cannot be allowed, and yet the stoppage is a hardship.

\section{e. Forest Pasture.}

This right allows the holder to graze his own cattle on the grasses and other herbage springing up in a forest belonging to some other person. The right to cut grass is not included. The forest owner has the power of closing certain areas in his forest, but cannot introduce changes of the system of management which will prejudice the right.

The species and number of grazing beasts may be defined, or not. If the species is not mentioned, animals such as the 
goat* and sheep, which are highly detrimental to forest growth, must be excluded, as in France they are by law, in spite of any right to the contrary. If the number of beasts is limited, sucklings are not counted in the total number admitted to graze. Should the number be undefined, as is generally the case, only so many head should be admitted into the forest as can be provided for without serious injury to the forest. $\dagger$ Unless specially stated, cattle intended for trade cannot share in this right. The right-holder must engage a herdsman to look after his cattle and is responsible for his conduct. The beasts can enter and leave the forest by authorised paths only. The fencing of closed areas is not obligatory on the forest owner, although fences prevent much contention and further his interests. The right of grazing his own cattle in his forest appertains, in every case, to the forest owner, unless the contrary is specially laid down; but he cannot graze them in portions of the forest that are closed to the right-holders' cattle.

\section{f. Acorns, Beech-Mast, and Fruits generally.}

The kinds of fruits to be collected will ordinarily be specified in the deeds regarding the right. The fallen fruit can be picked up only in compartments opened to the right, and on fixed days; the right-holder is held responsible for all damage done to the standing-crop. Plucking the fruits, and the use of iron rakes to collect it, are forbidden, and the usage must be limited to household requirements. Compartments, the fruit of which is required for natural regeneration, can be closed against this right, which does not include the right of pannage.

These rights do little or no damage to the forest.

\section{g. Pannage.}

This is the right to drive pigs into another person's forest to feed off the acorns and beech nuts, etc., lying on the ground, but the right of collecting the fruit by liand is not included.

An estimate of the quantity of mast in any year on which

* The possibility of prohibiting goats in India is discussed in "Forest Law," p. $349 . t f$.

† See p. 332 "Forest Law" as to the rules for fixing the number. 
the number of pigs to be admitted into a forest should be based must be prepared by an expert. The right-holder can only drive his own pigs into the forest, and the forest owner has an equal right. The pigs should be withdrawn when most of the acorns are eaten, or they will damage the forest. This servitude does little harm, but is becoming rare in Europe, as stallfeeding of pigs is more profitable. Pannage is still practised in the New Forest (vide p. 31).

\section{h. Litter.}

Litter to which right-holders are entitled may be defined or indefinite in amount, and may also be of special kinds; dead leaves and moss, weeds, etc.-in short, the right to strip the surface of its covering down to the soil may be implied.

An undefined right to litter means the right to take what is sufficient for the requirements of the right-holder, and in this amount, straw from his own lands must be reckoned. Owing to the prejudicial nature of this right on the fertility of the forest, it must never be stretched so far as to include the whole of the litter a forest may contain.

The necessary limitations as regards locality, time and manner of exercise of the right have been already given.* Sod-cutting should never be allowed, except from blanks, as where trees are standing, the roots would be exposed by this practice. The exceptional hurtfulness of this right to the productiveness of a forest, and the possibility that it may lead to its complete ruin, render it most essential that the forest should be freed from it by purchase or otherwise.

i. Quarrying or Digging Pits for Sand, Gravel, Turf, etc.

Rights to stones, gravel, sand, turf, etc., in another's forest, can extend only to places where the standing-crop and roads are in no danger from the right. Places for reception of refuse from the works, and export-roads must be designated.

These rights, if properly regulated, can do no injury worth mentioning, to the forest. 


\section{j. Collecting Berries, etc.}

The right is always unlimited in amount, and cannot be limited, as the produce is generally collected for sale. Except in the case of digging up truffles it is quite harmless to the forest, and need not be interfered with beyond fixing dates for its commencement and termination in any year.

Truffle-hunting, which is carried on with the help of a special breed of dogs resembling poodles, must be prohibited on the site of fellings, or amongst young growth.

\section{k. Shooting and Fishing.}

The right to kill game on another's property has been abolished by law in Germany. There, this right is not bound up with the ownership of the land, but is permitted only to an owner when his estate exceeds a certain area. It frequently happens, therefore, that the right of shooting on a number of small estates is leased in one lot, and the proceeds divided by the owners. In England, the Crown possessed rights to the game in certain manors, after it had parted with the other manorial rights, or actual property of the land, but these rights have now been surrendered, as in the Epping Forest. Baden Powell* states that in India no prescriptive rights to hunt in the State forests have ever been admitted; though people have always killed game in the forests, no right can have ordinarily become customary, for it is not necessary to the existence of agricultural villages, or communities, as is the case with grazing or wood rights. The question of hunting, with rules for the protection of game during the breeding season and when immature, is dealt with in different countries under special laws.

Fishing rights + in forest streams may exist, and are dealt. with by special laws regarding fisheries. These have chiefly reference to close-times during the breeding season;- and to protecting immature fish by fixing a minimum-sized mesh where nets are allowed; also to prohibiting the poisoning of streams, and other unsportsmanlike ways of catching fish.

* "Forest Law," pp. 338, 364.

$\dagger$ Regulations for the protection of game and fish in the State forests of India have been framed by the Local Governments of the different Provinces. 


\section{Sundry Rights (Easements).}

\section{a. Rights-of-Way.}

Rights-of-way if too numerous in a forest may tend to hamper the management, especially by causing danger from fire, and increasing the cost of fire-protection. It is therefore important to prevent new rights-of-way from arising by prescription, and where the law permits, to close altogether roads or paths which may have gone out of use, or others for which a more convenient substitute may be found. These rights may be subdivided into rights to footpaths, cart-roads (the right of removing timber over the land of a third party), or drift-roads (for the passage of cattle), ${ }^{*}$ the second category sometimes including the third.

In all these cases the question arises as to the legal breadth of the way, and whenever this is uncertain, it should be determined with reference to the breadth of the way required by the circumstances of the case, and according to local custom. The right of removing timber over another's land can be exercised only when the crops on that land would not be prejudiced by so doing, i.e. when the land is fallow, or when frozen, during winter. The right-holder whose cattle pass along a road to pasture, is responsible for any damage done to the forest growth beyond the limits of the road; and the owner of the forest, according to circumstances, may or may not be compelled to protect his forest by ditches, fences, or hedges.

\section{b. Rights to Water.}

Rights to water generally refer to the servient estate receiving the drainage water for a dominant estate, or allowing (not obstructing) the flow of (useful) water from the servient to the dominant. Sometimes it includes allowing a canal-cut, or irrigation channel being taken across the servient estate, in which case the maintenance of the water-channel is the business of the right-holder. Rights to use springs or wells in another person's forest, or to water cattle at them, all of which involve rights-of-way through the forest to the source of the water, are also included. 
c. Right to float Timber.

The kinds of timber to be floated should be specified and the owner of the stream has the same rights as the rightholders. The right of footpath along the bank of the stream may be also combined with this right, the breadth of the path being determined by custom. In India, this right is always exerciseable under the control of the State only.

\section{d. Rights of burning Charcoal, stacking Wood, etc.}

The sites where the charcoal is to be burned or the wood stacked, must be pointed out to the right-holder, and also the roads to be used for export, which should be as convenient as circumstances will allow. Wherever charcoal is burned, special precautions must be taken against danger to the forest from fire.

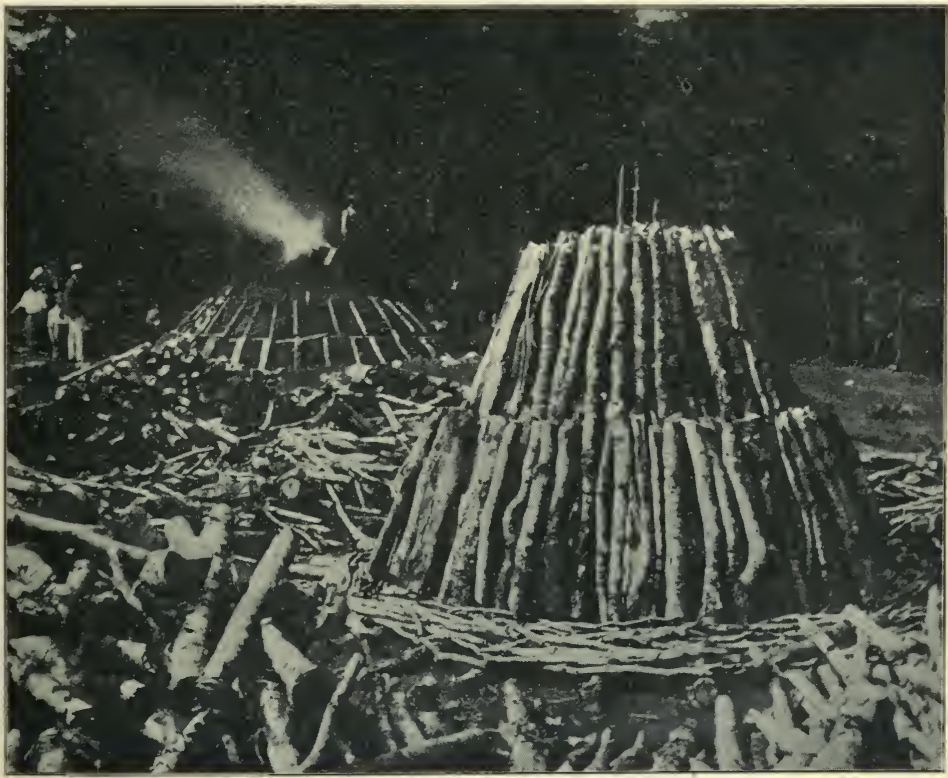

Fig. 21. - "Charcoal kiln in Black Forest." Photo by E. S. Carr. 



\section{PART II.}

PROTECTION AGAINST ANIMALS. 



\section{PROTECTION AGAINST ANIMALS.}

\section{INTRODUCTORY REMARKS.}

THe question of the usefulness or hurtfulness of wild animals indigenous in Europe may be considered from a forest, sporting, or agricultural point of view. Under Forest Protection only the forest point of view will be considered, but even under this heading some difficulty will be experienced, for the following reasons* :-

1. A number of animals are at the same time both useful and injurious to forests.

2. The degree of utility or harm done by one and the same animal differs according to its age, to local circumstances (season of the year, condition of the woods, etc.), so that it is hardly possible to lay down definitely that certain animals are absolutely injurious, or useful. Thus, the fox, though a great enemy to barn-door fowls and game, may be very useful, especially in a broadleaved forest, which suffers more than coniferous woods from rodents. Thrushes and blackbirds in spring and summer feed mainly on worms and insects, but in autumn chiefly on berries. The cuckoo and bats are always useful, while bark-beetles, the Nun-moth and other insects are absolutely injurious to forests.

3. The utility of certain animals to forests may be direct, or indirect. Thus the jay may be directly useful by carrying

* Intentional introduction of exotic animals to combat insect pests have not always proved advantageous. Thus, European sparrows were introduced into the N.-E. States of America in 1850 and 1867 to destroy canker-worms. The sparrows are now an unmitigated pest throughout N. America, while the canker worm has been replaced by a worse insect, which the sparrows never touch. Similarly the mongoose was introduced into Jamaica in 1872 to destroy the canepiece rat. This it did in ten years, but since then it has proved most destructive to ground-nesting birds, to insectivorous reptiles and batrachia, as well as to fruits and vegetables, so that the mongoose does much more damage than the rat. On the other hand the Australian ladybird (Vedalia cardinalis) introduced into California in 1889, has saved the citrus-growing industry from the cottony cushion scale, Icarya purchasi. 
about acorns, and dropping them in the forest, while certain mammals and many birds and insects are indirectly useful by destroying injurious mice or insects.

4. The injury done may also be direct or indirect; the former consisting in damage or destruction to forest produce, the latter in killing useful species. Most destructive kinds of animals are either mammals or insects, while birds are generally useful.

5. The amount of damage done to the forest depends on the species causing it, the local conditions, the season, etc. It is generally in inverse proportion to the size of the animal; the little bark-beetle, on account of its rapid increase and steady working, doing more damage to a forest than the large red-deer. The woodpecker is a good instance of the difficulties of deciding as to the amount of harm or good done to a forest by a particular species. This bird is useful in destroying numerous insects living in wood, but it sometimes damages healthy trees by boring holes into them, while these holes may be useful if subsequently occupied by bats or starlings, but injurious if occupied by stock-doves.

Protective measures in the case of animals may be either preventive or remedial, and will be dealt with under the following heads :-

Mammals $\left\{\begin{array}{l}\text { Deer and wild pigs. } \\ \text { Rodents. }\end{array}\right.$

Birds.

Insects.

As already stated, the present work can deal in detail only with European animals, but it may be mentioned, that in India, the Nilgai (Portax pictus) and the common antelope (Antilope bezoartica) do much damage in coppices and plantations adjoining agricultural land; whilst among birds, the pheasants and jungle-fowls do similar damage to that by grouse in Europe. For a fuller account and especially of Indian forest insects the reader is referred to "Indian Forest Zoology," * by E. C. Cotes, also "Injurious Insects in Indian Forests," * and other works by E. P. Stebbing.

* Published by the Superintendent of Government Printing, Calcutta, 1893. 


\section{CHAP'TER I.}

\section{PROTECTION AGAINST DEER AND WILD PIGS.}

\section{Section I.-General Account.}

\section{List of Injurious Species.}

Red-deer (Cervus claphus, L.).

Fallow-deer (Damus vulgaris, Brook).

Roe-deer (Cervus capreolus, L.).

Wild pig (Sus scrofa, L.).

\section{Damage Done.}

The above-named animals injure the forest by eating the fruit of trees, biting-off buds and young shoots, tramplingdown seedings, breaking-off leaders, bending-down stems, barking poles, exposing and gnawing roots. Further details regarding the damage will be given under the headings of each species.

The consequences of the damage done consist in loss of increment, stunted growth, diminution of timber as compared with firewood, increased danger from insects, fungi, storms, snow, etc. Hess considers it advisable to keep down the beasts by the efforts of the Forest Staff, and not to lease the shooting in forests, as this usually leads to inordinate numbers of deer, etc., and to great injury of the growing woods.

\section{Preventive Measures.}

The chief preventive measures are :-

(a) Formation in High Forest of large, connected regeneration-areas; small clearings in which game has not sufficient room, and strip-fellings near thickets or poles where the game habitually remains, suffer most of all. For sylvicultural reasons, however, very large felling-areas are not permissible. Periods 
of regeneration must be long and cleanings of inferior species delayed, until the shelter they afford to the better kinds of plants is no longer required.

(b) Covering endangered fruits, acorns, etc., in seedingfellings.

(c) Avoidance when possible of autumn-sowings, and preference of planting to sowing, the former with large and strong transplants. More plants per acre must be planted than where damage is not feared.

(d) Avoidance of the introduction of species specially liked by the game.

(e) Careful choice of system and great care in the management of forests containing game.

$(f)$ Care for the nourishment of the game by:-

Introduction of mast-producing species, oaks, chestnuts, etc., wherever the locality is suitable for them.

Protection of softwoods (aspen, willows, etc.) in cuttings frequented by game, and introduction of these if necessary.

Cultivation of fodder-crops for the game. Oats, buckwheat, turnips, potatoes, Jerusalem artichokes, clover, etc., according . to the species of game which is prevalent.

Encouragement of a growth of grass in the forest; stopping grass-cutting and pasture.

Feeding the game in the depth of winter, and when there is much snow on the ground. Loppings of aspen, willows, limes, or other softwoods, form suitable food in winter. The animals peel the bark from these loppings, and eat the buds and young shoots. Hay, unthrashed oat-straw, oats, maize, potatoes, etc., may be given and basic slag added to improve the horns of the stags. About one-thirtieth by weight of basic slag may be added to the fodder. The fodder should be placed in the older woods near water, and well distributed, so that several beasts can feed at once. In mountain forests, places sheltered from the wind and southerly aspects should be selected as feeding-places, as deer assemble in such places during winter.

\section{Remedial Measures.}

(a) Substantial fencing of forest nurseries and cultivations, or of the game-preserve. The kind and height of the fence 
to be used depends on the mode of life and size of the game. The fences must always be kept in good order. Digging a ditch outside the fence will afford additional security.

(b) Specially valuable trees should be separately fenced-in, or protected by rough stakes with the jagged ends of branches outside. Thorns, bad-smelling substances, or wire-netting may also be used.

(c) Scarecrows may be set-up in endangered localities, or dogs brought-in, blank-cartridges fired, etc. The scarecrows must be altered from time to time, as the animals get accustomed to them.

(d) Shooting-down the game to a restricted number which the forest can bear. Game need not be exterminated, and the chief difference between modern and old times consists in the fact that formerly the forest was managed for the game, but now it is recognised that the admissible quantity of game must be proportioned to the interests of the forest.

\section{Section II.-Red-Deer.}

\section{Damage Done.}

The damage done by red-deer consists in eating fruits, browsing, peeling, rubbing, trampling, etc.

\section{a. Eating Forest Fruits.}

The red-deer eats all kinds of fruits, but especially acorns, beech-nuts, chestnuts, mountain-ash berries, etc. Acorns are often beaten-out by the deer with their fore-feet and eaten, and sowings may be thus completely ruined.

\section{b. Browsing.}

The deer bite-off buds and young shoots, chiefly from late autumn till spring, and occasionally devour foliage in the summer.

The following species are preferred by red-deer: aspen, sallow, ash, oak, hornbeam, beech, ${ }^{*}$ maple, hazel, and amongst conifers the silver-fir and larch; the birch, alder,

* In the Ardennes, red-deer apparently leave beech alone. 
Scots pine, and spruce are least liked, but different circumstances, such as a mixture of species, system of management, growth of grass or supply of fodder, greatly influence the degree of damage done in any particular case. Deer and cattle are fond of tasting new and foreign species introduced into a wood.

In times of scarcity of fodder, young plants protruding through the snow may be completely browsed-down; in mound-planting this is especially noticeable.

Overshadowed plants are less freely browsed when compared with those growing in the open. Old stags and hinds do more damage than fawns, as they can reach higher. Southern and western aspects suffer more than northern and eastern ones, as the deer frequent the former in the winter. The lower parts of the warm aspects bordering on fields suffer most, as during winter the deer crowd together into such places. Here may be found those rounded, bush-like plants due to the annual formation of numerous side-shoots, exposed every year to the bite of the deer. The young plants also suffer much in frost localities, on account of their slow growth. Of great influence on the amount of damage done are the degrees of recovery shown by certain species, due to power of reproduction, rapid growth, and also to local circumstances. Beech and hornbeam recover well from browsing, although the former does not reproduce well from the stool. Oak when bitten also shows great power of recovery, the ash and maples less, also conifers, among which the silver-fir has the best power of recovery. The bite is, however, never clean, the deer having no lower incisors, so that recovery is difficult. Obviously, quick-growing trees on a rich soil, make the best recovery.

\section{c. Peeling Bark.}

A bad kind of damage done by red-deer consists in peeling the bark of trees, which is generally, but not always, eaten. Peeling is commoner in woodlands with a large stock of deer, that are fenced-in from the adjoining fields. 'The whole herd is probably taught to peel by one or two stags or old hinds. In open forests peeling is rarely practised. 
RED-DEER.

The following species are thus attacked :-

Chiefly spruce and oak.

Less, the ash, silver-fir, beech, hornbeam, maple, hazel.

Least of all, Scots and black pines, larch, alder, and birch.

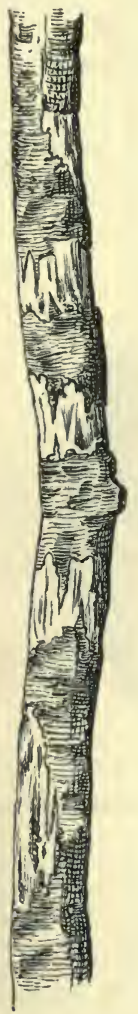

(Reduced.)

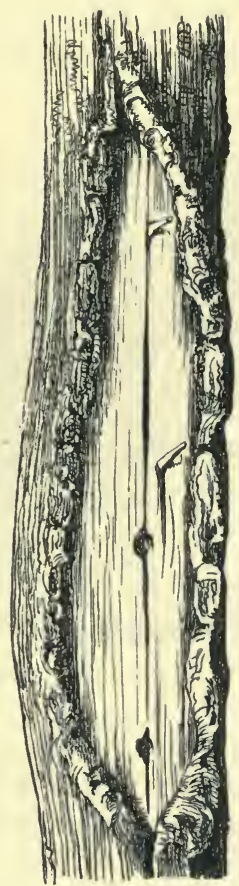

(Reduced.)

Fig. 23.-Summerpeeling.

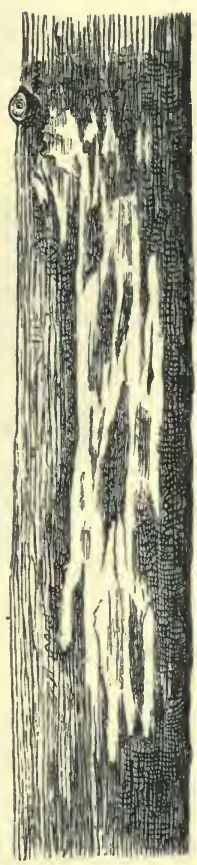

Fig. 24.-Winter-peeling on 40 - 50-year-old spruce.
18-20 years old, peeled by red-deer.

Spruce, from 20 to 40 years old, and 15 to 20 -year-old oak coppice-shoots are preferred, but spruce up to 60 years old are also attacked. In the case of Scots pine, after 20 years the bark becomes too thick to be injured. Well-thinned compartments are preferred, as the deer can get about better in them, 
and prefer a sappy bark developed in the light. The stag does the most damage in this way. The bark may be removed from all round the stem, or in strips. The former is much more hurtful, but is rare. Strip-peeling may be done on both sides of stems, but usually in spruce only on one side, the west and east sides being preferred. In the case of the oak and beech, the bark is often stripped-off in patches one above the other, as shown in Fig. 22.

The bark may be peeled in winter or summer, in the former case from absolute hunger. In the latter case, the deer bite

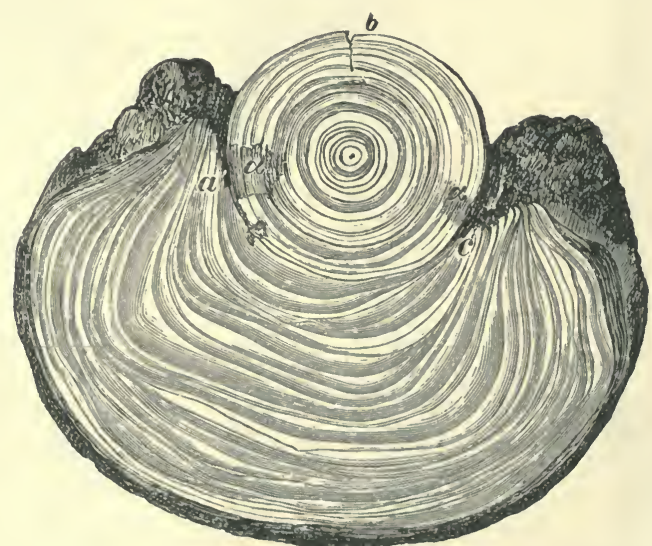

Fig. 25.-Transverse section of a spruce-stem peeled in summer (reduced).

through the strip of bark from below, hold it with their teeth, and then, walking backwards, and raising the head, strip it off in long pieces, which cause serious wounds in the tree. Their length may be 6 feet, and breadth from 2 to 6 inches, and they may reach down to the roots, but generally stop at about 2 feet above them.

Winter-peeling is generally less serious, the deer gnawing off and eating pieces of the outer bark, leaving the bast and part of the bark between the bared strips. When deep snow is on the ground these wounds may be pretty high up the stem.

Peeling is generally done in the morning after the deer have eaten a meal, and after rain, which softens the bark. 
The disastrous consequences of peeling consist in loss of increment and the formation of badly-shaped boles by the

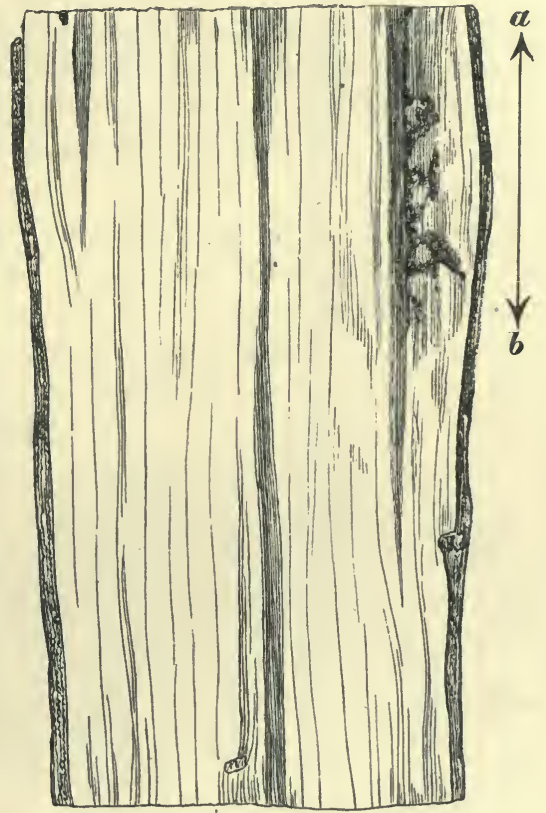

Fig. 26.-Longitudinal section of an oak-stem peeled from $a$ to $b$, and occluded. (Nat. size.)

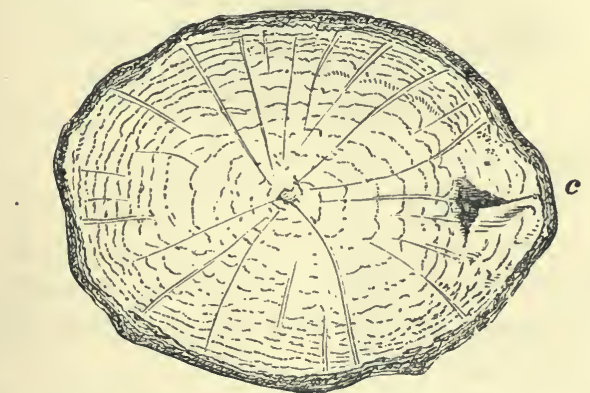

Fig. 27.-Transverse section of same oak. c. Injured spot.

bulging-out of the annual rings of wood, which may render the trees lop-sided, as shown in Fig. 25. 
Occasionally peeling gives rise to the formation of ad. ventitious buds from below the wound, and frequently to decay, such as red-rot in spruce, or Peziza Willkommii in larch. The stems which have been attacked become unserviceable except for fuel, and the tree often gets broken by wind or snow at or just above its injured portion. Insects, such as barkbeetles and wood-wasps, frequently attack the tree, which will die if completely girdled.

Such injuries to broadleaved species are soonest healed in the case of the oak. In favourable cases only little damage may be done, leaving small local traces of decay (Figs. 26 and 27).

The newly-formed rings of wood, however, never completely repair the damage when the sapwood has been exposed,

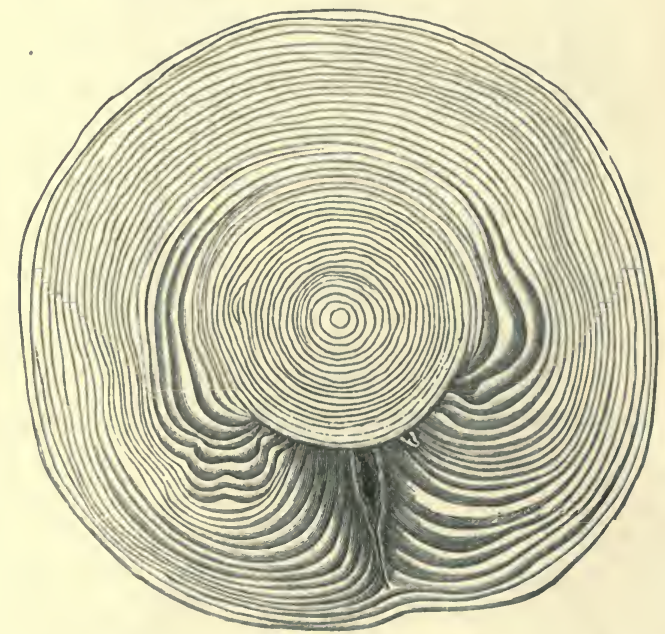

Fig. 28.- Transverse section of a $60-80$-year-old spruce, which has been occluded after being peeled by red-deer.

though they may occlude it. Wounds of the ash also recover rapidly, although the wood of this species is easily injured. Beech and hornbeam recover with greater difficulty, and the maple more slowly still.

Amongst conifers the following scale is in descending order of power of recovery:-

Silver-fir, larch, Weymouth and Scots pines, spruce. Such a thorough recovery as is shown in Fig. 28 is very rare. 
The gravity of the damage done depends, in other respects, on the size of the wounds, the season, repetition of the injury to the same tree, age of the wood, and nature of locality. Summer-peeling is more injurious than winter-peeling, although in the former case the antiseptic nature of the outflow of turpentine is to some extent a compensation.

At the commencement of spring most damage is done in this way. The younger the wood, the more fertile and moister the soil, the quicker the damage is repaired.

Bark-peeling by red-deer is a new habit; as long as mixed woods under the Selection system and coppice-with-standards offered plenty of nourishment, the deer left the bark alone, but the present density of growth, which excludes grass, and the substitution of conifers for broadleaved species, have rendered fodder scarce in the forests, and it is possible that the deer eat the bark medicinally, as well as from hunger, and also partly from sportiveness.

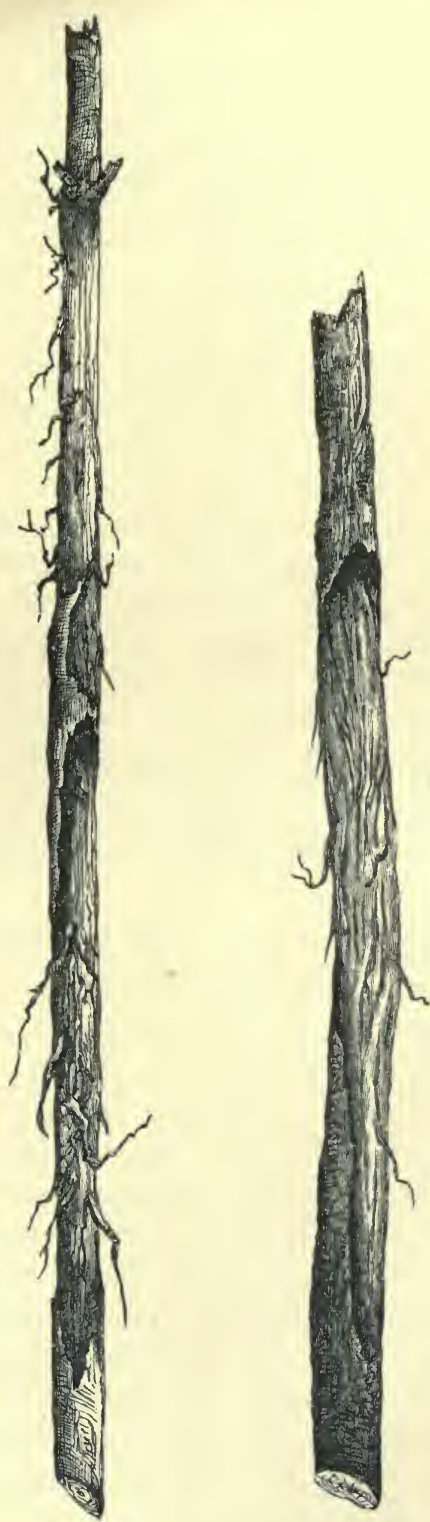

Fig. 29.--Spruce saplings rubbed by red-deer. 


\section{d. Rubbing and Striking.}

The stags rub their antlers against trees to remove the velvet at the end of July and August, generally by night, arrd they select for the purpose slender smooth poles of lime, aspen, sallow, larch, Weymouth-pine, silver-fir, maple, etc., especially when these species are scattered among other forest growth. Scots pine poles are also injured in this way by deer in the Ardennes.

Stags also strike their antlers against trees at rutting-time in September and October, and before they lose them in March and April. The damage done in this way is less than by peeling, as the same trees serve over and over again for the purpose. It can readily be distinguished from peeling by the filaments of bark which occur on the wound, and by the hairs of the deer adhering to it, from the deer's habit of rubbing its neck on the peeled stem.

\section{e. Trampling.}

Damage done by trampling is confined to young growth and sowings of conifers; 1 - and 2-year-old plants on steep slopes with loose soil suffer most of all, being frequently uprooted.

\section{f. Total Amount of Damage.}

More experience is required regarding the total amount of damage done to forests by red-deer. A forester who is at the same time a sportsman, should endeavour to ascertain clearly the amount of sacrifice of income his sport involves, so that he may be able to keep the number of deer within proper limits. Until the damage done under certain circumstances has been properly observed, sympathy with sport, or antipathy to it, give the question a wide range. It may not be possible to estimate the proportional amount of damage done respectively by browsing, peeling, trampling, etc., but in a forest frequented by deer, certain compartments might be fenced and others left open, and comparative yield-figures ascertained, from which the extent of the damage done, in the latter case, may be deduced.

As regards the damage to meadows adjoining forests that 
contain red-deer, Ihrig states that in the Odenwald, at Eulbach, 31 per cent. of the normal yield of hay is lost annually by the grazing of red-deer, the loss being estimated at 6 cwt. per acre, or $3 \frac{1}{3}$ cwt. per head of deer, worth $24 s$. (F. u. J. Zeitung, 1890, p. 451). The Exmoor deer feed chiefly on the adjoining farm-crops, the damage they do being very considerable.

\section{Protective Measures.}

Besides the general rules given above (p. 84), the following special rules relate to red-deer :-

\section{a. Maintenance of a Moderate Number of Deer.}

A sufficient number of deer must be killed annually so that the stock in a forest is not incompatible with economic forestry.

As the term moderate varies with the species of tree grown, the system of management, locality, nature of boundaries and grass-production, it is impossible to give good average figures.

According to G. L. Hartig, on 2,500 acres of forest the stcck of deer in the spring, before the young are born (May to June) may be as follows :-

Broadleaved Forest. Red-deer. Roes. Wild

Forests bordering on other Pigs.

forests $\quad . \quad \begin{array}{lllllllll} & . & & 8 & \ldots & 8 & \ldots & 4\end{array}$

Forests bordering on fields $\quad \begin{array}{llllll}4 & 4 & \ldots & 8 & \ldots & -\end{array}$

Forests surrounded by fields.

Ratzeburg considers 16 red-deer per 2,500 acres the proper number. In Compiégne forest, 20 deer for 2,500 acres are allowed.

Prince Charles of Schwartzenburg states that in Bohemia 15 to 35 head of red-deer are admissible, and places one reddeer as equal to two fallow-deer or four roe-deer. Von Dombrowski allows 40 head. These figures approach those for a forest overstocked with deer. Unfortunately as many as one head per 25 to 40 acres of woodland occur in many forests in Thuringia, the Harz and Taunus, so that economic forestry becomes impossible. 


\section{b. Sufficient Fodder must be Supplied to the Deer in Winter.}

Oats, turnips, acorns and chestnuts are best. Basic slag should be mixed with the food, as already stated (page 98 ). Feeding only with hay or leaf-fodder causes the deer to fall-off in health, and prevents the formation of good antlers, whilst acorns are best for the latter. The fodder should not be given on felling-areas, nor near recent thinnings, as the deer loiter about near the feeding-places and cause damage. Owing to the scarcity of food, antlers in the Highlands of Scotland are very poor when compared with Continental antlers, or those from English parks, or from Exmoor.

\section{c. Fences against Red-Deer.}

These should not be less than 7 feet in height, and on slopes another foot may be added to prevent the deer from leaping the fences.

\section{d. To Prevent Browsing.}

Young forest growth may be sprinkled with blood and cowdung, or open jars full of blood buried in the ground. Coaltar may be lightly painted on strong young conifers, excepting the buds. It is best done by passing the shoots lightly through the hand covered by a tarred glove. This should be done from September till November, and repeated when necessary. 'T'he spruce stands this treatment less well than the Scots pine, and broadleaved species suffer from the practice. 'I'he cost is not high, about $2 s .6 \mathrm{~d}$. an acre, including the purchase of 6 lbs. of tar. A woman can tar 300 plants in an hour.

Broadleaved species may be daubed with the following mixture :-

\begin{tabular}{|c|c|c|}
\hline Carriage g & rease & \\
\hline Petroleum & . & \\
\hline Alum & . & \\
\hline I'allow & . & \\
\hline
\end{tabular}

This gives enough for 600 plants. Plants may also be limed, the terminal buds being smeared with a brush dipped in whitewash. 'This costs for silver-fir 1s. 6d. per 1,000 plants, 
or $2 s .4 d$. an acre; $10 \mathrm{lbs}$. of lime are required for 1,000 plants. A woman can lime about 500 plants in a day on a slope, and 3,000 plants on level ground. This gives better results than tarring the plants, and the lime apparently does them no injury. Refuse hemp may also be lightly placed over plants, as it clogs the teeth of the deer and has proved efficacious.

\section{e. Measures to Prevent Peeling.}

Delay thinnings, so that deer cannot penetrate amongst saplings.

Pieces of rock-salt should be scattered about for the stags to lick, or the following composition :-

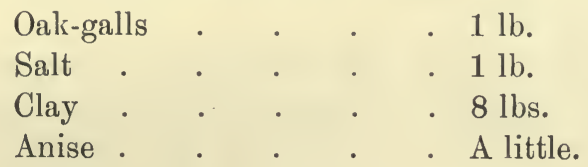

The galls should be Istrian, which cost 50s. a cwt. Each piece suffices for 100 acres of forest.

Beasts detected peeling bark should be shot, as young deer soon follow their example.

\section{f. Measures to Prevent Rubbing, etc.}

Valuable exotics, etc., can be protected against rubbing by smearing them with certain compositions up to 5 feet in height.

Such a composition is a mixture of lime, blood and sulphur.

\section{Section III.-Fallow-Deer.}

The damage done by the fallow-deer is of a similar nature to that by the red-deer; the former perhaps does more harm by bruising and trampling, as it is very restless, and particular about its food. However, it never peels in a wild state, only sometimes in fenced parks. The fallow-deer rubs its antlers at the end of August and in September, and strikes the same species as the red-deer. The protective rules are the same, except that precautions against peeling are unnecessary. 


\section{Section IV.-Roe-Deer.}

\section{Damage Done.}

Besides herbage, the roe eats beech-mast, acorns, wild fruit, and the cotyledons of beech and oak seedlings, and in winter browses on the buds and shoots of nearly every species of tree, especially young plants, and in summer on fresh young shoots and tender foliage.

The following species are preferred:-Oak, beech, maple, ash, elm, hornbeam, aspen, sallow and silver-fir; less-Scots and Weymouth pines and spruce; least of all--birch and alder. Young plants one or two years old may be entirely devoured. Exotic species and those occurring rarely in a wood are preferred.

Sunny aspects where the roe stays in winter suffer most, especially on poor soils. The roe rubs its horns in March and April on smooth-barked saplings about a finger's thickness, and strikes its horns on poles in rutting-time at the end of July and August, and before losing them in November. Larch, Weymouth-pine, Douglas-fir, aspen, lime, and mountain-ash are most exposed to these injuries.

In places where roe-deer crowd together, they trample-down many seedlings. The roe is relatively worse as a forest browser than the red-deer, as it is very dainty and tears the shoots like a goat; but on account of its small size, and as it abstains from peeling trees, it does a less absolute amount of damage.

\section{Protective Rules.}

Irrespective of the general rules given, the following hold good for roe-deer.

Suitable fodder are oats, acorns and foliage; they eat hay only as a last resource, when it is given quite dry and hung up in little bundles under the shelter of trees or thatched coverings and not strewn on the ground. Lopping branches of silver-fir, aspen, sallow, etc., in winter is very useful.

Fences against roe-deer need only be 5 to 6 feet high.

Scarecrows are of little good, as the roes soon become accustomed to them. 
Smearing dung, petroleum, or asafœetida on cultivations is useful.

Young coniferous cultivations may be tarred, as for red-deer, but with deep snow it is better to lime them. The cost of tarring is $5 d$. to $8 \frac{1}{2} d$. per 1,000 plants, at a daily wage of $7 d$. to $9 d$., and tar at $1 s .9 d$. per cwt.

To protect exotics (Douglas-fir, etc.), saplings may be encircled at about $1 \frac{1}{2}$ feet from the ground with a piece of paper as broad as the hand, fastened with string, or they may be surrounded with thorns, or by three jagged stakes.

\section{Section V.-Wild Pigs.}

\section{Damage Done.}

The wild pig does damage similar to that done by the tame pig, which has been already described, besides pulling-up fresh transplants, and destroying mound-planting, and birds'nests. As regards sport, it does much harm by killing fawns, leverets, etc.

Of late, in the Lower Rhine districts and also in the Ardennes, pigs have so largely increased in the forests, and do so much damage to the agricultural crops, that it has become necessary to hold battues, and fix a price for their destruction. From a forest point of view, however, wild pigs do much less damage than other game.

They may, however, do a considerable amount of good by breaking-up the soil, burying fruits and seeds and by the destruction of mice and hurtful insects.

\section{Protective Rules.}

Feeding with turnips, potatoes, oats, peas, acorns, wild fruit, etc., so as to keep the pigs from injuring forest plants.

Fences against pigs should be about 6 feet high and strongly built. Wild pigs travel considerable distances by night, and in France have been found to abandon forests where there is much wire-netting. 
Traps can be used to catch pigs. A pit about 6 feet deep and broad is dug, with walls vertical or even sloping inwards. A light covering of poles, brushwood and moss is covered with soil, dead leaves, etc., resembling the litter on the ground. Such traps should be made near wallowing-places in the

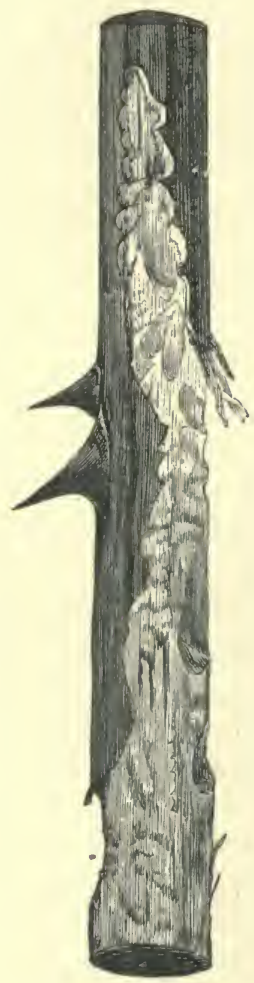

Fig. 30.-Robinia gnawed by hare (nat. size).

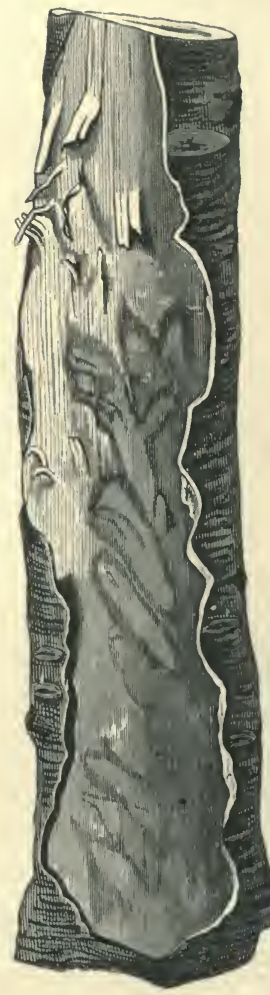

Fig. 31.-Beech gnawed by hare (nat. size).

breeding season (November to January). In making these traps the greatest care must be taken, the workmen must not smoke nor eat their food near the trap, and the earth dug out must be removed to some distance. Another excellent method for catching wild pigs is described in the "Indian Forester," vol. xi., p. 530. 
Pigs, when numerous in woods bordering on fields, must be kept down by battue-shooting. This is much more efficacious than trapping, which has almost been abandoned since 1878 in the Treves district. Thus, in the districts of Treves and Coblenz (1872-75), 658 and 257 pigs were shot, or respectively nine times and three times as many as those trapped.

The last wild pig was killed in England about 1593, in Chartley Forest, Staffordshire (J. E. Harting), but they probably lingered on to a later date in Scotland and Ireland. The Indian wild pig (S. cristatus) differs very slightly from S. scrofa. A large Indian boar may weigh over $300 \mathrm{lbs}$. and may stand up to $42 \frac{1}{2}$ inches at the shoulder. Pig-sticking with the lance on horseback is a favourite pastime in India. Wild pigs are numerous in Indian forests, where, however, they do little damage, though very destructive to agricultural crops.

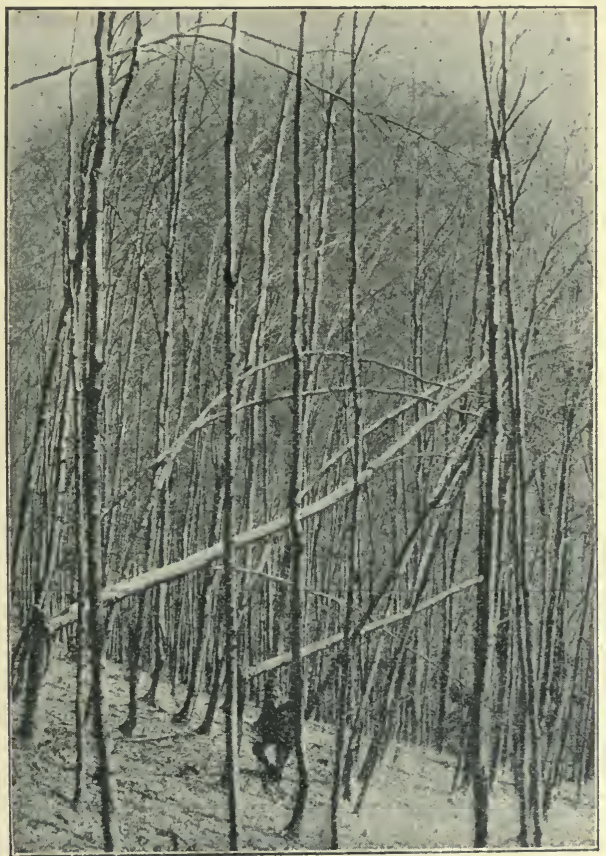

Fig. 31A.-Windbreak after damage by deer. 
CHAPTER II.

\section{PROTECTION AGAINST RODENTS.}

Section I.-General Account.

1. List of Injurious Species.

Hares and Rabbits (Leporilae).

The common hare (Lepus europaus, L.).

The mountain hare (L. timidus, L.):

The rabbit (L. cuniculus, L.).

Squirrels (Sciuridae).

The common squirrel (Sciurus vulgaris, L.).

\section{Dormice (Myoxidae).}

The loir (Myoxus glis, Schreb.).

The common dormouse (M. avellanarius, L.). The garden dormouse (M. nitela, Wagn.).

\section{Mice (Muridae).}

The common wood-mouse (Mus silvaticus, L.). The long-tailed field mouse (M. agrarius, Pall.).

Voles (Arvicolidae).

The water-rat (Arvicola amphibius, Desm.).

'I'he field vole, or short-tailed field mouse (A. agrestis, Blas.). The southern field vole (A. arvalis, Selys.). The bank vole (Hypudaus (A.) glareolus, Wagn.).

\section{Damage Done.}

The above-mentioned animals damage the forest by eating fruits and seeds, and gnawing young growth, breaking-off young shoots, eating buds, peeling bark, and burrowing in the ground. Rabbits, mice and voles do most harm, on account of their destructive voracity and their enormous powers of 
breeding. Young growth, sowings and plantations are often completely destroyed by them.

The damage done by hares, squirrels and dormice is not so great, being confined to individual plants, and these animals do not become so numerous as rabbits, mice and voles.

\section{Protective Rules.}

Proper precautions must be taken in the reproduction, tending and utilisation of woods. Enemies of these animals must be spared. Shooting, trapping, poisoning may be employed. More detail is given separately for each kind.

\section{Section II.-HaRes.}

\section{Damage Done.}

The common hare is found throughout Europe, except in mountains and the extreme north. In Scotland it occurs only in the lowlands and in valleys. In the British Isles the mountain hare is met with only in Scotland, and in Ireland, where it is known as the blue hare. At lower latitudes it turns white during winter, but remains white throughout the year in the extreme north.

The hare injures woody plants in winter by biting and gnawing their bark. Buds and young shoots of beech, hornbeam, elm, ash, maple and aspen are chiefly bitten, the conifers less, and spruce and Scots pine least of all.

As the hare affects certain localities, the damage is restricted in area, but very extensive where it prevails; so that a single hungry hare may cause considerable damage in young growth of beech on sunny situations, which it frequents in winter. The sharp teeth, cutting in pairs, give very distinct markings on plants attacked by háres.

As regards peeling, in snowy winters the one-year-old shoots of the robinia and other Leguminosa, including broom, are frequently stripped of bark, and the wood gnawed as shown in Fig. 30. Among ordinary forest plants, young beech and sycamore suffer most from peeling; older trees with rough bark escape. The hare frequently damages fruit-trees in orchards, chiefly the apple, next the cherry, least of all, the pear. 


\section{Protective Rules.}

(a) Fence nurseries, especially those of fruit-trees, with hedges or dead thorns, or with wire-netting 4 feet high.

(b) Bind fruit-trees from November till April with thorns branches of conifers or wheat straw.

(c) Fruit-trees may be smeared with stinking substances. A mixture of 10 quarts of bullock's blood, $\frac{1}{4} \mathrm{lb}$. of asafeetida dissolved in warm water, and some lime and cow-dung may be used.

(d) Shoot hares, especially in broadleaved woods.

\section{Section III.-Rabbits.}

A pair of rabbits during spring and summer may produce about 5-8 young ones every $4-5$ weeks. Young rabbits begin to breed when six weeks old, so that in New South Wales, under favourable circumstances, it has been found that a pair of rabbits may produce $13,718,000$ in three years. Rabbits cannot withstand the great winter-cold of the higher Ardennes, between 1,200-2,000 feet, but in milder situations throughout Britain and the North of France they are the most destructive enemies of broadleaved woods.

\section{Damage Done.}

Rabbits, which are chiefly found on hilly and sandy ground, do the same kind of damage to young growth as hares, besides injuring the roots of plants by burrowing. They are not nearly so destructive in biting off young shoots as by gnawing at the bark of plants. The seedlings of the Scots pine, the chief species on sandy soils, suffer most of all from biting, and next to this black pine and larch, also oak and ash.

As regards gnawing, nearly all species suffer, chiefly hornbeam, ash, robinia, aspen, sallow, hazel and fruit trees. This form of damage is most considerable in snowy winters, 1894-5, for instance. Fig. 32 shows the teeth-marks of rabbits very clearly. Not only is young growth attacked, but where rabbits are numerous, and when the ground is frozen or covered with snow, the base of large beech and other trees is barked, and the trees may be completely girdled. From experience in Windsor Forest, which is overrun with these pests, so that 
the underwood, so valuable in oak forests, which was plentiful twenty-five years ago, has now disappeared over large areas, the sycamore appears to suffer less than other species, and rabbits will not touch Rhododendron ponticum, which sometimes forms a dense underwood in parts of the forest infested by them. Hedges of whitethorn are often completely destroyed by the peeling of rabbits.

By burrowing, rabbits do much harm to cultivations and young seedlings. Hares avoid places frequented by rabbits.

\section{Protective Measures.}

(a) Protection of foxes, pole-cats, martens, stoats and weasels, which are the natural enemies of rabbits. A family of stoats may kill fifty rabbits in a week.

(b) Careful fencing 4 feet high, and use of wire-netting buried partly in the ground and sloping outside the area to be protected.

(c) Valuable trees may be bound round with thorns or wire-netting, or their bases smeared with coal tar.

(d) Use of traps or poisons, or smoking-out the burrows with sulphur. In Australia, poisoned grain is buried in shallow trenches to kill rabbits. Sheep are not thus endangered. Between April and

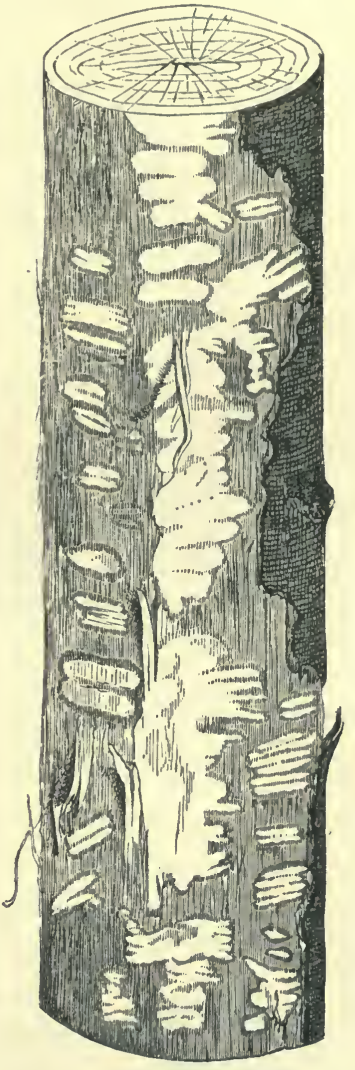

Fig. 32.-Willow gnawed by rabbits (nat. size). October, 1890, in a forest near Küstrin, 2,339 rabbits were trapped, in traps supplied by Grell, of Haynau, Silesia, costing 2s. each. A farmer in South Devon informed me that stoats, being very reckless, are readily caught in traps set for rabbits, and that since rabbits have been trapped 
in his neighbourhood, the stoats, which are their greatest enemies, have disappeared.

(e) Ferreting, the ferret being merely a domesticated variety of pole-cat. This is usually followed from October till the end of February, when rabbits do not generally have young. The ferret is sent into the burrow, and a net placed at its opening into which the rabbits run, or they may be shot when driven by the ferret out of their burrows.

$(f)$ Shooting. This is very useful, if carried on in summer when the rabbits are breeding and does are easily shot, especially in young plantations.

Every Enclosure Act allowing planting in Crown forests states, that no rabbits should be kept, on any pretence. whatever.

\section{Section IV.-The Squirrel.}

\section{Damage Done.}

The damage done by squirrels is greater than is generally imagined. They eat fruits and seeds, cotyledons and buds, and bite off young shoots, remove bark, and destroy eggs and young birds. 'Their utility in destroying beetles, larvæ of sawflies and other insects, does not compensate for the harm they do.

In $1901, \mathfrak{e} 80$ was spent in the Countess of Seafield's estate at Granttown in rewards for killing squirrels at $2 \frac{1}{2} \mathrm{~d}$. per head. 'T'bey had done much damage by girdling larch and Scots pine.

\section{a. Destruction of Fruits and Seedlings.}

Beech-nuts, acorns, hazel-nuts and seeds of spruce and Scots pine constitute the chief food of the squirrel. Besides these, it eats seeds of other conifers, fruits of horn-

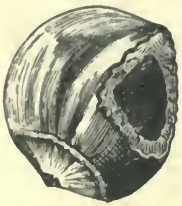

Fig. 33.-Hazel-nut opened by squirrel. beam and maple and of mountain-ash, and walnuts, apples and other garden fruits. A large proportion of the annual supply of fruit may thus be lost, and in coniferous woods, natural reproduction may be greatly reduced. Beech-nuts are often eaten in their involucres by squirrels from September.

Fig. 33 shows how the hazel-nut is attacked by this little animal, and Figs. 34 and 35 how the scales are stripped from the spruce-cones so that it can get 
at the seeds. Heaps of broken scales from cones lying under the trees show how busy the squirrel has been.

More harm again is done by the squirrel digging-out seeds and cotyledons from the ground, and biting-off cotyledons of the beech in seed-beds and reproduction-areas. It also

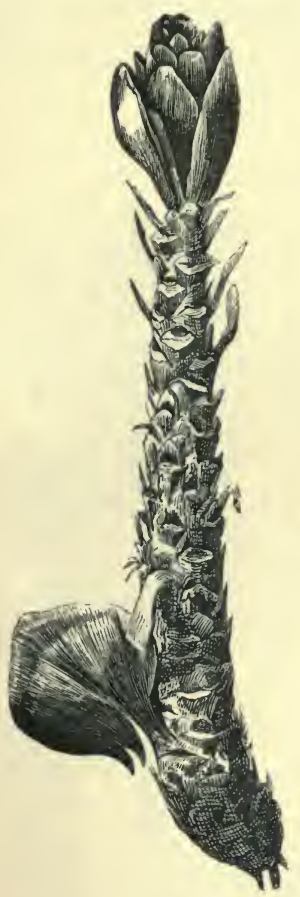

Fig. 34.-Spruce-cone stripped of scales by squirrel.

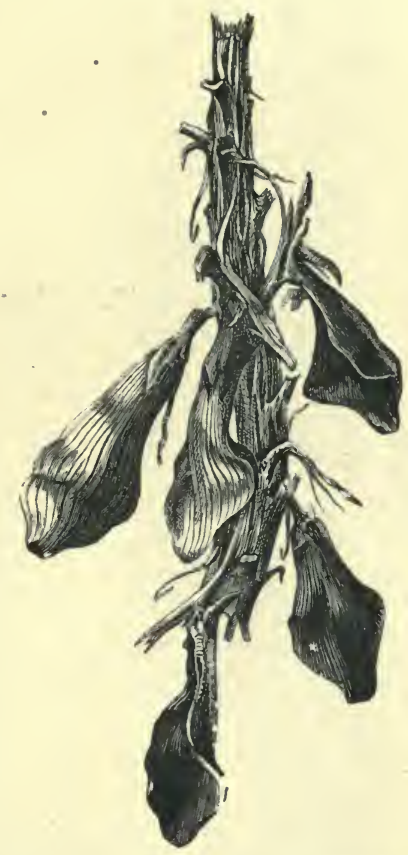

Fig. 35.-Portion of spruce-cone attacked by squirrel.

uproots young oak-plants to get at the remains of the acorns. Indian squirrels have similar proclivities to the above-mentioned species and sometimes completely strip trees of their fruit, besides being very destructive to peas, etc., in vegetablegardens.

\section{b. Eating Buds and Biting off T'wigs.}

As regards buds, the squirrel prefers those of the inflorescence, which are richer in nitrogenous substances and more 
nourishing than the foliage-buds. Spruce and Scots pine are preferred, but silver-fir is also attacked in this way. The destruction of these buds, in snowy winters, may entirely prevent seed from being produced. The methods pursued by the squirrel in eating the buds differ according to the age, height, and strength of the plants attacked. In plantations and thickets, from 1 to 6 feet high, which are not yet provided
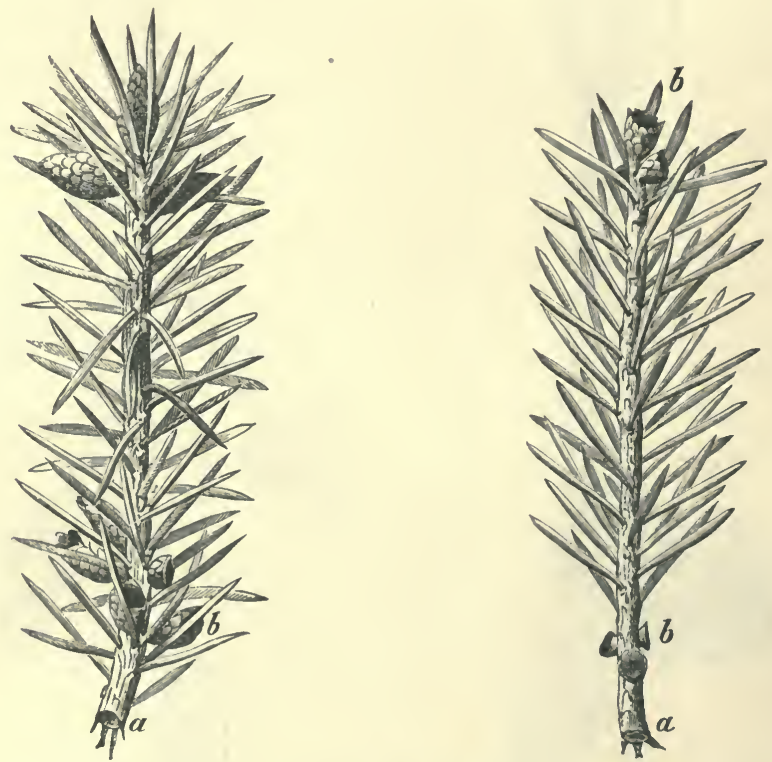

Figs. 36 and 37.-Twigs bitten off by squirrel (nat. size).

$a$. Points where twigs are bitten off. $b$. Bases of bitten-off buds.

with flowering-buds, the squirrels bite-off the top of the previous year's shoot, and the side-shoots of the last verticil, the buds of which are also eaten. Scots pines injured in this way, develop new leaders from buds just below the point of attack, whilst in the case of spruce, an uninjured side-shoot from the last verticil becomes a leader. In the case of poles and trees of these species, the squirrel bites-off the most external little shoots on which are the male inflorescencebuds, and then, holding the twig with its fore feet, goes back to the branch to eat the buds. It then lets the twig fall to 
to the ground, Probably the female inflorescence-buds are eaten as well, and very few cones are formed on trees where squirrels have lived during the winter. Silver-fir is also similarly attacked.

In the summer also, shoots of various lengths up to 8 inches are bitten off spruce trees by the squirrel and gnawed, as at this time there are no seeds or buds to eat.

\section{c. Peeling and Girdling.}

The peeling and girdling of young plants of larch, Scots pine and silver-fir, also of beech, hornbeam, aspen, willows and oak have been noticed, and are becoming serious in Britain. Plants fifteen to thirty years

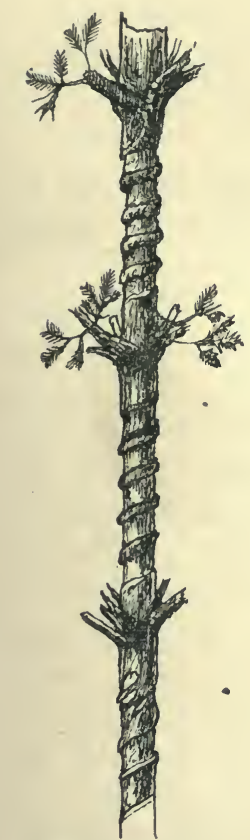

Figs. 38 and 39.--Spiral girdlings of Scots pine by squirrel.

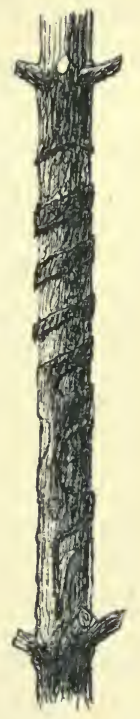
(1)

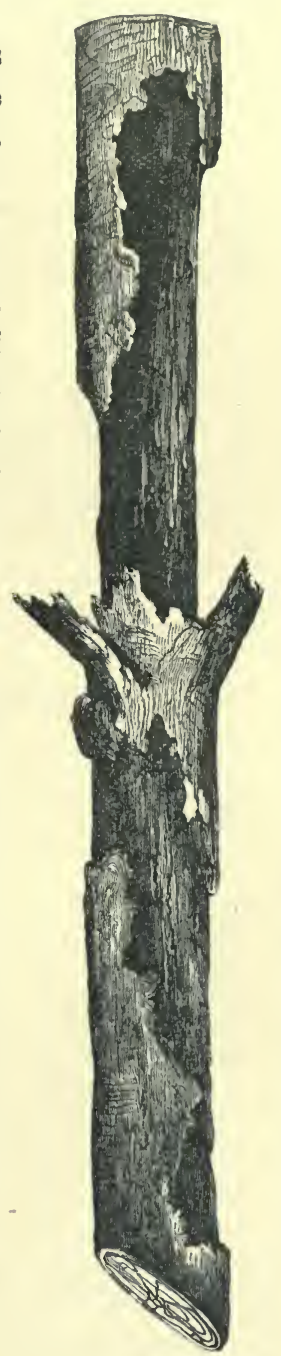

Fig. 40.-Girdling of Scots pine by squir$\operatorname{rel}\left(\frac{1}{6}\right)$. 
old suffer most, but also sixty-years-old woods. This is done from May to July chiefly in dry years. The damage is done to the stem in the crown where the squirrel sits, and is sometimes in rings or spirals, at other times quite irregular; as it goes down to the sapwood, the injured stems may die above the peeled place, as they sometimes do by hundreds.

\section{d. Destruclion of Young Birds.}

During the breeding season of birds, the squirrel frequently attacks their young, killing them and eating their heads.

\section{Protective Rules.}

Protection of the pine-marten (Mustela martes), a great enemy of the squirrel.

Shooting, with the help of dogs, in spruce seed-years, and near nurseries.

\section{Section V.-Dormice.}

\section{Damage Done.}

Dormice are squirrel-like animals, with bushy tails, and as

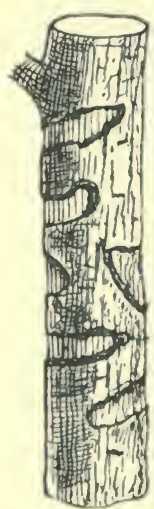

Fig. 41.-Girdling of alder by dormice.

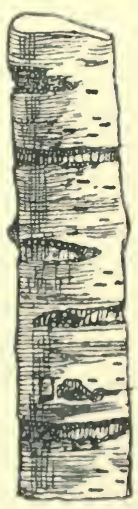

Fig. 42.-Girdling of birch by dormice. they move about at night, chiefly in broadleaved forest, it is difficult to state precisely the amount of damage they do.

The loir (Myoxus glis, in German, Siebenschläfer), the largest European species of dormouse, is found in southern Europe, but not in the British Isles. It feeds on mast of all kinds and also on spruce and other seeds, and orchard-fruit, bites-off the leading shoots of beech and silver-fir, and in spring, barks young stems, and robs birds' nests, doing injury of a similar nature to that done by squirrels.

It collects a provision for the winter in holes, but passes 
most of this season asleep. Barking is done in strips, or rings, on ten- to twentyfive-years-old trees of birch, hornbeam, hazel, etc., also of larch and silver-fir.

The loir also bites-off spruce-shoots in order to strip them of their needles and chew them, spitting out the debris.

The garden-dormouse (M. quercinus, L.) is rarer than the former, but has a similar habitat, going, however, further north ; it is fond of orchard-fruit, and also attacks forest fruits like the loir.

The common dormouse (M. avellanarius, L.), chiefly inhabits coppice, especially hazel-coppice, and is found all over Europe, from Sweden to Northern Turkey, but is less common in the south than the other two species. It does similar damage to them, but on a smaller scale, and owing to its fondness for hazel-nuts, is termed Hazelmaus in Germany.

\section{Protective Rules,}

Dormice may be caught like rats in iron traps baited with bacon, or for the last species, in wire-traps with almonds as a bait.

In the extensive beech forests of Carinthia, the capture of the loir is actively pursued, its flesh, which becomes very fat in autumn, being eaten, while the skins are exported, as many as 800,000 being captured in good years of beech-mast.

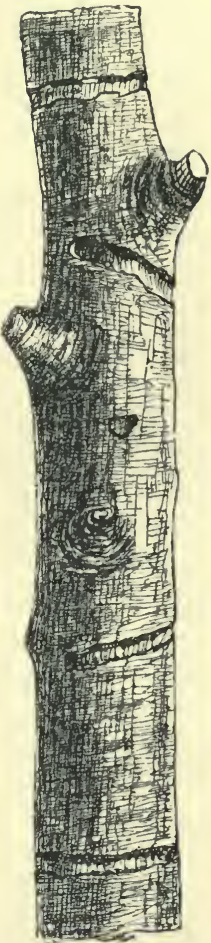

Fig. 43. - Girdling of beech by dormice.

\section{Section VI.-Mice.}

\section{Damage Done.}

Forest mice, especially the long-tailed field-mouse (Mus silvaticus, L.), and to a less degree Mus agrarius, Pall., are very destructive by eating forest fruits and seeds, biting and gnawing, burrowing in the ground and killing small birds. 
Chiefly beech and oak-mast and hazel-nuts are eaten, and autumn-sowings suffer more than those made in the spring.

In winter, and when the snow is on the ground, they gnaw buds, tender shoots, bark and sapwood of young forest plants, from 2 to 15 years old. Broadleaved species chiefly suffer, such as hornbeam, beech, ash, maple, hazel, sallow, and also oak, elm, aspen, etc. Handsome thorn-trees are often girdled by them. They gnaw the bark of plants up to 3 feet and higher from the ground, somewhat higher than voles, from which they can be distinguished in this way. Young stems up to 2 inches in diameter at the base are often gnawed through, and promising cultivations are thus ruined.

By their burrowing, many plants are uprooted and die, but this kind of damage is done on a much greater scale by voles.

Mice are chiefly destructive on sunny aspects in young woods full of grass undergrowth. Their powers of reproduction in dry summers are quite extraordinary.

Rats are frequently destructive to forests in India. There was a plague of rats in Berar, in 1902, described by E. E. Fernandez (Indian Forester, April). They destroyed cotton goods and grain and gnawed the bark of teak, up to 3 feet in girth, also of Butea frondosa, the lac tree, and other species.

\section{Protective Rules.}

These are about the same as against voles, and will therefore be given in full further on, but as the long-tailed field-mouse lives in forests throughout the year, it is more difficult to ward against its attacks than against those of voles, which come from the fields into the forest during winter. 'The chief remedy is to protect its enemies, the stoat, weasel, fox, owls, etc.

\section{Section VII.-Voles.}

Voles are distinguished from mice by their thicker, shorter head, by having ears buried in their fur, short legs and tail; true mice having a pointed head, large ears and a long tail. 


\section{Damage Done.}

Voles in daytime live chiefly in the soil, into which they burrow in all directions. Their burrows are just below the surface of the ground, and by burrowing in forest nurseries, plantations and natural regeneration-areas, they uproot thousands of plants and injure drains and ditches. They are chiefly vegetable-eaters, devouring fruits and seeds, cutting through the roots of young plants in the ground, gnawing their shoots, but they also attack young birds.

During winter they gnaw the bark of plants chiefly of broadleaved species from the collum up to ten inches, or as far as the grass reaches, in strips or rings.

Voles breed much more rapidly than mice, the southern fieldvole (Arvicola arvalis, Selys.)* being especially reproductive.

The water-vole (A. amphibius, Desm.), and the common field-vole (A. agrestis, Blas.), do the most damage. The watervole lives not only near water, but also in the forest, and does much damage by burrowing, and by cutting-off the tap-root of stems up to the thickness of a man's arm, that naturally kills them. Oak and ash suffer most in this way, also poplars, willows, apple-trees, etc.; less: beech and conifers. The watervole also frequently-injures banks and dams; it has done much damage in the forests occasionally inundated by the Danube, but is fortunately never very numerous.

The bank-vole (Hypudceus glareolus, Wagn.) is extremely active, and inhabits chiefly the borders of forests, bushy land amongst fields, and forest-glades with advance-growth, rather than dense forest. It gnaws larches, black pines, aspen, and other trees and shrubs, and eats and carries off the pine-buds.

The common field-vole (Arvicola agrestis, Blas.) is the greatest scourge of the agriculturist, and comes from the fields into light forests, where it does enormous damage. In the winters of 1822-23, 1830-31, 1840-41, 1856-57, 1861-62, $1863-64, \quad 1870-71,1871-72,1872-73,1878-79,1889-90$, 1892-93, this species was chief among the swarms of mice

* About 75 per cent. of them are o, and a mother vole has eight to ten young every six to eight weeks, from March till late in autumn. A o begins breeding when eight weeks old, and may have 10,000 descendants in a ${ }^{+}$year. 


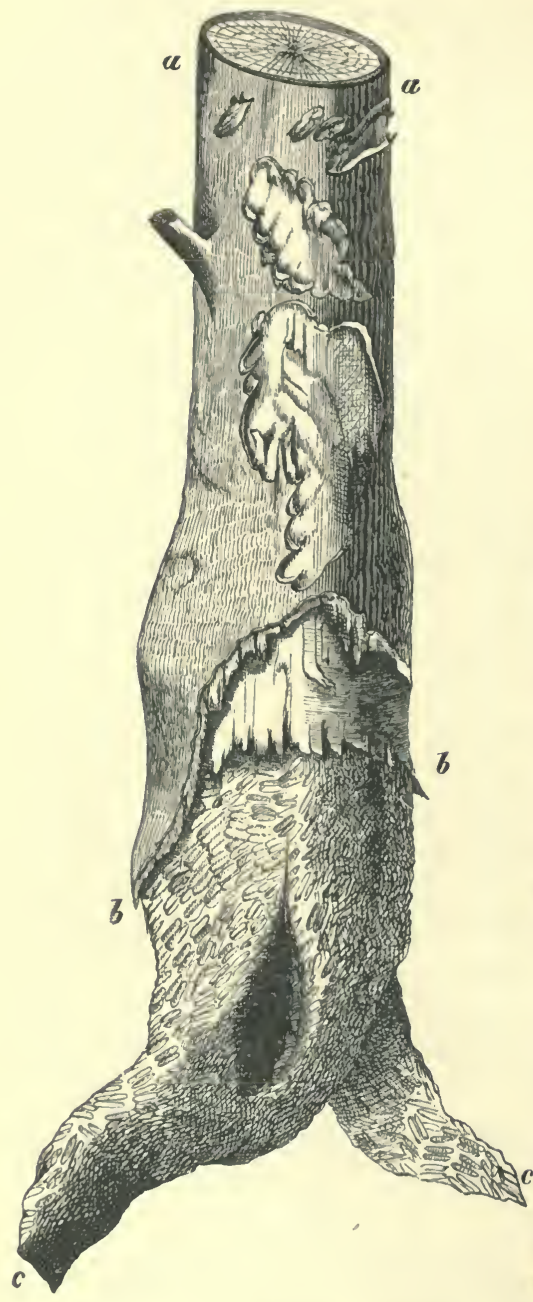

Fig. 46.-Apple-tree gnawed by hares $(a b)$, and by mice $(b c)$ (nat. size). which destroyed the young plantations on thousands of acres in Germany. The destruc. tion is greatest when it collects in swarms and wanders from place to place. Voles and mice are specially destructive in forest nurseries.

A description of the
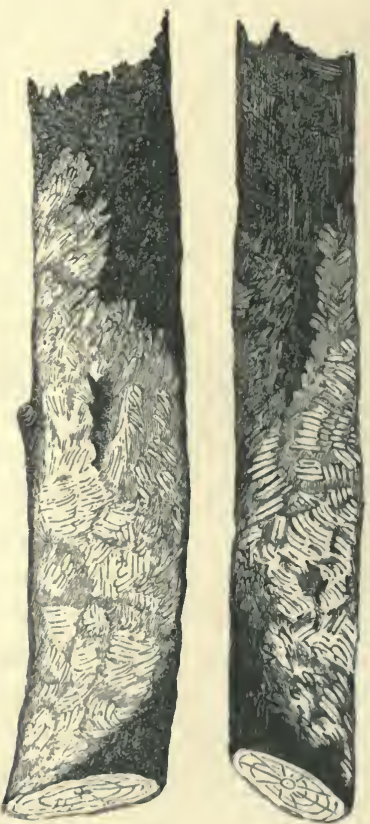

Fig. 44.-Beech Fig. 45.-Alder gnawed by gnawed by mice (nat. mice (nat. size). size).

damage done in 1814 by this species and the long-tailed fieldmouse is given in Nicholls' ${ }^{*}$ account of the Forest of Dean.

* Published by John Murray, Albemarle Street, London, 1858. 
They destroyed all the young oak-saplings in the forest except four or five per acre, eating through the roots just below the surface of the ground. The long-tailed species was found chiefly on wet ground, and the vole everywhere. To exterminate these pests, trenches 2 feet deep were dug 20 yards apart, and 100,000 tails were brought in for reward. Polecats, hawks, kites and owls increased enormously, and the mice ate one another in the trenches. Much damage was also done by field-voles in the Lowlands of Scotland in 1891-92. This species prefers hornbeam, beech, ash, hazel and sallow, but it also attacks all broadleaved species as well as pines and larch. It is specially fond of whitethorn. Young plants two to five years old are gnawed through at the surface of the soil, or peeled of bark, or bitten through above ground, or stripped of their side-shoots. Older plants and even poles up to 10 inches in girth are stripped of their bark up to a foot from the ground and killed. Voles strip the scales from the fir-cones and eat the seeds, they also eat grass with its rhizomes, thus destroying extensive pastures.

The southern field-vole living on the confines of forests in well-watered situations gnaws the roots and bark of beech and other trees in hard winters.

The only use of voles is that they eat larve, snails and slugs.

\section{Protective Rules.}

(a) Woodlands bordering on fields should be separated from them by ditches. Further reference will be made to this.

(b) Forest nurseries should not usually be made near fields. Wherever this cannot be avoided, rule $(a)$ should be followed.

(c) In years when mice are abundant, autumn-sowings, especially of acorns and beech-mast, should be abandoned; in any case, plenty of seed must be sown, and covered deeper than usual, but it is better to sow late in the spring, or to use transplants.

(d) In forest nurseries broadcast-sowing in seed-beds is preferable to sowing in drills. Small pieces of furze may 
be placed between acorns or other seeds in the nursery-beds. The seed should be covered with red lead by slightly wetting it and rubbing the red lead on to the seeds.

(e) For sowings in the forest, the following precautions are recommended :-Soaking the seeds for half an hour in a 2 per cent. solution of carbolic acid in water; 10 per cent. of the acid will kill the seeds. Acorns may also be soaked in a decoction of quassia. The seed-beds may be covered with a layer, 2 inches thick, of old tan or spruce branches, or strewn with calcium chloride, which is also a protection against certain insects. Seeds may be covered with red lead.

$(f)$ Endangered saplings in nurseries may be wrapped round spirally with 4-8 inches wide strips of asphalt paper and their barks surrounded with asphalt tar. The scent of this keeps off the mice. Hesse considers coal-tar as hurtful to plants. Various advertised preparations may be smeared over the plants, such as a mixture of cart-grease, petrol, alum and tallow.

(g) Felling-areas with grass-undergrowth should be pastured down in summer and autumn by cattle or sheep. The grass protects the mice from observation, and renders the bark of plants in it soft and fresh, which the mice like. The cattle disturb and trample down many mice.

(h) Beech seeding-fellings should be dark in order to keep down the grass.

(i) Pigs may be admitted into the forest as long as the soil is loose, especially near nurseries. They root-up the ground, disturb the mice, destroy their young, fill up their burrows, and also trample-down and eat many mice.

(j) Removal of low undergrowth, which shelters the mice.

(k) Branches. of softwoods or hornbeam may be spread about in young beech-woods, to attract the mice from the beech. They must however be frequently replaced, as dry branches are no longer gnawed, and then the remedy does more harm than good, the branches having attracted mice into the wood. This is a good precaution against the southern field-vole.

(l) Protection of Enemies.-Here we must restrict ourselves to the protection of mice-destroyers which may not do so 
much injury in another direction as to outweigh their usefulness in killing mice and voles. The following animals are useful in this way :-

\section{Mammats.}

The pole-cat (Putorius foetidus, Gray), the stoat (P. ermineus, Ow.), the weasel (P.vulgaris, Rich.), the badger (Meles taxus, Pall.), the mole ('Talpa europaea, L.), and the hedgehog (Erinaceus europaeus, L.), also the shrews, especially Sorex vulgaris, L. The mole does not inhabit Ireland.

The first three beasts also plunder nests and eat eggs, young birds and leverets. The badger eats fruits, mast and pheasants'

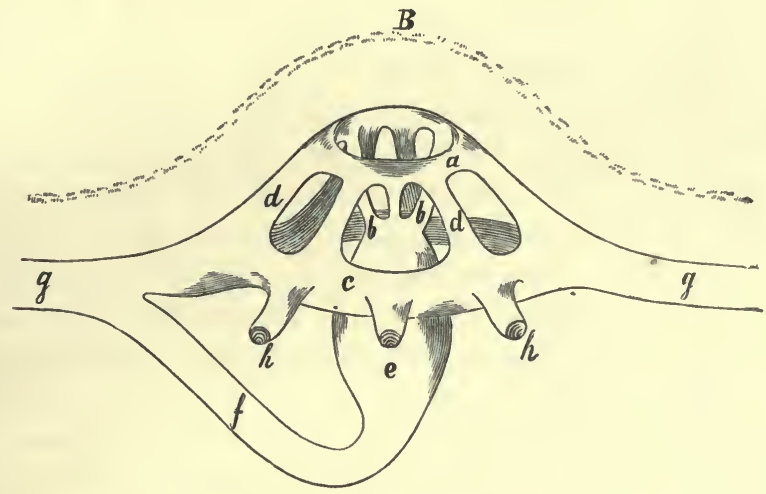

Fig. 47.-Diagram of mole-heap.

(B) Surface of ground.

(a) Upper gallery.

(b) Descending passages.

(c) Lower gallery.

(d) Ascending passages. (e) Central chamber.

(f) Passage to chamber.

(g) Moles' run.

(h) Diverging runs from lower gallery.

eggs. The mole is hurtful to forest nurseries from its habit of burrowing and throwing-up small heaps of soil. The hedgehog attacks nests. All these animals, however, are much more useful than hurtful. The well-known and much abused mole hunts for mice, crickets, snails, slugs and grubs, and is always at hand where these creatures abound, and extremely useful in destroying them. It increases rapidly, has $3-5$ young at a birth, and two broods in the year, in May and August, and is very voracious. Its ingenious nest (Fig. 47) 
affords means of escape when pursued by a rat, or other enemy.

A limited protection may also be afforded when mice are swarming, to the fox (Canis vulpes, L.), the pine-marten (Mustela martes, L.), the beech-marten (Mustela foina, Briss.) and the wild cat (Felis catus, L.), in spite of the damage they may do to game. A full-grown fox will eat two or three dozen mice daily, and in S. Sweden, where foxes are numerous, there are no plagues of mice.

\section{Birds.*}

The following birds are extremely useful in destroying mice:-The kestrel (Falco tinnunculus, L.) ; the buzzards, especially the common buzzard (Buteo vulgaris, Leach); owls, especially the long-eared and short-eared owls (Otus vulgaris, Flemm., and O. brachyotus, Cuv.); also, the tawny owl (Syrnium Aluco, Boie), the little owl (Carine noctua, Scopoli), and the barn-owl (Strix flammea, L.). To these may be added the hen-harrier and the marsh-harrier (Circus cyaneus and $C$. aeruginosus). Mr. Tegetmeier states that a pair of barn-owls brought food to their nest 5 times in three hours. This probably meant 150 mice in $4 \frac{1}{2}$ hours. The short-eared owl hunts mice in day-time and appeared in Scotland in large numbers during the plague of mice.

The rook (Corvus frugilegus, L.) kills mice, especially in the autumn, so do the black crow ( $C$. corone, Lam.) and the hooded crow $(C$. cornix, L.), which are sometimes said to be varieties of the same species and to interbreed freely. The above three species of Corvus occasionally attack acorn-sowings, and break off the leading shoots of conifers, and the crow does much damage by eating the eggs of partridges and other birds, but on the whole their utility is greater than their destructiveness.

Herons (Ardea cinerea) and storks (Ciconia alba, L.) occasionally feed on mice, and so does the black-headed gull (Larus ridibundus, L.).

"The scientific names for birds follow Yarrell, "British Birds," 4th edition. Revised by A. Newton, F.R.S., and H. Saunders, 187t-85. 
Most of the other flesh-eating birds do too much damage to useful birds to deserve protection.

\section{Remedial Measures.}

Remedial measures against mice may be with or without poison. The chief rule is to adopt measures every year which suit the locality, so as to prevent as far as possible any extraordinary increase in the number of mice and voles. According to trustworthy observation, there are far more females than males in the spring, and mice should therefore be destroyed as much as possible in February and March. Private enterprise, especially in forests where it is difficult to get at the mice, is not sufficient for this purpose, but the State must direct matters and induce private persons to assist in the energetic destruction of mice both in fields and in forest, which will be to the public advantage.

\section{a. Pitfalls.}

Trenches must be dug in the ground, and visited daily to keep them clear from leaves, etc., and to remove and kill the captives. They should be 8-10 inches wide, and 12-16 inches deep, with vertical smooth walls. The base of the pitfall must be beaten hard, and glazed earthenware vessels, or drain-pipes, one every 3 or 4 yards, buried level with the bottom of the pitfall. A few grains of wheat act as lures for the mice, and those which are found in the pitfall are killed with a pointed piece of coarse iron wire ; they will die otherwise of starvation. Such trenches are to be recommended against field-mice along the borders of fields and forests, and around forest nurseries and seed-granaries. In Mecklenburg, 10,800 mice were thús destroyed in autumn, 1872 , between a clover field and a sown plantation.

\section{b. Traps.}

Traps are useful, especially against water-rats and bankvoles, and various kinds of devices may be used to trap mice according to species and local circumstances. 
Traps resembling sugar-tongs are advocated by E. Heyer against the water-rat, as shown in the Figs. 50 and 51. They must be so placed that the rat, in running into its hole
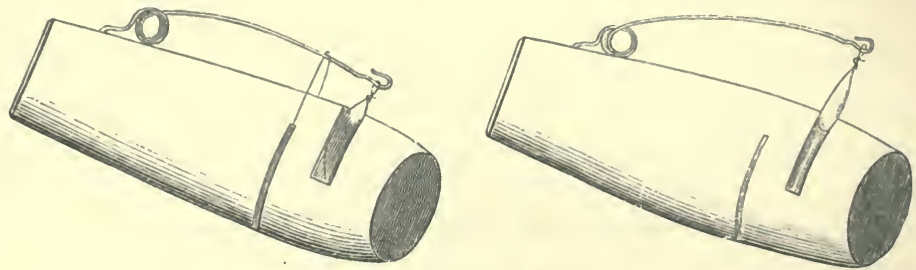

Figs. 48 and 49.-Tube-traps from IIohenheim ( $\frac{1}{3}$ nal. size).

strikes the plate $(a)$ with its head, and is then canght round the body by the pincers $(b)$. It is better to place two such traps back to back in a hole. For the smaller species the

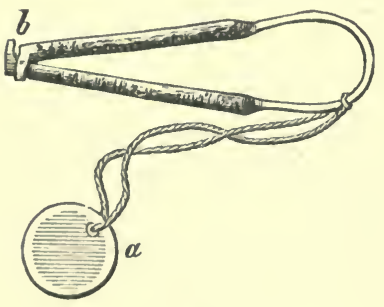

Fig. 50 .

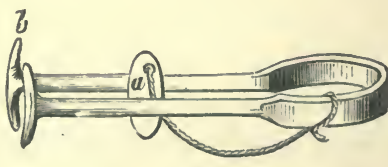

Fig. 51.

tube-traps from Hohenheim are very effective, Figs. 48 and 49 .

Ordinary spring-traps (Figs. 52 and 53) are more useful in

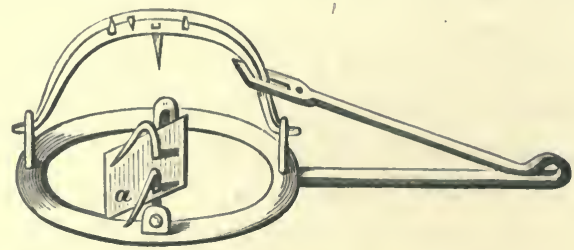

Fig. 52.-(1 nat. size).

closed rooms, such as seed-stores, but when concealed by foliage, etc., they may also be used in forest nurseries, carrots or beetroot forming a good bait. 
For seed-stores, a good trap for mice may be formed by a vessel full of water, over the edge of which a piece of wood or platform on which the bait is fastened is balanced. The mice

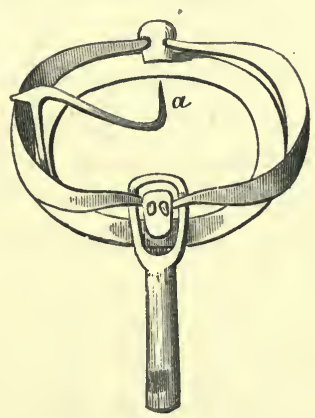

Fig. 53.-( $\frac{1}{2}$ nat. size $)$.

climb up a slanting piece of wood on to this platform, and going to the end of it to get at the bait, upset the balance of the platform and fall into the water.

\section{c. Smoking-out.}

Smoking-out mice is not possible in forests, owing to the nature of their holes amongst grass and dead leaves, and also on account of the danger of firing the forest.

\section{d. Poisoning.}

Poisoning is the most effectual method of destroying mice.

In poisoning mice in forests there is, however, great danger of killing useful animals, such as weasels, foxes or owls. Such a method can therefore be employed only after every precaution has been taken against danger to useful animals, and in cases where the mice have increased enormously in numbers.

Poisoning may be done by means of phosphorus, arsenic, strychnine, corrosive sublimate, or carbonate of baryta. Of these, strychnine is the most effective. Wheat, oats or barley grains, celery or radishes may be used with the poison, the grairs being first steeped in water, and then placed in the 
poisonous solution; or a meal prepared and the poison mixed up with it. It is then strewn about in pieces as big as a pea. In order as far as possible to prevent the poisoning of useful animals, the poisoned baits must not be placed on the bare ground, but in little cylinders of wood or of grass sods, or in glazed vessels or drain-pipes about $1_{2}^{\frac{1}{2}}$ inches in diameter, sufficient to allow passage to a mouse. The cylinders may be placed on the ground or in the mouse-holes, and must be inspected regularly in order to observe their effects. Glazed vessels are better than drain-pipes, as the latter let in moisture.

Phosphorus, owing to oxidation, soon becomes ineffectual in damp or rainy weather. Arsenic is more effective, but less rapid in its action. If either of theso poisons is used, the dead mice are generally found lying on the surface of the ground, as they run in search of air and water when feeling the pains of the poisoning. Strychnine and carbonate of baryta kill the mice in their holes after severe convulsions; it is better to change the bait and the poison from time to time.

A pest of mice rarely lasts more than 2 or 3 years, as heavy rain, frosts, inundations and disease soon kill them by thousands. It would not however be right to wait patiently for such an event to occur, for by timely energetic action the damage may be greatly reduced.

Attempts were made (as proposed by Loeffler) in 1890, to destroy the mice which were infesting the fields in Thessaly, by subjecting them to a parasitic fungoid disease termed mouse-typhus; this was communicated to the mice by pieces of bread which had previously been soaked in water containing spores of the fungus. The results in this case were excellent, and it has since been adopted on agricultural lands with success both in France and Germany. It was also successful in a German forest in $1892-3$, on 15 acres, at a cost of $5 s .6 d$. per acre.

\section{Treatment of Injured Plants.}

Broad-leaved poles and saplings which have been badly gnawed by mice should be cut-back in the spring close to the 
ground, below the injured place, sharp instruments being used for the purpose, so that they may send up new shoots, If the plants have been girdled too deeply towards the roots, such procedure would not save them, but of course the dead poles should be removed. The workmen should work in lines so as not to leave out any injured plants, and should be properly supervised. If the cutting is done too late in the spring, the new shoots will be very weak, as much reserve material then passes into the injured stems, and is consequently wasted when the stems are cut down.

Where conifers have been injured, new plants must be substituted for those killed by mice.

Beech plants that have been gnawed by mice, if under a foot in height, may be saved by heaping up earth above the wounded part of the plants. The latter then send out fibrous roots that grow down into the soil through the mounds. This costs about $1 d$. per 100 plants.

\section{Section VIII.-Beavers and Porcupines.}

The beaver is an animal now almost extinct in Central Europe, but which formerly did much damage to forest trees.* Beavers (Castor fiber, L.) are still pretty numerous in Russia and Scandinavia, in North America, and a few still exist in France in the Rhone Valley. They fell and bark many species of trees up to 9 inches in diameter, chiefly willows and poplars, but also ash, oak, and elm growing near streams. The trees felled are used by them in constructing dams to protect their dwellings, and they also eat the bark.

The porcupine (Hystrix leucura) is very common in Indian forests, and girdles saplings and poles of various species, especially of Leguminosae; it does much damage in forest nurseries by burrowing, and by devouring seedlings and vegetables. It should be excluded by strong wire-netting, partly buried at the foot of a fence, as in the case of rabbits. There are also two other species of Hystrix in India.

* In the Himalayas, the black bear (Ursus tibetanus) peels the bark from pines during the winter. 


\section{CHAPTER III. \\ PROTECTION AGAINST BIRDS.*}

\section{Section I.-General Account.}

The birds directly hurtful to forests belong to the orders Gallinae or game-birds, Columbidae or pigeons, and Passeriformae or perching birds.

\section{List of Hurtful Birds.}

Grouse (Tetraonidae).

Capercailzie ('Tetrao urogallus, L.). Black game ('Tetrao tetrix, L.).

Hazel-grouse (Bonasia silvestris, Brehm.).

Pigeons (Columbidae).

Ring-dove or Wood Pigeon (Columba palumbus, L.).

Stock-dove (C. oenas, L.).

Turtle-dove ('Turtur communis, L.).

(Corvidae).

Jay (Garrulus glandarius, Vieill.).

Nutcracker (Nucifraga caryocatactes, Briss.).

Finches (Fringillidae).

Hawfinch (Coccothraustes vulgaris, Briss.).

Greenfinch (C. chloris, Briss.).

Chaffinch (Fringilla coclebs, L.).

Brambling ( $F$. montifringilla, L.).

Siskin (F. Spinus, L.).

Crossbill (Loxia curvirostra, Gm.).

Parrot Crossbill (L. pityopsittacus, Bchst.).

* The scientific names are from Yarrell's "British Birds," th ed., 1882. 
A few other species of small singing birds are hurtful by eating seeds and biting-off buds, such as :-

Bullfinch (Pyrrhula europaea, Vieill.).

Mealy Red-poll (Linota linaria, L.).

Red-breast (Erythacus rubecula, L.).

Even titmice (Paridae) do some harm, and woodpeckers (Pici) make holes in trees; these families, however, do more good than harm. Birds which do indirect injury by killing other useful birds will be described further on under the heading Insects.

\section{Damage Done.}

Destructive species of birds eat-up seeds and fruits, bite-off buds, young shoots, and tender seedlings, but are generally useful by destroying insects, and the damage done by birds in forests is in general much less than that by the rodents and deer already referred to.

\section{Protective Rules.}

Delay sowing until the birds have paired, and cover the seeds well. The birds, after pairing, no longer fly about in large numbers, and they kill more insects than before pairing, both for themselves and for their young.

The seeds may be steeped in red-lead mixed with water, or in distilled water, lime-water, or very dilute acids, so as to hasten the germination, and the period of danger from seed-eating birds may thus be reduced to as short a space as possible.

Sowings may be covered with moss, or branches; in nurseries, with wire-netting over hoops of hazel, willow, etc.

Scarecrows may be used, or paper feathers on string, or stuffed birds of prey.

Watch the sowings till the young plants are large enough to be out of danger.

Fire off blank cartridges, or shoot the birds. 
Section II.-The Capercailzie and other Grouse.

\section{Damage Done.}

The capercailzie, which frequents extensive tracts of mountain forests, injures nurseries and cultivations of conifers in winter and spring by biting-off buds and young shoots; in nurseries, when the buds of the plants just appear above the snow, they are frequently cut-off in great numbers by these birds, the cock being more injurious than the hen. Birchbuds and small green pine-cones are also eaten. The capercailzie in winter frequents old woods with advance-growth, and feeds chiefly on the needles and buds of old spruce trees, but is very fond of the buds of neighbouring young spruce. In Scotland it prefers Scots pine. In the spring it scratches the soil in search of insects and worms.

The black-grouse lives in mossy heather-land, and does much less harm to forests than the capercailzie. It eats the buds and inflorescence of birch and other broad-leaved species, and attacks buds of conifers and young needles of the larch, but chiefly nourishes itself with berries and small shrubs (bilberry, heather, etc.), and keeps itself alive in winter by eating needles of old spruce trees. It goes higher in the mountains than the capercailzie.

The hazel-grouse is chiefly found in broad-leaved woods, in the Austrian Alps and the Russian Baltic Provinces; it feeds during winter on birch and alder buds and hazel-catkins. In summer it chiefly eats berries, but does less harm than black game.

Pheasants scratch-up sowings in the forest, and nursery seed-beds.

\section{Protective Rules.}

Fence-in nurseries with tall thorny bushes, as the capercailzie is very shy, and avoids places so protected.

Branches of spruce, etc., may be laid over sowings to impede the movements of the birds, and nursery seed-beds may be protected with wire-netting. Buy transplants. 


\section{Section III.-Pigeons and Doves.}

\section{Damage Done.}

Wood-pigeons and doves eat up forest seeds, especially of spruce and Scots pine, also buds, catkins, etc. The woodpigeon and the stock-dove in autumn also eat acorns, beechmast and beech cotyledons. Turtle-doves eat-up seedlings, doing most damage in March, and from April to October, when they often alight in flocks on sowings.

The wood-pigeon, the largest kind, prefers coniferous forest (spruce); the stock-dove, beech and mixed forest of broadleaved and coniferous species; the turtle-dove, the smallest kind, lives near water in small woods among fields and meadows. The wood-pigeon is one of the worst enemies to agriculture.

\section{Protective Rules.}

Those already given under the general heading apply here. Scarecrows are only useful at first, as the birds soon get used to them. Strewing seed-beds with spruce-needles instead of moss protects against turtle-doves. Shooting is best done at the breeding season with decoys, or over salt. Small vessels containing salted clay, anise, hempseed or wheat are placed here and there over the endangered sowings, and the pigeons flying down to them are shot.

\section{Section IV.-Jays and Nutcrackers.}

\section{Damage Done.}

The jay is extremely destructive, eating acorns, beech-nuts, walnuts, hazel-nuts, cherries and other fruit, digging-up germinating beech-nuts and young oaks to eat their cotyledons. It also destroys the young and eggs of other birds, and even attacks new-born hares. Once it has discovered a sowing of acorns, it will completely strip the bed. In acorn sowings in the Forest of Dean in 1899, it was found that, when the turf was broken up over the lines of sowings, the birds picked up most of the acorns. When the turf was taken up and 
replaced over the acorns, the birds did not recognise the place and left the acorns alone.

At the same time, by placing acorns and beech-nuts singly in holes in the ground, which it afterwards forgets, it assists in the spread of the oak and beech. Of more value is its power of attacking mice and insects, but the good done is less than the harm effected in other ways.

The nutcracker, though not uncommon in the spruce forests of the Schwarzwald, the Bavarian Alps, the Tyrol and Switzerland, is rare in Central and North Germany, and in the British Isles. Its food consists of hazel-nuts, acorns, and beech-mast, and especially the seeds of the Cembran pine, of which it is so fond as to pick them out of sowings and seedbeds in the very presence of the workmen who are sowing the seed. It also destroys the eggs and young of useful birds. 'This extremely restless. bird also sows seeds, and in this respect is more useful than the jay, as the localities it prefers in the high mountain regions are those where planting is extremely costly, and any assistance to man's action in reboisement is of great value.

\section{Protective Rules.}

Cover up endangered sowings with branches of thorn-bushes, immediately after sowing.

Shoot in autumn, when jays keep flying from one oak to another. Several hundred jays are thus shot every year in Epping Forest.

Section V.-Finches and other Syall Birds.

\section{Damage Done.}

The haufinch, rare in the British Isles, is very fond of fruits and seeds, especially those of the hornbeam, cherry, maples, oaks, beech, alder, elm and conifers. The traces of its activity are seen in the remains of the fruit lying under the trees. It also bites-off buds. In general, however, the damage done by this bird is greater in gardens and orchards than in forests. 
The greenfinch feeds its young on soft seeds, and by thus destroying countless weeds it is of great service to the gardener and agriculturist. Later on in the year, however, it unites in large flocks with the chaffinch and other finches and small birds, and they may do much damage to sowings in the forest.

The chaffinch is extremely fond of coniferous seeds, those of the pine, spruce, and larch, and bites off young cotyledons of conifers as long as they are covered by the testa. It also eats beech-nuts, and the cotyledons of beechseedlings.

The brambling appears in the late autumn and winter in large flights.like clouds, and attacks beech-nuts and coniferous seeds. De Montbeliard states that in 1765, after a good beech-mast year, for several nights 600 dozens were killed near the Rhine, and de la Fontaine computes a flight of bramblings in Luxemburg in February, 1865, at 60 millions. Stevenson in March, 1865, saw a flock of bramblings near Slough which passed him without intermission for 35 minutes. Both this species and the chaffinch are extremely destructive to coniferous and beech sowings, and to natural

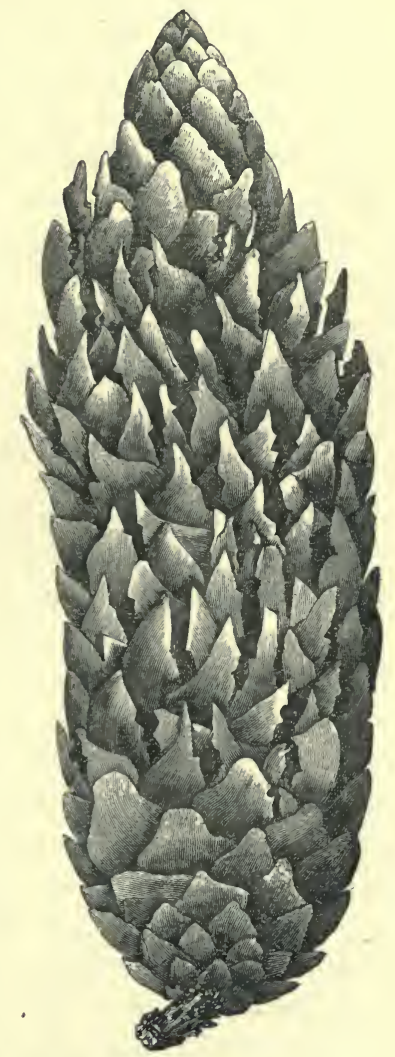

Fig. 54.-Spruce-cone attacked by crossbill. reproduction of beech, which it is extremely difficult to guard against them.

The siskin also appears in great numbers, and prefers the seeds of the alder, but also attacks sowings of birch, spruce, silver-fir, larch, and other conifers. Something may be said in favour of the finches on account of their destruction of 
insects; the hawfinch frequently catches cockchafers even when they are on the wing, and then, perching on a twig, picks them to pieces, letting the hard elytra and legs fall to the ground.

Crossbills are extremely ravenous, and appear in swarms when there are good seed-years of spruce and Scots pine. They live on the seeds and berries of trees of several species. They bite off cones by the base, and open out their scales with their beaks and pull out the seeds. The common crossbill can only open spruce-cones, but the parrot crossbill also attacks pine-cones. They eat mountain-ash berries when cones are scarce, and even thistle- and dock-seed, and have been seen to eat beech-cotyledons. They do some compensation by eating plant-lice.

\section{Protective Rules.}

Blue strings may be placed crosswise over sowings. .

Red-lead can be applied to the seeds in the following manner : In a wide vessel, water and $1 \mathrm{lb}$. of red-lead are stirred together, and 7 to $8 \mathrm{lbs}$. of spruce-seeds mixed up with it, about $1 \mathrm{lb}$. at a time, the water in the vessel being constantly stirred until the seeds will take up no more of the lead. The seeds can be sown at once without drying. This costs $5 d$. per 1 b. of seeds for labour and material. Dilute carbolic acid may also be applied to seeds, as already mentioned. Scarecrows are of very little use against finches.

The seed-beds may be watched during the dangerous time, and blank cartridges fired.

A good plan is to shoot some of the birds, and hang the bodies to stakes near the seed-bed.

Cones bitten off and dropped by crossbills may be utilised to secure the seeds remaining in them.

\section{Section VI.-Woodpeckers.}

The question whether woodpeckers are useful or hurtful to forests has been a subject of dispute, and will be here discussed. 


\section{List of Woodpeckers.}

In Central Europe the following species of woodpeckers are found :-

Black woodpecker (Picus martius, L.). Greater spotted woodpecker (Dendrocopus major, Koch). Intermediate spotted woodpecker (D. medius, Koch).

Lesser spotted woodpecker (D. minor, Koch). White-backed woodpecker (D. leuconatus, Bchst.). Three-toed woodpecker (Apternus tridactylus, Gould). Grey woodpecker (Picus canus, Gmel.). Green woodpecker (Picus viridis, L.).

The two last species are termed ground-woodpeckers. Of these the green woodpecker is the commonest in Britain, and D. major and minor also occur. Nos. 2, 3, and 7 are said to be commonest near Giessen, where Hess resides.

\section{Opinions of various Authors.}

Opinions regarding the utility or otherwise of woodpeckers from a forestry point of view have varied from time to time. Towards the end of the eighteenth century they were considered hurtful by pecking holes into trees which were sometimes sound ones.

In Beckmann's "Handbuch der Jagd wissenschaft," published at Nuremberg in 1802, this opinion was adopted, and in consequence a reward of $2 d$. per head was offered in Germany for their destruction. Bechstein was the first, in 1802, to consider them useful, and Walther in 1803; also Gloger about 1860. Foresters then went to the other extreme, considering woodpeckers as extremely active in destroying insects, and ignoring their propensity for making holes in trees. Altum in his "Forstzoologie" reverted to the former opinion, stating that woodpeckers were practically useless against dangerous bark-beetles, but attacked the larger and less important longicorn-beetles, and that they themselves did considerable damage to trees.

Altum wished, however, to protect woodpeckers on æsthetic grounds, because they enliven the forest and please the eye. Judeich follows Altum's views to a certain extent. König, 
Döbner, Vogt, the brothers Müller, Taschenberg, Borggreve, Nördlinger and others consider that the utility of woodpeckers outweighs the harm they may do, and Hess expresses himself

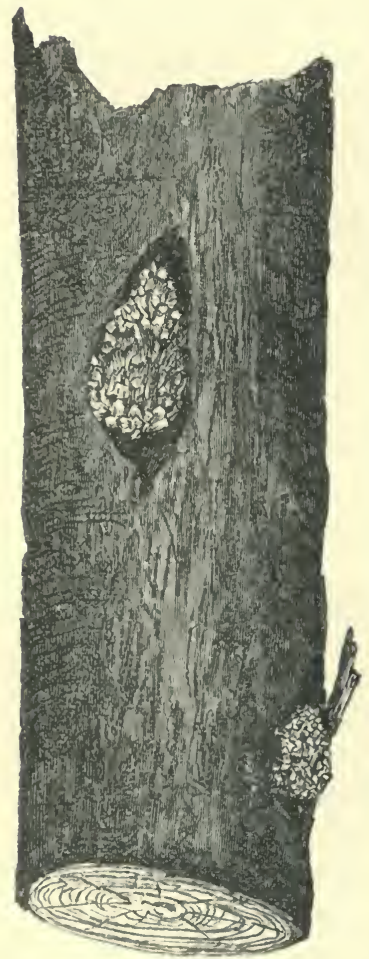

Fig. 55 -- Scots pine cones fixed into a tree by woodpecker ( $\frac{1}{4}$ nat. size).

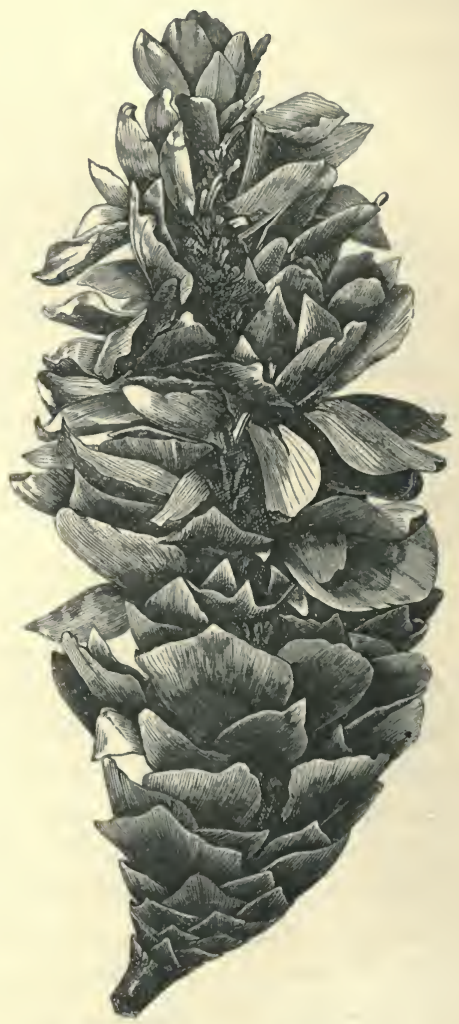

Fig. 56.- Spruce cone attacked by woodpecker.

as of the same opinion, from the most recent observations on the subject.

3. Damage done by Woodpeckers.

Woodpeckers eat forest-seeds, peck wounds in saplings, and holes in sound poles and trees; they girdle sound trees and destroy telegraph-poles and wooden roof-shingles. 
a. Destruction of Seeds.

Dendrocopus major alone of the woodpeckers eats large quantities of coniferous seeds. It wedges the cones, which it has plucked from trees, in a cleft in the bark, or in an angle between a stem and a branch, and opens them out and removes the seeds with its bill. We can distinguish between the action of the woodpecker and crossbill in this respect. Frequently the ground under a tree is covered with opened-out cones. Also walnuts, hazel-nuts, acorns, and other fruits are eaten by the great woodpecker. The damage done is not, however,

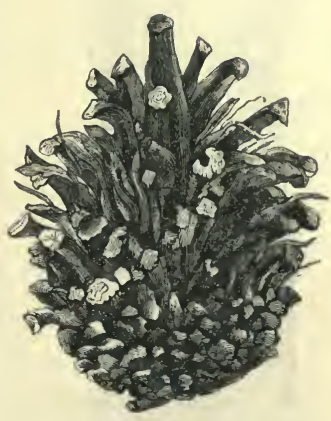

Fig. 57.-Cone of Scots pine attacked by woodpecker. very serious, as woodpeckers are solitary birds.

\section{b. Pecking Holes in sound T'rees.}

The black and the great woodpecker do most of this damage, and attack isolated trees and saplings. The woodpecker also attacks freshly planted saplings of oak, beech, acacia, exotics, etc., and the reason for its doing so is not very clear; in coniferous woods it may thus free the beak from resin derived from the cones it has been attacking.

Older trees are also attacked, such as avenue-trees (poplars, limes), oaks occurring in coniferous forests, boundary trees, etc. Most of this damage is done during spring and early summer but it is too rare to be of any practical importance.

\section{c. Girdling Trees.}

The same two woodpeckers, while hanging to the trunk by their feet with the support of their tail feathers, encircle trees with rings of holes arranged horizontally. A callus forms at each hole, but is pecked at again and again until quite a ledge has been made round the tree. Trees may sometimes be seen with several such ledges, one above the other, resembling the rings on bamboos. The reason for these attacks on sound trees has not yet been discovered (Fig. 58).

F.P. 


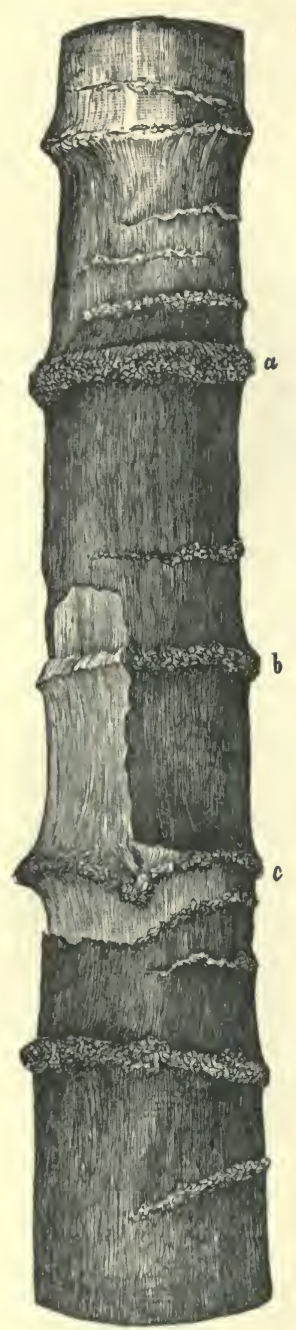

Fig. 58.-Scots pine girdled by woodpecker.

a Ring, with bark still remaining.

b Ditto, bark half removed.

c Ditto, bark entirely removed.

\section{d. Destruction of T'elegraph-Posts.}

The great woodpecker as well as the black and green woodpeckers share in this damage. Attacks have been observed both on coniferous or oaken posts, whether kyanised, or not, and generally commence at an old screwhole. In 1881, the Director of PostOffices for the German Empire issued a circular order that all holes in telegraph-posts should be filled with wooden plugs, and that holes freshly made by woodpeckers should be at once smeared with tar. Injuries done by woodpeckers to the wooden shingle roofs of forest lodges and other solitary houses have been noticed, but are rare and unimportant.

\section{Utility of Woodpeckers.}

a. Destruction of Insects.

The injurious insects, which woodpeckers devour, live either in or on the surface of the soil, or in the wood or bark of trees, and the latter kinds are preferred.

Woodpeckers chiefly seek animal food from April till late summer. They capture cockchafers, pick grubs from fruit, and eat the pupæ of moths and sawflies; they dig into ant-hills, consuming numbers of ants, which are said by Yarrell to be the chief summer food of the green woodpecker, and they peck holes into the ground in search of cockchafer grubs, wire-worms, etc. For the most part, however, they hunt on trees for weevils, bark-beetles, longicorn-

beetles and their grubs, sawfly larvae, gall-insects, spiders, etc. 
Fig. 59 shows a Scots pine stump attacked by woodpeckers in search of insects.

The tongue of woodpeckers, owing to its construction, is extremely useful in the search for insects; it is very long and thin, and is furnished near the tip with a few stiff barbs pointing back-

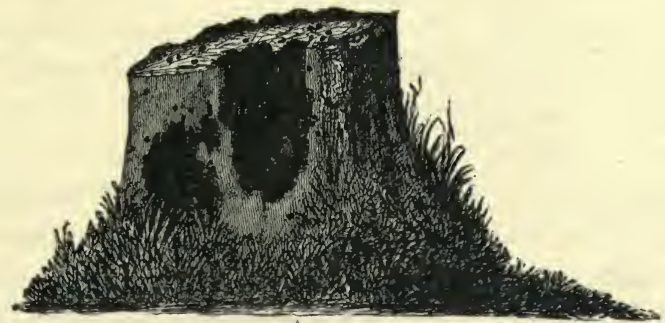

Fig. 59. - Scots pine stump visited by woodpeckers. (After Altum.)

wards. The cornua of the hyoid bones, which support it, curve round the back of the head to its upper surface, terminating in a cavity in the bones of the beak, and their mobility and great length allow the tongue to be freely extended. The woodpecker

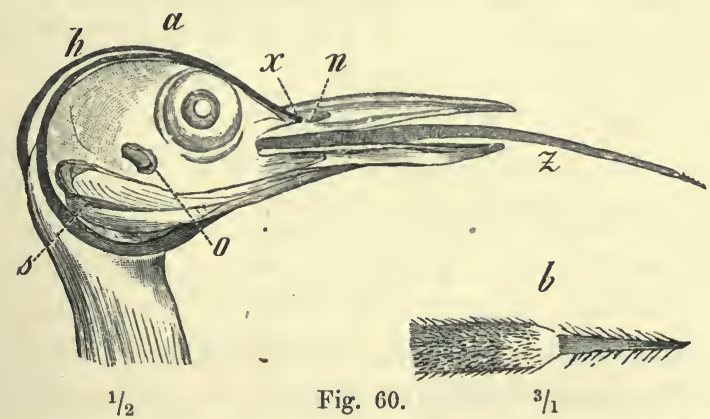

a Head of woodpecker (Picus canus, Gmel). $\quad b$ Tip of tongue with barbed hairs.

$h$ Cornua of the hyoid bone. $\quad x$ Opening in the maxilla for

$n$ Nostril. the cornua.

o Ear.

$z$ Tongue.

$s$ Salivary gland.

darts its tongue into cracks in the bark, using the barbs for detaching the insects, which are captured by adhesion to the slimy surface. The spotted and ground woodpeckers hunt in 
this manner more or less throughout the year, the former chiefly on trees, and the latter more on the surface of the ground.

Woodpeckers detect insects by the senses of sight, smell and sound; it is not yet decided which of these is predominant. It cannot be denied that they prefer the large but less harmful larvae of Cerambycidae, Cossus and Sirex, to the minute larvae of weevils and bark-beetles, but repeated observation shows that they are also keen hunters of the latter. Amongst the most hurtful species which they destroy may be mentioned Pissodes pini, L., P. notatus, Fabr., Myelophilus piniperda, L., and Hylastes palliatus, Gyll. The damage done by the black and ground woodpeckers to ant-hills may indeed be classed as injury to the forests, to which ants are useful, but living larvae of parasitic beetles are, when present, often preferred to ants by the woodpeckers.

\section{b. Nitification in Trees.}

Woodpeckers cannot make nest-holes in trees without injuring them, but this is done chiefly in the case of softwooded species, the aspen, lime, etc., or in rotten old hardwoods. The damage done is not great, and the holes are subsequently used for breeding by several useful birds, starlings, titmice, and flycatchers, the former frequently driving the woodpeckers from a new hole they have just made, in order to build their own nest there.

\section{Summary.}

The result of investigations into the utility of woodpeckers tends to show that these birds by their activity in the destruction of insects play a most useful part in Nature, and should therefore be protected by foresters. Hess holds the same views as Borggreve, that all useful birds tend to prevent an undue preponderance of insects, keeping their numbers more or less normal in ordinary years. In case of a great insect calamity, however, the action of birds is inadequate to protect the forests; ichneumon-flies and fungoid diseases eventually put a stop to the plague. 


\section{CHAPTER IV.}

\section{FOREST INSECTS. GENERAL ACCOUNT.}

\section{Section I.-Classification.}

Entomology is the science dealing with insects, which belong to the division of the animal kingdom termed Arthropoda, including all animals the bodies of which are bilaterally symmetrical and composed of segments, that is, of successive transverse divisions which present a more or less complete recurrence of structural features, and which have articulated appendages. The body and its appendages possess a hardened exterior, formed of a substance termed chitin, similar in character to, but not identical with, horn, and the muscles are internal, and attached to the external skeleton. The symmetry of the successive segments is not complete from end to end of the body, and is more evident in the body-walls and their appendages, than in the viscera. The segments are aggregated into definite groups, the components of which are more nearly related to each other, particularly in the structure of their appendages than to the segments of the other groups. This form of segmentation is termed heteronomous. The nervous system consists of a double chain of ganglia placed along the ventral surface of the body, connected with each other longitudinally and transversely by nerve-commissures, and traversed anteriorly by the digestive system; the vascular system is dorsal. Respiration is effected in various ways.

The four great Classes of Arthropoda are :-

1. Crustacea: respiring by branchiae or gills, or by the general surface of the body; with two pairs of antennæ and more than eight locomotive appendages, the latter forked or biramous. Crabs, lobsters, shrimps, woodlice, etc.

2. Arachnida: respiring in various ways, usually airbreathing; head and thorax united; with two pairs of jaws 
and four pairs of legs; abdomen destitute of limbs; no antennae. Scorpions, spiders, and mites.

3. Myriapoda: respiring by tracheae, or involutions of the integument; head distinct, remainder of the body formed of nearly similar segments; one pair of antennae; three pairs of jaws and numerous legs. Centipedes, millepedes.

4. Insecta: respiring by tracheae; head, thorax, and abdomen distinct, one pair of antennae; three pairs of legs on the thorax; abdomen without well-developed limbs; generally with two pairs of wings on the thorax. Insects.

A knowledge of the general anatomy of insects, and of the terms used in the present book in describing the different species, is presupposed.

Insects as a general rule before attaining maturity pass through a series of changes termed metamorphoses.

The different stages of their life consist of the egg, larva, pupa, and imago or perfect insect. Some insects, such as parasitic lice, do not appear to undergo any metamorphosis, the young on hatching-out resembling their parents in all respects except in size, although they may moult, or shed their skins frequently; they are known as ametabolic insects.

The larval stage is essentially the stage of growth and of active feeding. The larva undergoes several moults or ectyses, never possesses wings and is incapable of reproduction.

The larvae of insects may be destitute of legs, as in the case of fly maggots, or they may have three pairs of true legs, on the first three segments after the head, as in the cockchafer grub, or in addition to these, two, five, six, or seven pairs of clasping feet, or prolegs attached to the abdominal segments, of which the pair on the last segment are known as the anal prolegs or claspers. The larvae of Lepidoptera are termed cateritlar's.

The pupa of insects is usually inactive, and is protected by its dried and hardened skin; frequently, as in spinning Lepidoptera, it is surrounded by a protective case termed a cocoon, and constructed by the larva.

In the case of certain insects, as grasshoppers, the pupa differs from the larva only in having rudiments of wings; it is still active and feeds, and is termed a nymph. Such a pupa 
is converted into the imago by the liberation of its wings at the last moult.

The insects which undergo metamorphosis are consequently divided into metabolic insects, or insects with complete metamorphosis, in which the pupa is quiescent and does not feed, and in which the greatest weight and bulk is attained at the end of the larval stage; and into hemi-metabolic insects, in which there is an active nymph and the imago is the bulkiest and heaviest form. Metabolic insects form 95 per cent. of the whole class.

Insects may be grouped either according to the structure of their bodies, or their mode of life, and Entomology uses the former of these characters in their classification, but in Forest Protection it is of greater convenience to study the latter.

Much difference of opinion has existed regarding the classification of insects. The simplest method, based on the systems of Linnaeus and Fabricius recognises seven Orders. The former naturalist relied principally on the structure of wings in distinguishing the different orders of insects, and the latter on the parts forming the insect's mouth. The Orders may also be arranged, according to the degree of completeness of their metamorphoses, in two groups containing the metabolic and ametabolic insects respectively. Though the degree of metamorphosis is of the first importance as a guide to the systematic position of an insect, it is not, when taken alone, of the highest value in classification, as it cannot be decided by mere observation of any particular insect, without study of its life-history.

Certain writers who have attached great weight to structural differences, particularly of the wings, have increased the number of Orders to thirteen (Westwood) or sixteen (Packard). The groups which have been raised to the rank of additional Orders are of minor importance, and contain as a rule a small number of aberrant forms. In the present work, the broadest and most generally-received classification will be followed, in which the Insects are divided into seven Orders, characterised as follows :-

1. Orthoptera : with biting mouth-parts, a free prothorax, and incomplete metamorphosis. Cockroaches, crickets, locusts, 
termites or white ants, and dragon-flies, are examples of this order, the two latter belonging to a sub-order termed Orthoptera pseudo-neuroptera. In this sub-order the liead is horizontal and the wings membranous in texture; in the true Orthoptera (O. gemuina) the head is vertical and the wings are stronger and of a more leathery consistency.

2. Neuroptera: with biting mouth-parts, a free prothorax, two pairs of membranous richly-veined wings, and complete metamorphosis. Lace-winged flies (Chrysopa and Hemerobius) are examples.

3. Coleoptera: with biting mouth-parts, free and stronglydeveloped prothorax; two pairs of wings, of which the upper are horny, protective and not used for flight, being known as wing-cases or clytra, and the lower membranous; complete metamorphosis. It includes all beetles, of which the common cockchafer may be taken as a type.

4. Hymenoptera : with biting, or biting and partly suctorial mouth-parts; the prothorax fused at least dorsally with the mesothorax; two pairs of membranous wings with comparatively few veins, sometimes apterous; with complete metamorphosis. Examples: bees, wasps, ants, and sawflies.

5. Lepidoptera: with suctorial mouth-parts, the prothorax annular and fused with the mesothorax, two pairs of membranous wings covered completely or partially with scales; complete metamorphosis. The butterflies and moths belong to this order.

6. Diptera: with sucking moutl1-parts, an annular prothorax fused with the mesothorax, one pair of well-developed membranous fore-wings, the hind-wings rudimentary and reduced to small stalked knobs, forming the so-called poisers. Complete metamorphosis. 'This order includes all flies.

7. Hemiptera: with sucking mouth-parts, a free prothorax, and incomplete metamorphosis. Bugs, aphides, and scale insects belong to this order.

Forest Protection deals with forest insects only, namely, those insects that affect forest plants either-prejudicially, or beneficially, and this either directly, or indirectly. Injurious insects have a direct influence on forest plants by biting, sucking, or killing them. Both injurious of useful insects 
may be killed by other insects, which are thus indirectly useful or injurious.

The vast importance to foresters of forest insects, the enormous amount of damage which these small but mighty members of Nature's household can effect, combined with the fact that, owing to their small size and obscure mode of life, they escape observation much more readily than injurious vertebrates, render it necessary to spend more time on their study.

A full account of the anatomy of insects will not be attempted here, and the works of Altum, Ratzeburg, etc., may be referred to, the most comprehensive work on forest insects being the revision of the 8th edition of Ratzeburg's book by Judeich and Nitsche.*

The following works also merit attention: 5th Report of the United States Entomological Commission, "Forest Insects," by Dr. A. S. Packard, Washington, 1890; " Manual of Injurious Insects," by Miss Ormerod, London, Messr's. Simpkin, Marshall \& Co., 1890; "Indian Forest Zoology," by E. C. Cotes, Calcutta, 1893 ; and "Injurious Insects in Indian Forests," by E. P. Stebbing, now being published in parts. "Leitfaden der Förstinsectenkunde," by Dr. Nüsslin (Paul Parey, Berlin), an excellent work for students. 1905. Mr. A. T. Gillanders is now bringing out a comprehensive, work on Forest Entomology.

Section II.-Distribution of Insects.

The geographical distribution of insects may be considered both horizontally and vertically.

As regards the horizontal distribution of insects, the local mobility or the wandering nature of many species precludes the possibility of defining zones similar to those laid down for plants. It may be stated roughly that there are, in Central Europe; fewer species in the north and east than in the south and west. Beetles, however, form an exception to this rule, being more abundant in the north and east. As instances of special areas for certain insects may be quoted: The ash-cicada,

* "Lehrbuch der Mitteleuropäischen Forstinsektenkunde" (als achte Auflage von Ratzeburg's Die Waldverderber und ihre Feinde) herausgegeben von Dr. J. F. Judeich u. Dr. H. Nitsche. Vienna : Eduard Hölzel, 1889-95. 
which does not occur north of the river Main ; the oak procession moth is commonest in north and east Germany. The character of the insect fauna is, however, generally similar over the whole of the Palæarctic region, which includes Europe, the northern coasts of Africa, and Asia north of the great mountain chains that cross it from east to west. The number of species extending over the whole of this region is comparatively small, and there are no zones in it in which the character of the insect inhabitants is abruptly changed. As compared with continental regions under similar climatic conditions, the insect fauna of the British Isles is poor.

As regards altitude, the distribution of insects depends on that of the trees and shrubs on which they feed, and also on locality and climate. Most insects prefer the warmer plains and hilly districts, especially with a sandy soil, where beetles thrive. Soils naturally poor and those impoverished by removal of litter, sunny aspects, frost-hollows, and stunted vegetation are natural breeding-grounds for insects, and require the most careful supervision on the part of the forester. The number of species and of individuals alike diminishes with increasing altitude; this is especially the case with Lepidoptera, which are most dependent on climatic conditions, but beetles are found at a considerable elevation in mountains. Certain species of weevils and bark-beetles may be considered as mountain insects, such as Otiorrhynchus niger, Fabr., Tomicus cembrae, Heer, Hylastes glabratus, Zett. Even species of Chermes are found at elevations of between 3,000 and 3,600 feet.

Insects, especially beetles, can support severe winters. This was proved in $1870-1,1879-80$, the summers that succeeded these hard winters being rich in insects. Their horny elytra or wing-coverings protect them, and instinct impels them to creep under roots and into cracks in the bark of trees, or under moss or dead leaves for protection against the weather, or to burrow underground. Moreover, as their enemies, moles and insectivorous birds, cannot touch them when snow or frost covers the ground, and are themselves killed in very severe winters, such weather is really favourable to insect life. A warm winter, which is usually accompanied with 
much moisture, is very destructive to hibernating insects, especially hairy larvae, which suffer from fungoid diseases.

Insects' eggs and pupae are almost insensible to cold. Hairless larvæ are most sensitive, especially at moulting periods. Cold damp weather and cutting winds will then kill them off in myriads. Storms blow larvae by thousands from the crowns of trees. Uniformly warm years without heavy rains therefore tend to produce great swarms of insects. Very dry summers greatly reduce the food of some insects and consequently their numbers.

\section{Section III.-Life-History.}

\section{Generative Periods.}

Insects are distinguished from more highly organised creatures by having generally a definite limitation to their duration of life. The time which elapses between the egg and the fresh production of eggs is termed a generation. These may be single or annual, multiple, biennial or pluvennial.

A single generation occurs when an insect goes through all its stages within twelve months (not, however, within a single calendar year), and is by far the commonest. Thus, nearly all Lepidoptera have one generation in the year. A few Lepidoptera have more than one brood in the year, and, still more rarely, the life of an individual species may extend through two years, as Tortrix resinella, L., or even longer.

In the case of a multiple generation, several broods are produced during twelve months, so that the respective stages, eggs or larvæ, of the same species may be found in different months. A double generation is here commonest, as, for instance, in the case of many bark-beetles and sawflies. Many plant-lice produce five or more generations in a single summer, and the Bengal multivoltine silkworm completes a generation every month, except during the period from November to February. Three broods are sometimes produced within two years, for instance, by. Tomicus bidentatus, Hbst., but such cases are rare. A plurennial generation denotes that the insect takes more than one year for its full 
development, for example, two years in the case of longicorn beetles and Sirex, and three or four years for the cockchafer.

Of the several stages of the insect, that in which it hibernates lasts the longest, and is generally the larval stage. The egg and pupal stages usually last for about two to four weeks unless they happen to be the hibernating stage, and eggs laid after Midsummer do not generally hatch out till the succeeding year. As a rule, the imago stage is the least long-lived; but with beetles this is not the case, as the imagos very frequently hibernate. Many Hymenoptera are long-lived insects; bees, for example, live four or five years.

F. Rühl, of Zurich,* has observed the life-period of a few beetles in their various stages: eggs, 5-44 days; larvae, 47-1640 days (many longicorn larvae live longer); pupae, 8-39 days; beetles, 3-60 days. As a rule, insects with fully developed sexual organs live for a short time only, while unsexual insects live longer.

Many families of insects, for instance, bark-beetles, have irregular broods; the state of the weather, and the quantity and quality of their food may cause the development of one, two, or even three broods in a year. On the other hand, certain circumstances, such as unfavourable weather, want of opportunity for pairing or for laying eggs, may not unfrequently cause delay in a brood. Thus, for instance, a brood of the pine sawfly (Lophyrus pini, L.) has been known to extend over $1 \frac{1}{2}$ to 2 years, instead of there being one or two broods in the same year.

\section{Habitat.}

The habitat of insects varies according to their state of development and the season of the year. They are sometimes found on or under the surface of the ground, or on woody or herbaceous plants. They generally hibernate under the soilcovering, or inside the bark of trees. As a rule, all insects live near the material on which they feed, but many wander far, sometimes against their will, as when they are blown into the sea by storms of wind. They generally endeavour to return to their former abode, as in the case of bees and ants.

Examples of insects that have been imported to Europe * "Centralblatt für das Ges. Forstwesen," 1888, p. 156. 
are: The longicorn beetle, Gracilia pygmaea, Fabr., which came to Germany in the hoops of casks made of willows or oak. Species of Lyctus were imported in Australian wood. The destructive Colorado beetle (Doryphora decemlineata) came from America with a cargo of potatoes. The phylloxera (P. vastatrix, Planch) on American vines.

\section{Mobility.}

The mode and degree of rapidity with which insects move may be usually inferred from the structure of their organs of locomotion. Some insects have legs for running, as groundbeetles; for jumping, as fleas; for digging, as crickets ; for swimming, as water-beetles.

The imagos run or fly; their course being rapid (Carabus), or slow (Cerambyx); their flight is either fast (Bombus), slow (Melolontha), irresolute (Papilio), or hovering (Syrphus) ; extended (Sphynx pinastri, L.), or short (Gryllus). The flight of the $q^{*}$ is heavier than that of the $\delta$, especially when she is laden with eggs.

The mobility of the larvæ depends largely on the number of their legs $(6,8,10,16,18,22)$, all but six of which are soft and fleshy prolegs. Many lepidopterous caterpillars assist their movements by spinning threads, such as those of many Bombyces, Geometers and Tortrices (e.g. Tortvix viridana, L.)

\section{Food.}

Metabolic insects feed only as larvæ and imagos, and chiefly in the former state. Thus, the food of butterflies and moths is limited to the nectar of flowers. Some beetles, however, are destructive as imagos only (Hylobius abietis, L., etc.). Ametabolic insects also feed in the pupal stage. The appetite of larvae in both groups is enormous, and there are larvae which eat daily more than their own weight of food.

Insects may be termed carnivorous or phytophagous, according as their diet is animal or vegetable. Most insects useful to the forester belong to the former category, whilst plant-feeders are all more or less injurious.

* The symbol $q$ denotes the female, $\delta$ the male, and $\zeta$ the worker, or imperfect female. 
In accordance with their choice of nutriment, insects may be classed as mono-, poly- or pantophagous. Monophagous insects only attack certain plants or at most a group of plants, such as broadleaved, or coniferous trees. Polyphagous insects attack trees of both kinds, whilst pantophagous attack herbage as well, and are least numerous of all.*

Observations are not yet complete regarding the monophagy, or polyphagy of certain insects. The hitherto accepted monophagy of some insects has often been upset. Tomicus typographus, L., and $T$. amitinus, Eichh., formerly considered exclusive to spruce, have also been found on Scots pine and larch. Myelophilus piniperda, L., has been found on spruce, as well as on Scots pine. In this respect, the observation of beetles is more difficult than of Lepidoptera, that live in the open.

Even amongst carnivorous insects, monophagous and polyphagous species are to be found. Many parasitic insects, for instance, attack only a single species of moth, and in one stage only of its growth, in the egg, larval, or pupal state.

Conifers suffer much more than broadleaved species from insect-attacks. They afford nourishment to a greater number of injurious kinds, and do not recover from damage so readily, as they cannot replace injured members so easily as broadleaved trees. The Scots pine and the spruce are attacked by the greatest number of species of insects, and pure woods of these trees suffer most severely. Amongst broadleaved trees, oak, beech, poplars and willows suffer most, the birch and alder less, and less still hornbeam, maple, ash. Least of all robinia, mulberry, walnut, plane, sweet- and horse-chestnut.

Suppressed, weakly; and injured or diseased trees generally suffer more from insects than healthy trees; at any rate this holds good for mature trees with thick bark. Hence injurious insects increase and become more dangerous when trees have suffered from various climatic or physiological injuries, or those caused by abrasions, bad pruning, etc.

Species of insects which live on dying, dead or rotten wood

* This definition is that of Hess. As a rule, entomologists would hardly call a species that feeds indifferently on Picea, Pinus, and Larix monophagous, but would reserve the term for those insects whose diet is limited to a single species or genus. 
are of no importance to the forester; such are the stag-beetle (Lucanus cervus, L.), and many species of Anobiidae and Cerambycidae.

Many insects confine their attacks to fully-grown or old trees; others attack only young plants (Hylobius abietis, L.); others attack trees of all ages (Myelophilus piniperda, L.).

The attack may be on the roots (Gryllotalpa vulgaris,.L., Melolontha vulgaris, Fabr., in the larval state); on the bark (most species of Tomicus and Hylesinus); on the wood itself (Trypodendron lineatum, Gyll., species of Sirex and Cerambyx); on the leaves or needles (Chrysomela and most lepidopterous larvae); on buds (Curculionidae, Tortrix buoliana, Schiff.); on the blossom (Anthonomus pomorum, L.); on fruits (Balaninus nucum, L., Carpocapsa pomonella, L., Tortrix strobillela, L.) ; on the pith (Myelophilus piniperda, L.).

Many insects by biting and sucking produce malformations termed galls on leaves, shoots, fruits, etc. (Cynips, Aphis, Cecidomyia, Chermes and Coccidae, etc.); such damage is easily discernible, but is of subordinate importance.

Damage by insects reduces the production of good seed by the trees attacked. Dr. A. Hosaeus investigated the seed of Scots pine from trees attacked by and free from leaf-larvae, obtaining 1 and 45 per cent. of good seed respectively.

\section{Section IV.-Number.}

The number of individuals of a particular insect that may coexist is in many species limited, but in others may attain vast proportions, especially under favourable circumstances. Thus in 1884,*200 square miles of sál forest (Shorea robusta) in Assam, north of the Bramaputra river, were ravaged by the caterpillars of Dasychira Thwaitesi, the trees exhibiting complete or partial defoliation. The appearance of certain insects shows a periodicity, corresponding to the eleven years' weather periods.

Fortunately, the most prolific of insects, plant-lice, are not the most destructive to forests; these creatures, according to Réaumur, may produce 5,000 millions from one female in the

$$
\text { * "Indian Forester," vol. xx., p. } 256 .
$$


course of five generations, and in one summer ten such generations may occur. The average number of eggs of the commoner injurious insects varies between 100 and 200 (Ratzeburg). Warm, dry weather and plenty of food, and breeding-places, such as diseased wood, or branches broken by snow, are very favourable to prolific multiplication. Under such circumstances, insects that are generally of limited numbers may appear locally in destructive swarms. Besides the case of bark-beetles, such an abnormal increase is frequently met with in the case of the grey-tussock moth (Dasychira pudibunda, L.), allied to that species which ravages the Indian sál forests.

One favourable season is not usually sufficient to produce an insect-calamity, but two or more successive favourable springs and summers.

Most insects are solitary, but many, such as bees, ants, certain kinds of wasps, and termites, are social and have a wonderful organisation, framed on the principle of subdivision of labour. The larvae of some moths are also gregarious.

\section{Section V.-Useful Forest Insects.}

Carnivorous insects attack other species in various ways, and have been subdivided by Ratzeburg as follows:-

Predatory insects follow and kill other insects in every stage. Ground- and tiger-beetles belong to this group.

Predaceous parasitic insects, like the former class, seize other insects, but carry them to their nests, where their own larvae feed on them. Such are the fossorial wasps (Sphegidae or Crabronidae); they first sting their prey, but without killing them, and thus render them inert.

Finally, parasitic insects wound the larvae, pupae, or even the eggs of other insects with their fine ovipositors to lay eggs in them. The larvae hatching from these eggs feed on the juices of their hosts. Ichneumon-wasps and some flies (Tachinae) are examples of this group.

A classification of these insects according to their utility is scarcely possible; of predatory insects, the largest are generally the most useful, especially species of Carabus and Calosoma. 
Ichneumon-wasps and parasitic flies increase in numbers in proportion to the abundance of their hosts, which bring about an insect-calamity; they thus assist in suppressing it, whilst other animals, incapable of rapid multiplication, can only keep down the numbers of injurious insects in ordinary times.

\section{Section VI.-Injurious Forest Insects.}

\section{Damage done.}

The grouping of insects that are injurious to forests may follow either the degree of damage done, or the kind of damage, or nature of the attack.

\section{a. Degree of Damage.}

In accordance with the amount of damage they do, we may distinguish forest insects as highly injurious, decidedly, or slightly injurious. The degree of resistance of the species of tree, the part of the tree attacked, and the severity of the attack, as well as the abundance and voracity of the insect in question, decide the degree of injuriousness for any case. It is, however, impossible to assign any strict limits to the several groups.

An insect is considered highly injurious when by the nature and duration of its attacks, masses of plants or whole woods, otherwise healthy, may be killed over more or less extensive areas.

To this category belong, e.g., Melolontha vulgaris, Fabr., IIylobius abietis, F'abr., 'T'omicus typographus, L., Gasteropacha pini, L. The two former insects frequently destroy extensive areas of young plants, and the two latter large areas of forest trees.

Decidedly injurious insects destroy certain organs only of trees, such as the leaves, inflorescence or fruits, shoots, or stems, or they weaken and eventually kill plants here and there in the woods. Most injurious insects belong to this group.

Slightly injurious insects hardly deserve notice from a forest point of view, as they only cause trifling damage; they either attack dead stems or tree-parts without impairing their commercial value, or the damage done by them to leaves, shoots, 
etc., has no subsequient fatal effect on the plants. Such are tortrices and leaf-miners, and many gall-insects.

In a time of exceptional multiplication, a slightly injurious insect may become decidedly injurious, or a decidedly injurious insect, highly injurious. A single species of insect may also be injurious in a different degree to different species of trees: it may prefer one to another, or one tree may recover more easily than another from its attacks. Liparis monacha, L., e.g., is far more injurious to conifers than to broadleaved trees, and to the spruce than to the Scots pine.

\section{b. Kind of Damage.}

Insects may be classed according to the kind of damage they do, as commercially or physiologically injurious. The former class renders useless, or greatly reduces the commercial value of the part of the tree they attack, as when wood has been bored by Sirex, Cerambyx, Anobium, or Lyctus.

Physiological injury on the contrary is that which interferes with the vitality of plants, checking the growth, or even killing them outright, as when the cambium of a tree is eaten by Tomicus typographus, L., or the needles by Gasteropacha pini, L., or by Liparis monacha, L.

Insects coming under the second category are therefore more hurtful than those which merely destroy wood, although the burrows of the latter are sufficiently conspicuous. Moreover, most wood-borers live in dead wood. It is, however, possible to pay too little attention to commercially injurious insects.

The degree of physiological injury depends on the species of insect, its mode of attack, numbers, and also on the species, degree of healthiness and age of the tree, the season of attack, and on other local circumstances. Mention has been already made of the greater susceptibility of conifers; the spruce suffering most of all, then the Scots pine, silver-fir and larch, the latter bridging the way towards broadleaved trees. Young trees, especially one to three years old plants, suffer more than old ones; and injury in the spring is more harmful than that done in summer or autumn. Cambium eaters do more damage than wood-eaters; leaf-eaters more than flower or fruit-eaters.

The healthier and stronger the attacked plant, the better it 
resists insects. On poor sandy soil, and in unfavourable situations, frost-holes, etc., the damage done is greater than to plants in good localities, as the repairing force of Nature is then greatest.

\section{c. Character of the Attack.}

The attack may be either primary or secondary in character. In the former case, healthy trees are injured by insects attacking the leaves, buds, or seeds; by many shoot-borers, root-gnawers, and insects which attack young plants or saplings. The attack of other insects is only secondary, that is, it is made exclusively, or by preference, on plants already weakened by other causes (wild animals, fungi, drought, frost, etc.). This is specially true of bark and wood insects, which abound in old coniferous trees. The rich flow of turpentine from sound trees would kill the young larvae. Certain species, such as

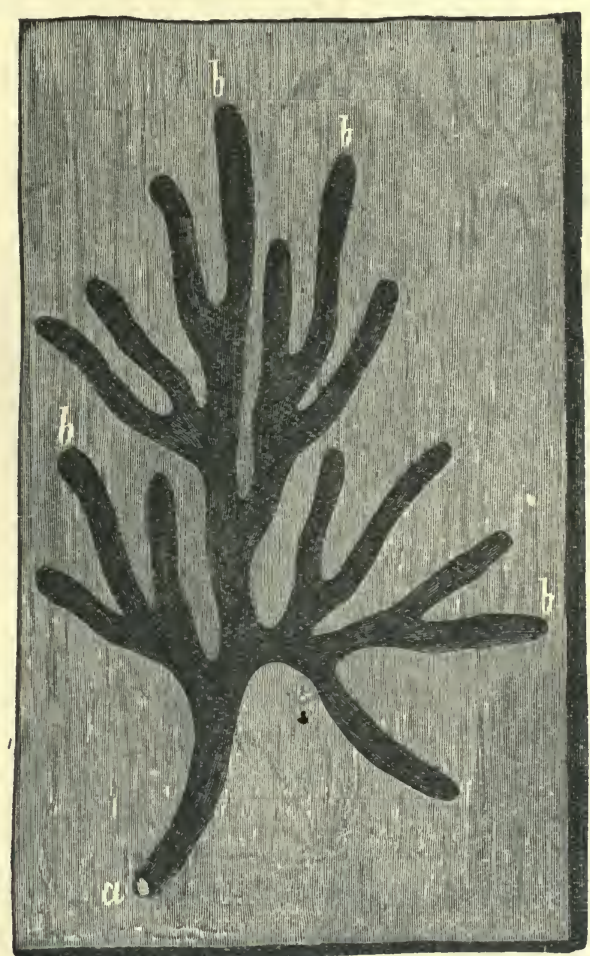

1/1

Fig. 61.-Galleries made by Tenthredo cingulata, Fabr. $a$ Common bore-hole. $\quad b$ Larval passages. the bark-beetles of broadleaved trees, according to circumstances, may make at one time primary and at another secondary attacks.

This distinction is of practical importance, as nothing can 
be done in cases of primary attack except to remove the parts of the trees which have already been attacked, together with the insects concerned; species which make secondary attacks can alone be caught by tree-traps.

Species of insects which occur in forests, but confine their ravages to grasses and herbage, are of no economic importance, unless these products are of exceptional value.

Finally species in themselves harmless, but which may be mistaken for highly injurious insects, are termed by Ratzeburg deceptive insects, e.g., Lithosia quadra, L., the larvae of which appear on all conifers, as well as on oak, beech, etc., in considerable numbers. It is quite harmless, feeding only on lichens. It greatly resembles Liparis monacha, L., for which it is often mistaken. Tenthredo cingulata, Fabr.; the larvae feeding on bracken, which they often completely devour, occupy galleries of bark-beetles under the bark of pines and make galleries of their own in pine bark, without injuring the trees in any way (Fig. 61). The forester must-therefore learn to distinguish harmless species from other injurious kinds which they may resemble.

\section{Preventive Rules.}

\section{a. Sylvicultural.}

Since the majority of injurious foreign insects, especially bark-beetles, prefer to attack sickly, stunted or weakly forestplants, and may spread from these to their healthy neighbours, the safest method for preventing insect attacks is to follow the rules which experience has laid down in sylviculture and forest utilisation for the formation, tending and harvesting of woods. In general, the following rules should be observed:-

(i) Choices of suitable species of trees and proper systems of regeneration. The species must be appropriate to the locality, and the system must correspond to the nature of the species grown. It is specially important to select strong healthy plants for plantations, and to plant most carefully.

(ii) Avoidance of extensive pure woods, especially in coniferous forest. It is better to grow mixed woods, and to mix broadleaved species with conifers. 
Even on sandy soils, where Scots pine naturally thrives, a mixture of Weymouth pine should be introduced, and a few birch, aspen and robinia. If the pines should be killed outright by insects, the wood will not become absolutely bare.

(iii) Careful and frequent examination of the woods for injurious insects. This precaution is most important in coniferous woods on poor, dry soil, in warm localities and especially during the spring.

It is most important to keep a careful watch round places where swarms of insects exist, and from which damage generally extends in all directions. The subordinate Forest Staff must be instructed to recognise and attend to the signs of an impending attack of this kind. Such signs are: unusual numbers of woodpeckers or cuckoos in a compartment; bitten-off leaves or needles lying on the ground; spun. threads hanging from the twigs; withering of foliage: excrement, or boring refuse, or bore-holes in the stems; exudation of resin; discoloration or peeling off of bark; and appearance of numbers of ichneumon-wasps or flies, etc.

(iv) Early and frequent thinnings, without interruption of the leaf canopy, are desirable. Such thinnings should remove all forest growth in a suppressed, sickly, or even suspicious condition. A foréster who merely removes dead wood does nothing to prevent insect attacks, for in it only unimportant species breed. Dying stems are the favourite resort of bark-beetles.

(v) Every attention should be paid to the rules for maintaining and improving the quality of the soil. This is best accomplished by careful preservation of the soil-covering, by draining away any superfluity of moisture, and by timely under-planting woods of light-demanding trees, such as oak, larch or Scots pine, with shadebearing ones, beech, silver-fir, etc.

(vi) Suitable preventive measures must be taken against damage by wind, frost, snow, ice, fire or insects. Broken wood must be worked up and removed from the forest as soon as possible, or at least barked.

(vii) In the clear-cutting system, avoid large felling areas, so 
that there may not be extensive tracts of even-aged woods. Several cutting-series should be established, by the use of severance fellings, if necessary. This gives a choice of the fellingarea for any particular year, and contiguous compartments are not cut in successive years. Fellings should be arranged against the prevailing winds, in order to avoid extensive windfalls and the consequent danger from bark-beetles.

(viii) Stools of felled trees should be extracted or carefully earthed over, especially in coniferous forests, as many highly injurious species of insects (Hylobius abietis, and several species of Hylastes) lay their eggs in stumps and roots.

(ix) Summer-felling in coniferous forests, together with careful removal of the bark. Wherever winter-felling is advisable for other reasons, some of the stems should be left lying as traps and barked in May, after the bark-beetles have laid their eggs in them. Wood felled during winter is now usually partially barked in strips, if it cannot be removed before the breeding season of the bark-beetles. If, however, these beetles do not find wood with the bark on lying in the forest they will lay their eggs in the bark of standing trees, while the cost of partial barking is considerable, and it is easier to destroy the larvæ in fallen timber than in standing trees.

(x) The forests must be kept clean, the fellings rapidly and thoroughly cleared, and material from thinnings carted away without unnecessary delay.

Further preventive measures against many species of insects are : turning-in swine for "pannage," the employment of caterpillar-trenches, wood-traps, grease rings, etc. As, however, these measures are remedial, as well as preventive, they will be discussed further on.

(xi) Rewards should be offered to the Protective Staff for discovering injurious insects and for special zeal shown in carrying out the rules for destroying them.

\section{b. Protection of Insectivorous Animals.}

Only those animals should be protected which do more good by the destruction of insects than harm in other ways. 
The following are the principal insectivorous vertebrates :-

\section{Mammals.}

All bats,* especially Vesperngo noctula, Shreb., V. discolor, Natt., V. pipistrellus, Schreb. The mole, shrews, especially Sorex vulgaris, L., the hedgehog, pole-cat, stoat, weasel and badger. These beasts, some of which have been already referred to as mice-destroyers, should be unconditionally protected.

The fox also devours numerous insects, particularly large beetles, and the wild pig is very useful in the case of insectattacks.

\section{Birds.}

The following birds deserve unconditional protection :-

The common cuckoo (Cuculus canorus, L.) ; woodpeckers, the wryneck (Jynx torquilla, L.); the night-jar (Caprimulgus curopacus, L.) ; the swift (Cypselus apus, L.); the tree-creeper (Certhia familiaris, L.); the nut-hatch (Sitta caesia, Wolf); all swallows (Hirundo, L.) ; wagtails (Motacilla, L.); pipits (Anthus, Bechst.); hedge-sparrow (Accentor, Bechst.); goldcrest (Regulus cristatus, Koch): wren (Troglodytes parvulus, Koch) ; redstart (R. phoenicurus, L.) ; stonechat (Saxicola rubicola, L.) ; wheatear (S. oenanthe, L.) ; flycatcher (Muscicapa, L.); titmice (Parus, L.) ; starling (Sturnus vulgaris, L.).

The various species of wagtail eat insects and also small snails, Limnaea sp., which are the hosts of the liver-fluke (Distoma hepaticum) that is so destructive to sheep. The goldcrest hunts throughout the year for the eggs, larvae and pupae of insects and for scale-insects on coniferous trees. So do titmice, especially the coal-tit (Parus major, L.), P. ater, L., P. caerulius, L., $P$. caudatus, L., and P. cristatus, L. The starling is especially useful in clearing off cockchafer grubs from meadows. They have been seen, at Coopers Hill, to pick them out of the nursery, from the side of Scots pine plants which showed no signs of attack. The bird walks along the line and hears the larvae working below. It also destroys wire-worms and surface caterpillars.

* Except the fruit-bats, called in India flying-foxes. 
Among Raptores, all owls except the eagle-owl (Bubo ignavus, Foster). Gulls; the black-headed gull (Lavus vibibundus, L.). This latter frequently follows the plough, and destroys cockchafer grubs and wire-worms. The cuckoo is exceptional among the above birds for its power of eating hairy caterpillars, which other birds reject. Altum found the remains of 97 young Cnethocampa larvae inside a cuckoo.

Of owls, the long-eared owl (Asio otus, L.) and the tawny owl (Syrnium aluco, Boie) are the most useful against insects.

The following birds merit conditional protection :-

Passeres : finches (Fringillidae); larks (Alaudidae); thrushes ('Turdidae); the jackdaw (Corvus monedula, L.); the common and hooded crows (C. corone, Lath., and $C$. cornix, L.); the rook (C. frugilegus, L.).

The above-mentioned passerine birds do damage in various ways, chiefly as grain-eaters, but are also useful in destroying - insects. Where the damage predominates, they must be kept down. Thrushes and blackbirds hunt in the forest for insect larvae and pupae, and distribute the seeds of useful shrubs and trees.

Raptores: the honey-buzzard (Pernis apirorus, Gray); common buzzard (Buteo vulyaris, Leach); the kestrel (F'alco tinnunculus, L.) hunts crickets and cockchafers, it does no harm to game.

Limicolae: woodcock (Scolopax vusticola, L.) ; snipe (Gallinago); golden plover (Charadrius plurialis, L.); lapwing (Vanellus vulgaris, Bechst.).

The lapwing destroys large numbers of wire-worms and beetles, aphidae, and the larvae of numerous insects feeding on crops. Unfortunately the search for their eggs is very persistent.

The following birds do indirect damage, by killing useful birds or eating their eggs :-

Passeres: shrikes (Lanius, L.) ; jay (Garrulus glandarius, L.) ; magpie ( Pica rustica, Scop.) ; raven (Corrus corax, L.).

Raptores: All species except those already mentioned.

It should be noted that shrikes kill mice and insects as well as small birds.

The mere protection of birds useful to forests is not sufficient ; 
means for promoting their multiplication should also be undertaken. The following points should be attended to :-

(i) Preservation of a few hollow trees in forests, as such trees harbour useful birds and bats.

(ii) The provision of boxes or vessels for nest-building on trees. These may be made of earthenware, of wood, of plaited straw, or tarred basket-work. Even dried hollow bottle-gourds may be used for titmice. The earthenware vessels should be of the shape given in the figure, and have a wooden base, and before hanging up should be tarred and covered with moss.
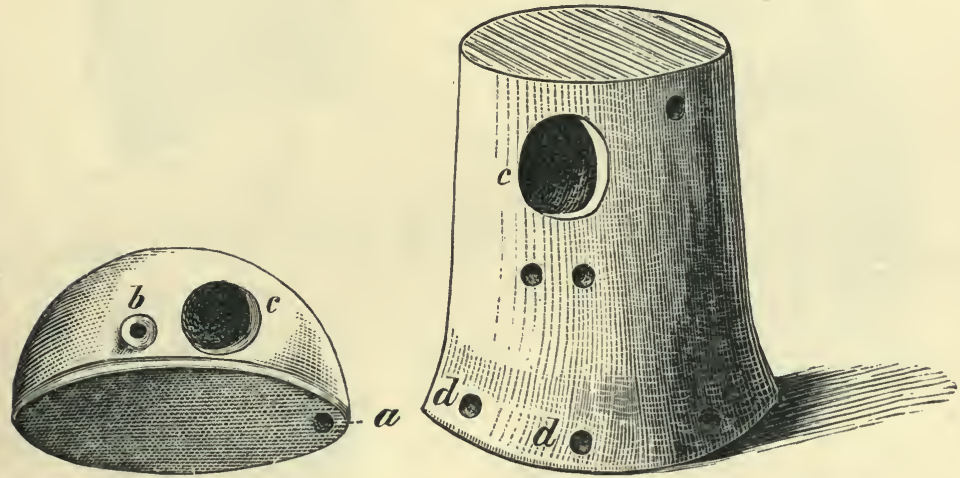

Figs. 62 and 63.-Earthenware nesting-pots.

$a$, Nail-hole for attachment to the tree. $b$, Hole for insertion of a wooden peg to assist the bird in entering. c, Flight-hole. $d$, Holes for the passage of a wire, to attach the bottom of the pot to a piece of wood.

The wooden nesting-boxes invented by Gloger* in 1853 are made out of half-inch boards, and tarred. There are six kinds, including those shown in the figures, and suitable for starlings, flycatchers, and titmice. Some are used for the birds to sleep in as well as for nests. The horizontal partition shown in the figures excludes cats, pole-cats, and other enemies, and also keeps the nest warm. It is essential to keep to the dimensions indicated by the reduced figures, or the nesting-box will be used by other species, for which it was not intended.

* "Nist-und Schlafkasten für Vögel." Allg. Frorst u. Jagd. Zeitung, 1864, p. 120. Prices are there given for the nesting-boxes. 


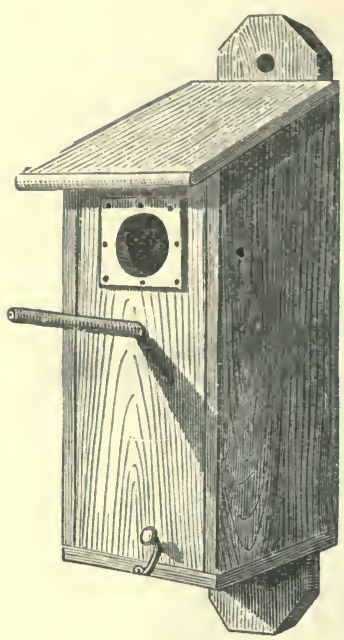

Outside.

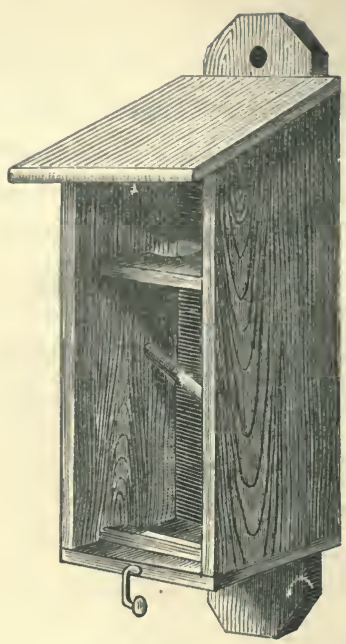

Inside.

Figs. 64 and 65.-Nesting-box for Starlings, Wagtails. Wrynecks.

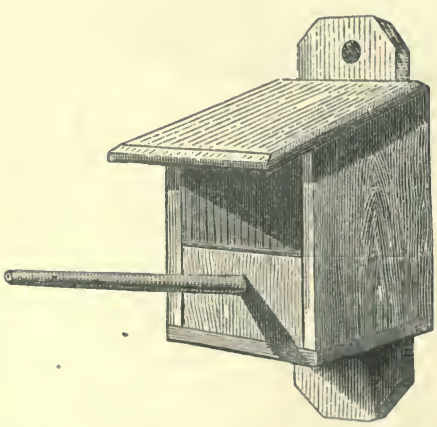

Fig. 66. -Nesting-box for the Flycatcher.

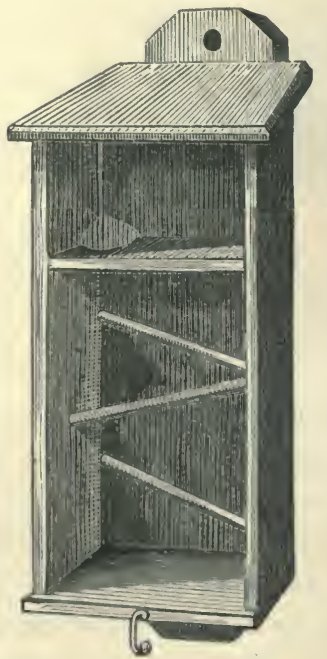

Fig. 67.-Inner view of a box with several compartments for a number of 'Titmice or similar birds.

NestiNg-BOXFs of Wood.

The figures reduced to $\frac{2}{13}$ of the natural size. 
The following rules apply to the manner of hanging-up the nest-boxes :-

The boxes should be hung facing towards the east or south only: never towards the west.

As starlings are sociable birds, several boxes for them may be hung at a height of 20 to 25 feet on the same tree, but for other species only one box should be hung on a tree.

Boxes for titmice should be hung 10 to 16 feet high in a dark place, best of all in coniferous forest, on silver-fir or spruce trees.

Boxes for redstarts and flycatchers, on the contrary, should be hung 10 to 16 feet high under light groups of trees, and on the borders of thin places and clearings.

(iii) Shrubs should be planted in sheltered places, along a brook, or by a spring, as water is a necessity for birds, also on rocks, steep places, etc. Suitable bushes are privet, honeysuckle, viburnum, elder, white thorn and wild roses; as an overgrowth, pollard-willows and mountain-ash. Undergrowth should also

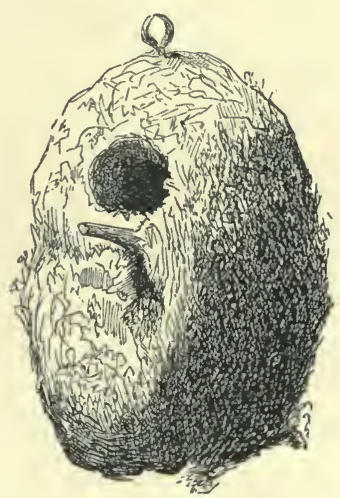

Fig. 68.-Nesting-box for the Starling, of tarred straw. be carefully preserved in high forest, unless it must be cut for sylvicultural reasons.

(iv) The birds should be fed when deep snow is on the ground. Bread or boiled pulse should not be given, as these substances become acid and unwholesome after wetting. For insectivorous birds pieces of suet or chopped meat are suitable. Thorns should be placed over the food, so that crows, doves, and sparrow-hawks may be kept off. The following places are most suitable as feeding grounds:-high ground for titmice, tree-creepers, woodpeckers and finches; roads for yellowammers and hedge and tree-sparrows; fields and gardens for robins, linnets, finches, and migratory birds from the north; for fieldfares, thrushes and blackbirds, the food should be placed under a shady conifer at the edge of the forest; the places 
which goldcrests and wrens frequent should be ascertained, and the birds fed there.

(v) Forest-litter should not be removed from March till July, as many useful birds nidify on the ground, or close to it, and would be disturbed.

(vi) Birdsnesting and the trapping or killing of useful birds should not be allowed.

In continental forests, enormous numbers of thrushes, fieldfares and similar birds are caught every year in the autumn and winter by means of horse-hair nooses attached to the trees. Wherever such bird-catching is allowed, the open season should be limited to the period between the 1st of October and the 1st of February.

Legal enactments to protect useful birds are necessarily made by the State, and should be properly enforced.

A convention, dated 19th March, 1902, has been made for the protection of useful birds between all the principal countries in Europe, except the United Kingdom, Holland, Belgium, Russia, and Norway. The Wild Birds Protection Act became law for the United Kingdom in 1880. It las since been slightly amended in 1881, 1894, 1896, and in 1902. As the destruction of vermin in country districts, the curtailment of the area of cultivation, and the protection afforded by the Act to wild birds have upset the balance of Nature-bullfinches, stailings, blackbirds, thrushes, and sparrows do much harm, especially in orchards. Except, however, for a scheduled list of rare birds, that no one may kill during a close time, owners and occupiers of land and persons authorised by them may kill other birds during the close time.

\section{Reptiles and Amphibia.}

Toads, frogs, and lizards are very useful as insect and slug destroyers, especially in gardens and forest nurseries, but they are not nearly so numerous as useful birds and mammals. Snakes and slow-worms are also useful, but the poisonous adder (1'elias berus, L.) will naturally not be protected. Adders are found all over Europe, in brushwood and on sumny slopes among stones. They feed chiefly on mice and moles. 
Insects.

A detailed account of the chief useful insects follows in Chapter V. Their number, especially that of ground-beetles, ichneumon-wasps and Tachinae, increases steadily with that of the destructive insects; this fact is all the more important as the activity of mammals and birds altogether fails to combat such calamities successfully.

\section{Spiders.}

Spiders (Arachnoidea) include two distinct families of insectdestroyers, Araneinae and Phalangiinae, both of which are great destroyers of insects. The common garden-spider (Epeira diadema, Cl.) and Steatoda sisyphia, Cl., may be taken as examples of the former class, and the common harvest-man (Phalangium parietinum, de Geer) of the other. The first catches many small beetles and other insects in its large vertical nets expanded in the underwood of forests, the second species destroys large numbers of Lophyrus pini, L., as well as other insects. The harvest-men become very active in the evening, moving about rapidly with their long stilt-like legs, and preying on small insects, plant-lice, etc.

The web-making spiders may do some slight injury to plants by their webs, which interfere with the full development of blossoms and foliage.

\section{Myriapoda.}

Centipedes, of which Lithobius forficatus, L., is an example, and millipedes, for instance, Iulus terrestris, L., live under bark, stones, and moss, and kill numbers of insects, also slugs and snails. Species of Iulus also attack fleshy roots in gardens and fields, as well as wheat, and fruit such as strawberries; they also appear to cut off seedlings at the collar in a manner similar to wireworms.

\section{Remedial Measures.}

In considering the measures to be taken in attacking insects, we must select the proper season, and adopt means which do 
not entail a greater expenditure of time, trouble, and money than the results will justify.

In general, the following rules may be adopted :-

(a) Collection and destruction of eggs, larrae, pupae or perfect insects. This is unfortunately impracticable for most injurious species, or is too protracted a method, except in the case of perfect insects. A knowledge of the life-history of any particular insect will inform the forester of the stage in which it is best attacked, but for practical reasons a season should
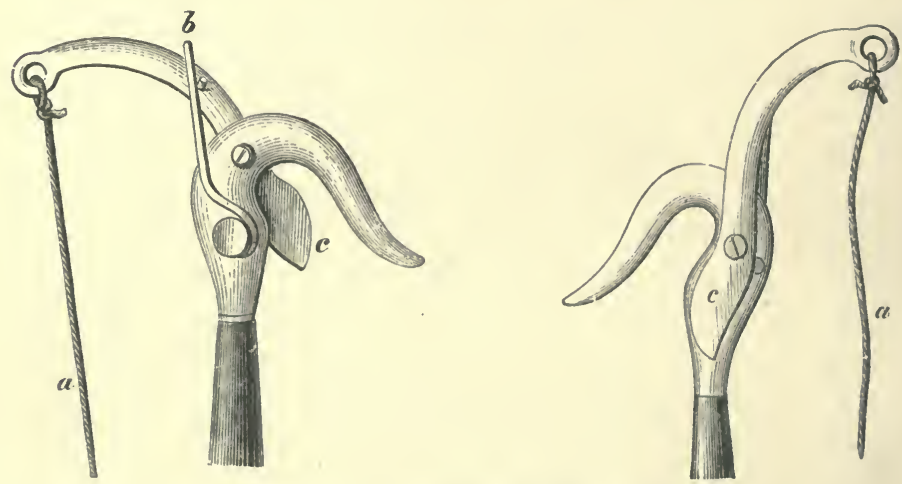

Figs. 69 and 70.-Caterpillar shears (reduced). Front. Back.

a. Cord. b. Spring. c. Moreable blade.

be chosen for their destruction, when the requisite labourforce is available.

Collections of insect-eggs can be made only when they are laid in clusters, as those of mole-crickets, the lackey-moth, and the black-arches moth. The simplest method of destroying the latter is to crush them on the tree.

The larvae of Lepidoptera and sawflies may be collected by shaking the attacked poles or saplings, or by beating with a mallet or the butt-end of an axe at the base of the branches of trees, so that the larvae fall on to a cloth spread on the ground. Care must be taken to protect the hands of collectors by gloves against hairy caterpillars, which, when handled, cause inflammation. When in groups on the trees, larvae 
may be crushed, and branches bearing the spun web-like nests of certain gregarious kinds may be cut-off with pruningshears (Figs. 69,70), or they may be burned on the trees by holding torches under them. Larvae fall most readily from trees in the early morning and evening or during moist, cool weather. The larvae of but a few species of beetles can be profitably collected, for instance, cockchafer grubs. In Massachusetts, during the great plague of the gypsey moth, 1897, Liparis dispar, L., matting, termed burlap-bands, was put round the trees and the larvae pupate under these, or rest under them in the day-time and may thus be destroyed.

The collection of pupae is best effected when they lie in clusters in the moss and dead leaves of the soil-covering, such as the pupae of Noctua piniperda, Panz., or hang low down the stems in bark cracks, or on undergrowth.

Perfect insects may be collected by simply picking them by hand from the ground, by shaking them, like larvae, from the plants on which they settle, or by means of traps made of strips of bark, laid on the ground flat or rolled-up, into which the insects crawl; this is a common method of catching great numbers of the pine-weevil (Hylobius abietis, Fabr.). The bark should be fresh and laid with the underside downwards. Other materials used as traps are faggots, logs, and brushwood. Cockchafers and pine-weevils are the injurious insects chiefly captured in this stage.

In collecting the imagos of insects, it is necessary to capture the female alone, and that before she has laid her eggs. This can only be done practically in the case of those Lepidoptera, in which the $q$ can be readily distinguished by her size and by the nature of her antennæ from the $\delta$.

Larvae, pupae, and imagos may be killed by pounding them in trenches, or by pouring boiling water over them, or by quicklime, etc.

(b) Preparation of Insect Trenches. These are useful on any but very sandy soil against larvae which wander on the ground, e.g., those of the pine-moth, also against certain beetles, for instance, the pine-weevil, Hylobius abietis, L. They should be made 10 inches broad, and 12 to 14 inches deep, with vertical walls, and with holes 8 to 10 inches deep 
every 10 yards along their floor. They cost $1 \frac{1}{2} d$. to $2 d$. a meter, or about 12s. per acre enclosed. The trenches must be inspected every morning, and the insects which have been caught should be killed.

(c) Greased barriers. A line of barked poles, covered with grease, is made, so as to exclude affected woods from surrounding hitherto immune woodlands, or to enclose small areas of unaffected woods. This method is applicable only for larvae that come down to the ground.

(d) Swine may be driven into woods which are attacked, and they kill numbers of larvae and pupae which are in the soilcovering. The swine must be given other food and driven daily to water. As a rule, they eat only hairless larvae (Noctua piniperda, Panz., Geometra piniaria, L.).

(e) Pulling-up plants and burning shoots which have been attacked; or buds attacked may be pruned off. Infested branches should be cut off.

Stems full of insects, or their eggs, etc., may be cut down and barked, and the bark burned or exposed to the sun. This should be done before the perfect insects emerge, usually in May and June. Great care must be taken as to the proper season for barking such trees, which form so many tree traps. If it be done too soon, before the bark-beetles have finished breeding, there is danger of other standing trees being attacked, and if it be done too late, after the perfect insects have forced their way out and flown away, then the very institution of tree-traps will have multiplied instead of diminishing the numbers of the insects. It.is therefore better to bark the traps before the larvae have pupated, and to be informed when this happens, infected trees should be observed, about every 14 days, in order that the development of the larvae may be known and the right moment chosen for destroying them.

(f) Preparation of tree-traps. Trees may be specially girdled to serve as traps before the eggs are laid. For such purposes stunted or sickly trees should be selected as for thinning purposes. After the insects have visited them they should be treated like trees attacked in the natural course.

(g) Grease bands made of various substances such as tar, glue, and grease, may be painted on trees, about chest high, 
in order to stop larvae on their way to the crowns of the trees, and starve them to death. They are used chiefly against the larvae of the pine-moth. High bands, $6-8$ metres high, are also made against young larvae that have just hatched out of the nun-moth.

(h) Clearance of infested areas. The whole wood may be cleared and the soil thoroughly cultivated after burning all the branches, etc., which are infested with larvae. This, of course, is a last resort. The thorough cultivation of the soil is necessary only when it is full of hibernating larvae or pupae, Lophyrus rufus, Ratz., etc.

(i) Spraying. Trees and plants in orchards or in forest nurseries may be sprayed with certain substances to keep off insects, such as lime-water, whitewash, potassium sulphidesolution, decoction of tobacco, etc. A good recipe appears to be $1 \mathrm{lb}$. of pure unslaken lime, mixed with about 70 gallons of water. The lime is slaked and then mixed with the water and stirred up to form a milky fluid, which is allowed to stand till the lime is deposited; the water is then used on the trees. The lime can be used again for five or six times the quantity of water. The application is useful as long as the insects are still in the larval or pupal stage.

The sulphur solution is made by dissolving one part of potassium sulphide in 500 parts of water, and the foliage is sprayed with this solution. 'This drives all the caterpillars at once from the tree, and sprinkled leaves escape further damage ; five men in two days, with $38 \mathrm{lbs}$. of potassium sulphide, and the necessary water, can sprinkle 250 trees, at a total cost of 50 shillings, or five trees for 1 shilling.

The most valuable mixtures for tree-spraying are arsenical washes or kerosene-emulsion. The former are made by stirring about $1 \mathrm{lb}$. of Paris-green or London-purple into 200 gallons of water, with the addition of a little flour or dextrin, and leeping it constantly stirred during the operation of spraying. As this mixture is poisonous, it cannot be used where there is risk of injury to game. If it scorches the foliage it must be further diluted.

Kerosene-emulsion is made by emulsifying 1 gallon of kerosene oil with half a gallon of boiling water in which a

F.P. 
pound of soft soap has been dissolved. It should be constantly churned for ten or more minutes, and is diluted for use by gradually stirring in $\mathbf{1 1}$ or more gallons of water. It is especially suitable for suctorial insects, whereas arsenical preparations chiefly serve for biting insects.

(k) Concluding Remarks.-A fuller account of all these methods will be given further on, under the heading of each species. Nature itself can relieve the forest best from insect attacks, for ichneumon-wasps, fungoid diseases, and damp, cold weather kill off myriads of insects and eventually put an end to any abnormal swarms of a destructive species which may occur.

As a rule, such a swarm lasts three years, but there may be a partial swarm one year before and after this period.

In Prussia and Saxony, very large sums of money have been spent on the destruction of forest insects; in Prussia according to the following table :-

$\begin{array}{llllll}1870-73 & . & . & . & . & £ 41,740 \\ 1876-80 & . & . & . & . & £ 98,738 \\ 1884-87 & . & . & . & . & £ 28,200\end{array}$

This shows a large diminution since 1880 , from which it may be inferred that insects are diminishing in the Prussian forests.

In Saxony during the years $1876-77, £ 55,852$ were spent in the destruction of pine-weevils and bark-beetles.

\section{Treatment of Injured Woods.}

Woods injured by insects should be felled only when there are signs that they have been fatally injured. Such signs are: drying-up or wilting of buds, shoots or twigs over the greater part of the crowns of the trees; development of small leaves or needles, the latter frequently in rosettes; exudation of watery turpentine from the bark; loosening and subsequent separation of the bark; appearance of brown or bluish spots on the bast or sapwood; abundance of insects such as species of Cerambyx, Sirex, and Anobium, which live only on dead or dying wood. In deciding on the importance of such signs, we must consider the special circumstances of each case, the 
insect, the species of tree attacked, its age, the locality, etc. Beetles kill trees sooner than caterpillars. Coniferous wood is more easily killed than broad-leaved trees, and whole spruce and pine woods are readily destroyed when badly attacked; silver-fir and larch make a better resistance. Broadleaved trees are not killed if every leaf on them is eaten, provided the buds are uninjured. Birch, elm, and ash die more readily than oak and beech. Young trees succumb more quickly to beetle attacks than older trees. On a good soil a recovery is more hopeful than on a poor one; clearance of the wood should be less readily undertaken in the former case.

'The best time for clearing is in the winter after the attack.

The large trees should first be felled, barked, and removed as soon as possible from the forest. Fire-wood billets should be got ready as soon as possible, and at least the larger pieces barked.

Before stacking, the split wood must be thoroughly dried, the stacks must be raised from the ground on transverse pieces, and placed apart in well-ventilated places. The removal of all split wood must be expedited.

Young plantations which have been attacked and killed must be replanted. Injured poles require the greatest care ; if they are so young that transplants can be brought in, this should be done, if necessary, after widening the blanks. Shadebearers, such as the beech, hornbeam, silver-fir, or spruce, are very suitable for planting in such cases, or else larch, sycamore, or Douglas fir, on account of their rapidity of growth. If, however, the poles are too tall, and still too dense to be underplanted, either a clearing must be made of the whole crop, and the area restocked by sowing or planting, or the wood should be heavily thinned and underplanted with a shade-bearer. 


\section{CHAP'TER V.}

INSECTS USEFUL TO FORESTS.

IT is most essential that in combating the attacks of injurious forest insects the forester should be able to distinguish insect friends from foes, and unimportant species from hurtful ones.

The following is therefore a short account of the most useful families of insects, which are found chiefly in the orders of Coleoptera and Hymenoptera.

\section{Order I.-Coleoptera.}

1. Cicindelidae ('I'iger Beetles).

Perfect insects of moderate size, slender; mandibles powerful, with three teeth; antennae filiform, with eleven joints. Legs long and slender, with five tarsal joints. Abdomen of six segments, the three first fused. Larvae long, somewhat flattened and humped in the middle, with a broad head and six feet.

The larrae dig vertical holes as thick as a quill in the sand, and remain at the entrance with projecting head, in wait for any passing insects or worms, which they seize. and suck dry. The beetles prefer sandy and sunny localities, especially white sandy roads, are very active, alternately running and flying over short distances, and greedily devour other insects.

One genus, Cicindela, with a few British species; of these, C. campestris, $\mathrm{L}$., is the only one with an extended distribution in suitable woodland localities.

\section{Carabidae (Ground-Beetles).}

Perfect insects variable in size, but often large; mandibles smooth or with only one tooth; antennae filiform, with eleven joints. 
- Few of the larger species have functional wings. Legs thin and long, for running, with five tarsal joints. Abdomen of six to eight segments, the three first fused.

Larvae long and cylindrical, with six legs.

The beetles live through the winter under moss, stones and pieces of bark, in old rotting stumps, etc., pair in the spring, and lay their eggs in the ground. The larvae live either in or on the ground, and eventually pupate in the soil.

Both the larvae and perfect insects destroy other insects in all their stages; the larvae in particular are very voracious, and mostly prey at night. The family is rich in genera and species.

The following large species are most useful in forests where they occur: Carabus catemulatus, Scop., C. granulatus, L., C. cancellatus, Ill., Calosoma inquisitor, L., etc.

Other species are found on the Continent, such as Procrustes coriaceus, L., Carabus auratus, L., C. auronitens, Fabr., C.sylvestris, Panz., Calosoma sycophanta, L.; the latter, which appears in great numbers when there is a plague of insects, and seels its prey in the crowns of trees, destroying the larvae of destructive Lepidoptera, is especially valuable.

Certain species of Harpalus and Pterostichus devour coniferous seeds when covered with moss, and Zabrus gibbus, Fabr., is destructive to young wheat.

\section{Staphylinidae (Rove Beetles).}

Perfect insects usually of small size, long-bodied, and characterised by very short elytra, which leave the greater part of the abdomen exposed. Antennæ generally threadlike, with 10 to 11 joints. Tarsi mostly 5-jointed, but occasionally with three or four joints.

The abdomen, consisting of 6 to 7 free segments, is turned up at the approach of any possible enemy.

The larvae are long, with six legs. The pupal stage occurs mostly in autumn, and the beetles live over the winter.

The mode of life of these very active beetles resembles that of the ground-beetles. Both larvae and imagos of the larger species feed on other insects, but from a forest point of view they are of less importance than the ground-beetles. 
The larvae are found especially under moss, but the beetles. chiefly in decomposing substances, such as fungi, dead leaves, dung, carrion, etc. There are nearly 800 British species. The largest species are: Ocypus olens, Müll. (the "Devil's coach-horse"), Staphylinus caesareus, Cederh., Creophilus maxillosus, L., etc. Larvae of small species of Staphylinidae occupy the galleries of bark beetles, and probably eat their eggs and larvae.

\section{Silphidae.}

Beetles flattened oblong or oblong-oval, usually with 11-jointed clubbed antennae; thorax with a flattened side-margin; anterior coxae conical ; tarsi 5-jointed. Usually dull, black, and often rugose or ribbed.

Both the larvæ, which have 6 legs, and the beetles live in carrion and decomposing substances. Some genera, such as Silpha, Fabr., attack insects. Silpha quadripunctata, L., lives in summer on oak trees, and feeds on caterpillars, etc. It has the margins of the thorax and the elytra ochre-yellow, the latter with two black spots on each.

\section{Nitidulidae.}

Beetles small, oval or oblong, with straight clubbed, 11-jointed antennae inserted under the frontal margin. Tarsi short, usually with 5 joints. Abdomen with 5-6 segments.

Larvae long, with projecting horny head and 6 legs. The flattened genera, Rhizophagus, Hbst., and Pityophagus, Shuck., which live under the bark of trees of both broad-leaved and coniferous species, are regarded as enemies to bark-beetles.

\section{Colydiidae.}

Beetles small, thin, and long, with 8-11-jointed clubbed antennae. Tarsi 4-jointed. Abdomen of 5, rarely of 6 , segments, of which the first three or four are fused. Larvae long, and sometimes with horny plates below ; 6 -legged.

The species of this family live in decaying wood, in fungi, or under the bark of trees, and are predaceous.

Colydium elongatum, Fabr., locates itself in old oak trees, and 
destroys the larvae of bark-beetles, such as Xyleborus dryographus, Er., etc.

The Colydiidae and the closely-allied Cucujidae, many of which have similar habits, are as a rule very rare in Great Britain and therefore of little local economic value.

\section{Coccinellidae,}

or Ladybirds, are small, smooth, hemispherical beetles, with red or yellow elytra, spotted with black. Antennae very short, clubbed, 10-11-jointed. Tarsi 3-jointed. Abdomen of five free segments.

The larrae are long and pointed behind, therefore somewhat lizard-like in shape; they possess six legs, and are covered with warty tubercles, pits, or spines. Those of the commonest species are slaty-grey, with four or six yellow spots. The beetles fly in the spring, and lay their yellow eggs in clusters on plants. The larvae pupate in July and August, hanging from the leaves; in 14 days the beetles appear, and they pass the winter under dead leaves, bark, etc. Both in the larval and perfect states, and especially in the former, they eagerly hunt and kill numbers of plant-lice or aphides, and mites, which do much mischief to fruit and forest trees.

Ladybirds are migratory when abundant, and sometimes appear in certain localities in enormous numbers. The commonest species are : C. septempunctata, L., the 7-spotted ladybird, and $A$. bipunctata, L., the 2-spotted ladybird. Certain species are found only in forests, as Halyzia ocellata, L., chiefly on pines, H. octodecimguttata, L., on spruce. Scymnus, Kugel., lives chiefly in coniferous woods.

\section{Malacodermata.}

This group of families is characterised as follows:-Beetles generally long, with soft flexible elytra. Antennae slender, 10-12-jointed. Tarsi 5-jointed. Abdomen of 6-7 free segments. The females sometimes resemble larvae. Lavrae long, flat, and generally hairy, with six legs.

The predaceous families included in this group are: the Telephoridae, black, brown, or yellowish beetles, about half 
an inch long, of which Telephorus fuscus is a common brown species. They usually feed on other insects, but that species and $T$. obscurus, L., have been observed suicking $5-15$ year-old shoots of oak and Scots pine, which then turn black and die.

Their larrae are also earnivorous, feeding on earth-worms and ground insects; they pass the winter in the earth, or under stones, and during thaws sometimes come out on the snow. They pupate in the spring.

The Cleridae are small, cylindrical, hairy beetles, with very short serrate antennae, somewhat thickened at the ends. Tarsi with 4-5 joints. Abdomen of six segments. Larrae long, and generally rose-coloured, with horny head,6-legged. The beetles pair in the spring, and the eggs are laid in the bark of trees, under which the larvae live. New beetles appear in the autumn.

'The larvae and beetles hunt the grubs of bark-beetles in their borings, and also eat dead animal substances.

Clerus formicarius, $\mathrm{L}_{\text {. }}$, is the best known species, and its larvae are frequently found in the borings of Myelophilus piniperda, L., and the beetle may be frequently seen in the forestrunning about over heaps of firewood and felled trunks. It is gaily coloured, black, with the greater part of the thorax and the base of the elytra red, the latter also crossed by two white bands. The species is locally common in conifer-woods in Great Britain, and is the most important insect-enemy to Scolytidae we possess.

\section{Order II.-Hymenoptera.}

\section{Ichneumonidae.*}

Certain allied families, such as the Braconidae, Chalcididae, and Pteromalidae, are included in this description. In this book these insects are termed ichneumon-wasps to avoid confusion with certain parasitic flies ('T'achinae) of similar habits belonging to the order of Diptera.

Imagos of various sizes, long and slender. Head with three ocelli. Antennae generally slender, rarely clubbed, and with

* For a complete account of German ichneumons, vide Taschenberg (I)ie Himenopteren Deutschlands), Leiprig, 1866. 
many joints. The veins of the wings, when a submarginal vein exists, form distinctly closed cells, but it may be absent and the system reduced to one or two veins.

Trochanters 2-ringed, tarsi generally 5-jointed.

Abdomen frequently stalked, and in the female provided with a long ovipositor, formed of a slender borer and two lateral sheaths.

Iarvae soft and tapering at both ends, generally white, and without hair or legs.

Pupae with the limbs free, soft, and white.

The season for the flight of these extremely useful insects falls between May and August. The $f$ lay their eggs either on or in other insects (Lepidoptera, beetles, and Hymenoptera), which they pierce with their ovipositors, generally attacking the larvae, less commonly the pupae, and seldom the perfect insects. Certain minute speoies attack the eggs. Only the larger larvae are attacked as a rule. An ichneumon will rarely attack an insect which has already been pierced.

The larvae appear soon after the eggs have been laid, and may pass the winter in the pupae of the host.

They pupate in cocoons, sometimes outside the host, sometimes enclosed in its own pupal skin ; the species of Pteromalus alone form exceptions to this rule. The ichneumon-wasps cut out a round piece from the cocoon to emerge, passing the winter under moss, in stumps, etc.

The whole series of transformations generally requires $3-6$ weeks, and the generation is usually single, but sometimes double.

Ichneumon-wasps are shy, and run and fly rapidly; they do not, however, go far from their birthplace; they may appear in great numbers, and are constantly quivering their wings.

Nost of the larvae are parasitic within their hosts, whose juices they suck, but some remain outside them (many species of Pteromalidae and Chalcididae). Infested larvae continue living, and eat ravenously in order to supply their parasitic guests as well as themselves; they do not, however, reach maturity, but die either as larvae or pupae. As a rule, ichneumon-wasps increase more than proportionally to the injurious insects. Thus, in the valleys of the Rhine and 
Main (1888-89) in the great plague of pine-moths, in the first year, only 8 per cent. of larvae were attacked by ichneumons, in the second year, 30 per cent.

It was formerly believed that most insects which did not attain full development were killed by insect-parasites, and breeding cages covered with coarse network were maintained in which all larvae infected by ichneumon-wasps or flies were placed and fed. The network allowed the latter when fully developed to escape.

These cages, $*$ however, have proved useful only in allowing the life-history of the parasites to be studied.

It is now well known that insects are destroyed in large numbers by bacteria and by fungi, the spores of which find entrance into their bodies either through their skin, or amongst their food. De Bary says: "If one carefully examines the dead leaves and moss of the forest soil in wet seasons, it is astonishing how many fungus-infected insects he will find." The infected caterpillars may be easily recognised by discoloured spots on their bodies, and by their reduced activity, and they die when the mycelium of the fungus has spread inside them. Thus, muscardine is a well-known disease of the silkworm, due to Botrytis bassiana, Bals., and this fungus attacks Noctua piniperda, Panz., Gastropacha pini, L., and other caterpillars. Wet years, being favourable to the fructification of the fungi, cause these diseases to spread amongst caterpillars. $t$

The question whether ichneumons or parasitic plants are of more importance from a forest point of view is still open. It was believed by Ratzeburg that ichneumons attack only

* In Bengal, where a Tachinid fly attacks silkworms, these are sometimes fed inside a framework covered with gauze to exclude the flies. The most usual plan, however, is to rear the Bengal multivoltine silkworm for silk in alternate months only (it has seven or eight generations in the year); during the other months a limited number of worms are carefully kept under gauze to produce eggs for the next brood. The flies, which have also a generation every month, not finding sufficient silkworms to lay their eggs in, are thus greatly reduced in numbers, whereas, if the silkworms are bred in the open every month, whole broods would be destroyed by the parasites.

+ For an account of fungi attacking insects, vide Cooke's Vegetable Wasps and Plant Worms, London, 1893, also Judeich and Nitche, Mitteleuropaischen Insectenkunde, Vol. I., pp. 164-182; De Bary, A., Vergleichende Morphologie und Biologie der Pilze, Mycetozoen, und Bacterien, Leipzig: W. Engelman, 1884. 
insects already diseased owing to infection by parasitic plants or the weather, and the importance of ichneumons is due in his opinion not to their secondary activity in attacking insects, but to the fact that the approaching end of an insect-calamity may be predicted from the increase in their numbers. $\mathrm{He}$ asserts that when 50 per cent. of the caterpillars are attacked by ichneumons, it is not worth while spending any more money on measures for destroying the caterpillars, as the calamity will then die out speedily.

Taschenberg* and Judeich, $\uparrow$ however, contest this opinion, and consider that perfectly healthy caterpillars are attacked by ichneumons; their view is now generally and properly held. It is impossible to imagine that an ichneumon, such as Pimpla, which inserts its long ovipositor through the cracks of bark to reach a concealed larva, can have any accurate perception of the state of health of its host; and the experiences of those who breed larvae in captivity show conclusively that this is a matter of indifference to the Ichneumonidae.

The families referred to are very rich in species, 5,000, of which 1,000 are parasitic on destructive forest-insects. Ichneumon-wasps are either polyphagous or monophagous; many are monophagous to such a degree that they attack only a particular species in a certain stage of development, either as larvae or pupae, etc. The greatest number of species (in all thirtynine) attack the pine-moth-Gastropacha pini, L. Many are found in the black-arches, the pine noctua, the pine sawfly, etc.

On eggs: 'Teleas laeviusculus, Ratz. (G. pini), and T.terebrains, Ratz., are parasitic.

„larvae: Microgaster globatus, Nees. (G. pini); Banchus compressus, Fabr. (Noctua piniperda, Panz.).

„pupae: Anomalon xanthopus, Grav. (G. pini); E. lophyrorum, Htz. (Lophyrus pini, L.).

„, larvae and pupae: Anomalon circumflexum, L. (G. pini);

Pimpla instigator, Panz. (Liparis monacha, L. dispar, Porthesia chrysorrhoea, etc.). $\ddagger$

„, imagos : sp. of Braconidae (Strophosomus coryli, L., etc.).

* Forstwirthschaftliche Insectenkunde, p. 271.

+ Waldverderber, 7th edition, p. 14.

† The names within brackets are those of the hosts in which the parasites live. 


\section{Sphegidae (Fossorial W'asps).}

Imagos with a large head and three ocelli. Antennae slender and moderately long. Fore wings flat and without folds, with 1-4 cubital cells. Legs with smooth femora and simple trochanters. Tibiae and tarsi fossorial, and furnished with strong hairs and spines.

Abdomen stalked, generally with seven free segments, and always terminating in the $f$ with a sting.

The larvae and pupae somewhat resemble the perfect insects, but have no legs.

These insects appear in summer, living in pairs and building their nests in sandy earth, in rotten wood, cracks in walls, etc. They attack plant-lice, larvae, beetles, grasshoppers, and spiders, wound them with their stings, and convey the disabled insects to their nests in order to lay their eggs on them. Some species close up the cells in their nests, and the larvae on emerging from the eggs feed upon the captives. Other Sphegidue feed their young with fresh material. Whilst these insects are hunting their prey, they carefully close their nests with particles of sand or splinters of wood.

The following are common:-Ammophila salulosa, L., and Pompilus viaticus, Latr.; both species live in sunny places in sandy localities.

\section{Vespidae (Wasps).}

Imagos moderately slender, almost free from hairs, black or brown with yellowish zones, with ocelli.

Antennae approximate at the base, elbowed, and witl 12-13 joints, thickened at the apex.

Fore wings folded longitudinally when at rest, with a radial cell reaching to the end of the wing, and $2-3$ cubical cells.

Legs simple, without prominent hairs or spurs.

Abdomen stalked, furnished with a sting in the $q$.

The larrae are white or yellowish, with brown heads, soft and legless.

'The species which form this family live either. socially, or are solitary.

Those which are most useful, from a forest point of view, are social wasps, consisting of three classes:- $\delta$ (drones), + , 
and $\eta_{2}$, workers which are unfertile females. The eggs are not laid by the female immediately after fertilisation; she hibernates and commences the construction of a nest for a new colony about April. From the spring until late in the summer she lays her eggs in the regularly hexagonal, prismatic, horizontal cells of the nest. She is gradually joined

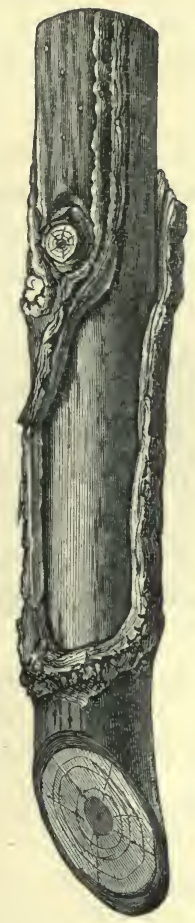

Fig. 71.-Hornet-injury to ash.

(Natural size.)

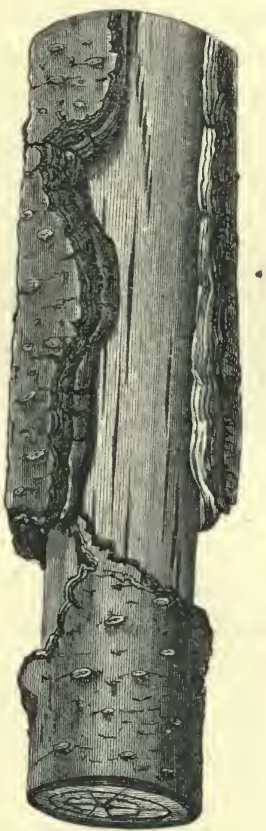

Fig. 72.-Hornet-injury to alder. (Natural size.)

in her labours by her progeny, of which first $\zeta$, then $q$, and lastly the stingless $\delta$ are produced. The latter die soon after pairing. If by any accident the mother wasp should die before any perfect females are produced, the whole colony would become extinct. The duties of the $h$ are to continue building the nest, to feed the helpless larvae, and to defend the colony against enemies. The nests are covered with a paper- 
like material, and are constructed on trees, in a hollow trunk or suspended from a branch, or in buildings or a hole in the ground. Just before pupating, the larvae spin covers to their cells. The $h$ become torpid in the autumn, and their last office is to massacre the undeveloped brood, which would otherwise die of hunger, as their food-providers themselves are speedily killed by the increasing cold. The fertile females alone leave the nest and survive the winter in a dormant condition, reviving in the spring to provide fresh broods for the future.

Wasps seize insects, especially moths and flies, partly for their own nourishment and partly to use their juices as food for their offspring, or even to feed them with

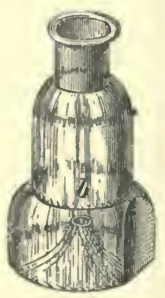

Fig. 73.-

Wasp-bottle. the living insects. They do a certain amount of damage by eating sweet fruits, plums, grapes, etc., and especially the hornet (Vespa crabro, L.), by girdling 2 to 4 -year-old shoots of beech, birch, hornbeam, etc., and by barking ash, white alder, etc. ; they prepare the bark by chewing and mixing with a sticky secretion, and use it for the fabrication of their nests. Barking of trees also causes a flow of sap which serves as food.

Where much damage is done, hornets' and wasps' nests may be smoked out, or tar, kerosene, or a solution of cyanide of potassium poured into the entrance holes. Glasses containing beer, etc., for catching them, as shown in Fig. 73, may be hung up on fruit trees.

\section{Formicidae (Ants).}

Ants also have three classes-males, females, and worker's. The head is triangular and very large in the $\zeta$. There are three ocelhi, at least in the $\delta$ and $q$. The antennae have 10-14 joints. The wings are long and with few veins. The abdomen is stalked and often spherical, with a sting at its extremity, or a gland which exudes formic acid. The $\delta$ are generally much smaller than the $q$; both these sexes have a well-developed globular thorax, wider than the head, and a large abdomen. In the $\zeta$ the thorax is very narrow, much 
narrower than the head, which is nearly as large as the abdomen; they are wingless.

The larvae are thickest, somewhat curved, white, and apodal. The pupae are soft and white, with the limbs separately invested, usually enveloped in thick white cocoons, when they are known as ants' eggs.

'The ants fly in July and August in still warm weather, often in cloud-like swarms. The + , which loses her wings after pairing, either lays her eggs the following spring in the old nest, or she forms a new colony in the ground or in a hollow tree. The larvae live in thousands in the ant-hills, and are fed and carried about by the numerous $h$, of which there may be 5,000 and more in one ant-heap. In case the ant-hill should be disturbed, the $\eta$ endeavour to carry the pupae to a place of safety.

The perfect insects come out at the end of May, or the beginning of June, after the $h$ have opened the cocoons. First appear the $q$, then the $\delta$, and last the $\zeta$. The $\delta$ die soon after copulation; as the cold increases many of the $q$ also die; the $\zeta$ live over the winter. Ants are endowed with a remarkable sense of locality; if their nest be injured, they eject formic acid, which slightly burns the skin.

For a long time past the usefulness of these little animals has been recognised. They attack and kill numerous insects and larvae, especially small caterpillars, and clean the forest of many dead insects. In utilising other insects they show extraordinary ability for creatures so low in the animal kingdom. Some ants, living in hollow trees, carry the larvae of a beetle, Cetonia aurata, L., into their nests, as these larvae chew up the wood into small pieces for them; in the same way Claviger foveolatus, Preyssl., lives in the nests 'of the yellow ants.

Plant-lice are also kept in ants' nests, as the ants use the honey-dew which exudes from them to feed their young, milking them like cows.

Trees at the foot of which there are ant-heaps remain uninjured during wide-spread devastation by caterpillars, like oases in the desert, and the fruit-cultivators in the province of Mantua place in the spring of every year a colony of ants 
at the foot of their fruit trees to secure them against insect attacks.

It is therefore necessary to protect ants in every possible way, though unfortunately their increase is greatly prejudiced by the search for the so-called ants' eggs for the purpose of feeding young pheasants, etc. This also deprives useful forest birds of a portion of their nutriment. Henschel* states that in the Austrian Alps the sale of dried ant.s' eggs of F'ormica $v$ vf $a$, L., amounts annually to 50-70 hectolitres, which means from 96 to 134.5 million ants, for 1 hectolitre contains about $1,920,000$ pupae.

In Russia also the business is carried on vigorously, the right of collecting pupae being leased on certain areas, one man having collected $£ 18$ worth in $1 \frac{1}{2}$ months.

The damage which ants occasion by constructing their galleries and nests in sickly trees, or by eating sweet fruits, or by burrowing into planting-mounds is trifling in comparison to the good they effect.

As representatives of the family the following may be mentioned :-

Formica rufa, L., the common wood-ant, makes great heaps of needles in coniferous forests, chiefly in those of Scots pine.

Lasius fuliginosus, Latr., in old trees and stumps of oaks, poplars, willows, etc.

Myrmica rubra, L., very common in forests under stones, sods, bark, etc.

There are species of ants which by hollowing out nests in standing trees, or by gnawing plants, or disturbing moundplanting, are injurious. These are Campanotus herculaneus, L.; C. ligniperdus, L. Both species hollow out large'standing and felled stems of conifers, chiefly of spruce and silverfir, to a height of 30 feet from the base of the trees, in a manner that is concentric with the annual rings, so as to render the timber unserviceable. Woodpeckers frequently increase the extent of the damage, which has also been observed on oaks, limes, and robinias. Lasius flarus, Latr. injures young plantations of spruce, silver-fir, beech, ash,

* Centralbl. tür das ges. Forstw., 1876, p. 160. 
larch, and sycamore, by gnawing the plants on or above the roots, underground. This damage continues from spring to July. As much as 60 per cent. of plants have been thus killed, the weakest being selected. The best protective measure is to use ball-planting, or to sow in autumn, with as little disturbance of the soil as possible. This damage was especially marked in Silesia, $3,000-4,000$ feet above sealevel, on dry, southern aspects.

\section{Apidae (Bees).}

The imagos are thickset and generally hairy, with ocelli, and with a special suctorial labium. Antennae approximate at their base, elbowed, the basal portion 2-jointed. Fore-wings not folded, with one radial and two to three cubital cells. Legs hairy, the first joint of the hinder tarsi very large, compressed and forming a triangular or quadrangular plate.

Abdomen stalked, with a poisonous sting in the $q$ and $h$, which breaks off after use. The larvae and pupae resemble those of wasps.

Bees are either solitary, as the mason and carpenter bees, or are social, as in the case of humble or honey bees. The former have no $\zeta$, which are the most numerous inhabitants of a hive of honey bees.

Social bees breed underground in mole runs, etc., in hollow trees, in the pith of sound trees and shrubs, as ash, walnut, rose and raspberry, or in artificial hives.

The imagos live on honey taken from plants and on pollen, and effect the fertilisation of many flowers by brushing off the pollen with their large hind legs, and carrying it to another flower. This habit is a good example of the direct utility of insects to plants.

Species.-Carpenter bees (Xylocopa violacea, Fabr.) live in old dry wood, especially in the case of leguminous trees. This species is not British, but many others are common in warm countries, and slightly injurious to timber. They are large and conspicuous blue-black insects.

The mason bee (Chalicodoma muraria, Fabr.) constructs its cells of grains of sand on walls, rocks, etc.

F.P. 
Humble-bees (Bombus terrestris, L.) live in the ground in societies of fifty to sixty members.

The honey bee (Apis mellifica, L.) is widely spread over the earth. A hive may contain 1 \&, 600 to $800 \delta$, and 15,000 to $30,000 \mathrm{~h}$. The $q$ (queen) lives for five years, the $\delta$ only for a few weeks, and the $\zeta$ for about six months.

\section{Order III.-Diptera.}

\section{Asilidae:}

Imagos long and generally slender, the face tufted with hairs. Eyes very prominent, 3 ocelli, the suctorial organs forming a pointed piercing tube. Antennae short, 3 -jointed, the third joint elongate, not annulate, terminated by a short bristle.

Wings when at rest lying flat on the body. Legs stout, with sharp curved claws. Abdomen with 8 segments.

Larvae long and cylindrical, with very clearly marked segments, white.

The eggs are laid in the ground, by choice in sandy soil. The generation is annual. The perfect insects are bold marauders, they attack other insects of all orders and suck their juices.

Species.-Asilus crabroniformis, L., common in Germany and England.

\section{Syrphidae.}

Imagos with oval bodies, very large eyes, and 3 ocelli. Antennae 3-jointed, the last joint generally flattened, sometimes very long, with a bristle-like appendage. Wings much intersected with veins. Abdomen variable in form, with 5 to 6 evident segments.

Larva leech-shaped, of varied colours.

Pupa coarctate, pear-shaped.

They fly in July and August in bright sunshine. Their flight is of a hovering nature; they remain poised over a blossom, darting away when disturbed, and resume their hovering at the end of their course, and they emit a buzzing noise.

The small white oval eggs are laid on leaves and twigs. The generation is double, or multiple. The larvae, which inhabit plants, destroy plant-lice by sucking out their juices. 
Common species.-Syrphus pirastri, L., frequently found on fruit trees and on Scots pine. S. balteatus, De Geer.

\section{Muscidae (Flies).}

Imagos generally short and stout. Eyes, as a rule, densely covered with hairs; ocelli present. Proboscis fleshy. Antennae short, 3 -jointed, the terminal joint the largest, not ringed, furnished with a bristle on its dorsal surface. Wings of moderate size, with few longitudinal veins. Legs strong and moderately long. Abdomens, with 4-7 apparent segments, generally scantily hairy, sometimes with an ovipositor in the $q$.

Larra without legs or distinct head, soft, and generally whitish.

- Pupa coarctate, round or elliptic, brown or blackish.

Flies lay their eggs sometimes in decomposing substances, sometimes on living animals.

In forest economy, only the parasitic flies are of importance, of which the chief are the Tachininae.

Many species of these flies are parasitic in or on the larvae and pupae of other insects, as moths and sawflies. Their importance is somewhat less than that of the ichneumon-wasps, but they, nevertheless, destroy great numbers of insects. They pupate generally outside the host, on or under the ground. The larvae not only suck the juices of their hosts, but, unlike those of the ichneumon-wasps, devour their viscera.

Species.-Echinomyia fera, L., frequent on larvae of Liparis monacha and Panolis piniperda.

The sub-family Anthomyinae contains a few species which are injurious to forest trees, for example, Anthomyia ruficeps, Meig. According to Theodor Hartig the larva of this species which lives in the ground, especially in burned sods, eats the seeds and roots of coniferous seedlings.

\section{Order IV.-Neuroptera.}

\section{Panorpidae (Scorpion-flies).}

Imagos of moderate size, head prolonged into a beak bearing the mouth at its extremity. Antennae many-jointed, setiform. Both pairs of wings of equal size, with few intersecting veins, 
and only partially covering the abdomen, sometimes imperfectly developed.

Larva with horny head and 22 legs.

The eggs are laid in moist soil, and the larvae pupate in oval, hollowed-out lumps of earth.

The larvae and imagos devour insects.

The common Panorpa communis, L., flies about around low bushes and hedge-rows, and destroys the pupae of Liparis salicis, L., etc.

\section{Sialidae.}

Imagos of moderate size, with broad head, long neck and fairly broad abdomen; with 3 ocelli, sometimes absent. Mouth-parts free, fully developed. Antennae short, usually setiform, and many-jointed. Wings many-celled, colourless, with bristles on the veins, sloping like a roof when at rest.

Larva with 6 short and stout legs. Pupa elongate, with the limbs free.

Example.-Rhaphidia, L. The perfect insects fly in May and June, and lay their eggs in or under the bark of Scots pine or spruce. The snake-like brown larvae live through the winter, and pupate in the spring, without any cocoon; about 2 to 3 weeks later the imagos emerge. $R$. notata, Schum., is very useful; its larvae greedily destroy the eggs and larvae of other insects which they find on and under the bark; common in coniferous woods.

\section{Hemerobiidae (Lace-uinged flies).}

Imagos long and delicate. Head small, with large hemispherical eyes; no ocelli. Mouth-parts free. Antennae long, setiform, many-jointed.

Wings similar in size, transparent and multicellular, sloping like a roof when at rest. Legs slender.

Larva elongate, and narrowed towards the ends, with two slender curved mandibles perforated for sucking, and 6 legs.

The flight-period is in the early summer, and again in autumn. The stalked white or greenish eggs are laid in groups on leaves. 
The larvae feed greedily on plant-lice, which they suck dry; they can generally be found wherever the latter are numerous.

They grow rapidly, and pupate in firm, almost spherical cocoons, suspended by a few threads between leaves, from which the imagos emerge in 2 to 3 weeks. Generation double. The commonest species is Chrysopa perla, $\mathrm{L}$.

\section{Order V.-Orthoptera (Pseudoneuroptera).}

\section{Libellulidae (Dragon-flies).}

Imagos long, usually very slender and brightly coloured. Head large, almost entirely covered with the large manycelled eyes; 3 ocelli. Mouth-parts strongly developed. Antennae short, fine, bristle-like, and generally 7 -jointed. Wings of equal size, many-celled, and membranous. Legs short, strong; the tarsi 3-jointed. Abdomen formed of 11 segments, with a short pair of forceps on the last.

The 6-legged larvae, and nymphs are characterised by an extraordinarily large labium, which can be extended forwards from beneath the head and serves for seizing prey.

The perfect insects fly in an extremely active manner in June and July, laying their eggs either on the surface of the water or on water-plants. The generation is annual, and dragonflies appear sometimes in incredible numbers.

The larvae and pupae live in the water, and prefer small, quiet ponds full of reeds.

In all three stages, especially as imagos, they kill other insects-even moths.

Species.-Blue and green dragon-fly-Aeschna juncea, L., A. grandis, L., common especially in mountainous countries. Libellula quadrimaculata, L., migrates, and therefore appears sometimes in large swarms.

L. depressa, L., very common.

\section{Order VI.-Hemiptera.}

The tribe Geocores (land-bugs) alone includes insects useful to the forester, and they may be characterised as follows :Head small and flat, generally with 2 ocelli. Antennae large, 
always longer than the head, 4 to 5 -jointed. Body flat. Forewings horny at the base and membranous at the extremities. All the legs generally similar. 'Tarsi 2 to 3 -jointed. Abdomen consisting of 7 to 8 segments.

Noticeable for their disagreeable odour.

The species which live in forests are useful by destroying larvae and plant-lice, but a few species are injurious, sucking young shoots, or the bast of older trees. The imagos come out late in the summer, and pass the winter among dead leaves or under bark. Pairing takes place in the following spring and the eggs are laid on leaves, shoots, and in cracks in the bark.

\section{Pentatomidae.}

Imagos somewhat long, with 2 ocelli. Antennae long, filiform or club-shaped, and generally 5-jointed. Scutellum large, and reaching at least to the middle of the abdomen. Tarsi generally 3-jointed, with two little lappets (pulvilli) between the claws.

Species-Pentatoma rufipes, L., common in pine-forests.

Pyrrhocoris apterus, L., often collects by hundreds at the base of large lime and other trees.

\section{Reduviidae.}

Imagos large, and longer than those of the preceding family, with projecting head and long beak. Ocelli generally present. Antennae long, filiform, thin, 4-jointed. Scutellum small. Forelegs somewhat thickened, and adapted for seizing prey. T'arsi short, 3-jointed, pulvilli absent.

All the species are predatory and able to inflict a poisonous wound with the beak. The most important as regards forests is :-

Gerris ragabundus, L., which lives in the leaf-galls, produced by certain aphides on elms. 


\section{CHAPTER VI.}

\section{INJURIOUS FOREST INSECTS (SPECIAL ACCOUNT OF COLEOPTERA).*}

The greatest number and the most harmful species of injurious forest insects belong to the orders Coleoptera and Lepidoptera. Next in importance to these come the members of the orders Hymenoptera and Orthoptera. The orders Diptera and Hemiptera, except for the few useful families already mentioned, include only species which are moderately or slightly injurious, and the Neuroptera in Central Europe include no injurious species, although in the south of Europe and in India and other hot countries, the family of Termites, or white ants, belonging to this order, is probably more destructive to vegetable substances, though chiefly when these are no longer living, than any other insect-family.

In the following pages the more destructive families of insects will be enumerated and described. The life-history of the most important species, and their relations to forest trees, and the best known ways of meeting their attacks, will also be dealt with, but many less important species which occur in Dr. Hess's book have been omitted. Hess has also separated the injurious forest insects damaging conifers, from those which damage broad-leaved trees. Owing to the smaller number of insects here dealt with, this distinction has been abandoned.

\section{Family I.-Scarabaeidae.}

\section{Description of Family.}

Imagos generally of considerable size and robust build.

Antennae short, elbowed, 10- or 11-jointed, the first joint elongate, the last 3 or more joints produced inwards into

* For a complete systematic deseription of British beetles, vide Fowler, "The Coleoptera of the British Isles," 5 vols., London, 1886-1891. 
plate-like lamellae which can be separated like the leaves of a book.

The forelegs are formed for digging, and the tarsi are 5 -jointed.

The abdomen consists of 5 or 6 segments. A generation lasts for several years in the case of the larger species, but only one year in the smaller ones.

The larvae are thick, cylindrical grubs, curved ventrally, with the last abdominal segment large and baggy; often covered thinly with short hairs, which may be bristly on the dorsal surface; head well developed, horny, with distinct antennae; legs 6 , strong. They generally live underground.

Pupae almost hairless, generally with 2 horny processes on the last abdominal segment.

In the perfect state these insects, some of which are very destructive, attack the leaves, needles and inflorescence of forest trees, whilst their larvae eat the roots of young woody plants. The larvae of other species live in rotten wood, dung, and in dead bodies.

1. Melolontha vulgaris, Fabr. (Common Cockchafer or

$$
\text { May-bug). }
$$

\section{a. Description.}

The beetle is 25 to $29 \mathrm{~mm}$. long; prothorax black, less often reddish-brown; elytra and legs red-brown, the former with 5 elevated longitudinal ridges, the depressions between them covered with fine down. Abdomen black, with 5 white triangular marks on each side, produced at the apex into an elongate tapering tail. Antennae 10-jointed; the club 7 -jointed in the $\delta$, in the $q$ smaller and only 6 -jointed. T'arsal claws with a broad tooth at the base.

\section{b. Life-history.}

The beetles appear at the end of April and in May for about 3 or 4 weeks. About 24 hours after fertilisation, the female burrows into the ground, selecting a bare spot and, where possible, a light sandy soil. In it, at a depth of 5 to $10 \mathrm{~cm}$. 
(2 to 4 inches), she lays about 70 dirty white subspherical eggs in little heaps containing from 12 to 30 each. She then returns to the surface to die.

The curved larvae appear from 4 to 6 weeks afterwards, in June or July, feed in the first year on humus in the neighbourhood of their birth-place, and eventually disperse in the second summer in all directions in the ground, in order to feed on the roots of plants. In the autumn they burrow deeper into the ground, returning near to the surface in April.
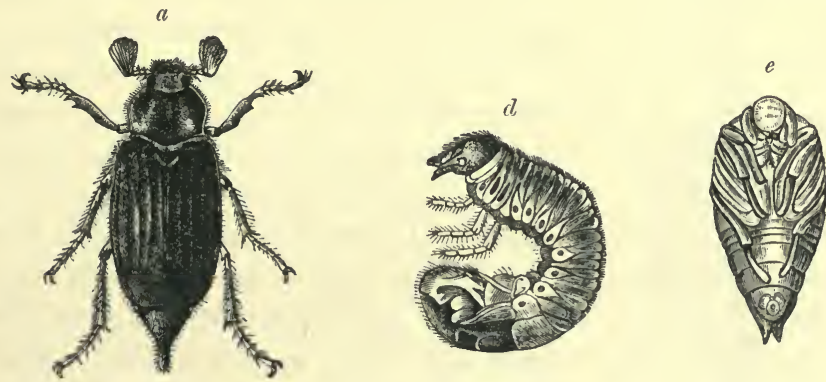

$b$
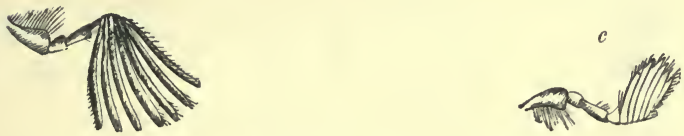

Fig. 74.-Melolontha vulgaris, Fabr.

$a$ Imago ( $\sigma) . \quad b$ Antenna of male with 7 lamellae. $c$ Antenna of female with 6 lamellae. $d$ Grub. e Pupa (ventral surface).

The larvae also go deeper down when about to pupate; this change takes place in July or September of the 4th (rarely the 3rd) year of larval life in an oval hole in the ground, the walls of which are internally smooth and water-tight. In certain isolated cases, pupation is deferred until the following spring.

The imagos generally imerge from the pupa from four to eight weeks later, but pass the winter in the ground, a few occasionally appearing on the surface. From the month of February in the 5th or 4 th calendar year, the cockchafers come up from below and take flight, leaving holes in the ground as if made by a stick. The favourite flight-time is on 
a fine evening in May, especially after a shower of warm rain. In mountainous countries, the cockchafer appears somewhat later than in the milder plains.

The generation differ's in duration according to latitude and climate, as a rule lasting 4 years in Great Britain and Europe

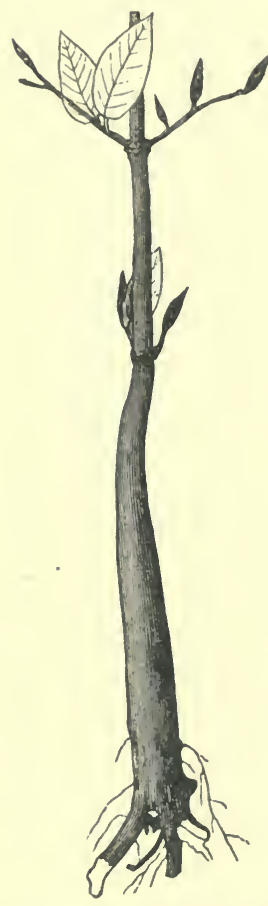

Fig. 75.-Three-year-old beech guawed by chafergrubs, with loss of roots.

(Natural size.) north of the river Main. This forms an approximate boundary, south of which the generation is triennial. In East Prussia, swarms of "cockchafers have been observed at intervals of 5 years. It follows therefore that the time of development of the cockchafer is not the same everywhere, but depends, within certain limits, on the latitude and longitude of a place, and on its corresponding climate. If there is an unusually large swarm in any given year the same thing will occur at stated intervals every few years according to the locality. These critical years are known as swarm-years; in the intermediate years at least a few cockchafers appear, either descended from stragglers, which have since continued to produce regular generations, or from irregular individuals in an existing generation. In Switzerland, there are three districts, in each of which there is a swarm of cockchafers every three years, but in different years for each district. They are termed the Bernese, Urne and Basel swarm - years, and there is every year a swarm-year in one of these districts. This fact has been observed for more than 160 years.

In Chorin, it has been observed for 30 years, that when in one part of the forest there is a swarm-year, there are no chafers in an adjoining part, and vice versâ. This is found to be due to the fact, that the larvae in a swarm-year eat all the larvae of the next year in their burrows. The strong larvae 
of a swarm-year also eat all wire-worms and other larvae they meet with, besides the plants.

These swarm-years have been little noticed in Great Britain and appear to be less marked than on the Continent, the number of chafers appearing each year being more uniform. There was a swarm-year at Egham, in the Bagshot sand district, in 1898.

The flight of the cockchafer is somewhat heavy, it flaps its wings up and down many times before ascending from the ground, in order to drive air into its trachae. It can endure unfavourable weather tolerably well, and the larvae can withstand a month's inundation 3 feet deep.

\section{c. Relations to the Forest.}

The cockchafer is injurious, both in the laval and perfect condition. The attacks of the larvae are less visible, but are more harmful, especially in coniferous woods, as they affect the roots and last for two or three summers. They are worst in the two last summers. Scots pine and spruce up to 10 years old are most endangered, then the larch, and the silver-fir does not escape. Broadleaved trees do not suffer from the larvae quite so much as conifers, but nearly every species is attacked, those with tender roots, such as beech and ash, being preferred to species like the oak, which speedily develops strong roots. The bitten surface is rough and fibrous, and not smooth as when bitten by a pine-weevil,

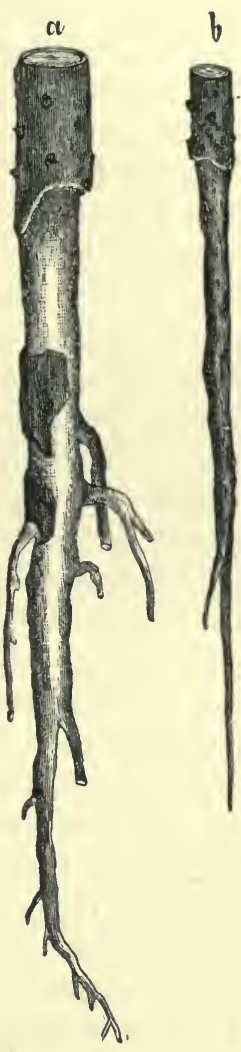

Fig. 76.-Scots pine roots attacked by chafer grubs.

a Three years old. $b$ Two years old. or gnawed by a mouse, the work of which latter can be readily distinguished by the characteristic paired tooth-marks.

The larva is extremely destructive in forest- and orchardnurseries and in broadcast sowings; whole rows of young 
seedlings or pricked-out plants may be seen with drooping and dying heads, and reddish foliage or needles. If they are pulled up, it will be found that the ends of the roots have been eaten, and occasionally the larva itself may be found in situ at the base of the injured root. Figs. 75 and 76 show the roots of attacked beech and Scots pine seedlings. The larvae are also extremely destructive to meadows and agricultural crops.

The imago attacks the foliage of broadleaved species from May till July, probably sparing the robinia and pear only. The oak is most subject to this attack; then follow maples, sweet- and horse-chestnut, poplars, plum and cherry-trees. The beech, hornbeam, willows, apple, birch, plane-tree, and many shrubs, etc., are also attacked, the order in which the different species are selected depending on the degree of development they have attained when the flight-time takes place. Conifers are less to their taste than broadleaved species, but the imagos in May and June will feed on young shoots and needles of larch, and the male catkins of Scots pine and spruce, occasionally on the spring shoots of isolated silver-firs. Trees standing in the open, and border trees are preferred, as the flight of the insect to them is less impeded than it is to trees in the midst of a wood. Lofty trees are also preferred to low growth. In 1878, in the Austrian coast districts, Quescus pubescens suffered greatly, and even the walnut was attacked, a rare event. The oak trees were completely stripped of leaves, but became green again by means of Lammas-shoots.

The larvae prefer sandy soil in sunny places, bare, or with a scanty covering of grass, and large forest cultivations after a clear cutting. Extensive cultivations of Scots pine bordering on agricultural land suffer most of all. Stiff soil covered with dense herbage, damp depressions and well-trodden paths are avoided. The pine forests of Brandenburg show how closely connected swarms of cockchafers are with the clear-cutting system.

\section{d. Prolective Rules.}

i. Natural regeneration under a shelter-wood system should be practised. Supposing that this is impracticable owing to 
local conditions of climate and species of tree, narrow clear-cut fellings, with reservation of standards, should be made. In any case, large clear-cut felling-areas should be avoided. Successive fellings should then be continued only after the young crop on the last adjacent felling-area has been secured. In districts where cockchafer damage is frequent, fellings should be reduced as much as possible the year before and during a swarm-year. Measures that keep the ground sheltered, cool and moist, render the soil less suitable for oviposition and for the larval life.

ii. In case sowing is advisable, broadcast sowing should be adopted in Scots pine woods, together with autumn sowings of corn, or of birch seed.

When only partial sowing is carried out, the seedlings come up closer together than in the case of broadcast sowing, and there is more danger of the whole crop being destroyed; the cockchafers avoid cereal crops and prefer not to lay their eggs in places covered with growing corn.

iii. Planting, and especially ball-planting with strong plants is to be preferred to sowing; otherwise, notching with as little disturbance of the soil as possible.

In the Eberswald, planting in pits the surface of which after planting is nearly a hand's breadth below the ground-level, was tried with success; the larvae which feed very near the ground-level in summer crawl from the surrounding earth on to the top of the pits, instead of getting to the roots of the plants.

iv. Pasturing herds of swine in all forest-glades. In the swarm-years this should be done in spring; whilst the larvae are in the ground, during the whole summer.

v. Protection of all enemies of the cockchafers. The badger, mole, shrew, hedgehog, rooks and crows, starlings, etc., attack the larvae; bats, owls, goatsuckers, shrikes, kestrels, and harriers destroy the cockchafers.

A starling will often carry off 5 or 6 larvae at once; these useful birds eat only the soft abdomens of the chafers. Boxes for starlings to nest in should be always set up around forest nurseries.

vi. When laying-out nurseries, the neighbourhood of oak 
woods should be avoided, and the area should be isolated by ditches. Beds are sometimes made with walls and bottoms of stones, and filled in with sifted soil.

vii. Oviposition may be prevented by covering the beds with dead leaves or twigs, or by sprinkling them with flour of sulphur.

\section{e. Remedial Measures.}

i. The areas to be stocked, in swarm-years, should be completely broken up with the plough, or trenched with spade or hoe, in order to destroy the larvae. This can be done only on fairly level ground. Gas-lime may be ploughed into the land, which must then lie fallow for six months.

ii. Collection in sacks of the larvae which are turned up in cultivating the ground, from June throughout the summer. This is best undertaken before a swarm-year, as the larvae are then nearest to the surface of the ground. It may be done both in nurseries and before restocking felled areas.

iii. Collection of the larvae by digging round plants which are attacked in the cultivations; this can be done throughout the summer.

iv. The construction of traps for larvae, as follows:-

a. Sods of grass or heather in square pieces measuring 8 to $10 \mathrm{in}$. in breadth are placed with the grass downwards on the cultivations. In the forest of Allstadt, Weimar, in the autumn of 1870 , on $7 \frac{1}{2}$ acres of ground covered with grass and heather, square grass sods 8 to 10 inches broad and 6 to 8 inches thick, were laid on the surface of the ground with the grass downwards, and from 3 to 11 larvae were found under each sod in July, 1871. 'T'hus, in a short time, 16,000 larvae were collected.

b. Rolls of bark filled witl loose soil, and placed in the ground. Successfully done in 150 Prussian ranges in 1883-84.

c. Heaps of turf, weeds, humus, burned sods, and dung.

Such heaps afford looseness, dryness, warmth, and nourishment for the larval development, and Heyer greatly recommends their use in nurseries. 'I'he females also readily lay eggs in 
heaps of dung alternating with layers of earth, and enormous numbers of larvae may be reared in them and subsequently destroyed.

d. Traps of sticks or bark. In a swarm-year and the year after it, at the beginning of the warm weather, fresh pieces of bark or thin-barked, sappy branches 20 to 40 inches long are placed horizontally, half covered with soil, in ground infested with larvae. This may be done between the rows of plants in nurseries, and aspen, sallow, ash, oak, and coniferous wood can be used. These traps attract the larvae. This plan was tried on a large scale in 150 forest ranges in Prussia in 1883 and 1884, but gave only poor results. In all the cases $(a$ to $d)$, the larvae must from time to time be collected and destroyed, and the traps occasionally renewed. Oviposition may be prevented by netting seed-beds, etc., in the spring.

$e$. Trap-trenches one foot wide and one foot deep are filled with moss. These are prepared in May and cleared of larvae once a month up to late autumn, the moss being replaced:

$f$. When a bed of seedlings or transplants has been seriously injured, the remaining plants and all weeds should be removed and fairly deep trenches dug round the bed. The larvae in the beds will then be starved to death, or come out into the trenches, when they should be killed. This is practicable only with larvae not ready for pupation.

v. Collection of the cockchafers in April and May is probably the best remedial method to be followed.

The chief points to be noted are:-The work should be commenced early in the season before too many cockchafers have emerged; then only is it practicable to catch the $q$ before they have laid their eggs. In order to ensure economy, children and women should be employed, and the collection made only in the morning or on cool days, when the insects are sluggish in their movements. The workers are provided with narrow-necked glazed vessels, or sacks in the opening of which the broken neck of a beer bottle has been fastened, to serve as a funnel through which the beetles may be dropped; the trees should be shaken over cloths, and payment should be by quantity. Birch border trees round pine plantations, planted 
as a protective belt, and border trees generally, should be first shaken, as the chafers collect there.

The larvae and beetles may be killed by :-

Crushing on hard ground.

Scalding with hot water, which gives rise to an extremely unpleasant odour.

Immersion in casks containing a mixture of water and petroleum, or 2 per cent. of naphthalin. Both larvae and beetles live for some time in water alone.

Burial in layers in a trench with unslaked lime, or powdered calcium chloride.

Subjecting the insects to fumes of bisulphide of carbon. This is the best method of destroying them, and was first discovered by Dr. A. Mayer. When done on a large scale, a clean empty petroleum cylinder or similar vessel may be used, in which the carbon bisulphide is poured on the insects.

In order that the gas may have its full effect, the tin should be covered with a sack, or woollen cloth, to keep out the air. Lights and fire must be kept at a distance during the operation. A bushel of cockchafers may be killed by less than an ounce of carbon bisulphide, and the insects die in from 5 to 10 minutes.

Where cockchafers are extremely abundant and injurious, as in Germany and France, the expense of collecting them is so serious, that it is lightened as much as possible by the utilisation of the captured beetles.

This is done in three ways: They are used as food for swine, fowls or geese, being mixed with three or four times their weight of potatoes or starchy material; for the extraction of a coarse oil suitable for cart grease; or for manure, being mixed with earth, bone dust, or stable-manure.

'Their value as a food-stuff is about $1 \mathrm{~s}$. per $10 \mathrm{lbs}$. ; as a manure, about $9 d$. per $10 \mathrm{lbs}$.

vi. A plague of cockchafers, like a plague of mice, being felt by agriculturists and fruit-producers, as well as foresters, must be met by energetic common action of all municipalities and village authorities, and in case the interested parties cannot agree as to any common course of action, the State 
should intervene to compel unanimity. This is done in France by order of the prefects. The damage done by cockchafers to agriculture in France annually, in great swarmyears, is estimated by Le Moult at $\$ 10,000,000$, the number of larvae per acre being up to 150,000 in bad cases.

vii. Cockchafer larvae, termed vers blancs, have been dealt with in France by infecting certain of them with Botrytis tennella or Isatis densa, and then putting them into the attacked field. The results were not satisfactory. Another plan, adopted in 1896, for forest nurseries is to prepare capsules full of bisulphide of carbon. These capsules are dibbled in, 7 or 8 inches deep, and the gelatine gradually dissolves, setting free its contents. One thousand capsules with $2 \frac{1}{2}$ grammes of the bisulphide cost 258 ., and about six are required every square metre.

viii. Nothing can be done to save conifers injured by the larvae, if, beside the tap-root, all side-roots have been bitten off. Should, however, some side-roots remain, larch at least may recover if severely pruned almost to the ground and earthed-up round the roots. The pruning limits the transpiration, and the earth round the roots prevents the drying-up of the existing roots and furthers the formation of new ones. These measures must be undertaken as soon as the injured plants begin to droop.

\section{Melolontha hippocastani, Fabr.}

The beetle greatly resembles the common cockchafer, but is smaller, being only 20 to $25 \mathrm{~mm}$. long. Prothorax generally red, rarely black. Antennae and legs dark brown or black. Tail shorter, more abruptly tapering, and somewhat clubbed at its extremity.

Life-history and economy.-In West and South Germany, similar to those of the common cockchafer with which it swarms, but in smaller numbers. In East and West Prussia in the midst of great Scots pine-woods this species alone destroys forests, the common cockchafer confining its attacks to agricultural lands. It does not merely attack the horsechestnut as its name implies, but nearly all trees. The larvae are highly destructive to young Scots pines, 3 to 6 years 
old, but in their fourth summer they attack the roots of poles 15 to 18 years old, and even those of older trees. Season for swarming somewhat early (April). The eggs are laid 8 to 14 days afterwards 10 to 14 inches deep in dry soil, but in moist soil only $2 \frac{1}{2}$ to 4 inches deep. The larvae appear in July, and pupate in August of the fifth year, about $1 \frac{1}{2}$ feet deep. The chafers come out in September and October, but remain underground till the next spring. A more northern insect than the common cockchafer; in Great Britain confined to Scotland and the extreme north of England.

Protective measures. - Same as for the common cockchafer.

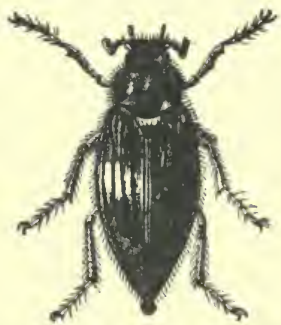

Fig. 77.-Melolontha hippocastani, Fabr.

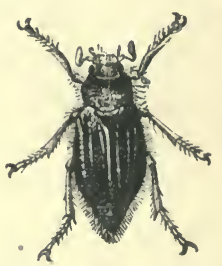

Fig $78,-$ Rhizotrogus solstitialis, L.

3. Rhizotrogus solstitialis, L. (June chafer).

a. Description.

Beetle 15 to $17 \mathrm{~mm}$. long, similar to the two former, but with the abdomen not produced into a tail. Brownish-yellow, with 4 raised carinae on each elytron; the prothorax, scutellum and underside covered with long hair. Antennae 9-jointed, the club 3-jointed. Claws with a small tooth at their base.

\section{b. Life-listory, etc.}

Similar to the common cockchafer. Flight-time somewhat later, in June and July. The beetle attacks young Scots pine shoots, but prefers the beech, hornbeam, poplars, willows, etc. The larvae devour the roots of small plants chiefly of grasses and grain crops. The insect is found in sandy soil, but is less frequent in forests than the two 
preceding species. It is locally common in many parts of Great Britain.

Protective rules and remedial measures as for the common cockchafer.

\section{Fanily II.-Buprestidae.}

\section{Description of Family.}

Imagos long and slender, generally with hard elytra which taper posteriorly, as a rule brightly coloured, with a metallic lustre. Antennae short, generally serrate and 11-jointed. Posterior angles of the thorax rounded. Front and middle pairs of coxae globose, the hind pair flattened. Legs short and weak; tarsi 5-jointed. Abdomen of 5 segments, of which the two anterior are fused. The active flight of these insects generally takes place in June and July in hot sunshine. A generation usually lasts two years.

Larvae cylindrical or flat, white, and without legs; the first prothoracic segment is broad. They live partly between the bast and sapwood of young trees, partly in

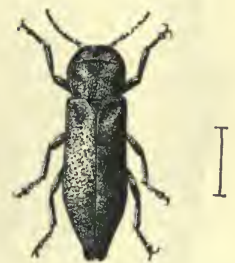

Fig. 79.-Agrilus viridis, $\mathrm{L}$. the stumps, or in old decaying trees. They pupate in situ in a cocoon made of fragments of wood. Flight-holes of the imagos transverse oval, nearly half-elliptic.

The most injurious species are found on broad-leaved trees, but in Germany a few species attack coniferous woods. In Great Britain all the species of Buprestidae are scarce, local and therefore unimportant. The following species, though very rare in this country, will serve to illustrate their lifehistory and economy :-

\section{Agrilus viridis, $\mathrm{L}$. \\ a. Description.}

Beetle 6 to $8 \mathrm{~mm}$. long, very variable in colour, being sometimes olive-green, bluish-green, blue, earth-coloured, etc.; under surface black. Thorax broader than long; the last abdominal segment rounded at the extremity; apices of the elytra diverging slightly from one another, and finely dentate. 


\section{b. Life-history.}

Flight in June and July, in brilliant sunshine.

Eggs laid either singly or by twos and threes on the bark of smooth saplings, especially at the base of stems exposed to the sun.

The larvae appear in August, and live over two winters before
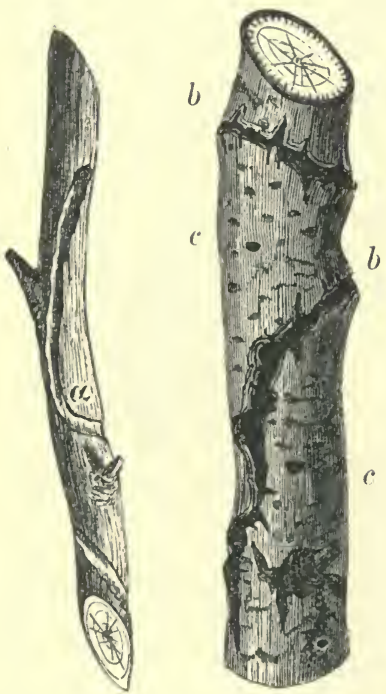

Figs. 80 and 81.-Injüry caused to beech-saplings by $A$. viridis, $\mathbf{L}$. (Natural size.)

a Larval gallery, exposed by removal of the bark.

$b$ old larval galleries exposed by rupture of the bark.

$c$ Transverse oval flight-holes of the imago. pupation, which takes place in April or May of the third summer in a pupal chamber made in the sapwood or bast.

The imagos emerge in June or July, leaving a hole oval below and straight above, thus : $\asymp$.

Generation lasting two years; the insects seldom appear in large numbers.

\section{c. Relations to the Forest.}

The beetle prefer's young beech plants, but also attacks alder, birch, oak, and aspen, especially weakly saplings, generally standing in the open, or along the edge of the forest. It is, however, only the larvae which are really destructive. They burrow through the bark down to the sapwood, and excavate in it a shallow, well-defined winding passage, sometimes extending deeper into the wood; it increases in breadth with the age of the larvae.

If the plant be girdled, the upper part of the stem dies, at least in dry localities. The bark projects somerwat all along the sides of the passage. In the case of saplings which recover, the bark splits, owing to the pressure of the callus forming over the wound. 


\section{d. Protective Rules.}

i. Care in planting out saplings, and choice of strong healthy plants.

ii. Smearing the saplings with a mixture of 2 parts of clay, 1 of lime, and 1 of cowdung, shortly before the flight of the beetles.

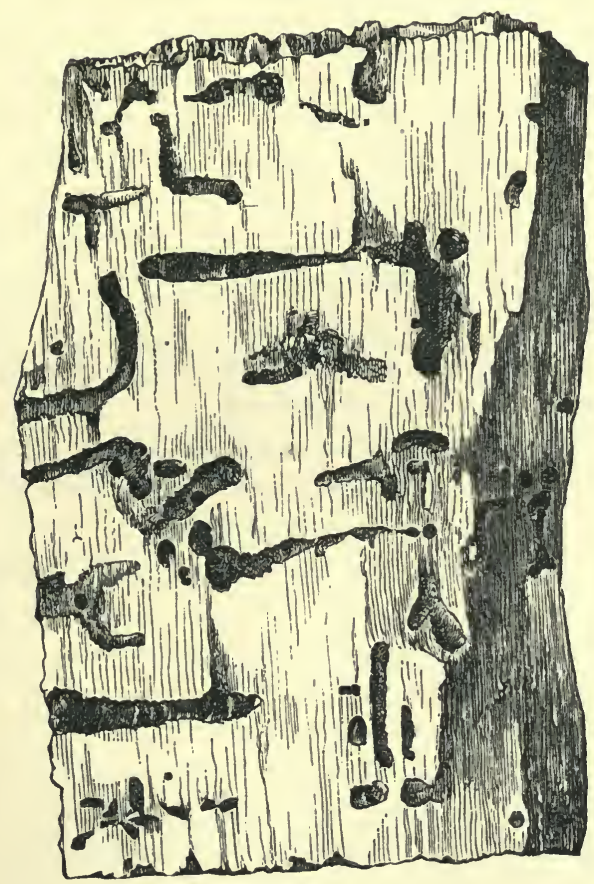

Fig. 82.-Poplar-wood bored by Agrilus sex-guttatus, Herbst. (Natural size.)

e. Remedial Measures.

Pulling-up and burning all infected saplings in May and the beginning of June.

\section{Other Species.}

Other species of Agrilus, such as A. angustulus, Ill., attack oak, hazel, birch, and other saplings, and should be treated in 
the same manner as A. viridis. A. sex-guttutus, Herbst, is common in France, where it riddles the wood of old poplars.

\section{Family III.-Elateridae (Click-Beetles).}

\section{Description of Family.}

Imagos long and slender, hard, resembling those of the former family in general appearance, but usually without metallic lustre. Antennae filiform, generally serrate or pectinate (๘), 11-jointed. Prothorax broad posteriorly, its hindangles produced and acute. Fore and middle coxae spheroidal, legs short and rather weak, tarsi 5-jointed. Abdomen of 5 segments. When laid on their backs they are able to spring up in the air with a clicking noise, alighting on their legs.

Generation, 3-4 years; length of time in laival stage probably dependent on supply of food, and lasting only three years when they are well nourished.

Larvae long and slender brownish-yellow grubs, termed wire-worms, with horny, flat, dark heads. They are lighter coloured below, and have 6 legs and a stump-like tubercle serving as an additional leg on the last segment; they generally live underground, or in old rotten stumps. They are omnivorous, devouring roots, rhizomes, seeds, fungi, decomposing vegetable and animal matter, and even other insects. 'They abound in newly broken-up pasture, or clover land, and are most destructive to agricultural crops, and in forestry to sowings in nurseries and in the forest of acorns, beech-mast, maple or hornbeam, and many coniferous seeds, and to the roots and bases of the stem of young coniferous and broadleaved plants.

Pupation underground in July. The beetles emerge a few weeks later, and may be found on flowers, or under bark or stones. Wire-worms are the larvae of beetles of the genera Elater, Athous, Agriotes, especially A.lineatus, which is the chief offender, and of other Elaterida.

The larvae of Dolopius marginatus, L., gnaw the roots of young spruce and Scots pine, and thus do much injury in nurseries and plantations. Agriotes lineatus, L., and A. obscurus, Gyll, devour acorns, and also coniferous seeds; Athous 
haemorrhoidalis, Fabr., beech-mast, acorns, hazel-nuts, and seeds of hornbeam. Some species also attack the young shoots of trees, in order to extract the sap. Lacon murinus, L., has been known to injure the oak in a similar way to T'elephorus obscurus, L., and certain species of Corymbites do similar damage, so that the shoots become black, dry and break off.

Protective rules.-The conspicuous brown larvae should be collected and destroyed when nursery-beds are dug up, and turf in which they are noticed may be burned. It is impracticable to collect the beetles.* Nursery-land full of wireworms may be dressed with gas-lime, which should be well dug in, and the land left without further cultivation for 6 months. The methods of destroying them are very expensive, requiring 1,000 lb. of liquid bisulphide of carbon per acre, or 10 tons of salt. Rooks, starlings and plovers devour them greedily.

\section{Fanily IV.-Lymexylonidae.}

Description of Family.

Imagos cylindrical, long and slender. Elytra not curved downwards and slightly gaping at the apex. Antennae threadlike, somewhat thickened in the middle, or serrate, 11-jointed. Fore and middle coxae cylindrical or spheroidal. Tarsi 5jointed. Abdomen of $5-6$ segments.

Generation annual.

Larvae long, cylindrical, soft-skinned, white, free from hair, and 6-legged. They are generally found in logs of timber in depôts and dockyards, or in stems of trees. The beetles fly round the trees and timber in June and July, and lay their eggs in cracks in the bark. Chiefly dangerous to broadleaved trees.

\section{Lymexylon narale, L.}

(a) Description.- o 8 to $10 \mathrm{~mm}$. long, black; elytra, abdo. men, and legs yellowish-brown. o 12-15 mm. long,

* For an account of protective treatment against wireworms, ride Miss Ormerod op. cit., ed. ii., pp. 111 to 118 . 
ochreous. The head, side-margins and apex of the elytra are blackish; the latter do not quite cover the abdomen.

Larva white, with a fleshy hump on the last segment.

(b) Life-history.-The beetle flies on warm days from the beginning to the middle of July. The eggs are laid on large broken tree-stumps, or on large barked oak logs, but never on sound standing trees. The larvae eat galleries into the wood of about $1 \mathrm{~mm}$. in diameter and deflected at right angles every few inches. The vertical burrows are somewhat crooked, but the horizontal ones are quite straight. This insect is chiefly injurious in timber depôts and dockyards.

In 1746, Linnaeus found the damage done to oak-timber in the Gothenburg harbour so great that he exclaimed how wonderful it was that so small a worm could do yearly so many thousands of dollars' worth of injury. His advice to the King of Sweden, at whose command he investigated the injury, was to sink the affected timber under water before the flight-time of the insects.

Lymexylon is scarce and local in Great Britain, but is liable to be imported in continental oak-timber.

(c) Protective rules. - Smearing felled timber with tar, when attacks are feared.

A similar species, Hylecoetus dermestoüdes, L., lives chiefly in the stumps of felled trees; it is locally common in Great Britain, chiefly in Sherwood Forest, but has never proved so destructive as Lymexylon to timber of commercial value.

\section{Family V.-Anobitdae. \\ Description of Family.}

Imagos small, cylindrical, similar to bark-beetles, with a cowled prothorax which conceals the upper part of the head. Antennæ slender, pectinate or clubbed, more rarely serrate, 8 to 11-jointed, folded under the prothorax when the insect is at rest. Fore and middle coxae cylindrical or spheroidal; tarsi mostly 5-jointed, but 4-jointed in the case of many species. Abdomen with 5 ventral segments. Generation often lasting several years. The beetles when disturbed lie motionless as if dead. 
Larvae strongly curved, somewhat square in transverse section, whitish, hairy and 6-legged. The beetles appear in the spring or early summer.

The beetles and larvae live chiefly in rotten wood, partly in standing trees, where they eat out galleries which cross one another; also in the pith of young pine-shoots, as for instance, Ernobius nigrinus, Er.; in spruce cones, Anobium abietis, Fabr., and others. They also live in fungi, in the woodwork of houses, and in furniture, for instance, Anobium pertinax, L., and $A$. domesticum, Fourc., a small brown beetle 2 lines long, known on account of the ticking noise it makes as the " deathwatch."

Xestobium tesselatum, Fabr.

Imago 5 to $6 \mathrm{~mm}$. long, convex, subcylindrical, dark-brown, very finely and closely punctured, and dappled with patches of short greyish-yellow hairs.

The imago and larva bore into and riddle the wood of old standing trees (oak, beech, sycamore, etc.) and also the timber-work of churches and old houses. Locally common in England.

The attack of Anobiidae on trees generally begins at an old wound, particularly on the stump of a branch.

Treatment. - The removal of attacked stems. Careful and timely dressing of exposed wounds and branch-stumps with tar.

\section{Family VI.-Curculionidae (Weevils).}

\section{Description of Family.}

Imagos small or of medium size, with the head produced into a straight or bent rostrum or snout, at the end of which are the small mouth-parts. Antennae nearly always elbowed, 8 to 12 -jointed, with a club of very variable structure; their basal joint is capable of being folded into a groove or scrobe in the snout. Elytra broader than the thorax. Fore coxae spheroidal or conical, hinder coxae small and transverse. Legs stout, the thighs sometimes adapted for leaping. Tarsi 4 -jointed, the last joint but one being generally heart-shaped, 
or bilobed. Abdomen of 5 segments, of which the two first are generally larger and united. Many species have no wings. Generation usually annual, but it may last for two years, or two broods may occur in one year.

Larrae thick-set, cylindrical, curved ventrally, the head horny, the body soft-skinned, wrinkled and thinly hairy, whitish and without feet.

Pupae recognisable by the conspicuous snout and antennae, generally with two posterior pointed processes. The larvae and beetles eat the roots, bark, bast, wood, leaves, blossoms, fruits or seeds of forest trees.

There are no galleries made by the parent beetles for oviposition, but the eggs are placed in situ by means of the snout. Some species are very destructive. Most of the beetles drop to the ground from the plant at the slightest shaking.

1. Apoderus coryli, Fabr.

a. Description.

'The beetle is 6 to $8 \mathrm{~mm}$. long, bright red, with the head, antennae, a median spot on the prothorax, and the underside black. The elytra are rather short and much wider than the narrow prothorax, with rows of strong punctures.

\section{b. Life-history, etc.}

The $q$ in May cuts the leaves of various broadleaved trees by a transverse incision made towards the

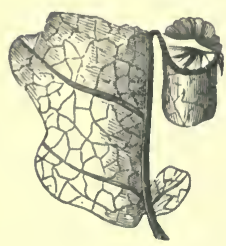

Fig. 83. - Oak-leaf, rolled up by $A$. cur culionoides, $\mathbf{L}$.

(Natural size.) base and reaching the mid-rib. She then rolls the terminal part into a thick cylindrical roll, in which a single yellow egg is laid. The larva feeds on the interior of the roll, which subsequently becomes detached, and when mature it pupates in the ground. The beetle is locally common, though never abundant, chiefly on hazel, also on alder, oak, beech and hornbeam; it frequents young shrubs and undergrowth, and in the perfect state feeds by gnawing holes in the leaves. 
When injurious it may be collected by shaking, and the rolls may be picked off.

Attelabus curculionoides, L., a very similar insect with almost smooth elytra, is locally common on oak and sweet-chestnut, chiefly on undergrowth.

2. Rhynchites betulae, L.

a. Description.

This beetle is 4 to $5 \mathrm{~mm}$. long, black and slightly hairy; rostrum hardly longer than the head; elytra broad with deep coarsely punctured striae; posterior femora strongly dilated in the $\delta$.

\section{b. Life-history, etc.}

The $q$ in May cuts the leaves of birch and other trees. on both sides down to the mid-rib in a curved line, beginning near the base of the leaf ; she lays an egg on the edge of the leaf in a little pocket made in the leaf by removal of a bit of its epidermis, and then rolls up the two sides over one another, so that the $\mathrm{gg}$ lies in the middle of the roll, which is open at both ends.

The larva feeds on the roll, and in the

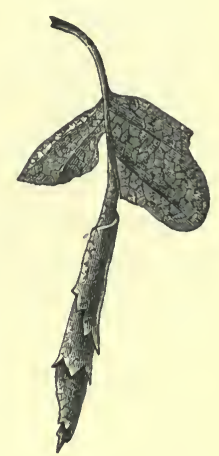

Fig. 84, - Birchleaf, rolled up by R. betulae, L.

(Natural size.) autumn falls to the ground with it, and pupates in the soil.

The beetle prefers the birch, on which species thousands of these rolls may be found; but it also attacks beech, poplars, alder, hazel, etc. It is common, and widely distributed in Britain.

\section{c. Protective Rules.}

The rolls may be collected and destroyed.

$R$. betuleti is very destructive to vines, and also attacks many broadleaved trees, as birch and hazel; and $R$. populi, L., attacks poplars and aspens. Both are local in Great Biitain. 
3. Strophosomus coryli, Fabr.

a. Description.

The beetle is 4 to $6 \mathrm{~mm}$. in length, short and thick, with the elytra convex and subspherical; covered with close-lying mottled brownish-grey scales, except over the base of the suture, which is black and bare; prothorax with a fine median furrow; antennae and legs ferruginous.

\section{b. Life-history, etc.}

Pairing takes place in June, and oviposition follows on small roots near the surface of the soil. The larvae lie under the surface-covering, especially in dry places, pupating in July and the beginning of August. The perfect insects are disclosed in August and September. They are wingless, and ascend trees by climbing, beginning in early spring to feed on the needles and bark of young pines and spruce (by preference about two years old). This insect, which is abundant both in conifer woods and in those of broadleaved trees, is occasionally very injurious.

\section{c. Protective Rules.}

Thorough grubbing-up of stumps and root-stocks; employment in cultivations of well-grown and not too young plants; trap-ditches; the collection of the beetles in August and September under pieces of bark on the ground, which are kept down with stones and visited daily. Collection of the perfect insects from the plants by shaking, which should be done in the spring; the beetles drop readily.

S. obesus, Marsh., and S. limbatus, Schönh., are allied species of similar appearance and habits.

Various other species, as Sitones lineatus, L., and the Plyyllobii, weevils covered with bright or dull green scales, also eat buds and shoots, chiefly of broadleaved trees. The usual treatment is the collection, by shaking, of the insects at the time of the injury. 


\section{Balaninus nucum, L. (Nut-veevil).}

\section{a. Description.}

Beetle 6 to $8 \mathrm{~mm}$. long, oval; black and covered with yellowish-grey hairy scales. Rostrum very long, thin and curved, reddish-brown. Legs dark rust-brown, with greyishyellow hairs.

\section{b. Life-history, etc.}

- The beetle pierces hazel and other nuts with its proboscis, whilst the shell is still green, from May to July, making in each nut a single hole as if pierced by a needle, in which an egg is laid. The larva (maggot) eats about half the kernel of the nut, and falling to the ground with the ripe fruit in autumn, gnaws its way out of the shell, and pupates in the earth till next spring. The perfect insect emerges in the summer. Worm-eaten nuts may be distinguished by either of the holes in them.

The species is common and may diminish the seed yield. An allied species, B. glandium, Marsh., chiefly attacks acorns.

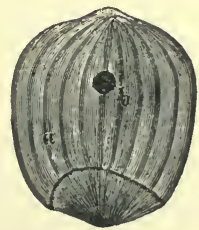

Fig. 85.-Hazelnut, bored by B. nucum, L. (Natural size.)

a Hole made by the parent beetle.

$b$ Exit - hole of larva.

\section{c. Protective Rules.}

Collection and destruction of the nuts which fall earliest (those infested with larvae). Collection of the beetles by shaking. Titmice attack the green nuts to reach the larvae.

\section{Orchestes fagi, Gyll.}

\section{a. Description.}

he Beech leaf-miner beetle is 2.5 to $3 \mathrm{~mm}$. long; black, with fine grey hairs. Elytra with striae of conspicuous, coarse punctures; rostrum depressed under the body; antennae and legs bright brown. Hind-legs adapted for leaping, their femora thickened and furnished with a small tooth before the apex. 


\section{b. Life-history, etc.}

The $q$ lays her eggs one by one on the under surface of undeveloped beech leaves, etc., biting holes for the purpose under the epidermis, near the mid-rib. The larva hatches in the month of May and bores in the leaf-parenchyma either towards the terminal point of the leaf, or sideways, forming a winding tumnel which continually increases in size till it becomes a large patch. The parts which have been eaten, at first whitish, become finally brown. Pupation takes place

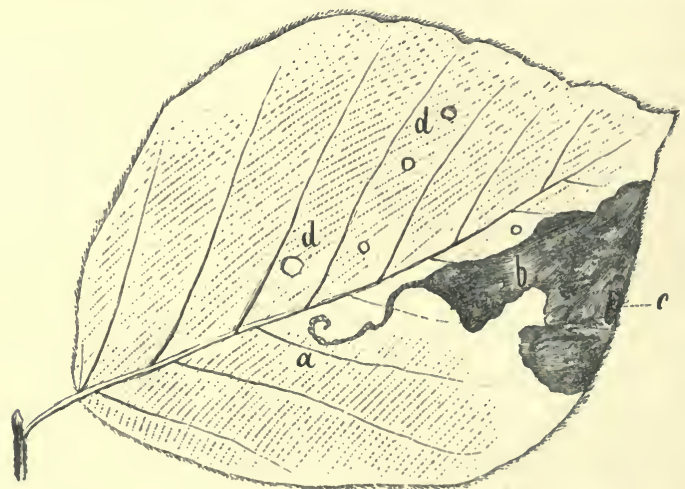

Fig. 86.-Beech-leaf attacked by 0 . fagi, Gyll. (Natural size.)

$a$ Commencement of larval mine by a gallery, which widens at $b$ into an irregular space. $c$ Pupa in a bladder-like cocoon. $d$ Holes of various sizes gnawed by the beetles.

near the border of the leaf, between the upper and lower epidermis of the area which has been eaten by the larva.

In June the beetle emerges, and passes the winter under the dead leaves on the ground.

When the larvae of this insect are abundant, the foliage of the beech trees appears reddish-brown, just as if it had been frozen by a late frost.

The beetle shortly after emergence has been known to feed on various substances ; for instance, fruit (cherries, raspberries, gooseberries), cauliflowers; it also pierces the capsules of beech nuts, causing them to open before the seed is ripe. In the early summer it riddles the beech leaves with small holes, and gnaws the female flower-buds. 
The insect attacks woods of all ages, but prefers old to young growth, and especially trees bordering the wood, or isolated trees, as shelter trees in a regeneration felling. It appeared in the Palatinate in 1869 in such numbers that in many beech woods scarcely a leaf was left uninjured. In the Spessart, in $\mathbf{1 8 8 8}$, the beetle seriously reduced the rich beechmast. In 1898, the beech leaf-miner was extremely abundant in beech woods, all over Germany. It is common in Great Britain. No protective measures other than the encouragement of insectivorous birds are practicable. The beetle is too active to be captured in numbers.

\section{Orchestes quercus, L.}

Beetle reddish-yellow, covered with grey hair, and with black eyes and breast, hinder thighs with serrate teeth. It attacks the oak just as the preceding beetle attacks the beech. It is commonest on suppressed oak undergrowth, under Scots pines, etc.

\section{Cryptorrhynchus lapathi, L. a. Description.}

Beetle 7 to $8 \mathrm{~mm}$. long, and very characteristically coloured; thorax and the basal two-thirds of the

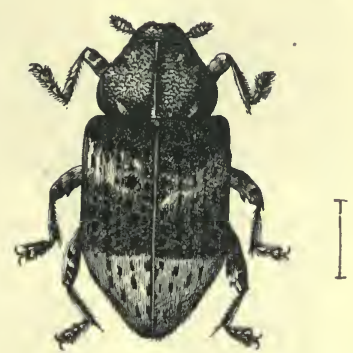

Fig. 87.-Cryptorrhynchus lapathi, L. elytra dark brown or black, with patches of erect black scales; flanks of the thorax, the anterior part of the under surface, the apex of the elytra and the femora thickly covered with white scales. The rostrum can be folded into a furrow under the thorax.

\section{b. Life-history.}

The beetle flies at the end of April and in May. The eggs are laid in May, in small holes gnawed in the bark of the stem, or of the branches of alders, etc.

The larvae appear 14 days later, in May or June, and pupate as a rule in autumn in their galleries. The beetle emerges in 
autumn, and passes the winter in these galleries or under moss ; but occasionally its emergence is deferred till the spring. Generation annual, sometimes lasting 2 years.

\section{c. Relations to the Forest.}

The black and white alder are preferred by it, then willows; but poplars and birch are also attacked. If attacking alder it

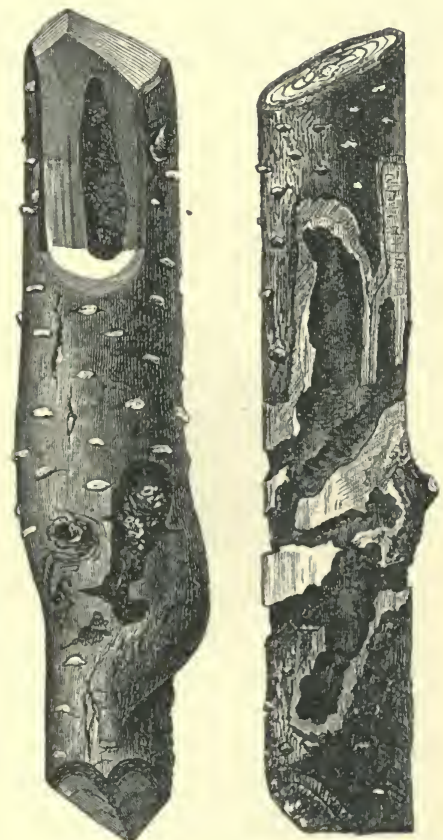

Figs. 88 and 89. - Larval burrows of C. lapathi, L., in Alder stems.

(Natural size.) selects young stems ( 2 to 4 years old), but older trees in the case of willows. It is therefore more dangerous to the alder, and especially the black alder. Willow-cuttings are also attacked without respect to species, and careless coppicing giving rise to gnarled stools increases the danger of infestation.

The insect is injurious both as a larva and imago.

The beetle eats the bark of young annual shoots down to the sap-wood. The larva then gnaws under the bark, and bores obliquely upwards or downwards into the wood and often to the pith, thus ruining the young stems, which die or break off (Figs. 88 and 89); in the latter figure the galleries of the larvae have been exposed.

The attack is indicated by discoloration and swelling-up of the bark, and later on by its depression over the points of injury, and by the brown wood-dust which is ejected from the burrows, or has fallen to the ground.

The beetle attacks and kills isolated stems along the banks of streams where the localities are not too dry, and since 1830 , it has been common near Tharand in Saxony. In 
Britain it is somewhat local, though not uncommon where it occurs.

\section{d. Protective Rules.}

Infested plants and coppice-shoots should be cut down by the end of July and burned.

The beetles should be knocked off the trees on to cloths. 'This should be done carefully, as the slightest shaking of the trees induces the beetles to fall and lie as if dead on the ground, where they may escape observation.
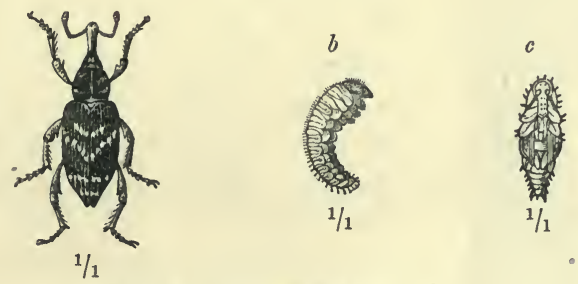

Fig. 90.-Hylobius abietis, Fabr.

a Imago. $b$ Larva. $\quad c$ Pupa.

8. Hylobius abietis, Fabr. (Pine-veevil).*

a. Description.

Beetle 8 to $13 \mathrm{~mm}$. long, of strong build, pitchy-brown, with 2 or 3 golden (rarely pale yellow) irregular stripes across the elytra, and a few spots of the same colour near their apex. Head with a strong, somewhat curved rostrum, thorax gradually narrowed from the middle to the apex, with coarse confluent punctation and a slightly elevated median ridge, clothed with patches of thick hair; elytra thrice as broad as the base of the thorax, and somewhat elevated at the shoulders. Legs brown, the femora toothed below (by which it may be distinguished from Pissodes pini, L., which otherwise greatly resembles it), and generally darker than the tibiae.

* The most valuable account of this very destructive forest insect is by Oberförster von Oppen, "Untersuchungen über die Generationsverhältnisse des Hyl. abietis." "Zeitschr. fr. Frst. u. Jgdw." 1885, pp. 81 and 141.

F.P. 


\section{b. Life-history.}

The chief swarming period of this beetle, which lives from

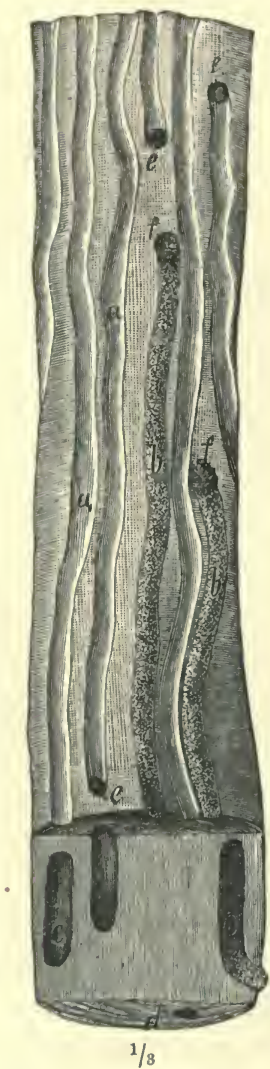

Fig. 91.-Scots pine root bored by $H$. abietis, L.

$a$ Boring free from wood. dust.

$b$ Boring full of wood-dust.

$c$ Longitudinal section of pupal chamber.

$d$ Transverse section of pupal chamber.

$e$ Flight hole.

$f$ Entrance to pupal chamber closed with bitten wood.
1 to 2 years, is in the spring or early summer (May or June); but pairing and reproduction go on throughout the whole of the warmer season up to September, so that no real period for swarming exists. Copulation generally takes place on the ground.

The eggs are laid from May to September on stumps and roots of the Scots pine and spruce, preferably on those of trees felled about 18 months before. 'The under-surface of rootsand especially of those which project out of the ground - is preferred. Hibernating beetles continue egg-laying in the spring.

The larvae appear after 2 to 3 weeks, and up to the middle of October eat galleries sometimes a metre long (Fig. 91) in the bast and sapwood of the stumps and roots; the burrows continually increase in breadth, and are filled with wood-dust. 'The larvae, at least those which have been hatched in the autumn, pass the winter at the end of these galleries. They do no injury of any economic importance, their sources of food being confined to valueless wood.

In the following spring, after having been dormant for about 9 months, the larvae pupate in the stump or roots, in a cocoon constructed of wood-fibres and boringdust. 'The pupal state lasts about 2 to 3 weeks. The perfect insects emerge from May till September of the second year. The period of disclosure thus extends over four months, corresponding to the 
season of pairing. Those beetles which emerge during the autumn do but little injury, as they do not appear in such numbers as in the spring; except for a few belated individuals, they proceed at once to copulate. Nearly the whole summer through both larvae and imagos may be found. The latter pass the winter under moss, dead leaves, in the ground, in hollow stumps, under stacks of wood, etc. Von Oppen found that they prefer to winter in dense thickets of 10 - to 15 -yearold plants rather than in older woods.

The generation lasts generally one year only, but may extend to 15 months; only under very favourable climatic circumstances can it be less than a year.

The beetle frequently appears in extraordinary numbers on felling-areas, where it is bred, and in plantations which it destroys. It is very common in most pine woods throughout Great Britain.

It rarely if ever flies, moves slowly along the ground, and in times of great heat or cold conceals itself in grass, refuse of felled trees, earth, etc.

\section{c. Relations to the Forest.}

This species is important in the perfect state alone, by the injuries it inflicts on young coniferous plants; weakly Scots pine and spruce of 3 to 6 years old are preferred, but younger plants, even yearlings, are attacked, and exceptionally other conifers (black and Weymouth pines, Douglas fir, silver-fir and larch). Even broadleaved trees are attacked, chiefly oaks and other species planted in old coniferous woods, or errployed as a shelter-wood for Scots pine. The insect is therefore clearly polyphagous.

The damage is done from May to September, the bark of the young plants being gnawed all along the stem, down to the rootstock. The bast or sapwood is exposed in patches, which may be as large as a bean, and resin exudes from the torn walls of the points of attack. More of the outer bark is always removed than of the bast, so that the injuries appear as irregular and shelving erosions of the surface.

Frequently in this way the young trees are girdled, and very small plants are completely peeled, up to their crown. 
In the case of the Scots pine the attacks of the beetle cause the development of numerous shoots from dormant buds; the spruce is sooner killed than the pine.

On plants over six years old, only those parts from 1 to 5 years old are attacked, as the six-year-old bark is too hard for the insect.

The damage done is much greater in the spring than late in the summer or in the autumn.
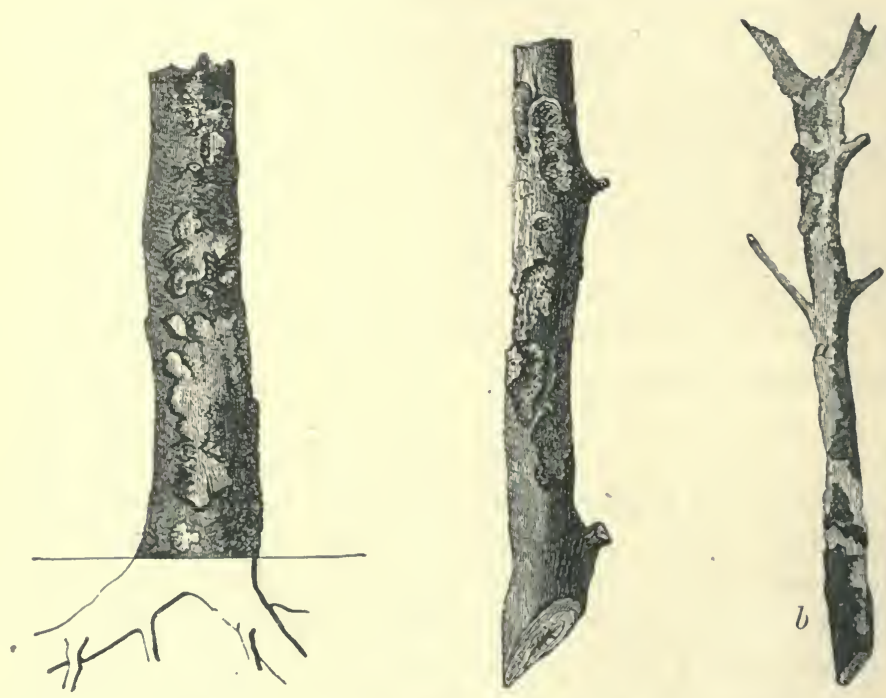

Figs. 92, 93, and 94.--Young spruce plants gnawed by $H$. abictis, Fabr. (Natural size.) In Fig. 94, $a$ indicates the gnawed parts, $b$ those still covered with bark.

Freshly planted, extensive, sunny clearings near old woods are preferred by the beetle; especially those in which the stumps have been left in the ground, or not thoroughly extracted. The beetle does not appear at altitudes over 3,000 to 3,300 feet.

\section{d. Protective Rules.}

The best means of prevention consist in supplying this destructive insect with as little opportunity as possible for 
breeding, in order to prevent its swarming in certain localities in the spring. The following are recommended :-

i. Establishment of small feeding-areas, as if these are extensive the reproduction of the beetle is greatly facilitated.

- Care must, however, be taken not to go too far in subdividing the felling-areas, as each area is a breeding place for weevils.

ii. Interruption in the order of successive fellings, so that when a felling has been made no adjoining area shall be felled till after the lapse of 3 to 5 years. In this way fresh breeding material is not afforded close to that of the previous year.

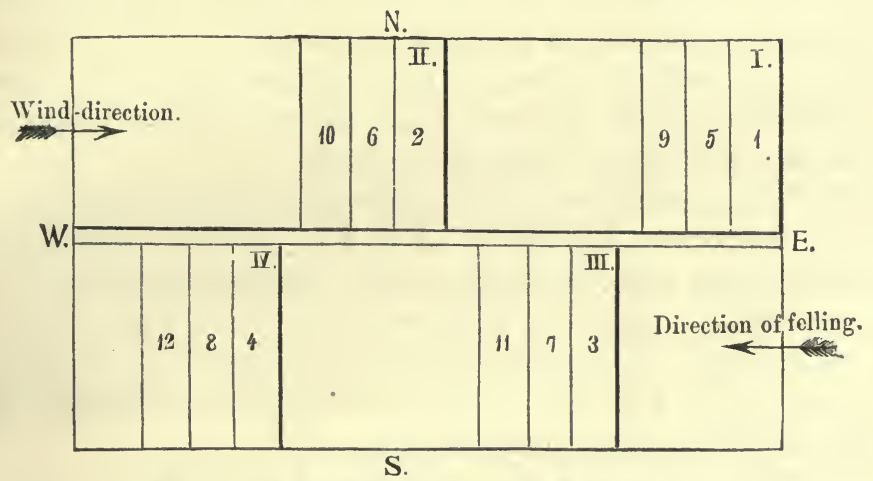

Fig. 95.-Arrangement of fellings as described in ii.

N. E. S. W. Points of compass.

Fig. 95 shows such a distribution of felling-areas, where fellings in adjoining areas come every three years.

iii. Timely and complete extraction of stumps and roots from felling-areas in coniferous forests, in order to reduce as much as possible the number of breeding places for the $q$. This is the most effective measure of all. The extraction of the stumps must begin with the felling and be finished by the commencement of the next winter. It is better to grub up the trees with the roots attached than to fell the trees first and then extract the stumps and roots, and the former method has been followed for many years in Hesse and Nassau with very good results as regards the diminution of the numbers of weevils. 
iv. The felling-areas should be rapidly cleared of all refuse, and all sickly and dominated undergrowth should be removed before the area is planted up, as such growth affords very favourable shelter for the weevils.

v. It has been proposed by Heyer and other authorities that planting should not be attempted until one or two years after the felling. By this time it is hoped the remains of the roots will have dried up and become unsuitable for breeding places. Dr. Hess considers that this involves too great a sacrifice of time and interest on capital, even if it avoids the necessity for replacing 50 per cent. of the plants, and also that the consequent deterioration of the soil entails more expense than the cost of replanting the failures. He estimates that an interval of at least 3 years, instead of 1 or 2 years, is requisite to cause the roots to dry up and become incapable of serving any longer as breeding places.

vi. Strong transplants should be used, together with 1 to 2 years' temporary field crops. Ball and mound planting are recommended, and Nördlinger prefers autumn planting, as the plants are less liable than those put in in the spring to attacks by the weevils. Temporary field-crops involve a thorough working of the soil, and this requires complete eradication of the roots of the former crop of trees.

In Saxony, wherever there is danger of an attack of weevils, sowing in patches is preferred to planting.

vii. The plants may be dipped in a mixture of chalk and water, up to half their length, before being planted. This, near Coblentz, cost 1s. 6i. per 1,000 plants and proved successful. Plants in situ may also be dressed with caterpillar grease at the rate of 500 plants per day's work of ten hours. The operator makes with his finger a small trench round each plant, greases the stem and top of root, and then heaps the earth again around the plant.

viii. Broadleaved trees may be mixed with the conifers.

ix. Sheep may be fed over the felling-area, as their droppings are obnoxious to the beetles.

$x$. Protection of insect-enemies: the fox, rook, crow, jay, starling, etc. The Nematoid worm, Allantonema miralile, is parasitic on this weevil. It lives in the abdomen of 
the beetle and produces living young. They come out and grow in the ground into a form of Rhabditis that lays eggs. The worms from these eggs eventually enter the Hylobius.

\section{e. Remedial Measures.}

i. Trenches to trap the beetle should be dug. These may be utilised either for isolating the plantations, or merely for catching the beetles. The isolating trenches are dug round the felling-areas early in spring in order to separate them from neighbouring cultivations, and to collect. the beetles which may appear within their radius. The other class of trenches for trapping the insects is dug within the fellingareas. If this plan is followed, all cultivations are isolated. The trenches must be kept in order, and repaired after rainy weather; all beetles which are found in them should be collected daily and crushed. As many as 1,200 beetles have been found in one of the holes made ten metres apart in such trenches.

Unfortunately these very effective measures are not always possible, for instance in stony or very loose ground, or on steep slopes. The dimensions for the trenches are given on p. 175.

ii. Artificial breeding-material may be supplied in June, in the form of smooth-barked pine or spruce poles 3 to 5 feet long and 2 to 4 inches thick, cut when in full sap and buried in the ground at intervals of 30 paces apart, obliquely, so that one end is $10 \mathrm{in}$. deep in the ground, and the other about 1 or 2 in. above the surface. In order that the bark may be preserved intact, the holes must be dug beforehand and the pieces of wood placed in them and covered with earth and sods, which should be slightly trodden down.

These traps should be placed both the years before and after a felling in the felling-areas, but are useless in cultivations; they should be carefully pulled out in September and October and burned, so as to destroy the larvæ they contain, and in order that none of them may be overlooked, they should be placed regularly, or a small stick should be stuck in the ground by each of them. 
The principle involved is to provide artificial breeding-places on areas where by careful contraction of stumps natural breeding-places are about. The larvae are thus fixed in definite localities, where they can easily be destroyed. Van Oppen in 6 years (1886-1891) protected 268 acres of felling-area in this way, and on 1,373 poles found 91,400 larvae, the cost being $7 d$. per acre, or $1 \frac{1}{4} d$. per pole.

iii. Traps made of pieces of bark lying on pieces of cloth may be distributed about the felling-areas and cultivations between the months of April and September, and must be renewed two or three times during this period as they become dry and cease to attract.

The best size is from 12 to 16 in. long $\times 6$ to 8 in. wide. They are placed with the bast downwards and sometimes several one over the other, and pressed down with clods or stones to keep them moist. They must be searched daily for the beetles. From 25 to 50 are required per acre, according to the abundance of the insects. Coniferous bark, and, by preference, that of the Scots pine, should be used.

Children collect the beetles better and at a cheaper rate than adults. It is a good thing to place fresh pine twigs from the youngest shoots under the bark to attract the beetles, which will be found eating these twigs when the bark is lifted up.

Wide flattish bottles containing a mixture of acetic acid, wood-tar and turpentine may be placed in the ground, the tops level with the surface and covered by a piece of bark. The beetles are attracted by the smell, creep under the bark, and fall into the bottles.

iv. Cultivations may be searched over for beetles by children or labourers engaged in plantation work just before the midday or evening rest, with good results, and at a very slight expense.

The above remedial measures, if steadily pursued, will render the attacks of these insects of no importance. The beetles should be killed by crushing on a hard surface or by scalding.

In Germany, Hylobius pinastri, Gyll, a smaller species of weevil, does similar damage to that caused by $H$. alietis, and should be dealt with in the same manner. $H$. pineti, Fabr., attacks young larch in like manner. Neither is British. 
9. Pissodes notatus, Fabr.

a. Description.

Beetle 7 to $8 \mathrm{~mm}$. long, of a reddish-brown colour, and irregularly sprinkled with bright-coloured squamous hairs; prothorax with about 8 yellowish-white spots, its hind-angles acute; elytra with impressed lines of punctures and two broad ferruginous or whitish bands, the anterior one interrupted at the suture.

\section{b. Life-history.}

Period of flight: April, May and June. The eggs are laid in the two latter months, generally on the stems of young

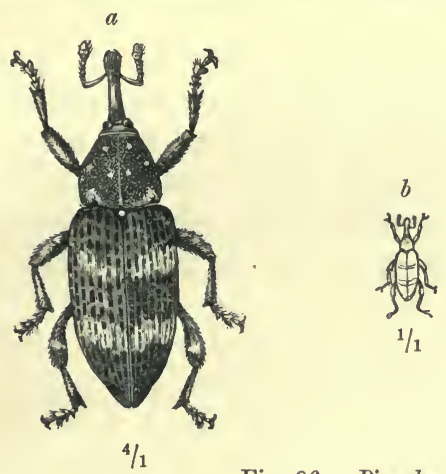

Fig. 96.-Pissodes notatus, Fabr.

$a$ and $b$ Imago. $c$ Larva. $d$ Pupa.

coniferous plants and preferably on the lowest internodes, but also on the trunk or roots of older plants, on felled trees and stacks of firewood, and on cones.

The larvae appear 3 or 4 weeks afterwards, in June and July, and live between the bark and wood, pupating in their burrows at the beginning of August.

The beetles emerge from the middle of August to the end of September, and hibernate at the roots, between cracks in the bark, under moss, litter, or in the ground.

Larvae and pupae of this insect may also be met with during the winter, and the beetles from these appear in the spring. Generation single. The insect is widely spread, but less common than Hylobius. This is decidedly the case in Britain, 


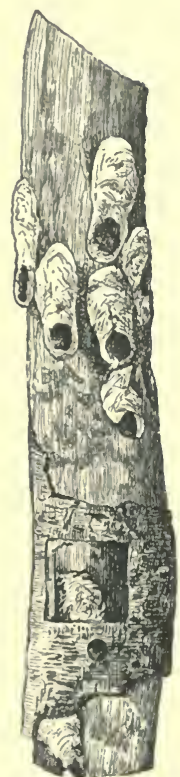

Fig. 97.-Cocoons of $P$. notatus, Fabr., on the stem of a young pine. In the portion covered with bark a square aperture has been cut, under which is a flight-hole.

(Natural size.)

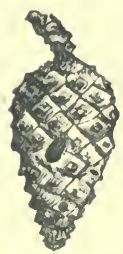

Fig. 98. - Pinecone from which P.notatus, Fabr., has been bred.

(Natural size.) where $P$. notatus is almost confined to the conifer woods of Scotland.

\section{c. Relations to the Forest.}

The beetle in May or June pierces the bark of Scots and black pines, more rarely that of the Weymouth pine, spruce or larch, near the rootstock down to the bark and sapwood, partly to feed on the sap, and partly to lay its eggs there. It prefers 4- to 8-year-old plants, but also attacks poles up to 30 years of age. The perforations resemble fine needle holes, and are very numerous.

The larvae eat their way between the wood and bark in descending, slightly winding, and constantly broadening passages, which become filled with wood-dust; at the extremity of the burrows they construct oval cocoons made of wood-fibres, out of which the beetle bores its way.

The insect is more destructive in the larval stage. Plants which are attacked may be recognised in July by small drops of turpentine on the bark, and by the reddening and eventual death of the needles. If it has not been girdled, a few green twigs may still be noticed on the wilting plant.

The larvae also live in the younger cones, often two or three together. Later on these cones become yellowish-grey, and may be recognised by the circular exit hole of the beetle, which is about the size of No. 6 or No. 7 shot.

\section{d. Protective Rules.}

i. All sickly plants and dominated stems should be removed.

ii. All rootstocks should be 'grubbed up, and all felling areas rapidly cleared.

iii. Woodpeckers should be preserved. 


\section{e. Remedial Measures.}

i. Young plants containing larvae should be pulled up and burned in June and July.

ii. All poles which have been attacked should be felled and barked.

iii. Billets of unbarked fir-wood should be laid about, as for $H$. abietis, in order to attract the beetles for egg-laying. They should be removed from the middle of June to the middle of July and burned.

iv. Cones attacked by the insects, and recognisable by the exuding turpentine, should be collected and burned.

\section{Other Species of Pissodes.}

Another species, Pissodes pini, L., attacks almost every species of pine and also young spruce in a similar manner to P. notatus. In Great Britain it is confined to Scotland, where it is locally common. It is a rather larger insect, with the anterior fascia on the elytra reduced to a few pale spots and the posterior fascia much narrower. Other species of Pissodes destructive to conifers in Germany are P. piniphilus, Hbst., on Scots pine; P. hercyniae, Hbst., on spruce, which has been very destructive in the Harz and other forest districts in Germany; and P. piceae, Ill., on the silver-fir.

\section{Family VII.—Scolytidae (Bark-Beetles).*}

\section{Description of Family.}

Beetles small and cylindrical, resembling the Anobiidae in their general form. Head globose, rarely produced into a short muzzle, and inserted deeply into the convex thorax; antennae short, more or less elbowed, and terminated by a large club, their funiculus composed of 2 to 7 joints. Legs short, the tibiae spined or toothed on their outer border, the tarsi with four evident joints, the third sometimes bilobed. Abdomen of 5 segments, the two first of which are generally fused.

* Eichhoff, W., "Die Europäischen Borkenkäfer." Berlin, 1881. The best monograph on the Bark-beetles. 
Generation : usually annual, sometimes biennial, or extending over a year and a half. Larrae cylindrical, curved, with tubercles bearing strong hairs, apodal, and closely resembling the larvae of weevils.

Pupae short and thick, with a few spines and hairs.

The larvae and beetles live almost exclusively in the bark, bast or wood, more rarely in the pith, of our forest trees. They attack roots, stems, branches, twigs and young shoots, and young or old wood, preferring the latter. The kind of tree which they attack, and the arrangement of their borings, is usually characteristic of each species. The beetles penetrate into the trees by boring a small entrance-hole, like a shotwound, through the bark. This is usually accomplished by the $q$, but in some polygamous species the $\sigma$ enters the tree and excavates in the bark a small pairing-chamber. From this chamber, or from the entrance-liole, proceeds the gallery, which is made by the $q$, and in the outer surface of which a few air-holes may be perforated. The galleries may be divided into those constructed in the bark or alburnum, parallel to the exterior surface of the tree, and those which run more or less vertically into the wood; the former may be subdivided into longitudinal or transverse simple galleries, forked galleries, or stellate galleries, the latter being formed by several $q$ boring radially outwards from the circumference of a pairing-chamber. The form of the gallery is in the main constant for each species, but may be modified by the size of the stem which is attacked, by the absence of knots, etc., or by the overabundance of insects boring in the same trunk. The $q$ lays her eggs as a rule in small hollows bitten out alternately on each side of the gallery she is gradually excavating, packing them in with wood-dust. The larvae, after hatching.out, eat galleries which radiate from the breeding gallery, becoming gradually wider with the growtl of the larvae, and filled with wood-powder; they pupate in a chamber formed at the end of the gallery either in the bark, bast or sapwood. Finally the beetles eat their way out through round holes-flight-holesof the diameter of their own bodies.

This is the general mode of life of the bark-beetles. The larvae of those few species of Scolytidae which eat wood do not 
make regular galleries, but merely enlarge the egg chambers in the wood of the tree, and the mature insects escape through the bark by the original boring made by the mother.

Bark-beetles are specially addicted to conifers, and most of these species are monophagous. An occasional departure which they may make from this rule is to be looked upon as an exception due to local circumstances. There are also numerous species of these insects which feed solely on coniferous trees or on broadleaved trees, but without attaching themselves exclusively to a particular kind of tree. Even the few polyphagous species show an individual preference for either coniferous or broadleaved trees. There are no pantophagous bark-beetles, which eat herbaceous as well as woody plants, whilst those which only attack herbaceous plants are very few in number and without interest to the forester.

Bark-beetles prefer freshly felled stems, but also attack standing trees; they then commence their attacks on sickly or injured stems. A certain degree of warmth is necessary for them, and the flight of, e.g., Tomicus typographus, L., begins only when the air temperature is $68^{\circ} \mathrm{F}$. Even the hardy B. chalgographus, L., requires a temperature of $61^{\circ} \mathrm{F}$.

This family of the Coleoptera is generally regarded as the most important which the forester has to guard against, owing to the large number of very injurious species which it contains. Fortunately, many of these are unknown in Britain, or are so rare as never to have been classed among our destructive insects.

Judeich and Nitsche distinguish the subfamilies of injurious bark-beetles as follows:-

Tomicini. True bark-beetles: Head hidden beneath the prothorax. Antennal funiculus $2-5$-jointed. Tarsal joints simple. Apical declivity prominent and generally toothed.

Hylesini. Bast-beetles: Head prominent, not concealed beneath the prothorax. Antennal funiculus 5-7-jointed. Third tarsal joint usually bilobed. Apical declivity without teeth.

Scolytini. Sapwood-beetles: Head prominent. Antennal funiculus 7-jointed. Third tarsal joint bilobed. Scarcely any apparent apical declivity. 


\section{A. Subfamily Tomicini.}

Description of Subfamily.

Head generally round, hidden beneath the thorax, and scarcely visible from above. Antennal funiculus 2 to 5 -jointed. 'Thorax not contracted in front, convex or subspherical, its surface covered in front with small asperate or tubercular projections, behind usually punctate or smooth. Tarsal joints simple, never bilobed, the first much shorter than the other three together. Elytra sloping downwards at the apex, the

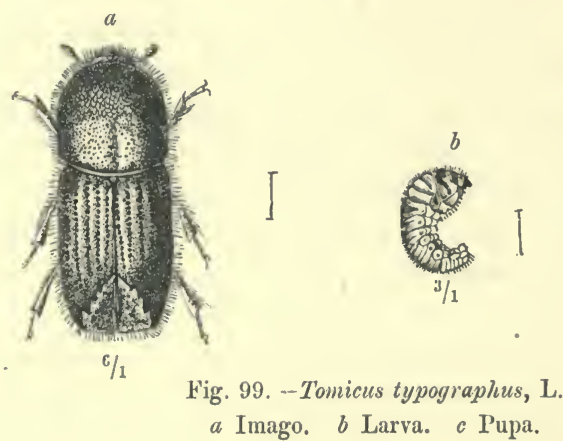

sloping portion, termed the apical declivity, sometimes impressed or excavate and often toothed. Under-surface of the abdomen flat. There are 11 genera and 29 species recorded from Britain.

They generally live between the bast and sapwood, some entirely in the wood, and a few in the outer bark, and are very common in coniferous forests.

\section{1. 'Tomicus typographus, L.}

a. Description.

Beetle 4.5 to $5.5 \mathrm{~mm}$. long, stoutly built, dark brown or blackish, shining, hairy, with testaceous antennae and legs. Head with a small tubercle immediately over the mandibles. Thorax as broad as long, its dorsal surface with rather fine sparse punctation over the posterior half. Elytra with deeply 
impressed striae, somewhat finer posteriorly, the intervals flat, not punctured except at the sides and apex; apical excavation dull and irregularly punctate, with four teeth on either side, of which the third is the largest.

\section{b. Life-history.}

Flight-time at the end of April or in May, at higher altitudes at the beginning of June. Under favourable circumstances a second brood may appear in July or August. The beetles are found in pairs boring into the trunks of large spruce trees under the crown, especially on the sunny side; when they reach the bast, they prepare a breeding chamber; after pairing the $q$ excavates one or more galleries running in the long axis of the trunk, which besides the original bore-hole, may contain 2 to 5 air-holes. On the right and left of the mothergallery she bites out little recesses of the size of a poppy-seed, and lays in each an egg, generally to the number of 30 to 50 , but sometimes as many as 120 , which she covers with fine wood-dust.

After 14 days the first larvae

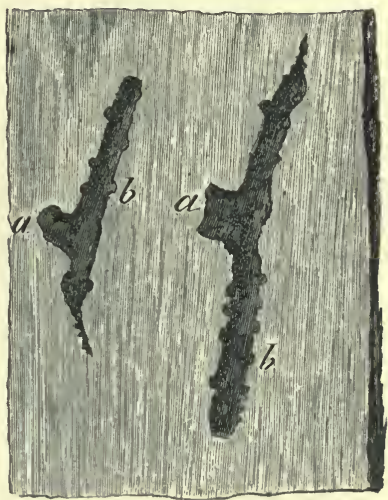

Fig. 100.-Burrows of T.typographus, L., in spruce-bark. (Natural size.) Commencement of mother-galleries with pairing-chamber $(a)$ and eggrecesses $(b)$.

appear in May and June, before the egg-laying is quite completed, and eat out slightly winding galleries in the bast, somewhat at right angles to the direction of the mother gallery, pupating at their ends in a chamber in the bast.

The newly disclosed beetles leave the trees through round holes in the bark in July or the beginning of August, and hibernate in stumps, cracks in bark, under bark, and more rarely in moss. When they come out early, before the end of June and under other favourable circumstances, they at once commence to lay eggs for a new brood, from which beetles may appear during September at the latest. 
The entire development lasts on an average for 10 weeks, which is thus distributed over the various stages: egg, $1 \frac{1}{2}$ to 2 weeks; larva, 2 weeks; pupa, 3 weeks; and imago, $3 \frac{1}{2}$ to 4 weeks. When circumstances are very favourable they can

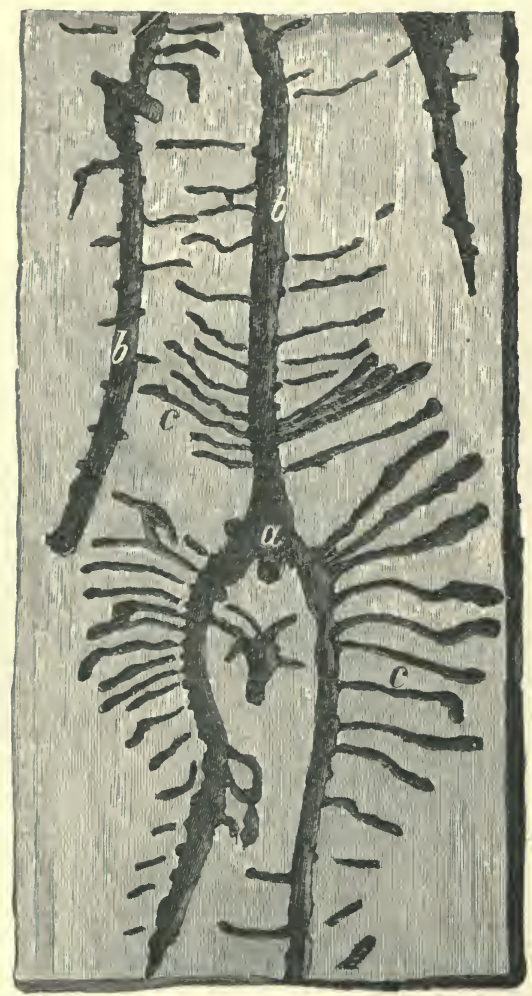

Fig. 101.-Burrows of T. typographus, I., in spruce-bark. (Natural size.)

$a$ Pairing-chamber (with entrance-hole).

$b$ Mother-galleries (vertical and forked).

c Larval-galleries (widening outwards). reach maturity in 6 or 8 weeks, but in very unfavourable circum. stances, damp cold weather, or in shady places, 12 to 13 weeks are required.

The generation is therefore either single or double, but in mountainous regions, such as the Thuringian forest and the Erzgebirge, a double generation is much rarer than in the plains.

In rare cases where there is abundance of food and a very large* swarm of beetles a three-fold generation has been observed.

This dangerous pest has fortunately been very rarely observed in Britain, and has never yet been recorded as a destructive insect. $\mathrm{Ob}$ servations on the duration of its generation in this climate are therefore wanting, but it is probably an annual one. As other insects, such as Xyleborus dispar, Hellw., which

* Von Kujawa often found in pieces of bark $10 \mathrm{~cm}$. long and broad, as many as 40 to 50 beetles, and 1,000 pairs of beetles attacking one tree in the spring are capable of producing as many as 800,000 by the autumn. 
are normally rare in Britain, may occur unexpectedly in some numbers and prove destructive, it is desirable that the forester

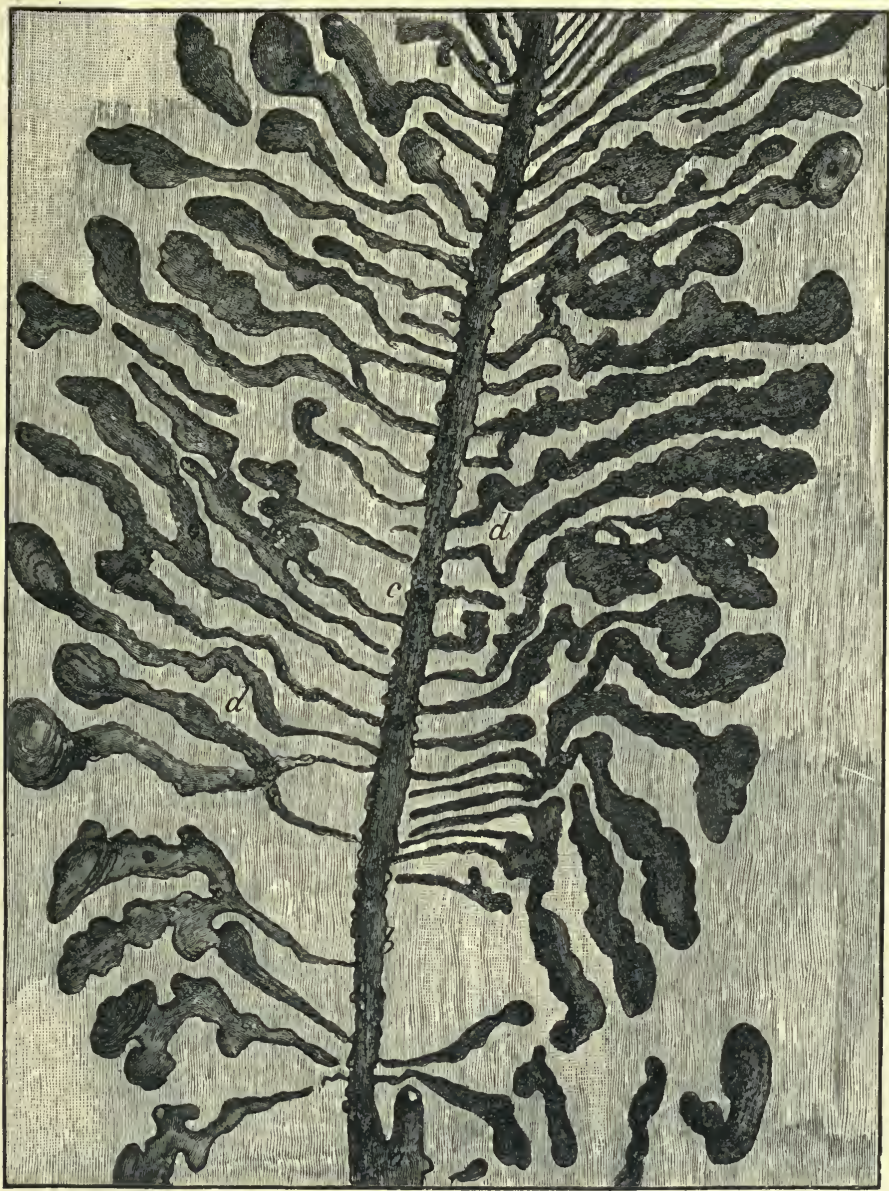

Fig. 102.-Burrows of T. typographus, L., in spruce-bark. (Natural size.)
a Pairing-chamber.
c Air-hole.
$e$ Flight-hole.
$b$ Mother-gallery.
$d$ Larval-galleries.

should be acquainted with the economy of such species as the present, so as to be prepared to meet a contingent outbreak, which is by no means impossible. T. typographus, L., 
may be imported from time to time in the bark of unseasoned spruce-timber.

Bark-beetles are generally slow and lazy insects, which only in very warm weather will fly to the top of trees. A flight of them to remote places is therefore a rare occurrence, due to over rapid multiplication and want of food.

\section{c. Relations to the Forest.}

The beetle, both as a larva and as a perfect insect, does physiological damage to conifers.

It chiefly attacks old spruce trees, generally those between 80 to 100 years old, and very seldom when under 50 years. It is said to have been found quite exceptionally on larch and Scots pine and on the Cembran pine. Even if, in these cases, it has not been confused with the extremely similar species 'T. amitinus, Eichh., on the larch, and T. cembrae, Heer, it must be admitted that $T$. typographus only appears in swarms in spruce woods, and only attacks trees with thick bark.

The injuries are confined to the bast-layer, and are fatal to the trees which are attacked.

The resulting disease is called spruce-canker. Symptoms of the attack are-yellow or red discoloration of the needles, greyness, loosening or falling off of the bark, numerous boreholes through its substance, and the presence on the trunk of boring-powder ejected from the burrows.

Trees infested in the spring appear differently affected to those injured in the summer. The needles change colour rapidly in the former case; in the latter the needles remain green, even whilst the bark has already partially fallen off. This depends on the difference in the movement and composition of the sap at the different seasons of the year. In the spring, the ascent of water from the ground is cut off from the crowns of the trees by the destruction of the bast, and the foliage at once begins to change colour. In the summer, the descent of the supply of nutritive material prepared by the leaves is cut off, while the crowns still get the nutriment, hence the needles remain green while the bast is killed. Nevertheless trees attacked in summer eventually die. 
This species of Tomicus is therefore extraordinarily destructive to spruce forests, and may be considered the most destructive of all European forest insects. The beetle prefers trees freshly felled during the season of growth and also sickly standing trees, but when it appears in large numbers, even perfectly sound trees are attacked. It avoids barked logs, and rarely attacks stools; it utilises only the upper layers of firewood-stacks for oviposition. Its favourite resorts are thinly stocked woods, and the borders of felling-areas, generally in sheltered, dry warm places with a southerly aspect. Its distribution extends far north and high on the mountains, which it prefers to the plains; it is hardy and but little affected by unfavourable weather.

\section{d. Protective Rules.}

i. Spruce-trees should be grown only in suitable localities. They should be mixed with silver-fir, and there should be early and frequent thinnings.

ii. The woods should be inspected every May, and all sickly trees should be removed.

iii. All rules applicable to the locality for protection against windfall, snowbreak, etc., should be observed, as all broken wood affords good breeding material for bark beetles.

iv. All broken wood should be speedily barked and worked up, including semi-erect trees the roots of which have been loosened by the wind. In this operation standing trees should be injured as little as possible.

v. Damage by game, especially peeling, should be guarded against.

vi. Extensive clear-cutting areas should be avoided, and the felling areas should be cleared as soon as possible. Above all, the woods should be kept clean.

Small felling-areas as are usual in the Thuringian forests should be adopted, in contra-distinction to the large fellingareas in the Harz, where the insect has been notoriously injurious.

vii. All logs intended to remain for any prolonged time in the forest should be barked.

It is imperative that this should be done to all larger logs, 
but this work need not be carried out till May, in order that the larvae, which may have developed in the logs may be destroyed. Barking in May is also cheaper than in winter, as the work is easier and the days longer. All large fuel logs should be split so that their bark may be limited to narrow strips. They should be stacked with the bark downwards. Stools remaining in the ground should also be barked.

viii. Trap-trees should be prepared for felling (see $e$, i.).

ix. All enemies of bark-beetles should be preserved. Tomtits, golden-crested wrens and woodpeckers are most important in this respect. When a swarm of bark-beetles is approaching extinction, ichneumon-wasps appear in great numbers.

\section{e. Remedial Measures.}

i. Trap-trees should be felled from March till September, and should be barked and the bark burned as soon as the larvæ are full-grown. Old or somewhat dominated sprucetrees with small crowns should be chosen, especially when the root-stock has been somewhat loosened from the soil by the wind, as such trees are more readily attacked by the beetles. In the spring, whilst the weather is still damp, it is sufficient to fell new trap-trees at intervals of from 5 to 6 weeks, but in summer this should be done at least once a month. The local flight-periods should be followed in this respect, and from 8 to 14 days before trap-trees are barked fresh ones should be felled.

In order to facilitate control the trap-trees should be numbered, and a register kept up to record the development of the beetles. Cogho reckons 5 trap-trees for 100 paces along the boundaries of the felling areas.

Ratzeburg recommends that the trap-trees should not be deprived of their branches, and that they should be placed on stumps or stones, so that the beetles may bore in from below as well as from above. Most authors agree with this advice, but Fischbach recommends the lopping off of the branches, as then the trees dry up the sooner, and he also maintains that the bark-beetles only attack lopped trees, which is contrary to experience. Hess recommends that the branches be left, both on account of the cost of lopping, and because numbers of bark-beetles of other species are attracted to them. The 
trap trees should be barked at latest as soon as pupation of the larvae has occurred, and all the bark must be burned.

If the barking be longer deferred, some of the beetles will escape, and if it be done too early too many trap-trees will be required, or the beeties will oviposit in standing trees.

The bark must be carefully removed over cloths, and this should be done on cool moist mornings, as the beetles are then most inert.

It is not sufficient to expose the bark to the effects of the sun; this may kill larvae which are really exposed, but in the case of thick bark many would escape, and pupae from which beetles are just ready to emerge would not be killed.

It is best to burn the bark during cool weather in natural hollows, or in trenches, and to surround them with a wall of glowing embers, so as to kill any beetles which might happen to creep out. The smaller branches and twigs should also be burned, as they generally contain many other smaller but dangerous bark-beetles, such as ' $T$ '. chalcographus, L. T. typographus, L., may also swarm in the branches.

It is no use burying the bark at a less depth than 16 to 18 in., as the beetles can find their way out from shallower pits.

ii. All standing spruce which shows signs of having been attacked should be felled and barked in June, and the bark burned.

iii. In the case of a large swarm of these beetles, all trees attacked must be felled, the larger logs barked and the remainder made into firewood or charcoal. All recently attacked trees should be felled first, as the beetles have probably left the trees which have been long attacked.

Some details may be given of the latest plagues of bark-beetles in the Bavarian and Bohemian forest (1872-76).* In the former about $24,500,000$ c. feet of wood was killed in six forest-ranges. The beetles were occasionally so numerous as to obscure the sun. Accompanying ' $T$ '. typographus, L., were 'T. chalcographus, L., T. pityographus, Rtzb., 'T'. autographus, Fab., Hyl. palliatus, Gyll, etc. In the Finsterau range 1,000 woodmen were engaged to fell and bark the trees, and, as local labour was insufficient, Bohemians and Italians were recruited for the work. 
In the Bohemian forest, the damage done was even on a larger scale: between 1872 and 1874 , on 9,012 hectares $(22,530$ acres), 3,632,050 cm. (127,964,000 c. feet) of wood, or about 450 c. feet per acre, were felled. Thus altogether in Bohemia and Bavaria 152,500,00 c. feet of wood was killed by these insects. The calamity attained its maximum in 1874 and ended in 1876.

After a severe windfall in the Vosges Mountains, in February, $1903, ' T$. typographus, L., attacked the spruce woods, especially in the Communal forest of Gerardmer, where, on 250 acres, 6,216 spruce trees were killed in 1904 , and were immediately felled, and the bark with the larvae burned. In 1905, about half that number of trees were attacked, and also felled by State agency, as well as all weakly trees on the threatened area. These latter and all windfalls were left lying as treetraps, and were eventually infested with larvae. They were carefully watched, and when full of larvae were barked and the bark exposed to the sun. At the same time, larvae of Staphylinidae (Homalium pusillum, Grv.), carnivorous beetles, were found in the galleries of the bark beetles (De Gail).

2. Tomicus amitinus, Eichh.

\section{a. Description.}

Imago 4 to $4.5 \mathrm{~mm}$. long. It greatly resembles the foregoing species, from which it can be distinguished as follows:- Head

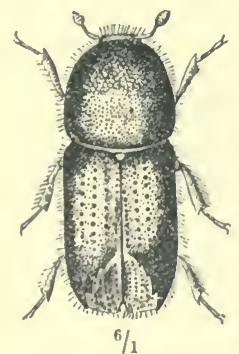

Fig. 103.-Tomicus amitinus, Eichh. without frontal tubercle; interstices between the elytral striae punctured throughout; apical excavation with a silky lustre, with regular rows of punctures.

\section{b. Life-history, etc.}

Similar to the foregoing species, but besides spruce the beetle attacks Scots pine and larch more frequently than 'T. typographus, L. Its mother-galleries are bifurcating and frequently stellate; the larval galleries start at an oblique angle to the former, and run in a zigzag direction, and

" “Der Borkenkäferfrass im Böhmerwalde." Allg. Frst.u. Jgdzstg., 1874, p. 349. 


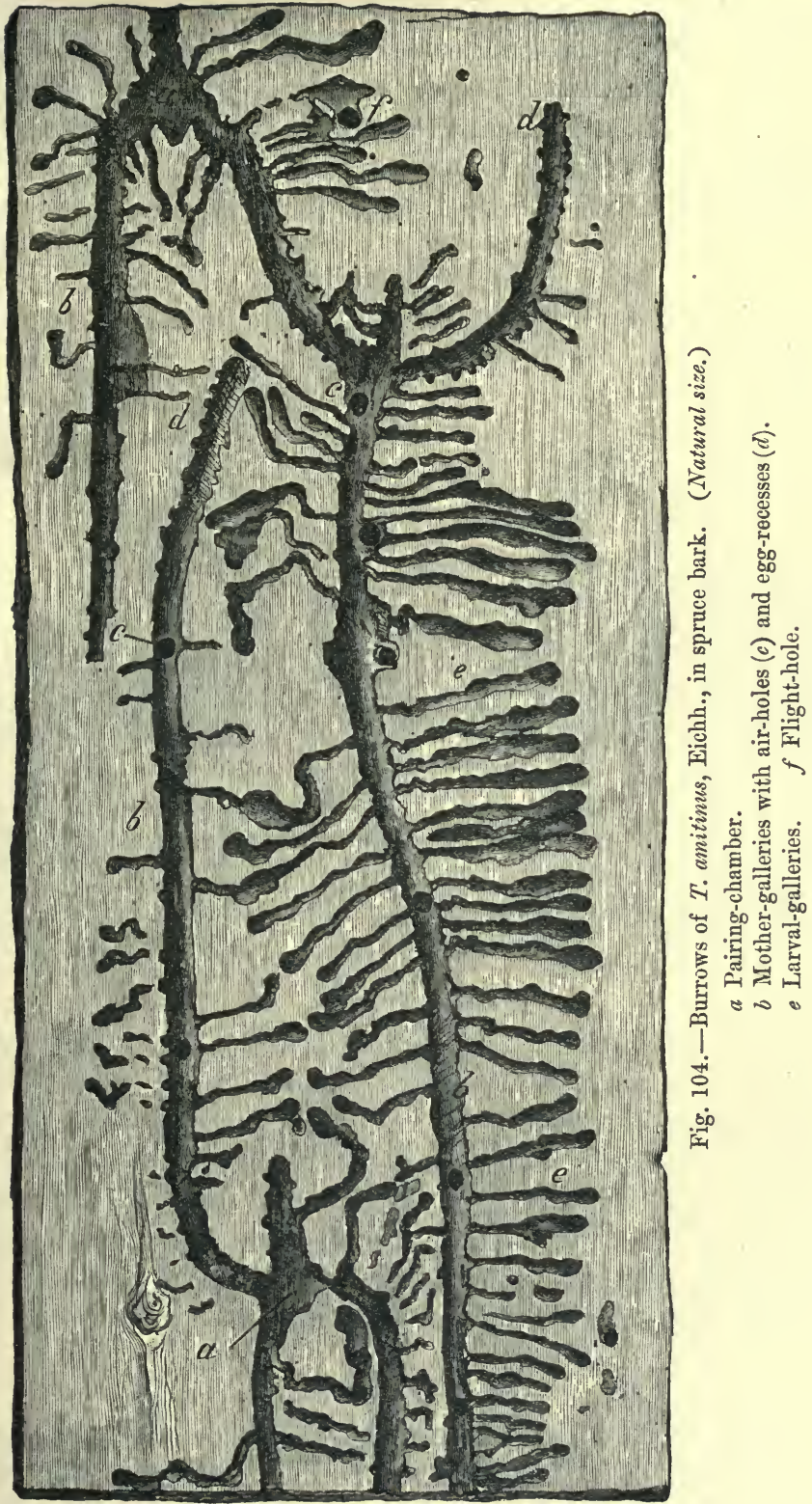


both galleries are more in the sapwood, whilst those of $T$. typographus, L., are confined to the bast. The insect, which is more active than T. typographus, L., is often commoner on the Continent. It is at present unknown in Britain, but is, perhaps, as likely to occur in injurious numbers as its congener, and is certainly a worse enemy to the Scots pine.

\section{c. Protective Rulcs.}

As in the former case, but in mixed coniferous forests, besides spruce, Scots pine and larch trap-trees should be felled.
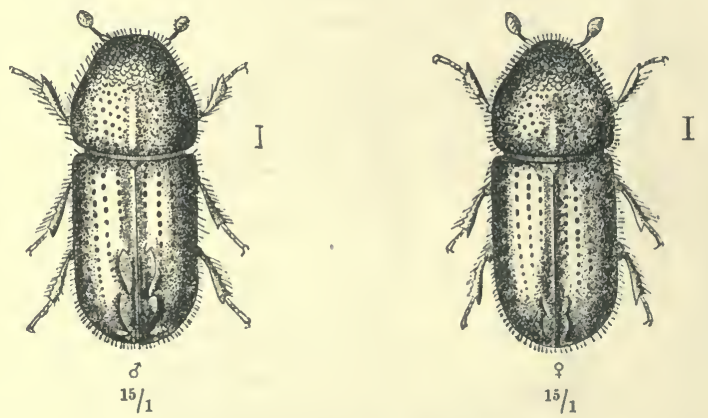

Figs. 105 and 106.-Tomicus chalcographus, L.

3. Tomicus (Pityogenes) chalcographus, L. (Small 6-toothed Spruce Bark-beetle).

a. Description .

Beetle $2 \mathrm{~mm}$. long. Very shining, almost glabrous, either entirely bright reddish brown, or with the thorax and the base of the elytra dark brown. Prothorax contracted towards the apex, its posterior half scantily punctured, with a smooth median line. Elytra with fine punctured striae, their interstices mostly smooth and impunctate, apical excavation narrow and deeply impressed, its elevated sides armed with 3 teeth on each elytron, which are larger in the $\delta$ than in the $q$.

\section{b. Life-history.}

Season of flight: April and May. The eggs are laid in spruce-bark. The larvae appear in May and June; pupation follows in June and July, and the newly-hatched beetles bore 
their way out generally in July. The insect may hibernate in the larval, pupal or imago stage; the generation is usually annual, sometimes twice in the year.

$T$. chalcographus is much less rare in Great Britain than $T$. typographus. It is, however, local and not usually common, resembling in this respect many other insects that feed on the spruce, which is not an indigenous tree. On the Continent it generally accompanies the two preceding species.

\section{c. Relations to the F'orest.}

This bark-beetle ordinarily attacks only the spruce. It has, however, occasionally been found in silver-fir, larch and Scots pine, and also on Weymouth, Cembran and mountain pines.

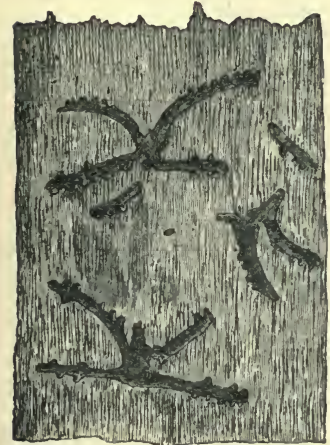

Fig. 107.-- Stellate galleries of

T. chadcographus, L., with egg-recesses, in spruce-bark.

(Natural size.)

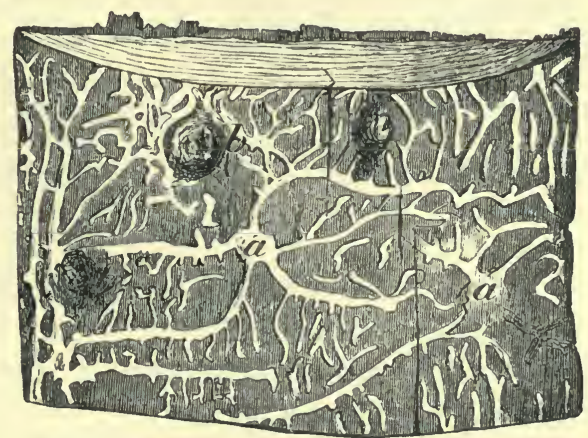

Fig. 108.- Stellate galleries of $T$. chalcogvaphus, L., on spruce sapwood, radiating from the pairingchambers (a). $b$ Knots.

(Natural size.)

It is very fond of interrupted pole-woods about 40 years old ; in the case of old trees it attacks only the branches and crown, leaving the destruction of the bast of the stem to the larger species. Exceptionally it may be found in 8 to 12-year-old spruce thickets which have been attacked by fungi (Aecidium abietinum, Alb. et Schw.).

The breeding-galleries are of characteristic stellate form, consisting of 4 to 7 slightly curved arms, which run transversely rather than longitudinally, groove the sapwood and spring from a pairing-chamber excavated in the outer part of 
the bark. From each side of these extend the larval galleries which run principally in the bast, marking the sapwood less deeply.

The protective rules are the same as for ' $T$ '. typographus, L.

\section{Tomicus stenographus, Duft.}

a. Description.

Bectle 6 to $8 \mathrm{~mm}$. long. The largest species of Tomicus. Elongate, cylindrical, shining, with long pubescence, brown, with yellowish-brown antennae and legs. Prothorax longer than broad, sparsely and moderately deeply punctured behind the middle, with a wide, smooth median line. Elytra with strong punctured striae, apical excavation deep, its elevated margins furnished with 6 teeth on each elytron, of which the 3 upper ones are small, and the 4 th is the largest.

\section{b. Life-history.}

Season of flight: usually somewhat later than for 'T. typographus. It is found in May and again in August and September.

It selects for oviposition large Scots pines with thick bark, and generally fallen or freshly-felled trees, windfalls and stacks of firewood; rarely standing trees. 'The development resembles that of $T$. typographus.

The larvae are found in June and July; the pupae in July and August; the newly emerged beetles in August and September. The latter forthwith pair, and a new brood commences. The insect hibernates under bark as an imago of the first or second brood.

Generation either annual or twice in the year.

\section{c. Relations to the Forest.}

The beetle attacks the Scots pine, and prefers old trees with thick bark. It has also been observed on black and cluster pines, and very rarely on spruce. In the absence of old woods it has here and there attacked poles 20 to 30 years old. The attack is on the bast, and resembles that of 'T'.typographus, but is less regular, and the breeding galleries are long 
and wide. Sometimes the numerous larval galleries coalesce, in which case the brood live together and completely undermine the bark. This beetle is more frequent in the plains than in the mountains, and may be considered rare. In Britain it has been found about as often as T. typographus, $\mathrm{L}$. The protective measures are the same as for that insect.

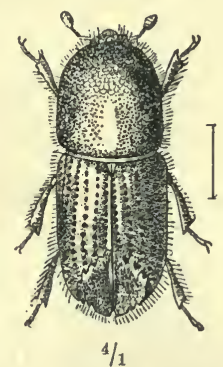

Fig. 109.-T. stenographus, Duft.

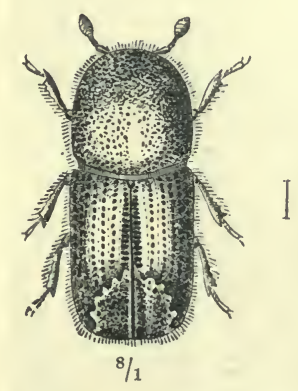

Fig. 110.-T. laricis, Fabr.

\section{5. 'Tomicus laricis, Fabr.}

\section{a. Description.}

Beetle 3.5 to $4 \mathrm{~mm}$. long, of cylindrical shape, dark brown, shining, thinly haired, with antennae and legs ferruginous. Thorax scarcely longer than broad, its posterior half sparsely punctured, with a less distinct median impunctate line. Elytra with regular punctured striae, the interstices with single rows of fine points, apical excavation almost circular, deep, its elevated margin with from 3 to 6 short blunt teeth, and an accessory tooth on the inner side of the 2 nd and $3 r d$ teeth.

\section{b. Life-history.}

Season for flight: April and May; a second brood appears in July and August.

The eggs are laid in the bark of various conifers. Stems injured by a forest fire, or felled trees, are selected in preference for egg-laying.

Larvae appear in June, and those of the second brood in August or September. Pupation takes place in the bast in June, July, and again in September and October. 
The first brood reaches maturity in July, and the second brood in October. The beetles hibernate under the bark.

The generation is therefore double, and may be threefold in Southern France. The beetle is found almost throughout Europe, and is common in most places. In Britain it is, perhaps, the least rare species

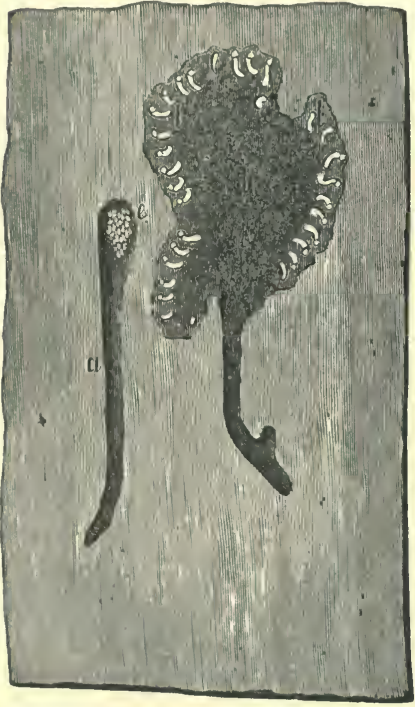

Fig. 111.-Burrows of $T$. laricis, Fabr., in Scots pine bark. (Natural size.)

a Mother gallery with eggs $(e)$.

$b$ Larvae feeding in family chamber. of the genus, if Tomicus bidentatus, Hbst., be excepted.

\section{c. Relations to the Forest.}

The beetle does not by preference attack the larch, but is found on all conifers, particularly on the Scots pine, and then on the spruce, rarely on larch or silver-fir. It attacks poles and mature trees, and exceptionally young growth.

The mother-galleries and larval chambers are in the bast. The former are generally vertical, slightly curved or bent at an angle at either end, with 2 to 4 air-holes (Fig. 105); the larvae eat together in regular family chambers, so that special larval-galleries do not exist (Fig. 105, a).

The beetle is said to gnaw young plants (Scots pine), near the collum, but this statement requires confirmation.

\section{d. Protective Rules.}

(a) Prevention.

Keeping the forest clean, and rapid clearing of felling-areas.

(b) Remedial Measures.

i. Trap-trees as for ' $T$ '. typographus, L.

ii. Poles or logs used for traps stuck and placed into the 
ground in March. These should be examined in June, and those containing larvae should be burned.

iii. All young plants which may be attacked and which may be recognised by the reddening of the needles, should be pulled up in June and burned.

\section{Tomicus (Pityogenes) bidentatus, Herbst.}

a. Description.

Beetle 2 to $3 \mathrm{~mm}$. long; pitchy-black, somewhat shining, with fine hairs; antennae and legs ferruginous. Thorax con-
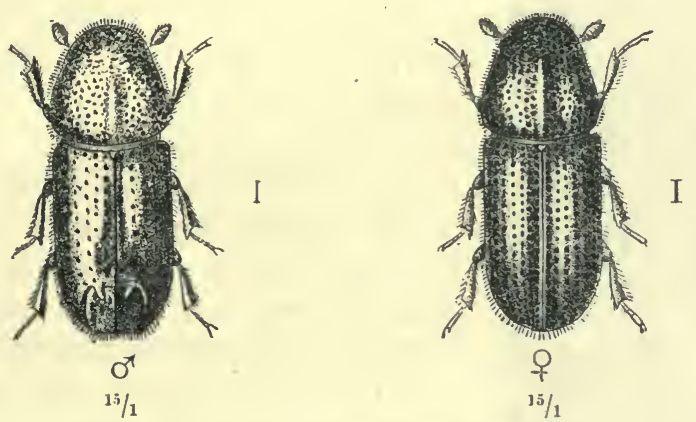

Figs. 112 and 113.-Tomicus bidentatus, Hbst.

stricted in front, and rather deeply punctate behind, with a smooth median elevated line. Elytra with rows of punctures, impressed towards the sides only, apical excavation somewhat deep in the $\delta$, with a single strong hooked tooth on each side; in the $q$ the declivity is impressed on either side of the suture, and the teeth are reduced to inconspicuous tubercles.

\section{b. Life-history.}

The $q$ lays her eggs in May and June in Scots pine woods, on young plants, poles, branches, and on refuse on felling areas. The pairing chamber is often furnished with short prolongations which are breeding galleries commenced but abandoned, and penetrates deeply into the sapwood. Portions of the stems covered by thick bark are avoided. 
The larrae appear in June and July; the second brood in August and September.

Pupation: in July and August, in the bast or sapwood ; the

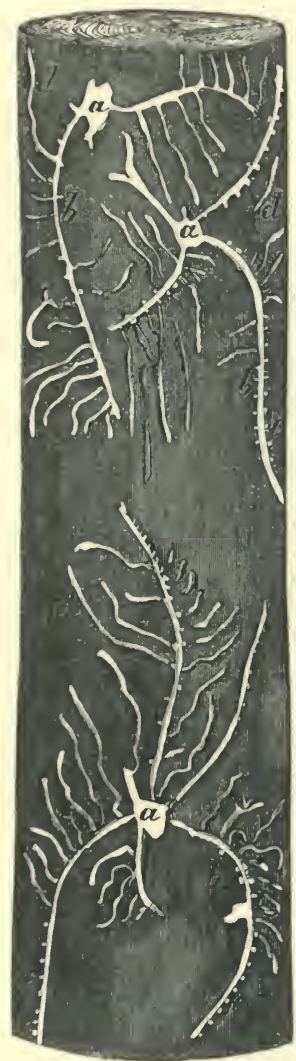

Fig. 114.-Burrows of $T$. bidentatus, IIbst., on pine sapwood. (Natural size.)

a Pairing-chambers. second brood, which hibernate as larvae, pupate in the following May.

Flight-period: in August. The second brood is mature by June of the following year, and is followed by a third brood in the autumn which winter in the beetle stage.

The generation thus extends over $1 \frac{1}{2}$ years. The beetle frequently appears in company with 'T. laricis, Fabr., and is widely distributed. It is common in conifer forests in Britain.

\section{c. Relations to the Forest.}

The common Scots pine is the chief tree attacked by this bark-beetle. It has, however, been also found in the Weymouth, cluster and mountain pines, and R. Hartig has noticed it on the spruce. It prefers the plants of 6 to 12 -year - old cultivations, and only attacks the branches and twigs of older trees, where the bark is thin. As, however, it attacks branches which are thoroughly sound, the crowns of trees are considerably thinned out by this beetle, especially when other barkbeetles and longicorn beetles join in the attack.

The bast and sapwood are both attacked. - The irregularly stellate mother-galleries are generally 4 to 7-armed, rarely 3-armed. The branches of these galleries run longitudinally rather than horizontally, and have a knotted appearance, as the egg chambers are large and comparatively far apart. The larval galleries are somewhat 
winding and sparsely distributed; both kinds of galleries may be clearly seen on the sapwood, though those made by the larvae are more marked in the bast.

This beetle readily attacks woods which have suffered from fire. Trees which have been severely attacked may be recognised by the yellowish colour of their crowns.

\section{d. Protective Rules.}

As for T. laricis, L.; but trap-trees are useless. Instead of these, branches may be used as traps, which should be burned as soon as they are stocked with larvae, and replaced by fresh ones every 4 to 5 weeks until the autumn. Poles seen to be attacked by larvae should be immediately felled and barked, and the bark burned.

\section{Tomicus acuminatus, Gyll.}

Beetle 3 to $4 \mathrm{~mm}$. long; brown, with yellow-grey pubescence. Elytra regularly punctate-striate, the excavation circular, acuminate at the apex of the suture, its elevated margin with 3 teeth on either side, the first a small tubercle, the last the largest, and situate about the middle of the margin.

\section{Life-history, etc.}

This species chiefly infests the crown of full-grown or old Scots pines. 'The mother-galleries consist of 3 to 5 branches, radiating from a spacious pairing-chamber and grooving the sapwood rather deeply when excavated in thin bark. The larval galleries are twisted, frequently coming into contact or even crossing, but as a rule scarcely marking the sapwood.

The species, though not very cornmon in Europe, is not rare in Scotland and the north of England, and must be considered as one of our injurious species. Its attacks must be treated on the same lines as those of other species of Tomicus.

\section{Tomicus lineatus, Oliv.}

a. Description.

Beetle 3 to $4 \mathrm{~mm}$. long, short and cylindrical, black, the hinder part of the thorax and the elytra yellowish brown. 
The latter with three black bands each, along the suture, in the middle and along the outer margin, of which the middle band is not always complete; they are marked with rows of large punctures; apical declivity not impressed nor toothed. Antennal club flattened oval, blunt at apex, without trace of sutures.

\section{b. Life-history.}

The season for flight is in March and April, and again in June and July.

The $q$ prefers felled trees, provided they are still sufficiently moist, also windfalls, and sometimes stems still in the ground, high stumps or broken trunks. A good

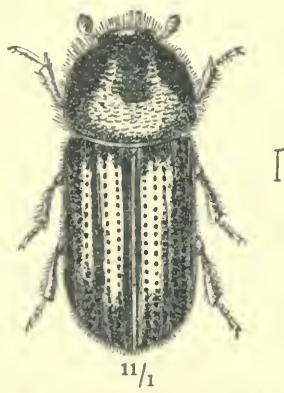

Fig. 115.-T. lineatus, Oliv. deal of care is shown in the selection of breeding places, and the material must be neither too fresh nor too dry. The beetle rarely bores into cleanly barked stems, and is only rarely found in standing liealthy trees. The $q$ bores vertically into the tree for an inch or more, constructing one or more brood galleries at the end of her tunnel, usually at right-angles to the entrance burrow, and always transversely to the long axis; in the floor and roof of these galleries she gnaws small cylindrical holes vertically into the wood for the reception of the eggs, and after oviposition, she blocks these holes with wood-dust, forming partitions between the secondary and primary galleries. There are generally from 30 to 50 eggs.

The larvae appear in May, and those of the second brood in July and August. They pupate in a cocoon of particles of wood in July, and again in August and September.

The imagos appear about the middle of July, and leave their birthplace through the old mother-gallery, after breaking through the partition, which remains intact up to that time. They at once set to work to produce a fresh brood. The species is widely distributed throughout Europe, but is confined in Great Britain to a few localities in the Tay and 
Dee districts of Scotland, where it has not as yet proved injurious.

\section{c. Relations to the Forest.}

The beetle attacks all conifers, but chiefly the silver-fir and spruce, and only large trees. The round-bored gallery penetrates at right angles to the axis of the tree. It consists of

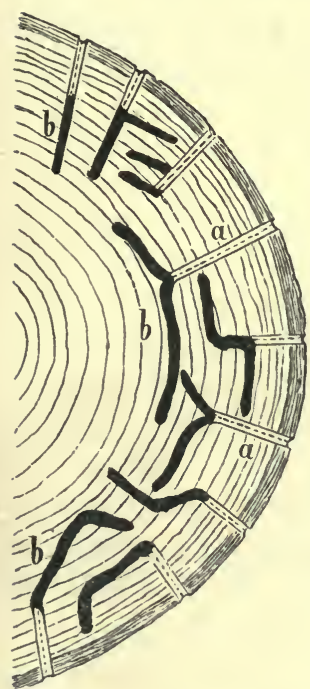

Fig. 116.- Transverse section of a spruce-stem (reduced) with burrows of T. lineatus, Oliv. (Natural size.)

$a$ Entrance-galleries.

$b$ Breeding-galleries.

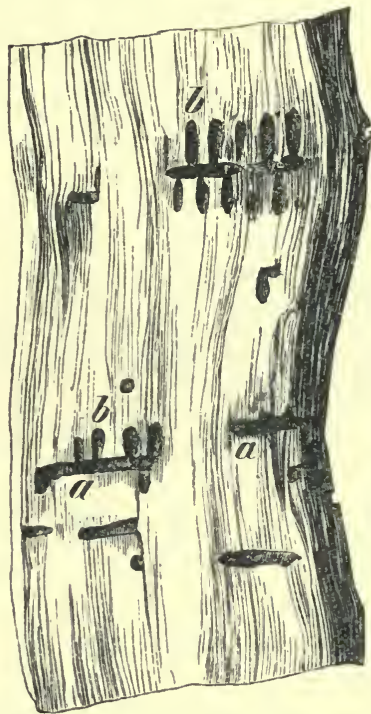

Fig. 117.-Radial burrows of T. lineatus, Oliv., in sprucewood. (Natural size.)

a Mother galleries.

$b$ Larval galleries and pupal chambers.

an entrance passage and breeding-gallery. The latter is either merely a prolongation of the former, or is usually composed of two branches, which generally follow the annual zone of the wood in the same plane. It is rare that several annual zones are traversed by it. The entrance gallery is generally confined to the sapwood. The larvae on emergence feed on the sap of the wood, and by gnawing extend their egg chambers to short cylindrical tunnels in which they pupate. 
In the secondary galleries, and on the partitions, white fungous mycelia (Monilia candida) appear, which are also devoured, not, as was formerly supposed, because they are the chief food of the larvae, but to clear the way for the larvae.

Later on, the walls of the galleries and the adjoining rood become black owing to fungoid growth.

The beetles damage the commercial value of the wood, the finest stems being frequently bored like a sieve, and rendered useless for most purposes. The insect is most frequently found in forests where much wood is broken by wind or snow, and where there are winter-fellings.

\section{d. Protective Rules.}

i. Immediate removal of all sickly coniferous trees and of broken wood and stumps from the forest. The latter should at least be barked, if their timely removal is not advisable.

ii. Felling in the growing season, and immediate removal of the bark.

It may happen, when the beetle is in great numbers, that barked trees may be attacked. If winter-felling cannot be avoided, and barking is impossible, the wood should be removed before March.

\section{e. Remedial Measures.}

i. Tree-traps may be felled in July and August to attract the beetles about to lay. These trees must be barked and split open to destroy the larvae, and fresh tree-traps provided continually till October.

ii. Firewood may be used as traps, but must be removed from the forest before the beetles come out.

\section{Tomicus domesticus, L.}

\section{a. Description.}

Bectle 3 to $4 \mathrm{~mm}$. long. Similar to the preceding species but more elongate, with the prothorax entirely black; the elytra livid yellow, regularly punctate-striate, and impressed 
at the apex on either side of the suture. Antennal club as in the preceding species, but produced into a blunt angle on the inner side of the apex.

\section{b. Life-history, etc.}

Similar to that of ' $T$. lineatus; but less important on account of its breeding chiefly in stumps and windfalls. It attacks not conifers but broadleaved trees, chiefly beech, oals and birch, also lime.

The mother-galleries do not branch as a rule, but run vertically into the wood for two or more inches. This insect is not uncommon in large woodlands in Britain. If it injures commercially valuable timber, the forest should be cleared of material containing the insects; spring felling is desirable.

T. quercus, Eichh., is still

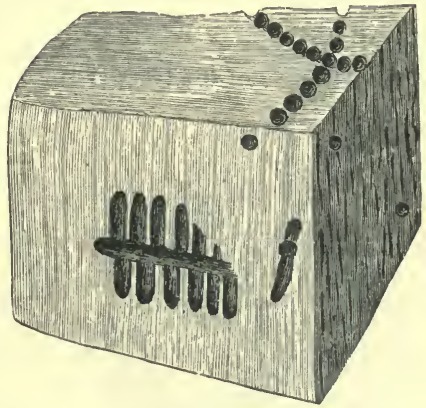

Fig. 118.-Radial galleries of T. domesticus, L., in beech-wood.

(Natural size.)

more like $T$. lineatus, Oliv., in appearance, but is distinguished by having the antennal club angulate at the apex, as in $T$. domesticus. In habits it resembles the latter species, but is much less common in Britain, being almost entirely confined to the neighbourhood of Sherwood Forest.

10. Tomicus dispar, Fabr.

\section{a. Description.}

Beetle ส $2 \mathrm{~mm}$. - $93 \mathrm{~mm}$. long. Pitch-black, the antennae and legs testaceous-red. o short, convex, ovoid and very hairy, with the thorax granular in front, punctured towards the base, with a smooth median line. The $q$ cylindrical, its thorax in front strongly asperate. Elytra strongly arched at the declivity, with rows of deep punctures, and raised tuberculate interstices between them. 


\section{b. Life-history.}

The season for flight is in May. The $q$ bores into several kinds of broadleaved trees to lay her eggs, in preference below a branch, but never near the ground, attacking felled wood and young standing trees.

The larvae appear in June, pupate in July in the secondary galleries, and the beetles emerge in August. They hibernate in the galleries, and there is only one generation. This beetle not everywhere common on the Continent, and till recently was regarded as one of the rarest British insects. But since 1891 it has been destructive in certain Gloucestershire fruit-orchards.
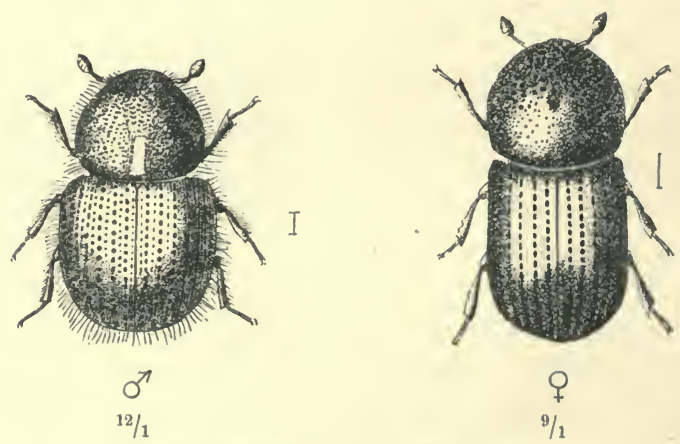

Figs, 119 and 120.-T. dispar, Fabr.

\section{c. Relations, to the Forest.}

Oak and fruit-trees, especially apple and pear, are chiefly attacked; also beech, hornbeam, birch, maple, ash, alder, horse chestnut and plane.

The $q$ bores a vertical entrance-gallery into the tree, like other species which enter the wood deeply, from which she excavates one or more transverse secondary galleries along the line of one of the annual rings; from these again are constructed tertiary brood-galleries which run longitudinally upwards or downwards. In the brood-galleries the eggs are laid in clumps; the larvae live in them, and do not bore but feed on the exudations of sap and on the fungi which overgrow the burrows. The galleries are bored at the height of the growing season in the outer zones of the wood of perfectly 
healthy saplings, which become diseased and die. The presence of the beetles may be detected by the borings, and the whitish bore-dust heaped up at the foot of the plant.

The beetle is very destructive in orchards, and sometimes to young oak-saplings.

\section{d. Protective Rules.}

Unbarked orchard-props should not be used, as it frequently happens that the beetle finds.its way from such props into the fruit-trees.

\section{e. Remedial Measures.}

i. The entrance-holes to the burrows should be smeared with tar.

ii. All plants which have been attacked should be removed and burned.

iii. The beetles may be killed inside the galleries with wire, and the bores blocked up by wooden pegs. This method of treatment is generally impracticable, but has been adopted with success in orchards.

\section{B. Subfanily Hyìesinini.}

\section{Description of Subfamily.}

Head prominent and not concealed by the prothorax, with a short and broad rostrum ; antennae witl a funiculus of 5 to 7 joints ; thorax narrowed in front, uniformly punctate on the back; first tarsal joint much shorter than the other three together, the third bilobed or heart-shaped (except in the case of Polygraphus pubescens, Er.); apical declivity convex and without teeth; under-

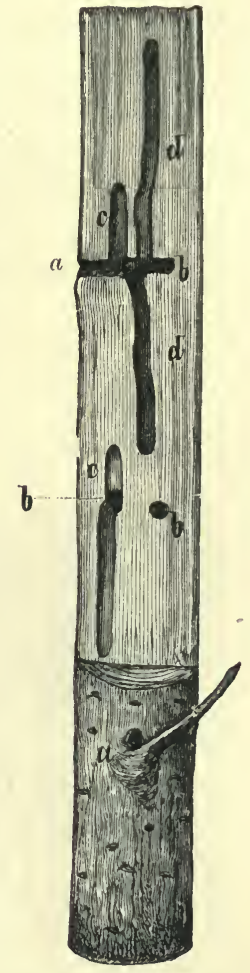

Fig. 121.-Burrows of $T$. dispar, Fabr., in an oak-sapling. (Natural size.)

a Entrance - hole, usually under a twig.

$b$ Mother-galleries.

$c$ Commencement of lateral galleries.

$d$ Completed lateral galleries in which the larvae lie. surface of the abdomen not abruptly flexed upwards.

Most species breed in the bast and especially frequent conifers; a few make pupal chambers in the sap-wood. 
1. Hylastes palliatus, Gyll.

a. Description.

Beetle 3 to $4 \mathrm{~mm}$. long, of stout build; thorax and elytra reddish-brown and covered with fine grey hairs; the former broader than long, strongly constricted in front, densely and coarsely punctured with a narrow median ridge. Elytra with rather fine punctured striae, the interstices rugose, tuberculate, and with a series of short hairs.

\section{b. Life-history.}

The flight-season is at the end of March and April.

Coniferous wood in logs, or stacks of fuel, chiefly when

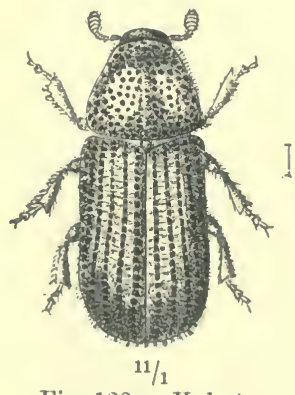

Fig. 122.-Hylastes palliatus, Gyll. damp and lying in shady places, are selected to receive the eggs.

The newly disclosed beetles appear from April or May until July; they at once pair and produce a new brood, and in July new breeding galleries are found amongst the larvae and pupae of the old brood.

The second brood of beetles appears from the beginning of October, and hibernates in cracks of the bark, moss, etc. There are two generations, and the species is common and widely distributed both in Britain and on the Continent.

\section{c. Relations to the Forest, etc.}

The beetle attacks all conifers, but chiefly spruce, and secondly Scots pine, silver-fir and larch exceptionally; only middle-aged and old wood; they also, both as larvae and beetles, damage the bark and bast.

The primary galleries are short and hooked, like intestines. They are sometimes forked. The secondary galleries are conspicuously long and irregular, often crossing one another and extending down to the sap-rood.

Authorities differ as to the destructiveness of this beetleliatzeburg, König and Kellner consider it very destructive; 
Stein thinks its destructiveness over-rated, and Eichhoff that it only does secondary damage.

More information as to its habits is therefore called for. The economic treatment of this species is the same as that of T. typographus, L.
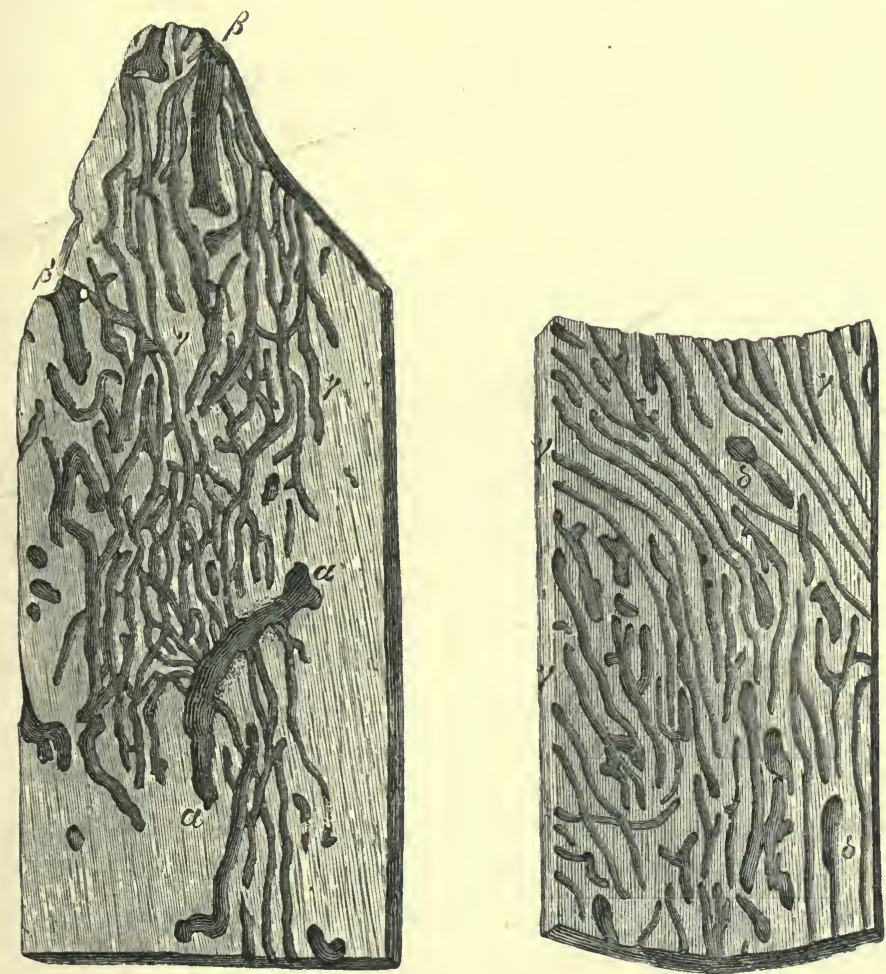

Figs. 123 and 124.-Burrows of H. palliatus, Gyll., in spruce bark. (Natural size.)

$\alpha, \beta$ Characteristic mother-galleries. $\quad \gamma$ Larval galleries. $\delta$ Mother-galleries where no larvae have been produced.

2. Hylastes ater, Payk. a. Description.

Beetle 4 to $5 \mathrm{~mm}$. long, of slender build; deep black, with brownish-red antennae and tarsi. Thorax much longer than 
broad, parallel-sided, closely and deeply punctured, with a smooth median ridge. Elytra deeply punctate-striate, with wrinkled and somewhat tuberculate interstices.

\section{b. Life-history.}

This species and $H$. opacus, Er., have a similar biological history, which is as follows:-They fly in March, April and May. Eggs are laid in stumps and roots of the Scots pine, in preference in those of trees felled in the previous year; but in the case of $H$. ater, eggs are sometimes laid in young pine transplants.

The larvae appear in April, and the mother and larval galleries then form a confused pattern.

The newly hatched beetles may first be seen in June, and according to Eichhoff they may produce a fresh brood, which comes out in October or November. The imagos hibernate in stumps or in plants which they have injured.

The generation is annual or double, or it may be biennial according to various observers; it requires further elucidation.

\section{c. Relations to the Forest.}

This beetle is only hurtful in the imago stage; before the middle of June they begin to wander from their breeding places to the neighbouring plantations and eat the bark of 2- to 6-year-old Scots and Austrian pine, and of other species of pine, especially at the collum and on the roots. The needles of the plants which have been attacked turn yellow and fall off ; the plants die, or become so loose in the soil that they can be easily pulled up. $H$. ater is common in Britain, and its ally $H$. opacus, Er., is nearly as frequent. The latter species is also recorded from elm and ash.

\section{d. Prolective Rules.}

i. Timely and thorough removal of stumps and roots, burning of the bark, or thickly smearing all exposed wood with tar.

ii. Thorough cleaning of the felling area.

iii. Careful planting, and avoidance of all deep planting. 
e. Remedial Measures.

i. Burying trap-logs, or laying out bark-traps as against Hylobius abietis, Fabr., page 225.

ii. Digging up all attacked plants with a spade, and burning them in kilns with the roots inwards.

3. Myelophilus piniperda, L. (Pine-beetle).

a. Description.

Beetle 4 to $5 \mathrm{~mm}$. long; head and thorax black, elytra blackish or dark brown; antennae and tarsi rusty red. 'Thorax
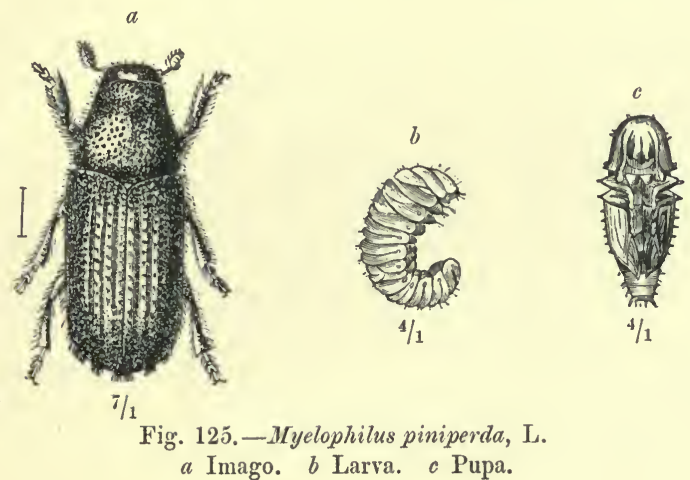

not longer than its width at the base and tapering in front, shining, with scattered deep punctures, obsolete towards the middle. Elytra with fine punctured striae; the interstices somewhat granulate, each with a row of bristle-bearing tubercles, absent on the apical portion of the second interstice (counting from the suture), which is slightly impressed.

\section{b. Life-history.}

The flight is at the end of March, April, and also in May; under favourable circumstances, again in June and July. The eggs, to the number of 100 and over, are laid similarly to those of T. typographus, L., on large Scots pines, etc., and in preference on the south-west side of the trees. There is, 
however, no breeding chamber, as copulation takes place outside on the trees. The of prefers dying or felled timber with rough bark, windfalls, stumps and broken trees. On standing trees the lower coarse-barked portion of the stem is selected, as the brood-galleries are entirely limited to the bark. If no old wood is to be found, the beetle attacks young poles.

The larvae hatch in April or May, in about 12 to 20 days after the eggs have been laid; they pupate in June or the beginning of July.

The beetles appear at the end of June and in July. Some later ones may emerge in August. The beetles which develop early, in June in mild localities, produce a second brood, which is ready by the end of August, and attacks the terminal shoots of the tree and branches; those which come out later do not pair but at once commence their destructive work in the crowns of the trees. Thus the whole development of the beetle may last from 60 days under very favourable circumstances, to 80 days. In order to hibernate, the beetle bores into the rootstock or roots of standing trees, sometimes into stumps, often into the thick bark at the lower part of the trunk.

The generation is either single or double. The insect is very numerous, and widely distributed; it is common in almost every pinewood throughout Britain.

\section{c. Relations to the Forest.}

The beetle generally attacks the Scots pine, but also the Weymouth and cluster pines and other species of pines. It has also been frequently observed on the spruce; rarely on larch.

It attacks old and young trees, but prefers the former, and is very rarely found in woods less than ten years old. Woods between thirty-five and forty years old are chiefly attacked. The insect does three kinds of damage.

First of all the beetles and larvae attack the bark and bast. The beetle makes longitudinal galleries, with one to three airholes, which may be straight, but generally commence with a characteristic hook-like bend. The entrance-hole is usually 
under a barkscale, and may be marked by ejected wood powder or by a drop of turpentine. The larvae eat out secondary galleries in the bast, which branch out at right angles to the primary gallery, soon becoming wide, irregular and confluent. They only graze the sapwood. The pupae and immature beetles are embedded in the bark, near its outer surface.

The second and most serious form of damage is done to the young shoots. The newly-disclosed beetles of the first or second broods, in August and September, bore into the pith of young pine shoots at a

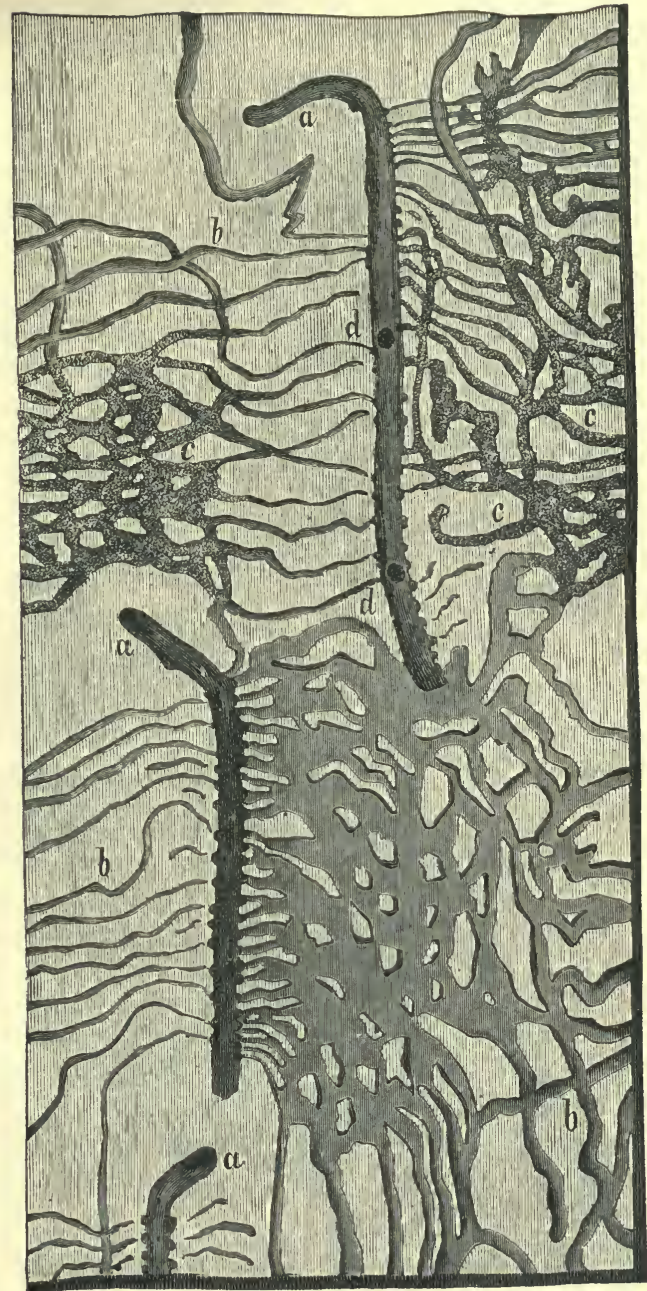

Fig. 126.-Burrows of M. piniperda, L., in pine-bark.

(Natural size.)

a Characteristic angle near the beginning of the mothergallery.

$b$ Larval gallery free of wood-dust.

$c$ Larval gallery full of wood-dust.

d Air-passages. 
distance of 1 to 3 in. from their extremities, choosing

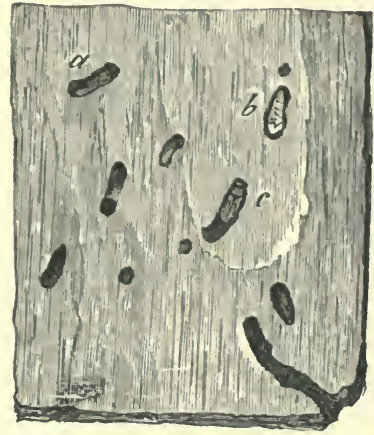

Fig. 127. - Pine-bark with chambers $(a)$, pupae $(b)$ and imagos $(c)$ I. piniperda, L.

(Natural size.)

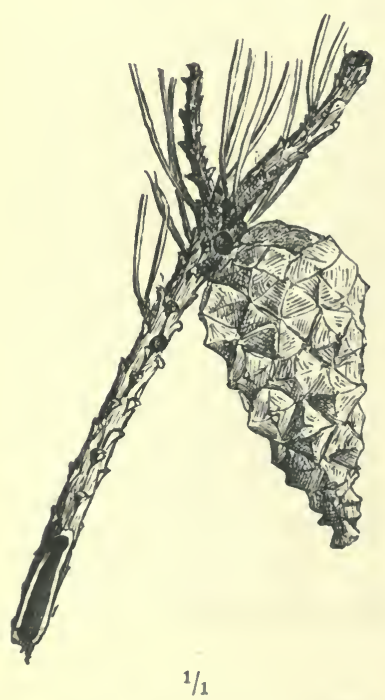

Fig. 128.-Pine-shoot, hollowed out by $M$. piniperda, L., with two beetle-holes. especially those of sickly or old trees, in preference on sunny borders of woods; they eat out a burrow about an inch long, working upwards to the buds. The entrance-holes into these shoots are surrounded by a whitish ring of resin. The beetle leaves the hollowed-out shoot either by the original bore-hole or by a fresh hole made at the end of the burrow, and recommences his destructive work in another shoot. In these galleries excrement is never found, and thus the action of $M$.piniperda,L., may be distinguished from that of 'Tortrix buoliana, Schiff., the caterpillar of which also bores out Scots pine shoots, but always leaves excrement in the borings. Weak side-shoots which have been bored break off generally at the bore-hole, and fall to the ground. Stronger shoots from the crown develop the suppressed buds between the pairs of needles, which with favourable spring-weather grow into short needles, and give the shoots a bushy appearance. The height, growth and development of the crown are thus seriously affected; and the production of cones being materially reduced greatly impairs the success of natural regeneration of Scots pine forests. Fig. 128 shows a hollowed-out twig bearing a cone. Such twigs may be found lying on the ground 
in thousands after an autumnal storm. Sometimes two beetles are found in the same twig, and some beetles hibernate in them, but this is probably a rare occurrence. Owing to the loss of these bored twigs, the crowns of trees, if repeatedly attacked by the pine-beetle, acquire a characteristic appearance which may be recognised from a distance. They

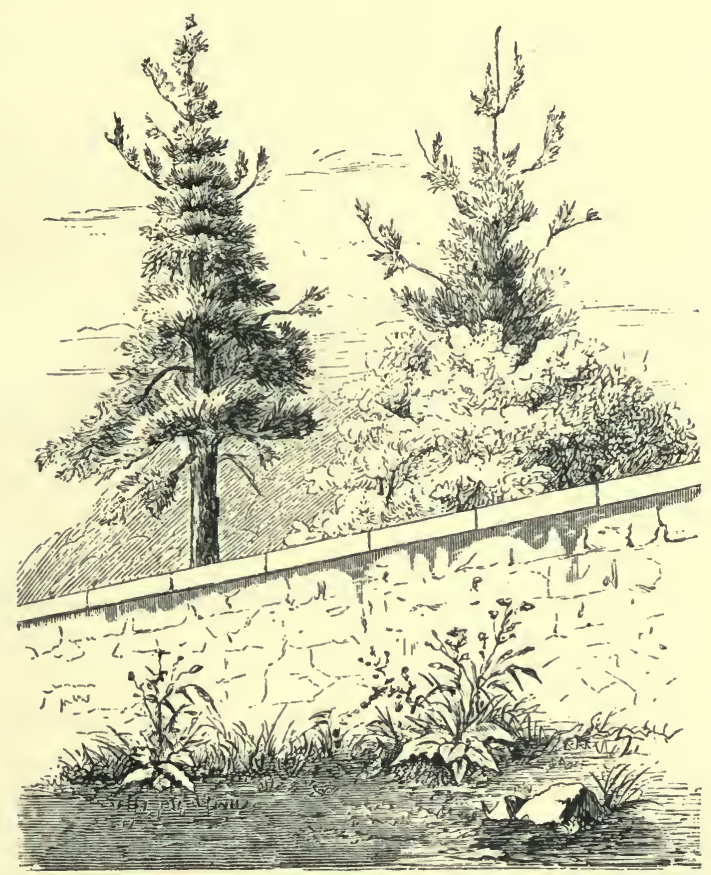

Fig. 129.-Weymouth pines injured by the Pine-beetle in the cemetery at Wieseck (near Giessen).

acquire the form of the cypress instead of possessing the usual dome-like shape, and here and there a few side-branches which have been spared may project outwards from the tree (Fig. 129). This curious aspect of the trees has given to the insect the appellation of Hortulanus naturae ("Waldgärtner" or Pruner).

Besides the direct damage (loss of increment, diminution of the seed-harvest) inflicted on attacked trees by the reduction 
of their assimilating organs, indirect damage is also done by reduction of the cover, and consequent exposure of the soil. As the cover of Scots pine woods is apt to open out even under favourable conditions, this form of injury is very serious.

Exceptionally, the beetles in summer eat out irregular longitudinal galleries in the first 5 to 6 years' growth of shoots on vigorous 12 - to 15 -year-old Scots pines, but without laying any eggs. Altum* states that these galleries, which run partly in the bast, partly in the sapwood, are only used to harbour the beetles.

Lastly the beetle does damage by boring down for 2 or more inches to the sapwood of the rootstock of sound standing trees in order to hibernate. If this should happen on a large scale, the trees might die, or at any rate would become sickly and attract more beetles in the ensuing spring.

The pine-beetle prefers forests in flat or undulating country, isolated trees, trees along the borders of woods, and those which have suffered from fire; it is also common near timberdepôts. Like all bark-beetles, it prefers windfalls or trees partly uprooted by the wind, and sickly trees, but does not exclusively attack such trees.

In a pine forest on the peninsula of Darss on the Pomeranian coast, which had been flooded with salt water on the 12 th and 13th November, 1872, and the trees thus rendered sickly, the beetle appeared in such enormous numbers as to completely destroy 2,500 acres of the forest.

In the spring of 1892 , about 100 acres of pine wood was burned near Caesar's Camp, in Windsor Forest. 'The next year there was a serious attack of pine-beetles, the trees that had been singed by the fire having multitudes of larvae between their bark and wood. These trees had all to be felled, while the surrounding forest trees were pruned in the most unsightly manner by the beetles.

\section{Protective Rules.}

i. Timely and frequent thinnings of pine woods, and quick removal of all sickly trees.

* "Ein neuer Sommeraufenthalt von M. piniperda," Zeitschr. fr. Frost. u. Jgdw., 1879 , page 264 . 
ii. Clearance of the felling-areas, at the latest by the middle of April ; removal from the wood of all valuable timber with thick bark before the beetles emerge.

iii. Uprooting of stumps and broken trees. If for any reason this is not practicable, they must at any rate be barked.

iv. Pine woods injured by fire must be felled.

v. All insect-eating mammals and birds must be protected, especially those referred to under T. typographus, L. (page 244).

\section{e. Remedial Measures.}

i. Trap-trees should be felled from February till September so as to keep up a supply of trees which are not too dry for the beetles to breed in. Thick-barked trees injured by storm, snow, caterpillars or fire should be selected; some of them should be barked in the middle of May and others at intervals of 4 to 6 weeks, and the bark burned in pits.

ii. All standing trees containing larvae or pupae should be felled and barked and the bark burned.

\section{Myelophilus minor, Hart.}

a. Description.

Beetle 3.8 to $4 \mathrm{~mm}$. long; closely resembling the preceding species in appearance, but with the bristlebearing tubercles continued on the second interstice of the elytra up to its apex, as on the other interstices.

\section{b. Life-history.}

Season for flight. April and May, about 8 to 10 days later than the preceding species.

Standing Scots pines are selected for breeding, but as a rule the thickly barked lower part of the stems is avoided, and the

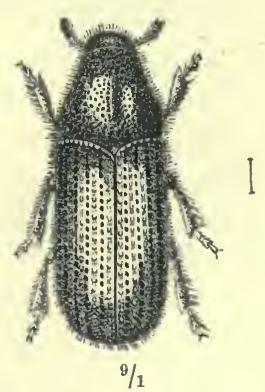

Fig. 130.-M. minor, Hart. upper portion where the bark is thinner is chosen. The young brood requires for its development somewhat fresher material than in the case of $M$. piniperda. 
The larvae hatch in June, and pupate in July in a chamber made in the sapwood.

The beetles emerge in July and August, and generally pair in the following year. Those, however, which appear early, usually produce another brood within the year, as in the case of the preceding species.

Generation single or double. The beetle is found in company with the former species, but is rarer, or at any rate more

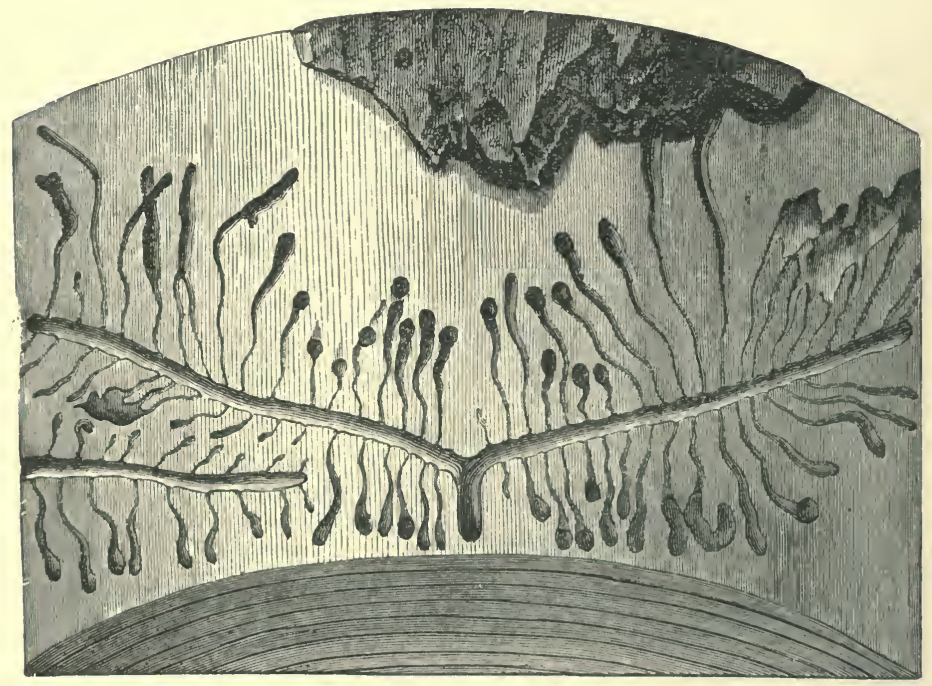

Fig. 131.-Burrows of M. minor, Hart., on pine sapwood. (Natural size.)

localised. In the British Isles it has only been found, and that very rarely, in the Dee district of Scotland, but it is so like the much commoner $M$. piniperda, L., that it is probably overlooked.

\section{c. Relations to the Forest.}

M. minor, Hart., chiefly attacks the Scots pine, but has also been found on the spruce. It prefers poles, but may attack 50- to 70-year-old trees. The mother-galleries are large, regular, double-armed, and horizontal, with a rather long entrance-burrow, and groove the sapwood deeply (Fig. 131). 
The injury which its breeding causes is greater than that of H. piniperda, as the circulation of the sap is more endangered by these horizontal galleries. It is not therefore surprising that quite sound trees are killed by it, or at any rate become stag-headed.

The larval galleries are short, not very numerous, and terminate in a deeply-cut pupal chamber. This beetle, unlike the preceding species, is said not to confine itself to the borders of a pine-wood, but to be found deeper in its interior.

M. minor also bores into the pith of young pine shoots in the same way as $M$. piniperda.

\section{d. Protective Rules.}

As for $M$. piniperda, but the trap-trees must have thin, smooth bark.

\section{Hylesinus fraxini, Fabr. (Ash'Bark-beetle). \\ a. Description .}

Beetle 2 to $3 \mathrm{~mm}$. long, short and thickset; pitchy-brown or $\mathrm{r} \in d d i s h$, variegated with short, closelying, ashy and fuscous scales, forming a series of irregular transverse bands on the elytra. Prothorax transverse, finely granulate; elytra with fine but distinct punctured striae; legs piceous with the tarsi reddish, antennae ferruginous.

\section{b. Life-history.}

Flight period at the end of April and beginning of May.

The eggs are laid on the branches and stems of healthy ash trees, as well as on

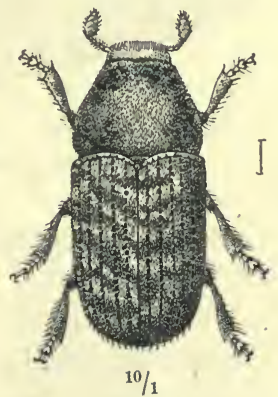

Fig. 132.-Hylesinus fraxini, Fabr. dead and felled trees. The larvae hatch in May, and develop in July to the perfect insects, which pass the winter in irregular borings in the bark.

Generation usually single, but has been observed double in Elsass, the second flight from end of August. Common and generally distributed throughout the British Isles.

F.P. 


\section{c. Relations to the Forest.}

The beetle bores into the bast of ash-poles and trees, constructing extremely regular, double-armed, horizontal galleries, with a short entrance-burrow (Fig. 133, a). The larval galleries are short but close together, cutting deeply into the wood, and are always very regular (Fig. 133, b). The pupal chambers are in the wood (Fig. 133,c). The beetles eat their way out in August, making numerous perforations, so that the bark is riddled, as if by shot. Once a tree has been

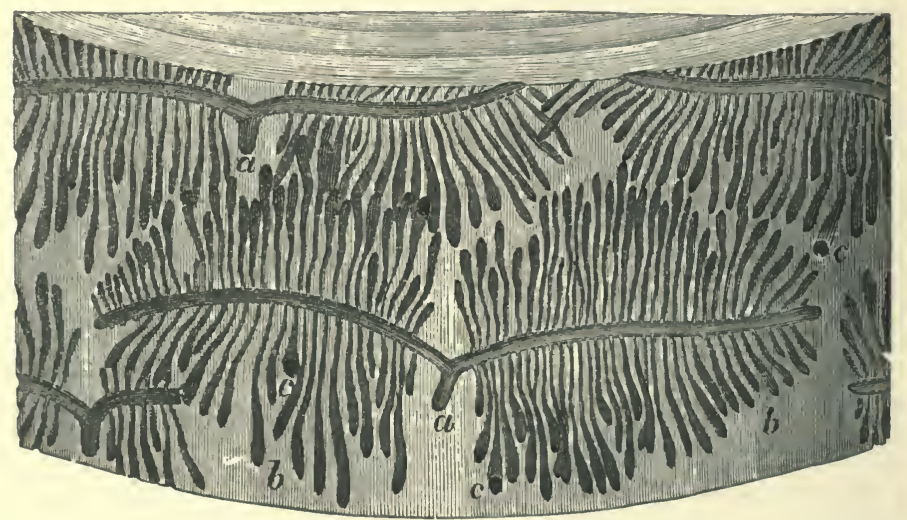

Fig. 133.-Burrows of $H$. fraxini, Fabr., on ash sapwood. (Natural size.) $a$ Mother-galleries. $b$ Larval galleries. $c$ Pupal chambers.

attacked, numerous galleries are excavated in it one over the other.

The beetle prefers quite sound trees, according to Hess, and kills them, but Miss Ormerod says that the damage is chiefly done to decayed or sickly trees. This insect also attacks large ash-trees standing in the open, boring down to the bast in order to hibernate there, and such winter-quarters are generally occupied again in the succeeding autumn by more numerous beetles, so that rough, scabrous, rosette-like prominences are eventually formed on the bark. It has occasionally been observed to attack the robinia and apple-trees, but its galleries are then vertical rather than horizontal. It may be laid down as a general rule that the smaller the branches which are 
attacked, the more do galleries which are normally horizontal tend to become vertical.

In the ecclesiastical forests of Temeser Banat, in Hungary, the ash woods have since 1888 been seriously attacked by this beetle. By the summer of 1890, 17 per cent. of the trees of a total standing crop of $2,570,000$ cubic feet were killed.

\section{d. Economic Rules.}

i. Selection of suitable localities for planting ash-trees, and attention to such rules of management as will keep the trees healthy.

ii. All infested trees should be barked in June and July, and their bark and branches burned.

iii. Trees attacked may be tarred.

\section{Hylesinus vittatus, Fabr.}

Beetle similar to $H$. fraxini, Fabr., but only $1 \frac{1}{2}$ to $2 \mathrm{~mm}$. long; with a white stripe on each elytron extending from the shoulder to the middle of the suture and enclosing a common oval dark patch; it makes double-armed horizontal galleries in the elm.

\section{Hylesinus crenatus, Fabr.}

\section{a. Description.}

Beetle 5 to $6 \mathrm{~mm}$. long; ovate, blackish - brown or black, its under surface hairy.

Thorax tapering in front, distinctly broader than long, thickly and coarsely punctured; elytra broadest at the middle, obliquely and not strongly. declivous behind, with coarse punctured striae, the interstices granulate and furnished with short black hairs; abdomen curved upwards towards the apex.

\section{b. Life-history.}

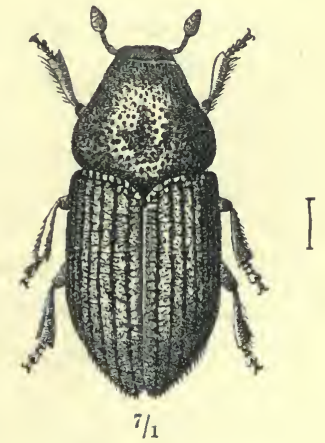

Fig. 134.-Hylesinus crenatus, Fabr.

Similar to that of $H$. fraxini; but the generation is said to be double. The flight-period is at 
the beginning of April, and again in October. When pairing takes place late in the spring (May and June) the generation is only single.

\section{c. Relations to the Forest.}

This beetle attacks the ash almost exclusively, and prefers large trees with fissured bark. 'The female makes short, slightly bent, generally two-armed

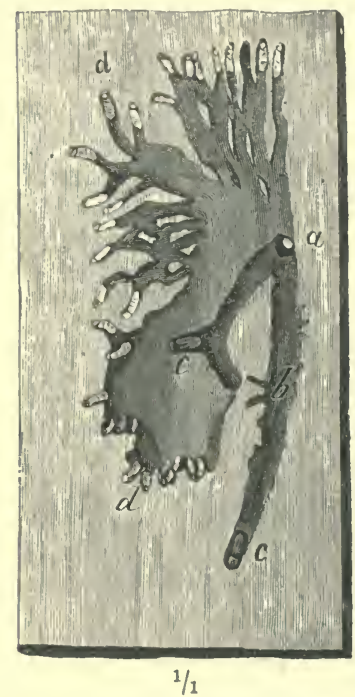

Fig. 135.-Burrows of H. crena. tus, in ash bark.

a Entrance-hole.

$\checkmark$ Mother-galleries.

$c$ Beetles excavating galleries. $d$ Boring larvae. galleries. The two arms are generally of unequal length and inclined at an acute angle; sometimes only one is present. The larval burrows run at first upwards or downwards, that is, at right angles to the mother-galleries, gradually curving and becoming horizontal; they are of great length, and are often abruptly bent on themselves once or twice in their course. Fig. 135 shows the appearance of a gallery, in which boring beetles as well as larvæ may be distinguished; the latter so closely packed that their galleries have coalesced. It is, however, hardly typical of the species. If the o do not lay, they bore simple tunnels, frequently just under the outermost bark, which then generally splits and flakes off over the point of attack. Exceptionally the beetle has been found attacking old oak-trees in the Russian Chersonese; the galleries in this case may be three-armed.

The attacks of this insect may be treated as for $H$. firaxini.

\section{Subfamily Scolytini.}

Description of Subfamily.

'I'his sub-family contains a single genus, Scolytus, the species of which possess a projecting head with a short, broad 
rostrum. Antennal funiculus 7-jointed. First tarsal joint much shorter than the succeeding joints together, the third bilobed. Elytra scarcely declivous behind. Under surface of abdomen flexed upwards from the base of the second segment.

They breed exclusively between the wood and bark of broadleaved trees, and sometimes make very regular galleries, which generally cut deeply into the sapwood. Pupal chambers in the outer layers of the sapwood.

\section{Scolytus Geoffroyi, Goeze (Elm Bark-beetle).}

a. Description.

This beetle is 4 to $5 \mathrm{~mm}$. long, black, with the elytra brown; antennae and legs reddish brown. Front of head and rostrum without any carina. Thorax broader than long, punctured, the punctures becoming weaker towards the middle of its upper surface. Suture of the elytra depressed from the base to its middle; their interstices broad, with two or three rows of punctures. Third and fourth abdominal segments in both sexes with a small tubercle.

\section{b. Life-history.}

Flight at the end of May and June, and sometimes again in August.

The eggs are laid in the bark of elms, by preference in sickly trees.

The larvae appear in July and the beetles fly in August, and at once proceed to pair. The larvae of the second brood hibernate in their borings, and pupate in the following spring, generally in the bark or less frequently in the sapwood.

The beetles of this brood come out at the end of May. The holes of exit are about the size of No. 5 shot.

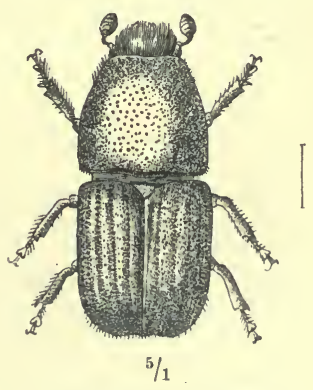

Fig. 136.-Scolytus Geoffroyi, Goeze.

The generation is usually double on the Continent, and apparently so in England in warm seasons. But in Britain, 
where the insect is common south of Scotland, a single generation is more usual, the larvae which hatch in May or June becoming full-fed at the end of July and remaining in the tree throughout the winter.

\section{c. Relations to the Forest.}

The beetle attacks old and young elm-trees, and sometimes also the ash.

The mother-gallery is broad, short, ascending and vertical, about $2.5 \mathrm{~mm}$. broad, and with 1 to 2 air holes. The secondary galleries ramify from it at right angles in a fairly regular manner, lie close together, are long, sometimes extending for more than 4 in., gracefully curved, and somewhat broader at their ends than the primary gallery. The pupal chambers when the bark is thin are excavated partly in the sapwood.

This beetle especially attacks elms in the neighbourhood of large towns ; thus in 1842, elms in Regent's Parl were infested, and in 1870, many elm-trees that had been weakened by a raising of the groundwater level were killed in Berlin.

\section{d. Prolectiv'e Rules.}

As a preventive measure, elms in avenues, parks, etc., may be smeared with Leinweber's* composition.

All stems attacked by the beetle should be felled, beginning in July, and the bark burned. Trees that have been felled may be used as traps, and treated accordingly.

\section{Scolytus intricatus, Ratz.}

\section{a. Description.}

Beetle, 3-4 mm. long; black, with the elytra, antennae and legs, pitchy-red, or brown; the former with close rows of punctures, the interstices narrow, closely wrinkled, the suture depressed round the scutellum; abdomen unarmed.

* 5 lbs. tobaeco, mixed with $\frac{1}{2}$ pailful of hot water, are kept hot for 24 hours ; the water is then squeezed out of the tobaeeo and mixed with $\frac{1}{2}$ pailful of bulloek's blood, 1 part of slaked lime and 16 parts of eow-dung. This is kept in an open tub and stirred onee a day, and used after fermentation has set in. The rough bark, moss, ete., is trimmed off the tree, and the latter painted with the mixture for three suceessive days, until a erust is formed whieh the rain will not wash off. 
b. Life-history, etc.

It lays its eggs on oaks, but otherwise resembles the elm beetle in its mode of life. It has, however, only one generation in the year.

It attacks several species of oak and more rarely the beech, and it prefers young stems and branches to older parts of trees.

The beetle bores a simple gallery; the larval galleries, 30 to 40 , run partly upwards and partly downwards, and are long and narrow. The pupal chambers groove the sapwood superficially. The beetles attack perfectly healthy oak saplings and kill them.

In the Bois de Vincennes, several years ago, about 50,000 30-year-old oaks were killed by this beetle, which breeds freely in oak-posts which have not been barked,

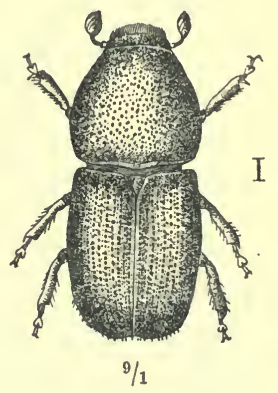

Fig. 137.-Scolytus intricatus, Ratz. and are used for fences.

Care in the management of plantations of saplings, and avoidance of unbarked wood in palings, are the chief protective measures available.

Two other species of Scolytus, S. pruni, Ratz., and S. vugulosus, Ratz., the latter a very small species, are especially attached to fruit-trees, plum and apple. Both are locally common in England, and sometimes injurious, but they are not important to the forester.

\section{Family VIII.-Cerambycides (Longicorn Beetles). Description of Family.}

Longicorn beetles are elongate, and generally of large or moderate size, with a cylindrical thorax, often spined at the sides ; elytra somewhat depressed, wider at the shoulders than the thorax, and tapering behind.

Antennae filiform or setaceous, rarely serrate, and always becoming thinner at the ends, usually very long, with 11 or more joints, the second joint always the shortest.

Legs slender and long. T'arsi four-jointed, the three basal joints flattened and spongy beneath, the third bilobed. 
Abdomen with 5 segments. Generation usually biennial.

Larvae soft, white or yellow, usually cylindrical, rarely somewhat flattened, with projecting broad thoracic segments, of which the first at least is furnished above with a horny plate. Their feet consist of six minute tubercles, or are entirely absent.

Pupae fusiform, and recognisable by the long horns bent down in a curve from the head.

Flight-holes transversely oval.

The larvae generally live under bark and in wood, but usually only in broken trees or in stumps; a few species are found in beams of houses. Their attack is of a secondary nature, as they bore into trees killed by bark-beetles and other insects, but on account of the large size of their galleries, and the quantity of boring dust which exudes, it easily attracts attention.

On sunny days the beetles may be found on flowers, shrubs, and felled trees; the females do not make mother-galleries.

Longicorn beetles are rare as a rule in the British Isles, and most of the species found are small and of little or no economic importance. In tropical countries they play an important part in the destruction of fallen and decaying timber.

1. Saperda carcharias, L.

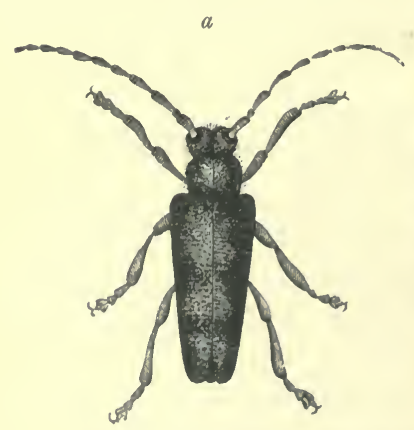

Fig. 138. - Saperda carcharias, I.

a Imago. $b$ Iarva.
(The Large Poplar Longicorn.)

a. Description .

Beetle 23 to $30 \mathrm{~mm}$. long, grey or brownish yellow, dotted with many shining black points. Thorax short and cylindrical. Elytra with the shoulders prominent, narrowed posteriorly and bluntly spined at the apex. Larva extending up to $36 \mathrm{~mm}$. in length, with out legs, cylindrical, and segmental shields 
brown, the latter on the dorsal surface of segments $3-10$, and the ventral surface of segments $2-10$.

\section{b. Life-history.}

Season for flight: June and July.

The eggs are laid in June in crevices in the bark of poplars, especially near the ground.

The larvae emerge in July and August, and live and hibernate in the wood, pupating in May of the 3rd year.

The pupae lie head downwards in a chamber blocked with a plug of wood-dust.

The imagos emerge in June of the third year.

Generation biennial. The insect is rather common in a few parts of Great Britain, chiefly in the Eastern Counties.

\section{c. Relations to the Forest.}

The larvae bore into young, healthy poplars, and also into willows ; aspen and black poplar up to 20 years old are specially attacked. Seedling-trees are liable as a rule to be attacked from their 5 th year, and suckers from the $3 r d$ year.

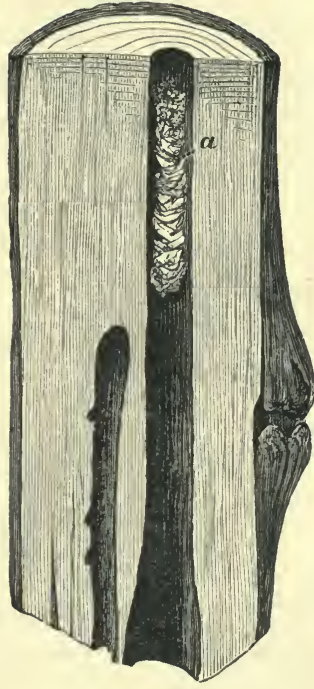

Fig. 139.-Larval burrows of S. carcharias, I., in the stem of a young poplar.

(Natural size.)

a Plug of boring dust.

The larvae make vertical galleries, which reach the centre of the tree: these become gradually filled with wood-dust, which is forced out of the tree by the grubs, through a bore-hole, and becomes heaped up at the base of the plants. The stem is attacked near the ground and reacts by developing a large irregular swelling, the bark of which is fissured. Such perforated saplings are easily broken by the wind. This insect is chiefly of importance where poplars are grown on a large scale, as in France. 
It is sometimes associated with Sesia apiformis, Fabr., and Cossus ligniperda, Fabr.

The beetles in June and July eat roundish holes in poplar leaves, but this injury is unimportant.

\section{d. Protective Rules.}

i. Poplar-nurseries should not be established near older poplars.

ii. Poplar-saplings liable to attack may be smeared in June up to 5 feet in height from the ground, with a mixture of clay and cow-dung, or Leinweber's composition (page 278). This treatment is to be recommended for nurseries.

\section{e. Remedial Measures.}

i. Collection of the beetles by shaking the saplings in June and July.

ii. Felling and removal of all attacked saplings before the beetles emerge.

2. Saperda populnea, L. (Small Poplar Longicorn).

\section{a. Description.}

Beetle 8-13 mm. long, greenish-grey to dark brown, covered with yellow-grey pubescence; thorax with 3 lines of pubescence; elytra with the median line, and a broad lateral stripe, and three or four spots on each side pubescent. Antennae blackish, and each segment up to two-thirds of the length of the antennae with grey pubescence. Larva 13-15 mm. long, yellowish and resembling that of the preceding species.

\section{b. Life-history.}

The female deposits her eggs in May and June in cracks on the bark of young aspens, less commonly on other species of poplar, sometimes on willows. Seedlings of 2 to 6 years old and suckers are preferred.

Generation biennial. The larva hatches in July, bores through the bark and eats a circular gallery round the sapwood. The stem, usually one of the smaller branches, 
reacts by forming a gall-like swelling, which however is not found on willows.

In the second summer the larva changes its course, boring upwards along the middle of the stem for about an inch. The flight-hole is circular and situated on the swollen portion. Pupation in April of the third year.

This insect is usually found in open sunny places, and is not uncommon in the Midlands and south of England. It seldom kills the trees, but cripples the branches and prevents growth. Where it is abundant, hardly a branch can be found free from its galls.

\section{c. Remedial Measures.}

Collection of the beetles in June by shaking; cutting and burning the attacked branches during the winter.

The Musk-beetle, Cerambyx moschatus, L., is a handsome dark or bluish-green longicorn with bright

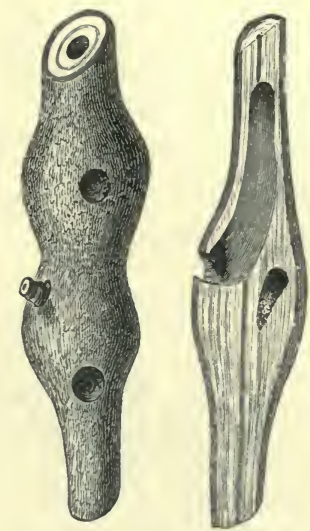

Figs. 140 and 141.-Burrows of $S$. populnea, L., in an aspen twig.

External view with two flight holes. View of interior with the larval burrows exposed. metallic lustre, it exhales a strong odour of musk. Its larvae live in rotting willow-stems, and also in old osier stools, where it may do some damage.

\section{Fanily IX.-Chrysonelide (Leaf-Beetles).}

\section{Description of Family.}

Leaf-beetles are small or of moderate size, convex and short, of an oval or hemispherical shape.

Antennae filiform, bead-like, or slightly thickened at the ends, 11-jointed. Legs usually short, strong, sometimes framed for jumping; tarsi 4-jointed, spongy below, the 3rd joint bilobed. Abdomen with 5 segments. Generation simple.

The larvae are short, flattened, usually either parti-coloured or black, with 6 legs, the last segment usually with a retractile process. Pupae thickset, sometimes hanging upside down from 
leaves. Some species are very injurious, both the imago and larva eating the leaves of broadleaved trees.

\section{Chrysomela populi, L. (Red Poplar-leaf Beetle). a. Description.}

Beetle 10 to $12 \mathrm{~mm}$. long, of an obovate shape, blackish-blue, the elytra brick-red, their extreme tip black; thorax narrower than the elytra, its sides rounded, broadly raised and coarsely punctured; antennae short, compressed, thickened towards the ends.
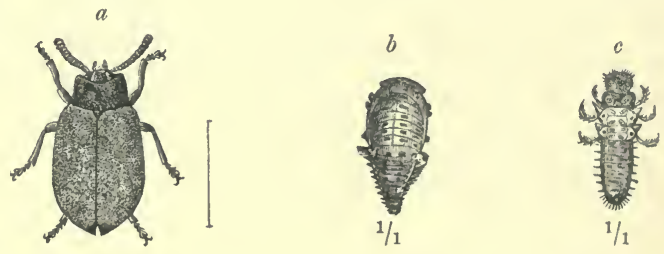

$\frac{1.5}{3}$

Fig. 142.-Chrysomela populi, I.

a Beetle. $b$ Larva. $c$ Pupa.

Larva 6-legged, of a dirty white colour, with many black spots, and two white lateral projections on the 2nd and 3rd segments.

Pupa sharply narrowed towards the posterior extremity, brownish yellow, with regularly distributed black spots and stripes.

\section{b. Life-history.}

The season for flight is in May and June.

The $q$ lays her yellowish-white eggs in clusters of 10 to 12 , in all 100 to 150 , on the under-side of the leaves of young poplars.

The larvae emerge in June or July, feed openly on the leaves, and if disturbed exude a milky-white fluid, with an odour of bitter almonds.

Pupation takes place in July and August; the pupae hang reversed from the leaves by their pointed end.

The beetles emerge by the end of August, and after October hibernate under leaves or moss, reappearing in the open in April.

Generation annual, but frequently double, when the beetles hibernate; larvae appear in May and June; pupae 3-4 weeks 
later, new peetles 10 days later. Fresh larvae in August, the second generation closing in the middle of September. Locally common in many parts of the British Isles, chiefly in South England.

\section{c. Relations to the Forest.}

The insect, both in the larval and beetle stages, attacks young poplars and sometimes aspen shoots. Occasionally they are found in osier-beds, especially on Salix purpurea, L., and S. pentandra, L., and to a less extent on $S$. rubra, L., etc. The larvae attack the leaves, which are completely skeletonised, the parenchyma being eaten and the veins left intact. The imago eats holes out of the leaves.

The attacks last from June to August.

\section{d. Protective Rules.}

Collection of the $a$ Leaf bitten by beetle. $b$ Leaf bitten by larvae. beetles on to cloths by

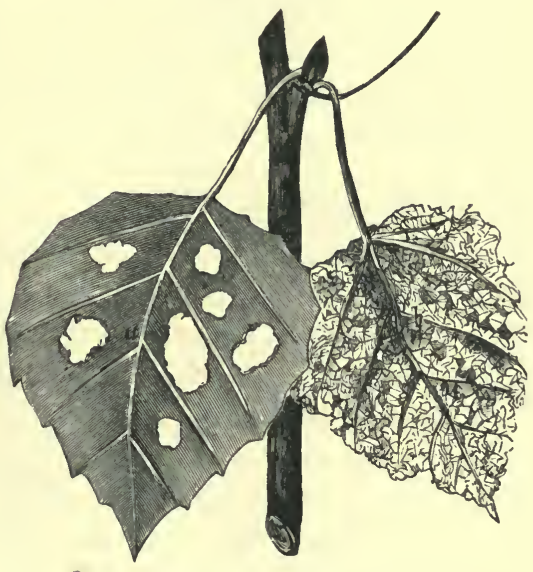

Fig. 143.-C. populi, L. beating the trees in May and June, and again in August to September.

C. tremulae, Fabr., is somewhat smaller than, and greatly resembles the above species, but has no black tips to its elytra. It is the more destructive of the two, sometimes completely destroying the foliage and shoots of young aspen. It also attacks osier-willows, especially Salix purpurea.

\section{Chrysomela vulgatissima, L. (Willow Beetle).*}

\section{a. Description.}

Beetle 4 to $5 \mathrm{~mm}$. long, oblong-oval, of a bronze or green .tint, sometimes coppery or indigo-coloured, violet or black. 
Elytra regularly punctate-striate. Larvae vary in colour, often nearly black above, witl an olive-green middle line, yellowish below.

\section{b. Life-history, etc.}

The beetles come out in the spring from their sheltering places, and lay their eggs on the under-surface of leaves of willows-Salix viminalis, L., S. purpurea, vubra, etc., and also on poplars. The imagos and larvae attack the young shoots and leaves, commencing with the under-surface, and eating their way through the leaf, or up to its epidermis.

Pupation takes place in the soil. The beetle lives through the winter, hibernating in various localities; it is found sometimes high up on willows in sheltered places, under the rough bark of old pollards, in hollow stems of herbaceous plants, among the terminal shoots of neighbouring young pine trees, or on the soil amongst fallen leaves and old stumps of osiers. They will also hibernate in the heaped-up peel of osiers, which should not, therefore, be left lying about.

Generation generally single, rarely double. This beetle is extremely common and decidedly injurious. In 1884, according to Miss Ormerod, in osier beds in the Lymm district, near the borders of Lancashire and Cheshire, it was estimated that the whole crop of osiers on 50 acres would have been destroyed if protective measures had not been taken.

\section{c. Protective Rules.}

i. Dragging across the osier-beds a rope weighted in the middle. This operation, which should be repeated several times, knocks off the beetles, which will lay their eggs on the ground, where they die.

ii. Sprinkling the osier-shoots with a strong solution of wood ashes, or with Paris green (arsenite of copper, see page 177).

iii. Knocking the beetles off the osiers into square tin vessels containing ashes, but this procedure must be done repeatedly.

iv. Collection of the beetles in their winter quarters.

Traps of birch-bark, planks, etc., may be put above the flood-level; under these the beetles collect in myriads for shelter, and may then be destroyed. 
WILLOW' BEETLE.

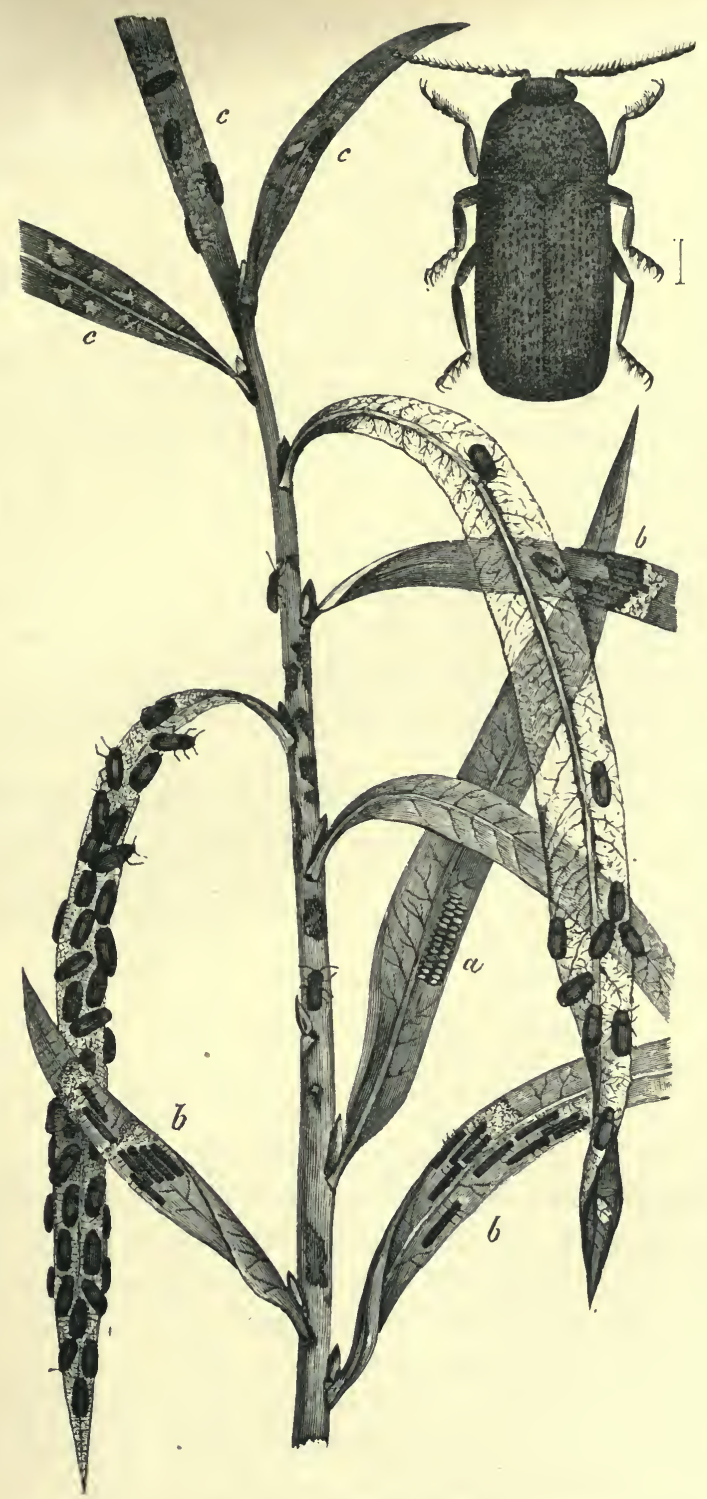

Fig. 144.-C. vulgatissima, L.

Willow twig with eggs $(a)$, larvae $(b)$, and beetles $(c)^{1} / 1$. To the right, beetle enlarged. From Eckstein. 


\section{CHAPTER VII.}

\section{LEPIDOPTERA-BUTTERFLIES AND MOTHS.**}

THIs order is subdivided into Rhopalocera or butterflies, and Heterocera, or moths. The former are distinguished from the latter by the possession of somewhat rigid slender antennae, which are clubbed or knobbed at the tip ; and by the absence of a fienulum or bristle attached to the base of the hind-wings and passing through a loop or retinaculum at the base of the fore-wings. In the moths the antennae are usually flexible, seldom rigid, and are at most thickened towards the apex with no well-defined club; they usually possess a frenulum.

Butterflies are of slender build, they fly by day and are often gaily coloured.

They are of no importance in Europe from a forest point of view, although the larva of Pieris crataegi, L., does much damage on the Continent to the foliage and inflorescence-buds of orchard trees, as well as species of Sorbus and Crataegus.

\section{Heterocera. Moths.}

Family I.-Sesiidae.

\section{Description of Family.}

Diurnal moths which fly rapidly in hot sunshine. Antennæ fusiform; 2 ocelli. Proboscis sometimes rudimentary. Wings narrow, more or less hyaline, and resembling those of Hymenoptera; frenulum present. Body stout.

Generation, 1 to 2 years.

Caterpillars cylindrical, yellowish white, with fine scattered hairs; 5 pairs of prolegs; head and prothoracic shield horny, and usually dark coloured.

* The most comprehensive work on the British species of Lepidoptera is "The Lepidoptera of the British Isles," by C. G. Barrett, London, 1892. 
Pupae slender, armed with circles of spines on the abdominal segments, in a cocoon spun out of chips of wood.

The larvae live in wood, chiefly of broadleaved trees, and bore galleries in the stems, twigs or roots.

1. Sesia apiformis, Fabr. (Hornet Clearwing Moth).

\section{a. Description.}

Moth with a spread of wing of 35 to $45 \mathrm{~mm}$.; body dark brown, with 3 pairs of bright yellow spots, behind the eyes, on the front and on the hinder part of the thorax; and with
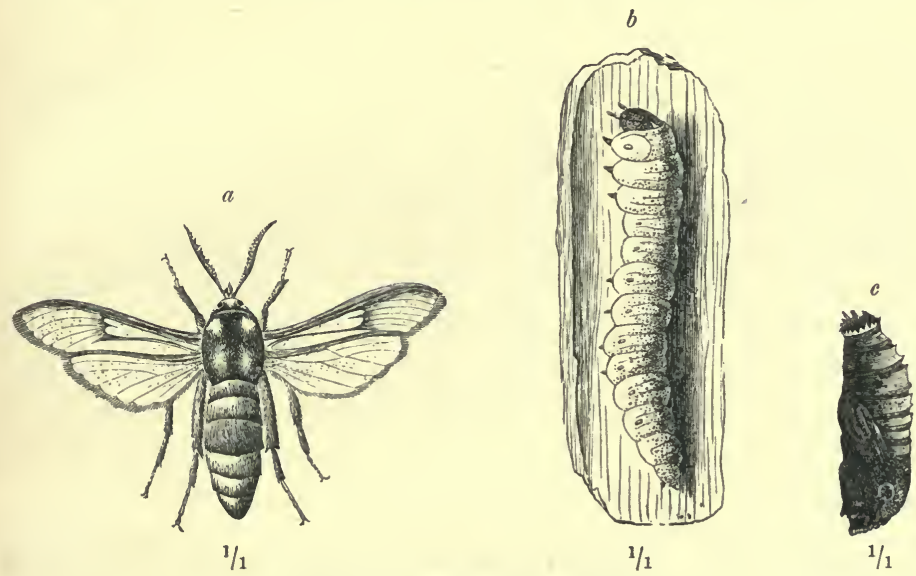

Fig. 145.-Sesia apiformis, Fabr.
a Imago.
$b$ Caterpillar.
c Pupa.

the last 3 segments, and the 5th segment of the abdomen, counting from the tail, bright yellow. Wings transparent, with rust-red borders and veins. Caterpillar with 16 legs, of a dirty white colour, with a reddish brown head and a dark line along the back. Pupa brown, with spines on the back of the segments and apex of the abdomen.

\section{b. Life-history.}

The moth flies in June and July.

The brown eggs are laid in July in cracks in the bark of poplars towards the lower part of the stem. The caterpillars 
appear in July and August, pass two winters in their galleries, and pupate in May of the third year, in a cocoon of wood-dust constructed inside their borings, near to the ground; exceptionally in the ground when the larva has bored low down towards the roots of the plant.

The imagos emerge in June, when the empty pupa cases may be seen projecting from the stems.

The generation lasts two years. The moth is widely distributed and often common among poplars; the injury caused by the caterpillars often accompanies that of Saperda carcharias, L. (page 280).

\section{c. Relations to the Forest.}

The larva bores cylindrical galleries in the wood of poplars, especially of the black poplar and aspen. As a rule it prefers trees less than 20 years old, but is sometimes found in older trees. It generally bores low down in the tree, and its attack can be recognised by the wood-dust which collects on the ground or blocks up the holes by which the moth will emerge, and through which the pupa can push itself by means of its spines. The injured saplings are frequently broken by the wind. The caterpillar is chiefly injurious in nurseries and avenues.

\section{d. Protective Rules.}

Saplings may be smeared as for protection against the poplar longicorn. The moths should be caught on the tree-trunks and destroyed at the end of June. Saplings infested with larvae should be cut down.

Family II.-Cosidae.

Description of Family.

Imagos of this family of wood-borers with setaceous or bipectinate antennae; without ocelli; the mouth-parts rudimentary. Body stout, and covered with close short hairs. Flight nocturnal, the wings strong, and roof-shaped when at rest. Generation extending over 2 or more years. Caterpillars smooth or cylindrical, and with a few scattered hairs. Pupae 
long, with rings of spines on the abdomen, in a cocoon spun up of chips of wood.

The caterpillars live in the wood of broadleaved trees.

\section{Cossus ligniperda, Fabr. (Goat Moth).}

a. Description.

Moth with a spread of wing of 65 to $70 \mathrm{~mm}$. ( $\left.\sigma^{*}\right)-80$ to $85 \mathrm{~mm}$. ( $q$ ). Body stout; head and neck covered with yellowish-grey hair ; fore-wings marbled with greyish-brown and light grey, with numerous dark brown transverse lines; hindwings ashy grey, or greyish-brown. Abdomen long and thick, of the same colour as the wings, with whitish marginal rings to the segments.

Caterpillar 90 to $95 \mathrm{~mm}$. long, with 16 legs, at first reddishyellow, and later cherry-red, darker above, with a brown head, and brown shield on the prothoracic segment; it possesses a very offensive smell. Pupa stout, reddish-brown, with rings of sharp spines on the abdominal segments.

\section{b. Life-history.}

The moth emerges in June and July.

The $f$ lays her eggs, up to 25 in number, in a cluster deep in cracks in the bark of willows and other broadleaved trees.

The caterpillar hatches in July, and bores into the wood, in which, or sometimes in the ground, it pupates in May of the third or fourth year in a large stiff cocoon with a smooth interior made of particles of wood roughly spun together. The moth appears 3 to 4 weeks later.

Generation, 2 or 3 years. - Found throughout Great Britain and generally common, at least in the south.

\section{c. Relations to the Forest.}

The caterpillars live chiefly in the wood of willows, but also of poplars, alder, elm, oak, birch, lime, fruit-trees, even the walnut, and occasionally in Scots pine. They prefer the lower part of the trunk. The mode of attack resembles that of Sesia, but many caterpillars may always be found in the 

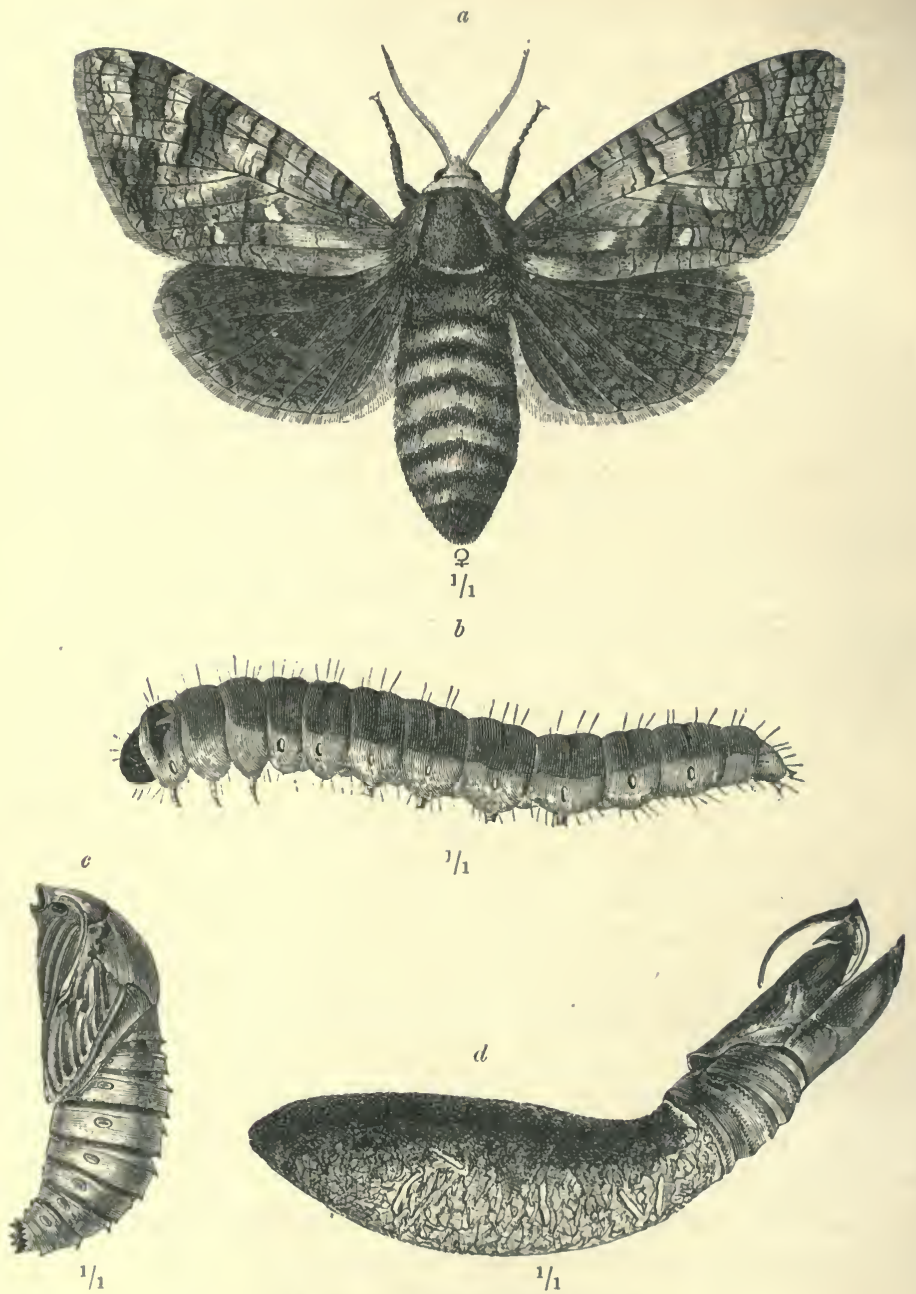

Fig. 146.-Cossus ligniperda, Fabr.

a Imago ( $\uparrow) . \quad l$ Caterpillar, not fully grown. $\quad c$ Pupa. $d$ Cocoon and pupal exuviae (after emergence of the moth).

same stem, sometimes 200 or more; they attack not only sickly trees, but thoroughly sound wood, and prefer solitary trees in hedgerows, along forest borders, etc. They are very voracious, and the wood which has been attacked is useless as 
timber. Infested trees may be easily recognised by. the bad odour due to the caterpillars, and by the wood-chips thrown out from their borings, which are of various sizes up to the thickness of a man's finger.

\section{d. Protective Rules.}

As for Sesia. Bats, owls, and goat-suckers attack the moths. Saplings which have been attacked should be felled, split, and burned with the caterpillars they contain.

2. Cossus aesculi, L. (Wood-leopard Moth).

a. Description.

Moth with a spread of wings of $45-50 \mathrm{~mm}$. (ð), $55-65$ $\mathrm{mm}$. ( $q$ ); white with numerous round steel-blue spots on the wings and six on the thorax; abdomen long, deep blue with white rings. Laria naked, yellow with black warts and dorsal shield, 16-legged. Pupa with rings of spines.

\section{b. Life-history, etc.}

The eggs are laid singly on saplings or branches of broadleaved trees. The larva emerges in August, bores into the sapwood in the first year, passes the winter in the stem, and in the second summer excavates a gallery running upwards along the middle of the wood. In this it passes the second winter, eventually pupating under the bark. Generation biennial. It attacks many species of trees, maple, ash, lime, apple, birch, beech, oak, horse-chestnut, elm, poplars and willows, and has even been found in mistletoe.

It is widely distributed, though rarely very abundant; sometimes it is rather common and injurious in the neighbourhood of large towns such as London.

Treatment consists in the cutting and burning of the infested stems and branches.

\section{Fanily III.-Bonbycidae.}

Description of F'amily.

Antennae short, pectinate in both sexes (simply pectinate in $q$, doubly in $\widetilde{\jmath}$ ); ocelli usually absent. Proboscis small 
and usually functionless. Wings ample, sometimes small in proportion to the size of the body, roof-shaped at rest. Body stout and long, generally densely hairy, usually larger in the ․ Flight as a rule nocturnal. Eggs frequently laid in clusters, and covered with hairs from the tail of the $q$. Caterpillars usually hairy, seldom naked, with 16 legs. Pupae stout and short, in a cocoon spun out of silk, often with the larval hairs interwoven.

The caterpillars feed on needles, leaves, etc., and are usually very voracious. Some of the most destructive species of insects in European coniferous forests belong to this family.

\section{Gastropacha pini, Ochsh. (Pine Moth).*}

\section{a. Description .}

Moth with a spread of wings of $60 \mathrm{~mm}$. (ठ ) to $80 \mathrm{~mm}$. (क). Body thick and stout; fore-wings whitish or brownish grey, in the $\delta$ with dark reddish-brown transverse bands, and with a long unicolorous patch, in which is a white lunate spot; in the $q$ the bands and patch are reddish brown; the hindwings in both sexes are rusty brown. The colouring and markings of the wings vary much in individual examples.

The caterpillar attains a length of $80 \mathrm{~mm}$., has 16 legs, and varies in colour from ash-grey to reddish brown, or dark brown; there is a dark dorsal stripe, and sometimes a series of lateral white patches. It is hairy with clusters of greyish bristles, and possesses on the 2 nd and 3 r $^{\circ}$ segments from the head two steel-blue bare stripes, which become apparent at the second moulting, and are very characteristic.

Pupa somewhat cylindrical, dark brown, enclosed in an elliptic, whitish grey cocoon, which is pointed at both ends, and of looser texture near the head of the pupa to facilitate the exit of the moth.

* This destructive pest is fortunately not a native of Great Britain. It plays, however, so important a part in the literature of European forestry, and has often proved so seriously destructive, that it has been thought desirable not to exclude it entirely from the present translation, but to present an abridgment of Hess's account. 


\section{b. Life-history.}

The moth emerges from the cocoon from July till the end of August. It lays in the second half of July about 100 to 200 bluish-grey eggs, as large as hempseed, in clusters of

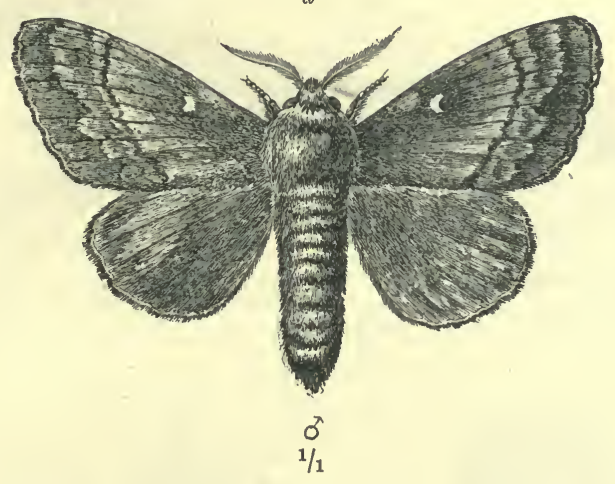

$b$

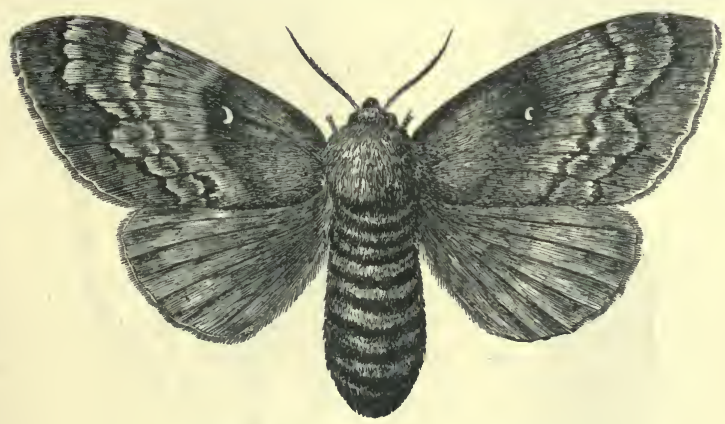

$$
\begin{gathered}
8 \\
1 / 1
\end{gathered}
$$

Fig. 147.-Gastropacha pini, Ochsh

$a$ Male. $\quad b$ Female.

about 25 to 50 in number, in the bark-crevices of standing Scots pines, usually at about the height of a man, or on the needles and shoots of young pines.

The caterpillars hatch after 20 to 25 days, about the middle of August. They at once devour their egg-shells, and then 
scatter themselves among the twigs, where they begin to feed. When about half grown, they descend the trees (in October
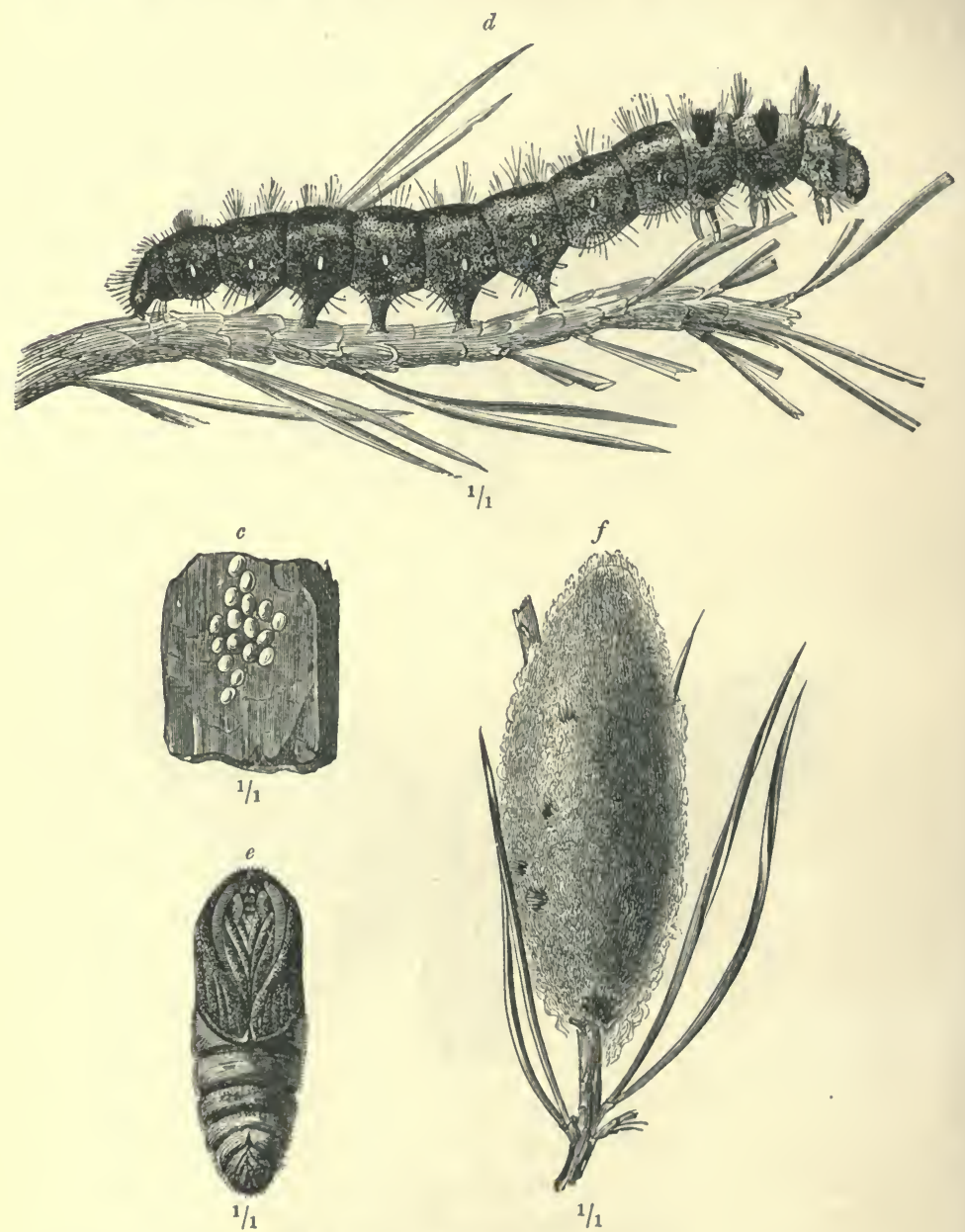

Fig. 148.-Gastropacha pini, Ochsh.

$c$ Eggs on pine-bark. $d$ Mature caterpillar, feeding on the needles of a pine-shoot. $e$ Pupa. $f$ Cocoon.

and November) to hibernate in moss, dead leaves, etc., at the foot of the trunks, and remain there till the next spring (March or April), when they climb again up the trees. 
Exceptionally they may hibernate in the bark-crevices. The time of reascension depends on the degree of warmth of the season and on the quarter from which the wind is blowing.

Pupation takes place at the end of June or beginning of July, either on the needles and twigs of the crown of the tree, or in the larger bark crevices.

The moth emerges in July, about 20 days after pupation.

Generation annual; but sometimes irregular when the insect occurs in great numbers. Very common in Germany.

\section{c. Relations to the Forest.}

This is the most destructive of all insects to Scots pine forests in Central Europe, as it may appear in large swarms throughout the summer for several consecutive years, and is enormously voracious. The caterpillar also attacks the Austrian and mountain pines, and in case of scarcity of food, both the spruce and larch. It prefers 60 - to 80 -year-old trees, but when abundant it will attack younger trees, and thickets of young growth and plantations.

The attack is on the needles. When the caterpillars are very young they gnaw the sides only of the needles, but fullygrown caterpillars eat them down to the sheath, usually leaving the latter, and in this manner completely strip the twigs.

Even the terminal buds may be eaten. The older caterpillars prefer needles of the previous year. A single caterpillar will eat a needle in 5 minutes, and may destroy in all 1000 needles. After complete destruction of the needles and buds the tree must perish, and as a premonitor of death a few clusters of stunted needles, termed rosettes by Ratzeburg, may appear.

The trees may recover, if for a pole 200 needles, and for an old tree 400 needles, still remain green. An attack commencing in April and lasting till June is the worst, as this affects the formation of wood. An attack generally lasts for 3, occasionally for 4 years, and is at its maximum during the 3rd year. Irregularity in the development of the insects, and degeneration of the caterpillars, which are largest in the 
first year and become successively smaller and weaker, rapidly ensue. At the same time, insect-parasites and bacterial diseases become

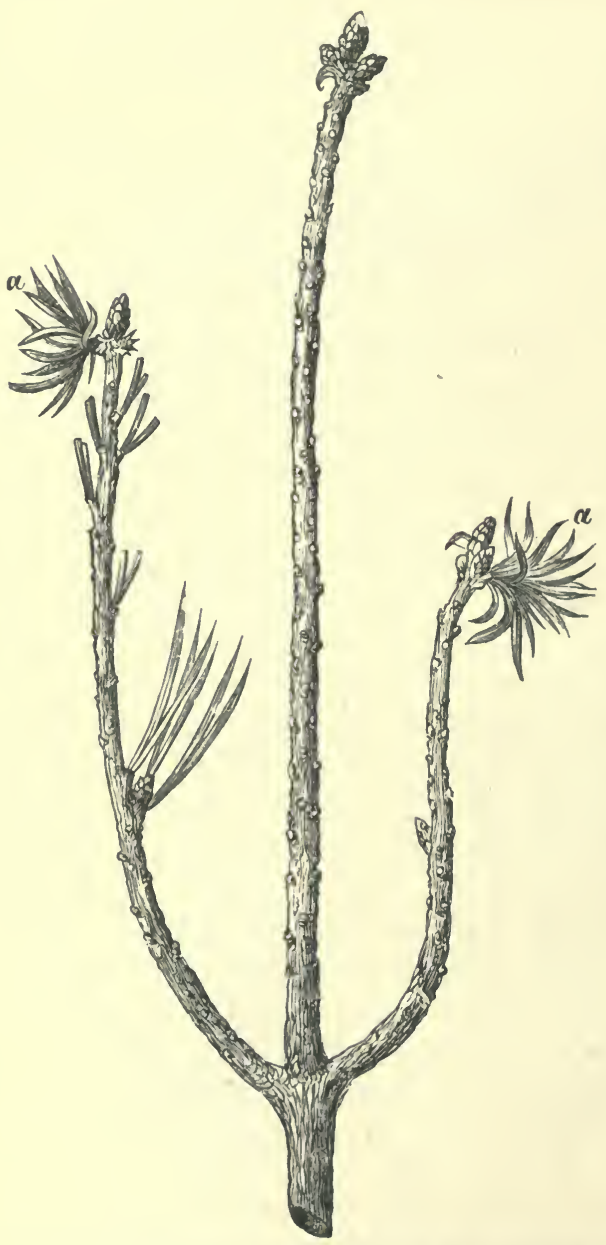

Fig. 149.-Rosette-needles $(a)$ on Scots pine, following defoliation by G. pini, Ochsh. (Natural size.) more and more active, until the caterpillars die from these causes in immense num. bers.

This pest is most dangerous in pure Scots pine forests, on sandy soils, in dry districts, and in the plains and hills of North and North-eastern Germany, less so in the south and west; it is rare in mountainous districts.

A succession of warm summers favours its multiplication to an extraordinary degree. In the ten years, 1863-72, in the forests from West Prussia to Saxony, 442,500 acres of Scots pine forests were attacked, and $70,000,000^{\circ}$ cubic feet of timber killed. In 1888-9, the valleys of the Rhine and Maine, in Hesse, were ravaged, and the caterpillars devoured the needles even of 10 -year-old pines. 


\section{d. Protective Rules.}

1. Avoidance, as much as possible, of pure Scots pine forests in localities exposed to the attacks of this insect.

2. Careful search for caterpillars, chiefly in November, when they are hibernating. The soil-covering round large trees is raked up and searched, and if 6 to 8 caterpillars are found around a tree, measures should be taken at once to destroy the caterpillars.

3. Careful management of thinnings. This removes sickly trees, admits the wind, which the moths dislike, and facilitates collection of the caterpillars.

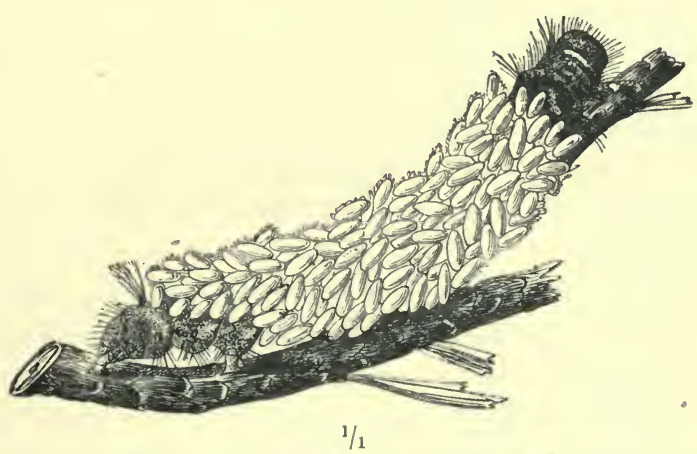

Fig. 150.-Caterpillar of the Pine Moth covered with Microgaster cocoons.

4. Protection of enemies: bats, badgers, cuckoos, owls, goat-suckers, etc. Titmice, golden-crested wrens, and treecreepers destroy the moths' eggs. A number of ichneumonwasps and parasitic diptera attack the larvae. Fig. 150 shows a caterpillar covered by the pupae of Microgaster globatus, $\mathrm{L}$.

\section{e. Remedial Measures.}

These are, briefly: The excavation of trenches in the ground to catch the caterpillars. Trenches are made for the purpose of either isolating attacked areas, or to catch caterpillars within the infested wood.

Collection of eggs, by scraping them from the trees; but this method also destroys many ichneumons. 
Collection of caterpillars.-This is undertaken either after November, or by shaking the trees in August.

This method is less efficacious than smearing girdles of tar on the trees, as at least half the caterpillars escape.

Collection of pupae.-In June and July.

Collection of the o moths.-This is carried out in July in the morning and on cold wet days before the eggs are laid.

By this means ichneumons are not destroyed.

Girdling the trees with grease-bands.-This is the best and safest method to adopt when the insects have appeared in large numbers. It was first employed in Silesia in 1829 against L. monacha, L., and first in 1866-7 at Glücksburg, against the present insect.

The details necessary to ensure success by this measure are carried out as follows:-

The woods which have been attacked are thinned, in order that tar may not be wasted on suppressed stems; all undergrowth which might serve as bridges for the caterpillars is cleared away.

The coarse bark is removed from the pines in rings 10 to $15 \mathrm{~cm}$. broad, in order to present a smooth surface for the tar. Care is taken not to injure the bast.

The smooth places are covered with a horizontal band of tar or grease 6 to $8 \mathrm{~cm}$. broad in February or the beginning of March, and this operation is repeated at intervals of 6 to 8 days, or again in April, when the former application has become too dry to catch the insects.

Ratzeburg has distinguished experimental tarring from general tarring. The former is used on lines of trees here and there throughout a wood, where a severe attack is feared, and if 5 or 6 caterpillars are caught on each tarred tree, then a general tarring of all the trees is undertaken. I'here is, however, a danger that the general tarring may come too late, and it is recommended to try the experimental tarring in the autumn, and if a general tarring is shown to be necessary, to take all preliminary measures for it during the winter. The best tar is made from pine roots and stumps; it should be of a cherry-brown colour and possess a proper consistency, be neither too thick nor too thin, and 
must be put on cold. Coal-tar must not be used for this purpose.

Certain compositions are also used which are superior to tar, such as tar mixed with 9 to 15 per cent. of resin, or 9 to 11 per cent. of acetic acid. For similar purposes in England, grease-bands are made of "cart-grease" or mixtures of Stockholm tar, unboiled linseed-oil, etc., etc.

In order that a composition may be really useful for this purpose, it must combine cheapness with prolonged stickiness. A thick coating should always be used, or else the substance is absorbed by the bark.

In order to spread the tar a paint-brush was originally used, but Boden and Kielmann, two German forstmeisters, constructed, in 1881, two wooden spatulas, which Fig. 151 represents. The broad and grooved spatula is about $36 \mathrm{~cm}$. long and $5 \frac{1}{2} \mathrm{~cm}$. broad at the top, where it is grooved on one side, but smooth on the other. The grooving gradually slopes from the handle to the extremity of the spatula, where it is $5 \mathrm{~mm}$. deep. The tar is taken from the barrel on the flat side of the
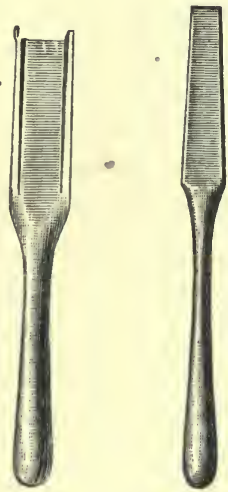

Front

View.

Fig. 151.-Boden's Spatula. broad spatula, and spread on the tree with the narrow spatula. The broad spatula is then turned round, and the groove pressed round over the tar. This makes a smooth ring $5 \mathrm{~cm}$. broad and $5 \mathrm{~mm}$. thick.

The quantity of tar used and the cost of painting the rings varies with the age of the woods, and in Prussia averages 40 to $50 \mathrm{lbs}$. per acre for old wood, and 50 to $60 \mathrm{lbs}$. per acre for young wood, the average cost in either case being $6 s$. and $9 s .6 d$. per acre for tar.

In 1878 in Plietnitz in West Prussia, 45 millions of cater pillars were destroyed by means of tar rings, at a cost of $7 \mathrm{~s}$. per 10,000 caterpillars. In woods under 60 years old the 
hibernating caterpillars were collected at a cost of $20 \mathrm{~s}$. per 10,000. The value of the annual increment of wood saved was $8 s$. per acre, as against $7 s$., the cost of the tar rings.

The efficacy of the tar ring is less interfered with by frost than by great heat, as the latter easily melts it and causes it to run down the tree. Most of the caterpillars which attempt to cross the rings adhere to the lower part of them; but about 3 per cent. of them, chiefly the larger ones, manage to cross the rings, although of these about 59 per cent. soon die from the effects of the tar, so that only 1.2 per cent. of the whole number really survive and pass the rings.

The caterpillars whose way to the tree-crowns is thus cut off, return to the ground and try to find their way to other trees; they are therefore prevented from so doing, by isolating, by means of trenches, the wood containing the tarred trees from other woods 'which have not been so protected.

Caterpillars infested by ichneumons, or fungoid diseases, may be introduced amongst those which are healthy.

In cases where the attack is very bad, but localised over a small wood only, the soil-covering is burned whilst the caterpillars are hibernating, or even the whole wood is burned, measures being taken in both cases to protect the adjoining woods from the spread of the fire.

Robert Hartig, in 1871, experimented near Eberswald on the effects of the different methods of protecting the Scots pine from these caterpillars, with the following results:-

The collection of hibernating caterpillars, as long as the moss and dead-leaf covering is replaced in position, has no bad influence on the growth of the tree.

The jarring of young trees in order to knock off the caterpillars involves local decay in the bast, and consequent reduction of increment.

Tarring does not hurt the trees in the slightest degree.

2. Bombyx neustria, L. (Lackey-Moth). a. Descriplion.

Moth with spread of wings of 30 to $40 \mathrm{~mm}$. Body and forewings ochreous-yellow or red-brown, the latter traversed across 
their middle by a darker band which is bordered by pale stripes; hind-wings somewhat lighter, crossed by a vague darker stripe.

Caterpillar extending to $45 \mathrm{~mm}$. in length, with $16 \mathrm{legs}$, marked with alternate stripes of blue, reddish-brown and

$a$
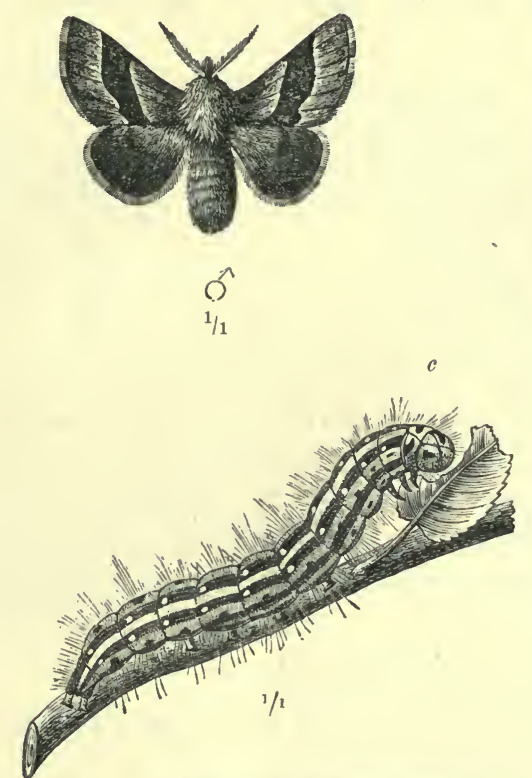

Fig. 152.-Bombyx neustria, L.

$a$ Imago ( $\widetilde{c}$ ). $b$ Egg-ring on a twig. $c$ Larva. $d$ Pupa.

white, thinly covered with long hairs, head blue with two black spots.

Pupa bluish-black, covered with short hairs, in a yellowishwhite thick cocoon.

\section{b. Life-history.}

The moth appears in July and August, flying in the evening and resting during the day in sheltered places.

The $q$, about 8 days after pairing, lays from 300 to 400 brownish-grey eggs in a close spiral, forming a cylinder round a young shoot. 
The caterpillars hatch in April or the beginning of May, and live socially in companies of 50 to 100 , until they are full grown, in web-nests spun by their joint labours, and increasing in size as they grow up. They leave these nests to feed on leaves, returning to them in wet weather or by night. In fine weather they are fond of sunning themselves. When disturbed, they let themselves down to the ground by threads, or after hanging some time in the air, draw themselves up again.

When full grown, in June, they disperse, and spin cocoons among the leaves, or in bark-cracks.

Generation annual; the insect is very common over the greater part of Europe and in England.

\section{c. Relations to the Forest.}

The caterpillar is found on many trees, especially on apple and other orchard trees, and on oak, hornbeam, and poplars ; also on elms, birch, maples, willows, thorns, briars, etc. Only ash and lime appear to be spared. Its attack commences on the blossom and leaf-buds, then extending to the foliage, and lasts from the end of April till the beginning of June. It is chiefly important in orchards, to which it does immense damage.

\section{d. Protective Rules, etc.}

i. Protection of enemies, notably titmice, the golden-crested wren, the cuckoo, finches, etc.

ii. Pruning and burning twigs bearing the egg-rings during the winter.

iii. Destruction of the young caterpillars in their webs by crushing with gloves, or short brooms, or by cutting off the webs and letting them drop into a pail containing paraffin. These remedies can be economically applied in orchards and tree nurseries only.

3. Bombyx pudibunda, L. (Pale Tussock Moth).

\section{a. Description.}

Moth with a spread of wings of $45 \mathrm{~mm}$. (ð), 50 to $60 \mathrm{~mm}$. ( $q$ ). Fore-wings whitish-grey, sprinkled with darker spots 
and with 2 to 3 narrow grey-brown transverse waved lines; abdomen and hind-wings somewhat lighter, the latter with a faint greyish band; $\delta$ darker and more spotted than the o .

Caterpillar, when mature, about $40 \mathrm{~mm}$. long, with 16 legs, at first greenish yellow, later becoming reddish or brownish, hairy, with four truncated tufts of yellow or brownish-grey bristles on the 4 th to the 7 th segments, separated by black

$a$

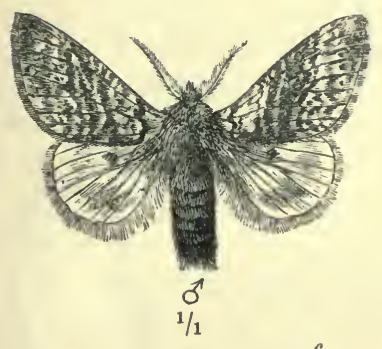

$c$ $b$

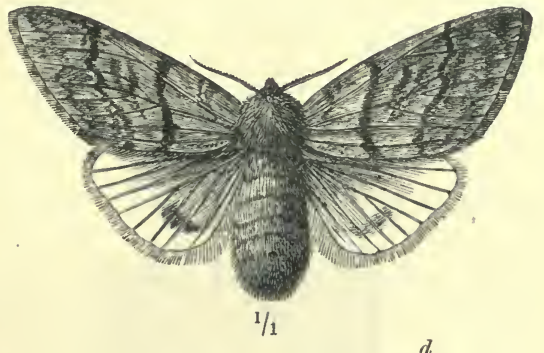

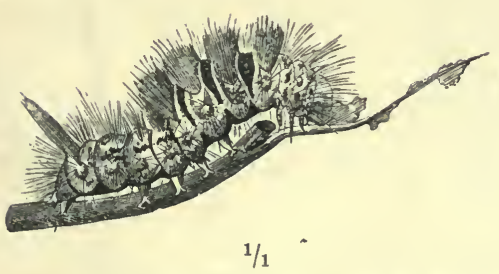

Fig. 153.-Bombyx pudibunda, L.

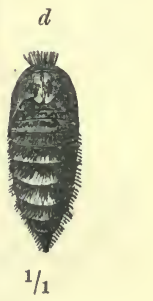

$a$ Male. $\quad b$ Female. $\quad c$ Caterpillar. $\quad d$ Pupa (dorsal surface).

velvety bands, and with a rose-red pencil of hair on the last segment.

Pupa thick-set, dark brown, covered with short grey hair, in a yellowish-grey cocoon spun up with the larval hairs.

\section{b. Life-history.}

The moth appears at the end of May or beginning of June. In June the female lays about 100 to 150 bluish-grey eggs in a cluster on the bark, generally low down, at about 1 yard from the ground, but often a few yards up, sometimes on twigs or dead wood on the ground, or even on grass or herbage. 
The caterpillars hatch after 3 weeks, in June or July, make their first meal off their egg-shells, and remain a sliort time in clusters, with their heads usually turned inwards; about the middle of July they separate and wander towards the crowns of the trees, coming down to pupate in September.

Pupation occurs at the end of September, or in October, usually under dead leaves, dead fallen wood, etc., on the ground, in the bark-cracks of oaks, Scots pines, etc., or among herbage on the ground.

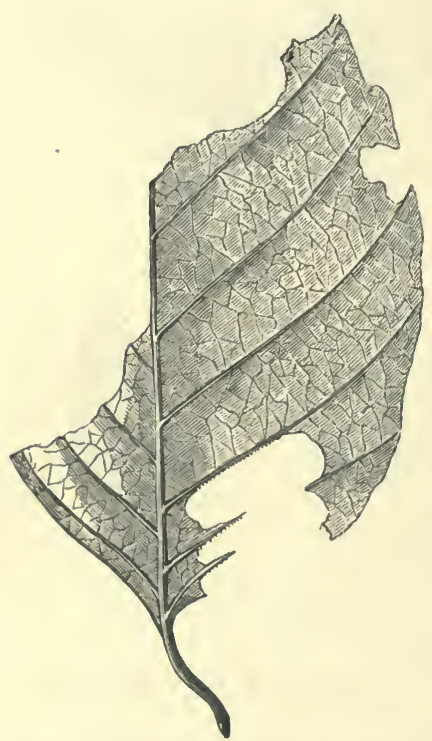

Fig. 154.-Beech-leaf, eaten by the larva of B. pudibunda, L. (Natural size.)

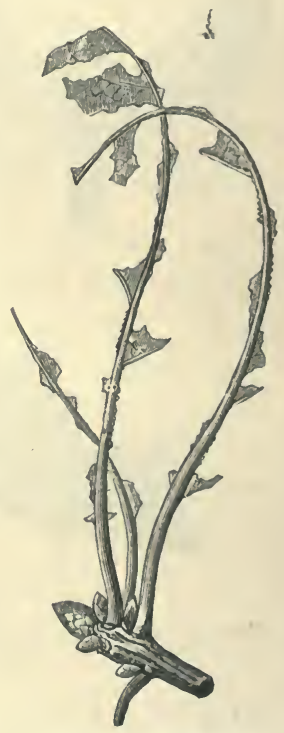

Fig. 155. - Oak - leaf, stripped by the larva of $B$. pudibunda, L.

(Natural size.)

The generation is annual.

The caterpillar is very hardy, and withstands snow and cold well.

\section{c. Retations to the Forest.}

The caterpillar lives singly on almost all forest trees, even conifers, but has only been observed in abundance on the beech, and occasionally on the hornbeam, oak or alder. It 
prefers dry, sunny, elevated places, and avoids valleys. It has often been noticed that an attack commences simultaneously at several points of high elevation, from which it spreads in all directions.

It prefers 40 - to 80 -year-old woods. The foliage is at first only skeletonised, but after August the leaves are almost entirely eaten and fall to the ground in thousands after the caterpillars have bitten through the petioles.

In the case of the oak, the petioles and mid-ribs remain.

'The damage done consists in loss of increment, and reduction in the production of seed, as fewer flower-buds are developed; the quantity of beech-mast is much diminished, and the nuts are often empty.

This is highly prejudicial to beech forests under natural reproduction.

The insect prefers southerly or south-westerly aspects; it is very common in North Germany, France and Belgium (Ardennes), being found at altitudes up to 1,300 feet above sea-level. It is tolerably common in Great Britain, but is seldom destructive, except in hop-gardens.

In 1892, the larvae of the pale tussock moth appeared on about $2 \frac{1}{2}$ acres of forest in the Grand Duchy of Luxembourg, and by October 82 acres were leafless. By the end of $1893,5,000$ acres of beech-wood were devastated, and the caterpillars were so numerous as to impede locomotives on the narrow-gauge railway. Owing to the increase of parasites and diseases, the epidemic stopped in June, 1894.

\section{d. Protective Rules.}

i. Ash, sycamore and conifers should be grown in beechwoods.

ii. Protection of enemies - crows, jackdaws, cuckoos, thrushes, finches, titmice, etc. -Ground-beetles and ichneumon-wasps are very efficacious, and a spider (Epeira, sp.) has been observed to be extremely destructive to the insect. A fungoid disease due to Isaric farinosa, Fries, with its higher form, Cordiceps militaris, Link, is also common. 


\section{e. Remedial Measures.}

i. Collection or destruction of caterpillars (end of September -beiginning of October), as they come down the trees to pupate.

ii. Collection of pupae in the winter.

iii. Girdling the trees with grease-bands at a height of 1 to 3 yards. This method has given fairly good results in the Eberswald. On 3 acres about 500 caterpillars per tree were caught at an expense of $11 \mathrm{~s}$. per acre. Unfortunately most of the eggs had been laid above the bands, and the eventful destruction of all the foliage of the trees was only delayed.* The Germans do not now spend money on destroying this insect, as complete defoliation lasts only one year and the attacked trees do not die.

\section{Bombyx chrysorrhoea, L. (Brown-tail Moth).}

\section{a. Description.}

Moth with a spread of wing of 30 to $40 \mathrm{~mm}$. White; the inner margins of the wings fringed with long hairs; forewings in the $\delta$ usually marked with small black spots about the middle and towards the anal angle. Abdomen brown towards the tip, which is furnished in the $\delta$ with a tuft of dark-brown down, thicker and red-brown in the 9 .

Caterpillar $35 \mathrm{~mm}$. long, 16-legged, with radiating tufts of long yellowish-brown hairs, brownish-grey above, with 2 red, slightly zigzag lines along the back from the 6th segment towards the tail, and 2 vermilion warts on the 9 th and 10th segments, grey beneath, with yellow spots and streaks.

Pupa dark brown, hairy, with pointed tail, in a brownishgrey cocoon.

\section{b. Life-history.}

The moth appears at the end of June and in July.

The o lays 200 to 300 brownish-yellow eggs on the lower surface of leaves of many broadleaved trees, and covers them with the dense fluff from her tail.

* Bombyx thwaitesi, Moore, is very destructive to foliage of the sal (Shorea robusta) in Assam, and sometimes loccurs in enormous numbers over very extensive areas. It also attacks the leaves of tea bushes. Indian Museum Notes, Vol. I., page 29. 
The caterpillars appear 2 to 3 weeks later, usually in August, and at once spin web-nests among the neighbouring leaves. In the autumn they spin large caterpillar-nests, as big as the fist, in which they hibernate, binding together many leaves with their threads, and thus forming chambers which they line with silk and fasten firmly to the twigs.

Pupation takes place in June in a thin greyish-brown cocoon between leaves.
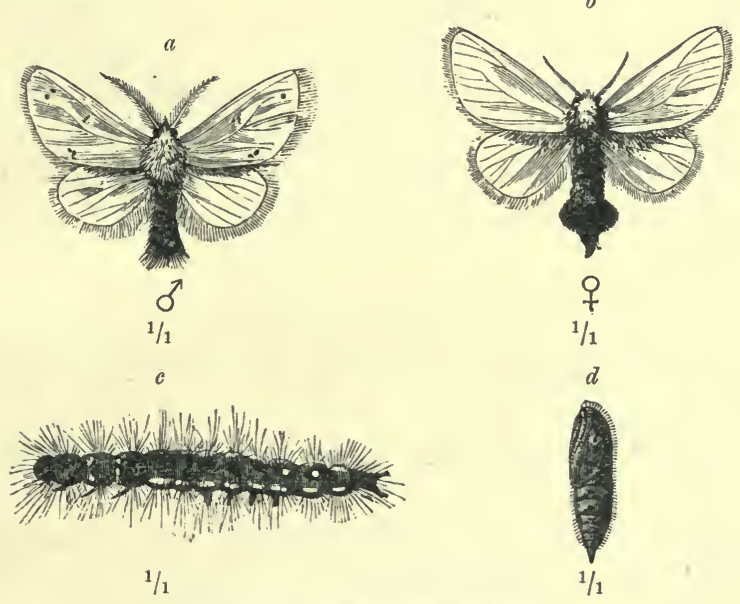

Fig. 156.-Bombyx chrysorrhoea, I.

$a$ Male. $b$ Female. $c$ Caterpillar. $d$ Pupa.

Generation annual. This insect is common, but rarely appears in great numbers. In the Berlin Zoological Garden they destroy the foliage almost every year. It is less common in Britain than the closely allied B. similis, Füss. (aurifua, Fabr.); an insect of similar appearance, but with the abdominal tuft of down golden-yellow. It resembles B. chrysorrhoea in habits, and especially attacks hedgerows and orchard trees.

\section{c. Relations to the Forest.}

The insect is polyphagous; the caterpillars are found on pear and plum trees, on oak, white-thorn, and also on beech, elm, maple, hornbeam, willows, poplars, roses; even on robinia when nothing else offers. 
The caterpillars, enclosed in their common web-nest, first gnaw the upper side of the leaves. Next spring, after renewing their nests, they feed on the buds and young leaves, and later, on the blossoms and fully developed leaves, except the petiole. In this way, the fruit is considerably reduced in quantity, if not entirely destroyed. Up to the middle of May, in bad weather and also during the night, they retire to their nests. After the third moulting, at the middle or end of May, they abandon their nests, and wander among the trees to feed.

The crowns of the trees which are attacked begin about the end of August to look as if they had been singed by fire; later, the woods become more or less completely defoliated. If defoliation takes place before Midsummer a second foliage may appear.

\section{d. Protective Rules.}

Protection of enemies. Titmice and the cuckoo are very useful.

Cutting off the caterpillar nests with shears, and burning them.

Collecting and killing the caterpillars in May, and the pupae in June. Care must be taken to protect the hands against the hairs, which cause inflammation. The above measures should be adopted for orchard and avenue trees.

\section{Liparis monacha, L. (Black Arches, or Nun Moth).}

\section{a. Description .}

The moth has a spread of wings of $40 \mathrm{~mm}$. (ठ ), up to $50 \mathrm{~mm}$. (q). Fore-wings white, with many black zigzag transverse lines and patches, hind-wings light grey; abdomen with broad, rose-red bands, separated by black bands, which are very well marked in the $q$.

The caterpillar is 40 to $50 \mathrm{~mm}$. long, with 16 legs, hairy, tapering slightly towards the tail, reddish-grey above and greenish-grey below; with 6 bluish warts bearing tufts of long hairs on each segment, and on the 6 th a velvety-black heartshaped spot. 
The pupa is at first greenish, later dark brown, with a bronze lustre, and covered with shaggy hairs.

\section{b. Life-history.}

The moth appears in July and at the beginning of August, and may exceptionally be found till the end of September.

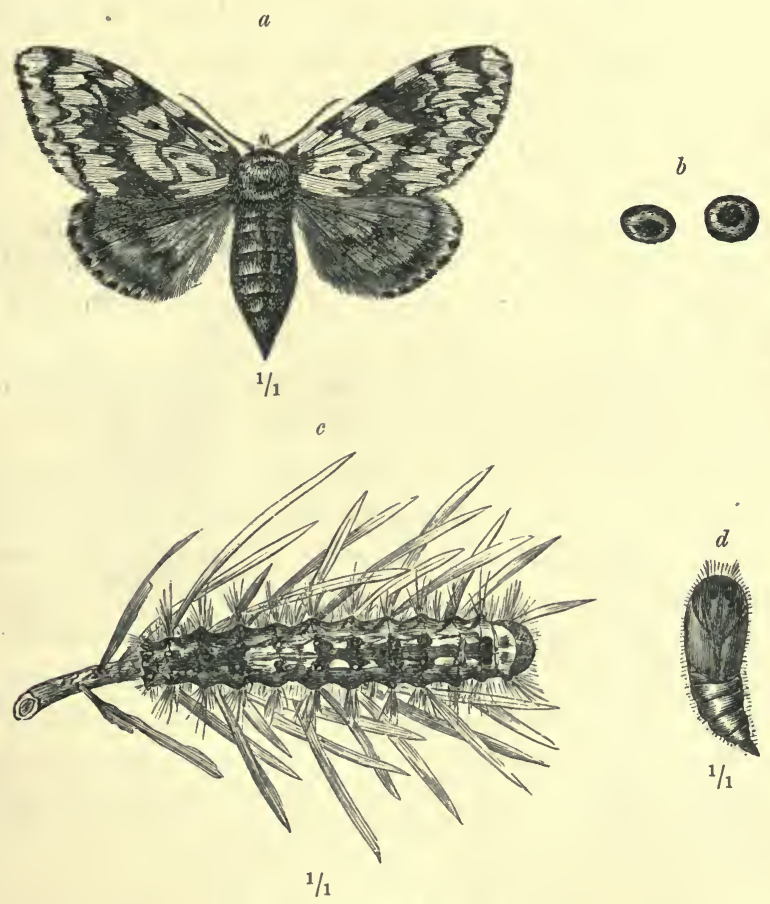

Fig. 157.-Liparis monacha, L.

$a$ Imago ( $\$$ ). $b$ Eggs (enlarged). $c$ Caterpillar. $d$ Pupa.

Both sexes usually sit at daytime on the stems at a moderate height from the ground.

In the month of August the $q$ lays about 150 eggs of a reddish-bronze colour in groups of from 5 to 50 in bark-cracks, or among the moss and lichen of large poles and tree stems, of Scots pine or spruce, usually at 10 feet from the ground. When the insect swarms, spruce boles are covered with eggs 
up to the top, but in Scots pine, only as far as the rough bark extends. Later the eggs become of a pearly grey colour, and hibernate without any protective covering.

The caterpillars hatch at the end of April, or the beginning of May. They remain for a few days (2 to 6) in small groups neal their hatching place, and then ascend to the crowns of the trees. Until they are half-grown, they are able to let - themselves up and down by threads should they be disturbed. They become full grown by the end of June, or the beginning of July. When young, they are rather sensitive to changes of weather, and are easily blown down by the wind, and may then fall on to young forest growth.

Pupation takes place at the end of June or the beginning of July, and the pupae may be found fixed by a few threads in bark-cracks low down on the stems, also on needles of low branches, and even on undergrowth.

The moth emerges in 15 to 20 days after pupation, the active $\delta$ appearing a few days before the $q$.

Generation annual. The insect appears sometimes in truly formidable numbers. The moths, especially the $\delta$, are very active, and may fly for long distances in swarms, but usually remain localised.

L. monacha is tolerably common in many localities in Britain, chiefly in the south of England, but is not generally regarded as an abundant insect. It is rare in conifer woods and, consequently, seldom if ever destructive; its usual foodplant appears to be the oak. Indeed most British lepidopterists seem to be unaware that it is a conifer feeder.

\section{c. Relations to the Forest.}

This species attacks all conifers, but prefers the Scots pine and spruce, and tall poles and old trees of these species to younger ones; it also, lowever, attacks young growth and also broadleaved trees, such as beech, hornbeam, bircli, oak, orchard trees, least of all the ash and alder. In cases of scarcity of other food, it will not disdain low shrubs.

'The caterpillars devour the needles and buds. When young they bore into the tender shoots, causing them to wilt; the 
older larvae attack the fully formed needles, and in the case of spruce, eat them from the apex downwards. They feed on Scots pine in a most wasteful manner, biting off the tops of the needles and letting them fall to the ground, and only eating their lower portions. The quantities of half-eaten
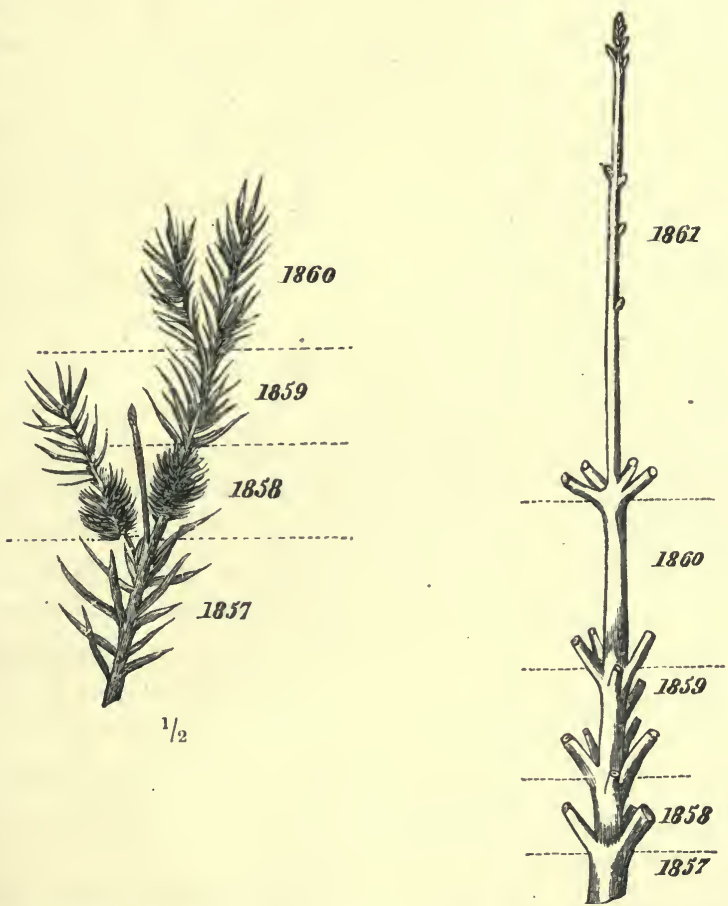

Fig. 158.-Shoot with a lateral branch- Fig. 159.-Leading shoot (lopped)of a spruce fir which had been stripped by Liparis monacha, $\mathrm{L}$.

Date of injury, 1856 ; production of short growth, 1857 ; of bristle-needles, 1858 ; of short growth, 1859 ; of nearly normal growth, 1860 ; of normal growth with latral dormant buds, 1861.

needles lying on the ground then betray the presence of the enemy.

In high coniferous wood the older needles are preferred to the younger, and the attack spreads downwards and outwards from the summits of the trees. Among young growth, on the contrary, the young shoots are eaten first. If the attack is 
extensive, and towards its end, the caterpillar's return in swarms to the summit of the trees and eat off all the younger shoots. Repeated observation has proved that these caterpillars are all sickly and eventually. die, and inside them a great variety of parasites is found.

The attack lasts from May till July, and is repeated for about 3 years. In the 2 nd or 3 rd year it culminates, and complete . defoliation may kill the whole wood. The spruce is more sensi-

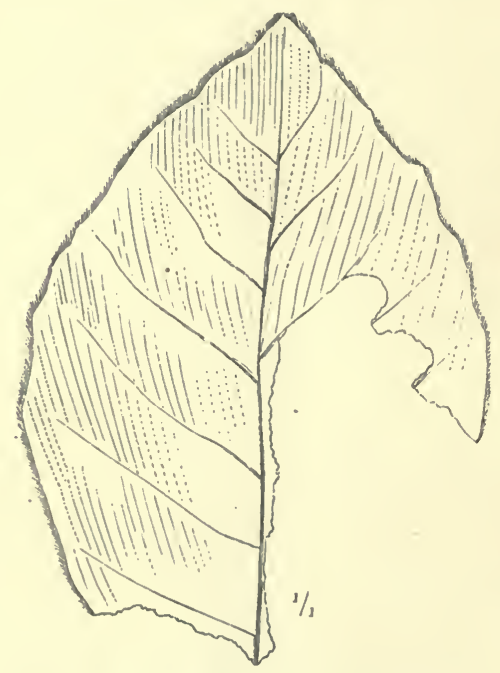

Fig. 160.-Beech leaf eaten by a caterpillar of $L$. monacha, L. tive to the attack than the Scots pine. The latter may recover the loss of half its foliage.

The process of recovery in the spruce is shown in Figs. 158, 159, which represent portions of trees attacked in Silesia during 1855 and 1856 . The length of the internodes was least in 1858 , the normal growth not being resumed till 1861, and a characteristic growth of stunted " bristleneedles" appeared, a feature which not unfrequently occurs in the case of Scots pine.

The insect is found both in the plains and in hilly country. The most severe attack by the "Nun" during the present century was during 1853-1858 in East Prussia, Lithuania, and Poland; in 1858 a bark-beetle attack followed, and the calamity only stopped in 1860. From the 29th July, 1853, to the 27th June, 1855, in the Rothebude. Forest, where the attack commenced, 6,375 acres of forest were completely stripped of needles, and about half as much more nearly stripped. The larval droppings covered the ground to a depth of 5 to $8 \mathrm{~cm}$., in many places to $15 \mathrm{~cm}$., and kept falling to the ground. with a sound like heavy rain. Up to the 1st 
October, 1862, 31,360,000 cub. feet of wood were killed, $30,823,000$ cub. feet by the Nun, and 437,000 cub. feet by bark-beetles. The ravaged area exceeded 21,000 acres, and in East Prussia, between 1853 and 1863, over 467,000,000 cub. feet of wood had to be felled, while 267,000 acres were devastated.

The damage done in the neighbouring Russian province was still greater, and it has been computed that by the Nun and bark-beetles 6,400 geographical sq. miles of forest in Russia, and in Prussia $600 \mathrm{sq}$. miles, altogether 7,000 sq. miles of forest, were destroyed, and at least $6,427,500,000 \mathrm{cub}$. feet of timber killed. It was noted as a curiosity that the manuring of the forest soil by. the dung of the caterpillars, and the opening-out of the woods, produced such a heavy growth of grass that the stags, owing to the greater abundance of provender, bore antlers of unusual size.

In 1889 and 1890 this insect proved very destructive in Bavaria, south of the Danube, the expenses of the campaign against it amounting to as much as $£ 100,000$.

In attacking broadleaved trees, the caterpillars frequently eat the base of

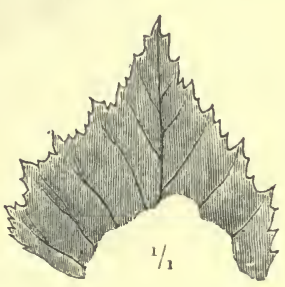

Fig. 161. - Birch leaf eaten by the caterpillar of $L$. monacha, $\mathrm{L}$. the leaves, letting the remaining portion fall to the ground: this is the case with birch and aspen, whilst with beech and oak only a portion of the leaf is eaten, the leaf-stalk being usually untouched (Fig. 160).

The attack is never fatal to broadleaved trees.

\section{d. Protective Rules.}

i. Avoidance of pure spruce or Scots pine woods and introduction of suitable species, especially beech, in intermixture with such woods.

ii. 'Thinning.-By careful thinning future remedial measures are facilitated, and a better control over the collectors of eggs, larvae or pupae is maintained.

iii. Protection of encmies : bats, cuckoos, woodpeckers, crows, starlings, titmice, golden-crested wren, etc. 'The two latter 
are extremely useful in destroying the eggs throughout the winter. The ground-beetles, Carabus glabratus, L., and Calosoma sycophanta, L., are also very useful on the Continent, the larvae of the latter attacking the moths' eggs, and the beetles

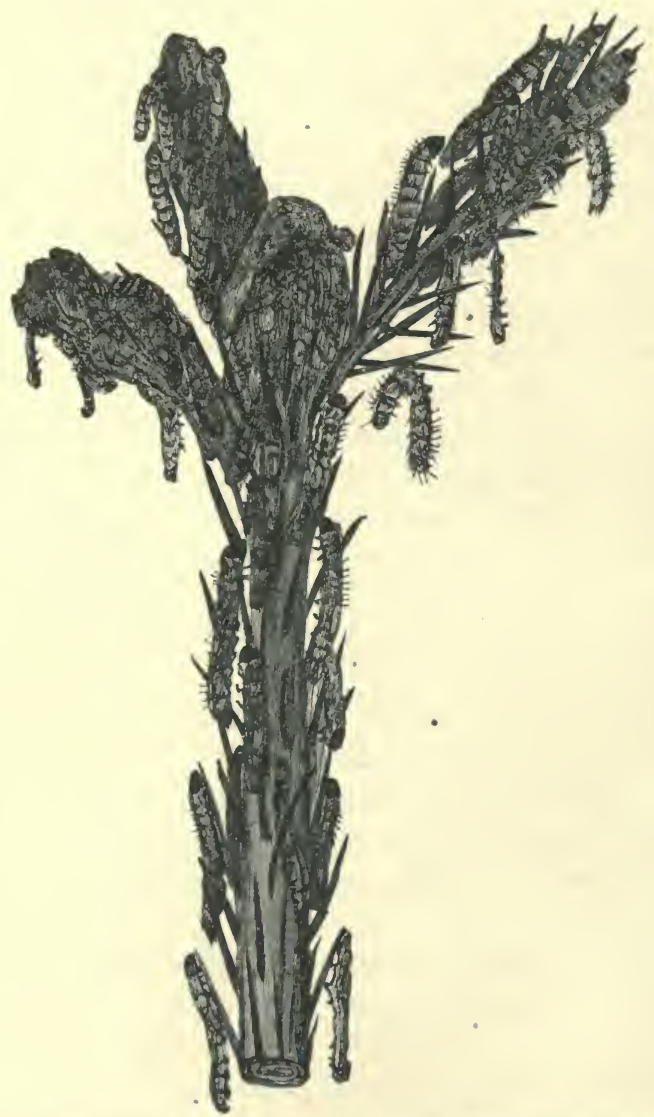

Fig. 162.- Spruce leader, with infected (sleepy) larvae of the Nun moth.

the caterpillars. Many ichneumon-wasps and 'I'achinae attack the caterpillars, for instance, 'T'achina monachae, Ratz., ' $T$ '. phalaenarum, L., etc.

In $1892 \mathrm{~J}$. Gold found that in N. E. Bohemia 59 per cent. of the caterpillars were attacked by 'Tachinae and 11 per cent. by 
ichneumon wasps. Finally, towards the end of the last great swarm of the Nun moth in Bavaria, 1890, fungi, especially bacteria, were destroying the caterpillars, the latter became sleepy, and hung bent like horseshoes on the twigs, or in masses at the tops of the trees. If such caterpillars are squeezed, a brown stinking liquid exudes, whilst healthy caterpillars exude green liquid.

\section{e. Remedial Measures.}

i. Collection, and destruction of the eggs by fire, from autumn till the middle of April. The piece of bark on which the eggs are laid is removed, and the eggs scraped off with a knife into a bag furnished with a wooden funnel-shaped mouth. The stems are cleared up to 16 feet high, preferably by daylabourers, at first on foot and then with a ladder, and the woods in which many moths have been observed should be first treated. This treatment is easier in smooth-barked polewoods of spruce than in older woods with rough bark.

One gramme-weight of eggs contains about 1,200, and the cost of collection is about $3 d$. to $1 \mathrm{~s}$. for: 15 grms. In the winter of 1839-40, in the Biesenthal forests near Eberswald, 10 tons of eggs were collected. The eggs should be burned in small lots, as otherwise they explode like gunpowder.

ii. Killing the clusters of newly-hatched caterpillars in April and May by means of cloths, brushes, or by rubbing them with moss, sods, etc. Great care must be taken to seize the proper moment for this operation, and a delay of only a few days may prevent its being done. The cloths, etc., used may be soaked in tar to render their action more efficacious. This operation is also best done by daily labour, but under careful supervision, one overseer being appointed for every 20 to 30 workmen. One man should be able to work over 6 to 8 acres per diem, and the most suitable place to work in is among young poles, where the caterpillars can be readily seen, and are not too high up the stems.

iii. Collection of caterpillars and pupae, commencing in June. Small caterpillars are usually collected in young growth, on to which they have been blown; later on, when they have ceased 
spinning, they are shaken down from the poles. It is preferable to collect the pupae.

iv. Collection of $q$ moths from the beginning of July. 'This should be done as soon as they emerge, and in the earliest hours of the morning; it gives the best results during cool weather. A cloth may be covered with adhesive matter, and used to daub the insects.

It is not yet fully decided whether this measure is very effective or not, some authorities, such as Altum, ranking it as the best to be adopted, and others, as Ratzeburg, considering it as almost useless.

In the forests near Ebersdorf in Reuss-Greiz, between the 26th June and the 12th August, 1868, 600,000 $q$ were destroyed

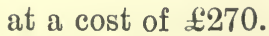

v. Trenches are usually of little use. Smearing the stems in winter from the ground up to the large branches with a

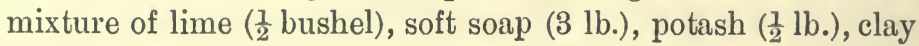
and cow-dung destroys the eggs. 'This method can be used for orchard trees only.

vi. The application of high grease-bands about 2 in. wide at a height of 16 to $20 \mathrm{ft}$. from the ground, above the places where eggs are laid. This should be done at the end of March or April, and the bark here is sufficiently smooth, and requires no preliminary scraping. The rings are smeared by means of a broad brush fastened at right angles to a long pole. This has in many cases proved an excellent remedy. The little caterpillars remain sitting in thousands below the rings, which cut off their way to the crowns of the trees. The composition used should retain its fluidity for some time, but need not be very sticky, as the caterpillars to be caught are so small.

Large fires lighted at night in the forest to attract and burn the moths have failed to do any good. In 1890, in the Bavarian forests the moths were attracted by electric lights to the mouth of a large funnel into which they were sucked by an exhaust current of air produced by steam power. Large numbers were collected by this method, and killed, but it cannot be stated whether the utility of this proceeding is commensurate with its expense.

Low grease bands, as already described, page 300 , for the 
pine-moth, are also useful, as many nun caterpillars spin themselves down or crawl down to the ground. They have such an objection to the grease bands that they sit below them by thousands and die of starvation.

The collection of eggs, caterpillars, and pupae gives good results only at the beginning of an attack. When the insect appears in swarms, the collection of moths and the use of low grease bands are the most effective measures. High grease bands cost too much. In the case of low grease bands, the undergrowth must be cut and burned, the areas attacked should be isolated by a sufficiently broad grease barrier, and so should intact areas.

Although the Scots pine is usually first attacked, it does not suffer so much as the spruce, as the stem of the latter bears eggs up to the top and the young caterpillars begin by eating the yearling needles. In the Scots pine they commence lower down with the old needles. The Scots pine is not therefore killed, as long as the year's needles are spared, while the spruce dies if 80 per cent. of the needles are eaten.

Liparis dispar, L., the gypsey moth, which in Europe attacks all broadleaved trees, was introduced into Massachusetts by a person who wished to interbreed it with a silk-moth. This pest increased in numbers over 350 sq. miles, and became so destructive to trees and crops that the State had to organise measures for its extermination on an immense and expensive scale, 375,000 dollars being spent in 1890-1894.

\section{Family IV.-Noctuidae (Night Moths).}

\section{Description of Family.}

Moths with long, setaceous antennae, usually covered with fine hairs, and sometimes pectinate in $\delta$; ocelli present; proboscis long; wings narrow, during repose roof-like or level ; frenulum present. The markings of the fore-wings are usually characteristic and take the form of three or four transverse lines of which the second from the outer margin is elbowed, and of three spots; two are situated near the anterior margin, the outer being kidney-shaped (reniform stigma), the inner circular (orbicular stigma); the third is elongate, and is 
beneath the orbicular spot (claviform stigma). These markings are constant in position, but some or all of them may be absent. The body is thick, and usually covered with down; the head surrounded by a collar. Flight nocturnal or during twilight, hardly ever by day.

Caterpillars usually bare, rarely hairy, commonly with 10 prolegs, sometimes with 8 or 6 .

Pupation of the bare caterpillars generally takes place in the ground, in a cocoon made of grains of sand bound together by a few threads. The hairy caterpillars spin a cocoon above ground. Pupae usually slim, spindle-shaped and dark coloured. Many of the caterpillars live on woody plants, eating needles and leaves, but the majority of them feed on grasses and low plants. A few species are highly injurious to forests.
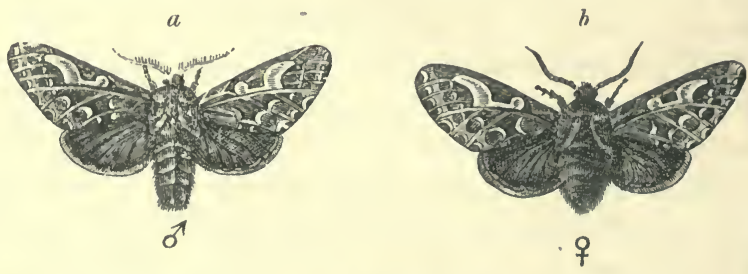

$c$

$d$
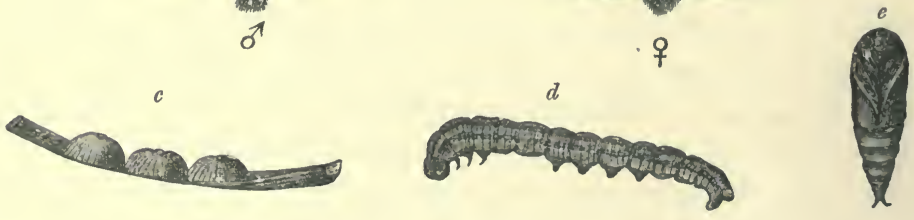

Fig. 163.-Noctua piniperda, Panz. (Natural size; fig. $c$ enlarged.)

a Male. $b$ Female. $c$ Eggs on a pine-needle. $d$ Caterpillar. $c$ Pupa.

1. Noctua piniperda, Panz. (Pine Beauty, or Pine Noctua).

\section{a. Description.}

Moth with a wing-expanse of $35 \mathrm{~mm}$.; fore-wings russet-red marbled with grey; orbicular and reniform stigmata yellowishwhite, conjoined, the latter large, oblique and produced towards the tip of the wing; hind-wings and abdomen greyish-brown.

Caterpillar $40 \mathrm{~mm}$. long, with 16 legs, almost hairless, of a yellowish-green, with 3 or 5 whitish-coloured stripes and a light-brown head. 
Pupa somewhat elongate, of a bright brown colour, with two spines on its tail.

\section{b. Life-history.}

The moth appears from the end of March to the beginning of May.

The 9 lays 30 to 70 round, dull-green eggs on the needles of old Scots pines.

The caterpillars hatch out in May, spin freely when young, and are fully grown by the middle of July.

Pupation takes place at the end of July or beginning of August, under moss, dead leaves, on or in loose earth, usually under the cover of the tree on which the insect feeds. The pupæ are sometimes found in colonies, in the holes whence stumps, etc., have been extracted.

Generation annual. The caterpillar sometimes appears in enormous numbers, but is susceptible to changes of the weather. It is tolerably common in pine woods throughout Great Britain.

\section{c. Relations to the Forest.}

The caterpillar attacks chiefly the Scots pine, especially when 20 to 40 years old, but in case of necessity it may feed on older trees and other conifers, such as spruce, Weymouth pine and juniper.

When young the caterpillar, according to Ratzeburg, bores into the bud-sheaths of the spring shoots, which thus become brown, wilt and die. Later on the needles are attacked, beginning with their edges, and finally they are entirely devoured, usually on the lower branches, but also high up in the crown. The attack lasts from May till July, but is not so destructive as that of Gastropacha pini, L., as the Scots pines, even if extensively stripped by it, usually form new buds and recover. One should therefore await results before felling woods that have been completely stripped of needles. Only when the fatal rosettes of needles (Fig. 143) appear is the death of the trees imminent. The insect inhabits hilly regions, and is most common in forests where the soil has become impoverished by removal of litter. 


\section{d. Protective Rules.}

Mix broadleaved trees with Scots pine.

Protection of enemies : Fox, badger, hedgehog, shrew, cuckoo, crow, starling, thrush, titmice, golden-crested wren, etc. Calosoma sycophanta, L., is very useful on the Continent, and many parasitic insects and fungi attack the larvae.

Fungi (Empusa sp.) killed nearly all the caterpillars in the Tuchler Haide in 1867, their bodies being covered with yellowish-grey sporangia, which after rain became dark brown. The infected caterpillars were brittle like the pith of elder, and filled internally with a yellowish substance.

\section{e. Remedial Measures.}

i. Pigs may be admitted to the woods from July till hard frost sets in. In the forest district of Cloppenburg in Oldenburg in 1845, 58 pigs in 29 days (November and December) are estimated to have destroyed $16,000,000$ pupae.

ii. Caterpillars may be collected from the middle of May onwards by beating the stems, or in July by picking them from lower growth, or at the foot of the stripped trees, where they often collect in numbers.

iii. Pupae may be collected during the winter, under moss, etc. ; the holes whence stumps have been extracted should be specially examined.

iv. Moths may be collected by striking the trees in cloudy weather or by "sugaring."

'I'renches are not of much use, as the caterpillars are little given to wandering about.

\section{Noctua (Agrotis) restigialis, ${ }^{*}$ Rott.}

\section{a. Description.}

Moth with an expanse of wing of 30 to $35 \mathrm{~mm}$. Fore-wings ashy grey, mingled with brown, variable in depth of colour, with fine black veins, the three stigmata conspicuous, darker

* Larvae of the different species of Agrotis usually live in the ground; they gnaw through plants above the raats, and in America are appropriately termed cut-worms, 
than the ground, the orbicular and reniform with light borders, the former sometimes reduced to a point. ' Hind-wings light grey with darker borders.

Caterpillar $35 \mathrm{~mm}$. long, with 16 legs, of a dull brownish grey; head with a triangular frontal spot, and another on the vertex, meeting at their apex, their borders forming $a \times$.

Pupa brown, terminated by two very short points.

\section{b. Life-history.}

The moth appears from the middle of August till the middle of September.

The eggs are laid on the ground amongst the grass and herbage.

The caterpillars hatch in September, and hibernate in the
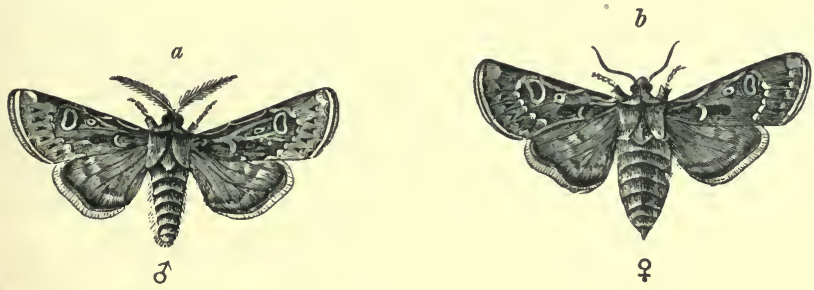

Fig. 164.-Noctua vestigialis, Rott. (Natural size.)

soil when half-grown; as they are earth-coloured it requires an accustomed eye to detect them.

Pupation takes place from the end of June till August, either in the ground, in a cocoon, or exceptionally among the needles of young Scots pine.

Generation annual.

The caterpillar dislikes the light, and during the day remains in the ground or concealed under the leaves of the plants on which it feeds.

\section{c. Relations to the Forest.}

The caterpillars of most species of Noctua are termed "surface caterpillars," and those of the present species ohiefly feed on agricultural crops, young shoots of grasses, potatoes, turnips, etc., towards harvest time. It also attacks the Scots pine and the larch as seedlings in their first and second years, 
and exceptionally the seedlings of broadleaved trees. The little one-year-old-seedlings are usually bitten off by it in April and May close to the collum, never deeper than 1 in. under ground. The larva then feeds on the root, the lower part of the stem, and lastly on the needles. In June, when the plants are somewhat older, they are bitten off at about the middle of their height, and the stem and roots gnawed.

Two-year-old seedlings usually have their weaker side shoots bitten off, more rarely the leading shoot as well, and some of the needles are eaten; the bark may also be gnawed, but such plants commonly recover from the injury they have received.

The damage is usually done at night, when the caterpillars crawl along the surface of the ground from one plant to another; during the day-time they proceed under ground.

Poor sandy soil in plain districts is most frequented by this pest.

This insect has recently become very injurious in North and North-east Germany. It is tolerably common on the coasts of the British Isles, but is rarely met with inland, and has attracted little or no attention as an injurious species.

\section{d. Protective Rules.}

i. Areas both in nurseries and in the forest which are to be sown up should be thoroughly weeded in the previous year, as the $q$ will not lay her eggs except among grass and herbage.

ii. For planting-out, not seedlings of the first year, but 2- to 3-year-old plants with balls of earth should be employed, as the caterpillars find it difficult to bore through the firm earth of the balls.

iii. Protection of enemies.

\section{e. Remedial Measures.}

Pigs may be driven into places where this pest has appeared. The ground may be ploughed up or trenched with hoe or spade, and the caterpillars collected and destroyed. In quite loose sand the plants may be lifted by hand, and those uninjured or slightly injured replanted. 
The caterpillars may be poisoned by laying baits of cabbage or lettuce-leaves sprinkled with arsenic along the beds.

The moths may be caught by " sugaring," and destroyed.

3. Noctua (Agrotis) segetum, Schiff. (Turnip Dart-Moth). a. Description.

Moth with a wing-expanse of $40 \mathrm{~mm}$. ; fore-wings yellowishgrey or yellowish-brown, with darker marks, stigmata of the same ground-colour as the wings, the reniform and orbicular margined with black; hind-wings milky-white, with no lunate spot.

Caterpillar $50 \mathrm{~mm}$. long, with 16 legs, coloured like that of
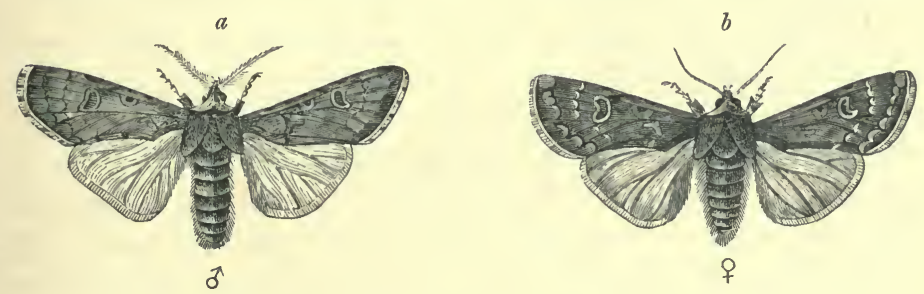

Fig. 165.-Noctua segetum, Schiff. (Natural size.)

the former species, but with the triangular spots of the forehead and vertex separated at their apices by a space, $、$

Pupa light brown, with two long anal points.

\section{b. Life-history.}

The moth appears from the end of May till the middle of June. The $q$ flies a few days later than the $\delta$. The larval life is passed in the ground, the caterpillars hatching out in June and July, and pupating in April and May.

Generation annual. Very common everywhere in Germany and in the British Isles.*

\section{c. Relations to the Forest.}

The caterpillar chiefly attacks the roots of grasses, cereals and root-crops, also seedling and one-year-old spruce plants. In some Prussian forest districts it has also been observed

* Vide Miss Ormerod, op. cit., p. 201. 
attacking one-year-old plants of Scots pine and beech. Except during hard weather in the winter its attack lasts from August to April. Seedlings are bitten off below the cotyledons, and one-year-old plants gnawed about the collum, so that they frequently die. In 1864 this insect proved very destructive in Silesia. In 1880, it destroyed spruce, Scots pine and beech near Stralsund. It is said to destroy wheat in Russia. The protective measures are the same as for the previous species.

\section{Family V.-Geometridae (Loopers).}

Description of Family.

Antennae of the imago either filiform or setaceous, with a thickened basal joint, not unfrequently pectinate in $\delta$; ocelli absent; proboscis short; wings large, broad and delicate, usually lying more or less level in repose, sometimes sloping; frenulum always present. Bodies slim, resembling those of butterflies. Flight usually at dusk, or by night; a few species fly in sunshine. Caterpillars bare, or only slightly hairy, with 10 (rarely 12) feet; they move about by looping, owing to the absence of the first 3 or 2 pairs of sucker feet; hence their name, loopers or span-urorms.

Pupae long, with a short pointed tail, bright brown, lying usually without cocoon under grass, moss, or in the soil.

The caterpillars feed on needles, leaves, buds, etc., and a few species are injurious to forests.

1. Geometra piniaria, L. (Bordered-white or Pine Looper-Moth). a. Description.

Moth with a wing-expanse of $35 \mathrm{~mm}$. $\approx$ bright yellow, with a sharply-defined area at the tip of the fore-wings and the margins of both pairs black-brown, hind-wings with two transverse dark bands; antennae bipectinate. \& reddish-brown, the tip of the fore-wings, borders, and 1 or 2 transverse bands on both wings dark brown; antennae setaceous. In both sexes the under-side of the wings is brownish, with dark lines and numerous spots, and a broad light-yellow band across the middle of the hinder pair. 
Caterpillar $35 \mathrm{~mm}$. long, with 4 prolegs, smooth, yellowish green, with 3 white dorsal stripes, of which the middle one is broadest, and two broad yellow stripes along the spiracles.

Pupa at first green, later bright brown, with sharply-pointed tail.

\section{b. Life-history.}

The moth flies in May and June. The $\delta$ is fond of flying about on sunny sultry days; its flight is unsteady. The $q$ is also very active. When resting, the moths have their wings upright, or else half-raised.

$a$

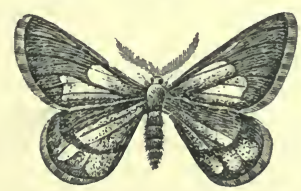

万

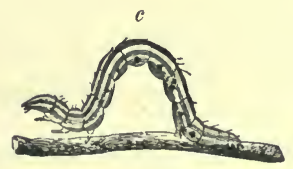

$b$
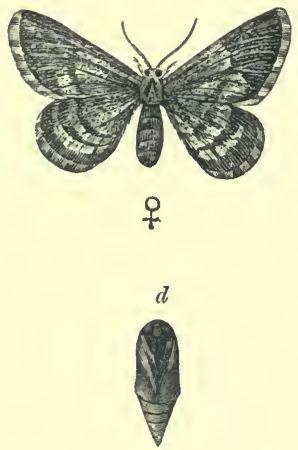

Fig. 166.--Geometra piniaria, L. (Natural size.)

$a$ Male. $b$ Female. $c$ Caterpillar. $d$ Pupa.

The smooth, somewhat flattened green eggs are laid in a row $(2-12)$ on Scots pine needles in the crowns of the trees. The caterpillars hatch out at the end of June or the beginning of July, and are fully grown by October, when they let themselves down from the trees by threads. If the weather be mild, caterpillars may even be found in December. Pupation occurs in October and November under moss or other soilcovering, or in the soil, usually under the cover of the trees on which they have been feeding,

The moth emerges in May or June.

Generation annual. Very common, and widely distributed in pine woods. 


\section{c. Relations to the Forest.}

The caterpillar attacks the common Scots pine, rarely other pines, the spruce or silver fir, and prefers 20 - to 40 - yearold trees, but will even attack trees up to 60 years of age.

The needles are eaten from the beginning of July to the end of October, but not the buds. At first the shoots of the current year are spared, but later on they are also attacked. The young caterpillars gnaw the sides of the needles (Fig. 166); as they get larger they eat down to and beyond the mid rib.

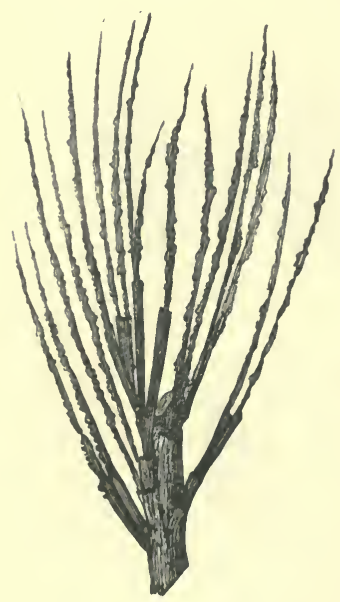

Fig. 167.-Scots pine needles attacked by $G$. piniaria, L.

The full-grown larvae cut off the points of the needles, but eat the remainder completely. Complete defoliation seldom results in the death of the trees, as the attack commences late in the season, and the buds well provided with reserve material produce fresh foliage the ensuing year. Only when a wood has been seriously attacked for two successive years, the second attack destroying most of the needles, do the trees die. If, however, a cold and prolonged winter should succeed a somewhat early attack of the preceding year, the buds may become too weakened to produce useful needles and the trees may die, after one attack only. As long as the cambium is found healthy the wood may be saved. It is therefore unnecessary to commence immediate felling of defoliated woods, as after an attack of the pine-moth. Dense woods in sunny aspects of warm hill districts are preferred by this moth, and windy borders of the woods are avoided.

\section{d. Protective and Remedial Rules.}

Mix beech with conifers.

Protection of enemies, as for Trachea piniperda.

Admission of pigs from October to April (50 pigs to 500 acres). 
Collection of pupae in winter.

Collection of caterpillars in August by shaking the poles.

Painting rings of grease or lime-whiting 12 to $15 \mathrm{~cm}$. broad on the trees at $1 \mathrm{~m}$. from the ground. This costs $7 \mathrm{~s}$. to $8 \mathrm{~s}$. per acre for tar, and $4 s$. to $6 s$. for lime, and has proved effective.

Raking up into heaps, and burning the soil-covering. This method gave excellent results over about 190 acres in Pomerania in 1881-83; about $\frac{1}{2}$ to $\frac{3}{4}$ of the pupae were burned with the litter, and most of the remaining ones being exposed by the removal of the soil-covering were eaten by birds. Where the soil-covering had been left intact, the moths appeared in the following spring in large numbers. The ashes must be spread over the ground. In dealing with the attacks of this looper, the forester should continually fell sample trees, in order to become acquainted with the progress and condition of the insects, the appearance of parasites and the degree of resistance offered by the trees.

The extensive Scots pine forests near Nuremberg, weakened by the wholesale removal of litter, suffered greatly from the pine looper in 1893-96, about 125,000 acres being ravaged of State, communal, and private forest. Twelve hundred workmen were engaged at $4 s$. a day to work up the dead wood, $64,000,000$ cubic feet.

2. Geometra (Cheimatobia) brumata, L. (Winter-moth). a: Description.

Male with a wing-expanse of 25 to $30 \mathrm{~mm}$.; fore-wings ample, grey-brown, with several darker transverse wavy lines; hind-wings lighter, with a faint dark waved stripe in the middle. Female $8 \mathrm{~mm}$. long, of a brownish-grey, wings short and aborted, with two dark bands across them, antennae and legs long, the latter strongly developed.

Caterpillar $16 \mathrm{~mm}$. long, with 4 prolegs, hairless, at first grey, later yellowish-green, with a dark dorsal line, and 3 bright longitudinal lines on either side.

Pupa $11 \mathrm{~mm}$. long, thickset, yellowish-brown, with two small outwardly-pointed hooks on its tail, in a loose cocoon. 


\section{b. Life-history.}

The moth appears from October to December, and the o flies especially at evening-time.

The eggs are first greenish, and later on reddish; in all 200 to 300 are laid, either separately or in clusters of 3 or more, on buds, veins of leaves, and points of twigs of almost all broadleaved trees. The $q$ ascend the trees usually by the east and north-east sides, which are protected from rain.

The caterpillars hatch at the end of April or in May, are full grown by the middle of June, and in July let themselves down by threads from the crowns of the trees in order to
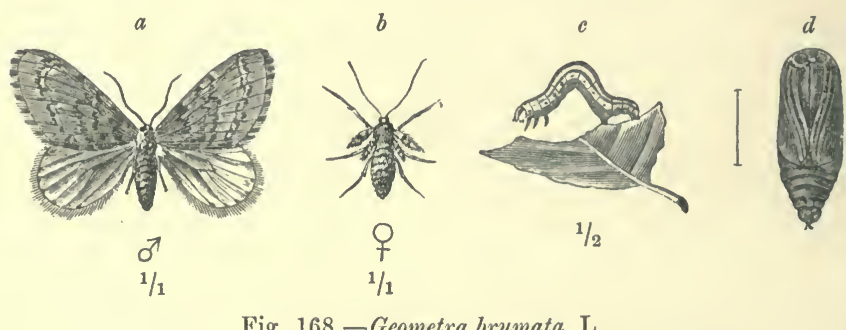

pupate; this takes place at the bottom of the trees in a smooth hole 2 to $3 \mathrm{in}$. deep in the ground.

Generation annual. Very widely distributed and common, a well-known orchard pest* throughout England.

\section{c. Relations to the Forest.}

The caterpillar attacks several broadleaved trees, especially orchard trees, the oak, hornbeam and lime; to the former, especially to apple and pear trees, it is most destructive, the fruit-crop being weakened or destroyed. When young, the caterpillar bores into buds through the side, and later attacks blossoms and leaves, as well as the green shoots and young fruits. It continues to spin during these attacks, and when disturbed will let itself down and climb back again to the tree by a thread. After destroying the foliage of standards over

* Vide Miss Ormerod, op. cit., p. 338. 
coppice, it will attack the underwood up to the middle of June, and great damage is thus done at times.

\section{d. Protective Rules.}

Protect enemies.

Grease-bands should be applied to the trees in the middle of October in order to catch the ? moths on their way up the trunks. The trees are usually encircled with paper strips 4 in. broad, bound to the tree by string above and below, and the tar or composition is painted on to the paper, the lower part of which being bent upwards to prevent the composition from trickling down.* These bands catch many other insects which are destructive to orchard trees, such as the apple-blossom weevil, Anthonomus pomorum, L., and the codlin moth, Carpocapsa pomonella, $\mathrm{L}$. The caterpillars of the last species creep under the paper to pupate.

The practice of spraying with arsenical washes before flowering, or after the blossom is set, is a valuable method of treatment.

Other species of Geometridae, which emerge in the winter months, and the females of which are apterous, such as Hibernia defoliaria, L., etc., may be dealt with when injurious in the same manner.

The pupae may be destroyed in orchards from July to September by trenching the ground a foot deep below the trees, and stamping it firm.

\section{Family VI.-Tortricidae (Leaf-roller Moths).}

\section{Description of Family.}

Moths with somewhat short, filiform, or bristle-like antennae with a thick basal joint; 2 ocelli. Wings rhomboidal, the anterior pair usually bright-coloured, roof-shaped in repose; frenulum present.

Generation usually annual.

Caterpillars with a few short hairs on little warts; with 10 prolegs; usually with a horny shield on the prothoracic segment and a horny anal flap. Very active, and strong spinners.

* For a good account of thèse grease-bands and nature of the grease to be used, see Miss Ormerod, op. cit., p. 342. 
Pupation in a cocoon either above or in the ground. Pupce with rows of spines on their backs. The caterpillars attack the buds or shoots, the fruits and seeds, or the needles or leaves of broadleaved or coniferous trees. The characteristic rolling up of leaves is only practised on broadleaved species. Many insects injurious to forests are included in this family.

\section{Halias chlorana, L. (Green Willow Leaf-Roller).}

\section{a. Description.}

Moth with wing expansion of $20 \mathrm{~mm}$; fore-wings and thorax light green, the former with a whitish anterior border; head, hind-wings and abdomen white, the latter sprinkled with greenish-grey scales.

Caterpillar $15 \mathrm{~mm}$. long, with 16 legs, of a dirty flesh-colour, with a dark dorsal stripe, and a few bristles. Pupa light brown, with rounded head and smooth hinder extremity.

\section{b. Life-history, etc.}

The eggs are laid in April and May on the terminal buds of young willows, especially on Salix viminalis, L. The solitary caterpillar hinders the development of these buds in May, spinning up the terminal leaves into a bundle which is bent towards one side of the shoot in which it lives; it feeds from May till July, not only on the leaves, but on the tender young shoots of the osiers. The lengthening of the osiers is thus rendered almost impossible, and a straggling production of side-shoots results. In July the larvae pupate on leaves or shoots, in white boat-shaped cocoons. The moth appears 14 days after pupation. Neither Hess nor Judeich are clear about the subsequent life-history, but as osiers are cut down in December, there is probably a second generation, eggs being laid in July, pupation in September and the pupae libernating near the ground.

\section{c. Protective Rules.}

Cut off the shoots containing the caterpillars, in May and June and again in August. Each bundle contains only one larva, which should be killed. 
2. Tortrix viridana, L. (Oak Leaf-roller).

a. Description.

Moth with wing-expansion of 18 to $22 \mathrm{~mm}$.; fore-wings uniformly light green, and hind-wings light grey; whitish fringes to all the wings.

Caterpillar $15 \mathrm{~mm}$. long, with 10 prolegs, at first greenish grey, afterwards dull green, with head and anal flap black, with warts on the back. Pupa $11 \mathrm{~mm}$. long, slender and black.
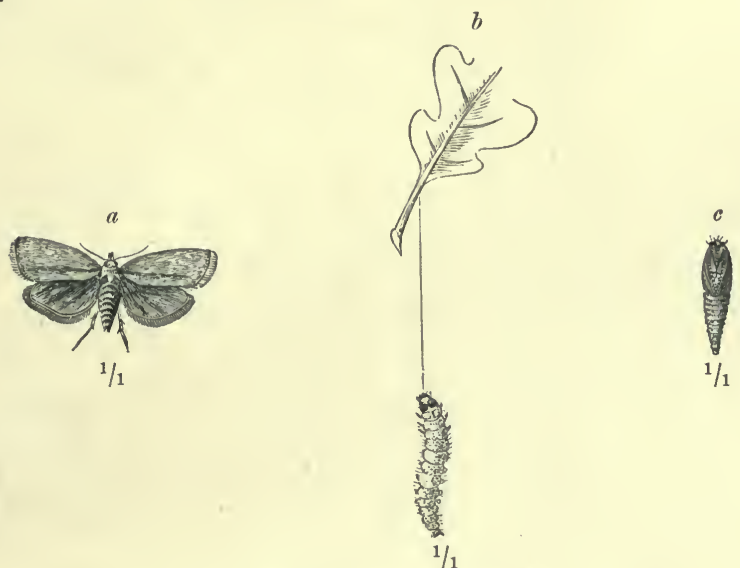

Fig. 169.-Tortrix viridana, L.

$a$ Moth. $\quad b$ Caterpillar suspended by a thread. $\quad c$ Pupa.

\section{b. Life-history.}

The moth flies during daytime at the end of June and the beginning of July. The eggs are laid singly or in little clusters on the already bitten buds of the oak, and pass the winter there. The caterpillars appear in April and May, and, as pupation approaches, spin threads by which they let themselves up and down from the branches; they pupate usually at the beginning of June, on the twigs of the trees which have been attacked, generally in the upper leaves, which they roll together, and also in bark-cracks.

Generation annual. Everywhere tolerably common, and sometimes present in enormous numbers. Very destructive to foliage in oak-forests in the south of England. 


\section{c. Relations to the Forest.}

The oak leaf-roller moth infests oaks only, chiefly the pedunculate oak because it shoots before the sessile oak, and

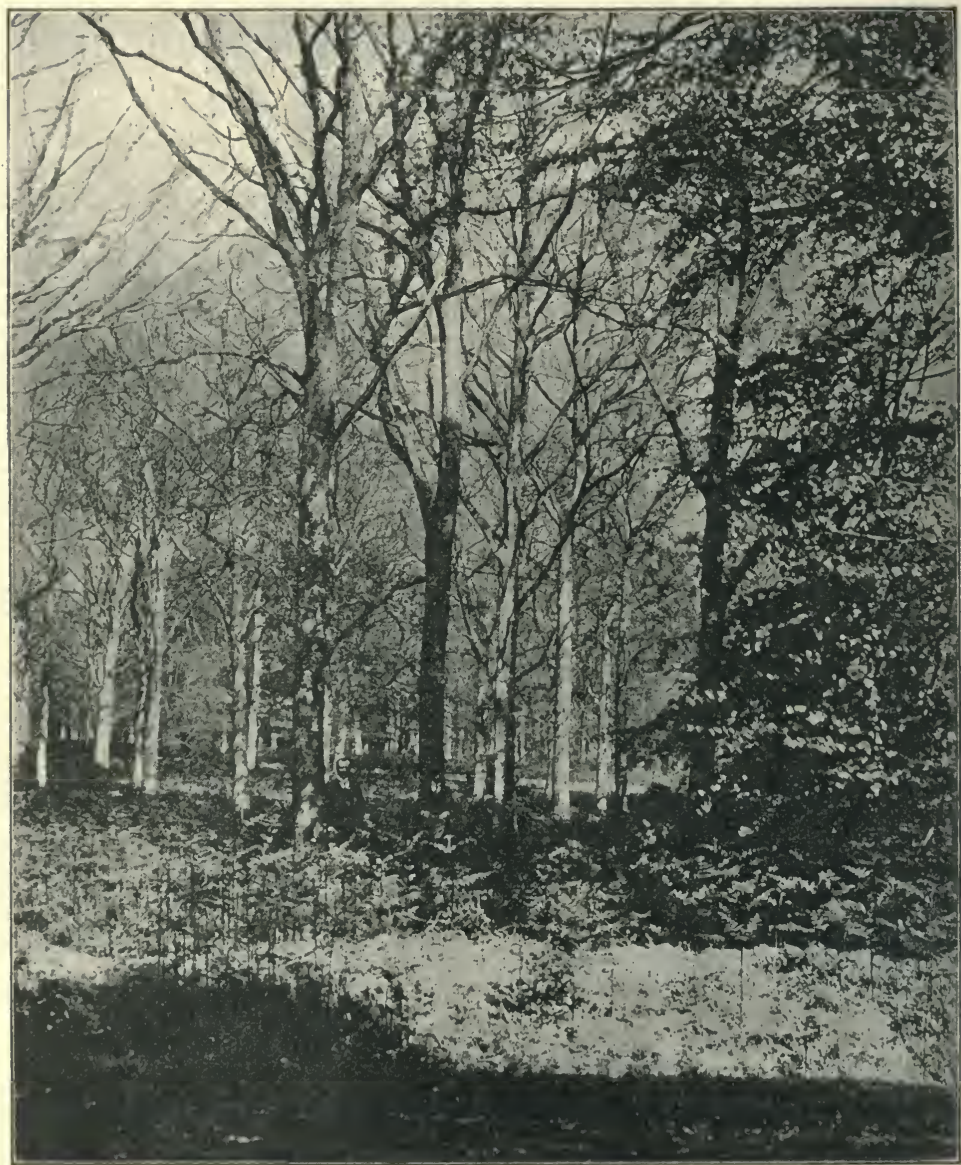

Fig. 170.-Oak trees stripped of foliage in Windsor Forest by T. viridana; beech in full leaf. Photo by W. F. Perrée.

chiefly tall poles and mature trees. The attacks of the caterpillar involve the buds, leaves and inflorescence, and spread from the summit of the crown downwards. The 
formation of foliage, blossoms and acorns for the year is seriously compromised, and sometimes the former is completely destroyed, and may then be restored by Lammas-shoots.

In coppice-with-standards oak standards and underwood only are attacked. The attacks of this moth are very persistent, having lasted for 4 years, in the Steigerwald from 1869-72, and in Windsor Forest during 1890-94.

\section{d. Protective Measures.}

Protection of enemies : starlings, rooks, jackdaws, etc. Hardly any remedial measures can be tried in forests. The caterpillars of the Dunbar moth, Cosmia trapezina, which are carnivorous, are useful in clearing off their attack, as well as that of the winter moth. This Noctuid moth has a spread of wing of about $30 \mathrm{~mm}$.; the fore-wings are variously marked with pale grey, rust-colour, or brown, with transverse dark and pale lines, the hinder wings greyish - brown. 'The $q$ lays her eggs chiefly on oak. The caterpillars are pale dull-green, apple-green beneath, and have 5 pale whitish or yellowish longitudinal stripes, and numerous small black warts, each surrounded by a white ring, eight to a segment, arranged transversely on the first three segments behind the head, and in a square of four, with two below on each side on the succeeding segments.

Pimpla scanica, Grav., is the commonest ichneumon-wasp that attacks the oak leaf-roller.

3. Tortrix (Retinia) buoliana, Schiff. (Pine-shoot 'I'ortrix).**

\section{a. Description .}

Moth with wing-expansion of 19 to $22 \mathrm{~mm}$.; fore-wings narrow, reddish-yellow, traversed by $6-7$ broad, wavy $\gamma$-shaped

\footnotetext{
* Vide Miss Ormerod, op. cit., p. 248.
} 
silvery marks, hind-wings dark grey; both pairs with light grey fringes. Thorax orange, abdomen grey.

Caterpillar $14 \mathrm{~mm}$. long, with 10 prolegs, bright brown and smooth, the head and first segment black.

Pupa yellowish-brown, with a row of fine prickles on the back of the abdomen.

\section{b. Life-history.}

The moth appears from the end of June till the end of July.

During the day it sits somewhat concealed amongst the pine needles, its colour assimilating with the withered pine shoots, but it becomes active with the approach of twilight. The eggs are laid among the terminal buds of young Scots pine plants. The caterpillars hatch out at the end of August and in
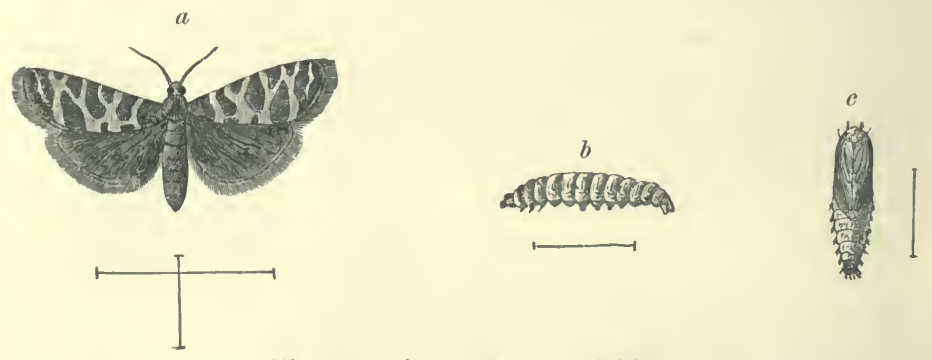

Fig. 172.-Tortrix buoliana, Schiff.

a Imago. b Larva. c P'upa.

September, they hibernate in the buds, becoming full grown in the following May.

Pupation takes place at the end of May or June, at the base of the injured shoot. The pupa is exposed, and the empty pupal case may be seen for some time on the shoot.

The moth emerges 4 weeks later.

Generation annual: . The insect is commor and widely distributed wherever Scots pine trees are grown in Europe.

\section{c. Relations to the Forest.}

The Scots pine and occasionally the Weymouth, black and cluster pines are attacked.

The insect exclusively attacks young growth, and prefers weakly 6- to 12-year-old plants on poor soil and in sunny situations. 
The attack is made by the larva boring into buds and shoots. Late in the summer the buds, particularly the terminal buds, are slightly gnawed at their base, so that turpentine exudes. In the following spring, as soon as the plant begins to shoot up, the caterpillar bores right through the pith of the young shoots. Shoots eaten on one side become curved as in the

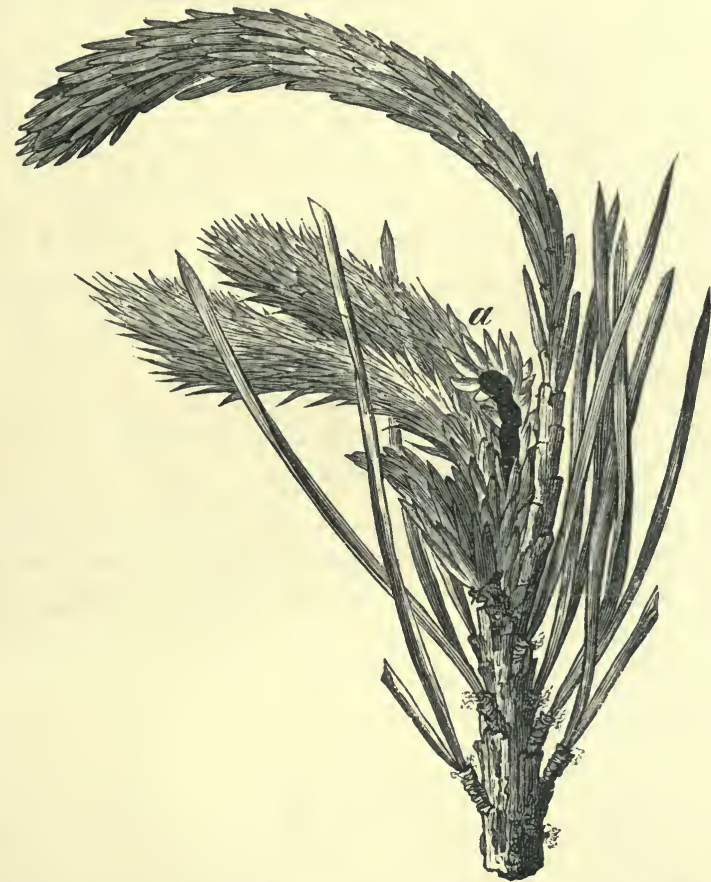

Fig. 173.-Pine-branch, showing distortion after antecedent injury by T. buotiana Schiff. A larval gallery is exposed in the broken shoot, a. (Natural size.)

figure, and if. no further injury is done, will recover their vertical position, but the perforated shoots dry up, turn brown and fall off. After destroying the terminal shoot, the larva directs its attention to the side shoots; it sometimes spins several together, and passes from one to another. The attack can be distinguished from that of the pine beetle by the crumbling excrement found in the borings.

The injury causes the pine to send out brush-like sheots as

F.Y. 
lateral buds develop on all sides of the point of attack, and the resulting loss of increment is considerable, as frequently the pest recurs year after year.

\section{d. Protective Rules.}

Protection of birds, titmice, etc.

Careful planting and rearing of plantations of vigorous pines, without undue crowding.

The shoots which are attacked may be broken off and burned, from the middle of May to the end of June. This plan is advisable only on small areas and at the commencement of the attack. If made late, it destroys numerous parasitic enemies of the caterpillars.

Removal of all misshapen stems at the first thinning, till which time they are spared to help to cover the ground.

\section{Tortrix (Retinia) turionana, Hb.}

\section{a. Description.}

Moth with a wing-expanse of $16-18 \mathrm{~mm}$; fore-wings brown-grey, ochreous towards the tip, with leaden-grey transverse wavy lines; hind-wings whitish, the tip greyish $(\delta)$ or ochreous ( $q$ ). Head and thorax ochreous; abdomen grey.

Larva $10 \mathrm{~mm}$. long, with 16 legs ; light brown, with black head and thoracic shield.

\section{b. Life-history, etc.}

The eggs are laid in May or June singly on the middle buds of the whorls of the stem of young Scots pines (usually $5-15$ years old). The caterpillar bores as a rule into the middle bud, and hollows out the pith-canal in the course of the summer. The shoot is checked from the commencement of its growth and takes on a blackish-grey colour; eventually it dies and the lateral buds, which are seldom attacked, become abnormally large.

Pupation takes place in the following year (at the end of April or in May) in the hollowed bud, which is spun over with a thin web, and the moth emerges at the end of May or the beginning of June. 
Other species of pine, such as the Weymouth pine and Pinus ponderosa, Dougl., are liable to attack. The insect is less common than the preceding.

\section{c. Remedial Measures.}

The injured buds, which can be recognised by their small size and dark colour, should be cut off towards the end of April.

5. Tortrix (Retinia) resinella, L.

$$
\text { a. Description. }
$$

Moth with a wing-expanse of 16 to $18 \mathrm{~mm}$. ; fore-wings slatygrey with numerous shining leaden - grey transverse lines forked on the fore-margin; hind - wings grey-brown; the fringes pale. Body slaty-grey.

Caterpillar $11 \mathrm{~mm}$. or more in length, with 16 legs, orangebrown, with brownish-red head and thoracic shield.

\section{b. Life-history.}

The eggs are laid in May and June, just under the whorl of buds of the recently-grown shoots of young pines, usually on the lateral shoots. The caterpillar bores into the pith and thus causes the growth of

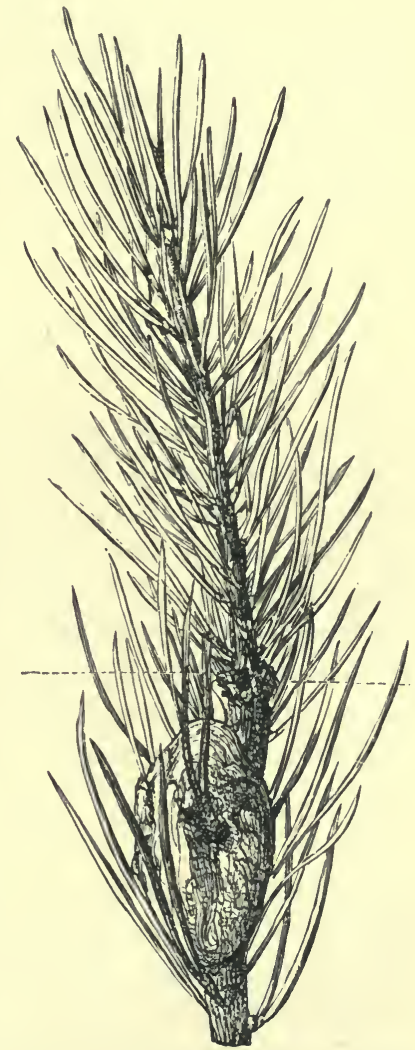

Fig. 174.-Resin-gall of $T$. resinella, L., on a pine shoot. (Natural size.) a hollow gall-like resinous mass, as large as a pea, in which it passes the winter. In the spring it continues feeding, causing the gall to increase to the size of a cherry or of a small walnut, and form a swelling on the underside of the shoot which encircles two-thirds of it. On section the gall is seen to be divided into two compartments by a strong vertical partition. In the larger one the larva lives and pupates (in 
April or May of the third year); the smaller one contains its excrement.

The moth flies about May; the generation extending over two years. As a rule the pine recovers its injuries; but in an unfavourable situation or after bad weather the attacked shoots perish. The species is tolerably common in a few localities in Scotland and in Windsor Forest.

The treatment consists in the destruction of the galls during the second winter, and in cutting off affected shoots.

\section{Tortrix rufimitrana, H.-Sch.}

\section{a. Description.}

Moth with wing-expansion of 12-16 mm.; fore-wings dark greyish-brown, with lead-coloured wavy lines at their base, a rusty yellow median band with a lead-coloured border, and a round dark spot on a rusty yellow patch near the corner of the wings; hind-wings brownish grey, with grey fringes; thorax rusty yellow near the head, abdomen brownish-grey.

Caterpillar $10 \mathrm{~mm}$. long, with 10 prolegs, of a dull yellowishgreen above and yellow below, with reddish-brown head. Pupa $6 \mathrm{~mm}$. long, bright brown.

\section{b. Life-history.}

The moth flies from June till the end of July, sometimes also in May. The eggs are laid on silver-fir needles, where they remain during the winter.

The caterpillars hatch in the succeeding spring, and when fully grown at the end of June, let themselves down by threads, and pupate in the soil-covering in a cocoon made of silk and bits of earth. 'I'he moth appears 2 to 3 weeks later. Generation annual.

\section{c. Relations to the Forest.}

I'he caterpillar, commencing operations as the young shoots appear in May or the beginning of June, eats the needles and youngest shoots of the silver-fir. It devours the young needles, bites off the older ones at their base and gnaws the epidermis of the young shoots, spinning a thin web over the 
parts attacked. The insect prefers woods of 60 to 100 years old, but when the moth appears in swarms, younger wood is also attacked. The edges of the crowns of the trees become reddish, and after attacks repeated for several years the trees become stag-headed, the topmost branches being as bare as brooms, and die. There have been several severe attacks in Germany on silver-fir by this moth since 1876, and in 1879 , 1,800 acres of forest were ravaged in Nagoldthal, and the attack spread to the surrounding districts.

\section{d. Protective Rules.}

Mixture of other species with the silver-fir, and clean woodcraft.

Protection of enemies: titmice, the wren, etc.

\section{e. Remedial Measures.}

Smoking out the caterpillars by burning green branches in damp weather. This is done in May, by thinning affected woods and collecting branches from trees and poles felled, which are burned in heaps after taking necessary precautions. In damp weather the smoke penetrates the leaf-canopy and causes numbers of larvae to fall, which are swept into the fire. This was done by Forstmeister Koch, with excellent results, near Karlsbad.

Admission of pigs to the forest as soon as the cocoons are in the soil covering, during the first half of June.

Raking-up and removing the soil-covering whilst the pupae are there.

Felling trees which are badly attacked.

\section{Tortrix pinicolana, Zll.}

\section{a. Description .}

Moth with wing-expansion of 18 to $22 \mathrm{~mm}$. ; fore-wings long, with strongly sinuate inner border, bright ashy-grey, with numerous dark brown wavy stripes; hind-wings somewhat broad, of a uniform brown or ashy grey colour; both pairs with brownish-white fringes. 
Caterpillar $10 \mathrm{~mm}$. long, with 10 prolegs, dark green, darker on the back, with two brighter green stripes along the sides; head and prothoracic shield shining black.

\section{b. Life-history.}

The moth appears in August and the beginning of September.

The eggs are laid at the base of young larch shoots, and remain over winter. The caterpillars appear in May or June, and pupate at the end of July or in August in a silken cocoon amongst the needles, on twigs or, when the insect is very numerous, in bark cracks. Generation annual.

\section{c. Relations to the Forest.}

The caterpillars usually attack only old larch, and chiefly sickly trees, but when very numerous
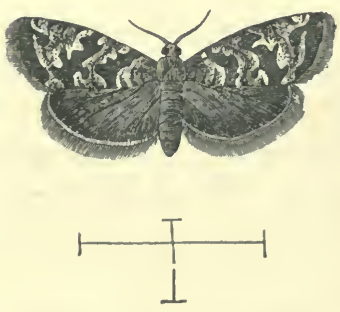

Fig. 175.-Tortrix pinicolana, Zll. they also attack healthy trees, and underwood of spruce or $P$. Cembra growing below the larch. They eat the needles, at first those of the lower shoots, subsequently climbing to the summit of the trees. The insect sometimes appears in such numbers as to completely strip the trees of needles, and entire woods may then appear with a brown canopy, as if the needles had been burned. As a rule fresh needles appear during an attack, but if it should last for 2 to 3 years, even the healthiest trees will succumb. Badly stocked woods on shallow soil and with a southerly aspect suffer most of all.

'This insect is common in Switzerland, and has been observed over fairly large tracts of forest in 1855-56-57, 1864-65, 1878-79 in the Ober Engadin, Wallis and Graubundt. In 1879 in the Ober Engadin, where larch is the dominant species, over 15,000 acres of forest were attacked by it. Also in 1889, in the Tyrol. It is not uncommon among larches in Britain. 
d. Protective Rules.

Protection of birds.

Smoking out as described for the preceding species.

\section{Family VII.-Tineidae.}

\section{Description of Family.}

Imagos with long filiform or setaceous antennæ, seldom pectinate; ocelli usually present; wings long and narrow, usually pointed, and, especially the hind-wings, characterised by long fringes, during repose either roof-shaped or folded over the body; frenulum present; legs stoutly spurred. Generation annual.

Caterpillars slightly hairy, usually with 10 prolegs. A few species have only 6 to 8 prolegs, and those reduced in size (leafminers).

Pupation usually in a cocoon. Pupae with a thin hairless skin, rarely with spines on the abdominal segments, but characterised by the elongate wing-cases which reach almost to the apex of the abdomen.

The caterpillars generally live in rolled-up leaves, or in shoots, flowers, fruits, seeds, etc. Many species are leafminers, living on the parenchyma of leaves, between the upper and lower epidermis. Others bore into the pith, wood, bark or buds. Few of them, however, are important enemies of the forest.

1. 'Tinea (Hyponomeuta) variabilis, Zell.

a. Description.

Moth with wing-expanse of 18 to $20 \mathrm{~mm}$. : fore-wings white, clouded with brownish grey on the anterior border, with 3 irregular longitudinal rows of black spots, and a group of smaller spots along the outer margin; hind-wings browngrey ; fringes pale-grey or whitish.

Caterpillar $18 \mathrm{~mm}$. long, with 16 legs, yellowish-grey, marked with round black spots, with black head and thoracic shield. Pupa light brown. 


\section{b. Life-history, etc.}

The eggs are laid at the end of June and in July on buds, usually of underwood. The larvae do not hatch till the spring, when they attack buds, leaves and blossoms under the protection of a conspicuous gauzy web, which they spin in common over the ends of the branches.

'The chief food-plants are the plum and apple trees, the mountain-ash and especially the lawthorn. This caterpillar has also committed great ravages among willows in Hungary. It is very common in the British Isles, and often completely defoliates hawthorn trees and hedge-rows in the open spaces of London. Pupation takes place on the branches or trunk in June or July in a white cocoon.

\section{c. Remedial Measures.}

Cutting-off and destruction of the caterpillar-webs at the beginning of June. Destruction of the moths (July), which often sit in conspicuous groups at a moderate height on the trunks.

Where defoliation is an eyesore, as in public parks, the trees may be carefully sprayed with a weak arsenical mixture or syringed with a stronger jet of plain water or soap-mixture.

Other species of Tinea-e.g. T. padi, Zell., on the gean (Prunus padus, L.) and on Rhamnus Frangula, L.-are closely allied in appearance and habits.

2. Tinea curtisella, Don. (Ash-twig Moth).

a. Description.

Moth with a wing-expanse of $16 \mathrm{~mm}$.; fore-wings, head and thorax white; the former

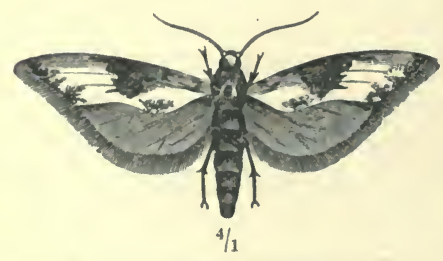

Fig. 176.-Tinea curtisella, Don. with a large triangular darkgrey blotch on the anterior margin and with the base and outer margin clouded with blackish marks; hindwings and abdomen greybrown, the latter lighter beneath; fringes grey-brown.

Caterpillar 7 to $10 \mathrm{~mm}$. long, with 16 legs, bright 
honey-yellow with brown head and dorsal shield. to Stainton the larva is greenish, marbled with reddish-brown.)

Pupa yellow-brown, glossy, in a neat cocoon, pointed at each end and of a silken lustre, constructed away from the larval feeding-place.

\section{b. 'Life-history.}

- The moth flies in June and lays its eggs on the leaves of ash, which are mined in July by the newly-hatched larva. The larvae pupate early in August on the ground among dead leaves. After eight days' pupation, the moth appears in the middle of August and lays eggs on the leaves. Generation double. In the autumn, when the leaves turn yellow and fall, the caterpillar, which is still very small, after mining the leaves till near leaf-fall, bores into the sheathing scales of the terminal buds; here it moults and excavates a hole in which to hibernate. Its presence is indicated by the fine powder visible in the entranceburrow. As soon as the buds begin to swell in the ensuing spring, the caterpillar begins to feed on the buds, and reaches maturity about May. The injured bud is incapable of development and is outstripped in growth by the next uninjured shoot, causing the ends of the branches to become

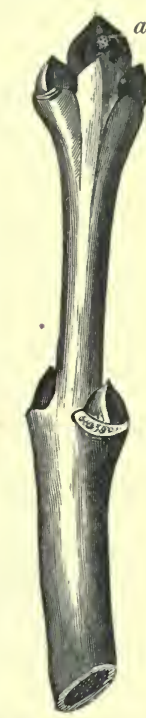

Fig. 177.Ash - twig inhabited by larvae of ash - twig moth.

a Exuded excrement. (Natural size.) forked.' The larvae then generally attack the leaves again, and pupate at the end of May, the pupa being attached by a thread to a twig. Chiefly young plants and saplings are attacked. The summer attack is harmless, but the spring attack causes forking.

The species is tolerably common wherever ash is grown.

\section{c. Remedial Measures.}

Cutting off the injured buds early in July, together with one of the adjacent lateral buds. This prevents forking but is practicable only in nurseries and on saplings. 
3. Coleophora laricella, Hbn. (Larch-miner Moth).

\section{a. Description.}

Moth with wing-expansion of 9 to $11 \mathrm{~mm}$.; wings very narrow, shining ashy-grey, with very long fringes, especially to the hind-wings.

Caterpillar 4 to $5 \mathrm{~mm}$. long, with 10 prolegs, dark reddishbrown. Pupa 4 to $5 \mathrm{~mm}$. long, narrow, dark brown, with fine bristles.

\section{b. Life-history.}

The moth flies in the daytime in May and June.

The $q$ lays its little roundish yellow eggs on healthy larch
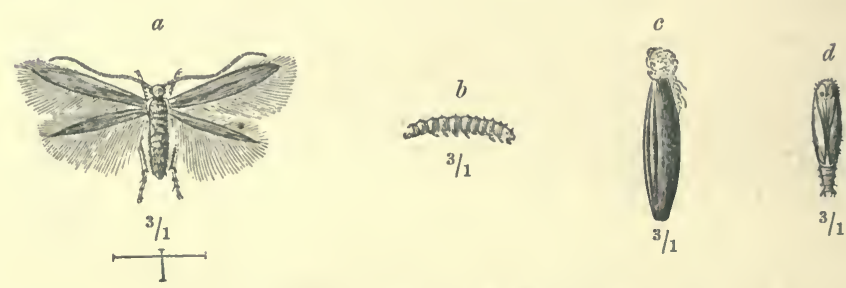

Fig. 178.-Coleophora laricella, Hbn.

$a$ Moth. $b$ Caterpillar. $c$ Larval case. $d$ Pupa.

needles, usually only one egg on a needle. After 6 to 8 days the eggs become grey.

The caterpillars hatch in June, and continue to grow till September. They hibernate on the needles in a case. The pupal stage is passed from the middle of April till May in a case on the needles. The moth emerges in the latter half of May.

Generation annual. Very common. The caterpillar is very susceptible to late frosts, wet and cold rainy weather and hail.

\section{c. Relations to the Forest.}

This insect is a most dangerous enemy of the larch, and prefers 10- to 40-year-old trees, but may also attack woods which are older or younger than these. When other nutriment fails, the insect attacks young spruce or pines that are either under or among the larches. 
The little caterpillar, as soon as it has emerged from the egg, bores into the young larch-needles to about half their length, so that their upper ends shrivel up and turn yellow, as if injured by frost. The attack usually commences on the lower branches and proceeds upwards, the top of the tree being spared in moderate attacks. The appearance of a plant which bears a large number of infested needles is very conspicuous and characteristic.

In September the fully grown caterpillar prepares a little case out of the dry part of the needle, which it cuts off for the purpose, and in this it hibernates on the twigs, usually at their tips, or in barkcracks, or among lichens on the stems.

In the spring the caterpillar, carrying its case with it, bores again about half-way into a larch needle, and about the middle of April finding its old case too small, it fastens it along the freshly hollowed-out needle, like two fingers of a glove. It then cuts out the adjacent walls of its old case and of the needle, thus preparing a new case twice as wide as the former. This troublesome work occupies several days, during which an observer might imagine that there were two larvae on a needle. When

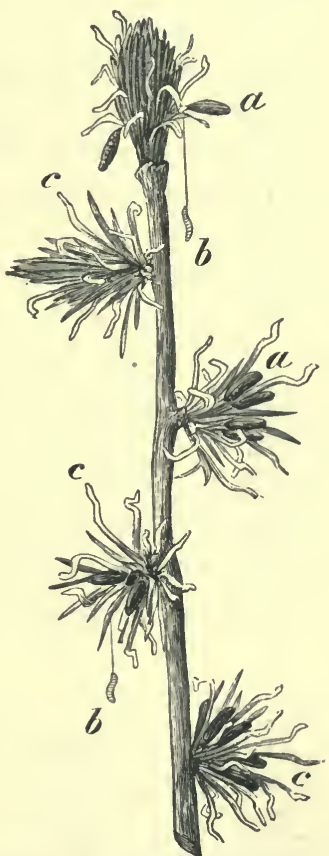

Fig. 179. - Larch-needles injured by $C$. laricella, Hbn. (Natural size.)

$a$ Larval cases. $b$ Spinning caterpillars. c Hollowed and twisted needles. the insect is ready for pupation it spins the new case firmly to a needle.

The little insect likes sunny warm localities, sheltered from the north and east, and prefers the westerly borders of woods, avoiding isolated trees, probably on account of their exposed position. It has been observed in Switzerland up to an altitude of 3,000 feet, and in Germany and Britain it constantly 
accompanies the larch, and has recently become abundant in Switzerland, where the larch is indigenous. It sometimes appears in myriads, 50,000 larvae having been found on a plant only 12 years old in Schlucken, 1895 .

Independently of its large numbers and wide dissemination, its great hurtfulness results from its eating the needles twice during the same year, and appearing year after year in the same localities. As the larch disease almost always accompanies this insect, the latter probably renders the tree susceptible to this highly destructive fungus. The loss of increment is considerable, owing to the destruction of needles in the spring, so that trees are often so weakened by repeated attacks that they die.

\section{d. Protective Rules.}

Choice of suitable localities for larch, and planting it widely apart.

Mixture of larch with beech, spruce, silver-fir, etc.

Early thinning, and removal of the thinned material, at the latest, by the end of March.

Protection of titmice and other small birds.

\section{e. Remedial Measures.}

Pruning the lower branches of larch trees, on which the insect usually appears.

Removal of badly attacked and weakened trees from the middle of June till the end of August. The caterpillars in the needles of these trees will not then become fully developed.

The little cases may be picked off the trees, and destroyed during the winter and spring, but this plan can be followed in forest nurseries only. 


\section{CHAPTER VIII.}

DESTRUCTIVE INSECTS (concluded).

\section{A. Hymenoptera: \\ Family I.-Tenthredinidae (Sawflies).}

Description of Family.

Sawflies have straight, usually filiform or setaceous antennae, rarely club-shaped, occasionally serrate, or in $\widehat{\sigma}$ doubly pectinate, and with 3 to 30 joints ; 3 ocelli ; prothorax usually very short; wings with full complement of veins, the fore-wings with 1 or 2 radial and 3 or 4 cubital cells.

Legs with a double trochanter; the anterior tibiae with two apical spines; tarsal joints often furnished below with membranous expansions, sometimes cup-shaped.

Abdomen sessile, of 8 segments; in $q$ with protrusible serrate ovipositor.

Generation usually double, sometimes treble, but in the cocoon-spinning sawflies it may be plurennial.

Larvae usually bright-coloured, with 8 or 18 to 22 legs, resembling caterpillars but distinguishable usually by the greater number of legs and by a conspicuous simple eye on each side of the head; they are social, and after 5 to 6 moultings spin a firm cocoon which is of oval or oblong-oval form and often parchment-like in consistency.

Pupation takes place in the cocoon about 2 weeks before the sawfly emerges. The pupae are soft, and encased in a barrelshaped cocoon.

The larvae feed on needles and leaves; they are often social when young, and when disturbed assume a characteristic S-like attitude. The perfect insects usually feed on honey. Some species (Cimbex) girdle young beech-shoots probably in order to get the sap. A few species are very destructive. 


\section{Lophyrus pini, L. (Pine Sawfly).}

a. Description.

Male with a wing-expansion of $15-16 \mathrm{~mm}$.; body black, abdomen reddish at apex, spotted with white on the underside of the first segment; antennae doubly pectinate; hind-wings with a dark border.

Female with a wing-expansion of $18-20 \mathrm{~mm}$. ; body dullyellow, with the head, 3 spots on the thorax, and the middle
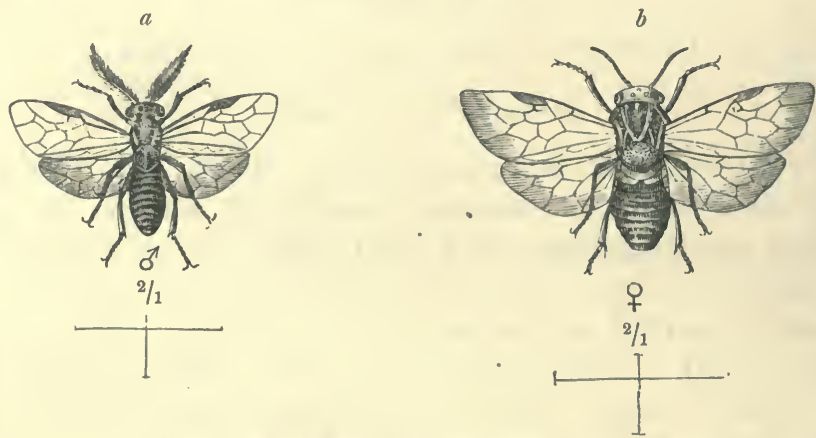

Fig. 180.-Lophyrus pini, L.

$a$ Male. $b$ Female.

of the broad abdomen alone blackish ; wings yellowish, slightly infuscate along the outer margins.

Legs yellow in both sexes.

Larva $25 \mathrm{~mm}$. long, with 22 legs, changing colour as it becomes older, finally of a dull green, with oblique rows of little rugosities and a round brown head, and black semicolonshaped marks above the prolegs.

- Pupa enclosed in a $10 \mathrm{~mm}$. long, leathery, and usually dark brown cocoon.

\section{b. Life-history.}

The sawfly appears in April and May, and again at the end of July and in August. Only the $\delta$ appears to fly. The much more numerous ? creep lazily along the twigs and needles. The $q$ in April and early in May cuts slits into Scots pine needles with her saw-like ovipositor, and lays a sausage-shaped egg in each slit, depositing 10 to 20 in each 
needle, and 80 to 120 altogether; she seals up each egg with a frothy secretion.

'The larvae hatch 2 to 3 weeks later, in May and June, and those of the second brood in August and September. They frequently moult, the empty skins hanging on the needles. The second brood hibernate in cocoons under moss, or on stems or twigs. There is not, however, always a second brood, and the larvae of the first brood may then hibernate. Pupation takes place at the beginning of July* in a compact brown cocoon, among the needles, or in bark-cracks on the stems of the pine. The second brood pupate in March or April in cocoons under moss at the foot of the tree they have attacked.

The sawflies of the first brood appear at the end of July or early in August, about 2 to 3 weeks after pupation. The insect when ready for flight cuts a circular lid off the cocoon. If an ichneumon fly should emerge instead of the sawfly, a little hole appears at the end of the cocoon $(\odot)$ instead of the lid. The

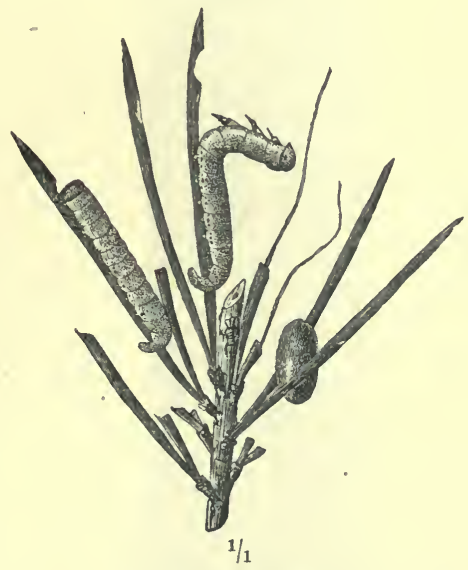

Fig. 181.-Pine-needles, with larvae and cocoon of L. pini, L. second brood usually emerge in April, but sometimes not till July, when the sawflies of the two broods become intermingled.

Generation double, but frequently lasting over a year. In rare cases it has lasted for 2 to 3 years. The insect is very common on the continent of Europe and in the British Isles.

The naked larvae are susceptible to cold and wet weather.

\section{c. Relations to Forest.}

The larvae attack the Scots pine, and prefer sickly poles where the leaf-canopy has been interrupted, 20 to 30 years

* Theodor Hartig states that cocoons spun under moss are dull brown, and those on the tree silky ash-grey, dirty white, or yellowish. Even clean white and rusty red cocoons may occur. 
old, on poor soils and with a sunny aspect. They also attack young growth and trees up to the age of 120 years. Border trees especially suffer.

The larvae till half-grown eat the needles in dense companies of 60 to 80 and more. When young they merely gnaw the edges of the needles; later on they eat them in short strips parallel to the mid-rib, which they leave intact. An attack

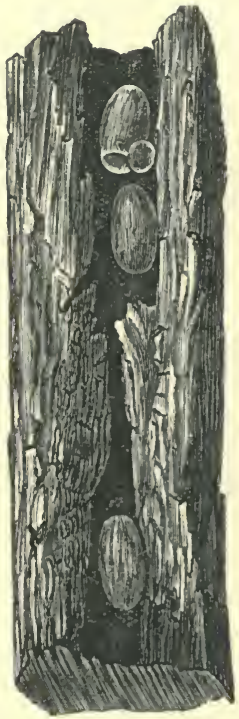

Fig. 182. -3 cocoons of the Pine sawfly on pine bark.

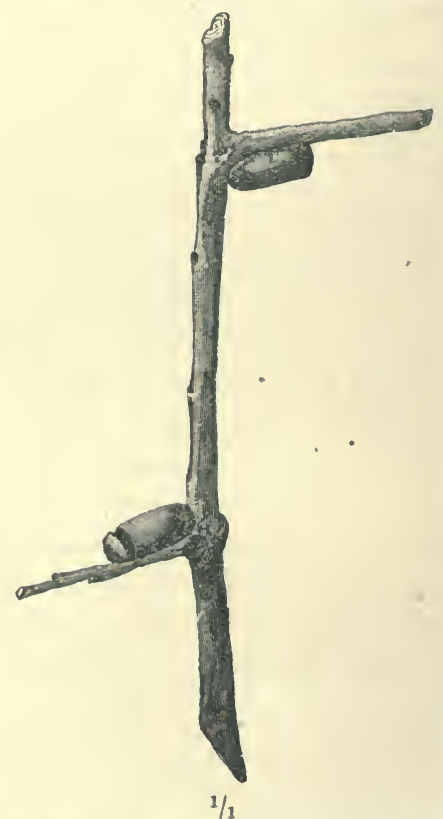

Fig. 183.-2 empty cocoons of the Pine sawfly on an oak-twig. 'The upper one has lost the lid.

by the pine sawfly may be at once recognised by the remaining yellowish, thread-like mid-ribs (Fig. 184).

The older caterpillar's only leave short stumps to the needles. The first brood chiefly devour 1-year-old needles, and the second brood those of the current year. The larvae also gnaw the soft young bark in patches, often down to the wood. After the crowns of larger poles are stripped, smaller Scots pine poles, underwood, and young plantntions are attacked. 
This and all other species of Lophyrus have the habit, when disturbed, of bending the front part of their bodies in the figure S (vide Fig. 181).

\section{d. Protective Rules.}

i. Maintenance of healthy well - stocked Scots pine woods, so that the soil may not be impoverished.

ii. Protection of enemies : cuckoo, starling, crow, goatsucker, swallows, etc. Mice and squirrels open the cocoons during the winter, and devour many larvae. Even the badger and fox eat the larvae and pupae.

Many* parasitic ichneumon wasps and Diptera attack the larvae. So do spiders, e.g., Steatoda sisyphia, Cl.

\section{e. Remedial Measures.}

i. Collection of larvae by stripping or shaking them from the trees on to cloths spread on the ground, in May and June, and again in September and October. One man shaking the trees, with two boys to collect the larvae, can clear fifteen 25 -

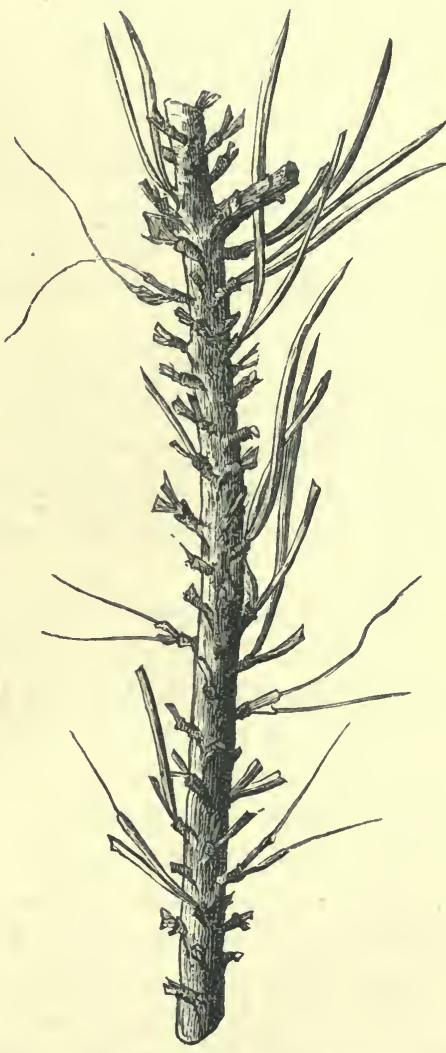

Fig. 184.-Pine-shoot with needles eaten by L. pini, L., (Natural size.) year-old trees before 9 a.m., and such work is most efficacious in the morning when the larvae are slightly torpid.

ii. Collection of cocoons under the moss in winter. They may be found generally near the base of the attacked trees, and sometimes in masses as large as the fist.

iii. Admission of pigs in September and October, when the

* For a list of these, vide Taschenberg, $n p$. cit., page 230.

F.P. 
larvae come down to hibernate. The pigs will not eat the cocoons, which are too tough for their taste, but crush them in numbers.

iv. Planks smeared with tar may be put up to catch the sawflies, the tarred sides being turned towards the sun, and the tar renewed from time to time.

v. Mixture of quicklime with the litter and then watering it. 'I'he heat thus engendered kills the larvae and pupae that are in the litter, and preserves the latter for the forest. This remedy was tried with success on 6 acres of $12-15$ Scots pine plantation with heather undergrowth, and cost $12 s$. an acre.

vi. If no other remedy should be found effective, the damaged wood must be cut down, and the roots grubbed up late in the summer or winter; branches may be spread on the soil and burned before grubbing up the roots, and one or two field-crops harvested before the land be restocked with pines.

Several other species of Lophyrus of generally similar habits also attack Scots pine. Miss Ormerod* states that much injury was done in 1890 to three or four thousand acres of young Scots pine in Argyleshire by L. rufus, Klug, the larvae of which are dull greenish-grey, with black heads. 'The flies appeared in August only, and the $f$ are reddish and the $\delta$ black; both sexes have red legs.

Plants 2 to 6 feet high were more subject to attack than older ones. In Germany the sawflies appear in May, and the larvae May - July, to attack trees of all ages, but to prefer those 10 to 15 years old, and one-year-old needles. It attacks the Austrian as well as the Scots pine, and appears to have a single generation. It is not so common as $L$. pini, and should be treated similarly.

The larvae of various species of Nematus (with 14 prolegs) and Lyda (2 prolegs) also attack spruce, larch, and pines. $N$. ericksoni, Hrtg., has been very destructive to young larch in Cumberland in 1906. Its larvae may be recognised by their grey colour, with a darker medium zone. $N$. laricis, Hrtg., also attacks larch; its larvae are green. 


\section{Family II.-Uroceridae (Wood-Wasps).}

\section{Description of Family.}

Wood-uasps have straight filiform or setaceous antennae, always shorter than the body, and with 11 to 30 joints; 3 large ocelli; body long and cylindrical; wings elongate with complete venation. Legs with double trochanter, anterior tibiae with a single apical spine. Abdomen sessile, with 9 segments; ovipositor elongate, projecting beyond the end of the abdomen, and consisting of two lateral sheaths and a strongly serrate median borer.

Generation lasting at least two years. Larvae cylindrical, soft, and whitish, with 6 legs, and a spine at the rounded posterior extremity. Pupce soft and white.

The larvae live chiefly in coniferous wood, in which the perfect insects lay eggs with their long ovipositors. Pupation also takes place in the wood, and the wood-wasp emerges by a circular hole.

\section{Sirex juvencus, L. (Steel-blue Wood-wasp). \\ a. Description.}

The insect attains a length of $12-30 \mathrm{~mm}$. ( $\mathrm{\sigma}$ ) and, including ovipositor, $16-36 \mathrm{~mm}$. ( $q$ ); thorax and abdomen steel-blue, the latter in the $\delta$ with the 4 th to the 7 th segment inclusive, yellowish red; in $q$ the steel-blue ground-colour of the abdomen is iridescent, with a coppery sheen. Wings yellowish, with brown margins. Legs chiefly reddish-yellow. Ovipositor shorter than the abdomen. Larva up to $30 \mathrm{~mm}$. long, with 6 very small feet, white.

\section{b. Life-history, etc.}

The $q$ in July bores the bark of the Scots pine, usually of trees in pole-woods, down to the sapwood, and lays an egg in each hole. The larva eats out in the wood a curved burrow of circular section; at first it lives in the softer layers of the sapwood, but after the first hibernation it bores deeper into the tree, living on the resinous and starchy matters in the burrow, the dust of which it packs behind it.

After a second hibernation, in the early summer of the $3 \mathrm{rd}$ year, it constructs a pupal chamber at the end of the burrow, 
lining it with a glazed coating. The wood-wasp emerges in July, by a larval-gallery, or by boring. for itself a short way through the wood. The flight-hole is circular (being thus distinguished from those of longicorn beetles that are oval), and

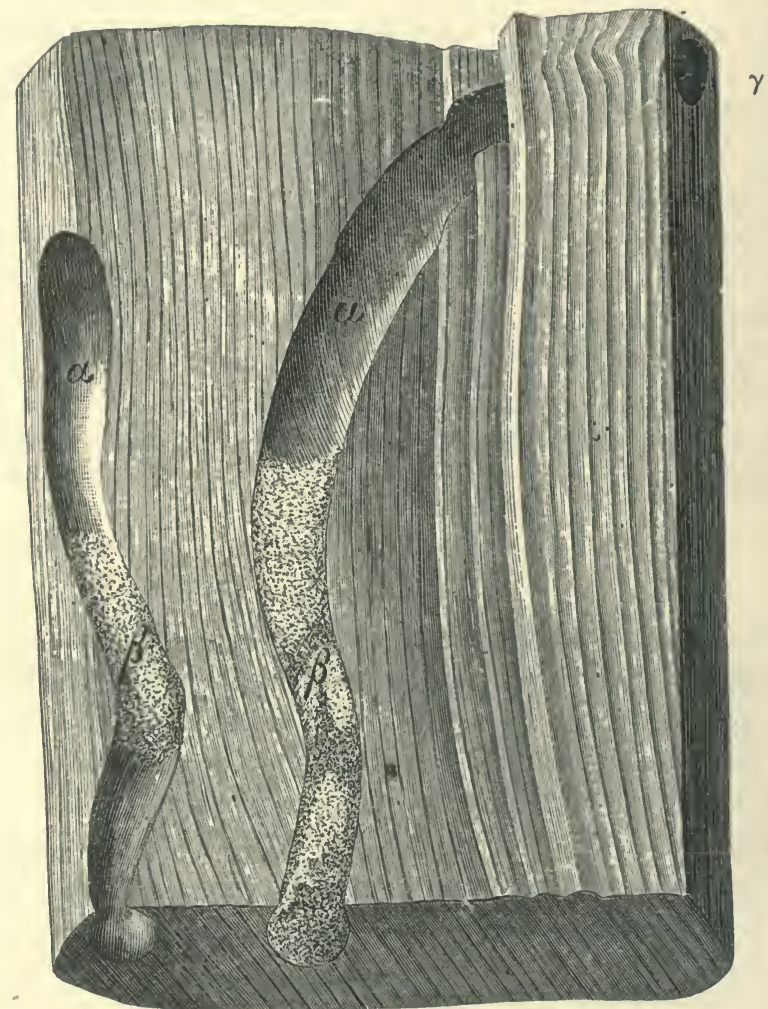

Fig. 185.-Pine-wood bored by the larva of Sirex juvencus, L. (Natural size.) $\alpha$ Larval burrows partly filled with boring-dust $\beta . \quad \gamma$ Circular flight-hole.

about the fourth of an inch in diameter. The gencration lasts at least two years, and sometimes longer, the wasps appearing from wood which has been worked up for some time.

In Germany, it sometimes attacks spruce as well as Scots pine, and in the British Isles* it has been observed on larch, 
silver fir, and other conifers. All wood-wasps prefer weakly trees, which have been injured by deer, lightning, or wind, and especially trees felled in the growing season and stripped of bark. 'They never attack actually rotten wood, or perfectly sound standing trees. Miss Ormerod relates an instance where, at Workington, Cumberland, in $1889,1,700$ c. feet of silver-fir valued at $£ 30$ were irretrievably ruined. The damage done is economic, not physiological.

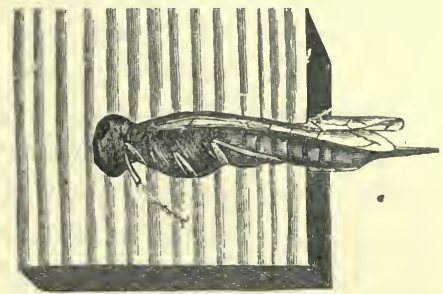

Fig. 186.-Wood-wasp in the act of boring, exposed by splitting the wood.

\section{c. Protective Rules.}

Removal of all high stumps and broken wood. Felling of all weakly or damaged poles and trees in the thinnings, and rapid removal of coniferous timber from the forest.

\section{Sivex gigas, L. (Yellow wood-vasp).}

\section{a. Description.}

Imago 20-32 mm. (ठ ) to $45 \mathrm{~mm}$. ( ( ) in length; black, head with a large yellow spot behind the eyes; abdomen ( $\overline{\text { ) }}$ reddish-yellow, with the first and last segments black, ( $q$ ) black with the 2 anterior and 3 posterior segments yellow; legs black, with the knees yellow; ovipositor nearly as long as the body.

Larva, like that of the preceding species.

\section{b. Life-history, etc.}

This species is particularly attached to the spruce, but is sometimes found in silver fir. Its habits are the same as those of $S$. juvencus, L.

It is tolerably frequent in Britain, and prefers large trunks.

The treatment of its attacks is similar to that adopted for S. juvencus, L. 


\section{Family III.-Cynipidae (Gall-wasps).* \\ Description of Family.}

Imagos with straight, filiform antennae, with 13 to 16 joints; ocelli far back on the crown of the head. Forewings with only 6 to 8 cells, with no stigma, and with 1 radial and 2 to 3 cubital cells. Some species have no wings, or only abortive ones. Abdomen pedunculate, laterally compressed and truncate at apex, much shorter than the wings. ot usually very small. Larrae usually thick and fleshy, curved, smooth, white, and apodal. Pupae thick-set, smooth, and white. They are divided into 3 groups: True Gall-wasps, Secondary Gall-wasps, and Parasites.

\section{True Gall-wasps.}

The true gall-wasps bore with their ovipositor into leaves, buds, shoots, fruits and other parts of woody plants, and they insert one or more eggs in the wound. The egg hatches in due time and the larva lives in a chamber formed in a growth or gall, often of hard or woody consistency, formed by the proliferation of the surrounding plant-cells. The growth of this gall is not due to the irritation caused by the mother, but to the stimulus caused by the internally-feeding larva. Galls may be on roots, bark, buds, leaves, blossoms or fruits. They may also contain one larval chamber, or many, the former being most usual. The insect usually hibernates in the gall, rarely under dead leaves.

The oak is attacked by about fifty species of gall-wasp, and galls are chiefly found on badly-growing underwood in coppice or high forest. This is probably due to the fact that tannic acid flows into the gall tissues, which are thus rendered immune to birds. The consequent damage is not serious, as the attack is chiefly on foliage. At the same time galls on buds or bark, when very numerous on seedlings or coppiceshoots, may cause stunted growth. Some species, on account of the tannic or gallic acid they contain, are useful in producing the galls used in commerce.

Probably the most harmful species is the common marble

* As the family of Diptera, known as Cecidomyiidue, contains many species of gall-flies, it is preforable to term the Cynipidae gall-wasps. 
gall-wasp (Cynips kollari, Hart.), which sometimes occurs in large numbers on young oak plants. The galls* may be cut off with a knife while they are still young and soft, and if thrown away they dry and shrivel, and the maggots within perish. Titmice are very useful in oak nurseries, as they pick the maggots out of the galls.

It is interesting to know that in many species of gall-flies, a wingless, hibernating, parthenogenetic generation always alternates with a winged generation of both sexes. As an example, the wingless agamic female form, Cynips aptera, is hatched from galls on the roots of the oak, and hibernates in the soil, laying in the spring, on the terminal buds of the oak, a number of unfertilised eggs. These cause galls on the terminal shoots from which the winged forms of both sexes, $C$. terminalis, Fabr., develop. The fertilised $q$ of this insect lays her eggs on the roots of the oak, and from them $C$. aptera is hatched out, and so forth. $t$

\section{Secondary Gall-Wasps.}

These are also termed Inquilines, or fellow-lodgers, as their $q$ lay eggs in galls made by the true gall-flies, and their larvae are either parasitic on the larvae of the latter, or else merely live with them in the same gall, e.g., Synergus vulgaris, Htg., lives in galls of Cynips folii, L.

\section{Parasitic Gall-wasps.}

The $q$ lay their eggs in other insects in which their larvae are parasitic, and thus form a connecting link with the Ichneumonidae, e.g., Allotria erythrocephala, Htg.

Parasitic on the Rose aphis.

Hess gives a summary account of the chief species of gall-wasps.

* Miss Ormerod, op. cit., p. 237.

$\dagger$ Many so-called galls, or malformations of plants, are caused by fungi or bacteria as well as by gall-wasps and gall-flies. A beautifully illustrated book on "British Vegetable Galls," by E. T. Connold, was published in 1901, by Hutchinson \& Co., Paternoster Row, London, and the author is now preparing for the press a second volume, on oak-galls only. 


\section{B. Diptera.}

Family I.-Cecidomyinde (Gall-gnats).

Flies with long thread-like or moniliform antennae, with

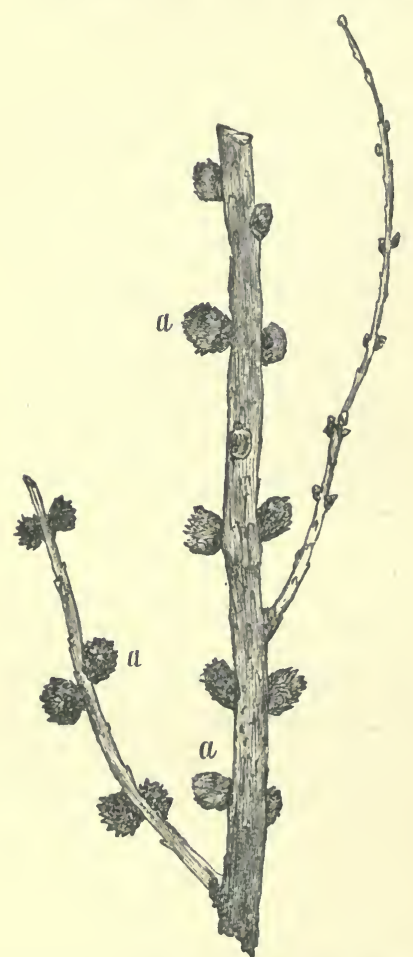

Fig. 187.-Larch twig, with galls made by $C$. kelneri, Huschl.

(Natural size.) 10 to 36 joints, usually with whorls of hairs ; body delicate ; wings moderately large with rounded anterior border, constricted at the base, often iridescent, with 3 to 5 longitudinal veins; abdomen cylindrical, consisting of 8 segments, in $q$ pointed and often furnished with a projecting tubular ovipositor ; legs slender, the tibiae unarmed at apex.

Larvae long fusiform legless maggots, slightly flattened, without chitinous mouth-armature, but with a chitinous fork or "anchor-piece" embedded in the skin of the ventral surface; usually pale yellowish or reddish.

'I'he imagos lay their eggs in needles, leaves or bark, in which the young larvae feed by sucking, and thereby cause galllike swellings.

Several species are common on willows.

1. Cecidomyia saliciperda, Duf. (Willow Gall-gnat). a. Description.

Fly 2 to $3 \mathrm{~mm}$. long; black-brown ; the wings milky-white with whitish hairs; antennae shorter than the body.

Lavea yellowish red.

b. Life-history, etc.

The eggs are laid during May in rows on the bark of the branches up to the thickness of one's arm of pollard-willows 
and on 4- to 8-year-old shoots of willows. Salix triandra, L., S. fragilis, L., and S. alba, are all attacked. The maggot bores horizontally through the bark, in which from July to the following April it excavates short irregular vertical galleries. This causes the appearance of spindleshaped swellings of the bark and underlying wood, at least in the larger stems, which eventually become rough owing to the irregular detachment of the bark. Pupation takes place in the same spots, and the emergence of the flies riddles the bark with small holes.

This species is sometimes decidedly common and injurious to planted willow cuttings. The only satisfactory treatment is the timely cutting-off and burning of the infested shoots before emergence of the gnats.

The family of Cecidomyiidae also contains the Hessian-fly, $C$. destructor, Say, one of the greatest of pests to cereal crops, and various species attacking conifers, of which $C$. kellneri, Hnsche., gives rise to galls on the buds of larch. Others produce galls on beeck leaves (C. fagi, Htg.), and on birch leaves C. betulae, Wtg.

\section{Hemiptera,}

\section{Faniliy I.--Aphididae (Plant-lice).}

\section{Description of Family.}

Insects with long, usually filiform or setose antennae, of 3 to 7 joints; ocelli either absent or 3 in number; rostrum usually well developed. Wings membranous, often absent, especially in 9 . Legs usually long and thin; tarsi of 2 joints. They move by flying, or running.

The species of Chermes comprise those aphides, that are of most importance as being injurious to forest-trees, especially to coniferae.

The mode of life of plant-lice is as follows: The hardshelled eggs that resist the cold are laid during autumn in rows or groups on needles, leaves, buds or shoots, and hibernate. In the spring, small wingless $q$ producing parthenogenetic wingless $q$ issue from the eggs, and thus several generations 
arise of parthenogenetic insects. The last generation in autumn is winged and produces $\delta$ and $q$; from the latter eggs are produced and hibernate. Besides this dimorphism, in the genus Chermes the insects migrate from one species of plant to another in order to change their food. By piercing plants or sucking them, they produce galls and other malformations, on leaves, needles, buds,

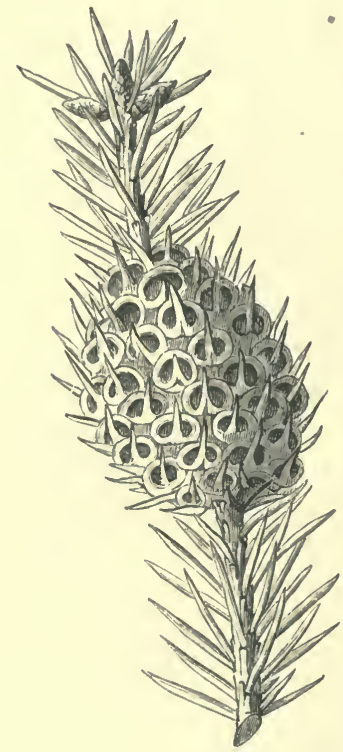

Fig. 188.-Gall of Chermes abietis, L., on a spruce-twig. (Natural size.) flowers, etc., especially on broadleaved plants. Most species are monophagous, almost every species of plant having its peculiar plantlice. Most plant-lice produce honeydew from leaves, this being their excrement.

In Chermes, there are three different imagos: winged parthenogenetic $q$, wingless parthenogenetic $q$, and wingless sexual imagos of both sexes.

The wingless parthenogenetic o, stem-mother or fundatrix, hibernates alone on spruce buds. After three moultings in the spring, she sucks the opening buds, lays a number of eggs and dies near them. The sucking of the mother causes a gall to form, and from the eggs, very shortly, wingless lice arise, which force their way deeper into the gall, which therefore increases in size, chambers being formed round the lice. The latter, after 3 moultings, acquire rudimentary wings, and, opening the gall-covering, come out as nymphs on the needles. After another moulting they acquire wings.

Then some of the winged lice remain on the tree, and lay eggs from which the hibernating parthenogenetic fundatrix arises. She continues to act as already described and corresponding broods arise for several years.

The other winged lice leave the spruce for other conifers, 
silver fir, larch, or pines, and lay eggs from which wingless lice arise that winter on the tree and lay eggs next spring.

From these eggs some of the nymphs eventually become winged lice that fly back to the spruce and lay eggs there from which $\delta$ and $q$ arise. The other wingless parthenogenetic $q$ continue their life on the other trees.

1. Chermes abietis, L. (Spruce-gall Aphis).

a. Description.

Wingless stem-mother, yellowish-green, becoming darker when full-grown. Body covered with white wool. Galldwellers bright yellow.

Winged lice, 2-2.4 $\mathrm{mm}$. long, with dark head and back and yellow undersurface. Sexual insects bright yellow.

\section{b. Relations to the Forest.}

The galls (in size from that of a cherry to that of a walnut) which result from their injury are at first soft and green, becoming later purplish-red in places and finally, when hard and dry, brown. They contain a quantity of tannin. Their size is characteristic, as is the fact that they are topped with a sprig of needles, as long as, or longer than, the gall. This is the stunted young shoot. The injured shoots take on a characteristic curvature towards the side on which the gall is growing. The loss of growth may be considerable.

The other hosts of this insect are larch, Scots pine, Cembran pine, and in Russia, the Siberian spruce.

The spruce-gall aphis is common both in plains and in hilly country, and attacks young spruces especially in nurseries and those which have been injured by frost or animals. It is also common on the border-trees of 10- to 20-year-old plantations. Fortunately the attack is usually confined to the side-shoots, and the leading shoot escapes.

\section{c. Remedial Measures.}

Protection of the smaller insectivorous birds: tits, the nuthatch and golden-crested wren. A spider (Theridion) is an active destroyer of this insect, spinning its web over the galls and preventing the escape of its inmates. Direct treatment is 
troublesome; the galls if on seedlings may be snipped off, and the experiment may be tried of spraying the young trees in April with kerosene-emulsion. (See the following species.)

\section{Chermes coccineus, Rtzb.}

The winged $\&, 1.6 \mathrm{~mm}$. long, are dark red. The galls formed on the spruce by this insect are at first yellowish green, then red, and lastly brown, but are much smaller than those of C. abietis, L. They are also always on side-shoots, and are never topped by a sprig of needles.

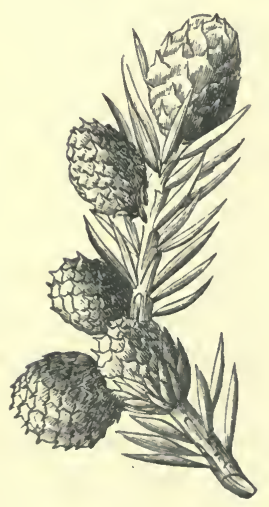

Fig. 189.-Gall of C. coccineus, Rtzb. (Natural size.) Isolated and border plants are usually selected.

The intermediate hosts are the common silver-fir and other firs. The winged emigrants lay their reddishyellow eggs below the needles of firs. The brown, later blackish, wingless plant-lice, which come from these eggs in 2-3 weeks, suck the needles and lay yellowish or reddish-brown eggs covered with wool, that hibernate. These give rise to other wingless plant-lice in the spring, on the young twigs, from the eggs of which are produced winged and wingless $q$. The former fly back to the spruce and the others remain on the silver-fir. From eggs laid by the former the $\delta$ and $f$ arise.

Those that remain on the silver-fir cover the bark, which looks as if it had been powdered. Damp places sheltered from the wind are preferred. Young silver-fir may be seriously weakened by this attack, which is very destructive to silver-fir in Scotland. Abies grandis, Lindl., is said to escape injury.

Remedial measures as for $C$. abietis, $\mathrm{L}$.

3. Chermes strobilobius, Kltb.

Galls on the spruce, intermediate in size between those of C. abietis and $C$. coccincus. It looks like an unripe strawberry, with, or without, a sprig of needles at top. 
The larch is the intermediate host of this insect, and the

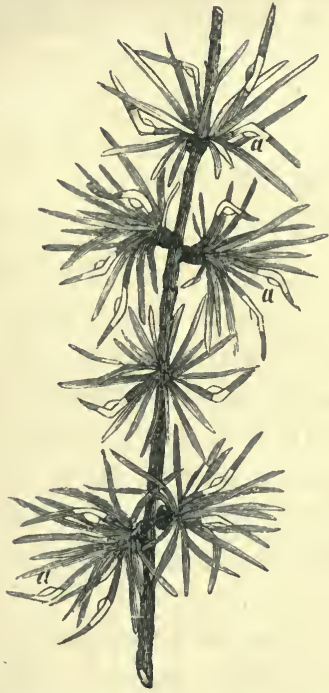

Fig. 190. - Larch - shoot attacked by Chermes laricis, Hart. (Natural size.)

$a$ Insects feeding on the needles, which show a characteristic angular bend.

plant-lice on the larch were formerly known as Chermes laricis, Hart. (the larch aphis).

\section{a. Description.}

Imago o , rather smaller than the preceding, blackish - brown, covered with a white woolly down; the winged form dirty green, or with the head and thorax reddish-brown. No male is known.

\section{b. Life-History.}

The wingless females pass the winter on the larch, like those of C. abietis, Hart. ' 'They lay their eggs and from April to August the aphides sit and feed on the needles, which become discoloured and acquire a peculiar elbowed shape. No gall is formed. They acquire wings in August and disperse to other larches, or to the spruce. When they are abundant, the larches look as if they had been sprinkled with snow.

\section{c. Ireatment.}

Spraying with kerosene-emulsions, soft-soap, limewater or weak solutions of corrosive sublimate. Keep spruce away from larch nurseries.

\section{Chermes sibiricus, Choldk.}

The winged females greatly resemble those of $C$. coccineus, Rtzb., and C. strobilobius, Ktlb.

The galls, $3-10 \mathrm{~cm}$. long, consist of a but slightly altered bent twig, the needles on the inside of which become thick and woody, but not coalescing as in the former galls. The dark red plant-lice eventually produce winged offspring that fly to the Scots, Weymouth or Cembran pines, and these lay reddish-yellow eggs. 'Those that stay on the pines, formerly 
termed Chermes stroli, Htg., attack plants from five years old and mature trees. Young plants become greatly weakened by theseattacks, and many Weymouth pines have thus been killed in the Woburn Woods, Bedfordshire.

Remedial measures, as before.

\section{Family II.-Coccidae (Scale-insects).}

\section{Description of Family.}

Very minute insects with moniliform antennae, of 6 to 25 joints; rostrum rudimentary in the $\delta$. $\delta$ with 2 or 4 membranous wings without cells; $q$, except one apterous species, Aleurodes chalidonii, Latr., swollen, more or less shield-shaped; one tarsal joint. The $q$ burrow their beak deep into the planttissues and swell up into spherical bodies, and in May and June lay numerous eggs on plants, and die on the eggs. 'The eggs hatch into $\delta$ and $q$ larvae that pupate in autumn or spring. Single generation.

The imagos and larvae, under the protection of shields or puparia, partly composed of fibrous secretion, partly of the cast-off exuviae, suck the young shoots, leaves, bark, etc. of perfectly sound plants, and cause blistering and disease in the organs which they have attacked. In this way, beech, spruce, oak, ash, robinia, and other plants may be attacked by different species.

The most effective treatment known for nursery plants so attacked is to wash them with limewater in the spring, or cut off and burn infected twigs. The plants may also be treated, when practicable, with paraffin emulsion or washes made by forming a soap with boiling water, resin and potash. The scales may also be scraped off with a blunt knife, or rough brush, and the plants smeared with soft-soap and water.* When scale appears on coppice-shoots or saplings, cut and burn the affected plants.

\section{Coccus fagi, Bärensp. (Scale-felt, or Beech woolly aphis).}

Hitherto only the $q$ is known. 'This is a very small, paleyellow, legless, apterous scale-insect, measuring about $\frac{1}{25}$ inch

* For apple-scale Miss Ormeror recommends 2 lbs. soft soap, 1 lb. flowers of sulphur, 14 gallons of water. 
in length, it is lens-shaped, being flattish below and highly convex above. 'The mouth is on the underside of the body, and composed of three hair-like appendages, united to form a long sucking tube; with it this insect pierces the bark and sucks the sap. She has no power of locomotion. Almost immediately after leaving the egg, she cover's her body with a white, felted, waxy secretion, which forms an excellent coat, impervious to rain. Within this coat, she lives, lays her eggs and dies.

The larvae are very tiny and active, and scarcely visible to the naked eye. They possess three pairs of legs and a pair of antennæ, and like their parent are yellow. They can move over the bark of the tree, but usually settle down under the body of their dying or dead parent, preferring the deepest parts of the bark-fissures, where they remain sucking the sap. Each larva protects its body with wool, which is added to that produced by previous generations. The secretion therefore gradually thickens and spreads over the tree-trunk, forming a more or less continuous mass. Larvae wandering over the bark are borne by the wind or by birds or insects to other trees and spread the infection. The larvae hibernate, and eventually lose their legs and antennae and become parthenogenetic $q$.

Young and old beech trees are attacked, the sheltered side of exposed trees being selected. The attack sometimes lasts for years without apparent injury to the tree, while others die, the foliage gradually becoming discoloured and thin and the smaller branches dying, the bark peeling off the branches and trunk.

In the extensive beech forests near Brussels, the absence of thinning is said to favour the disease, and where thinnings are made it is generally absent. It is extremely rare in the beech woods of the Chiltern Hills, which are usually over-thinned.

Remedial measures. As given above.

\section{Lecanium hemicryphum, Dalm.}

Lecanium differs from Coccus by the $q$ swelling up over the eggs and its back being chitinised to form the scale. This scaleinsect and the accompanying fungus, Apiosporium pinophyllum, 'Tuckel., nourished by the honeydew, cause a black, paste-like 
coating on branches and twigs of 5 - to 15 - years-old spruce,

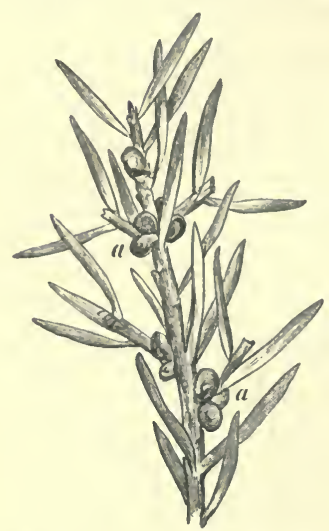

Fig. 191. - Spruce - shoot attacked by Lecanium hemicryphum, Dalm. (Nutural size.)

a Feeding scale-insects. which makes them languish for several years. It has done much damage to spruce plantations in Saxony, and near Tharand was found on mature spruce, which had been injured by locomotive smoke. This insect is attacked by a parasitic weevil (Brachytarsus varius, Fabr.). Lecanium fraxini, Sign., attacks ash.

Another injurious genus of scaleinsects is Aspidiotus, in which the o live under a coat formed of larval skins and a waxy scale, the $\sigma$ under a smaller waxy scale and one larval skin. Aspidiotus salicis, L., attacks poplars, willows and ash, and frequently kills black poplar. When crushed, a blood-red fluid exudes from the insects. This species greatly impairs the growth of young ash.

\section{Orthoptera.}

\section{Family I.-Gryiliddae (Crickets).}

Description of Family.

The insects of this family possess a thick, free head, with long bristly antennae of many joints, and 2 or 3 ocelli; hindwings folded longitudinally, and projecting beyond the wingcases, but often aborted, or absent, not roof-shaped in repose. Body cylindrical; fore-legs formed for burrowing; tarsi 3-jointed. Ovipositor long, sometimes absent. The species produce a chirping noise by rubbing the wing-cases together.

They dig holes in the ground, and live partly on larvae and worms, partly on the roots, seeds and fruit of forest plants, or on grass and herbage.

1. Gryllotalpa vulgaris, Latr. (Common Mole-cricket).

$$
\text { a. Description. }
$$

Imago 35 to $45 \mathrm{~mm}$. long, reddish-brown or dark brown, and lighter beneath; the wing-cases short with black veins, not 
covering the wings; abdomen with two caudal processes. Fore-legs sturdy, resembling hands, used for burrowing, like those of the mole. The larva and nymph greatly resemble the perfect insect in form and colour, but have the wings undeveloped.

\section{b. Life-history.}

Pairing takes place underground, from the beginning of June till the middle of July.

The $q$ during the month of June lays 150 to 250 pale yellowish eggs, as large as hempseed, in a hole of the size of a hen's egg, and about 10 to $12 \mathrm{~cm}$. below the surface of the ground, with which it communicates by a tunnel or shaft, with a circular section.

The earth above and around the hole is rendered more compact by the saliva of the $q$. The $q$ watches the nest carefully, and when disturbed returns to it by the tunnel.

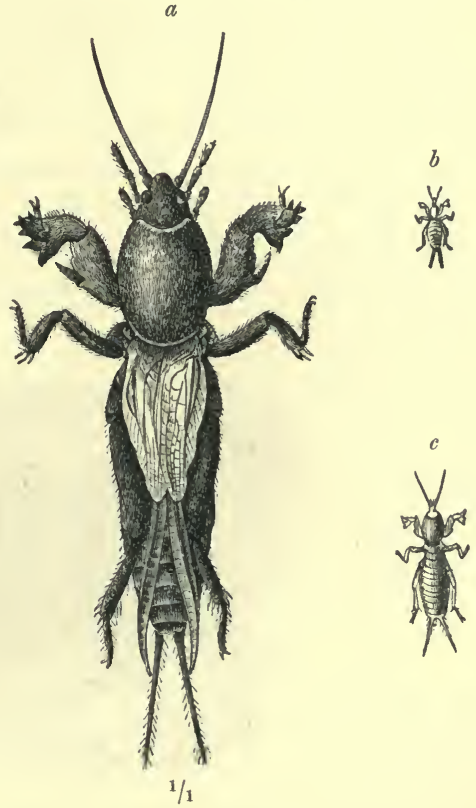

Fig. 192.-The mole-cricket, Gryllotalpa vulgaris, L.

$a$ Perfect insect. $b$ and $c$ Larvae in early stages.

The young larvae appear after 2 to 3 weelss, and remain 3 to 4 weeks in the nest; they then begin to burrow in the ground, moult 3 times before October or November, and then hibernate in the ground.

The nymph-stage takes place at the end of May or beginning of June with the fourth moulting, the nymph being active and feeding; with the last moult, instead of the little lappets which represent the wings in the nymph, 4 true wings appear, and the form of the perfect insect is assumed. 
Generation annual, but occasionally the larvae may persist over another year.

\section{c. Relations to the Forest.}

The insect, in all its stages, damages forest plants. It bites through the roots of young conifers, especially of spruce and Scots pine, when 1 and 2 years old, while making its burrows, which are about a finger's width. It also uplifts young plants, which fall over and die. The mole-cricket also bites off the germinating shoots of oak and beech before they reach the surface of the ground, and the roots of young broadleaved seedlings, tearing the latter with its fore-legs.

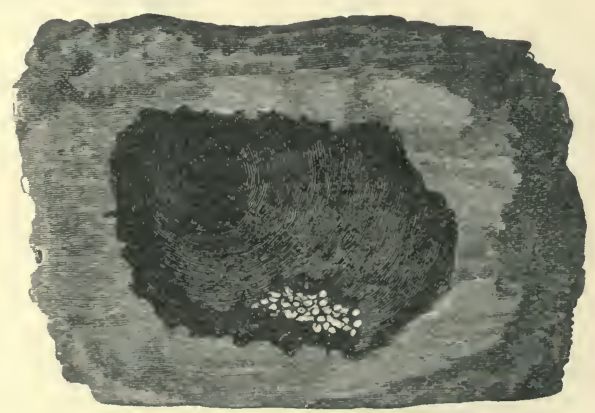

Fig. 193.-Nest and eggs of the mole-cricket.

On the other hand the mole-cricket is useful by destroying numbers of underground grubs. The $q$ has been observed to eat some of her own brood.

Favourite localities for this insect are loose level sandy soils, free from vegetation, but it is also found on clay lands. Thinly stocked beds of seedlings are preferred to densely stocked beds, and patches to lines of seedlings.

The mole-cricket also cuts through the roots of agricultural crops. It is not yet decided whether it damages plants for its own nourishment, or to clear the way for its burrows.

The mole-cricket is only local in England, and does not occur in the north. It is perhaps commoner than is generally supposed, as owing to its underground habits it is seldom seen. 


\section{d. Protective Rules.}

i. Isolation of seed beds by trenches 25 to $30 \mathrm{~cm}$. deep and wide; if flower-pots or vessels with smooth sides be placed with their tops level with the bases of these traps, many crickets will be caught and may be destroyed.

ii. Protection of enemies. Mole, shrew-mice, crow, starling, etc. The larvae of ground and rove-beetles also attack molecrickets.

\section{e. Remedial Measures.}

i. Destruction of nests in June and July. They may be discovered from the circular orifice in the ground which leads down to them, and by the wilting plants which may be near them. They are dug out, and trampling, pouring hot water over them, or exposure to the sun will kill the brood.

ii. Destruction of the full-grown crickets in June. Great caution must be exercised, as the creatures are very shy. Just after dusk, the worlser, who should be barefooted, approaches cautiously the places whence the chirping arises, and exposes the concealed cricket by a stroke of the spade. When seized the insect emits a thick black excrement.

iii. Ordinary flower-pots, 2 yards apart, may be placed in nursery-beds, so that the crickets may fall in during their nocturnal rambles. This method is most effectual at pairingtime.

iv. Pour petrol, or tar and turpentine in equal parts, into the holes, and then water till the holes are full, in order to drive out the crickets. At Seligstadt, 100,000 crickets were thus destroyed between June and August, 1897.

\section{Familly II.-Acriditdae (Locusts).}

\section{Description of Family.}

Insects with vertical heads, the antennae shorter than the body, with not more than 25 joints; wings roof-shaped in repose, the fore-wings narrow; body laterally compressed; tarsi with 3 joints, usually with a lappet between the claws; abdomen with an auditory organ on each side of the first segment, ovipositor short. 
Locusts are plant-eaters, and feed chiefly on the produce of fields and meadows, but also on the foliage of broadleaved trees and shrubs, especially when they come in swarms, and they can then be extremely hurtful.

The commonest European species is Pachytylus migratorius, L., and its area of sub-permanent distribution is from lat. $40^{\circ} \mathrm{N}$. in Portugal to $48^{\circ}$ in France and Switzerland, and rising eastwards to $56^{\circ}$ in Russia, Siberia, N. Japan. Its area of occasional distribution is wider, and it has visited England and Scandinavia. It is also found in S. latitudes in New Zealand and Australia, and in Mauritius and Africa. Only an occasional visitor to India.

Acrydium peregrinum is permanent in Africa and tropical Asia, especially India, and occasionally visits the South of Europe, and in 1869, was found over a large part of England.

\section{Pachytylus migratorius, L. (Migratory Locust).}

\section{a. Description.}

Imago 35 to $48 \mathrm{~mm}$. long ( ऊ), 42 to $55 \mathrm{~mm}$. long ( $q$ ), coloured greenish, or brownish; pronotum produced into a blunt point in front; wings yellowish, or pale brown, almost transparent, slightly darker at the tips; chest with white hairs; hind femora bluish on their inner side, with a black ring in front of the joint; hind tibiae yellow.

Lavva with broad brown bands on the front part of the back, and wingless until it has moulted four times.

\section{b. Life-history.}

The eggs are laid in the ground 3 to $4 \mathrm{~cm}$. deep, in groups of 70 to 80 , and as the $q$ die immediately after laying, their dead bodies lying on the ground show where eggs have been laid.

\section{c. Relations to the Forest.}

Locusts devour chiefly agricultural produce, sometimes appearing in such countless swarms as to leave nothing green over many square miles of country. South Russia, with its extended grain-producing plains, is specially liable to this scourge, and so is Hungary. Its permanent home appears to 
be the barren steppes of Central Asia. It occasionally spreads westwards over Germany and as far: as Belgium, and even into the British Isles. While, however, devouring chiefly agricultural crops, the locust does not spare the young leaves and terminal buds of broadleaved trees, though it but rarely strips off all the foliage of a forest. In 1880, in Istria, chiefly oak and ash were attacked by it, other broadleaved trees being spared. Vineyards were also attacked.

\section{d. Protective Rules.}

i. Destruction of eggs. Very difficult to carry out on a large scale.

ii. Destruction of larvae-which is the best method.

They have been exterminated in Cyprus by an organised system of digging trenches, into which the larvae are driven; strips of cloth on stakes lead up to the trenches, and the locusts are crushed by thousands when the trenches are nearly full, and then fresh trenches are dug. In South Africa, the larvae, which may accumulate in masses, are killed by spraying with coarse blue soap and water. The soap blocks up their tracheae and kills them readily.

iii. Destruction of the full-grown locusts may be effected during wet.weather, when they fly with difficulty.

\section{LIS'T OF DEŚTRUCTIVE INSECTS.}

A list is here given of all the destructive insects dealt with in this book, arranged according to the species of tree attacked and the different organs of it which suffer.

The following details are given in the list :-

Organs of tree attacked : root, bark, cambium, wood, buds, young shoots, needles, leaves, blossoms, fr'uits and seeds.

Stage of the insect at the time when it is injurious: larva, imago; or sometimes, in the case of Ortioptera, or Hemiptera, all stages, including the nymph or pupa.

Grade of injuriousness of insect.

Age of woods attacked: seedlings, young plants, poles, or trees.

Characteristics of attack, which serve to indicate the offender. 


\section{The following abbreviations are used :-}

1. Imago.

L. Larva.

A. All stages.

(V.G.) Vertieal gallery.

(F.G.) Forked

(H.G.) Horizontal ,

(L.G.) Ladder , ; the elaraeteristic form of Trypodendron.

(S.G.) Stellate gallery.

S. Seedling.

\section{THE SPRUCE.}

Roots.

PAGE

Dolopius marginatus. I. (Y.P.) 214

* Gryllotalpa rulgaris. A. S... 369

* Melolontha vulgaris. L. 2 to 3

summers. (Y.P.)

*.M. hippocastani. Id. ........... 209

Toctua segetum. L. S. 325

BARK.

*Iylolins abietis. I. (Y.P.) ... 225

*II. pinastri. Id. ................. 232

Pissodes notatus, Id.† ........ 233

P. pini. I. (Y.P. \& P.)........ 235

P. heseyniae. I. T.............. 235

Strophosomus coryli. I. (Y.P.) 220

S. obesus. Id. .................. 220

\section{Cambiom.}

Hylastes palliatus. I. \& L. (V.G.) (P. \& T.). 262

Myelophilus piniperdu. I.\& I.

(V.G.) T.t 265

MI. minor. J. \& L. (H.G.) (P.

\& T.) $†$ 271

Pissod es notutns. I. (Y.P.\& P.).† 233

P. pini. Id. .................... 233

P. hereyniae. L. T. ........... 235

*Tomicus typographus. I. \& L. (V.G.) $T$....................... 238

*T. amitinus. I. \& L. (F.G.) \& (S.G.) T...................... 246

OT. bidentatus. (Y.P. \& P.)

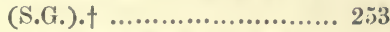

*T. chalcographus. I. \& L. (S.G.) P. \& T. ............... 248

OT. stenngraphus. I.\& L. (L.G.).† 250

T. laricis. I. \& I. (V.G.) J'. \& 'T.
(Y.P.) Young plants.

P. Poles.

'T. Trees.

* Highly injurious.

O slightly

Insects not marked with either of the above signs are moderately injurious. Those with the mark + plaeed after them rarely occur in the ease referred to.

\section{WoOD.}

P.IGE

IIylecoetus der'mestoïdes. I.\&I.T. 216

Sivex jureneus. L. T.† ........ 355

s. gigas. L. (P. \& T.).......... 357

*Tomicus lineatus. I. \& L.

(L.G.) (P.\& T.) …....... 255

\section{BUDS}

*Liparis momacha. I. (P. \& T.) 310

\section{YOUNG SHOOTS.}

Chermes abietis. A. (P. \& T.)

Large galls...................... 361

* Hylubius abietis. I. (Y.P.) ... 225

Jecanium hemicryphum. A.

(Y.P.\& P.) 367

\section{NEEDLES.}

Geometra piniaria. L. (P.\& T.) +326 Lecanium hemicryphum. A. (Y.P. \& P.) 367

*Liparis momacha. I. Trees of all ages ........................ 310

O Melolontha spp. I. (P. \& 'T.)... 200

Noctun piniperda. I.(P.\&'T.) +320

Sitones lineutus. I. (Y.P.) ..... 220

Strophosomus coryli. I. (Y.P.) 220

S. obesus. Id. .................. 220

INFLORESCENCE.

O Melolontha rulgavis. I. (P.心 T.) 200

CoNes.

Anobium abistis. I. 217

Germinating Seeds.

Agriotes spp. L. 214 
2. SILVER FIR.

Roots.

* Gryllotalpa vulgaris. A. S. ... 369

* Melolontha spp. L. (Y.P.) 2 to

3 summers

200

\section{BARK.}

O Chermes coccincus. A. (P.\& T.) 364

*IIylobius abietis. I. (Y.P.)† ... 225

O Lecanium spp. A. (Y.P. \& P.) 367

Pissodes piccae. I. P. ........ 235

O Strophosomus obesus. I. (Y.P.) +220

\section{Cambium.}

Hylastes palliatus. I. \& L. (V.G.) (P. \& T.) ............ 262

Pissodes piceae. L. (P. \& T.)... 23ว

Tomicus chalcographus. I. \& L. (S.G.) (P. \& T.) † $2 \pm 8$

T. laricis. I. \& L. (H.G.) (P. \& T.) $\dagger$ 251
Woop.

O IIylecoctus dermestoüdes. I. \& L. T. 216

Sirex spp. L. (P. \& 'T.)........ 355

*Tomicus lineatus. I. \& L. (L.G.) T. $25 \tilde{5}$

BuDs.

Tortrix rufimitrana. L. T. ... 340 Young SHOOTS.

O Chermes spp. A. (P.\& T.) ... 363 Strophosomus obesus. I. (Y.P.) 220 Tontrix rufimitrana. L. T. ... 340

\section{NEEDLES.}

*Liparis monacha. L. T.† ..... 310

O.Melolontha spp. I. (P.\&T.) ... 200 OStroph osomus obesus. I. (Y.P.) 220

*Tortrix rufimitrana. I. T. ... 340 Germinating Seeds.

O Agriotes spp. L. L............ 214

\section{SCOTS PINE.}

Roots.

O Dolopius marginatus. L. (Y.P.) 214 * Gryllotalpa vulgaris. A. S. ... 369 * Melolontha spp. L. (Y:P.) 2 to

3 summers 200

*Noctua vestigialis. L. S. ...... 322

*N. segetum. Id. 325

\section{BARK.}

*Hylobius abietis. I. (Y.P.) ... 225

*H. pinastri. Id. ................ 232

Lophyrus pini. L. (Y.P.\& P.) 350

L. rufus. La. .................. 35

*Pissodes notatus. I. (Y.P. \& .

P.) 233

*P. pini, Id...................... 235

*P. piniphilus. I. (P. \& T.) ... 235

Strophosomus coryli. I. (Y.P.) 220

S. obesus. Id. ................... 220

\section{Cambium.}

IIylastes palliatus. I. \& L. (V.G.) $\mathrm{T}$
*II. ater. I. (Y.P.) Near the collum........................... 263

II. opacus. Id.................. 264

*.1yelophilus piniperda. I. \& L. (V.G.) Trees of all ages ... 265 * $M$. minor. I. \& L. (H.G.) Trees of all ages ............. 271 * Pissodes notatus. L. (Y.P.\& P.) 233 P. pini. Id. .................... 235 *P. piniphilus. L. (P. \& T.) „. 235 OTomicus typographus. I. \& L. (V.G.) T.† .................. 238

$\bigcirc$ T. amitinus. I. \& L. (F.G.) \& (S.G.) T. $\dagger$.................... 246

OT. chalcographus, I. \& L. (S.G.) (P. \& 'T. $)$.................... 248

*T. stenographus. I. \& L. (V.G.) T.............................. 250

*T. laricis. I. \& L. (V.G.) (P. \& T.) 251

*T. bilentatus. I. \& L. (S.G.)

Trees of all ages .............. 253 T.acuminatus. I. \& L. (S.G.) T. 255 
WooD.

Sirex jureneus. L. (P. \& T.)

2 summers

S. gigas. Id...................... 357

Tomicus lineatus. I. \& $\mathrm{L}$.

(L.G.) (P.\& T.) † .....

BuDs.

* Gastropacha pini. L. (P.\& T.) 294

Liparis monacha. Id. ........ 310

*Tortrix buoliana. L. (Y. P.\& I'.) 335

T. turionana. Id. 338

\section{YouNG SHOOTS.}

Ernolsius nigrimus............... 217

Hylobius abietis. I. (Y.P.\& P.) 225

H. pinastri. Id. ................ 232

* Myelophilus piniperda. I. Pith

of trees of all ages ........... 265

*M. minor. Id. .................. 271

*Tortrix buotiana. L. Pith of

trees of all ages .............. 335

T. turionana. L. (Y.P. \& P.) 338

$\bigcirc T$. resinella. L. 2 years. (Y.

P. \& P.) Resin-galls 339

\section{NEEDLES.}

*Gastropaeha pini. L. (P. \& T.) 294
PAge

* Geometra piniaria. L. (P.\& T.) 326

*Liparis monacha. I. (Y.P.)

(P. \& T.) .................... 310

*Lophyirus pini. L. (Y.P. \& P')

Social ........................... 350

*L. rufus. Id. ................... 354

* Voctua piniperda. L. (P. of T.) 320

N. restigialis. L. (Y.P.) ..... 322

O lihizotrngus solstitialis. I. (P.

\& ' $\mathrm{T}$.)

Strophosomus coryli. I. (Y. P.) 220

S. obesus. Id. .................. 220

S. limbatus. Id. ................ 220

INFLORESCENCE.

O A nobium abietis. I. .......... 217

O Melolontha vulgaris. I. (P.

\& T.) 200

\section{Germinating Seeds.}

O Agriotes spp. $\quad$ L 214

The above-mentioned insects also attack other species of pines, such as P. Strobus, Laricio, Cembra, montana; but none suffers so much as $P . s y l$. restris.

\section{LARCH.}

RooTs.

* Gryllotalpa vulgaris. A. S. ... 369

*Melolontha spp. L. (Y.P.). 2

to 3 summers ................... 200

Noctua restigialis. L. S........ 322

BARK.

Chermes larieis. A. Trees of all ages ....................... 365

Hylobius abietis. I. (Y.P.)† ... 225

H. pineti. I. (Y.P.) ........... 232

Pissodes notatus. I. (Y.P. \& P.) 233

\section{Cambium.}

Pissodesnotatus. L. (Y.P.\& P.) 233

*Tomicus typograplius, I. \& L. (V.G.), T.†................. 238

*T. amitinus. I. \& I. (F. or S.G.) 'T. 246
T. chalengraphus. I. \& L. (S.G.)

(P. \& T. ) .................... 248

T.laricis. I. \& L. (V.G.), P.\&'T. 251 WOOD.

Sirex jurencus, L. T. .......... 355

Tomicus lineatus. I. \& $\mathrm{L}$.

(L.G.) T. $† \ldots \ldots \ldots \ldots \ldots \ldots \ldots . . \ldots 255$

BUDs.

Cecidomyia kellneri. L. Trees of all ages 361

\section{NEEDLES.}

O Chermes laricis. A. (Y.P. \& P.) 365

* Coleophora laricella. L. (Y.P.

\& P.) 346

Jiparis monacha. L. (P. \& T.) 310

O. Melolontha spp. I. (P. \& T.) 200

Nematus eriksoni. L. (Y.P.) 354

Noctua restigialis. I. (Y.P.) 322

Tortrix pinicolana. I. T. ..... 341

(i eRMinating SEeds.

Agriote's spp. .................... 214 


\section{BEECH.}

Roots.

Gryllotalpa vulgaris. A. S. ... 369

*Melolontha spp. L. (Y.P.) ... 200

\section{BARK.}

Hylubiusabietis. I. (Y.P.) †... 225

Tespa crabro. I. (Y.P. \& P.) 190

\section{Cambium.}

*Agrilus viridis. L. (Y.P.) 2

summers

211

A. angustulus. Id. †............ 213

OScolytus intricatus. I. \& L.

(H.G.) P. and branchest ... $27 \mathrm{~S}$

\section{WOOD.}

Cossus aesculi. L. (Y.P.) 2

summers

293

O Hylecoetus dermestö̈des. $\quad$ L. T. 216

Tomicus domesticus. I. \& L.

(L.G.) T. 258

T. dispar.

I. \& I. (F,G.)

(Y.P.)

259

Xestobium tesselatum. I. \& L. T. 217

\section{BUDS AND LEAVES.}

PAGE

O Apoderus coryli. I. \& L. (Y.P.)

Leaf-rolling ................ 218

*Bombyx pudibunda. L. (P.

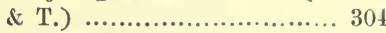

B. chrysorrhoea. Id........... 308

OB. similis. L. (P. \& T.)........ 309

O Hibernia defoliaria. L. (P.\& T.) 331

*Liparis 'monacha. L. (P.\& T.) 310

Melolontha spp. I. (P.\& T.)... 200

Orchestes fagi. I. \& L. (Miner).

Trees of all ages ............. 221

Phyllobius spp. I. (Y.P.)..... 220

O Rhizotrogus solstitialis. I. (P.

$\&$ T.) $\ldots \ldots \ldots \ldots \ldots \ldots \ldots \ldots \ldots . . . . . . . .210$

O Rhynchites spp. I. \& L. (Y.P.)

Leaf-rolling ................... 219

Strophosomus caryli. I. (Y.P.) 220

S. obesus. Id. .................. 220

\section{Fruits.}

Athous haemorrhoidalis. I. ... 214

Orchestes fagi. I. Unripe fruits 221

\section{OAK.}

Roots.

O Cynips spp. I. \& L., Galls ... 358 Gryllotalpa vulgaris. A. S. ... 369 *Melolontha spp. L. (Y.P.), esp.

S. 200

\section{BARK.}

О Coccus spp. A. (Y.P. \& Р.) ... 366 O Cynips spp. I. \& L. Galls ... 358 OHylubius abietis. I. (Y.P.)†... 225 Vespa crabro. I. (Y.P. \& P.) 190

\section{Cambium.}

Agrilus viridis. L. (Y.P.) $† 2$ summers

*A. angustulus. Id. ............. 213

Hylesinus crcnatus. I. \& L. (H.G.), T. 275

Scolytus intricatus. I. \& L. (H.G.). P. and branches ... 278
WOOD.

Cossus ligniperda. L. T. 2 summers ...................... 291

O C. asculi. $\quad$ L. (Y.P.)...... 2

summers ........................ 293

O Hylecoetus dermestoüdes. $\quad$ L. T. 216

Lymcxylon narale. L. T. ..... 215

*Tomicus dispar. I. \& L.

(F.G.), (Y.P.) .............. 259

O Xestubium tesselatum. I. \& L. T. 217

\section{Buds AND Leaves.}

*Bombyx neustria. L. P. \& T. 302 B. chrysorrhoea. L. (P. \& T.) 308 ○ Cynips spp. I. \& L. Galls.... 358

* Geometra brumata. L. (P.\& T.) 329 Hibernia defoliaria. L.(P.\&T.) 331 О Phyllobius spp. I. (Y.P.)..... 220 Strophosomus spp. I. (Y.P.)... 220 *Tortrix vividana. L. (P. \& T.) 333 
Leaves.

OApoderus coryli. I. \& I. (Y.P.)

Leaf-rolling

PAGE

O Attelubus murculimoides. Id. 219

Bombyx mudibunda. $\mathrm{I}_{4}$ ( $\mathrm{P}$.

\& T.) ....................... 304

Liparis monacha. I. (l'. \& D.) 310

* Melolontlua spp. I. (P. \& T.)... 200

Oorchestes quercus. I. \& I.

Suppressed growth ........... 223

(See preceding section.)

Young SHOOTS.

Corymbites spp. I. (Y.P.) .. ... 215
OCynips spp. .I. \& L. Galls... 358 IIylobius alretis. I. (Y.P.) †... 225

Lacon murinus. I. (Y.P.) ...... 215

*Pachytylus migratorius. I.

(Y.P.)....................... 372

Strophosomus spp). I. (Y.P.) ... 220

Telephorus obscurus. I. (Y.P.) 184

\section{ACORNS.}

Agriotes lineatus. I. ........... 214

A. obscurus. Id. ................ 214

Athous huemorrhoidalis. L. ... 214

Balanimus glandium. I. \& L. 221

O Cynips spp. I. \& L. Galls. ... 358

\section{HORNBEAM.}

Roots.

*.Nelolontlla spp. L. (Y.P.) ... 200

WOOD.

Tomicus dispar. I. \& L. (F.G.), (Y.P. \& P.)......... 259

O Testobium tesselatum. I. \& L. 'T. 217

\section{Buds AND Leaves.}

*Bomby.x neustria. I. (P.\& T.) 302 B. similis. Id.................... 309

* Geometra brumata. Id........ 329 Ilibernia defoliaria. Id. ...... 331

\section{LEAVES.}

Bombyx pudibunda. L. (P. \& T.) ........................... 304

*B. chrysorrhvea. Id. ........... 308

Liparis monacha. Id........... 310 Melolontha spp. I. Trees of all ages ....................... 200 ORhizotrogus solstitialis. Id. ... 210 (See preceding section.)

\section{Fruits.}

Athous haemorrhoidalis. L.... 214

\section{ELM.}

Roots.

Gryllotalpa vulgaris. A. S. ... 369

*.Melolontha spp. L. (Y.P.) ... 200

\section{Самвium.}

O IIylesinus rittatus. 1. \& L. T. 275 Scolytus. I. \& I. (I.G.) (P. \&

T.) 277
WOOD.

Cossus ligniperda. L. (P.\& T.)

2 summerst ................... 291

C. aesculi. L. (P. \& 'T.) ........ 293

\section{BUDS AND LEAVES.}

Bombyx neustria. L. (P.\& T.) 302

B. chrysorrhoea. Id. ........... 309

B. similis. Id................... 309

IIbernia defoliaria. Id. ...... 331

\section{ASH.}

RooTs.

${ }^{*}$ Helulontha splp. L. (Y.P.) ‥ 200
BARK.

Vespa crabro. I. (Y.P. \& 1')

On young shoots 190 
CAMBIUM.

*Iylesinus fraxini. I. \& L.

PAGE (H.G.) (P. \& T.) Bark rosettes 273

H. crenatus. I \& L. (H.G.) T. 275 Sculytus Geoffroyi. I. \& L. (F.G.) (P.\& T.) † ........... 277

WooD.

Cossus ligniperda. L. (P. \& T.). 2 summer s............. 291

C. aesculi, L. (Y.P.). 2 summers 293
PAGE I. I. \& L. (F.G.) (Y.P. \& P.) . ........ 259

\section{BuDs.}

Tinea curtisella. I. (Y.P. \&

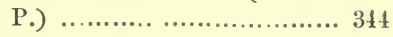

\section{LEAVES.}

Melolontha spp. I. Trees of all ages ...................... 200

*Pachytylus migratmrius. I. (Y.P.) ....................... 372

\section{MAPLE.}

Roots.

*.Velolontha spp. L. (Y.P.) .. 200 Wood.

Cossus ligniperda. L. (P. \&

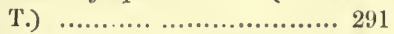
* $C$. aesculi. L. (Y.I'.) 2 summers ..................... 292

O Hylecoetus dermestö̈des. L. T. 216 Tomicus domesticus. I. \& L. (L.G.) T. 258
T. dispar. I. \& L. (F.G.) (Y.P. \& P.)

O Xestobium tesselatum. 1.\& L. T. 217 LEAVES.

* Melolontha spp. I. Trees of all ages ....................... 200

Bombyx pudibunda. L. (P.

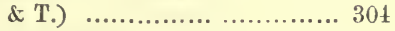

B. chrysorrhoea. Id........... 308

Liparis monacha. Id.......... 310

\section{ALDER.}

Iioots.

*.Velolontha spp. L. (Y.P.) ... 200 BARK.

Cryptorhynchus lapathi. I. (Y. P.) 223

Vespa crabro. I. (Y.P. \& P.) 190 CAMBIU⿴囗十

Agrilus viridis. L. (Y.P.) 2 summers

WoOD.

O Cossus ligniperda. L. T. 2 summers....................... 291

OC. aesculi: L. (Y.P.) 2 summers 293
*Cryptorrhynchus lapathi. L. (Y.P. \& P.)................... 223 Tomicus dispar. I. \& L. (F.G.) (Y.P. \& P.).................... 259 O Xestobium tesselatum. I. \& L. T. 217

LEAVES.

OApoilerus coryli. I. \& L. (Y.P.) Leaf-rolling $\dagger \ldots \ldots . . . \ldots \ldots \ldots . . . .218$ Bombyx pudibunda. L. (Y.P.

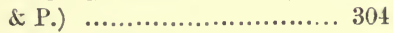

Liparis monacha. Id........... 310

Rhynchites spp. I. \& L. (Y.P.)

Leaf-rolling† ................. 219

\section{POPLAR.}

Roots.

*Melolontha spp. L. (Y.P.) ... 200
BARK.

Cryptorrhynchus lapathi. I. (Y.P.) ...................... 223 


\section{CAMBiUm.} summers. (Aspen.)........... 211

OA. sexguttatus. L. T. 2 summers.

\section{WOOD.}

Cossus ligniperda. L. P. \& T.

2 summers 291

C. aesculi. L. (Y.P.) $\dagger 2$ summers ........................ 293

Cryptorrhynchus lapathi. $\quad$ L. (Y.P.) 223

* Sapcrda carcharias. L. (Y.P. (E P.) 2 summers............. 280 S. populnea. Id. Branches... 282 Sesia apiformis. Id. ........... 289
BuDs.

PAGE

O Bomby.x neustria. L. (P. \& T.) 302

\section{LEAVES.}

Bomby neustria. I. (P. . T T.) 302 OB. chrysorthoea. Id. ........ 308

Clurysomela populi. I. \& L. (Y.

P.) (stool shonts) ............. 28t

C. tremulae. Id. ................ 285

C. vulgatissima. I. \& $\mathrm{L}$. (Y.P.) † ..................... 286

O Liparis monacha. L.(P.\& T.) † 310 Melolontha spp. I. (P. \& T.)... 200 Rhizotrogus solstitialis. Id. ... 210 Rhynchites spp. I.\& L. (Y.P.)

Leaf-rolling .................. 219

\section{WILLOW.}

Roots.

*.Melolontlia spp. I. (Y.P.)..... 200

BARK.

Cryptorrhynchuslapathi. I. (Y.

P. \& P.) $22: 3$

Vespa crabro. I. (Y.P.)........ 190

\section{WOOD.}

Cccidonyia saliciperda. $\mathrm{L}$. Gall-like swellings ........... 360 * Cossus ligniperda. L. (P.\& T.) 2 summers .................... 291 C. aesculi. L. (Y.P.) Osiers. 2 summers...................... 293 Cryptorrhynchus lapathi. L. (Y. P. \& P.) 223

Saperda carcharias. L. (Y.P.

\& P.) 2 summers 280

S. populnea. Id. 282

\section{BuDs.}

Bombyx neustria. I. (P. \& T.) † 302 O B. chrysorhoea. L. P. \& T. ... 308 B. similis. Id. .................. 309 YouNG SHooTs.

Ilalias chlorana. L. (Y.P.) Osiers 332

\section{LEAVES.}

O Bombyx neustria. L.† ........ 302 B. chrysorthoea. L. ........... 308 Chrysomela populi. I. \& L.(Y.P.) 284

C. tremulae. Id. ................. 28a

*C. vulgatissima. Id. ........... 286

Halias chlorana. L. (Y.P.)

Terminal leaves bound together ........................... 332

Liparis monacha. I. Sallow 310 O Melolontha spp. I. ............. 200 †Rhizotrogus solstitialis. I...... 210

\section{BIRCH.}

Roots.

Gryllotalpa vulgaris. A. S. ... 369

* Melolontha spp. L. (Y.P.) ... 200

\section{BARK.}

Vespa crabro. I. (Y.P. \& P.) 190
Cambium.

Agrilus viridis. I. (Y.P.) 2 summers

\section{WOOD.}

Cossus ligniperda. L. (P.\& T.)

2 summers 
PAGE:

C. aesculi. L. (Y.P.) 2 summers 293

O Hylecoetus dermestoïdes. L. T. 216

Tomicus dispar. I. \& L.

(F.G.) (Y.P. \& P.) .......... 259

T. domesticus. I. \& L. (I, G.) $\mathrm{T}$. 258

LEAves.

Bombyx pudibunda. L. (P. \& T.) 304 similis. L. (P. \& T.)........ 309

Hibernia defoliaria. Id........ 331

Liparis monacha. Id............ 310

Melolontha vulgaris. I. Trees

of all ages ..................... 200

ORhynchites betulae. I.\& L. (Y.

P.) Leaf-rolling ............. 219

OR. betuleti. Id. ................ 219

Strophosomus spp. I. (Y.P.)... 220

15. LIME.

Wood.

O Cossus ligniperda. L. (P. \& T.)

2 summers .................... 291

C. aesculi. L. (Y.P.) 2 sum-

mers ......................... 293

Tomicus domesticus. I. \& L.

(L.G.) T.† 258
BUdS AND LeAves.

OBombyx similis. L. (P. \& T.) 279

Geometra brumata. L. (P.\& T.) 329

Hibernia defoliaria. Id. ...... 331

LEAVES.

Liparis monacha. L. (P. \& T.) 310

\section{ROBINIA.}

\section{Roots.}

Elateridae spp. L. .............. 214 । Melolontha spp. L............. 200

\section{HAZEL.}

BARK AND SAPWOOD.

Agrilus angustults. L. 2

summers

213

Buds AND LEAves.

Balaninus nucum. I. .......... 221

Geometra brumata. L. ........ 329

Strophosomus spp. I.............. 220

\section{Young SHOOTs.}

ORhynchites betuleti. I. \& L.... 219

Strophosomus spp. I. ......... 220
LEAVES.

OApoderus coryli. I. \& L. Leafrolling........................... 218

Liparis monacha. L. .......... 310

ORhynchites spp. I. \& L. Leafrolling......................... 219

\section{Fruits.}

Athous haemorrhoidalis. L.... 214

Balaninus nucum. I. \& L...... 221

B. glandium. I. \& L.† ........ 221

In concluding this Chapter, it is desirable to impress strongly on the forester the necessity for a careful study of forest insects. Inattention to these little creatures has already in many cases been severely punished by the sacrifice of the labour of years. It must not be imagined that insects 
always attack in a secondary manner, that is, after a plant has been weakened by previous injury or disease, nor must the danger arising from them be under-estimated, and this is especially important as regards coniferous forests.

The most effective means for combating insect attacks consist in careful and cleanly forest management, and in repressing an attack at its very commencement; once it has attained large dimensions man's efforts against it are almost powerless. In order that his attempts at repression may be successful, the forester must know the life-history and relations to the forest of injurious insects; for this purpose mere book-learning will not suffice, but must be supplemented by careful and continuous observation in the forest.

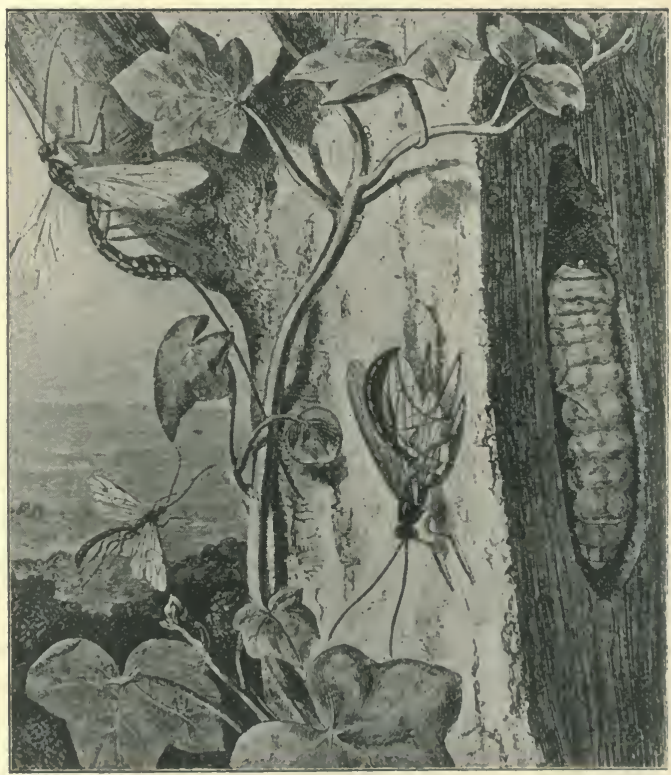

FiG. 194.-Ichneumons (Pimpla manifestator). $\delta$ in flight, $\&$ on tree. From "Cassell's Natural History." 


\section{PART III.}

PROTECTION AGAINST PLANTS. 



\section{PROTECTION AGAINST PLANTS.}

Plants injurious to forests are either weeds that cover the soil, or climbers and parasitic phanerogams or fungi, which attack trees and forest plants. The following sections will contain an account of these dangerous enemies of the forest.*

* Books for reference on forest botany are: Döbner, Dr. E. Ph., "Lehrbuch der Botanik für Forstmänner." Berlin, 1882. Schwartz, Dr. F., "Forstliche Botanik." Berlin, 1892. Thaer, Dr. A., "Die landwirthschaftlichen Unkıäuter." Berlin, 1893. Capital illustrations and directions how to exterminate weeds. The systematic names of the weeds are taken from Bentham and Hooker's

"British Flora," 5th edition, 1887. 


\section{CHAPTER I.}

\section{PROTECTION AGAINST FOREST WEEDS.}

Section I.-General Account.

\section{1)efinition of the term Forest Weed.}

'T'He term forest weed usually comprises wild plants, which by their vigorous growth in masses more or less retard the development of young forest plants. By extending the meaning of the term, shrubs, and even many otherwise useful trees, may be included, which when young injure the growth of the principal local forest species. When, for instance, sallows or aspens spring up in large numbers in beechwoods, or birches among conifers, or even the hardy and fruitful hornbeam in the pole stage competes too freely with beech, it becomes necessary to remove these inferior species in cleanings. More detail on this point is given in sylviculture; it may, however, be noted here that the most numerous and dangerous forest weeds are woody plants of more or less rapid height-growth, the most bushy ones, and those producing rootsuckers being the worst. In Burmese teak forests, bamboos which grow to heights of fifty feet and more within a few weeks, may render teak reproduction impossible, until the bamboos seed gregariously and die, or are killed by fires.

\section{Classification of Forest Weeds.}

In classifying forest weeds, the forester should be guided by the following points:-

(a) Structure of the stem.

(b) Duration of life of the weed.

(c) Local occurrence.

(d) Preference for any particular soil.

(e) Amount of mineral matter in its ash.

(f) Demands as regards light and shade. 
(g) Kind of injury done.

(h) Relative amount of injury.

It is highly interesting to note the changes which take place in the constituents of the soil-covering in a forest according to the species of tree grown, and the degree of density of the cover.

\section{a. Structure of Stem.}

Weeds may be either woody or herbaceous. To the former class belong broom, heather, bilberry, hawthorn, blackthorn, brambles, elder, etc. : to the latter, willow-herbs, groundsell, belladonna, foxglove, grasses (except bamboos), sedges, reeds, and rushes.

\section{b. Duration of Life.}

Weeds may be either annuals, biennials, or perennials.

Most herbaceous plants, except some grasses, are annuals. Mullein (Verbascum) and foxglove are biennials, producing foliage in the first year and flowers and fruit in the second year. This class is, however, rare among forest weeds, and all woody plants and the rootstocks of many herbaceous plants are perennials.

\section{c. Local Occurrence.}

Forest weeds may be classed as belonging to the plains, to swamps, hills, or mountains. Of these, the flora of swamps and of high mountains are most specialised.

\section{d. Nature of Soil.}

Weeds may be partial, or restricted to certain soils, or indifferent as to soils.

The restricted class is divided into plants special to sand, clay, loam, calcareous soil, or to peaty and sour soils. It should, however, be remembered that the plants produced in any locality are affected by the subsoil and surrounding conditions as well as by the surface-soil, so that we must not be surprised if a sandy soil, for instance, occasionally produces plants peculiar to other soils.

Most forest weeds are indifferent as to soil, and appear on soils differing from one another both physically and chemically. 
On sandy soils we find chiefly ling (Calluna vulgaris, Sal.) and heather (Erica), broom (Cytisus scoparius, Link.), lymegrass (Elymus arenarius, L.), maram-grass (Psamma arenaria, Beauv.), sand-sedge (Carex́ arenaria, L.); Festuca glauca, Schrad.; Panicum glabrum, Gaud. ; etc.

On clay soils: coltsfoot ('T'ussilago Farfara, L.), woundwort (Stachys palustris, L.), marestail (Equisetum), cottongrass (Eriophorum), rushes (Juncus).

On loam, on account of its favourable nature, very numerous weeds abound, such as all good meadow-grasses, bindweed (Convolvulus), Veronica, etc.

Calcicolous weeds are Viburnum Lantana, L. (way faringtree; rock-rose (Helianthemum vulyare, Gaertn.) ; Stachys germanica, L.; Rubus saxatilis, L.; many Papilionacee, and of grasses, Melica and Sesleria.

On rich humus soil: raspberry (Rubus Idaeus, L.), balsam (Impatiens Noli-me-tangere, L.), hemp-nettle (Galeopsis Tetrahit, L.), black night-shade (Solanum nigrum, L.), etc.

On peats: we find mint (Mentha pulustris, L., etc.); bog myrtle (Myrica Gale, L.) ; Vaccinium uliginosum, L.; Carex, Eriophorum, Juncus, Scirpus, lousewort (Pedicularis), dock (Rumex), loosestrife (Lythrum Salicaria, L.), peat-moss (Sphagnum, sp.), etc.

On saline soils : sea milk-wort (Glaux maritima, L., Plantago maritima, L.), samphire (Crithmum maritimum, L.), marshsamphire (Salicornia herbacea, L.), salt-wort (Salsola Kali, L.), Armeria vulgaris, Willd.; sea-lavender (Statice), sea-holly (Eryngium maritimum, L.), maram-grass, etc.

\section{e. Mineral Substances in Ashes of Weeds.}

'Ihe mineral character of the soil on which plants will thrive cannot be decided by the quantity of any substance such as silica, calcium carbonate, or sodium chloride, which may be found in their ashes. Different parts of the same plant also contain different proportions of chemical substances. Thus, there is much silica in the stem of grasses, and more phosphates and potash in their seeds.

The physical nature of the soil, i.e., its degree of moisture, 
capacity for being heated, porosity, etc., has more influence on the growth of plants than its chemical composition, though the latter has an indirect influence on the physical nature of soils.

In the strife between weeds and cultivated plants, the former gain ground by the easy dissemination of their seed by wind, water, or birds, as well as by their superiority in the struggle for light and for space for their roots. If cultivation of the fields were to cease in Europe, it is certain that, in 100 years, only grassland, forest, or swamp would be found, according to the degree of humidity of the soil.

\section{f. Demands as to Light.}

Plants are termed lightdemanding or shadebearing according to their relative demands for light, or capacity for bearing shade.

Heather is a decidedly lightdemanding plant, bilberry (Vaccinium Myrtillus, L.), a half shadebearer: the holly, juniper, and Daphne are shadebearing plants, as they flourish in dense woods. Ivy (Hedera Helix, L.) and butcher's broom (Ruscus aculeatus, L.) are also even more shadebearing.

\section{g. Kind of Injury done.}

Weeds may overtop young trees and deprive them of light and dew; they may constrict them, as in the case of the woodbine, or, like the bindweed, completely stifle them by growing over them; they may smother and bend them down -when pressed on them by snow, as dead bracken; or, like the peat-moss, Sphagnum, cause swamps. Some weeds, such as bilberry, may form a dense mat with their roots, so that natural regeneration of trees may be obstructed.

\section{h. Degree of Injury done.}

Weeds may be classed as very injurious, injurious, or only slightly injurious. Many forest weeds are either technically or indirectly useful, as will be explained in the next paragraph. 


\section{Utility of Certain Weeds.}

Some weeds are directly or indirectly useful in woods.

Many weeds, such as grasses, are directly useful for fodder, thatch, or litter, or may be used by manufacturers, or for medicine. A full account of such plants is given under Forest Utilisation. The fruits of many shrubs afford useful food for men, mammals, and birds.

Weeds may also be indirectly useful in the following ways :-

(a) Soil-indicators. Giving evidence of certain physical or chemical qualities of soils.

(b) Soil-fixers. Binding the soil on steep slopes, or on shifting sands (sand-fixing grasses).

(c) Soil-improvers. Enriching the soil with their detritus, and maintaining its moisture, reducing radiation, and especially by preventing extremes of temperature in the surface soil (mosses), other than Polytrichum and Sphagnum.

(d) Nurses, for young tender species in localities exposed to frost, dry winds, or insolation. Thorny bushes and weeds of an erect habit, such as the broom, are most useful in this respect. Thorny bushes also protect all kinds of forest plants against grazing animals or deer, and afford shelter to useful birds.

On these grounds forest weeds should not always be extirpated, but only when they do more harm than good.

\section{Damage done by Forest Weeds.}

\section{A. General Nature of Damage.}

The damage done by forest weeds is either direct or indirect, many weeds being hurtful in both ways.

Directly injurious are poisonous plants, such as Daphne Mezereum, L., nightshade, or belladonna, which are hurtful to animals grazing in the forests. A dense growth of blackthorn, roses, brambles, etc., is also a great hindrance to fellings, and may therefore be considered directly hurtful.

The indirect hurtfulness of weeds is due to the following causes:- 
i. The matted roots of many weeds increase the difficulty of reproduction of the forest, as in the case of heather, bilberry, and couch-grass.

ii. The removal of valuable mineral matter from the soil, which thus becomes impoverished, for instance, of potassium phosphate in grass-seeds.

iii. Mechanical injury to young forest plants by birch, aspen, sallow, grasses, etc., owing to deprivation of light, heat, air, dew, or rain. Lightdemanding plants are thus soon killed, and even shadebearing species cannot long withstand such injuries.

iv. Injuries by smothering or constricting plants, as, in summer, by honey-suckle, clematis, convolvulus, wild hops, etc. In winter, by being pressed down on the plants by snow; bracken, tall grasses, etc.

v. Retention of excessive moisture in the surface-soil during wet weather, and formation of swamps; consequent increase of damage by frosts : all peat-plants, and especially Sphagnum, increase the swampiness of the soil.

vi. A dense growth of grass or weeds may prevent dew or light rains, which merely dry off the surface of the weeds, from penetrating the soil, and is thus very hurtful to plantations and sowings during droughts. This may be easily proved by digging up a sod and examining the soil beneath it. Besides excluding moisture from the soil, the grasses, etc., draw up the soil-moisture from below and transpire it into the air, so that the denser the growth of grass, the drier the soil becomes.

vii. Certain plants produce a sour or dry humus which is unsuitable for most forest trees: this is the case with heather, reeds, and other sour grasses, sedges, etc.

viii. Shelter is afforded by grass and herbage to mice and insects.

ix. Weeds and especially heather, increase danger from forest fires.

x. Parasitic plants, other than fungi, that remove sap from forest plants. They may be classified as follows:-

a. Parasites germinating and growing in the living tissues of their hosts (mistletoe and Loranthus). 
$\beta$. Parasites, such as dodder (Cuscuta), germinating on the ground, but eventually attaching themselves to forest plants.

$\gamma$. Parasites nourished partly by their own roots, and partly by attaching themselves to useful plants. Broomrape (Orobanche) on broom, furze, ivy, hemp, lucerne, etc. Lathraea squamaria, L., on the roots of trees, especially hazel.

xi. Epiphytes. Lichens do not remove sap from forest plants, but live on water, air, and rotting bark, but when attached to trees they are injurious by blocking the lenticels and preventing necessary aëration of the internal tissues. 'They harbour numerous insects, and increase the weight of snow on the crowns of trees during winter. Trees with rough bark, such as spruce, larch and pines, are most subject to attacks of lichens, which increase in number with the age of their hosts. The branches are more subject than the boles to these attacks.

Incrustating lichens, such as Imbricaria, Hatysma, and Lecanora are worse than beard-like lichens, Usnita, Evernia, and Alectoria. Jichens do most damage in moist valleys and in crowded woods.

xii. Some weeds serve as hosts to injurious fungi, which may afterwards spread to forest trees or to agricultural crops. Many parasitic fungi are most frequently found on weeds, or attack agricultural crops only after passing one stage of their existence on a weed.

Thus, certain grasses-o.g., Arrhenatherum and Arenaspread certain kinds of rusts on to cereal crops, such as Tilletia caries, Tul., and Ustilago carbo, Tul. Puccinia graminis, Pers., on wheat comes from Aecidium Berberidis on the barberry; and oat-rust ( $P$. coronata, Corda) from buckthorn. Foresters should always look with suspicion on any fungus appearing on wild plants.

\section{B. Special Forms of Damage done by Weeds.}

The amount of damage done to forests by particular weeds depends on their wide dissemination and on the vigour and special nature of their growth. These are determined chiefly 
by the locality, the prevailing system of forest management, and the state of the weather during the growing season. In the second place, by the species of tree and age of crop.

Weeds are disseminated chiefly by winds which carry light seeds and fruits by millions, as, for instance, the fruits of Composite; many birds, especially thrushes and blackbirds, disseminate seeds either by pecking at the ripe fruit-heads and causing the wind to disperse the seeds, or by eating the fruits and voiding the indigestible seeds. This is especially the case with hawthorn. Other birds, such as finches, eat the seeds of many weeds and are so far serviceable. Hares, deer, and other animals also carry seeds about in their fur. The seeds of many riparian plants are carried down by streams and inundations.

i. Damage according to Species of Tree.

Slowly growing species are more easily injured by the growth of weeds than fast-growing ones, and of these, lightdemanding species suffer most. The vigour of the weeds is greatest on the most fertile soils.

The following scale shows the degree in which the different trees suffer from a strong growth of herbage.

Suffer most:-Osier-willows, elm, ash, maples, sweet chestnut, silver-fir, and spruce.

Suffer less :-Beech, hornbeam, and lime.

Suffer still less:-Oaks, alder, tree-willows, Scots and Black pines, and larch.

Suffer least:-Birch, aspen, poplars, sallows, robinia, species of Sorbus, Pyrus, Prunus, and Weymouth pine.

This scale, of course, will vary for different localities which suit certain trees better than others.

\section{ii. Systems of Management.}

In high forests with natural regeneration, or artificially planted under cover, the soil is not so liable to become covered with weeds as in the clear-cutting system, which favours the spread of weeds in the highest degree. The shelterwood compartment system, also, if not very carefully managed, sometimes gives rise to masses of weeds on the felling-areas.

On fresh, and especially damp, rich soils, after a clearcutting, a dense growth of grass and weeds springs up in a 
surprisingly short time. Thus, foxgloves and groundsel on sandstone rock; balsams and willow-herbs on basalt; brooms and genista on sandy soils-spring up in masses after a felling. This can be explained only by a supposition that the seeds of these weeds remain dormant in the soil, and germinate only when the removal of the trees allows enough heat and air to reach them.* Jhuming, or the thorough burning of branchwood on the soil, after a clear-felling, may destroy seeds of weeds in the upper layers of the soil, and thus keep it free from weeds until it has been restocked with forest growth.

\section{iii. AGE OF WOOD.}

Forest trees are most endangered by weeds in the first few years of their life. Forest nurseries and cultivations, therefore, suffer most of all, and of these, sowings and natural regeneration-areas more than plantings. Where weeds abound, very small transplants should not be used, and frequently four or five-year-old plants are preferable.

Some poles and coppice-shoots, and especially osier-willows, are attacked and frequently killed by climbers and parasites.

In tropical countries, trees of all ages are liable to be killed by the strong woody climbers and twiners (lianes) which abound in the forests of these regions and attain several feet in girth. These lianes may mount to the top of the highest trees, depriving their crowns of light and bending down and breaking poles with their weight. The twiners also constrict trees, moulding their stems into corkscrew shapes, and in the case of trees with a sapwood, the passage of sap may be so interfered with, that the trees are killed.

\section{iv. LOCALITY.}

Fertile, fresh, and moist soils, especially on basalt, produce more weeds than soils over dry sandstone rock. Damp air also favours the growth of weeds, as can be seen from the vigorous weedy growth on mountains. Fortunately, on good soils, the growth of forest trees also enables them to get out of the reach of the weeds sooner than in unfavourable localities.

* "Culturversucbe mit ruhenden samen," Centrallblatt f. d. ges. Forstwesen, 1894, p. 133. 
v. Density of Forest Growth.

The growth of weeds which have taken possession of the soil after a felling, makes way for a covering of moss, needles or dead leaves, after the forest has been reconstituted. When age again begins to open out the wood, or when, owing to bad management, or to accidents, thin places and blanks appear, weeds reappear in direct proportion to the amount of light admitted to the soil.

vi. WEATHER.

Damp warm years are most favourable to a growth of weeds, and during such years tender forest species require little or no shelter. Hence for both these reasons weeds are then most hurtful.

vii. Habit of the WeEDs.

Perennial weeds, and especially those which produce rootsuckers, are much worse than annuals. Also those with dense foliage and those which are social over extensive areas, or gregarious in patches, injure forest plants more than scantily foliaged and solitary growing weeds. Species such as blackthorn, aspen, and forest-willows soon get the upper hand of other weeds.

Weeds which by their decomposition yield dry or acid humus are also hurtful, as they produce soil unsuitable for forest vegetation. Dry humus formed of lichens, etc., contains little carbon dioxide, easily crumbles, decomposes with difficulty, and absorbs very little water. Acid humus, on the other hand, formed by sedges and peat-plants, injures by exhaling marsh-gas, and by containing certain organic acids that are detrimental to tree-life.

\section{Protection against Weeds.}

a. Preventive Measures.

The following rules for keeping down forest weeds should be observed:-

i. Maintenance of the Density of the Forest.

Great care must be taken in the shelterwood systems, on soil liable to become weedy, that the fellings are not too open. The seeding-fellings must be dark, and the secondary fellings 
made gradually. All blanks should be speedily filled in with strong transplants.

ii. Moderately Long Rotations.

Long rotations should be avoided, and woods of lightdemanding species (oak, Scots pine, or larch), should be underplanted at the right time with shadebearers (beech, silver-fir, spruce, Weymouth pine, etc.).

If a soil-protection wood is to serve its proper purpose, it must be introduced before grasses have sprung up and helped to dry the soil.

iii. Rapid Replanting of Cleared Areas.

Clear-cuttings should be rapidly restocked with strong transplants planted closely.

iv. Maintenance of Soll-Covering.

The natural soil-covering of dead leaves, needles or moss should be maintained, by keeping up a dense cover, and by preventing the removal of litter.

\section{v. Drainage.}

Drainage should be carried out on very damp localities, before they are re-stocked.

vi. Grazixg.

A dense growth of heather may be kept down by sheep. Cattle are useful in young deodar woods, with a dense growth of shrubs, which grow most luxuriantly in the Himalayas.

vii. Rules for Forest Nurserites.

Nurseries should not be too near fields. The seed-beds and nursery lines should be carefully weeded or hoed before the weeds blossom, and during rainy weather. Burned sods should be used as manure, as this destroys the seeds of weeds. Manure from old manure heaps is often full of nettle-seed, and when burnt compost is not strong enough for a nursery, artificial manures, such as basic slag, in autumn, and sodium nitrite or kainit, in the spring, should be sprinkled between the lines of plants. If farmyard manure is used, it is better to grow a crop of potatoes before restocking with forest plants. 
Spaces between plants may be covered with moss, dead leaves or sawdust. This prevents the soil from caking and retains moisture near the surface, and thus replaces completely the expensive processes of working the soil, weeding and watering. In damp places, burned compost introduces liverwort (Marchantia polymorpha, L.), but this does no harm to the plants.

\section{b. Remedial Measures.}

The nature of remedial measures to be adopted depends on the habit of the weeds, their degree of development, and the nature of the locality. The simplest measures will often suffice, but sometimes special measures must be taken as follows :-

i. In order to remove too great a soil-covering of grass and herbage, cattle may be admitted, or the weeds may be pulled up or cut down, always before the blossoming period. In very bad cases the hoe or plough may be used all over the area, and the land made to produce a field-crop before being restocked with forest growth. 'The cutting of grass and .herbage may be profitable, or the cost of the operation at least covered by the sale of the produce. The weeds when mixed with lime may be collected into heaps, and then yield valuable manure for forest nurseries, or they may be burned and their ashes spread over the soil.

ii. If the soil is covered with short woody plants they may be mowed down or pulled up, as in the case of heather ; raspberries may be simply beaten down, and softwoods, such as sallows, pulled up, or cut off at about one foot from the ground, or the woody plants may be girdled close to the ground.

This cutting should be done in July, at the height of the growing season, when the power of reproduction is least, as there is then least reserve-material in the roots and rhizomes. In coppice and coppice-with-standards, inferior species such as blackthorn should be cut out several years before the underwood is felled. Binding tightly suckers or shoots of woody weeds with wire is sufficient to kill them.

iii. To remove from trees the coating of lichens and moss which close their lenticels and deprive them of air, various 
instruments may be used, as shown in the figures; but this would only be done for specially valuable trees or in orchards. A mixture twenty parts by weight of wood-ashes with one part carbolic acid may also be used. This is boiled and smeared on the stems with a brush, and in a few days' time all the lichens will fall off. Limewater has the same effect. A mixture of $3 \mathrm{lbs}$. of blue stone, $2 \mathrm{lbs}$. of lime, and 30 gallons of water may also be used. It is best to remove lichens on dry days in spring, or autumn, as, thus, numerous injurious insects are also killed.

iv. In Indian forests, woody climbers are cut periodically,

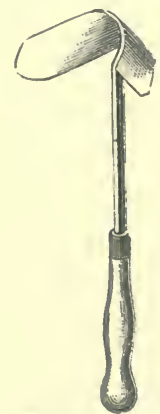

Fig. 195.-

Tree-scraper.

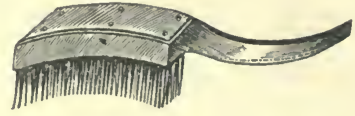

Steel. wire brush.

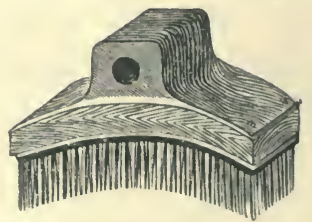

Ditto, with hole for handle.

and especially two years before fellings, as they then rot and no longer bind trees to be felled to others intended to remain standing.

\section{Section II.-Special Account.}

The following is a list of the weeds most hurtful in the forests of Central Europe, with an account of the special means of combating them. It is best to consider them in order of their demands on light and the amount of injury they do, and not according to their systematic botanical arrangement.

The following groups occur:-

1. Lightdemander's, which generally spring up on blanks and felling-areas.

2. Half-shadebearers, occurring in the interior of woods as soon as they become too light. All shrubs and herbs belonging to this class grow all the better in the open. 
3. Shadebearer's, springing up in more or less closed woods.

4. Weeds of wet or turfy soils.

5. Lianes.

6. Parasitic phanerogams.

7. Weeds acting as hosts to injurious fungi.

In each group, first the woody species and then herbaceous ones will be considered.

\section{Lightdemanding weeds.}

These weeds injure forest plants by overtopping them and excluding light and other atmospheric influences, or by occupying the soil with their roots, or in both ways. They may also produce a humus which is unfavourable to forest growth.

\section{a. Broom (Cytisus scoparius, Link.).}

This evergreen shrub attains six feet and more in height, and prefers deep sandy or loamy soil ; it springs up on clearings in mild localities, and is found throughout Europe. The seed may remain dormant in the soil for many years. It may be submerged in water for several decades without losing its germinative power. Burning undergrowth often results in the germination of dormant broom seed, and in the Ardennes, where basic slag is put on to heather soil, a dense crop of broom often results.

Broom, when not growing too densely, may be useful to young broadleaved plants, such as oak-saplings and stoolshoots, by affording them shelter against frost, but a dense growth of broom is very destructive to one- and two-year-old pine and larch sowings.

\section{Protective Measures.}

It is best to uproot the young broom at its first appearance, or it may be cut off at mid-stem, when the stems dry up and do not shoot out again. This plant, as well as all other weeds, should be removed before the seeds are ripe, in this case in July. Its removal may repay the cost, as it is used for litter, fuel, and for making brooms, hedges or thatch. It may be browsed down by sheep. In Italy, between the Alban and 
Sabine mountains, regular crops of broom are cultivated with rotations of five or six years, and used for fuel.

$$
\text { b. Furze (Ulex). }
$$

There are two species of furze common in Britain, Ulex suropaeus, L., and $U$. nana, Forst. 'The latter blossoms in the autumn, when the larger species is in fruit, the former in the spring and early summer.

In order to clear furze from tracts that are to be planted, it is best to burn it in the summer, and then cut down the burned stems. It grows slowly from the rootstocks, and a new plantation will come away from it.

There are several species of Genista, termed in England dyer's-weed, needle-furze, etc., which may be treated like broom, but are never so troublesome here as on the Continent.

\section{c. Wild Briar (Rosa).}

There are several species of wild briar, the commonest being Rosa canina, L. They spring up wherever the soil is not too wet, both in plains and hills. 'Their great power of sending out suckers renders them very injurious to forest growth, and the best way to get rid of them is to dig them up by the roots.

\section{d. Common Ling and Heather.}

Ling (Calluna vulgaris, Salisb.), Scotch heather (Evica (inerea, L.), and cross-leaved heather (E. Tetralix, L.), as well as other species of Erica, cover large areas, the first chiefly in Central and Northern Europe, the second in Western Europe, from the south of Spain to Norway, and the last to the west in Southern Europe, but in the north extending eastwards as far as Sweden and Livonia. They grow in very variable soils, but prefer sandy tracts, especially when poor and dry. A luxuriant growth of heather is a sure sign of a poor, shallow, sandy soil, or of one that may have become impoverished by bad management. Heather is injurious not only by filling the ground with its roots, and excluding atmospheric influences, but also by producing as it decays an unfavourable humus, on which only pines, birch and aspen thrive. It is highly inflammable in the spring, and when burning in dry windy weather may cause extensive conflagrations in coniferous 
forests. Heather is soon killed by the shade of trees. In Scotland, lichens fostered by the moister air produced by the shelter of tree-growth attack and destroy heather.

Heather reproduces itself chiefly by seed carried by the wind, and less by suckers and shoots.

\section{Protective Measures.}

i. Maintain a close forest growth.

ii. Graze the heather down by sheep, but this can be done only as long as the heather is young and tender. Old, tough heather will be eaten by sheep only as a last resource; they will prefer young forest plants.

iii. Cut down or mow the heather, specially strong scythes being used for the purpose. This should be done either early in spring or late in summer, in order to keep the soil somewhat protected against the heat of summer and the winter's

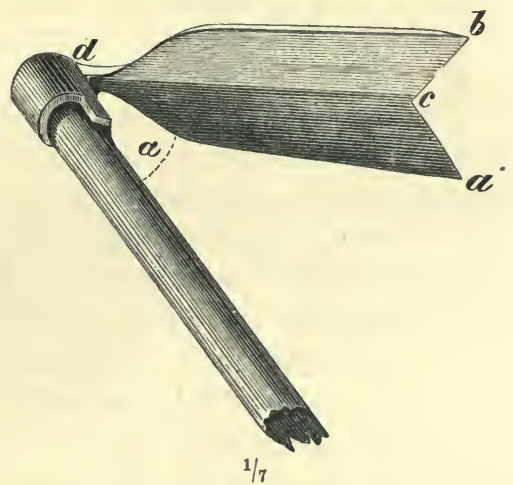

Fig. 197.

$a b=4$ inches ; $c d=10$ inches : $\left\lfloor a=60^{\circ}\right.$. cold. The material may be used as fuel, thatch or litter, or made into brooms.

iv. Burn the heather in situ. This may be done when there are no forest plants in it the destruction of which should be avoided, or immediately after a coppice felling. Fire-traces of sufficient width should be made around the areas to be burned, and the burning should be done on dry, still days in March or April, the fire being lighted to leeward, or downhill, and closely watched.

v. The ground may be stripped of sods containing the roots of the heather, and a crop of oats or rye produced, if advisable, before planting it up with Scots pine. The mineral soil must be exposed, so that the plants' roots are not in the sour humus. The instrument shown in Fig. 197 is used for this purpose. If there is a superficial pan it should be pierced.

F.P. 


\section{e. Birch.}

The two species of birch (Betula alba, L., and B. pubescens, Ehrh.) ascend to $5,000 \mathrm{ft}$. The former is indifferent as to soils, and the latter prefers boggy ground. They are sometimes hurtful in coniferous forests, as their hard, whip-like branches break off the tender spring-shoots of conifers. Owing to their rapid growth when young they may be also prejudicial to young oak plants, but may act as useful temporary nurses to the latter against frost and drought. As birch has a number of collum-buds, it should be cut below the level of the soil. It does not usually produce suckers.

\section{f. Other Lightdemanding Weeds.}

The best remedy for the remaining lightdemanding weeds is to effect natural regeneration of the wood, or to replant it, if clear-cut, as soon as possible. They are St. John's-wort (Hypericum); balsam (Impatiens Noli-me-tangere, L.), which grows in damp, fertile soil, in masses often a yard high and over large areas; willowherb (Epilobium angustifolium, L.) on similar soil, the seed of which appears to remain latent for a long time, and is carried far and wide by the wind; groundsel (Senecio), springing up in masses on sandy soils, the seed carried far by wind (these plants also act as hosts to parasitic fungi); hawkweed (Hieracium); Atropa Belladonna, L., on fertile damp soil in shady mountain forests of Europe and Asia (Himalayas), is very poisonous : foxglove (Digitalis) may grow in such masses that the hill-side appears red, both species, D. purpurea, L., and the yellow one, D. grandiflora, which is not indigenous in Britain, are poisonous; Verbascum, four species found on dry, stony ground; nettles (Urtica urens, L.), an annual, and the perennial nettle, with strong rhizomes (U. dioica, L.), are frequently troublesome in forest nurseries ; wood-rush (Luzula), four species common in mountain forests.

Grasses deserve a separate paragraph. The most common injurious kinds are:-Species of bent-grass (Agrostis); Aira caespitosa, L., and A. flexuosa, L.; Mclica ciliata, L. ; sheep's fescue (Festuca ovina, L.), and other species of fescue; couchor twitch-grass (Agropyrum ('Triticum) repens, Beauv.) ; lymegrass (Elymus arenarius, L.); mat-grass (Nardus stricta, L.); 
spreading millium (Millium effusum, L.). Grasses with fairly broad leaves grow on deep, moist, fertile soil-they are termed Haingrïser, in German. Angergräser is the term applied to narrow-leaved grasses, that grow on shallow, dry and poor soil.

The damage due to a dense growth of grass is of several kinds: the soil may become matted with its roots, which may prevent the seed of forest trees from reaching the ground; young growth may be choked, the soil dried up, or moisture kept in, and frost increased; damage may also be done by mice and insects which shelter in the grass. When grass grows densely, it is a sign that the forest is too thin and admits too much light. Twitch flourishes in sandy soils, creeping in all directions through the soil and filling it with rhizomes; it may even penetrate roots of living plants, and thus interfere with their growth.

Weedy places may be treated as already stated for heather, and are best recruited by means of transplants. Twitch is got rid of by repeated ploughing, and by collecting and burning its rhizomes; three years' grazing on land where it grows is very useful, as finer grasses then gradually replace it.

In tropical and sub-tropical countries, the dense growth of grass, frequently exceeding six feet in height, is one of the most serious impediments to forestry. Such grassy tracts are burned annually, the fires extending for miles, and wherever the grass borders on forests, or in the form of savannah is intermixed with thinly stocked trees, danger from fire occurs during every dry season.

\section{Half-shadebearers.}

These are all woody plants, except ferns and mosses.

(a) Blackthorn (Prunus spinosa, L.) is common on moist, loamy, and clay soils, and on marls, and ascends to 3,000 feet in mountains. It stands frost better than hawthorn, and replaces it for hedging in very frosty localities. It sends out roots and suckers, and has a spreading root-system, and does much harm in regeneration areas and among coppice. It is best to dig it up by the roots in clearings, or cut it back several years before the coppice is felled.

(b) Bramble (Rubus fruticosus, L.). There are numerous 
varieties of this species, termed blackberry or dewberry bushes, the latter ( $R$. caesius, L.) growing in moister localities than the common blackberry, which prefers well-drained soils and hedgerows.

Brambles frequently cover large areas in fresl and moist soils, sending out new suckers every year. To keep down these widespread pests of the forester, seeding-fellings should be dark. Admission of cattle is also useful. In case there be a dense growth of brambles on the ground it should be trampled down round plants that require protection, or be beaten down with a billhook. Brambles should be cut as little as possible, as this only increases the production of suckers. Plants which they are crowding should be set upright, and their branchlets placed over the brambles. If this be done early in the summer then little will be needed in the autumn, but it may be necessary to repeat the operation the succeeding year; by the second winter, the plants will probably get out of reach of the brambles. Cutting or digging up the brambles is expensive, and not so effectual as the above procedure. Where a reproduction area is overgrown with brambles, and there is little natural regeneration, it will be better at once to plant up the area.

(c) Raspberry (Rubus Idaeus, L.). This grows chiefly on fertile but stony soils rich in humus. Its habit is straight, and it does not produce such dense growth from suckers as the bramble, but may become dangerous, and should then be treated similarly to the latter. Grazing has a very repressive effect on the growth of raspberry canes.

\section{d. Hawthorn (Crataegus Oxyacantha, L.).}

Hawthorn is not particular about locality, and is widely spread up to altitudes of 3,000 feet. The rich shoots and extensive root-system of this slow-growing shrub, which attains a height of 20 feet, are destructive to young conifers, but in forests open to grazing it protects oak, ash, maple, and other broadleaved trees until they have grown above it, when it forms a thorny defence around them until they are too large to be injured by cattle. It also forms capital hedges, bearing trimming well, and shelters the nests of many useful birds 
from small carnivora and other enemies. Where it is harmful to yourg growth, it should be dug up or cut back in cleanings and thinnings. Various thorny bushes in India similarly afford great protection to bamboos and other valuable species in grazed forests.

\section{$e$. Other Shrubs and Bushes.}

The wild gooseberry-bush (Ribes Grossularia, L.), elder (Sambucus), guelder rose (Viburnum Opulus, L.), wayfaring tree (V. Lantana, L.); the spindle tree (Euonymus europaeus, L.), and privet (Ligustrum vulgare, L.) are widespread, the latter and Viburnum Lantana, L., chiefly on calcareous soils in hills. None of these plants are, however, particularly hurtful to young forest growth, except the herbaceous dwarf-elder. (Sambucus Ebulus, L.), which grows in masses from rhizomes in damp places. Daphne Mezereum, L., is a small shrub growing in hilly and mountain woods on damp soils, and is highly poisonous.

\section{f. Forest Willows:}

Sallow (Salix Caprea, L.) flourishes, especially in beech woods, on fresh soils in plains and hills, but will also grow on dry soil and in mountains up to 5,500 feet, attaining at times the dimensions of a small tree; it sends out numerous stoolshoots, but has a shallow root-system, so that it may be easily pulled up by the hand, as well as the other willows mentioned below. Its heartwood is bright red.

Sallow takes root anywhere, even on exposed rock, and grows about six feet in height in a single season, so that it is extremely injurious in young plantations.

Salix cinerea, L., a variety of the sallow, is a smaller plant of a shrubby nature; it sends out suckers on damp soils and along water courses; ascends to 3,000 feet.

Salix aurita, L., resembles the sallow in its habit, but sends out suckers; it ascends to 5,000 feet, indifferent to wet or dry soils.

Salix repens, L., is a small, straggling bush, growing chiefly on turfy and heather land, and also near swamps; ascends to 3,500 feet.

All these willows when hurtful to forest growth should be cut back or pulled up in cleanings and thinnings. 


\section{g. Aspen (Populus tremula, L.).}

Aspen is a tree which is disseminated throughout Europe, except in the extreme south, up to $70^{\circ} \mathrm{N}$. latitude, and 5,000 feet altitude; it is often very hurtful to valuable forest plants. owing to its rapid growth and abundant production of suckers. The roots of a felled aspen, which spread far from the stump, close to the surface of the ground, remain dormant for years after the parent tree has been removed; they then send up numerous suckers from adventitious buds after the wood in which the aspen formerly grew has been cleared. The aspen is not particular as regards soil, but can grow on cold, wet soils, and is frequently found in frosty localities, as, for instance, on the London clay in Epping Forest.

The aspen is also a host for an injurious fungus, Melampsora Tremulae, Tul., which, in the forms M. Pinitorqua, Rostrup., and $M$. Laricis, Hartig, attacks pines and larch, and will be described further on (pp. 444, 469).

Cutting down the suckers is of little avail, nor is extracting the stumps and longer roots of felled trees, but girdling a standing tree gradually dries it up and in about two years prevents the formation of suckers. The tree may also be felled about three feet above the ground, and the stump barked.

\section{h. Bilberry (Vaccinium Myrtillus, L.).}

This is a small shrub attaining 16 inches in height, and growing throughout Europe up to 5,000 feet altitude, in masses, on fresh, damp, and even somewhat sour soil. Its seeds remain for two seasons in the ground before germinating. It may also be found on dry sandy soils, but not on calcareous ones. It prefers a slight shade, especially of pines. When it appears in masses it denotes insufficiency of stock and deterioration of the soil, and the surface-soil becomes choked with its roots. Its berries are valuable for making alcohol and preserves.

The cowberry (Vaccinium Vitis-Idaea, L.) is an evergreen plant attaining 8 inches in height, and growing on loose, damp, sandy soils in high, cool places; it is gregarious, and has a distribution similar to that of the bilberry, growing, however, in moister soil than the latter. A dense growth of either of these species hinders natural regeneration and increases the 
difficulty of artificial restocking. There is then no alternative but to take up these plants in sods, beat off, in situ, all the soil attached to their roots, and remove them. The cowberry plant is also the host of a fungus that attacks silver-fir (p. 419). Planting is better than sowing where bilberries prevail, and spruce is the best species to plant on soil that produces them.

$V$. uliginosum, L., is found on swampy land and mountaintops, and the cranberry ( $V$. Oxycoccos, L.) in patches on peaty soils. Both species are unimportant to the forester.

\section{i. Ferns.}

The commoner kinds of ferns found in forests are: Polypodium vulgare, L., Beech fern (P. Phegopteris, L.), Male fern (Nephrodium Filix-mas., Hooker), Lady fern (Asplenium Filix-faemina, Bentham), and Bracken (Pteris aquilina, L.).

The above prefer damp and stony ground, and their appearance denotes a fertile soil, as well as a slight opening out of the leaf-canopy. They spread above and below ground often to the prejudice of young forest plants, by causing excessive moisture, and depriving them of light, and by being pressed down on them in a rotting state in winter by the snow. This frequently kills lightdemanders. Bracken often covers wide stretches of deep sandy land, but its sub-aërial parts are extremely sensitive to frost.

In the case of bracken, the best plan is to knock off the soft young shoots in early summer, which can be done easily with a stick before they have unrolled. This injures the rhizomes, so that only weakly shoots are produced, which may be knocked off or neglected. Dried bracken is largely used in England and elsewhere for litter, and in the Forest of Dean, repeated early cutting, in August, instead of October, has greatly weakened the rhizomes of the plant, so that only a short weak crop is produced, as compared with that in the Windsor and New Forests, where it is cut later in the autumn.

\section{Mosses.}

Two, out of 42 species of Polytrichum, are hurtful mosses common in forests: Polytrichum commune, L., and P.juniperinum, Hedw. The former produces dense convex tufts in damp places, and the latter on drier ground. These tufts may be 
distinguished at a distance by their darker green colour from the paler and branchy mosses, Hypnum and Hylocomium, which form a useful soil-covering in forests. They are chiefly found in high forest, and especially in spruce woods, and do harm by.favouring excessive moisture in the ground and injuring the germination of seedlings. The tufts should be turned over and broken up.

The branchy mosses that form the normal soil-covering in coniferous woods (about 123 species) may become so thick, as to render the soil too moist for the germination of naturally fallen seed. Or they may be tall enough to overshade natural seedlings. In such cases, the mossy covering should be removed, so as to expose the mineral soil.

\section{Shadebearing Weeds.}

These are all woody plants. Alder-buckthoin (Rhamnus Frangula, L.) is common throughout Europe on damp ground, and chiefly in lowlands; it produces many suckers, and is spread much by birds which eat the berries. It is used for gunpowder-charcoal.

The common buckthorn ( $R$. catharticus, L.) is a thorny shrub with spreading roots and many suckers, found on similar soil to the former, and along banks of streams.

Both kinds are hosts of a fungus destructive to cereals (p. 418). They may be dug up during cleanings.

Dogwood (Cornus sanguinea, L.), on fertile moist soils, ascends to 2,600 feet in mountains, and sends out numerous stool shoots. The wood is used for skewers, and was formerly employed for arrows.

Holly (Ilex Aquifolium, L.), a large evergreen prickly shrub or small tree, found chiefly on good damp loam or loamy sand: it coppices well. Where it abounds it is possible to plant only strong transplants between the lolly bushes, and the latter need constantly cutting back, until they are no longer dangerous. Holly makes excellent hedges, but requires plenty of humus. It is calciphobous like sweet-chestnut, and attains a height of $30-40$ feet in Britain, but on the Continent chiefly a bushy undergrowth in forests.

Holly (German, Hulst) was considered a holy or preservative plant, preserving one from evil influences, hence its use in house 
and church decorations at Christmas, and as a sign before a public-house. Birdlime is made from its cortical parenchyma.

Butcher's broom (Ruscus aculeatus, L.) grows in dense woods in the south of England, it is unimportant for the forester.

Nightshade (Solanum Dulcamara, L.), a small shrub growing in shady, damp, low lands and along banks of streams, climbing up to 10 feet in height on pollard willows and osiers. This plant, as well as $S$. nigrum, L., which chiefly grows along roadsides, is highly poisonous.

Common juniper (Juniperus communis, L.) is a coniferous shrub widespread all over Europe, in plains and mountains, up to 6,000 feet in the Alps. It is very hardy and indifferent to soils. It spreads owing to thrushes which swallow the berries. Grows well in the open and also in dense pine woods. This species and J. Sabina, L., are hosts of fungi that attack Pomaceae (p. 419). Should be cut down or pulled up when dangerous to young growth.

\section{Forest Weeds of Wet Peaty Soil.}

To this group belong the numerous species of the following genera.

Rushes (Juncus, L.), (Scirpus, L.), Cottongrass (Eriophorum, L.), Sedges (Carex, L.), Reeds (Calamagrostis, Adams), and Marestail (Equisetum, L.).

All these, except the last, may be termed half-grasses, and they all form sour herbage, and are chiefly found in lowlands, or on peat, and are somewhat lightdemanding. Equisetum arvense, $\mathrm{L}$., is a troublesome weed in somewhat wet sandy loam in forest nurseries, its rhizomes being deep down in the soil, and their extraction requiring deep trenching.

Sphagnum. Several species of this peat-moss exist and grow chiefly in the open, in opposition to Polytrichum, which grows under cover. 'They are most dangerous mosses, producing peat and swamps, and rendering the soil unsuitable for forest growth. They discharge their spores with an audible sound.

T'he invasion of sour herbage and peat-mosses is best kept down by maintaining the leaf-canopy. If a swamp has been formed it must be drained; sometimes, however, on flat land, with a tendency to swampiness, as shown by the presence of 
these weeds, after a forest crop has been cleared, ash and

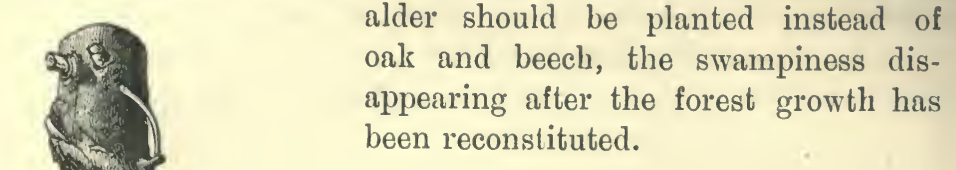

\section{Lianes.}

The first three European lianes given are woody, and the others herbaceous. The shoots of all lianes should be cut repeatedly below the ground till no more appear. There is no necessity to unwind the twiner, unless it is a woody species, as it soon dries up after being cut from the root.

(a) Traveller's joy (Clematis Vitalba, L.) is widespread throughout Europe, chiefly on hills and mountains; it is a half-shadebearer and attains a height of 20 feet, climbing up stems, bushes, and rocks. The shoots may strike root whereever they rest on soil, and the plant sometimes grows in masses and is dangerous to young forest plants.

(b) Honeysuckle or woodbine (Lonicera Periclymenum, L.), a twiner growing in hedgerows, edges of woods, and inside woods throughout Western Europe; it is found on damp soil and chiefly in lowlands. A half-shadebearer, twining round saplings to a considerable height, and thus producing misshapen spiral stems as in Fig. 198. If no suitable stems are available, it covers the ground and the herbaceous plants growing on it. It does much damage to valuable saplings in coppice-withFig. 198. - Woodbine climbing spirally round a young spruce and partly enclosed by the wood of the latter.

standard and also to larch plantations. L. Caprifolium, L., with connate upper leaves, is common in Southern Europe, 
and has become wild in certain localities further north; it has similar habits to the former.

(c) The common Ivy (Hedera Helix, L.) is widely distributed and extends over the milder parts of Europe, Northern Asia, into India and Japan, and North Africa. It climbs trees, rocks and walls by means of its adhesive rootlets, which however suck no nutriment from the host on which it is growing, but merely support the ivy. The smaller forest variety is said not to flower, and sometimes covers the soil of a forest. Ivy grows away from the light, except its blossoming shoots, which have undivided leaves and grow towards the light. Matthieu* considers ivy hurtful to forest trees by interfering with the passage of the sap, and by covering the crowns of trees with its foliage, and it certainly, at times, like the honeysuckle, constricts oak and other saplings and poles. The ivy, however, rarely ascends higher than the middle of the crown of a growing tree, and may be useful in preventing the formation of epicormic branches on standards. It dries the surface of walls on which it is growing, and also the soil when creeping over it. Ivy sometimes attains very large dimensions, a plant at Montpellier being 450 years old and $9 \frac{3}{4}$ feet in girth.

(d) Bindweed (Convolvulus, L.) : C. arvensis, L., chiefly found in fields and waste places; $C$. sepium, L., in hedges and thickets. Both species are extremely troublesome in nurseries and in osier beds, as their deeply seated rhizomes fill the ground, and their shoots twine round and bear down the young plants.

'To deal with these pests, the ground when bare should be trenched, and the soft whitish rhizomes of the bindweed collected and burned. It is difficult to do this thoroughly, as the roots go down to 18 inches in the soil.

Black bindweed (Polygonum Convolvulus, L.) is chiefly found in fields and waste places, and has similar habits to the above. It is however an annual plant and injurious only in nurseries.

(e) Wild hop (Humulus Lupulus, L.). The hop is found in damp places in lowlands; it twines from right to left up woody plants and drags them down. The rootstock alone is

* Flore forestière, 1897, p. 200. 
perennial. Hops are injurious in osier beds and in alder coppice. They should be dug up.

\section{Parasitic phanerogams.}

a. Mistletoe (Viscum album, L.).

This interesting plant lives as a semi-parasite (obtaining carbon from the air, but water, nitrogen, and mineral matter from the sap of its host) on many conifers and broadleaved trees, and chiefly on their branches. The hosts, or trees on

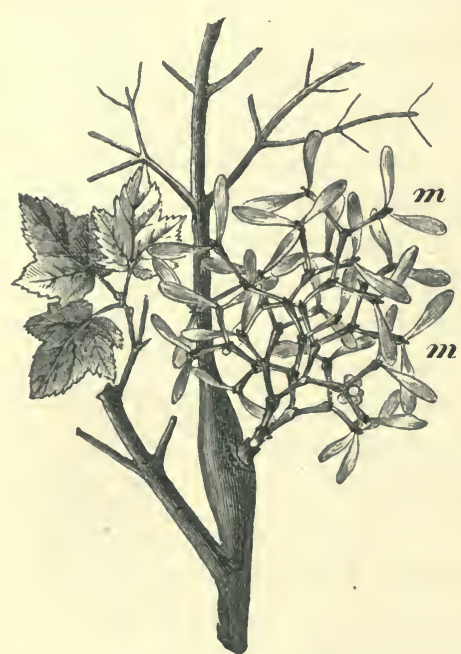

Fig. 199.-Acer vubrum, I., attacked by mistletoe $(m)$. (Reduced.) which it lives, are, most fiequently, the apple tree, both wild and cultivated varieties; next, the silverfir ; fiequently, birches, poplars (except aspen), limes, willows, Scots pine, mountain-ash, and hawthorn; occasionally, robinia, maples, horse - chestnut, hornbeam, and aspen.

It is very rarely found on oaks, but has been observed on pedunculate oakat Thornbury, Gloucestershire, and elsewhere in Europe, also on Quercus coccinea, Mœnch., and $Q$. palustris, Mœnch. The alder's, beech and spruce appear to be always free from mistletoe, and it very rarely attacks pear-trees.

It is commoner in Southern Europe than in the North, and is extremely abundant where cider is made. In the N.-W. Himalayan districts, it is frequently found on apricot trees, which are the commonest fruit-trees there.

Its white berries are eaten by birds, chiefly by the misselthrush ('Turdus viscivorus, L.), and the seeds are either rubbed by the beak against branches of trees, or voided on to them; the seeds, owing to the viscous nature of the pulp surrounding them, then become attached to the branches. 
The plant sends down modified roots (haustoria), termed sinkers, through the bark as far as the wood. It also emits lateral shoots, or cortical roots, into the bast, chiefly in the longitudinal direction of the branch of its host, and these do not grow down into the wood. The growing point of the cortical root obtains nourishment from the bast, but does not injure the cambium ring; the cortical root sends down as far as the wood fresh sinkers, which also absorb nourishment: upward shoots from it pierce the bark into the air ; these, like the original sub-aërial shoots, ramify and become covered with foliage, -and bear fruit. The haustoria elongating outwards like medullary rays become deeply embedded in the wood of the host by the growth of the latter; thus the older part of the cortical root gets gradually driven outwards by the growth of the bast until it is cut off by the formation of corky tissue within the bast, when it eventually falls off with the older bark. The sinkers thus losing connection with the living mistletoe die inside the wood by which they are gradually surrounded. As

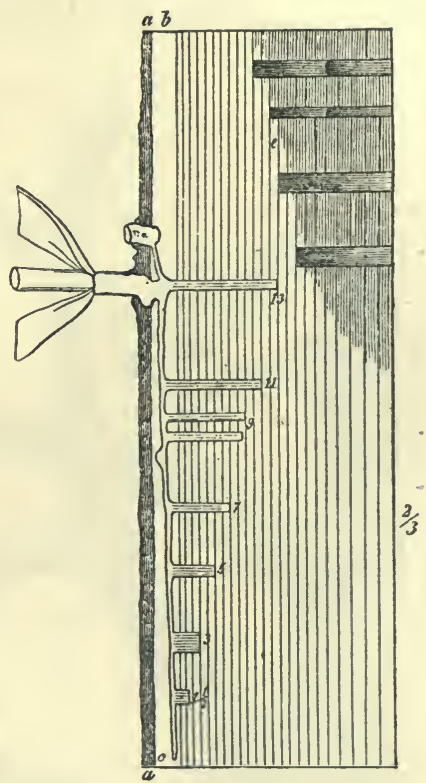

Fig. 200 (After Hartig).-Diagram representing the growth of the cortical root and sinkers of mistletoe. The terminal point of the cortical root $(c)$ is close to the wood. The growth of bast $(b)$ drives the cortical root nearer and nearer to the outer bark. (e) are dead sinkers, the cortical root of which has been cut off for several years by the production of cork in the bast. they are formed of soft tissue, they soon decompose and eventually disappear, leaving a series of holes in the wood.

This dying of the cortical root is quicker in the Scots pine than in the silver-fir owing to the earlier formation of rhytidome, or true bark, in the former.

The portion of the host to which the mistletoe is attached 
generally swells owing to a supply of carbohydrates being absorbed by it, produced partly by the mistletoe. Where only a branch is attacked, the damage done to forest trees is not worth mention, but when this extends to the stem, the wood becomes technically injured, being no longer suitable for timber, and is liable to be broken by the wind.

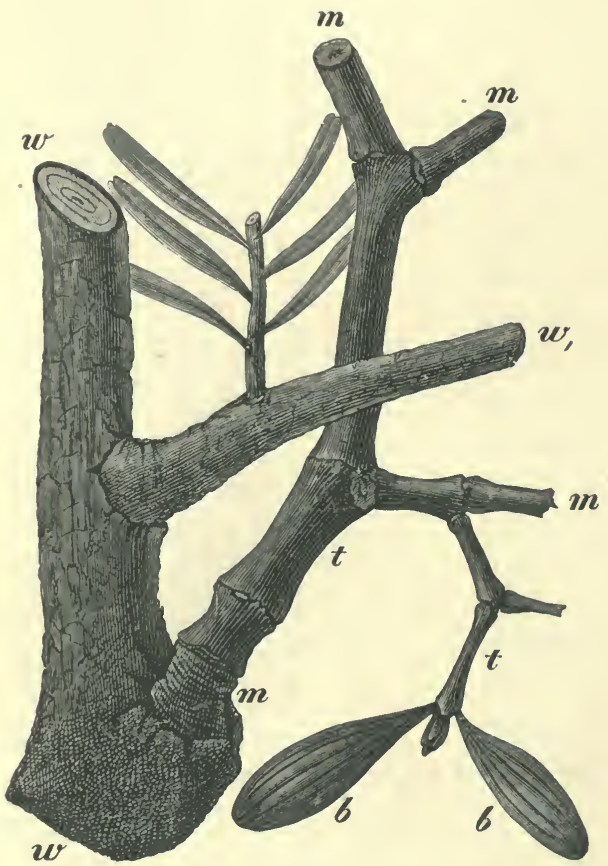

Fig. 201.-Silver-fir $(w)$ attacked by mistletoe $(m)$. $(t)$ Annual shoot $(b)$ opposite leaves of latter.

(Natural size.)

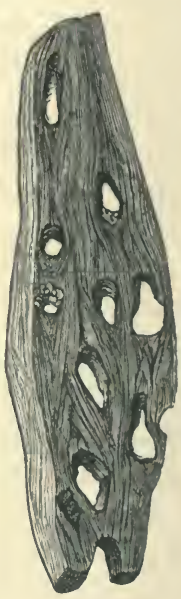

Fig. 202.--Silver-fir wood perforated by mistletoe, the haustoria of which have been absorbed.

Extensive damage is thus sometimes done in old Scots pine and silver-fir forests, owing to neglect in removing infected trees in the thinnings; nearly every tree in a compartment may then be attacked by mistletoe.

As a remedial measure, pruning off the mistletoe is useless, for the cortical root sends out new shoots, which break through the bark of the host and develop into new plants. The only effective plan is to prune off the whole infected branch 
and cover the wound with tar, or to cut down infected trees in the thinnings. For fruit-trees, and in nurseries, the former method should be adopted.

Mistletoe makes good fodder for cattle, and for roe-deer in winter. Steamer loads of it are sent from Normandy to London for Christmas decorations.

\section{b. Loranthus europaeus, I.}

This species attacks chiefly oaks, Quercus Cerris, L., Q. sessiliflora, Salisb., less frequently, Q. pedunculata, Ehrh. and Castanea vulgaris, Lam.; also lime. It is found throughout Southern Europe and as far north as Saxony, not in Britain. It grows chiefly on the branches of standards over coppice.

The main difference between the growth of this parasite and mistletoe, besides its outward
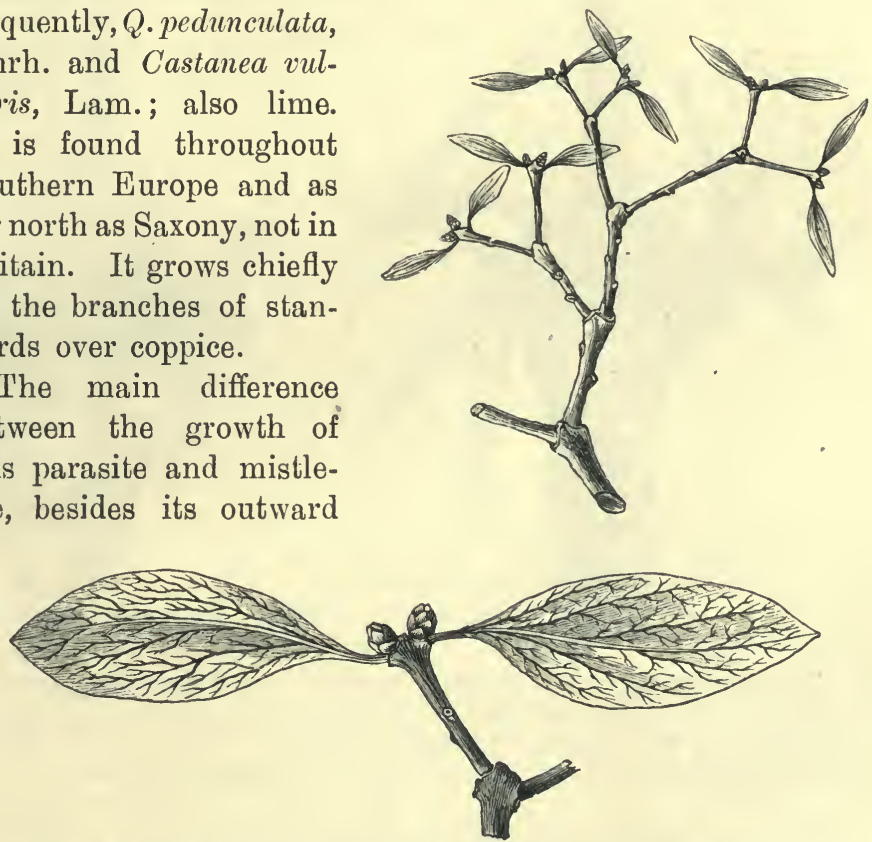

Figs. 203 and 204.-Loranthus europaeus, Jacq. Fig. 203 reduced, Fig. 204 natural size.

appearance with bright yellow berries, is that the lateral shoots of the first haustorium occur in the cambium and sapwood and not in the bast, and continue to grow parallel to the woody fibres of its host, sending out no sinkers. These shoots terminate in a wedge that looks as if it splits the wood as it proceeds, but at the commencement of their 
second season, they can no longer proceed except in the cambium, now further outward, and therefore grow from a new growing point above the old one; this occurs at the commencement of each season's growth, so that a series of wedge-shaped steps are produced in the sapwood of the host.

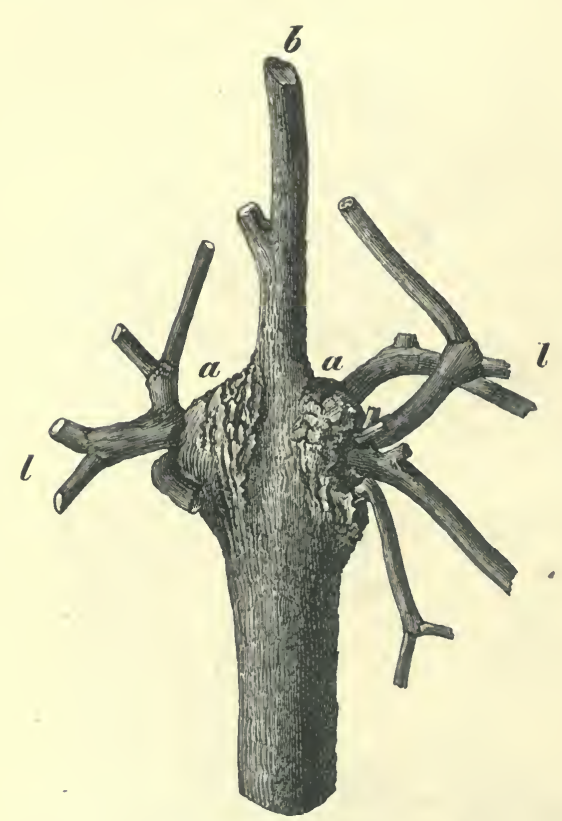

Fig. 205.-Quercus Cerris, L., with two Loranthus parasites (l). (a) Swellings produced by the parasites. (b) Stunted leader of the oak which will eventually die.

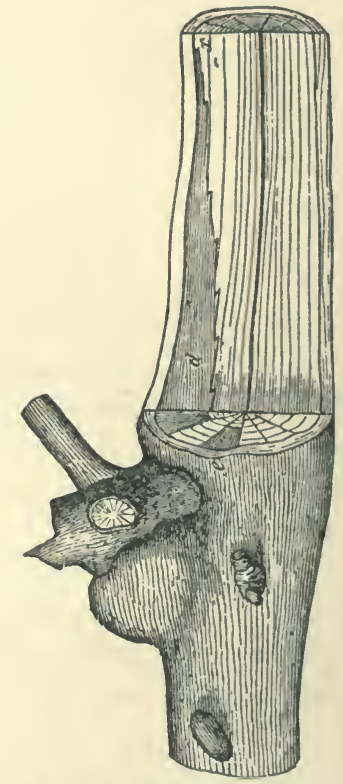

Fig. 206 (After Hartig).Loranthus europaeus, L. (d Haustorium growing in sapwood. $(x)$ Terminal part of ditto. (e) Section of another haustorium.

Places on the host where the parasite is exposed to the air swell up into masses as big as a man's head, whilst the branch of the host not only suffers in growth, but frequently. dies. The damage done is therefore greater than by the common mistletoe. The seeds are carried on to the trees by birds, and chiefly by the missel-thrush. The younger portions of the shoots of this parasite absorb from its host water and nitrogenous and mineral matter, while it partially nourishes the host with carbohydrates formed by its own aërial branches. 
There are in India many species of Loranthus, which grow on various species of forest trees*; these they seriously injure. Fortunately, infected trees are not generally found except along the borders of a forest. Infected trees should be cut out in thinnings. Arceuthobium Oxycedri, M. Bieb., is a small loranthaceous parasite, on Juniperus excelsa, M. Bieb., in the N.W. Himalayas; also on a juniper in the French Alps, Algeria, and Asia Minor ; also on several pines, in N. America. It often kills its host.

\section{c. Dodder (Cuscuta, Tournef).}

There are several species of Cuscuta, of which C. Epithymum, L., is the commonest in Britain, growing chiefly on furze, thyme, ling, etc.; and also on clover and lucerne; whilst $C$. Epilinum, Weihe, chiefly grows on flax; and C. europaea, L., on hops, nettles, vetches, etc., and also on many trees and shrubs, such as hazel, willow, poplar and blackthorn.

The various species of dodder germinate in the ground, but speedily die unless they become attached to weeds or agricultural or forest plants, on which they climb and pierce down to their woody bundles by means of haustoria, or sucker-like roots.

'l'he plants attacked by these parasites are killed or weakened, or bent down by the weight of the dodder, and much damage is thus done in India to small forest- and avenue-trees, and to fruit-trees.

Of European forest plants, osier-willows suffer most, as an abnormal growth is produced at places where the haustoria have pierced the cortex of the host, thus rendering the osiers unfit for basket work.

In the case of agricultural crops, care should be taken to obtain seed free from dodder-seed. Where the dodder attacks osiers, the shoots with the dodder on them should be cut as low down as possible, at the beginning of the blossoming period (end of June and beginning of July), and forthwith burned. This operation should be repeated in consecutive

* Vide paper by G. M. Ryan, "Indian Forester," December, 1899, p. 472 Loranthus longiflorus, Desrousseaux, is very common on teak standards over coppice in the Bombay Presidency.

F.P. 
years, as seeds of the dodder may remain 2 and 3 years dormant in the ground. Hares spread the infection by swallowing the seeds and passing them undigested on to the ground.

As dodder spreads from forest plants, and hedgerows where it is very frequent, to crops, its destruction is urgent from motives of general utility.

\section{Forest Weeds acting as Hosts for Injurious Fungi.}

The common barberry (Berberis vulgaris, L.) is a shrub widely spread over Europe, both in the lowlands and mountains, and generally along the edges of forests. It grows even on poor sandy soil, soon attains a height of 12 feet, and sends out its deep root-system in all directions. Barberry is very hurtful as the host of black-rust (Puccinia graminis, Pers.) that attacks wheat and other cereals, and should therefore never be used to form hedges. Its use for this purpose has been prohibited in Prussia since 1880.

Puccinia graminis, Pers., forms yellow lines of sporangia on the blade of wheat and other grasses which afterwards become reddish-brown, and in this way the nourishment of the plants attacked is intercepted and the crop reduced. It lives alternately in the form known as Aecidium Berberidis, Pers., on species of Berberis, or Mahonia, the spores of which falling on cereals and other grasses hibernate as $P$. graminis, the spores from which re-infect the barberry and so on. Another form, crown-rust, $P$. coronata, Corda., which also forms a rust on cereals, and especially on oats, arises from Aecidia that form golden-yellow swellings on Rhamnus catharticus and R. Frangula, the two species of buckthorn already described.

Species of Ribes are the hosts of Cronartium ribicolum, Dietr., which produces Weymouth Pine blister (Peridermium Strobi, Kleb.).

Species of Senecio harbour Coleosporium Senecionis, Fr., which alternates in the form of Peridermium Pini acicola, Pers. (p. 461), a fungus attacking the needles of Scots and other pines, and described further on. Species of Coleosporium 
growing on Euphrasia and Tussilago also produce pine-needle blister.

The aspen (Populus Tremula, L.) has its leaves infected with a fungus, Melampsora pinitorqua, Rostrup., so that its foliage may appear quite golden-yellow in August, and then rapidly fall. The sporocarps of this fungus on aspen leaves eventually turn dark brown, hibernating on the fallen aspen leaves, and in the spring, the spores infect Scots pine and larch with the fungi. The alternate forms (pp. 444, 470) on pine and larch will be described in the next chapter.

Vaccinium Vitis-Idaea, L., acts as host to Melampsora (Calyptospora) Goeppertiana, Kühn, which, growing on the stem of this plant, develops spores infecting the needles of silver-fir with Aecidium columnare, Alb. (p. 462).

Species of juniper form the alternate hosts of several species of Gymnosporangium, a rust-fungus attacking several pomaceous species:

Gymnosporangium clavariaeforme, Jacq., infects the common juniper, and its spores subsequently attack pears, hawthorns, or whitebeams (Pyrus Aria, Ehrh.)

G. Sabinae, Winter, on the common juniper and on the savin (Juniperus Sabina, L.), also occurs on pear trees.

G. confusum, Plowr., spreads from junipers on to pears, medlars, quinces and hawthorn.

G. juniperinum, Winter, occurs on rowan (Pymus Aucuparia, Gaertn.), and perhaps on apple leaves.

Species of starwort (Stellaria) and Cerastium are the hosts of a fungus causing silver-fir canker and witches-broom (p. 448).

The forester should always look with suspicion on weeds or shrubs in his forests that may be infested with fungi, and if the injuriousness of these fungi to agricultural crops or forest or fruit-trees is proved, he should if possible eradicate the wild plants on which they first appear. 
8. Classification of Forest Weeds according to their Powers of Injury to Forests.

Hess has classified forest weeds as very injurious, less, and least injurious. As the amount of harm that weeds occasion varies greatly with circumstances, it would appear to be sufficient to give the following list of the most injurious forest weeds :-

\author{
Woody Plants. \\ Broom (To conifers). \\ Heather. \\ Brambles. \\ Aspen. \\ Bilberry. \\ Mistletoe. \\ Loranthus. \\ Blackthorn. \\ Forest Willows. \\ Birch. \\ Honeysuckle. \\ Herbaceous Plants. \\ Grasses. \\ Bracken. \\ Sphagnum. \\ Dodder. \\ Bindweed. \\ Epilobium.
}

And other tall weeds, when growing in masses. 


\section{CHAPTER II.}

\section{PROTECTION AGAINST FUNGI.}

\section{Section I.-General Account.* \\ 1. Position of Fungi in the Vegetable World.}

Plants belonging to the lowest division of cryptogamous plants-which is termed Thallophyta, and includes among other families bacteria and fungi-have at most only rudimentary differentiation into stems, leaves, and roots; and consist of cellular tissue, which may, however, in certain cases become hardened.

Bacteria-termed also Schizomycetes, or fission-fungi, from their habit of constantly dividing to form new cells, are plants consisting of cells the diameters of which are usually considerably less than $\frac{1}{500}$ of a millimetre. They are parasitic or saprophytic on organic substances, and under certain conditions may multiply enormously in the blood or digestive organs of men or animals, and cause highly infectious diseases such as cholera, malaria, typhoid fever, etc.

Marshall Ward has published some papers in the "Proceedings of the Royal Society" proving that sunlight is prejudicial to the growth of bacteria, which cannot therefore thrive on or in the young sub-aërial organs of forest plants; certain. bacteria, however, according to Hartig, cause bulbs and potato tubers to rot, yet he states that the only disease in European

* Cf. "A Text-book of Plant-diseases caused by Cryptogamic Parasites," by G. Massee. London : Duckworth \& Co., 1903.

"Fungoid Pests on Cultivated Plants," by M. C. Cooke. London: Spottiswoode \& Co., 1906.

Von Tubeuf, Dr. Karl, "Pflanzenkrankheiten durch kryptogame Parasiten verursacht." Berlin, 1895. English translation by W. Smith. Longmans, London, 1899.

Hartig, R., "Lehrbuch der Baumkrankheiten." Berlin, 1889. English translation of earlier edition of above by Somerville and Marshall Ward. Macmillan $\&$ Co., London, 1894.

Nisbet, "The Forester." Blackwood \& Sons, 1905. Vol. II., pp. 141-187. 
trees hitherto ascertained to be due to bacteria occurs in the case of Pinus halepensis, Mill.

By their presence in the soil, bacteria greatly assist vegetation by decomposing and dissolving organic refuse, and the fact that a forest soil when exposed for some time to the action of the sun's rays becomes less fertile than when it is constantly sheltered by trees is in complete accordance with Ward's researches.

As already stated, bacteria, and certain fungi as well, also protect forests by killing insect pests in enormous numbers. The only thallophytes which cause serious injury to plants are fungi that are devoid of chlorophyll and therefore obtain their nutriment from other dead or living organisms. In the former case, they are termed saprophytes and in the latter, parasites. Another class of fungi obtaining nourishment from humus, but becoming attached to and rendering abnormal the roots of many trees and shrubs, deserves notice. Fungi growing on the exterior of other plants may be termed epiphytic.

The number of known fungi is very great, over 5,000; here only those which affect the growth of forest plants will be considered.

\section{Classification and Importance of Fungi from a Forest} Point of View.

\section{a. Saprophytic Fungi.}

As saprophytic fungi live on dead or dying organisms, they do not cause disease, but follow or accompany an already diseased condition of their hosts. Fortunately, the majority of known fungi belong to this class. Fungi that are saprophytic in certain cases, as Armillarea mellea, Vahl., on rotten stumps of beech and other broadleaved trees, may be parasitic on other trees, such as conifers.

\section{b. Parasilic Fungi.}

Parasitic fungi attack healthy plants, and either cause a sickly condition or actual death to their hosts. Some parasitic fungi subsequently become saprophytic in tissues which they have killed. 


\section{c. Epiphytic Fungi.}

Among epiphytic fungi the family Tuberacei deserve mention, as they sometimes form underground mycelia in soils rich in humus, and thus cover the roots of Cupuliferae, conifers, willows, limes and other plants, to the exclusion or modification of their root-hairs. This altered root with its matted coating of mycelium receives the name mycorhiza, and the fungus has the power of absorbing nutritive matter from the soil and conveying it to the roots of the host. These fungi* do not in any way injure the plants on which they grow, but feed them more richly than the plants can feed themselves by their own root-hairs, in the absence of the fungi. Edible truffles belong to this family, and are commonly found in oak forests in the South of England and the more southern part of Europe.

The study of fungi should be followed as carefully by the forester as that of injurious insects, although the damage recognised as done to forests by insects is much greater than by fungi and the remedies against them are more effective, it being often difficult, if not impossible, to combat hurtful fungi. As, however, no remedy can be devised without studying the causes of diseases which break out among forest trees, the importance of the study of fungi injurious to our trees must be admitted. The forester should be able to say whether any fungus is the cause, or merely a consequence of a disease or injury; he must know how to observe phenomena in the forests, and should hand over the specimens he may collect to be examined by mycologists.

The treatment of the question here adopted is therefore purely from a forest point of view. The anatomy and physiology of fungi should be studied, and a knowledge of mycology is pre-supposed. A few remarks on the life-history and distribution of fungi are, however, advisable, and a short account of the structure of fungi cannot be dispensed with.

\section{Mode of Life of Fungi.}

Fungi are cellular plants without chlorophyll, and are either unicellular or formed of many branching elliptic cells, as in

* See Frank's "Lẹhrbuch der Botanik," 1893, 
yeast, or of elongated cells termed hyphae with apical growth, which may remain undivided or become divided into cell-rows by septa, or transverse membranes.

They are best known and classified by the forms of their reproductive structures, which are generally sub-aërial, as in the common mushroom; but the mass of the hyphae grows and spreads through living or rotten wood, in humus, or other media, forming a collective growth termed a mycelium. The mycelia of fungi may consist merely of branching hyphae, but large masses of mycelium are sometimes formed in hollows of rotten wood, as by Polyporus sulphureus, Fr.

The reproductive organs of fungi are often formed on special branches of the hyphae termed sporocarps, certain cells of which produce myriads of isolated cells or spores, which on escaping into the air or soil are capable, under suitable conditions, of giving rise to new individual fungi. Spores may be produced either sexually, or asexually by division, the latter mode being by far the commoner, the spores thus formed by the abscission of cells at the terminal points of hyphae being termed conidia. For an account of the formation of sexual spores (carpospores) special books* may be consulted. Among them are certain thick-walled spores termed oospores, or resting spores, which are rich in nutriment and, unlike conidia, do not germinate as soon as they are mature, but may remain dormant for prolonged periods, as in Phytoplithora Fagi, R. Hrtz. Sporidia are secondary spores produced by promycelium by the germination of resting spores.

As a rule, conidia remain only for a few days in a condition fit to germinate and produce new individuals, but they appear in immense numbers in the air or soil, are of microscopic size, and are sometimes carried for miles by wind or water, or even by men and animals. Infection may also be conveyed by seeds in the case of certain rusts, which Dr. Cook $\uparrow$ says attack seeds, such as those of celery, wheat, or hollyhock by various species of Puccinia. The resting spores are usually larger than the conidia, better protected and richly provided

* Dr. K. Goebel's "Outlines of Classification of Special Morphologs of Plants." Translation by H. E. F. Garnsey, Oxford Clarendon Press, 1817. De Bary, "Morphology and Physiology of Fungi," etc., same translator and publisher.

† Gardener's' Cirron., 13 May, 1905. 
with protoplasm, and in certain cases may remain alive up to 3 or 4 years. Conidia and carpospores germinate when they meet with favourable conditions of temperature and moisture; it may be laid down as a general rule, that conidia serve to reproduce the fungi in great numbers, while the carpospores carry on the species over winters or prolonged dry seasons.

Fungi do not usually require the same amount of heat as the higher plants for their development, and their fructifying organs are usually most numerous in October. As already stated, they may be either saprophytic or parasitic, while some fungi are epiphytic, living on the epidermis of leaves or shoots, and merely piercing into it from time to time with delicate minute haustoria, or root-like ramifications of the hyphae, which are devoid of any root-cap. 'The mycelia of parasitic fungi live on or in the tissues of living plants or animals, their spores gaining admission into the former through wounds, lenticels or bark-cracks, or through the stomata of leaves ol young shoots, or the soft growing points of roots. I'here they germinate, and emit tender thin-walled, generally colourless hyphae, which, when very young, are filled with protoplasm; but cell-sap or bubbles of air soon occupy part of their lumina, the protoplasm then merely lining the walls of the hyphae or passing into younger cells. Oil may also be found in the hyphae, especially when they pass through tissues of the host which are rich in reserve-material. This oil is frequently of a golden-yellow colour, as in many kinds of rusts on leaves or shoots.

'l'he hyphae grow by their apices, and their terminal cells are always rich in protoplasm. In the case of parasitic fungi, the hyphae may grow either in an intercellular manner between. the tissue elements or in the resin-ducts and other intercellular spaces, merely sending their haustoria into the lumina of the tissue-elements, or, if the hyphae are furnished at their apices with a ferment capable of decomposing the cell-walls, they themselves penetrate through the cell-walls of their host, and thus pass from one cell to another. As they proceed, the younger cells of the hyphae procure protoplasm from the older cells, in which eventually nothing but air is left. 
The walls of the hyphae are at first always soft and colourless, but when older they may be considerably thickened and coloured brown or greenish-blue, as in rotten spruce- or beechwood. Sometimes the hyphae unite into compact bundles with hard walls, termed rhizomorphs, which resemble roots, and serve to carry the mycelia through unnutritious or dry media. These are very conspicuous in Armillarea mellea, Vahl. Hyphae also sometimes unite into small tuber-like bodies termed sclerotia, which have thick cell-walls, and are richly supplied with protoplasm and oil, and, as in Rosellinia quercina, R. Hrtg., may remain for some time dormant and resist desiccation, but under favourable conditions develop new mycelia or sporocarps.

In this way the mycelia of parasitic fungi live on the tissues and nutritive material of their host, and interfere with its transpiration and assimilation; they also dissolve the cellwalls and their contents, often causing hypertrophy or excessive formation of cells, and chemical change in the cell-wall. In the latter case, they cause the death of the host. Insects frequently attack trees which have become weakened by fungi. Eventually the fructifying organs, which are characteristic for each species of fungus, break out on leaves, twigs, bark or at the scars of dead branches, sometimes through perforations made by bark-beetles, sometimes on the roots of the host, or on rhizomorphs, as in Armillarea mellea, Vahl. Innumerable spores issue from the sporocarps, some of which find suitable resting-places, and the fungus-life recommences in fresh hosts.

Most fungi are very transitory, and their life occupies only a few months or weeks. In the case of others, the resting spores hibernate, and the mycelia of some fungi may live for two, three, or many years. Most of the destructive forest fungi have the latter character. The polymorphy which exists in the case of certain fungi requires an explanation here. From the spores of certain fungi the same form does not always appear, but sometimes one perfectly distinct, unlike the parent fungus, and living on a different host; its spores may even produce a third form, though eventually the original fungus is reproduced. Thus, many fungi, formerly considered 
as distinct species, are now recognised as being merely stages in the development of one species. The most highly organised of these stages, in the case of any species, is considered to be that which bears sexually fructifying organs or their equivalents. Fungi which thus grow in different forms on different hosts are termed heteroecious; some, however, go through all their forms on the same host.

\section{Distribution of Fungi.}

The spread of fungi is favoured by certain conditions of the weather and locality. It depends chiefly on heat and moisture, light being prejudicial, many fungi growing in the interior of trees or in the ground. Fungi can flourish and become numerous only under suitable conditions, so that in damp years, and especially in damp sheltered localities, they thrive better than in dry years and exposed places. Thus, in a wet June, Melampsora pinitorqua, Rostrup., is most destructive to pine trees. Nutriment rich in nitrogen favours their growth.

Parasites attack not only weakly plants but the most flourishing individuals. The conditions which most favour their spread-damp air and wet soil-are, however, unfavourable to many woody species, and external injuries of any kind to trees admit the spores of fungi to the inner tissues of the injured tree and thus favour fungoidal attacks. Wild plants, especially when growing in masses, are just as exposed to their ravages as cultivated plants. Coniferae suffer more from fungi than broadleaved species, because the latter recover more readily from injuries.

The question, whether a fungus is the cause or consequence of a disease can be solved only by infecting a perfectly healthy plant with the spores of a fungus, and observing the results. The external circumstances which favour and hinder the development of the disease must also be noted. Such observations are troublesome and difficult, and demand great care and foresight to avoid deceptive conclusions. Much information has, however, already been obtained, and every year is adding to our knowledge of the subject.

A glance must be given over the species and modes of attack and the spread of a disease. In the case of diseases which 
are induced by certain conditions of soil and weather, the whole of a wood almost simultaneously shows symptoms of disease. An attack by fungi, on the contrary, is propagated by infection from one or a few individuals which are first attacked, and therefore starts from a centre, spreading generally in a centrifugal manner, like the fairy-rings in a meadow due to Marasmius oreades.

\section{Protective Measures against Fungi.}

In order to prevent the attacks of fungi, good sylvicultural rules must be observed as regards the regeneration and tending of the crops of trees.

The most important of these are: to grow species suitable to the locality; to cultivate the plants scientifically, and to plant strong plants and in suitable mixtures, especially of broadleaved trees with conifers; early cleanings; timely thinnings; pruning from November till January; avoidance of injuries to standing trees during fellings; tarring wounds.

To combat the individual fungi successfully, their lifehistory must be known. Special rules are:

Isolation of attacked plants by trenches; removal of diseased plants; pruning attacked branches; destruction of weeds that serve as hosts for injurious fungi; spraying diseased plants with fungicides*; removal of infected fallen needles or leaves. All infected material should be at once burned in situ.

\section{Section II.-Fungi attacking Conifers.}

The next two sections give a list of the fungi which experience has shown to be injurious to forest trees, with a short description of their external appearance, the classes of woods and localities liable to be infected, and the distribution-areas of the fungi; also an account of the damage done and the means for combating it. The most injurious species are marked with an asterisk. For a full description of the pathology of each disease induced by fungi, reference is

* Cf. Lodeman, "The Spraying of Plants." New York: The Macmillan Co.; Iondon, Macmillan \& Co., 1903. 
invited to the works of R. Hartig,* on which these notes are chiefly founded.

It is best for the purpose of Forest Protection to distinguish fungi attacking coniferous trees from those attacking broadleaved trees, and within each group according to the organ attacked (roots, stem, branches, needles or leaves, or fruits).

\section{A. Root-fungi.}

*1. Armillarea mellea, Vahl.

a. Description and Mode of Attack.

The honey fungus, formerly named Agaricus melleus, L., which is one of the commonest in the British Isles, causes a

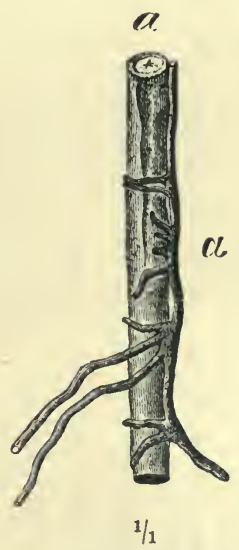

a Root of a Scots pine killed by ${ }^{\circ} A$. mellea, Vahl. a Rhizomorph, external to root, which it bores at $\alpha$.
6

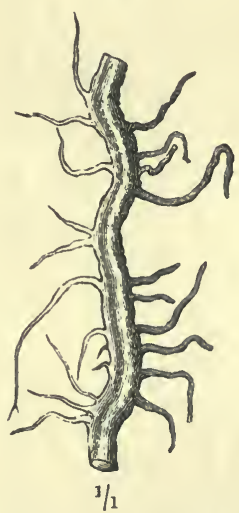

$b$ Flattened rhizomorph passing between the dead wood and bast of a, Scots pine; its left-hand branches are white, and resemble ordinary mycelia.

Fig. 207.

well-known disease in conifers. The symptoms are:-Yellow colour in the needles, which gradually dry up, and fall; the shoots wilt; the base of the stem swells up, and the bark peels off, whilst turpentine exudes freely, clogging together the soil around the tree; the bark decays, and fibrous fungoid tissues

* "The Diseases of Forest Trees," R. Hartig. Translated by Somerville and Marshall Ward. Macmillan \& Co., London, 1894. 


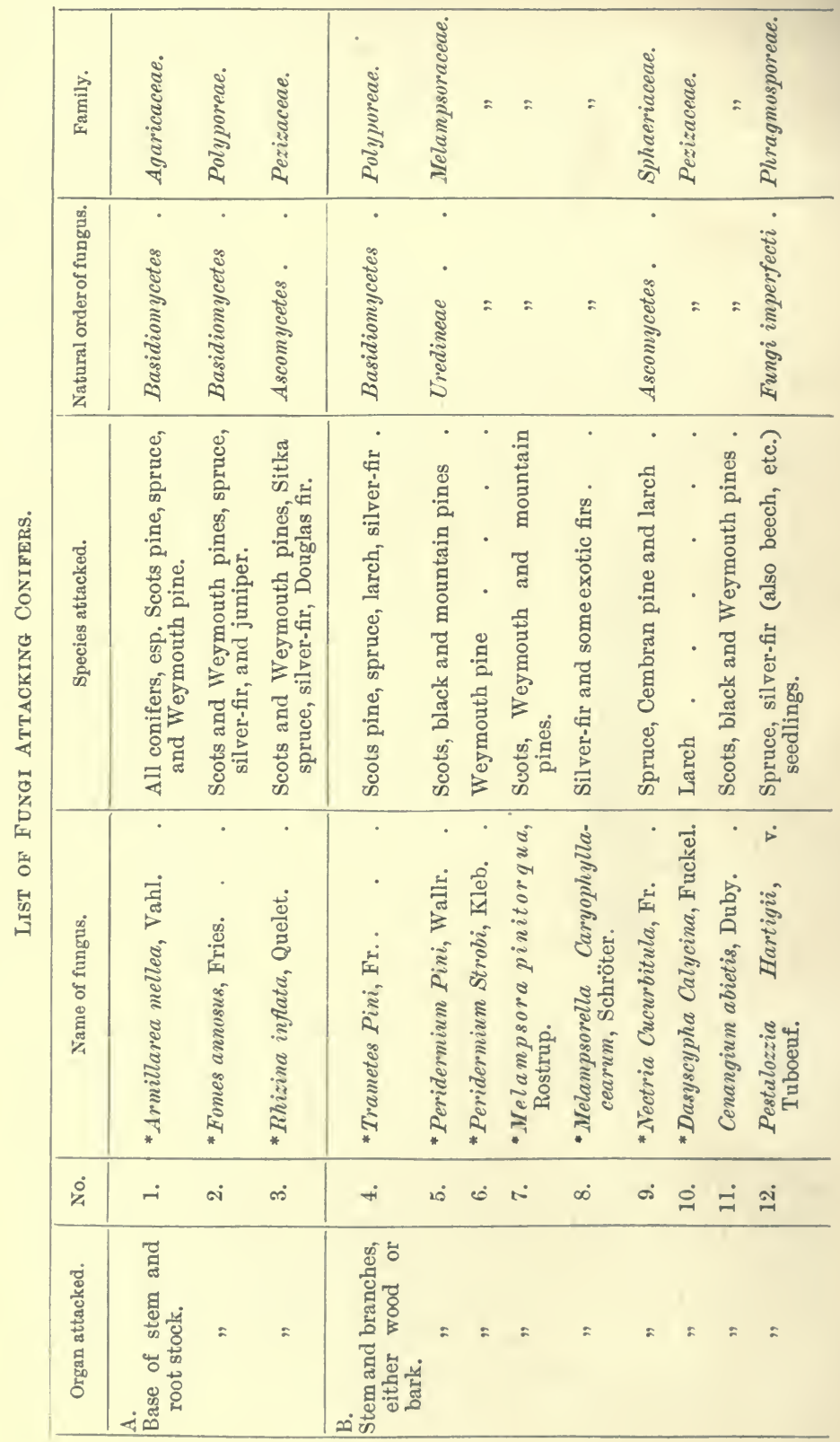


GENERAL ACCOUNT OF FUNGI.

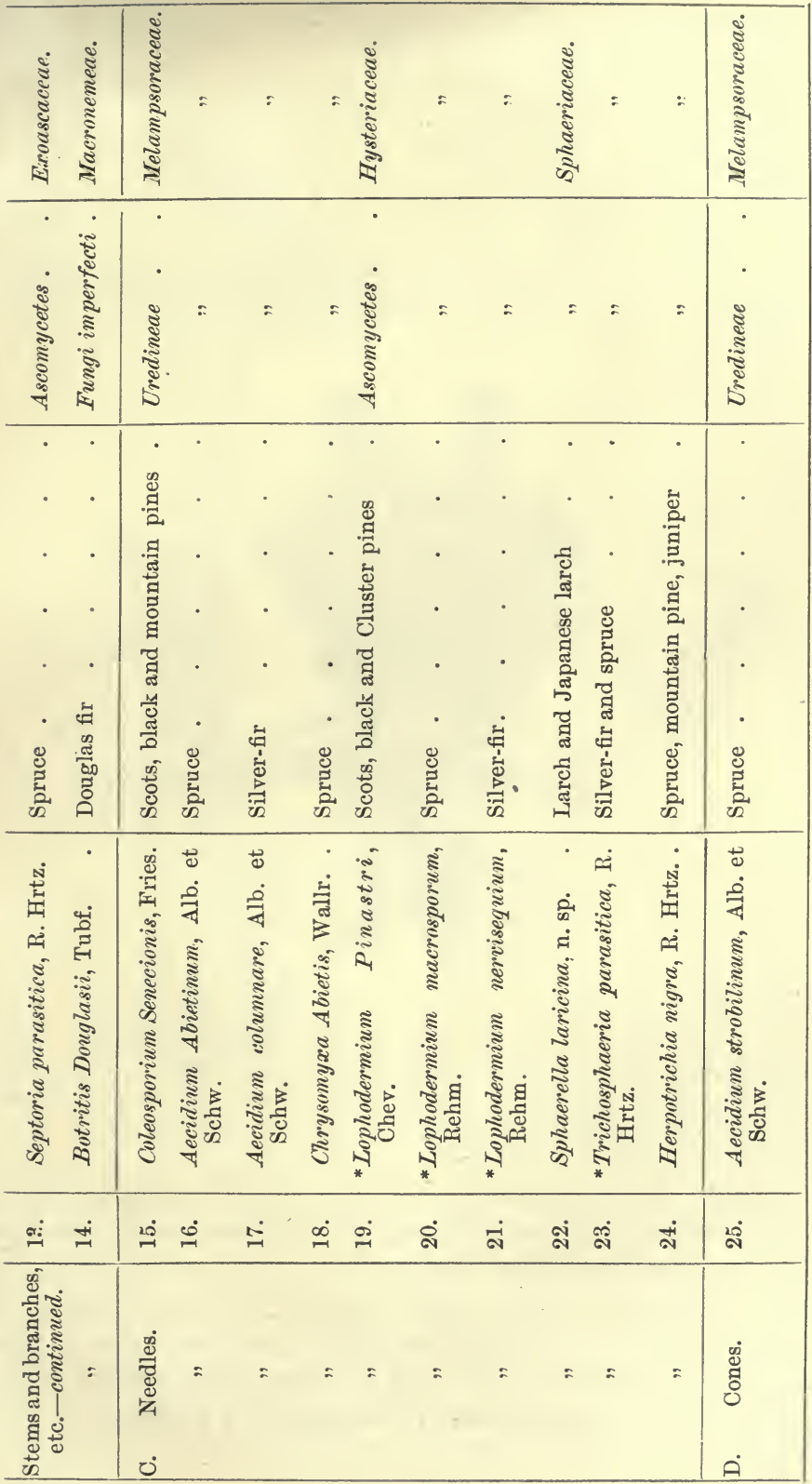


appear in the soil, seldom deeper than four inches, that are termed rhizomorphs. These latter are persistent mycelial hyphae like sclerotic fibres, and resemble branching roots; they sometimes anastomose. White ribbon-like bands of mycelium are formed between the bast and sapwood and in hollows in the dead bark and bast, and often spread like a net; mycelial strands which pass into the soil from these white bands are round and dark-brown rhizomorphs, which may also develop between the wood and the cortex, but are then flat.

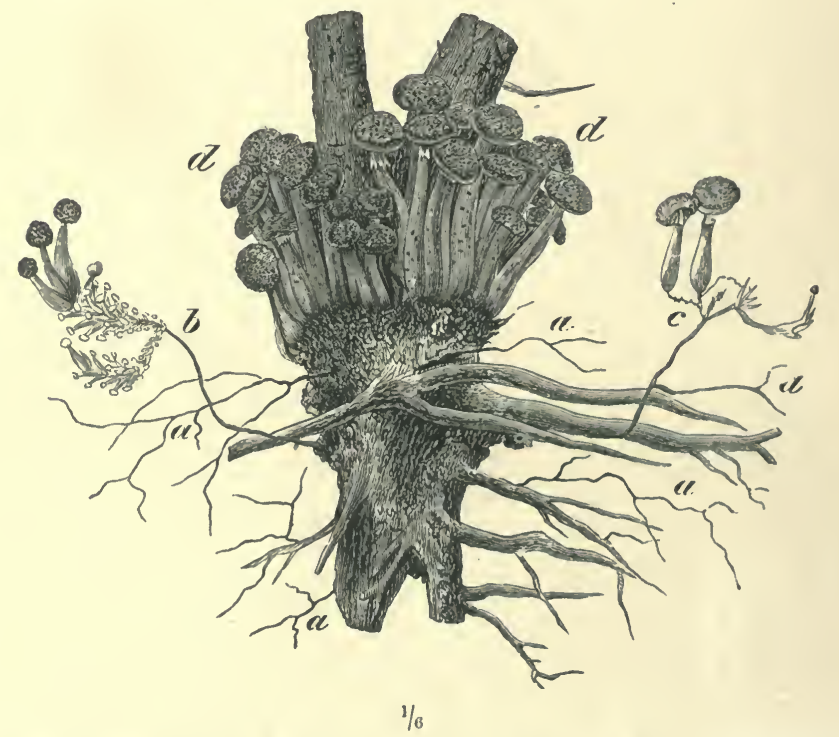

Fig. 208.-Eight-years-old Scots pine killed by $A$. mellea, Vahl. a Sterile rhizomorphic strands. $b$ and $c$ Fertile ditto; some of the sporophores are abortive. $d$ Sporophores springing from mycelia under the bark. (Reduced.)

Plants which have been attacked eventually die, and when young generally in the first year of the disease. If the dead plant be examined microscopically it will be found that the bast and cambium have been destroyed, the resin-ducts are full of hyphae and enlarged and deprived of resin; fine hyphae also proceed along medullary rays towards the centre of the tree. Starch is transformed into turpentine which flows from the tree. 
The edible sporocarps first come to light in great numbers during damp weather in October, at or near the base of the dead trees, and spring from the rhizomorphs.

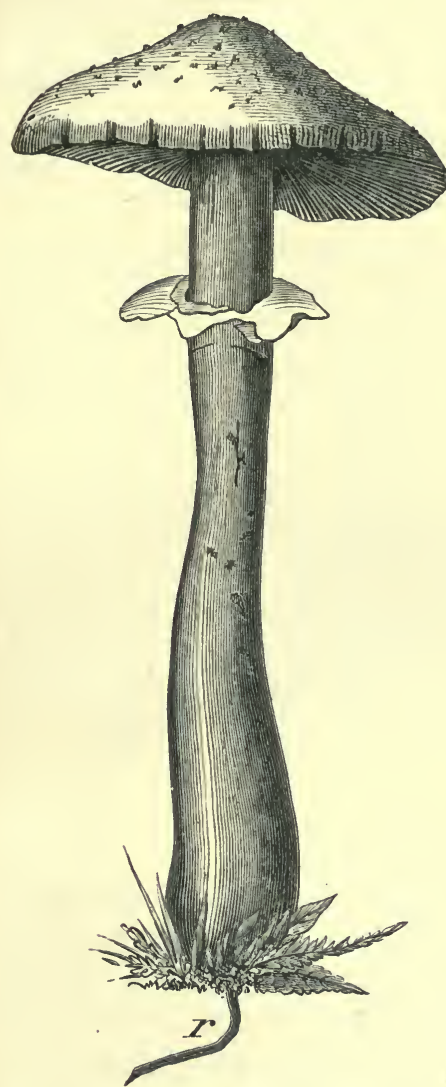

Fig. 209.-Fully-grown sporophore of Armillarea mellea, Vahl. $r$ Rhizomorph. (Natural size.)

Fig. 209 represents a sporocarp. Its cap varies in colour from that of honey to a dirty brown, with dark, hairy scales; its lamellæ are yellowish-white, and become later on speckled with reddishbrown. The cylindrical stem of the sporocarp is at first dull red, and bears a flocky white ring. The sporocarps emit myriads of white conidia, which spread the infection to other coniferous plants and to dead broadleaved species, on which it is saprophytic.

The brown rhizomorphs grow in all directions through the soil, and by means of their soft apices bore into the roots of neighbouring plants and trees, which they eventually kill. In dense young growth, whole groups of plants may be thus killed and considerable blanks produced. In old woods, the attack is more confined to individual trees, and the disease spreads several feet up their stems

\section{b. Subjects of Attack.}

The fungus attacks all indigenous or exotic conifers, especially the Scots and Weymouth pines and the spruce; the larch not unfrequently suffers, but the black pine rarely. Plants

F.P. 
may be attacked from four to a hundred years old, but especially between four and fifteen years. In dense sowings and multiple plantings the disease is at its worst, especially when the wood was originally stocked with broadleaved trees on which the fungus is saprophytic, such as beech, oak, hornbeam, birch, species of Pyrus and Prunus, ${ }^{*}$ etc. The stumps of broadleaved trees left in the ground of a plantation form nurseries which propagate the fungus. The fungus also attacks timbers of bridges and other forest-works.

Plants which are attacked generally die either between April and July, or from the middle of October to the end of November, and frequently the healthiest and most flourishing plants succumb. It is difficult to recognise plants which are attacked until the year before they die, when their needles turn pale and their shoots are stunted.

In older crops of trees, bark-beetles frequently come with the fungus; it is not yet decided whether the fungus is always the primary cause of injuries in such cases.

In Russia, the fungi are collected for food, and spores may easily escape from the sacks in which the fungi are transported, and spread the disease. Attacks of bark-beetles frequently accompany the fungus in Russia.

\section{c. Protective Rules.}

i. All stumps and roots of broadleaved trees should be thoroughly extracted before plantations of conifers are established on the site of a broadleaved wood, and where the disease has once appeared dense sowings of conifers and multiple planting should be avoided. When the disease shows itself-

ii. All plants which are attacked must be dug up with all their roots and the rhizomorphs and burned. Should this produce a blank, the ground must be thoroughly trenched and all strands of rhizomorphs extracted before it is replanted, and then it is best to plant broadleaved species.

* A. mellea, Vahl., is said by Hartig to be sometimes parasitic on species of Prunus. Mr. C. G. Rogers reports that a sycamore, forty years old, was killed by this fungus in 1897, at Hartley, near Plymouth. 
iii. Small isolation-trenches should be dug round plants, or groups of plants which have been attacked, so as to localise the injury and prevent a further spread of the rhizomorphs. The trenches should be far enough from the attacked plants to exclude all rhizomorphs from the healthy trees.

\section{*2. Fomes annosus, Fries.}

a. Description and Mode of Attack.

This parasite, formerly named Trametes radiciperda, R. Hrtg., is very destructive in pine and spruce forests of North Germany, and is not uncommon in the British Isles; it causes root-rot in the Scots pine, spruce and other conifers, and has

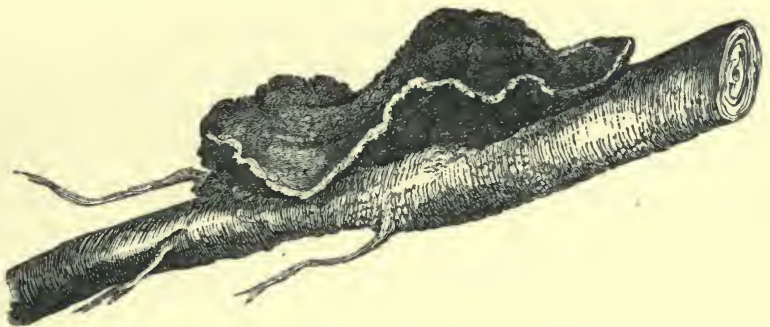

Fig. 210.-Sporocarp of Fomes annosus, Fries., on a Scots pine root. (Reduced.)

been found on old stumps of birches and beech which have been injured by mice, although it is probably not parasitic on broadleaved species. Trees attacked by it are eventually killed. Root rot may, however, be due to other causes.

The infection usually comes from the diseased roots of a neighbouring tree, but also from conidia. The colourless soft mycelium is more delicate than that of the honey fungus, resembling tissue paper, and is developed in the bast and wood of the root-system of trees. The walls of the bast and wood-cells are bored and disintegrated by numerous hyphae until the roots become totally rotten. The rot proceeds from an infected root upwards into the stem and from the collar downwards into the hitherto sound roots, only in the Scots pine does the resinous root-stalk form an impediment to the ascent of the mycelium. In spruce-wood, the 
presence of this parasite is decidedly shown by the appearance of black spots surrounded by white colour in the spring-wood. Outwardly the mycelium penetrates cracks in the bark, in the form of small yellowish-white tufts.

The sporocarps are chiefly on the root-stalk, but also on the roots, either in the form of incrustations or masses like yellow or snow-white grapes. Under favourable circumstances of growth they may assume the form of brackets.

The disease generally spreads rapidly, turning the wood first brown and then white and causing large hollows in it. By the artificial infection of six ten-year-old Scots pines, five of them were killed in a year and a half. (R. Hrtg.).*

\section{b. Subjects of Attack.}

The fungus has been observed on the Scots and Weymouth pines, the spruce, silver-fir, of all ages up to 90 years, also on juniper and on Scoṭ pine transplants from five years old. Pinus rigida, Mill., is very susceptible to its attacks. Its spread is favoured by mice and other animals which carry the spores in their fur. Trees which are attacked have pale needles and. stunted shoots, as in the case of the honey fungus.

\section{c. Protective Rules.}

i. Mixing broadleaved trees with conifers.

ii. Removal of all infected trees and of all rhizomorphs, as soon as they are noticed, and filling up the gaps with broadleaved species.

iii. Digging up and charring all roots which show traces of sporocarps. Hess considers isolation-trenches of little use in this case, as they only favour the production of conidia from the exposed hyphae. Hartig, however, considers it possible to scrape the walls of the trenches free from conidia, though this could probably be done only in isolated cases of the disease. Isolation trenches will at any rate prevent the infection of

* Mr. B.T. Butler, cryptogamic botanist to the Government of India, wrote a paper ("Indian Forester," Nov. 1903) showing that F.annosus, Fries., has black rhizomorphs. Such were also discovered by Dr. Mayr, Professor of Forestry, Munich. They penetrate the soil to a depth of $20-30 \mathrm{~cm}$., one descending $3 \mathrm{~m}$. 
healthy trees by contact between their roots and those of diseased ones.

\section{Rhizina inflata, Quelet.}

a. Description and Mode of Attack.

This root fungus, also named $R$. undulata, Fr., kills Scots pines of various ages. As the malady spreads in a circle, centrifugally from the point of infection, it is termed in France "Maladie du rond." It may be recognised by the dying and falling of the needles of affected trees, from the month of June. On digging up affected plants, the ground around their roots is found bound together by numerous hyphae, but there is no flow of resin, as in the case of the honey fungus. From the bark of the pine-roots protrude numerous white mycelial hyphae, like Rhizoctonia, ${ }^{*}$ which grow to three or three and a half feet from the affected plants in a richly branched, threadlike mycelium. 'Their whiteness is due to drops of etherial oil, exuding from the fine hairs at the ends of the hyphae. These hyphae spread in the soil, infect neighbouring plants, and penetrate their wood.

Massee states that the fungus is saprophytic on stumps and on peat. It was so destructive to Scots pine, on a loamy soil, in the Forest of Bellême (Orne), in France, that its cultivation had to be abandoned.

The sporocarps resemble morels, are from 1 to $5 \mathrm{~cm}$. in diameter, and of a dark chestnut or chocolate colour. They occur in the ground, connected with the mycelium.

\section{b. Subjects of Attack.}

The fungus attacks plants of all ages, from four years old. In Bellême, 50 years old trees were attacked. Besides Scots pine, Weymouth pine, silver-fir, larch, Douglas fir and Sitka spruce, also sweet chestnut have been attacked. It is saprophytic on old felling-areas.

\section{c. Protective Rules.}

Mix broadleaved trees with conifers. Choose conifers suitable for the locality. Isolate affected trees by trenches.

* Rhizoctonia crocorum, D.C., forms a subterranean web of filaments, termed " copper web," and attacking the crocus. 


\section{B. Wood and Bark Fungi.}

*4. Trametes Pini, Fr.

a. Description and Mode of Attack.

The mycelium of this fungus develops in the heartwood of the Scots pine and other trees causing ring-shake. The spring-wood of the annual zones becomes gradually reddishbrown, with numerous regularly distributed perforations coated with white, and at length disappears. The remainder of the wood, and especially the resinous autumn-wood, remains intact for some time, but eventually succumbs so that the tree

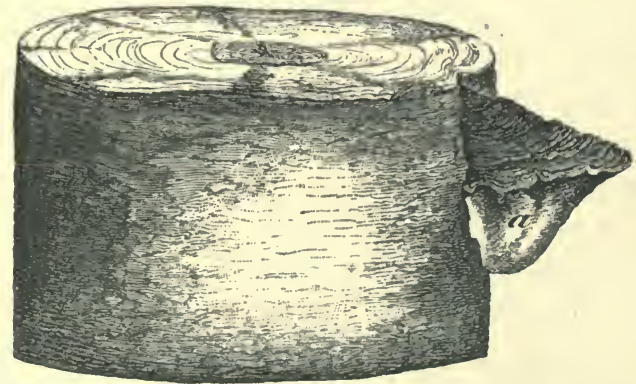

Fig. 211.- a Sporophore of Trametes pini, Fr., on the smooth cortex of a Scots pine.

may become completely hollow. As the mycelium develops most rapidly lengthwise along the infected ring, we find zones of attacked and sound wood alternating. I'he rotting wood, except in the slightly resinous silver-fir and in spruce branches, is generally bordered by a zone rich in resin which prevents the outward spread of the mycelium. The spores gain admission to the wood through fresh wounds in branches, where green branches have been broken or pruned, and at other wounds. The hyphae destroy the cell walls and penetrate the heartwood, usually leaving the sapwood unaffected.

At the scars of dead branches in the case of an infected pine or larch, or anywhere on the bark of a spruce or silverfir, bracket-like brown sporocarps eventually appear and emit spores which may germinate on fresh wounds, unclosed by resin, on other trees. 


\section{b. Subjects of Attack.}

This disease is commonest near villages and towns where forests are much exposed to mischief, and also in forests liable to wind- or snow-break.

Trametes Pini is prevalent on trees from forty years old and upwards, as it does not generally attack sapwood owing to its turpentine, and because wounds in young trees are usually soon closed with resin. It attacks the larch, spruce, and silver-fir, as well as the Scots pine. In the silver-fir, decay spreads to the youngest woody zones which contain little turpentine.

The sporocarps may become very old, up to sixty years, and attain large dimensions. The technical value of the wood is greatly impaired by the disease. The fungus is common in the Scots pine forests of North Germany, and in the Harz and Thüringer-Wald and South Germany, chiefly on the spruce. In the Carpathians it attacks silver-fir and larch woods. It occurs in the British Isles.

\section{c. Protective Rules.}

i. Mix broadleaved trees with conifers.

ii. Pruning living branches of Scots pines which already contain heartwood must be abandoned. Living branches may be pruned up to thirty years of age, as they contain no heartwood, and the infection is less liable to occur in young wood. In any case prunings should be clean cut with a saw, and, in silver-fir, at once tarred over.

iii. All infected trees should be removed during thinnings. In this way the sporocarps may be destroyed and the spread of spores hindered; also wood of diseased trees may be utilised before the decay has gone too far, as it is at first frequently confined to the upper part of a tree.

Wherever rot is due to wound-fungi, it may be avoided by attention to the rules given for Trametes Pini, Fr.

\section{Notes regarding Fungi causing Red or White Rot.}

A short account will here be given of certain fungi belonging to the order Basidiomycetes, family, Polyporeae, which assist 
in causing red or white rot in standing trees, the origin of which may, however, be due to certain bad conditions of the soil (pp. 673 and 679).

In the case of red rot, the substance of the cell-wall is dissolved by a ferment contained in the protoplasm of the hyphae of the fungi, and a residual substance consisting of gum, tannin, mineral matter, etc., remains, which, owing to the oxidation of the tannin, assumes a reddish-brown colour.

Red Rot is caused by the following fungi :-

\section{a. Polyporus vaporarius, Fr.}

On spruce and Scots pine, and rarely on silver-fir, both roots and wounds above ground being attacked. Wood attacked by this fungus becomes dark-reddish brown, and full of rectangular cracks, as in the case of Merulius lacrimans, Fr., which causes dry rot in timber. When rubbed between the fingers, the rotting. wood falls as a yellowish dust. Snowwhite branching mycelia, several yards long, are formed; the sporocarps form white incrustations. The spores gain entrance to the trees through wounds, and the fungus is also common on beams in buildings.

\section{b. Polyporus Schweinitzii, Hrtz.}

This is termed $P$. mollis, Pers., by Hess, but Hartig has now given the correct name as above. It is found on Scots pine, and also Weymouth pine and larch. Resembles $(a)$, but no white branching mycelia occur. Sporocarps reddish-brown brackets.

\section{c. Polyporus sulphureus, Fr.}

On the larch and silver-fir ; it is also a very common parasite on several broadleaved trees, and will be described further on.

White Rot is produced when the ferment of the hyphae decompose the lignine of the cell-walls, leaving the white cellulose untouched, which accounts for the light colour of the decomposed wood. Some of the causes of white rot are the following :-

(d) Polyporus borealis, Fr. On the spruce; the wood turns brownish-yellow, and characteristic radial grooves appear in 
the spring-wood which are filled with white mycelia, the latter having a strong tendency to spread horizontally. The sporocarps are annual, bracket-shaped, and frequently in tiers.

(e) Polyporus fulvus, Scop. It produces white rot in the silver-fir, and rarely in the spruce. It is frequently associated with silver-fir canker, described further on, its spores entering the wood by the cracks in the cankerous swelling. The wood becomes yellowish, and if clean-cut, àppears intersected by numerous white longitudinal bands. Narrow dark lines appear at the junction between the sound and rotting wood. The mycelium is yellowish, at first growing strongly, but becomes later on very fine. 'The bracket-like sporocarps are yellowishbrown above, ashy-grey below, and almost smooth. This fungus is found also on cherry-trees.*

\section{*5. Peridermium Pini, Wallr. var. corticola.}

(Pine-blister.)

a. Description and Mode of Attack.

Scots pines infested with this disease, which is very common in the British Isles and called pine-blister, are termed foxy trees by English foresters (Fig. 296, p.681). Massee states that it is notyet(1903) known how this fungus inoculates trees, and the teleutospore form of it is unknown. It may be a form of Coleosporium senecionis, Fries., described further on, but this is denied by Cornu and Klebahn. Hess described the disease, in 1866 , being probably the first to do so.

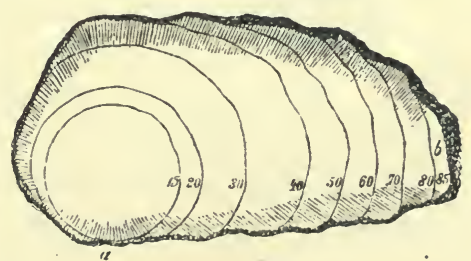

Fig. 212.- Section of pine attacked by pineblister at $a$ for seventy years. (After Hartig.)

The disease may be recognised by the compressed orangeyellow coloured little tufts of the aecidia, or sporocarps, which break through the bark of branches and stems of the Scots pine in June, and eventually burst and set free their spores.

\footnotetext{
* For a further account of red and white rot, see pp. 673 et seq.
} 
The empty sporocarps then appear white. As a rule only bark infected in the previous year produces aecidia. The colourless, septate hyphae of this fungus grow perennially in the intercellular spaces of the bark, bast and medullary rays of its host, sending short haustoria through the cell-walls to the cell-cavities. The mycelium is developed chiefly in the

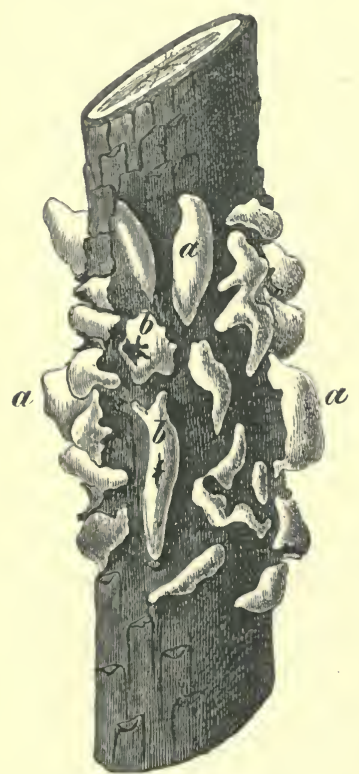

Fig. 213.-Peridermium pini, Wallr. (corticola), on a 5-yearold shoot of a mountain pine. The sporocarps are closed $(a)$, or have already burst (b). (Natural size.) bark and bast, but penetrates into the wood to a depth of a hand.

The mycelium converts the starch in the wood-cells into turpentine, which becomes infused by drops in the tissues, and cuts off the supply of sap. Every year it spreads chiefly longitudinally from the diseased to the sound wood, so that the canker, which is covered with resin, constantly increases in size. The sap being confined to the sound portions of the wood, produces abnormally large annual zones on the side of the tree away from the canker (Fig. 212), and when the infection has gone nearly round the tree, its crown dies above the point of attack, sometimes within a year, but in other cases a long period up to sixty or seventy years may elapse before the crown is killed.

Hot dry summers accelerate the death of the crowns of infected trees, as the wood surcharged with resin cannot pass on enough water to supply the loss by transpiration. Although the summit of the tree is dead, the lower part of it may continue to live, provided there are enough living branches below the canker to nourish the tree.

Whether or not infection must always proceed from a wound in the cortex of the tree is as yet undetermined. Parts of the stem older than twenty to twenty-five years appear incapable of being infected. 
The spores of this fungus germinate on the leaves and stem of Vincetoxicum officinale, Mnch., and on other species of Vincetoxicum, producing the fungus, Peridermium Cornui, R. et Kleb. The teleutospores from this again infect pines. As, however, there is no Vincetoxicum in Britain, where pineblister is very common, there appear to be two forms of the disease, one P. Cornui, R. et K., and the other P. Pini, Wallr., the teleutospore form of which is unknown.

\section{b. Subjects of Attack.}

Scots and black pines of all ages are attacked by pine-blister, but preferentially fifteen to twenty years old poles. It attacks only organs two or more years old, and is commonly found at verticils of branches and in the crown of the tree. It has been often observed in mixed forests of pine with beech or hornbeam, where the branches of the broadleaved species, swayed by the wind, have rubbed off the bark of the pines.

The disease is well known all over Europe west of Poland.

\section{c. Protective Measures.}

Fell infected pines as soon as the disease is noticed.*

\section{Peridermium Strobi, Kleb.}

(Weymouth Pine-blister.)

a. Description and Mode of Attack.

The Weymouth pine-blister resembles the ordinary pineblister externally. It attacks the cortex of stems and branches, and especially at the verticils, causing long swellings. From these, yellow pustules eventually break out, which on bursting emit spores in a dark yellow powder. The mycelium grows for years in the cortex, and produces blisters (æcidia) every year. The disease kills the stem and branches above the seat of infection, and sometimes the tree.

The disease is contracted by an intermediate host. This is either a currant or gooseberry bush. Among the former, Ribes nigrum, L., R. rubrum, L., and $R$. aureum, Pursh., are

* See Klebahn, Dr. H., "Förstliche Blätter," 1891, p. 151. Id. Forstlichnatuewissenschaftliche Zeitschrift, 1897, p. 334. 
the chief infectors. The uredospores appear on the lower surface of the leaves of these plants, at the beginning of June, as small yellow cushions. The teleutospores that arise from them are brown and in rows. The sporidia that come from them and germinate on the Weymouth pine, cause swellings, in which a mycelium grows, and next spring, spermagonia are formed, and rcidia later on. Species of Ribes are again infected, and the disease becomes widely spread. The fungus on the Ribes is named Cronartium ribicolum, Dietr.

\section{b. Subjects of Attack.}

The fungus attacks young plants and poles of Weymouth pine, chiefly on their stems. It also attacks lateral branches of older trees; tree-parts older than 20-25 years appear to escape.

In 1880, about 30 per cent. of the Weymouth pine in Bremen Town Park were attacked and seriously injured by this fungus. The disease has also appeared in other districts in $\mathrm{N}$. and S. Germany and in Denmark. It is reported to have originated on Cembran pine (?) in the Baltic provinces. It has not yet been noticed in America, the home of the Weymouth pine.

\section{c. Protective Measures.}

i. Secure healthy plants of Weymouth pine, when buying from nurserymen.

ii. Remove and burn all infected plants.

iii. Cut out infected poles in thinnings.

iv. Do not allow any species of Ribes to grow within at least fifty yards of Weymouth pine plantations.

*7. Melampsora pinitorqua, Rostrup.

(Pine Branch-twist.)

a. Description and Mode of Attack.

This fungus, formerly named Caeoma pinitorquum, A. de Bary, is developed, especially in North Germany, in the cortex of the young shoots of the Scots pine. Before they have attained their full length, at the end of May or beginning of 
June, long yellow sporocarps of the fungus appear, which eventually turn reddish yellow, and become raised like cushions until the epidermis of the host splits and so allows the dissemination of the spores, whilst turpentine exudes from the split. As the growth of the pine-shoot is checked at the split,
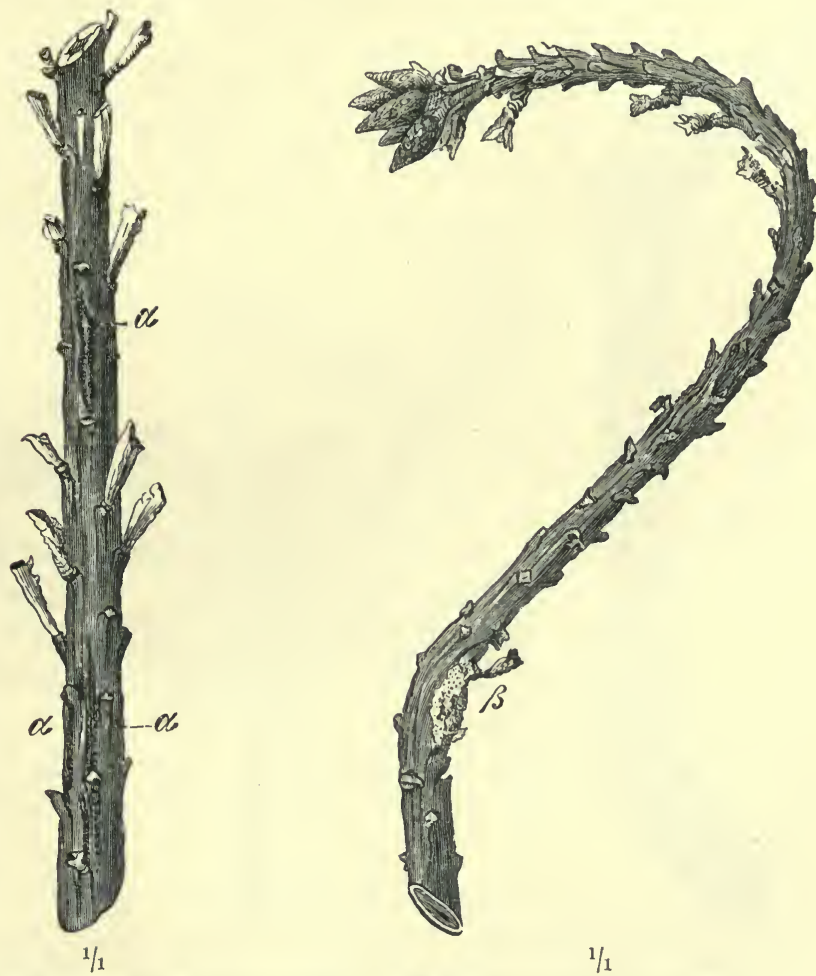

Spring shoots of Scots pine attacked by Melampsora pinitorqua, Rostrup.

Fig. 214.-Part of shoot in middle of June with sporocarps $(\alpha)$.
Fig. 215.-Entire shoot $(\beta)$ exuding resin. The needles have been pulled off.

but goes on normally elsewhere, the infected part becomes concave, and the healthy part bends over it. If the attack is slight the sickly place may heal over, and the branches recover their erect position. Often, however, splits follow one another so frequently that the shoots become twisted in various directions. At length it may happen that the bark is attacked all 
round the shoot, the supply of water is then cut off, the needles turn yellow, and the shoot dies towards the end of June or in July, hanging down as if it were frozen.

The plant, by sending out several side-shoots at the base of the lost leader, endeavours to replace $\cdot$ it; but these shoots

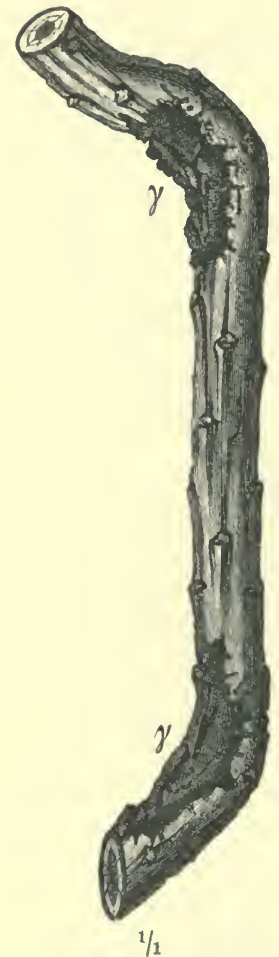

Fig. 216.-Part of a twoyear-old shoot, bent at $\gamma$ owing to the wounds caused by Melampsora pinitorqua, Rostrup.

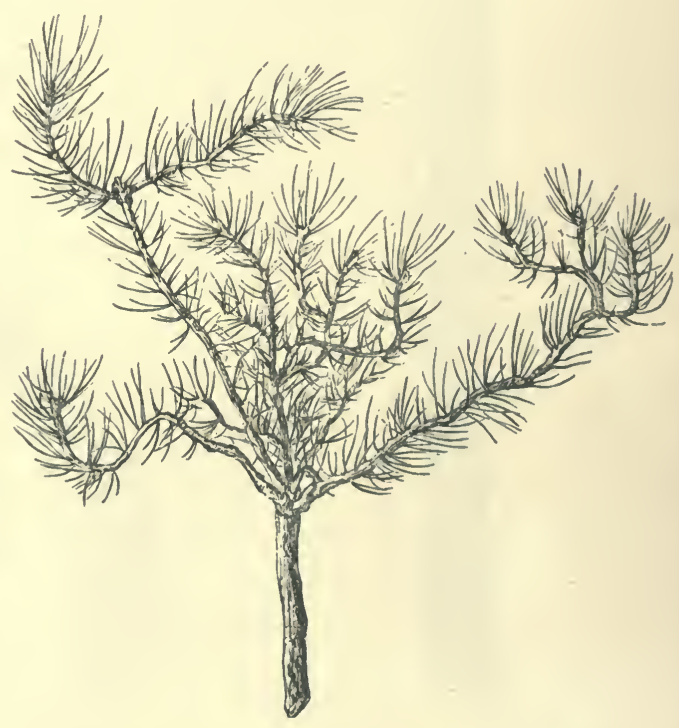

Fig. 217.-Crippled condition of a Scots pive shoot which has been attacked by $M$. pinitorqua for several successive years. (Reduced.)

usually become infected in succeeding years. The mycelium of the fungus grows in the green cortex and becomes perennial in a plant which is once attacked, while sporocarps annually appear in the spring-shoots, except in very dry springs. The infected wood becomes brown down to its pith. 
This fungus alternates as Melampsora Tremulae, Tul., on the leaves of the aspen, which produces resting-spores or teleutospores; these hibernate on the dead aspen leaves, and produce promycelia in the spring from which spores develop, which then infect young pines. Rostrup first discovered, in 1883 , that Caeoma spores generated on aspen leaves.

\section{b. Subjects of Attack, and Distribution.}

This fungus attacks chiefly young-one to ten years oldScots pine, also Weymouth and mountain pines, but never trees over 30 years old ; it is most frequent on damp soils, and in cold, moist, early summers. The exemption of older pines from the attacks of this fungus is probably due to the fact that the spores proceed from dead aspen leaves lying on the ground.

One to three years old cultivations of pines may be entirely destroyed by it, the disease spreading centrifugally from a centre of infection; and in older woods, especially after a succession of rainy years, such misshapen stems may be formed that the marks of the damage always remain patent; the development of the malady is however retarded by dry weather, and the disease disappears about the thirteenth year. This disease is known all over Germany, especially in the north, and did great damage between 1870 and 1873. For attacks by $M$. Tremulae, Tul., on larch needles, vide p. 469 .

\section{c. Protective Measures.}

Careful choice should be made of suitable localities for growing Scots pine.

Immediate pruning and burning of infected shoots should be effected.

Remove aspen from pine woods.

\section{Witches-broom .}

Witches-broom is an abnormal hypertrophy of twigs appearing on many broadleaved and coniferous trees, and is caused by the action of animals as well as of plants. 
- i. Action of Animals.

Biting by cattle, chiefly goats, or by deer, mice, mites, or insects. The witches-broom on lilac, for instance, is caused by mites (Phytopus Loewi, Nal.); also on willows (Phytopus trivadiatus, Nal.), etc.

\section{ii. Action of Plants.}

Parasitic fungi cause witches-broom on silver-fir (Melampsorella Caryophyllıcearum, Schröter), No. 8. On hornbeam (Exascus Carpini, Rostr.) ; Birch (E. betulinus, Rostr.) ; cherry (E. Cerasi, Fuckl.), etc. It is not known what causes witchesbroom on Scots and Weymouth pines, spruce, larch, or beech. Hoffmann, of Giessen, states that two species of Cladosporium cause this hypertrophy on Scots pine, but this is still unproved.

- Goeppert states that it is due to a local swelling of the cambium, but does not explain how this arises. These witchesbrooms, as well as those on the Scots pine, do not appear to be very prejudicial to their hosts : that on silver-fir is described under next heading.

\section{*8. Melampsorella Caryophyllacearum, Schröter, formerly} named AEcidium elatinum, Link.*

(Silver-fir Canker.)

\section{a. Description and Life-history.}

This fungus causes the well-known silver-fir canker and witches-broom. The latter may be distinguished from normal shoots of silver-fir by its erect, brush-like growth, resembling the parasitic growth of mistletoe, on the drooping branches of the fir, and by the small yellowish-green needles growing all round the shoot, which fall off in their first autumn. 'There is also a slight swelling of the affected shoot, and in it the mycelium of the fungus grows in the cortex and bast of the host, passing into the younger shoots and needles till the witches-broom, which appears to live only for sixteen years, dies; the mycelium still lives in the cortex of the cankerous swelling, but apparently not in the wood. It does not grow down

* "Der Weisstannenkrebs," Dr. Karl N. Heck. Berlin, Springer, 1894. Also two papers by E. Fischer in Zeitschrift für Pflangenkraukheiten, Vol. XI., pt. 6, 1901 and 1902 , pp. $321-343$. 
through the cortex of an infected branch into the stem, but a stem-canker is produced when the stem grows over the infected base of a branch.

The canker may be distinguished externally by a swelling either on one side of, or all round the stem, on which the bark is deeply cracked and dark brown, showing here and there a little resin; it crumbles away in parts, exposing the wood. It may be found at any height on young or old trees or their branches, and may attain a large size. The mycelium which grows in

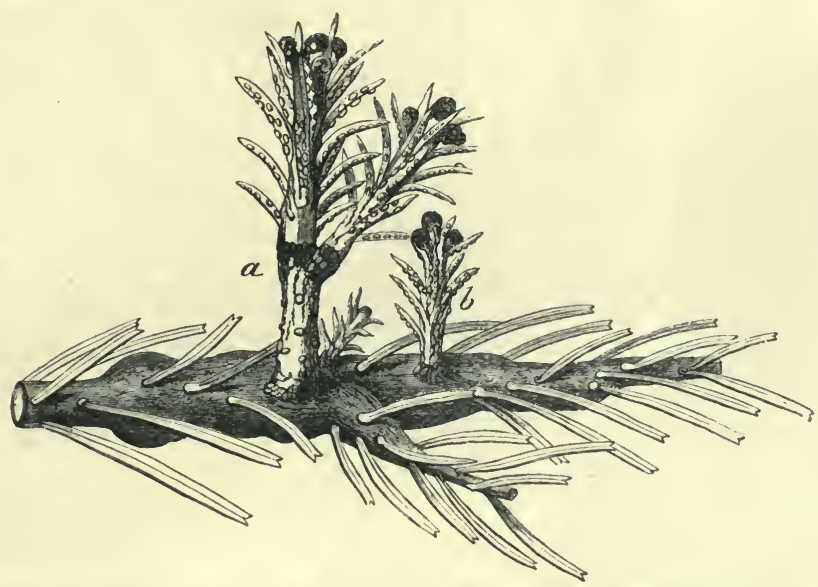

Fig. 218.- Shoot of Silver-fir attacked by M. caryophyllacearum, Schröter.

$a$ Cankerous swelling. $b$ Needles of the witches-broom. (Natural size.) After Hartig, from Proc. of Royal Soc., Vol. 47.

the cortical parenchyma is the same as that which produces a witches-broom, but the latter is formed only when the mycelium reaches a living bud. If, however, the shoots are old and have no living buds, no abnormal shoot-production takes place, and the canker alone is formed. The infection appears to spring from a wound in the shoots affected.

'The golden or orange-coloured sporocarps (Spermagonia and Stylospores) are formed on the under surface of the diseased leaves. They appear in two rows, open and emit their spores in June, the needles subsequently dying. The witches-broom continues growing for about 16 years, chiefly upwards, and branching freely, resembles a mistletoe plant on the usually horizontal branches of a silver-fir. It at length dies, and only

E.P.

G $\mathrm{G}$ 
the canker remains, which does not produce any sporocarps. Hess stated (1900) that no one has yet succeeded in infecting a tree artificially by the spores of this fungus, and that

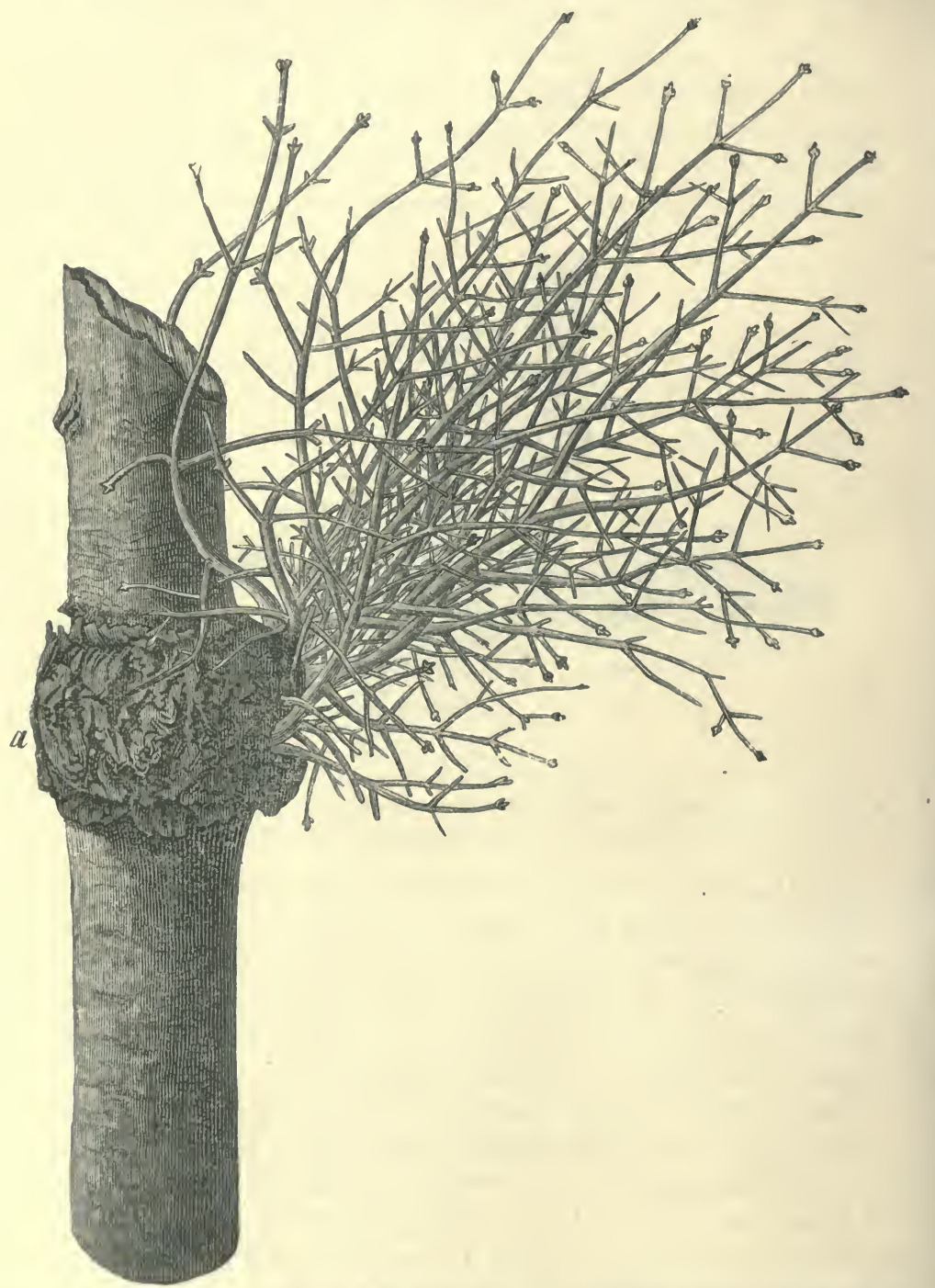

Fig. 219_-Old witches-broom on the Silver-fir. a Cankerous swelling caused by the mycelium of the fungus. 
a case of polymorphy may be concerned here, but the alternate host of the fungus, if one existed, was not then known. In 1901, however, E. Fischer, of Berne, succeeded in infecting species of Stellaria with spores from a silver-fir witches-broom, and obtained Melampsorella Caryophyllace"rum, Schröter, also named Melampsora Cerastii, Pers. This fungus attacks species of Stellaria and Cerastium, common weeds in fields and hedgerows adjoining silver-fir forests.

The damage done is direct and indirect, the former consisting in loss of increment and depreciation of the quality of the wood, as cankered wood cannot be used for constructions. The indirect damage consists in increased danger of breakage by storms or snow, and a greater disposition to insect attacks and those of other fungi, such as Polyporis fulvus, Scop., and Agaricus adiposus, Fr., which soon render the wood very brittle. A practical distinction is made be-

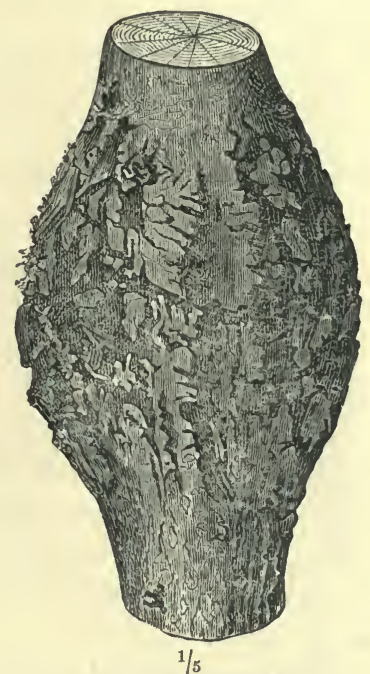

Fig. 220.-Canker on a Silver-fir about 45 years old caused by $\boldsymbol{M}$. Caryophyllacearum, Schröter. tween sound and diseased cankers; sound cankerous wood is 30 per cent. heavier than uncankered wood, it is also harder, less fissile, and absorbs only half as much water. Sound cankerous trees yield some pieces of good timber, but badly cankered trees are only fit for fuel.

Several cankers may be sometimes seen on the same tree, and cankered trees may die outright in hot summers. The canker may live for 50 years and longer. Mr. H. Ingold has calculated, that, in the Vosges, 21 cankered trees are broken, to one sound tree, and 11 dry up, to one sound tree.

\section{b. Subjects of Attack and Distribution.}

The disease is everywhere widespread in silver-fir forests, both mixed and pure, and especially in the Black Forest, 
where in a mature crop of 240 trees per acre, on the average 14-16 trees are cankered. It is common in Windsor Forest. The fungus also attacks Abies picta, Forb., A. balsamea, Mill., A. Nordmanniana, Lk., A. cephalonica, Loud., and A. Pinsapo, Boiss. Cankerous stems are found on every soil and locality, but the disease is less prevalent on sandy soils and at high altitudes than on loam or in or near the plains, where the progress of the disease is more rapid.

The damage in old woods is greater than in young ones on account of the increase in value of the trees, and in pure high forests than in mixed selection-forests.

\section{c. Protective Rules.}

Mix other species not subject to the disease with the silver-fir.

Prune off the witches-brooms, which chiefly appear on young trees, by sawing off infected branches close to the stem before the spores are dispersed, and tarring the wounds.

Remove cankerous stems in thinnings and preparatory fellings, and transport them speedily from the forest. Even dominating cankerous trees should be removed, and dominated trees left to replace them. Those cankered all round should be first felled, as the crop must not be overthinned from fear of "windfall.

Old woods full of cankerous trees should be felled before the prescribed period. 'I'he group-system practised in Baden allows this to be done, and it is the most effective remedy.

Weed away Stellarias and Cerastia from the neighbourhood of silver-fir woods, and do not grow silver-fir near the outer boundaries of such woods. It is probable that the disease originates otherwise, besides from infection from the weeds referred to.

\section{*9. Nectria Cucurbitula, Fr. \\ (Spruce Nectria.) \\ a. Description and mode of Attack.}

'This fungus produces the spruce-bark disease, and more rarely attacks the Cembran pine and larch. Its external symptoms are :-Pale colouring of the needles, the bark and bast turning brown and drying up, generally after insect attacks, and less frequently after wounds from hail or other causes. Numerous clusters of little red, gherkin-like sporocarps 
appear in the bark, which may run into one another like felt. Conidia issue from them from late in the autumn till the spring, and infect surrounding plants through any wounds they may have, and spread the disease.

The branching mycelium grows chiefly in the sieve-tubes of the soft bast and the intercellular spaces between them. The growth of the fungus is very rapid, but appears to proceed chiefly in the season of rest of the barktissues, not in that of their vegetation, when it is usually arrested. When the fungus has spread all round the stem, the tree dies, or at least that part of it which is above the point of attack. If however, the diseased tree can retain any sound bark on one side till the ensuing spring, it is saved, for it protects itself by producing a corky sheath between the sound and diseased part, which stops the further progress of the fungus. The dead bark is then thrown off, and the cankerous place grown over.

\section{- b. Subjects of Attack, and Distribution.}

The fungus appears chiefly on young spruce from three to thirteen feet in height, and both in pure spruce woods and in mixtures of spruce and beech. It has also been observed on Cembran pine and larch. It is very common in frosty localities. The conidia gain admission to the tissues only through external wounds, which are therefore extremely dangerous in localities where the fungus is present. Badly-growing plants are the more subject to its attacks,

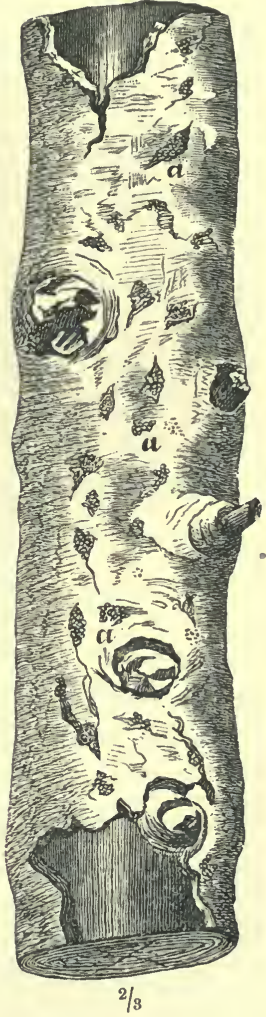

Fig. 221. - Spruce attacked by Nectria cucurbitula, Fr.

$a$ Clusters of sporocarps on the dead bark. as injuries by insect or hail heal up less readily than in the case of vigorous plants, and are therefore longer exposed to the attacks of the fungus. 
In 1850, the moth 'Tortrix pactolana, Zell., had ravaged the spruce forests of Bohemia; damage by this insect is, however, generally only of a temporary nature, but in this case, it was followed by Nectria, and great destruction of the spruce occurred. The fungus has also appeared recently in the forests of Bavaria and Würtemberg, but seems to be absent from North Germany. Nisbet states that it is common in Britain, though generally as a saprophyte on dead branches only.

\section{c. Protective Rules.}

Cut down young stems and shoots attacked by the fungus with a pair of vine-shears in autumn and early winter. This method does not cause the spores to be so scattered as when the stems are felled with a billhook. It costs about 1s. $6 \mathrm{~d}$. an acre.

The larger stems attacked must be felled at the same time. In both cases all the infected parts should be removed carefully, and burned in an out-of-the-way place, as the spores easily spread from any pieces left lying about.

*10. Dasyscyipha calycina, Fuckel.

(Larch-blister.)

a. Description and mode of Attack.

The nomenclature of this fungus has passed through several stages: Willkomm, in 1867, described it as Corticium Amorphum, Fr., ${ }^{*}$ which in reality attacks the cambium of silver-fir ; but in 1868, H. Hoffmann (Giessen) named it Peziza calycina, Schum. In 1874, R. Hartig showed that the larch fungus differed from $P$. calycina, Schum., which attacks silverfir, spruce and pines. He therefore named it P. Willkommii, R. Hrtg. This has large aski and elliptic spores, the former fungus having oval spores.

Masseet states that the spores are globose and names the fungus Dasyscypha calycina, Fuckel, and states that a very

* Conticium amorphum, Fr., in the cambium of silver-fir, may cause the whole tree to dry up and die without losing its needles. Large blanks have thus been caused in a forest near Neuchâtel, Switzerland. "Rev. des E. et F.," Feb. 1 1897.

+ Vide paper in Transactions Royal Scottish Arboricultural Society by G. Massee, 1903. 
similar fungus, D. resinaria, Rehm., attacks chiefly spruces, but also larch. This latter fungus also attacks Pinus excelsa, Wall., and, in America, is very destructive to Abies balsamea, Mill. Both species are wound-parasites, but can enter the tissues of the living tree through wounds made by a minute parasite, Exosporium, the spores of which in damp atmosphere can germinate on the cortex of seedlings or young branches. The sporocarps of Exosporium appear on the surface of the larch as minute black dots and cause cracks in the bark, filled with resin, through which Dasyscypha spores can gain admission.

Dasyscypha calycina, Fuckel, causes the destructive larchblister, of which the symptoms are as follows : - Appearance of little swellings on the stem and branches, chiefly below the crown; the bark splits and tur-

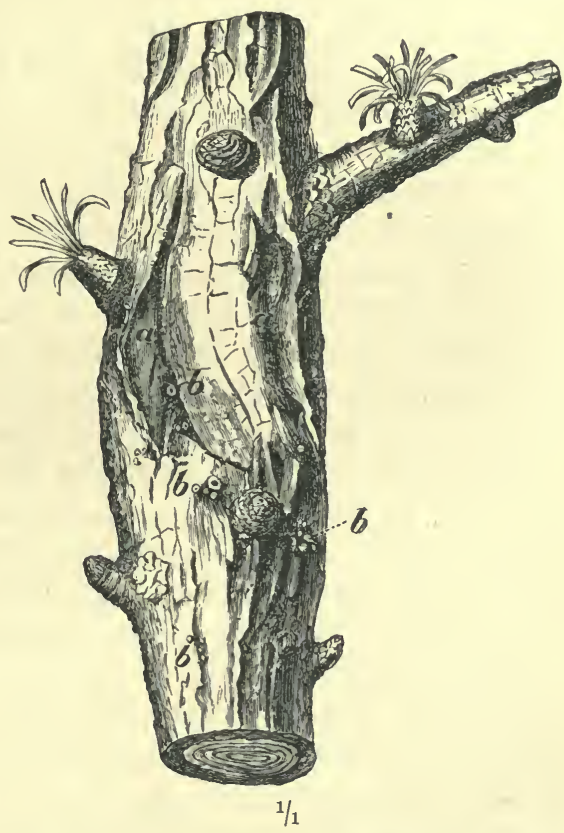

Fig. 222.-Portion of Larch-stem attacked by ${ }_{\mid}$Dasyscypha calycina, Fuckel.

$a$ Cracks with outflow of resin. $b$ Sporocarps. pentine exudes, forming light grey-coloured patches, and the split increases till the wood is exposed. Little yellowish-white sporocarps of the size of a pin's head appear in the cracks. These are incapable of at once producing fertile spores, and merely wither away if exposed to dry winds. Where they are surrounded by moist air, however, they develop into cup-shaped fructifications, whitish above and pale red below, and these give rise to fertile spores, which infect other trees, The dead parts of the tree 
turn black, and owing to the sivelling of the walls of the canker and the local stoppage of the growth, its centre forms a spoon-shaped depression, and the canker itself is spindle-shaped. Several cankers may appear on the same tree.

The fungus can gain admission only through wounds, frequently of brachyblasts eaten by Coleophora laricella, Hbn. (vide, p. 346), punctures made by Chermes (pp. 361-364), or due to snow-break, etc. After the entrance and sprouting of the spore the richly-branching mycelium traverses the bast, but only during the spring, as its further progress is cut off by the formation of corky tissue separating the diseased place from the still healthy bast. The exposed wood exudes turpentine, and in the autumn the mycelium grows again from the cambium into the healthy bast and increases the size of the canker. Fresh layers of cork again cut it off, and the growth of the mycelium is repeated, a protracted contest between the tree and the fungus usually ensuing. In the Tyrol, a living lareh tree has been seen affected by a canker 100 years old.

When the canker is small and the growth of the larch vigorous, on account of the locality being suitable for it, the damage done is limited to the point of attack. When, however, the parasite grows fast and the growth of the tree is not vigorous, the mycelium may penetrate the wood by the medullary rays even down to the girth, and the flow of sap is seriously interrupted. The tree then begins to languish, needles turn pale, twigs dry up and die, while fresh cankers develop, especially in damp places. In such localities the cankers may be of reduced size, but the mycelium spreads throughout the wood, and the sporocarps appear in all directions on the bark.

\section{b. Suljects of Attack, and Distribution.}

D. calycina, Fuckel, attacks Larix europaea, D.C., wherever it grows. It occurs in Britain, also, on Scots pine, mountain pine and silver-fir. Japanese larch, L. Leptolepis, Gord., has also been attacked (Berlin, 1895, Hennings).

'The larch-blister or canker is found in localities which differ widely from one another, but is most prevalent in damp places with moist air and in frosty and cloudy localities. The 
disease spreads most rapidly in plains and-valleys and among low hills. Trees ten to twenty years old suffer most, but the attack is rare in the case of trees more than forty years old. Dense stocking does not suit the larch, and assists in spreading the disease; sowings therefore suffer more than plantations, and pure woods more than mixed woods. Larches growing with broadleaved trees are least liable to canker. Mr. Michie, in his book on larch (Blackwood \& Sons, 1885), says, that after the first fifteen years tree-parts are safe from attack. Hence, in a larch tree, 30 years old, and 45 feet high, the first twenty feet or so are safe.

The disease originated in the Alps, and when during the first twenty years of this century extensive larch 'plantations were made all over Northern Europe they escaped the disease, even when on inferior soils, but spores of the fungus probably found their way down with larch seed from the Alps, and the disease became widespread in more recent plantations. In the Alps, it is usually confined to individual trees, and does not ruin whole woods as in Germany, Denmark, and Britain.

The reason is, that, in the Alps, there is a sudden change from winter to quite warm weather, so that the needles develop rapidly, whilst at lower elevations the soil becomes heated at the end of March, and the larch needles then appear, but are subjected to the treacherous spring weather, and do not harden till the beginning of May. During this prolonged period of development of the needles they are liable to attacks of Coleophora laricella, Hbn., and of Chermes, which promote the spread of the canker. In the Alps, moreover, the fertile spores are only produced in damp places, near the lakes for instance.

It should also be remembered that, in its native country, larch has its roots covered by deep snow till May, and that the soil contains plenty of moisture throughout the year, though, owing to the sloping ground on which the larch grows, this moisture is never stagnant. In Britain, then, whenever there is not much winter snow, a moist covering of dead beech leaves, or a deep porous soil resulting from much disintegrated rock, are the best substitutes for Alpine snow. 
The larch roots can then spread freely and obtain plenty of nourishment, and the tree then grows vigorously, and either escapes the disease or grows away from it.

It is probably everywhere in the British Isles damp enough for the fertile spores to be produced, though the disease is not yet prevalent in Ireland; but it is stated that on good fertile soil near the Scotch lakes the larch grows so rapidly as to outgrow the disease, even when infected.

Vigorous larch trees are growing at Colesborne, in Gloucestershire, on the banks of a stream in a damp valley, and the larch-blister is more fatal in the drier, flatter eastern parts of Britain than in the moister hilly west, or in Ireland.

The disease causes loss of increment, and reduces the quality of the timber, it encourages insect attacks and snow and wind break, and may kill trees outright. Wherever, therefore, larch grows badly owing to unfavourable soil, or climate, it is better to give up planting it.

\section{c. Protective Rules.}

i. Great care should be taken in the selection of sites for larch plantations; pure larch-woods should be avoided, except in early youth, and larch should be given plenty of room. It prefers northerly aspects and well-drained but not dry soil, slopes of hills and mountains, fertile but not too binding soil, plenty of room for root-development, and abundance of dead leaves or snow on the soil, so that the ground may not be lieated and the larch forced into growth early in spring and afterwards retarded by the spring-frosts. No tree requires more light or room than the larch.

ii. Larch grows best when mixed with beech, silver-fir, or spruce, which may be introduced after the larch poles have been thinned.

iii. Great care should be taken in thinnings to avoid wounds, especially in knocking off dead branches, which should never be done with the sharp side of a billhook.

iv. All badly cankered larches should be cut out in thinnings. Plantations ruined by the disease should be felled and replanted with another species. 


\section{Cenangium Abietis, Duby.}

(Pine-shoot Fungus.)

\section{a. Description and Mode of Attack.}

'This fungus causes the death of isolated shoots of young pines. As a rule, only yearling shoots are attacked, but sometimes 2 to 3 years old shoots also, chiefly at their tips. The shoots die from April till June, from the top downwards. Mycelia are found in the dead shoots, including their buds. The cells of the cortex turn brown and become filled with resin, the tissues are rent. The inner tissues down to the girth also turn brown. The mycelium is most abundant in the buds. The needles die from the base, contrary to those attacked in the pine needle-cast (p. 465). They turn yellowish green, yellowish brown, and eventually brown.

'This is not a wound-parasite. The sporocarps are dark brown roundish cushions, breaking out from the mid-nerves of the needles or from the base of yearling shoots, but chiefly from those $2-5$ years old dead shoots. The spores germinate only after the dead shoots have fallen to the ground, where they obtain sufficient moisture.

If the number of infected shoots is sufficiently numerous, the trees attacked may die, otherwise the damage consists in loss of increment only.

\section{b. Subjects of Attack, and Distribution.}

This fungus specially attacks Scots pine, of any age, but chiefly 12-20 years old thickets and polewoods. Also black and Weymouth pines. Until 1883, it was considered as saprophytic only on dead spruce and silver-fir branches. Then F. von Thümen suggested that it is parasitic on Scots pine. This was proved to le the case in 1892 by Frank., the fungi having appeared in 184 Prussian forest districts. The exceptional nature of the weather in 1892 certainly assisted in its spread. The fungus occurs in France and Sweden, as well as in Germany.

Hartig considers that the damage done in 1892 was due to the intense insolation in February and March, while the 
roots of the pines were in frozen ground, and could not therefore supply the water lost by insolation.

\section{c. Protective Rules.}

Remove affected poles in the thinnings.

\section{Pestalozzia Martigii, Tubf.}

This fungus causes a disease in spruce and silver-fir seedbeds and nursery-lines. Its first symptoms are that a number of plants turn pale and die, and when pulled-up it will be noticed that their cortex close to the ground is withered, whilst above this withered portion the stem has attained its usual dimensions. The mycelium of the fungus may be found in the bark, where the contraction in the stem takes place, and sporocarps spring from the point of attack.

This disease appears to attack several broadleaved species as well as conifers, and all infected plants should be at once pulled-up and burned. For instance, in a beech-nursery at Vicdessos, Ardêche, altitude 1,350 m., the plants were lined out at two years old, and by August became chloritic and dried up. Those remaining in the seed-beds were not attacked.* Pull up and burn all affected plants.

\section{Septoria parasitica, R. Hrtg. •}

(Spruce-shoot Fungus.)

This fungus causes the wilting and death of young spruce shoots, especially lateral shoots. The needles of the attacked plants become brown and wilt, as if they had been attacked by late frost, and generally break off. In the course of the summer globose black pycnidia appear at the base of the shoots, from which threadlike conidiaphores arise. These appearing in white rows, spread the disease in May on the fresh opening shoots. Sitka spruce is also attacked.

This disease has been observed chiefly in young spruce, in nurseries and plantations. It also attacks the leading shoots of poles, and sometimes causes groups. of plants to die, as in Ehrenfreidersdorf, in Saxony. It is common in the Hertogenwald, near Spa, in the Ardennes.

Cut off and burn diseased branches.

* Henry : “Rev. des E. et F.," 1901, p. 537. 
14. Botritis Douglassii, Tubf.

This fungus, termed Douglas-fir blight, and known for several years. as attacking 2-6 years old Douglas firs, in 1895, was found on young Scots pine in Holland (Ritzema Boos). Wellingtonia seedlings have also been attacked at Kew.

The needles, especially the upper ones, wilt, and the whole plant's growth is weakened. A brownish grey mycelium appears on the upper shoots, which become curved and die, the needles falling off. Conidia form on the fallen needles and minute black sclerotia on the dead branches. The latter produce conidia if the air be moist. Young plants are frequently killed. Nisbet states that this fungus is identical with Sclerotinia fuckeliana, De Bary (B. cinerea), the vine pest. This, however, appears to be doubtful.

Spray with Bordeaux mixture and burn affected plants.

\section{Needle-fungi.}

15. Peridermium Pini acicola, R. Hrtg.

(Pine Needle-rust.)

During April and May, on the one-year or two-years needles of young pines of different species, orange - yellow blis-

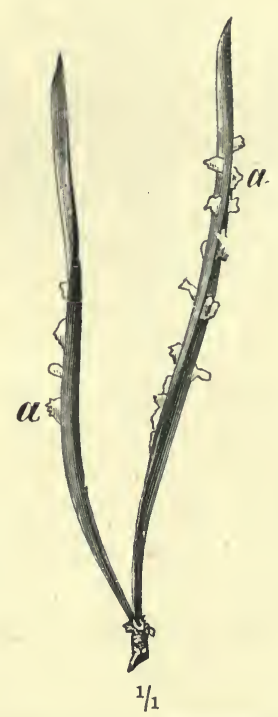

Fig. 223.-Peridermium Pini acicola, R. Hrtg., on Scots pine needles. a Burst sporocarps. ters appear, about the size of a mustard seed, often several of them being in a row on one or both - ides of the needles. When ripe, they turn brown and split, emitting their spores and leaving on the needles blackish spots with lighter borders. The mycelium is perennial on the needles, and without killing 
them, may, during the ensuing year, develop fresh aecidia. The needles die and fall only when the disease is very intense. The pine needle-rust, as the disease is termed by Massee, comes from spores of species of Coleosporium senecionis, Fr., a fungus infesting several species of Senecio, chiefly biennials, S. vulgaris, L., S. viscosus, L., S. vernalis, W. et K.

The fungus prefers plants 3 to 10 years old, but may attack trees up to 30 years; it is widespread throughout Europe, including the British Isles, but does little harm to the trees it attacks. Weed out groundsell from pine woods that it attacks.

\section{Aecidium Abietinum, Alb. et Schw.}

This fungus causes a needle-rust, which appears at midsummer on the previous year's shoots of the spruce, the needles then assume a dull reddish-yellow colour; during August, bright-red aecidia of the size of a pin's head project from the needles, and at the end of August or the beginning of September they burst and emit their yellow spores in a cloud of dust. The affected needles, which on lateral shoots are usually only on the upper side of the branches, die and fall before the close of the year, and the fungus may be thus distinguished from Chrysomyxa Abietis, Ung. 'The alternate hosts of the fungus are several species of rhododendron in the Alps, and Ledum palustre, L., in Finland and parts of North Germany, and these plants carry the disease through the winter. Spruce trees of all ages are affected, especially in the Alps, from an altitude of 1,000 metres to the highest limit of spruce, where whole spruce-woods sometimes assume the yellowish-red colour. The disease is also very prevalent in Russia; no practical remedy has been devised against it.

17. Aecidium columnare, Alb. et Schw.

(Silver-fir Needle-rust.)

Aecidia break out in July and August on both sides of the mid-rib of silver-fir needles, in the shape of long yellow blisters full of spores. This fungus alternates as Melampsora Goeppertiana, Külm, on the cowberry (Vaccinium VitisIdaea, L.), and causes that plant to become abnormally 
tall, with a thickened spongy stem, at first whitish, then rosy-red, and eventually dark brown.

The fungus kills silver-fir needles and causes them to fall, but it is not widely spread and becomes dangerous only when young thickets of silver-fir spring up among cowberry plants, when the latter should be uprooted and destroyed.

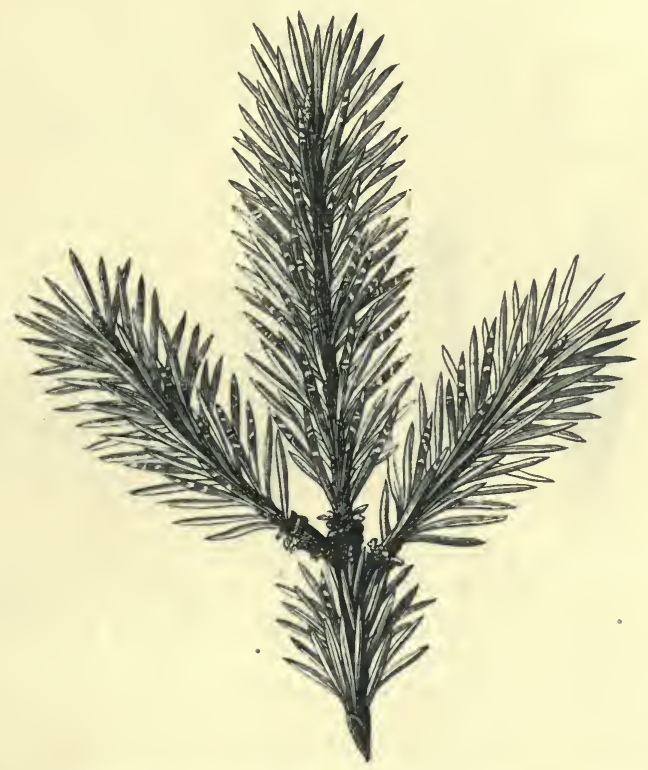

Fig. 224.-Spruce twig attacked by Chrysomyxa Abietis, Ung., in autumn. (Natural size.)

18. Chrysomyxa Abietis, Ung.

(Spruce Needle-rust.)

a. Description and Life-history.

This form of spruce needle-rust may be recognised by dull yellow bands appearing from May to the middle of June on yearling spruce needles.

They gradually become broader and assume a brighter yellow colour. Towards the end of August brownish longitudinal stripes appear on the affected needles, which by 
November assume a golden-yellow colour, and swell up slightly on one or both sides of the mid-rib; the fungus hibernates on the tree in this condition. 'T'he swelling becomes greater at the beginning of spring, and from April to the middle of May the epidermis of the needle bursts and the spores are scattered, the affected needles, parts of which are still green, wilting and falling in June and July. The spores which are disseminated in May, when the young shoots of the spruce are forming, can then infect

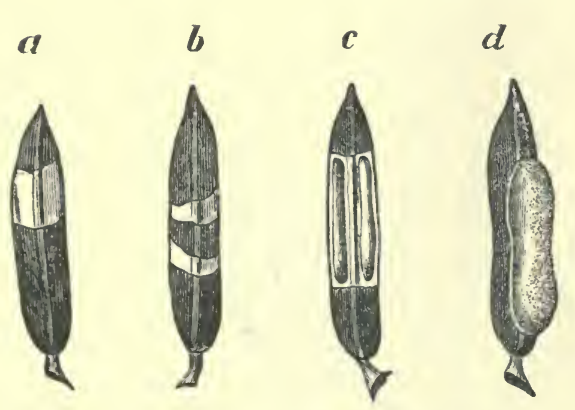

Fig. 225.-Spruce needles attacked by Chrysorıyxa Abietis, Ung. (Somewhat enlarged.)

$a \& b$ First appearance of disease in the form of pale-yellowish marks on needles.

c Needle with reddish-brown longitudinal blisters (end of March and beginning of April).

$d$ Needle with fully formed orange-yellow cushion (May). them and continue the disease.

\section{b. Subjects of Attack, and Distribution:}

The fungus attacks only yearling needles, usually those on the lower branches, and rarely near the top of the tree.

Spruce is most sub-. ject to this disease when from 10 to 40 years old. In damp, dense, 10 to 20 years old thickets, the fungus is most common, but the nature of the soil does not appear to have any influence on it. It is met with up to altitudes of 5,000 feet, and is most frequent on south and south-west aspects, or in valleys exposed to the south, whilst damp weather favours its spread, wherever spruce is extensively grown.

The damage done consists chiefly in loss of increment, and exposure to attacks by bark-beetles, but the trees are not often directly killed by it. Spruce trees are not usually sufficiently advanced in growth to become infected when the spores ripen, and thus frequently escape.

The disease occurs in Germany Denmark, and Sweden. 


\section{c. Prolective Rules.}

i. Careful choice of suitable localities for spruce.

ii. Carry out early and strong thinnings, especially on trees affected by the disease, and promptly remove the latter from the forest.

*19. Lophodermium Pinastri, Schrad.

(Pine Needle-cast.)

a. Description and Life-history.

On the primordial needles of young Scots pines, solitary brown spots may appear in July or later on in the year, and if the affected needles are examined microscopically, the mycelium of Lophodermium (Hysterium) Pinastri, Schrad., will be found in them. Black spermagonia subsequently appear before winter, but their spores do not germinate, as ascocarps do not develop till the second year after infection. As a rule the diseased primordial needles die in the spring, without falling from the plants, and older needles frequently turn completely brown in March and April and fall off, owing to the formation of cork at their base. This sudden shedding of pine needles is the characteristic of the disease so widely spread in Germany and termed Schütte, or needle-cast, which may, however, be due to other causes besides the fungus, as explained on p. 685 . If, owing to a mild, wet winter and spring, the black
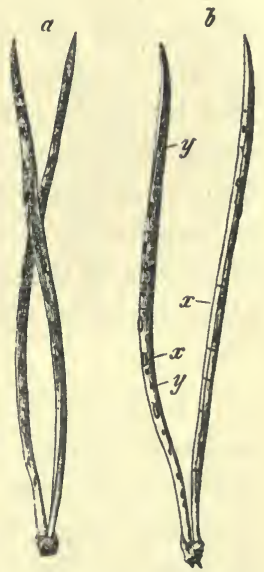

Fig. 226.-(a) Yearling Scots pine needles attacked by Pine needle-cast, the base green. (b) Dead two years old needles. Ripe apothecia $(x)$ and empty pyenidia (y), in April. After Hartig. sporocarps should burst, which only happens when they are exposed to much moisture, the spores issue from them and infect fresh plants. 'This, however, frequently happens only after the needles have fallen. Dry summers and cold winters therefore impede the spread of the fungus, which is frequently only saprophytic on old, dying 
pine needles, in crowded seed-beds. This saprophytic form of the disease was always present in the Scots pine nursery at Coopers Hill College, but never injured the pine seedlings or transplants. The latter were kept two years in seedbeds and two years in nursery-lines, and about 50,000 healthy four years old plants were removed from the nursery every year from 1891 to 1900 .

\section{b. Subjects of Attack, and Distribution.}

Needle-cast attacks Scots pine wherever it is grown; also black and maritime pines are attacked.

As a rule, the fungus attacks only 1 to 5 years old plants, but it has been observed on poles up to twenty years old. Damp cloudy localities are favourable to its spread, and plains and lowlands suffer more than mountains and hills. Large regeneration-areas and dense stocking also favour its spread. Under certain unfavourable conditions of soil and climate, the cultivation of Scots pine must be abandoned, owing to this disease, and the area stocked with Weymouth pine,* or some other resisting species.

\section{c. Protective Measures.}

i. Spray 2 to 3 years old plants, in July, with Bordeaux mixture, 50 gallons water, 6 lbs. $\mathrm{CaSO}_{4}, 4$ lbs. unslaked lime, 6 lbs. soft soap. A French nurseryman thus treated Scots pine seedlings; in the following February, not a single plant sprayed showed a sign of disease, while 80 to 100 per cent. of those unsprayed were dead.

ii. Mix spruce or Weymouth pine with Scots pine, in lines or belts running from north to south, so as to interfere with the dissemination of the spores by damp westerly winds.

iii. In nurseries, the seed should not be sown thickly in drills, and the yearlings should be transplanted into nurserylines, or at once into the forest. New Scots pine nurseries should be made in localities free from the disease, best among broadleaved trees, in any case not near pine-woods, which are

* According to Hartig, the Weymouth pine in Germany and Denmark suffers from a similar fungus, Hypoderma brachysporum, Rostr., and the larch from Lophodermium laricinum, Duby, which however may be only a saprophyte. liostrup states that black pine is attacked by $L$. gitvum, which kills its needles. 
especially dangerous to the west of the nursery. The spaces in nursery-beds between the rows of seedings should never be covered with pine branches, which favour the spread of the disease, but with leaves of broadleaved trees or moss.

iv. Burn carefully all affected plants.

20. L. macrosporum, R. Hrtg.

a. Description and mode of Attack.
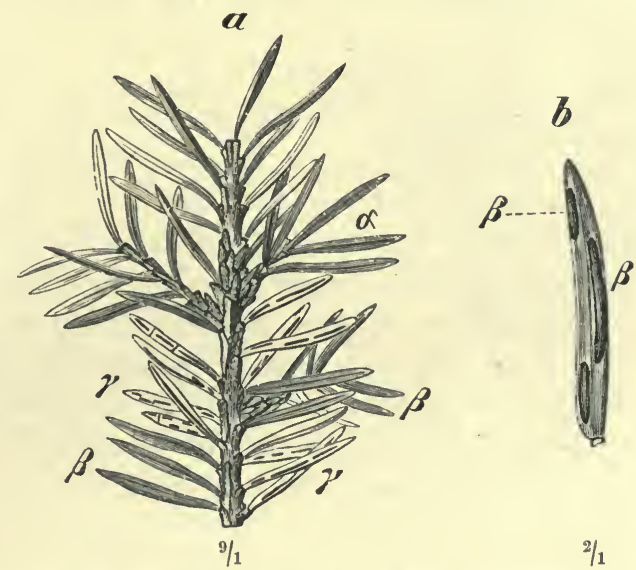

Fig. 227.- $a$ Under surface of a spruce twig in winter, attacked by Lophodermium macrosporum, R. Hrtg.

$\alpha$ Dead brown needles at the base of the second year's shoot.

$\beta$ Freshly attacked third year's needles.

$\gamma$ Needles with black perithecia.

$b$ Brown needles with ripe perithecia $(\beta)$ not yet burst.

This fungus on the spruce, according to R. Hartig, causes either needle-rust or needle-cast.

The former disease appears in mountainous regions at midsummer as a rusty discoloration of needles on two years old shoots, and in the plains later during autumn; finally black sporocarps (Perithecia) appear on the under surface of the infected needles, which burst longitudinally and emit their spores in the succeeding April or May. The needles with the empty sporocarps remain on the tree for several years. At first only the needles on two years old and older shoots are attacked; later on, those of yearling shoots as well. This is 
due to the fungus requiring from six months to three years to develop its sporocarps. At first, the needles are more resistant, but when the tree becomes weakened, they are more easily killed.

In the case of needle-cast a more virulent form of the disease occurs, and the needles turn red in August, then brown, and fall before the winter.

The spores of all species of Lophodermium gain admission through the stomata, and the wetter the weather, the sooner the spores ripen.

\section{b. Subjects of Altack, and Distribution.}

The disease affects chiefly pure crops of 15 to 30 years old spruce, especially in the lower part of their crowns, but is unimportant except when needle-cast takes place. Dense crops are most affected; mixtures of spruce with other species suffer less. The mineral nature of the soil and the altitude appear to have no influence, but in Saxony, the disease is worst on fertile, moist soil and on S. and W. aspects, where the spores ripen, at the time of the prevailing winds. When badly attacked, the trees die, in the third year of an attack.

\section{c. Protective Measures.}

i. Avoid pure crops of spruce, wherever the disease is common.

ii. Cut out and burn affected subjects.

iii. Remove the soil-covering of dead needles near affected trees, and do not use this litter in spruce woods.

\section{Lophodermium nervisequium, D. C.}

This is a very similar fungus to that described above, and affects the previous year's and older needles of silver-fir, turning them brown and eventually causing them to fall from May to July. Numerous dark brown pustules may be noticed on the upper surface of infected needles, and long dark-brown sporocarps eventually break out in the mid-rib of their lower surface. The spores are only half the size of those of No. 20.

They ripen in April of the succeeding year, on the needles 
in their third year, or on older needles, but a large number of the infected needles have generally fallen before this occurs.

This disease is widespread in silver-fir forests, and has proved destructive in the Erzgebirge, where the trees lose most of their needles.

Burn affected subjects.

22. Sphaerella laricina, n. sp.

(Larch Needle-cast.)

a. Description and mode of Attack.

Often in July, smaller or larger brown specks appear on larch needles, on which later very small black conidiophores project in groups. From beneath these, the colourless my-

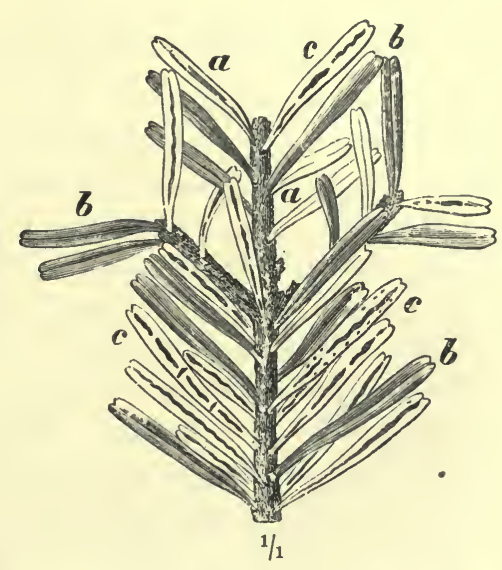

Fig. 228.-Twig of Silver-fir attacked by L. nervisequium.

a Unaffected needles.

$b$ Attacked needles turning brown.

$c$ Needles with ripe sporophores. celium, which is richly ramified, develops in the needles, partly in their intercellular spaces, partly in the cells of their parenchyma.

Inside the conidiophores, small hollows develop with very fine basidia, at the ends of which are very small conidia. These fall off and are carried away by wind, or washed out by rain, and reach the young twigs of the tree, where, after a few hours, they germinate and infect the needles. The needle-cast thus increases progressively in intensity. By the death of the twigs, the longitudinal growth of the affected plants suffers, and owing to crowding by neighbouring trees, they often die. 'The fall of sickly or dead needles commences in July.

On the needles that fall to the ground in the following summer, globose, dark brown perithecia develop, which spread the disease. The mycelium growing in the needles becomes hard, thick walled, and is coloured light brown. 
The club-like asci in the perithecia contain eight 1-celled and later 2-celled spores. The perithecia ripen at the end of May and the beginning of June. In three weeks from the moment of infection, they produce fresh conidiophores.

\section{b. Subjects of Attack, and Distribution.}

The fungus appears to attack larch of all ages. Dry, breezy localities are less liable to the disease than damp foggy ones. For this reason, larches on mountains, where the summer air is dry, whenever the air is cloudless, are less endangered than those on hills and in lowlands. The season during which the fungus can form conidia is much shorter in mountains than in lowlands.

The danger is greatest in pure larch woods and in mixed woods of larch and spruce. In the former, the infection is easy, owing to the propinquity of the larch trees; in the latter, the fallen infected larch needles lie in masses on the spruce branches, where the ascophores can easily infect the larch. A mixture of beech and larch is favourable, as the dense fallen beech leaves hinder the spores from ascending.

Japanese larch is also attacked.

In the cold, wet summer of 1894 , this disease was so prevalent in Upper Bavaria, that by the beginning of August most of the larch needles had fallen.

\section{c. Protective Measures.}

i. Grow larch in suitable localities.

ii. Mix larch with beech and not with spruce.

Melampsora 'T'remulae, 'I'ul., also named Caeoma laricis, Hrtg., p. 447 (Fig. 238, p. 486), also induces larch needle-cast. Aspen should not, therefore, be grown in larch woods.

\section{3. 'Trichosphaeria parasitica, R. Hrtg.}

a. Description and mode of Attack.

The fine colourless mycelium of this fungus covers the twigs of the silver-fir down to the buds, especially on their under surface, and spreads to the lower needles, whilst the shorter upper needles usually escape infection. T'The mycelium 
forms superficial white cushions on the white lines of stomata of the needles. They therefore become discoloured, and at length quite brown; they do not, however, fall from the tree, but hang down, being still attached to the twig by the mycelia of the fungus.

In November, on the brown cushions appear small globose tomentose perithecia, containing greyish spores, which easily germinate when they fall on twigs of silver-fir, and the disease is thus spread. 'T'he mycelium hibernates on the twigs and needles and grows again on to the new spring-shoots, attacking the needles from the base upwards, so that needles on the older shoots which escaped during the previous year may now be attacked.

'Irees once attacked by this fungus appear never to become free from it, from which its dangerous nature is evident.

\section{b. Subjects of Attack, and Distribution.}

This disease is widespread in silver-fir forests and espe-

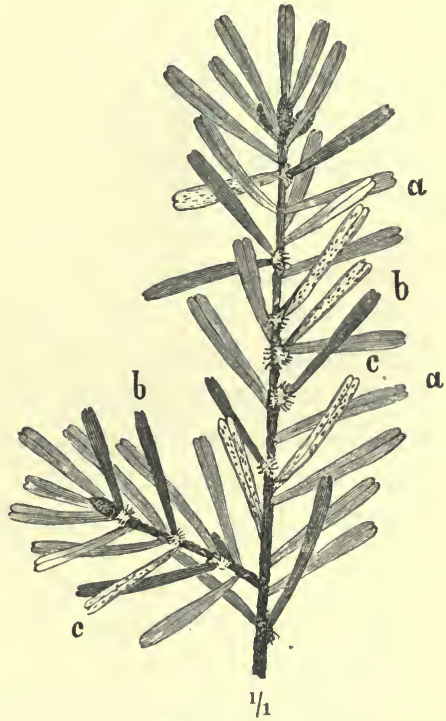

Fig. 229.-Twig of Silver-fir attacked by - Trichosphaeria parasitica, R. Hrtg. a Sound needles.

$b$ Dead brown needles fixed to the twig by mycelial strands.

$c$ Under surface of needles with white mycelia and dark sporocarps. cially among 20 to 40 years old woods on the lower branches and on advance-growth, and according to von Tubeuf, it also attacks the spruce, but is rarer than on silver-fir. It has done much damage in the Bavarian forests, near Passau and other places. It has been noticed that lower branches of silver-fir attacked by Trichosphaeria parasitica, R. Hrtg., escape attacks by Corticium amorphum, Fr. (p. 454), when neighbouring silver-fir are attacked by the latter fungus. 


\section{c. Protestive Measures.}

Underwood, and diseased branches and twigs, should be removed by clearing, pruning and cutting off twigs with shears.

24. Herpotrichia nigra, R. Hrtg.

(Spruce Black Needle-rust.)

a. Description and mode of Attack.

The grey mycelium of Herpotrichia nigra, R. Hrtg., forms an irregular, dark coat on twigs and needles of the spruce, the mountain pine, and the juniper, up to about a meter from the ground.

\section{b. Subjects of Attack, and Distribution.}

This fungus occurs in the Bavarian Alps only in mountains where snow lies long, and there is very deadly, natural regeneration being sometimes entirely prevented; it is less hurtful at lower altitudes. It covers the young plants, in seed-beds, under the snow, to such an extent that in spring they cannot remain upright. It also does much damage to mountain pine. Juniper is also attacked.

\section{c. Protective Measures.}

i. No nurseries should be made where snow lies deep in mountains.

ii. Plant close to the stumps of felled trees.

\section{Fungi attacking Cones.}

25. Aecidium strobilinum, Alb. et Schw.

(Spruce-cone Fungus.)

This fungus develops its mycelium in the still green scales of spruce-cones and destroys them. The hemispherical brown aecidia are crowded together on the inner surface of these scales.

The infected cones which have fallen to the ground may be easily detected by their opened-out appearance. Sposes enter the young cones early in spring. The teleutospores are not yet known. The disease occurs wherever spruce is grown.

Another fungus, Aecidium Conorum Piceae, Rss., also affects spruce-cones, and may be distinguished from the above by 
there being at least two aecidia on each scale of the affected cones. After the aecidia burst and disperse their spores, pale spots are left on the scales.

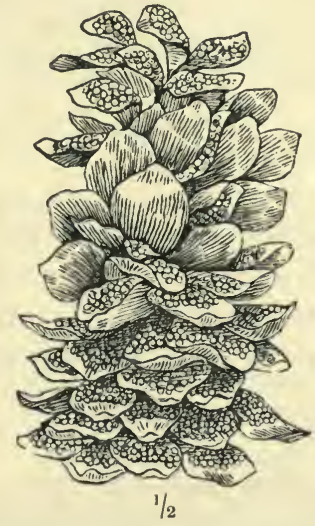

Fig. 230.- Spruce cone attacked by Aecidium strobilinum, Rss.

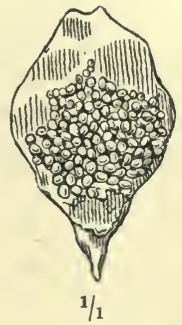

Fig. 231.-Sporophores of $A$. strobilinum, Alb. et Schw., on the under surface of a scale of a spruce cone.

\section{Section III.-Fungi attracking Broadleaved Trees.}

The numbers of dangerous fungi attacking broadleaved trees may be limited for description here, to eight, besides some wound-parasites. The most destructive are marked with an asterisk, as in the list given on the next page.

\section{A. Root-fungi.}

\section{*1. Rosellinia quercina, R. Hrtg.}

a. Description and Life-history.

The leaves of infected 1 to 3 years old oak seedlings become gradually pale and at length dry up. This commences with the topmost leaves and proceeds downwards. At the top of the taproot just below the surface of the ground, the bark and wood turn brown and shrivel up, and this at length spreads to the whole taproot and the plant dies. On pulling up the plant and examining its tap-root, black spheroidal sclerotia of the size of a pin's head are seen, which spring from numerous brown rhizomorphs, which have branched freely and surround the plant's roots, and are prolonged into 
the soil. These rhizomorphs readily communicate the disease to roots of neighbouring plants, as in the case of the honey fungus.

\begin{tabular}{|c|c|c|c|c|c|}
\hline Organ attacked. & No. & Name of fungus. & Species attacked. & Natural order. & Family. \\
\hline A. Root-system & 1. & $\begin{array}{l}{ }^{*} \text { Rosellinia quer- } \\
\text { cina, R. Hrtg. }\end{array}$ & Oak . . . & $\begin{array}{l}\text { Pyrenomy- } \\
\text { cetes. }\end{array}$ & Melanomeue. \\
\hline \multirow{4}{*}{$\begin{array}{l}\text { B. Stem and } \\
\text { branches (in } \\
\text { the wood or } \\
\text { bark). }\end{array}$} & 2. & $\begin{array}{c}\text { Polyporus sul- } \\
\text { plutreus, Fr. }\end{array}$ & Oak and birch & $\begin{array}{l}\text { Basidiomy- } \\
\text { cetes. }\end{array}$ & Polyporeae. \\
\hline & 3. & $\begin{array}{l}\text { *Nectria ditis- } \\
\text { sima, Tul. }\end{array}$ & $\begin{array}{c}\text { Beech,oak and } \\
\text { other broad- } \\
\text { leaved trees. }\end{array}$ & Ascomycetes & Sphaeriaceae \\
\hline & 4. & $\begin{array}{l}\text { N. cinnabarina, } \\
\text { Fr. }\end{array}$ & $\begin{array}{l}\text { Maple, lime, } \\
\text { horse chest- } \\
\text { nut, elm. }\end{array}$ & $"$ & $"$ \\
\hline & 5. & $\begin{array}{l}\text { Aglaospora tal- } \\
\text { eola, Tul. }\end{array}$ & Oak . . . & $"$ & $"$ \\
\hline \multirow[t]{3}{*}{$\begin{array}{l}\text { C. Cotyledons } \\
\text { and leaves. }\end{array}$} & 6. & $\begin{array}{l}\text { *Phytophthora } \\
\text { fagi, R. Hrtg. }\end{array}$ & $\begin{array}{l}\text { Beech, maple, } \\
\text { ash, robinia, } \\
\text { and conifers, } \\
\text { esp. spruce, } \\
\text { S. pine. }\end{array}$ & $\begin{array}{l}\text { Phycomy- } \\
\text { cetes. }\end{array}$ & $\begin{array}{l}\text { Perono- } \\
\text { sporeae. }\end{array}$ \\
\hline & 7. & $\begin{array}{l}\text { Rhytisma aceri- } \\
\text { num, Fr. }\end{array}$ & Maples . . . & Ascomycetes & Hyteriaceae. \\
\hline & 8. & $\begin{array}{c}\text { Melampsora.Har- } \\
\text { tigii, Thüm. }\end{array}$ & Willows . . & Uredinea & $\begin{array}{l}\text { Nelampsor- } \\
\text { aceae. }\end{array}$ \\
\hline
\end{tabular}

The method of infection is very interesting; as the tap-root, except at its lower extremity, is protected by cork, the shoots of the mycelium attack the side roots. At the places where these branch off from the main roots, little fleshy swellings are formed, which send out conical processes through the cork into the inner tissues of the tap-root. The fungus grows only in damp warm weather, and if the weather be dry, the infected plant can delay the progress of the fungus, by cutting it off by cork-formation from the still healthy tissues. By means of the sclerotia, the fungus can persist through dry periods, or 
hibernate, which the ordinary mycelium cannot do. The disease is also perpetuated by conidia springing from the portions of the mycelium growing above ground, or by spores produced either from the sub-aërial portion of the oak-plant or in the ground, these as a rule only germinate in the year following that of the original infection.

\section{b. Subjects of Attack, and Distribution.}

This fungus is very dangerous in seed-beds and dense sowings in the open up to $2,600 \mathrm{ft}$. altitude, especially in wet years. It is common in North-West Germany, also in Württemberg, where, in 1890, it killed 100,000 1-3 years old seedlings.

\section{c. Protective Rules.}

i. Places where the fungus has appeared should be isolated, by digging trenches one foot deep to prevent the spread of the rhizomorphs.

ii. Plants which have been attacked must be at once removed and burned, which can always be done in nurseries.

\section{B. Stem and Branch Fungi.}

2. Polyporus sulphureus, Fr.

This widely-distributed fungus, which is very common in the British Isles, and has been already referred to as attacking the larch and silver-fir, destroys the wood of oaks, sweet chestnut, poplars, tree-willows, alders, birch, etc., and fruittrees.

'The infection occurs at wounds in the branches of trees; the wood, in consequence, turns reddish-brown, cracked and dry, the mycelium spreading through the cracks and forming large felted white sheets, it also fills the vessels, which on the different sections of the wood appear like white lines or points. At the scars of dead branches, or other parts of the stem, large sulphur-yellow, fairly smooth, fleshy sporocarps appear annually which are somewhat reddish above and very conspicuous.

All infected trees should be felled if this does not open out 
the wood too much, and great care should be taken during fellings to avoid wounds. Broken or forked branches, which it is advisable to remove, should be sawn off cleanly and the section tarred.

Other Wound-Parasites attacking Oak and other Broadleaved Trees.

All such fungi gain admission through wounds and broken branches, so that they can be avoided by good silviculture.

\section{a. Polyporus dryudeus, Fr.}

White and yellow irregularly shaped longitudinal marks appear in the wood, which at length becomes cinnamoncoloured and rotten. The sporocarps are large, brown and hoof-shaped, but do not last long.

\section{b. Polyporus igniarins, Fr.}

The commonest cause of white rot. Infected wood becomes pale yellow and gradually lighter in colour and softer. The tannin is at once attacked and decomposed by young mycelia of this fungus, so that oak-wood loses its characteristic odour, the absence of which is an excellent practical test of incipient unsoundness. This fungus also occurs on fruit-trees and other broadleaved trees. 'Sporocarps, hoof-shaped.

P. betulinus, Bull, and P. laevigatus, Fr., cause red and white rot respectively in birch, the former having roundish sporocarps, and the latter, incrustations.

\section{c. Hydnum diversidens, Fr.}

Also causes white rot in oak and beech. 'The wood, and especially its spring zones, turns ashy-grey, at first in stripes. The sporocarps are yellowish-white incrustations or brackets.

\section{d. Thelephora perdix, R. Hrtg.}

Produces the well-known partridge-wood form of rotten-wood (Rebhuhnholz), which is common in Germany, but not known as British by Marshall Ward. 'The dark reddish-brown rottenwood becomes honeycombed with whitish blotches surrounded 
by hard walls. Later on, these blotches become greyish-yellow, and are filled with mycelium. The sporocarps, brownish-yellow incrustations.

\section{e. Stereum hirsutum, Fr.}

Snow-white or yellow longitudinal bands surrounded by brown tissue appear in the wood; which is said to be yellowor white-piped. Sometimes the whole of the wood turns uniformly yellow. The sporocarps, at first mere incrustations, later on assume prominent brown horizontal edges. Common in Britain.

\section{*3. Nectria ditissima, Tul.}

(Beech-canker.)

\section{a. Description and mode of Attack.}

Beech-canker, which may be recognised by the local destruction of the cortex, resembles silver-fir and larch canker. It may be produced on the beech, either by Nectria ditissima, Tul., or by insects (Lachnus exsiccator, Alb., Coccus fagi, Barensp., p. 366), or by frost. The disease is sometimes occasioned by several of these agents.

The attacks of the fungus may be diagnosed by the local destruction of the cortex, and the appearance of small white tufts of conidiophores; and later on by dark-red, spherical sporocarps on the canker. The infection always arises at a wound caused by abrasures of bark by felled trees, hail, etc., and from the point of infection the fungus spreads more or less regularly in the wood, but most quickly along the stem. The wood turns brown and dies wherever it is attacked. The diseased portion of the wood appears sunk into the stem, owing to the hypertrophy of the growth of the portions of the stem round the canker.

Thus the attacked branches and stems become spindleshaped. The canker becomes every year deeper and more open.

\section{b. Subjects of Attack, and Distribution.}

The beech-canker chiefly attacks the beech, but oaks, ash, hornbeam, hazel, alder, lime, cherry, maple, and especially 
apple, are also attacked. It is found in thickets 5 to 7 years old, but also in 100 years old woods, and is worst amongst healthy smooth-barked trees.

Infected branches eventually die, and infected trees in the

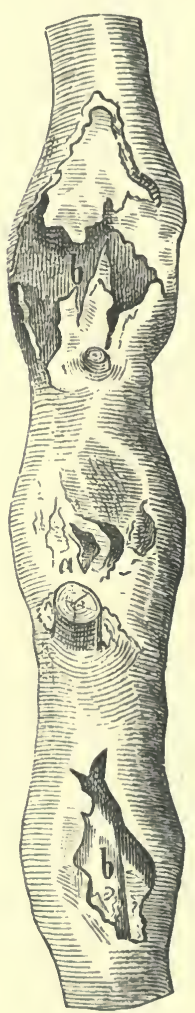

$2 / 3$

Fig. 232. - Nectria ditissima, Tul., on a beech. $a$ Commencement of the disease, which has proceeded deeper into the wood at $b$.

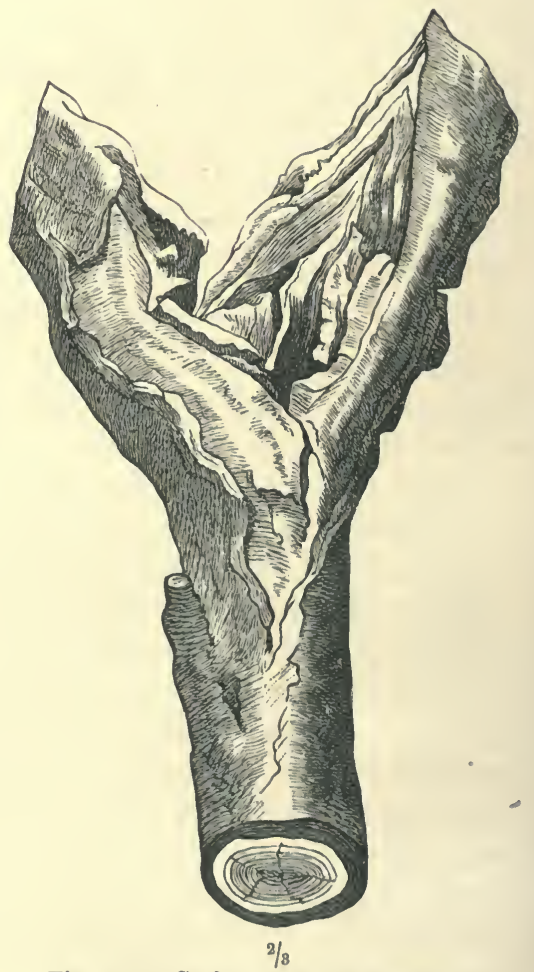

Fig. 233.-Canker on an oak caused by Nectria ditissima, Tul.

course of time assume extraordinary shapes, and are fit only for firewood.

'I'he disease has been known since 1865 in the Saxon Erz mountains and in the extensive beech forests in Hesse. It is 
common in the British Isles, especially on apple trees. It is frequently associated with the attacks of the insects mentioned above, which expose the cambium zone to the admission of spores, by the wounds they make in the bark.

\section{c. Protective Rules.}

Cut out all infected trees in cleanings and thinnings, provided too large gaps are not thus caused in the standing-crop.

Avoid all injuries to the bark during felling operations.

Affected branches in orchards should be pruned down to the sound wood (October till March), and the exposed sections covered with coal-tar.

Burn all cankered wood.

4. Nectria cinnabarina, Fr.

(Coral-spot Disease.)

a. Description and mode of Attack.

The presence of this parasite in living broadleaved trees may be diagnosed by the breaking out of the vermilioncoloured sporocarps, which eventually turn brown and finally white, on the stem or branches of the tree, chiefly in the autumn, after rainy weather. Healthy shoots suddenly dry up and die, the wood turning green or black. The infection takes place at a wound of some kind, chiefly of branches, but also of roots. The mycelium grows rapidly in the wood, pierces the walls of the wood-fibres, decomposes the starch, and leaves a green substance within the infected tissues. The cambium and bark remain sound, but by the destruction of the wood, the water-supply is cut off from the crown, the leaves wither and drop off, and the shoots dry up. The sporocarps appear in autumn or spring on the dead bark of the infected trees, and the:danger of infection is then greatest. Severe frost or sun-blister may produce wounds, through which the spores gain admission to the wood.

\section{b. Subjects of Attack, and Distribution.}

This fungus is saprophytic on the dead branches of various broadleaved trees and shrubs, such as maples, cherries, robinia, 
dogwood, blackthorn, birch, etc. Marshall Ward notes that it may be often seen on pea- or bean-sticks, which become dotted with red points.

As a parasite, it attacks young plants of maple, lime, horsechestnut, elm, and mulberry, and soon kills them. It is very widespread throughout Europe.

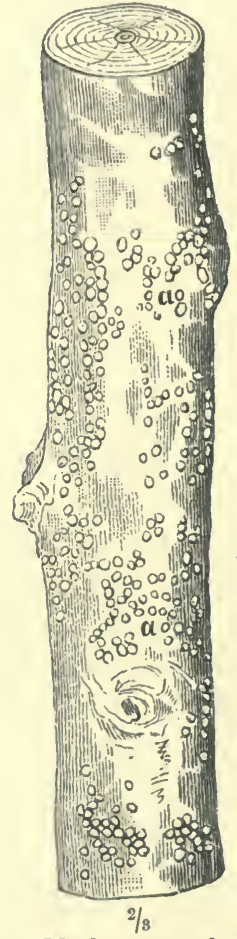

Fig. 234.-Maple stem showing the vermilion coloured sporocarps $(a)$ of Nectria cinnabarina, Fr.

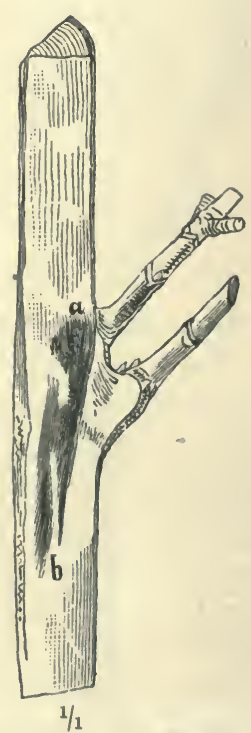

Fig. 235.-Section of Maple stem attacked by Nectria cinnabarina, Fr. Between $a$ and $b$ the wood is coloured bright green owing to the decomposition of the tissues.

\section{c. Protective Rules:}

i. Clean pruning of broken branches and tarring the wounds.

ii. All twigs, branches, or stems which show sporocarps of the fungus should be cut off and burned. 
5. Aglaospora taleola, Tul.

(Oak Bark-blister.)

The bark of oaks that still possess a smooth cortex, becomes brown in patches, either on one side only, or all round, and the affected part dies. The dead bark may be either in little patches surrounded by living bark, or may extend to a yard and more along the estem. The diseased places vary in breadth, being pointed at their upper and lower extremities. The mycelium grows in the cortex, and penetrates also into the sapwood, which may become brown and die; the heartwood is not affected.

Between the diseased and healthy tissues, a broad zone of cork develops, which excludes water from the inner tissues. The border of the diseased cortex therefore dries up and produces no sporocarps. Between this dry border zone and the rapidly decaying bark, cracks occur. The cortex under the cork, which persists for a few years, decays and is finally thrown off. The cankered spot thus produced quickly forms a callus and heals up.

In the second year of the disease, round or oval sporocarps appear in the cortical parenchyma, under the cork. In the midst of them, one or two (rarely three) little prominences pierce the cork zone and exhibit openings of one or several perithecia surrounded by white powdery conidia. The sporocarps in the cortex consist of dark brown pseudo-parenchymatous mycelia. The bottle-shaped perithecia, containing ascospores, protrude from this mycelium. As a rule, several of these ascospores coalesce.

It is not yet decided whether or not this infection does any injury to the affected parts.

Pestalozzia Hartigii, 'I'ubf. (p. 460), attacks young broadleaved plants in nurseries and on natural regeneration areas. It is commonest on 2-5 years old beech, maple and ash, which it eventually kills. The disease runs the same course as that already described for conifers. It was very prevalent in different parts of Germany during the wet summers of 1888,1892 .

F.P. 


\section{Seedling and Leaf Fungi.}

* 6. Phytophthora Fagi, R. Hrtg. (Beech-seedling Mildew.)

\section{a. Description and mode of Attack.}

This very destructive fungus, also named $P$. omnivora, De Bary, causes great damage among beech seedlings; these, when affected, turn black and die from below upwards, during their germination or immediately after the cotyledons have: appeared. The little stem shrivels up and turns brown above and below the cotyledons, whilst they are still green, or dark specks appear on the cotyledons or on the young leaves. Within six or eight-days after the first appearance of the disease, it attacks the whole plant, especially in protracted rainy weather in the months of May and June. In dry weather the attacked plants appear as if singed by fire. It is frequently accompanied by Lachnus fagi, L., a species of aphis.

The first infection of the beech by the parasite comes from oospores that have remained in the ground since former sowings. The mycelium, which is intercellular, spreads into the stem and cotyledons, and numerous hyphæ break through the epidermis or stomata, and produce lemon-shaped sporangia. After the bursting of these, fresh sporangia are formed, and the spores are spread in all directions, and in this way the disease may extend over a considerable area of young plants by attacking their cotyledons, or primordial leaves. The development of the fungus is so rapid that in rainy weather and in damp localities, in 3 or 4 days after the first appearance of the disease, sporangia are formed on the host. At the same time, thick-walled oospores are produced sexually within the cotyledons; these fall to the ground in the rotting tissues, and may then remain alive for four years and more. These oospores reproduce the malady from year to year if the place be used again for sowing beech. In dense sowings on damp soil, the fungus infects the roots of the plants until whole rows of them die at once.

Beech natural reproduction in shady woods, beech seedbeds and nursery lines, as well as those of other species, suffer greatly from this fungus. 


\section{b. Subjects of Attack, and Distribution.}

The fungus has been observed to attack beech, maple, ash, and robinia, at the seedling stage, and several conifers, especially the spruce and Scots pine. Hence the name "omnirora." The symptoms are similar in these other cases. If only the leaves of the seedling are affected, it may recover, but whenever the stem is attacked from below, it succumbs. Worms drag down infected seedlings into their holes, and hence gaps sometimes arise in what was formerly a flourishing nurserybed.

This fungus causes considerable damage to all the species it attacks, and the spores are transported by wind, mice, roedeer, and by the tread of men or horses, or even cart wheels. Damp, warm years are favourable to the spread of the fungus. It has been noticed all over Germany.

\section{c. Protective Rules.}

i. Use Bordeaux mixture, as already described (p. 466).

ii. Pull up all infected plants and collect leaves lying on the ground as soon as the disease is noticed, and burn them.

Seed-beds should be carefully watched in May and June for this malady. The workman should wear an apron, in which he places the infected plants, and should take care not to tread on the beds and bury any oospores. Any bed which has been attacked should be examined daily.

iii. The soil in nurseries may be thoroughly burned, by digging trenches $30 \mathrm{~cm}$. deep and $30 \mathrm{~cm}$. apart, and filling them with dry brushwood and burning this. Keep the fire going for two days.

iv. Beech and coniferous seed-beds, where the disease has appeared, should for several years be used only for transplants, and it is then best to change the species grown.

\section{Rhytisma acerinum, Fr.}

(Sycamore Leaf-blotch.)

This fungus causes black spots on the leaves of maples, especially of the Norway maple and sycamore.

During damp weather in July, round yellowish spots $\frac{1}{4}$ to 
$\frac{3}{4}$ inch across appear on maple leaves, and turn black in August, retaining a lighter tint on their borders. The leaves fall earlier than is usual. On the fallen leaves during winter and the following spring numerous sporocarps develop on the black spots, and they open in long cracks in damp weather. The spores which issue from them in the spring germinate on

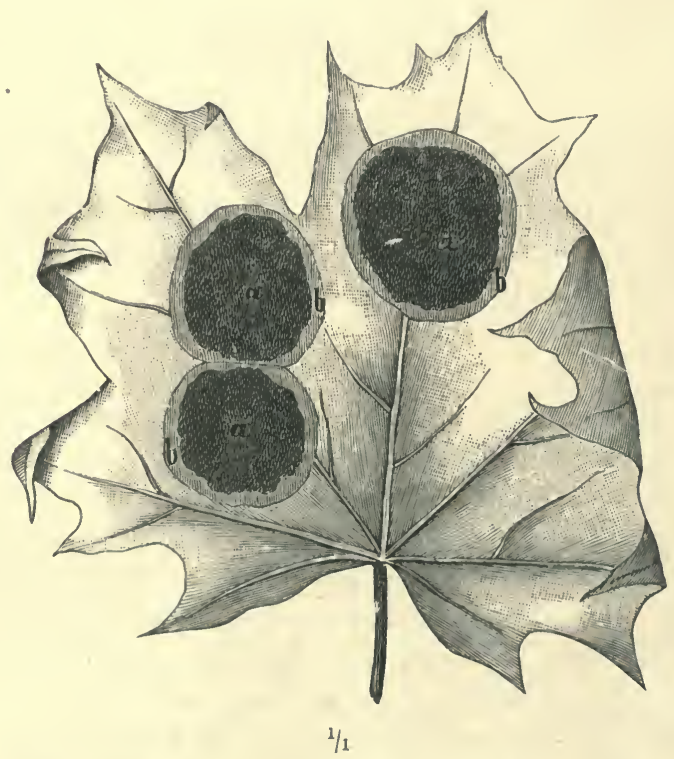

Fig. 236. - Rhytisma acerinum, Fr., on a leaf of Norway Maple. The dark blotches (a) are surrounded by a dead lighter coloured zone (b).

the leaves and produce fresh spots as before. The parasite appears to be an annual, and is very common.

The damage done is mostly due to reduced assimilating powers of the leaves and is relatively unimportant.

Where the dead leaves are swept up and burned, as in parks and gardens, the disease does not spread, but in places where dead maple leaves are allowed to lie about in ditches, etc., it may recur annually to the detriment of the beauty and shade of the trees. 
8. Melampsora Hartigii, Thüm.

(Willow Leaf-blister.)

a. Description and mode of Attack.

On the leaves of several species of willow, and especially on their under surface and the ends of their young shoots, little golden-coloured cushions, subsequently turning brown and then black, may appear at the end of May or the beginning of June. Leaves which have been attacked soon become marked with black blotches and fall off; the badly infected shoots also die from their. tips downwards. The sporocarps hibernate on the dead leaves lying on the ground and produce promycelia and sporidia. in the spring, the spores from which spread the malady by germinating on fresh leaves and shoots.

The same disease infects species of Ribes (currant or gooseberry plants), as Caeoma Ribesii, Link., but this intermediate stage is unnecessary in the life of the fungus. 


\section{b. Subjecls of Attack, and Distribution.}

The fungus which occurs in Britain, is most destructive in its attacks on the Caspian willow (Salix acutifolia, Willd.), but also attacks $S$. daphnoides, viminalis, purpurea, etc. Yearling shoots suffer most, and 2 to 4 years old shoots are less liable to infection.

\section{c. Protective Rules.}

Cut off and burn all infected shoots as soon as they are noticed. All infected dead leaves should be collected during the autumn or spring and burned.

Infected osier-beds may be sprinkled by means of an ordinary white-washing brush with dilute carbolic acid, one part to 500 of water. 'This should be repeated several times, and costs about $1 s$. an acre. Bordeaux mixture may be used.

Cultivation of the Caspian willow may have to be abandoned when the fungus is prevalent, which is much to be regretted as this willow thrives on dry soils and has proved useful on railway embankments, sand-hills, etc.

Melampsora Salicis-Capreae, Pers., is common on S. Caprea, L., S. aurita, L., and S. cinerea, L., and develops aecidia of Caeoma Eronymi, Gmel., on the spindle-tree.

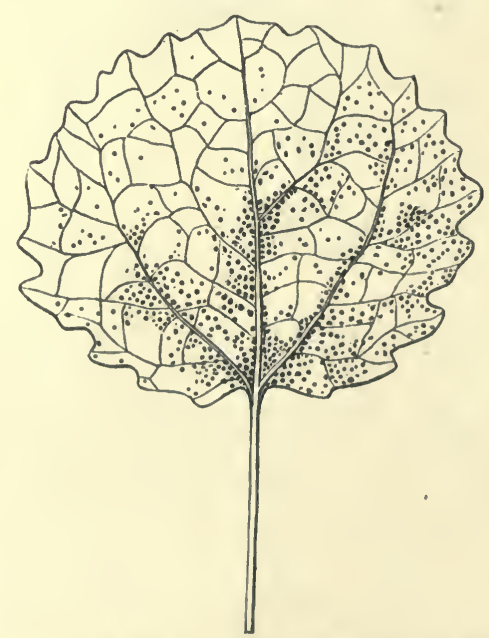

Fig. 23S. - Aspen leaf with sporocarps of Melampsora Tremulae, Tul. After Hartig. 


\section{PART IV.}

PROTECTION AGAINST ATMOSPHERIC INFLUENCES. 



\section{PROTECTION AGAINST ATMOSPHERIC} INFLUENCES.

Forests from the seedling stage up to maturity are subject to the influence of the weather, and may thus be injured in various ways. The chief meteorological phenomena in question are frost, heat, wind (especially storms), heavy rainfall, hail, snow, rime and ice.

As a matter of ccurse, these phenomena frequently act beneficially on vegetation; frost disintegrates the soil and prepares it for the reception of seed and the growth of forestplants; the wind disseminates the seed of many trees and shakes snow from off their crowns which might otherwise be broken by its accumulating weight; atmospheric precipitation and heat are indispensable for vegetable growth; snow is a bad conductor of heat, it keeps the soil comparatively warm in winter, and protects young plants from frost. Snow also absorbs much air and with it carbon dioxide; the decomposition of mineral matter on which the formation of soil chiefly depends is expedited by carbon dioxide, so that winters with heavy snowfall are highly advantageous in this respect.

Forest Protection has, however, less to do with the beneficial action of these phenomena than with the damage they may inflict on forest plants, and the means acquired by experience for protecting them.

The amount of damage done is conditional on several circumstances. In the first rank are the extent and intensity of the phenomenon, but the season and the state of the weather before, during and after the calamity are also of importance.

In the second place, the nature of the wood and locality should be considered; of great importance are the species of tree grown, the system of management of the forest, and the age and density of the injured woods, as different species and age-classes suffer in different degrees from bad weather. As 
regards locality, the soil and configuration of the ground affect the amount of damage done, as they determine the energy of growth of the forest plants from their youth up. The chief points here are the chemical and physical nature of the soil, the altitude and aspect of the locality. The nature of the soil-covering may also be of importance. Since then all these items may be combined in a great variety of ways, the damage done must vary greatly according to circumstances.

The mode of occurrence of frost, wind, hail and snow should be studied under meteorology, the importance of a thorough knowledge of which to the forester is obvious.* More or less complete meteorological observations and records have been made during the last twenty years at the German and French forest experimental stations. Of special importance, as regards Forest Protection, is a steady and complete record of serious damage by frost, storms, hail, snow, rime, either in one of the registers provided for by a working-plan, or in a special Record of forest calamities, giving not only a complete account of the area affected and amount of damage done, but also of all local facts that favoured or attenuated the evil. The results of the protective measures adopted must also be narrated. Localities specially liable to damage by frost, storms, or snow, should be marked in special colours on the range maps.

By circulating suitable directions, and by adopting a uniform system of recording facts, the compilation of a general account of experience in various forest districts will be considerably facilitated.

* Among numerous works on meteorology, the following may be referred to : Mohn, H., "Gründzüge der Meteorologie," 5th edition, with 24 charts and 45 woodcuts. Berlin, 1898. Hann, Julius, "Handbuch der Klimatologie." Stuttgart, 1897. English translation by Robert De Courcy Ward. London, Macmillan \& Co., 1903. Davis' "Meteorology." Boston, 1893. "Metenrology," Encyclopædia Britannica, Vol. xxx. 


\section{CHAPTER I. \\ PROTECTION AGAINST FROST.}

As regards its distribution, frost may be either widespread or local; as regards season, early frosts occur in the autumn and late frosts in the spring. Early or late frost may be either widespread or local. Late frosts are commoner in Europe than early frosts, and occur chiefly in lowlands, early frosts being more prevalent in mountainous regions. The - extensive damage done by late frosts is due not only to their frequency, but also to the susceptibility of plants during the revival of vegetation in the spring. Frosts in May are usually most fatal, June frosts being rare. April frosts are less dangerous, vegetation not being sufficiently advanced to suffer greatly. In the North-West of India, early frosts usually do most damage, as the bright days and cold nights of November sometimes involve daily ranges of temperature of $40^{\circ}$ and even $50^{\circ} \mathrm{F}$., that are fatal to the sappy shoots of trees.

Winter-frosts in Europe rarely injure indigenous trees, though they may kill unprotected exotic evergreen plants such as laurels, etc. 'The mild winters experienced in the west of France and of the British Isles, render possible the outdoor cultivation of many plants whose natural habitat is further south, and which would succumb to the severe winters of more easterly European countries, as was the case with the common gorse, and many exotics, in Surrey, in 1895. Seeds have been subjected to temperatures of liquid air $\left(-180^{\circ} \mathrm{C}\right.$.) for 110 hours without injury, germinating just as freely as other test seeds not so treated (Mr. Horace Brown and Prof. Dewar, 1897).

Frost damages forest-plants in four ways :-

i. By freezing to death young woody plants or young organs of pliants. 
ii. Splitting the stems of trees.

iii. Causing canker in stems of trees.

iv. Uprooting young plants.

\section{Section I.-Frozen Plantr-Organs.**}

1. External Appearance of Injured Plants.

Frozen plants, or organs of plants, become soft, flexible and hang down or wilt. When dead they eventually turn brown or black. These outer signs result from the reduced tension of the tissues injured by frost, and from their inability to fulfil their proper functions. Foliage frequently falls prematurely owing to early frosts, a film of ice forming at the base of the petiole, as in robinia and elder, which may become leafless in a few days, the fallen leaves remaining quite green and apparently unaffected by the frost. In other trees, as hornbeam, beech or oak, the frozen foliage may die and turn brown, and remain on the tree until the buds swell in the spring, the normal autumnal leaf-fall being prevented by the fact that the leaf is killed before the usual layer of cork, which causes defoliation, has formed at the base of the petiole.

M. Mer relates ("Rev. des E. et F.," July, 1897, p. 424) that in a frost in February, 1895, in the Hautes Vosges, near the Lake of Longemer, young silver-fir attacked by frost did not lose their lower branches, which were protected by snow, while their middle branches, above the snow, were killed. The buds of the two or three highest verticils remained dormant for a year, producing no shoots in 1895 , and some of them not even in 1896 , whilst the terminal bud produced a leader in the summer succeeding the frost. Hence it appears that organs may be affected by frost, without being killed, and that the most vigorous organs, such as terminal buds, best resist frost.

\section{Explanation of the Action of Frost.}

Death by freezing is usually caused by late frosts, less by early frosts. Winter frost rarely kills indigenous plants.

* Göppert, Dr. H. R., "Ueber das Gefrieren, Eurfrieren der Pflanzen und Schutzmittel dagegen." Stuttgart, 1883. 
The death by freezing of plants, or certain parts of plants, is usually due to a rapid thaw rather than to the direct effects of the low temperature to which they have been exposed. This is because, owing to the low temperature, the liquid contents of the affected tissues becomes denser, and a change ensues in them. The cell-sap, when converted into ice, expands 10 per cent., and sets free part of the air which it contains; this increases the size of the pores and the permeability of the membranous lining of the cell-wall, which loses its powers of resistance to the passage through it of certain substances, and allows the cell-sap to pass into the intercellular spaces of the plant, where it freezes. The injured tissues thus become limp from loss of water.

A similar resuit happens in the case of frozen starch-paste, in which the water and starch become separated, and will not reunite after a thaw. The air escaping from the frozen tissues may also decompose the chlorophyll, and hence the brown and eventually black colour of the dead organs. If, however, the ice formed in the intercellular spaces thaws slowly, the cell-wall may recover its normal elasticity and reabsorb the water before the chlorophyll has decomposed. With a rapid thaw this is impossible, as the water then remains in the intercellular spaces, and death ensues.

The effect of allowing the thawed water to become reabsorbed may be well observed in a meadow after a sharp frost in May, when the grass has been in full growth. No bad results follow from the frost, unless men or animals tread on the frozen grass, but wherever they do, the crushed grass appears black and dead, as if singed by a red-hot iron. This is because the crushed tissues will not allow the return of the sap when the thaw sets in. The more water an organ or plant contains, the more it is subject to be frozen. The old theory that plant-cells are split by the freezing of the cell-sap, and consequent expansion of the ice, is not true; in the first place, the cell is not filled with sap, and secondly, the cellwall is sufficiently expansible to resist an extension of $\frac{1}{10}$ th of its volume, supposing it were full of sap and the sap converted into ice.

Hartig states that cortex and bast containing concentrated 
sap do not freeze so readily as young wood and leaves, which contain a more watery sap, and which, owing to the scarcity of intercellular spaces in wood, turn to ice within the lumina of the cell, at the same time depriving the cell-walls of their water and causing them to slirink.

Severe frost may thus impair the young zones of sapwood in a tree without killing the cambium. The formation of heartwood may thus be hindered and several zones remain intermediate between sapwood and heartwood, forming a ringshake in the wood. Or the sapwood may be actually killed and separated from the cambium, which continues the circumiferential growth of the wood outside the dead wood, so that after the tree has been felled the inner portion may be found completely separated from its outer zones by cup-shake.

Molisch agrees with $\mathrm{H}$. Müller 'Thurgau in the theory that Sachs' view that rapid thaw kills plants is not generally correct. Hess, however, considers that the results of experience in vineyards and forest nurseries are strongly in favour of Sachs' view, and also states that Thurgau has reconsidered his opinion, and has shown that a frozen plant may be saved by slow thawing, that would certainly be killed if thawed rapidly.*

3. Amount of Damage done.

a. General Nature of Damage.

Late and early frosts often kill young plants and destroy the foliage, shoots, blossoms or young fruit of trees. 'I'his retards their upward growth, causes a loss of increment and reduction in quantity or complete loss of the crop of fruit; thus the management may be impaired, especially when natural regeneration is desired. Early frosts hinder the complete ripening of the wood, especially in coppice-shoots; by the early fall and killing of leaves forest trees suffer a loss in potash and phosphoric acid, if these substances have not completely returned to the stem, as they do before the normal leaf-fall. Owing to the narrow annual zones of wood which are formed in years of severe frost, they may be recognised on

* Molisch, H., "Untersuchungen über das Erfrieren der Pflanzen." Jena, 1897. 
an inspection of a cross-section of a stem. Frost also causes certain forms of canker in broadleaved trees.

The physiological effects of severe winter-frost consist chiefly in killing wood which is not fully ripe, and which has been spared by the early frosts. In this way, either the youngest shoots, the autumnal woody zone, or the whole annual ring of wood inside the cambium-zone may suffer and cause cup-shake in wood. Where cup-shake is thus caused, the concentrated sap in the cambium-zone preserves it from damage, while the zone of the sapwood next to it becomes so dried by the freezing of the sap within it as to separate partially or entirely from the cambium. Mechanical injuries done by winter-frost will be described further on.

The damage done under the headings: species, tree-part, system of management, age, locality, soil-covering, density of stock, and weather will each be considered separately.

\section{b. Species of Tree.}

As a rule, broadleaved trees are more susceptible to frost than conifers, and species which prevail in the south suffer more than those from the north. As special conditions affecting the extent of the damage done by frost, the degree of development and power of recovery of the plant are important. Thus the beech and oak are equally liable to injury by frost, but the oak suffers less than the beech, as it shoots out later in the spring. .

As regards recovery from damage, the oak is also more favoured than the beech, for if its leader be frozen, lateral buds develop new leaders, but the beech having fewer dormant buds cannot do this so well. The oak can also put out a second foliage during the year if the first be frozen, but the beech cannot. Hence wood-formation is less hindered in the oak than in the beech. Similar considerations affect other species. As regards conifers indigenous in Central Europe, the. silver-fir is most susceptible, but I have had a bed of yearling silver-fir at Coopers Hill, quite unprotected during the winter 1902-3, and planted them out safely under cover in spring. Older silver-fir in the nursery had their young shoots severely frozen in the spring. 
A classification of woody plants according to their susceptibility to frost is not impossible, but can only be of local value, as the earlier or later shooting out of a tree depends on the altitude, as well as on the species grown.

The following list groups trees according to their susceptibility to late and early frosts :-

\section{i. Very Frost-tender Species.}

Ash, walnut, plane, sweet chestnut, beech, oaks, ${ }^{*}$ robinia (early frosts), silver-fir.

\section{ii. Moderately Fiost-tendel Species.}

Sycamore, Norway maple, Salix viminalis, L., spruce, larch, cluster pine. In many localities, spruce suffers so severely as to be placed in group $\mathrm{i}$.

\section{iii. Frost-hardy Species.}

Hornbeam, elms, rowan, aspen, poplars, willows (except S. viminalis, L.), aldęrs, birches, horse-chestnut, limes, hazel ; Scots, Black, Weymouth, Cembran and mountain pines; juniper.

In the case of very severe late frosts, species in the last group, such as the Scots pine, may suffer, or be killed when quite young.

If the locality be taken into account, as sea-coast, flat, hilly, or mountainous land, some modifications must be made in the above groupings.

In general, local trees which shoot out early are more or less frost-hardy, for instance, the birch, alder, and sallow; frost-tender species such as the oak and ash shoot out later in the spring, and the beech, which shoots earlier than either, owes its immunity from frost to its power of resisting cover under which spring frosts do not occur. The faculty of producing adventitious buds (oak and silver-fir) is helpful to those species.

The larch, which shoots out early in the spring, suffers in low situations from late frost.

* Some North American oaks and ash-trees suffer less thạ Europcan species; Turkey oak is less hardy than either. 
As regards extreme winter-cold the following somewhat different scale applies :-

\section{i. Very Frost-Tender Species.}

Sweet chestnut, plane, walnut, many fruit trees, such as apricot, peach, quince and cherry.*

\section{ii. Somfinhat Frost-tender Species.}

Pedunculate and sessile oaks, ash, elms, beech, robinia, silver-fir, yew.

\section{Frost-hardy Species.}

Maples, horse-chestnut, lime, poplars, willows, hornbeam, birch, alders, Pyrus sp., hazel; spruce, Scots, Weymouth, Mountain and Cembran pines, larch, juniper.

Pyramidal poplar is the least hardy of the poplars, rowan least hardy of the Pyrus sp. The Weymouth pine may send out second shoots in summer, which are usually killed in autumn or winter.

As regards the susceptibility of exotic trees that have been introduced into Central Europe, the following experience has been gained in Germany :-

\section{A. Susceptibility of Exotic Trees to Late and Early Frost.}

i. Very Frost-tender Species.

Black walnut, all hickories, Turkey oak; Abies Nordmanniana, Spach. (Caucasus), Douglas fir, Jeffrey's pine, Pinus ponderosa, Laws.

Black walnut is slightly less susceptible than common walnut. Carya amara, Nutt, is the hardiest hickory. Nordmann's fir, sprouting late, is less susceptible than common silver-fir.

\section{ii. Frost-tender Species.}

American ash, grey walnut (Juglans cinerea, L.), sugar maple, Californian maple (A. circinatum, Pursh.); Sitka (or Menzies) spruce, Corsican pine, Japanese larch.

* Apricots and peach trees are killed by $26^{\circ}-30^{\circ} \mathrm{C}$, walnut by $30^{\circ}-32^{\circ} \mathrm{C}$, the cherry-tree by $31^{\circ}-32^{\circ} \mathrm{C}$.

F.P.

K K 
iii. Frost-hakdy Spreies.

Canadian poplar, cherry birch (Betula lenta, L.), white spruce, Pinus vigida, Mill (pitch pine), Lawson's cypress, Sequoia Wellingtonia, Seem., red cedar (Juniperus virginiana, L.).

Young seedlings of pitch pine are occasionally killed by early frosts. Lawson's cypress and Wellingtonia are somewhat susceptible to frost for the first $4-5$ years.

\section{B. Susceptibility of Exotic Species to Winter-Frost.}

It appears useless to give Hess' list of delicate species, as it includes some plants that are quite hardy in the British Isles.

\section{Frost-hardy Species.}

Red oak, ashleaved maple, sugar maple, American ash, all hickories, cherry birch, Canadian poplar, Nordmann's fir, Balsam fir, Douglas fir, Sitka spruce, white spruce, Pinus ponderosa, Laws., Japanese larch, Lawson's cypress, Wellingtonia, red cedar.

From these lists, it appears that the introduced exotics hardly suffer more from frost than indigenous species. Several species not mentioned by Hess, such as Thuja gigantea, Nuttall ('T'. plicata, D. Don., according to Sargent), T'axodium distichum, Rich., are frost-hardy in Britain. In the west of the British Isles numerous species thrive, which cannot withstand the frosts of Central Europe, or even of the eastern counties of Great Britain.

\section{c. Part of Tree.}

The inflorescence, opening leaves and young shoots suffer most; the developed leaves and needles less, and least of all the buds. In silver-fir and spruce the damage is nearly always confined to the spring-shoots, the old needles escape, and as in the silver-fir the terminal buds open out later than the lateral buds, the latter are more often frozen.

\section{d. System of Management.}

Coppice, especially with short rotations, suffers more than high-forest, as the susceptible young growth occurs so 
frequently. If the cutting of coppice is delayed in the spring, the annual shoots may not be completely lignified before they are exposed to early frosts. The underwood in coppice-withstandards suffers less than simple coppice, owing to the shelter afforded by the standards. The various shelterwood systems constantly afford shelter to young growth, and are therefore less liable to danger from frost, than the systems of Coppice and of Clear-cutting in High Forest.

\section{e. Age of Wood.}

Woods are most exposed to danger in youth, especially during the sprouting of the seed; a single frosty night at this period may at once annihilate the results of a forester's care. The chief danger continues until the young plants have grown above the local frosty zone. As, however, this varies according to the configuration of the ground, a scale of susceptibility for each species, according to age, cannot be attempted.

Quick-growing species in breezy hilly localities are most favourably situated, while slow-growing tender plants in valleys and plains suffer most.

In the case of widely-spread frosts and exceptionally low temperatures, the leaves and shoots of taller trees may suffer.

\section{f. Locality.}

The following localities are specially liable to injuries by frost :-

i. Damp, low-lying places with stagnating air, for instance, narrow, closed-in valleys, or small depressions in the ground, termed frost-hollows. In such places, frost-hardy species such as hornbeam, aspen, and birch are naturally invasive, whilst the more valuable species become stunted, and there is generally a plentiful coating of lichens on the trees. If, in such depressions, the soil is moist or wet, or there are water-courses or swamps near at hand, the evaporation of the water still further reduces the temperature, whilst owing to the absence of air-currents the cold air is not replaced by warmer air from the neighbourhood. If, on the contrary, the soil is dry, the plants become cooled by their own radiation, and by the 
descent of lieavy, cold air from above, which collects like a lake over the low ground and causes sharply-defined frost-limits.

ii. Woods on north-easterly, easterly, south-easterly or southerly aspects suffer most from frost; on the two former aspects, because, unless sheltered by a hill, they are exposed to cold frosty winds, whilst the sudden exposure to the sun's rays after sumrise increases the danger of easterly aspects. On south-easterly and southerly aspects growth begins earlier in the spring than on colder aspects, prolonging the period of exposure. On south aspects the variations of temperature are also greater than on cooler aspects. Northerly and westerly aspects are least exposed to injury by frost.

iii. High plateaux are more heated by the sun than lowlands, where the atmosphere is denser ; vegetation on them.is therefore more precocious. But the radiation of heat at night is greater than in lowlands, and consequently there is a greater range of temperature, while woody plants stand sudden changes from heat to cold worse than intense cold.

As a rule, valleys, lowlands, and plateaux suffer more from frost than lills and mountain sides.

iv. Wet impermeable soils, such as cold clays, induce low air-temperature, and frost holds out longer there. 'The richer and deeper the soil, the more quickly do plants recover from freezing and grow out of the reach of frost.

\section{y. Nature of Soil-covering.}

A dense and ligh growth of grass and herbage increases the danger from frost, as it prevents the soil from being heated, diminishes the circulation of the air, and reduces the temperature by transpiring moisture and radiating heat. From observations made at Viernheim in Hesse, the temperature over an area covered with grass may be $16^{\circ} \mathrm{F}$. lower than on a plot of similar land bare of vegetation. On the other hand, a lightly shading growth of birch, sallow, thorns, broom, etc., will reduce radiation and thus preserve from frost plants of valuable species which may be growing among the woody undergrowth. Under conditions otlerwise the same, frost penetrates nore slowly and less deeply into a soil covered with 
humus, dead leaves, etc., than on bare soil, though in the former case the frost remains longer.

\section{h. Density of Stock.}

Natural regeneration-areas as well as plantations and sowings under a shelterwood, which reflects. back the radiated heat towards the ground, whilst the crowns of the shelter trees prevent rapid changes of temperature, suffer much less from frost than sowings and plantations in the open. Young plants suddenly exposed by the removal of a shelterwood are highly susceptible to damage by frost, and large areas of spruce 6 feet in height may be thus killed.

Damage by frost is much less in well-stocked woods than where blanks or thinly-stocked places occur. Unrestricted radiation of heat and non-circulation of the air expose such places to frost; in the same way young growth surrounded by tall woods is often frozen.

\section{i. State of the Weather.}

The clearer the sky during day-time and the brighter the night, the greater is the danger from frost, especially with an east wind. It seldom freezes with a cloudy sky, as then the heat radiated from the ground is reflected back again by the clouds. Late frosts accompanied by rime are more dangerous than black frosts, as the coldness of the air is still further increased by the evaporation of the frozen dew. In a prolonged frost, accompanied by cold dry winds, the frozen twigs may be dried up and killed. A wet autumn generally increases the subsequent bad effect of the winter's cold.

As a rule, in Central Europe, all danger from frost is over by the middle of May, but exceptions may occur, and in 1892 the grass-temperature at Coopers Hill, in Surrey, from the 13 th to the 16 th June, varied between $25^{\circ}$ and $32^{\circ} \mathrm{F}$., so that potato-shoots and bracken were frozen and killed in the neighbourhood. In mountainous regions, late frosts are to be feared till July. In the north of India, nightfrosts may occur, on clear nights, from October till the end of March, and they cause considerable damage to 
Sál (Shorea robusta) and other winter-green and ever green trees.* Very extensive damage was done to saplings and poles in N.-W. Iudia by severe frost in February, 1905.

\section{Register of Serere Frosts.}

Damage by frost is usually local. There are, however, years in which damage is done over extensive areas, these years being termed frost-years. 'The dates below refer solely to frost-year's.

In Central Europe, during the fifty-two years from 1848 to 1899, severe late frosts occurred, on the average, every other year; the worst years for persistence and severity of these frosts being $1854,1866,1876,1878,1880$ and 1894. Not a single month is absolutely free from frost, not even July or August. On May 21st, 1894, the foliage of the oak standards in the lower ground of Prince's Coverts, near Esher, in Surrey, was entirely destroyed by frost, whilst much damage was also done to the ash and other underwood; the crowns of the oak trees, which were blackened by the frost, did not become completely green again till the middle of July. A similar event happened in the Forest of Dean on May 29th, 1819. $\dagger$

In Central Europe, during the present century, there has been one hard winter every five or six years, the coldest years previous to 1895 being 1829-30 and 1879-80, when at Giessen, on the 10th December, 1879, and in February, 1830, temperatures of $31^{\circ}$ and $25^{\circ}$ below zero, F., were observed. 'The lowest temperatures measured at Coopers Hill were $16^{\circ} \mathrm{F}$., in December, 1879 , and $10^{\circ} \cdot 1$, in February, 1895. Loughborough is one of the coldest places in Britain, and its minima on the 8 th, 9 th, and 10 th February, 1895 , were $5^{\circ}, 4^{\circ}$ and $1^{\circ}$ below zero, F. During 1895, the frost continued night and day at Coopers Hill from January 25th to February 18th, and skating lasted till the middle of March.

\section{Protective Measures.}

Protective measures against frost may be taken during the formation and utilisation of woods.

* Many trees in India lose their leaves in the spring after retaining them throughout the winter.

† "The Forest of Dean," by H. G. Nicholls. J. Murray, Iondon. 1858. 
a. During the Formation of Woods.

i. Drain wet places and all swamps in the forest before restocking.

Moisture is not always favourable to frost, for Wollny states that dry humus has a low specific heat and is a bad conductor, while wet humus has a high specific heat and is a good conductor. In accordance with this principle, cranberry swamps in Carolina are irrigated during the blossoming period, when frost is feared ; also, in Northern India, vegetable gardens and sugar-cane crops are irrigated in order to obviate danger from frost. In sphagnum peat-bogs, a thin layer of peat is left at the base of the bog, when the peat is cut, in order to reproduce the peat, and unless this is kept wet, frost and drought kill the peat.

ii. Abandon attempts to grow frost-tender species in the open. Such species as beech and silver-fir should not be grown in bad frost localities, and, in any case, should be protected by planting beforehand, or simultaneously with them as nurses, fast-growing hardy trees, such as Scots pine, larch, birch, or white alder.

iii. Natural regeneration under a shelterwood and keeping seeding-cuttings dark should be preferred, especially on easterly or southerly aspects. Low, branching shelter-trees should be pruned to promote air-circulation.

iv. Strong transplants should be used, plants with balls of earth and mound-planting being preferable for frost localities. On wet ground, ridge-planting may be adopted.

v. Protective belts, 30 to 40 feet wide, of spruce, or Scots pine, may be established along the easterly boundaries of a wood.

vi. Where areas to be restocked are covered with a dense growth of grass or herbage, this should be removed before planting or sowing is attempted.

vii. Transplants should be lifted from the nursery early in the planting season and heeled-in in shady places near the area to be planted, in order to delay their sprouting. Silverfir planted out late in the spring suffers less from May frosts than spruce planted out early or in the previous autumn, because its buds open later. 
viii. Wherever frosts are to be feared in forest nurseries, the following rules should be observed:-

They should be situated on northerly or north-westerly aspects.

Seed should not be sown too early, say before the 1st of May ; it should be well covered.

In autumn, beds of seedlings may be covered with brushwood, and seed-beds with dead leaves, moss, or saw-dust. In spring, brushwood or shelter-mats may be used. These latter may be placed on light wooden supports and can then be removed and replaced at will.

Smoky fires may be kindled during the night, the clouds of smoke preventing radiation from the ground. This practice is extensively followed in French vineyards, coal-tar, or small boxes filled with refuse resin, being burned.

Plants which are covered with rime may be watered with cold water before sunrise so as to delay their thawing.

Nurseries should be kept free of weeds.*

(ix.) Tender ornamental evergreen plants may be wrapped up during winter in matting or straw, until they have grown beyond the reach of frosts. The so-called hardening of transplants which have been a few years in the ground is due to the fact that their roots get gradually deeper into the soil, and conduct the heat of the soil to the plants better than superficial roots. Covering the base of transplants with cinder-dirt or dead leaves also protects them from frost.

All parts of plants, which in spite of these precautions have been killed by frost, should be pruned, and frozen plants, such as oak-saplings, which lıave collum-buds, may be cut back level with the ground. Dead conifers and plants like beech, which coppice badly, must be pulled up and the vacant spots replanted with strong transplants.

\section{b. During the 'T'ending of Woods.}

i. Prune all stems of their lower branches that stand over young growth, both in high forest and coppice-with-standards,

* Mr. W. Forbes states that in his nurseries, exposed to severe frost on the 27th May, 1899, the spots which carried most weeds experienced the greatest injury. 
in order to favour the interchange of air in the lower strata of the atmosphere.

ii. Preserve the natural soil-covering of dead leaves, needles and moss.

\section{c. During the Utilisation of Woods.}

i. In natural regeneration-fellings, the shelterwood should be only gradually removed, the final felling being delayed till the plants have grown out of the reach of late frosts. In frosty localities, regeneration-periods will be long-from 20 to 30 years.

ii. In the case of clear-cuttings, only small areas should be cleared at one time.

iii. A protective belt should be left intact on exposed easterly and north-easterly borders of a wood, at any rate until the young growth which it protects is out of danger from cutting winds.

iv. Coppice-fellings must be effected in the spring; if made in autumn, winter-frosts would injure the stools; they should also run from west to east, so as to protect the young growth from cold winds; this precaution is specially necessary for oak coppice, as frozen oak-shoots thaw rapidly when exposed to the rising sun.

\section{Section II.-Frostcrack.}

\section{External Appearance.}

Frostcracks are long splits caused in stems by winter-frost, which start at the bark and proceed radially and more or less deeply towards the centre of the tree. They are frequently followed by the formation of projecting longitudinal ridges on the stem of an affected tree, which are termed frost-ribs.

\section{Explanation.}

Frostcracks are due to the contraction of the wood along its periphery and radius, owing to extreme cold.

It has been proved by actual measurement, that the diameters and girths of trees of various species are lessened by their loss of heat during severe winters, and that there 
is a certain ratio between the degree of frost and the girth of the tree (Duhamel, Caspary, M. Hartig, Nördlinger, Vonhausen).

The contraction of the wood, the reasons for which have been explained in the preceding section, commences at freezingpoint and increases as the mercury falls, but the stem recovers its original dimensions during a thaw. If, therefore, the temperature but slowly decreases, so that the tree becomes gradually colder from the exterior, inwards, the volume of the

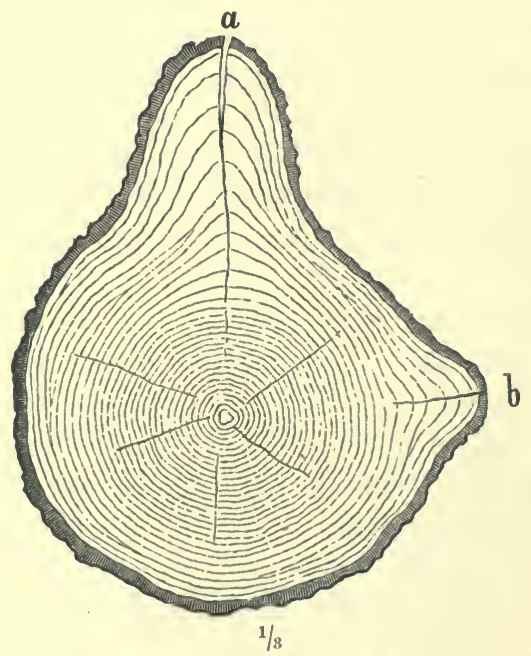

Fig. 239. - Transverse section of an oak with two frostcracks, $a$ and $b$.

bole contracts equably, and no rupture of the wood occurs. For a tree to crack there must be a rapid fall of temperature, down to $-18^{\circ} \mathrm{C}$. $\left(0^{\circ} \mathrm{F}\right.$.). The external layers of wood (sapwood) then freeze to such a degree that much water passes from the cell-walls and passes into the cell-cavities. The central zone (heartwood, or imperfect heartwood) is either unaffected or much less affected than the outer zones; it remains, therefore, either unfrozen or much less frozen than the latter. The circumferential contraction is therefore chiefly confined to the outer zones of the wood, and consequently they can no longer enclose its unshrunken central portion, and the outer zones therefore split radially and longitudinally, the crack thus 
formed penetrating more or less deeply towards the centre of the tree. The expansion of the sap, which flows into the crack and freezes, also assists in further splitting the tree and in extending the crack to the centre.

Most frostcracks occur on cold nights, between midnight and 8 a.m., when the temperature is lowest, and the contraction of the wood is consequently greatest; the split is accompanied by a noise like a pistol-shot.

\section{Damage done.}

\section{A. General Nature of Damage.}

The timber of trees cracked by frost is of reduced technical value, and secondary damage by insects or fungi may supervene.

The extent of the damage depends on the depth of the crack, which varies with the severity of the frost.

Frostcracks close again with the rising temperature, after the ice which has formed in the wood has thawed, and the sap fills the cell-walls again. A new zone of wood forms over the wound; owing to the reduced pressure of the bark, this new zone is broader than the previous ones. If the cold continues to increase the crack increases in length and depth. Frostcracks may attain lengths of 6 feet and more.

In subsequent years considerably less degrees of cold in winter suffice to open out the crack again, as there is only the thin wood of one year's zone to be cracked. It is closed up again during summer. If this process be repeated for several successive cold winters, owing to the successive superposition of annual callus growths, a bevel-edged projection, termed a frost-rib, is eventually formed, as shown in Fig. 239. If there should be a succession of mild winters, a frostcrack may heal up and not extend any further. But the bark, which freezes much less readily, and is therefore less liable to contraction, than the wood, may exercise tension on the latter and prevent it from cracking, even in liard winters. In such cases internal frostcracks result, which may be either radial or peripheral. In the oak, such internal frostcracks are said to occur only on the root-stock. As secondary damage, 
attacks by insects and fungi (Nectria and Polyporus sp.) may frequently ensue.

\section{B. Damage done in Particular Cases.}

(a) Species.-Hardwoods with large, medullary rays are most subject to frostcrack. Deep roots also favour it, as they pass into zones of soil which are only slightly affected by the air temperature and thus keep the stem comparatively warm. This difference of temperature between the outer and inner zones of the wood of a tree increases its liability to crack.

Oak, beech, walnut, elm, ash and sweet chestnut are the trees most subject to frostcrack, and Turkey and sessile oaks more than pedunculate oak. The sap, which pours from the wound after a thaw, turns dark brown and betrays the injury which the tree has received.

Frostcracks also occur in the case of softwoods, such as the horse-chestnut, lime, poplars, and tree-willows. They are rare on conifers, and then chiefly on the silver-fir.

(b) Part of 'Tree.-Frostcracks usually occur in the lower part of the stem of a tree, especially at places where the growth is uneven near the root-stock, at knots, or where the stem is eccentric.

Splitting is furthered by local wounds owing to the admission and freezing of sap, and is very common in the case of coppiceshoots which have been allowed to grow into trees, and which are always unsound at their base. Splits from the root-stock proceed upwards and from a knot downwards; on eccentric stems, they are always towards the largest diameter.

In the case of stems of a regular shape, the south side suffers most from frostcrack, and then the east and north sides, the westerly side suffering least of all. The south side suffers most, because the most vigorous circumferential growth takes place there, and the tissues are consequently very sappy.

(c) Systems of Management.-Standards over coppice suffer most, as they are exposed to cold winds, whenever the underwood is felled. Standards in high forest, which are exposed after growing in a dense wood, are also very liable to frostcrack. 
In the Kottenforst, near Bonn, an area of 7,400 acres at an altitude of 426 feet, where the treatment is that of coppice-with-standards, and the soil, clay with an impermeable substratum, over twenty per cent. of the oak standards are frosteracked. Frosterack is also very prevalent in the seventy to eighty-year-old oak-woods in Windsor Forest, owing to the absence of underwood, and it is also extremely common in the open parts of the Forest of Dean, where the underwood has been browsed down by sheep.

(d) Age of 'T'ree.-Large old trees, as a rule, suffer more from frostcrack than younger trees, because the differences in temperature between their outer and inner woody zones are greater.

(e) Locality.-Fertile and moist soils favour frostcrack. It is very frequent in narrow valleys along watercourses, where the night temperature falls exceptionally low in winter.

(f) Season.-Frostcracks generally occur late in the winter, when the sap begins to flow, provided intense cold should set in. The sapwood then rapidly cools and contracts, while the inner zones of the wood retain a higher temperature and do not contract. Long-protracted and gradually falling temperatures are not so dangerous. Storms increase the danger by blowing the frozen stems backwards and forwards; Hess even considers it probable that storms may occasion frostcracks at the commencement of a thaw, but as the outer zones of the wood would then be expanding, whilst the inner zones remain cold, a cup-shake, or separation of the wood along a portion of the whole of an annual ring, would probably result.

\section{Protective Rules.}

i. Thoroughly drain wet soils.

ii. Keep up the density of woods, and "underplant all pure oak high forests with a shade-bearer, such as beech or silver-fir.

iii. Establish protective belts of spruce along the northeastern, eastern, and south-eastern boundaries of a wood.

iv. Abandon the practice of reserving oak and other standards in places where frostcrack is common. 


\section{Section III.-Frost-Canker.}

Cankers may be caused by frost among young broadleaved species, such as oaks, ash, maples, beech, fruit-trees, etc., which have not yet grown above the local frost-level. Thus, at the base of a young $\mathrm{s}^{\prime}$ 'oot, which has been repeatedly frozen down to the main stem, the living bark separates from the dead wood. A callus forms round the wood in the growing season, but is frozen on the recurrence of severe frost, and as, in frost-hollows, this may happen annually, a canker is thus formed, and the wood may be killed down to the pith, on the side from which the branch arose. These cankers are formed near the root-stock of oaks and ash growing in depressions on stiff clay soil ; they may be distinguished from others caused by fungi, as they increase in size only after severe frost.

Frost-cankers on Shorea robusta are very common in frosty depressions in Northern India, the shoots being killed down to the ground annually until an abnormally large flattened stool is formed. Coppice-shoots of a variety of sweet chestnut from the south of France are also similarly frozen down in Alsace, while the common variety of the tree produces splendid coppice-poles.

\section{Section IV.-Uprooting of Seedlings by Frost.}

\section{General Account.}

During February and March, when night-frosts alternate with thaws in the day-time, it is often found that young seedlings are raised with the soil, and in the subsequent thaw, when the soil sinks back again, their roots lose their hold on the ground, and the plants fall over and die. This action is termed frostlifting, the seedlings being lifted by the alternate frost and thaw.

In such cases the surface-soil is raised by the conversion of the water in it to ice-crystals, and the little seedlings are thus lifted above their original position. When the thaw sets in, and the soil gradually softens and returns to its original level, the plants cannot do so, as their roots are in the deeper and still frozen soil, while the surface-soil is thawing; when, therefore, the soil has completely thawed, the plants lose their root-hold and fall over, as shown in Fig. 240. Even when the 
soil is thawed completely, the plants cannot resume their original position, their roots not being stiff enough.
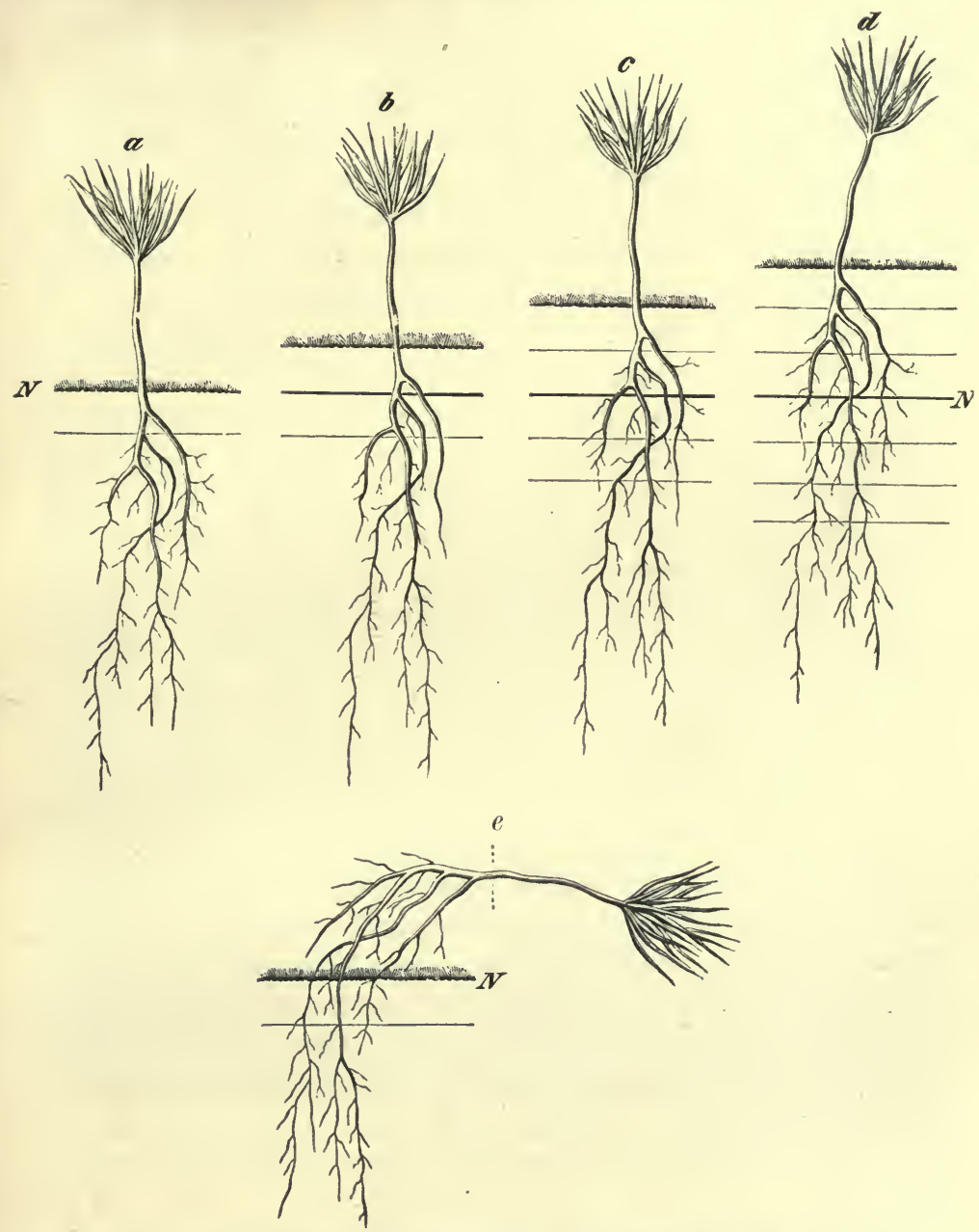

Fig. 240.-Spruce seedling $(a)$ lifted $(b),(c)$ and $(d)$ and uprooted by frost $(e)$.

$(N)$ Original ground-level.

2. Damage done in Particular Cases.

(a) Species and Age of Plant.-Nearly all woody plants may be uprooted by frost during the first two years of their life, 
and especially those of shallow-rooted species, such as spruce, birch, alder, beech, hornbeam, etc. Even ash, sycamore, and silver-fir are not unfrequently uprooted in this way. Sweet chestnut, hazel and oaks escape this form of injury on account of the depth to which their tap-root descends during germination. The greatest damage is done in nurseries to seed-beds and beds of transplants, and to sown areas in forests.

(b) Locality.-Certain soils and localities suffer more than others in this way. 'Thus, provided they are moist-fine soils, such as peat, fine sand, marls and loam, are most exposed to frost-lifting. Dry sandy soils do not suffer. As a rule, the finer-grained a soil is, the more water it absorbs, and plants are therefore more easily lifted in such soils, whilst in coarse-grained, sandy soil the water descends, and the surface is therefore not subject to lifting. Soil bare of herbage is also more easily lifted than soil which is kept down by the roots of grass and weeds.

As regards locality, deep depressions suffer most, as there is then less chance of the moisture draining away. Warm aspects, except westerly ones, suffer most, as, on them, thawing and freezing follow one another most frequently; northerly aspects hardly suffer at all from frost-lifting.

\section{Protective Rules.}

(a) For the Forest.-Drain away all superfluous moisture by open drains; drain-pipes may be used only in nurseries. Planting should be preferred to sowing, and ball-planting is the best security against this evil, while spring-plantings suffer less than autumn-plantings. Where sowings are adopted, oats may be mixed with the seed, which should be sown rather densely. Preserve the natural soil-covering of weeds when plantations are made on soil liable to be lifted by frost.

(b) For Forest Nurseries. - Mix clay soils with 25 to 33 per cent. of sand. Raise the seed-beds so as to secure good drainage. Sow deeply and densely, and cover the spaces between the drills or rows of plants with straw, dead leaves or sawdust, all of which are bad conductors of heat; even cinderdirt mixed with sand may be used; this delays thaws. After 
weeding between the rows of plants, fill with good soil all inequalities thus produced in the beds.

It is advisable in autumn to leave a few weeds in the beds, as their roots give coherence to the soil. Any plants which have been uprooted by frost, should be at once replaced, and fine soil placed round them. This is not an expensive operation if boys are employed, and costs only from threepence to fourpence per thousand plants.

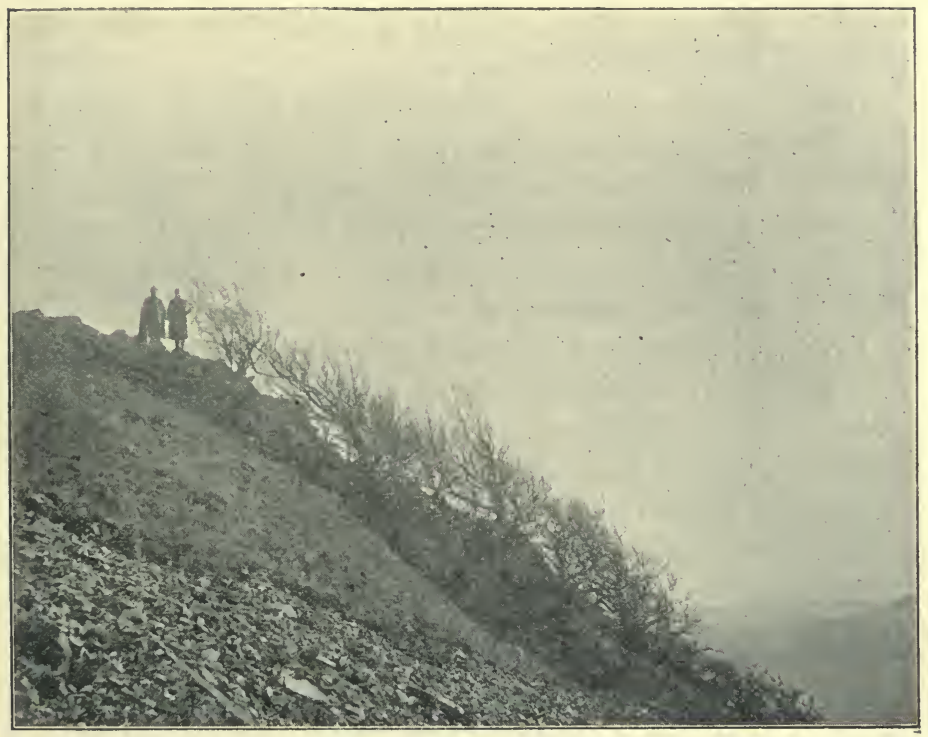

Fig. 241,-Effects of Wind on Beech. Altitude, 2,500 ft, Photo. by R. E. Marsden. 


\section{CHAPTER II. \\ PROTECTION AGAINST INSOLATION.}

Insolation may dry up seeds and young plants, or twigs and - branches of trees; it may also scorch or crack the bark and wood of trees.

\section{Section I.-Drought. \\ 1. Appearance and Cause of Injury.}

A period of more than 14 consecutive days without rain is termed "absolute drought"; a "partial drought" is when for 28 days the average daily rainfall is not more than one-hundredth part of an inch.**

Woody plants, and parts of them which have been dried by the sun, have much the same appearance as if they had been killed by frost; blossoms, leaves, needles and young shoots first wilt, then gradually turn brown and shrivel up; they finally fall off, although dried leaves may remain for a long time hanging on the trees.

This drying-up of leaves and shoots is the result of prolonged hot, dry weather, which abstracts much moisture from plants and from the soil; transpiration being thus greatly increased, plants pass off more watery vapour into the air than their roots can absorb from the soil, which, becoming continually drier, is less able to meet their demands. The action of heat on forest plants is therefore indirect, as the sun's rays do not kill them directly.

\section{Damage done.}

\section{A. General Account.}

Owing to the want of the necessary moisture in the soil usually caused by high degrees of heat, seeds may not secure sufficient water for germination, and young seedlings may be killed. In the case of older plants the foliage dries up and falls prematurely, the younger shoots may be killed, and the annual wood-increment considerably reduced.

Drought at the commencement of the growing season reduces * "British Rainfall" (Ed. Stanford, Long Acre, 1906). 
the height-growth (1893); at its close, it reduces radial growth (1887): Dry years, as well as frost years, may be detected on the transverse sections of a bole by narrow annual zones.

Professor Henry,* of Nancy, measured 250 trees in order to ascertain the loss of diameter increment, in the very dry summer of 1893, with the following result:-

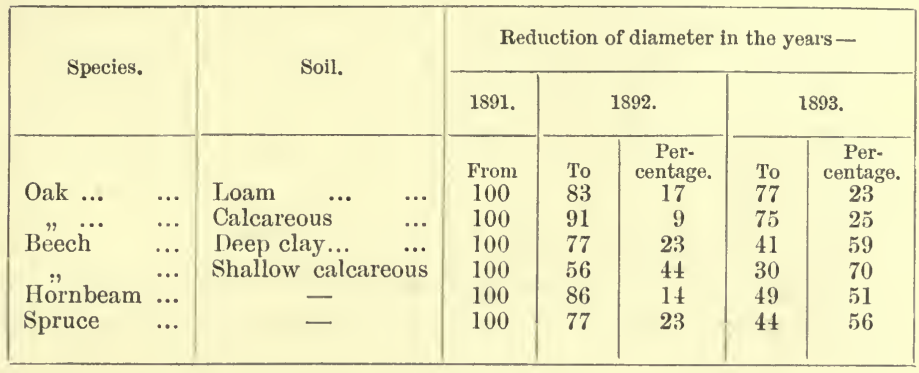

- Occasionally single stems, or groups of poles, may be killed by insolation; this is frequently the case with beech standards, which after growing in a dense wood are exposed, as mother-trees, in seeding-fellings. The yield of dead wood in dry years is very considerable.

In seasons of drought plants cannot obtain sufficient nitrogen compounds from the soil; E. Mer also proved that starchproduction in the leaves is weakened. Plants by premature leaf-fall also suffer a considerable loss of combined nitrogen and phosphoric acid, that prejudices the formation of fruit and seed.

Professor Kraust analysed the leaves of lilac, Cornus mas, L., and horse-chestnut with the following results:-

\begin{tabular}{|c|c|c|c|c|c|c|c|}
\hline \multicolumn{4}{|c|}{ Chemicals. } & \multicolumn{2}{|c|}{ Dead Leaves in Summer. } & \multicolumn{2}{|c|}{ Autumn Leaves. } \\
\hline $\begin{array}{l}\mathrm{N} . \\
\mathrm{P}_{2} \mathrm{O}_{5} \\
\mathrm{~K}_{2} \mathrm{O} \\
\mathrm{Ca}_{2} \text {. } \\
\text { Other }\end{array}$ & $\begin{array}{l}\ldots \\
\cdots \\
\cdots \\
\cdots \\
\text { mine }\end{array}$ & $\begin{array}{l}\ldots \\
\ldots \\
\ldots \\
\ldots \\
\mathrm{ral}\end{array}$ & $\begin{array}{l}\ldots \\
\ldots \\
\ldots \\
\ldots \\
\text { ter }\end{array}$ & $\begin{array}{r}1,947 \\
522 \\
2,998 \\
1,878 \\
8,028\end{array}$ & $\begin{array}{c}\text { Percentage. } \\
24 \\
6 \cdot 5 \\
37 \cdot 3 \\
- \\
-\end{array}$ & $\begin{array}{r}1,370 \\
373 \\
3,831 \\
2,416 \\
9,636\end{array}$ & $\begin{array}{c}\text { Percentage. } \\
14 \\
3 \cdot 8 \\
39 \cdot 7 \\
- \\
-\end{array}$ \\
\hline
\end{tabular}

* "Rev. des E. et F.," 1895, p. 75.

† "Die Sonmerdürre der Baüme," "Central Blatt für das Gesammte Forstwesen," 1875, p. 206. 
Thus, nitrogen and phosphoric acid are only about half as bulky in autumn leaves as in summer-dried leaves, potash being nearly equal in both, while lime and other mineral matter is greater in the autumn leaves.

Similar figures hold good for the leaves of other forest trees, and it is therefore evident that nitrogenous matter and phosphoric acid pass back in the autumn from the leaves into the twigs, and that if the foliage should fall prematurely, the trees must lose a quantity of these valuable substances.

Other secondary dangers caused by drought are a greater liability of trees to insect-attacks, and increased danger from forest fires.

\section{B. Damage under Special Conditions.}

(a) Species.-The relative susceptibility of trees when very young to be injured by insolation is shown in the following groups :-

i. Vegry Susceptirle Species.

Beech, ash, sweet-chestnut, black alder ; silver-fir, spruce.

\section{ii. Susceptible Species.}

Hornbeam, sycamore, Norway maple; limes; white alder, birch; Cembran pine, larch.

\section{iii. HARDY SPrcies.}

Oaks, elms, field-maple, horse-chestnut, robinia, planes, Pyrus spp., wild cherry, poplars, willows; Scots, Austrian, Weymouth and mountain pines, and juniper.*

The drought of the year 1893, according to Mer, caused the silver-fir in the Vosges Mountains to produce only $\frac{2}{3}-\frac{3}{4}$ of its normal diameter-increment and $\frac{1}{4}-\frac{2}{3}$ of the normal lengthincrement.

(b) Age of 'Tree.-Sowings and plantings in the open are most exposed to damage during the early years of their life, until they have completely covered the ground. On poor, shallow soils, and in hot places, without lateral shelter, plants aged up to twelve or fifteen years may die from drought. It has been observed that older transplants on weedy ground suffer more from drought than younger transplants on fresh

* Austrian pine has proved very successful for planting dry calcareous rock at Rochefort, in Beigium. 
clearings, as in the latter case dew and rain have more access to the soil. When once a plantation has closed in, so as to cover the soil completely, the chief danger from drought is over; but occasionally spruce poles have been killed by prolonged drought.

(c) Locality.-In plains and hilly lands, the danger from drought is greater than in mountains where the most extensive forests are found, as then damper air, more frequent precipitations and moister soil prevail. Regions over 1,500-1,800 feet altitude have little to fear from drought. Small flat hills and narrow ridges suffer most of all.

As regards aspect, the southern and south-western slopes suffer most from drought, and the northern slopes least of all. In very narrow valleys which have been cleared of trees, or are scantily wooded, the reflection of the heat from side to side greatly increases its effects, and rows of houses have the same effect on street-avenues.

As regards soils, woods growing on calcareous soils, and especially on stony superficial soils above calcareous rocks, suffer most from heat; then those on stiff clays, whilst sandy soils are more favourable as regards drought, especially when the grains of sand are fine; woods on sandy loams and loams stand drought best of all. This is due to the following causes: poor shallow calcareous soil is not retentive of moisture, while the porous rock beneath it drains away water rapidly from the surface; marls and clays become hard when exposed to lieat and crack in all directions; coarse sands suffer more than fine sands on account of the greater capillarity of the latter, which attracts water from below; loams readily absorb rain, dew and snow-water, and retain moisture in the subsoil, and can, therefore, easily replace the loss of the surface-water.

(d) Soil-covering.-Weeds, and especially a dense tall growth of grass, increase the dangers of drought, filling the soil with their roots and absorbing and transpiring its moisture, which would otherwise be available for the woody plants growing in or above the grass. A light covering of isolated shrubs, on the contrary, may prove beneficial by shading the valuable species.

Leaves and moss and the humus resulting from their 
decomposition on the surface of the ground shelter the roots of trees from the sun.

(e) Density of Crop.-Woods in which the trees stand somewhat far apart from one another suffer more from drought than well-stocked woods. Isolated, clean-boled standards with smooth bark, such as beech, hornbeam, birch, silver-fir, especially at noon, reflect the rays of the -sun on to the soil, as shown in Fig. 242, and thus dry up the soil around them;

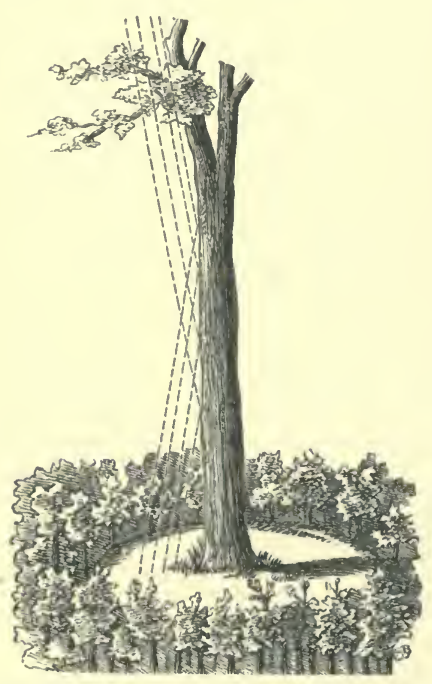

Fig. 242.-Damage to young growth by reflected heat. young natural-regeneration may fail completely around such trees.

(f) Weather and Season of the Year.-The drying-up of little plants owing to drought may be recognisable early in the summer. A dry May with a continuance of cutting east winds soon disperses the moisture in the soil that has accumulated during winter, and if there is insufficient rain in June, many plants on areas recently sown or planted may be killed. If the dry weather should continue throughout July, more damage will be done, and it is generally from the middle of July till the middle of August that the plants die, for the maximum summer-temperature is attained at about a month after Midsummer-Day.

Not until the beginning of September, therefore, can young plantations and sowings which have hitherto escaped be considered out of danger from drought.

\section{Register of Dry Years.}

During the past century, the following have been years of drought in Central Europe : 1800, 1807, 1811, 1812, 1822, 1834 $1842,1846,1857,1858,1859,1863,1865,1868,1874,1876$, 
1881, 1883, 1889, 1893, 1898 and 1906 (autumn); or, on the average, one year in five. To give a local example, the monthly rainfall and maximum temperature observed in 1893, at Coopers Hill College, Surrey, are here given.

\begin{tabular}{|c|c|c|c|c|c|c|c|}
\hline \multirow{2}{*}{ Months. } & \multicolumn{3}{|c|}{$\begin{array}{l}\text { RaINFALL IN } \\
\text { INCHES. }\end{array}$} & \multicolumn{3}{|c|}{$\begin{array}{l}\text { Average Max. } \\
\text { TEMPerature } \\
\text { in Denrees Fahr. }\end{array}$} & \multirow{2}{*}{ REMARKS. } \\
\hline & 1893. & $\begin{array}{c}\text { Aver- } \\
\text { ages } \\
1875-92 .\end{array}$ & $\begin{array}{c}\text { Diffe- } \\
\text { rences. }\end{array}$ & 1893. & $\begin{array}{c}\text { Aver- } \\
\text { ages } \\
1875-92 .\end{array}$ & $\begin{array}{l}\text { Diffe- } \\
\text { rences. }\end{array}$ & \\
\hline January ... & $1 \cdot 29$ & 1.98 & -69 & - & - & - & $\cdot 3$ in. of the March rainfall \\
\hline February... & $3 \cdot 07$ & $1 \cdot 70$ & $+1 \cdot 37$ & - & - & - & fell on the first 5 days of \\
\hline March ....... & $\cdot 38$ & 1.52 & $-1 \cdot 14$ & $55 \cdot 4$ & $47 \cdot 1$ & $+8 \cdot 3$ & the month, about 5 in. fell \\
\hline April ....... & $\cdot 12$ & $1 \cdot 77$ & $-1 \cdot 65$ & $63 \cdot 6$ & $53 \cdot 2$ & +10.4 & on the 12 th July, and 2.5 in. \\
\hline May .......... & $\cdot 76$ & 1.92 & $-1 \cdot 16$ & $66 \cdot 4$ & $59 \cdot 8$ & +6.6 & on the 10 th October. \\
\hline June.......... & $\cdot 75$ & $2 \cdot 22$ & $-1 \cdot 47$ & $73 \cdot 6$ & $66 \cdot 3$ & $+7 \cdot 3$ & The temperature was \\
\hline July .......... & $2 \cdot 14$ & $2 \cdot 72$ & $-\cdot 58$ & $67 \cdot 4$ & $68 \cdot 7$ & $-1 \cdot 3$ & above $80^{\circ} \mathrm{F}$. on the $21 \mathrm{st}$ \\
\hline August...... & $1 \cdot 35$ & $2 \cdot 38$ & $-1 \cdot 03$ & $72 \cdot 4$ & $68 \cdot 8^{*}$ & $+3 \cdot 6$ & April, on 4 days in June, 5 \\
\hline September.. & 101 & $2 \cdot 26$ & $-1 \cdot 25$ & $68 \cdot 1$ & $6 t$ & $+4 \cdot 1$ & days in July, 8 days in \\
\hline October ... & $6 \cdot 10$ & $* 2 \cdot 61$ & $+3 \cdot 49$ & - & - & - & August, and once in Sep- \\
\hline November.. & $1 \cdot 84$ & $2 \cdot 54$ & $-\cdot 70$ & - & - & 一 & tember, the maximum being \\
\hline December .. & $3 \cdot 00$ & $2 \cdot 01$ & $+\cdot 99$ & - & 一 & - & $91 \cdot 8^{\circ}$, on the 19 th August. \\
\hline 'Totals ... & $21 \cdot 81$ & $25 \cdot 63$ & $-3 \cdot 82$ & & & * For & 7 years only. \\
\hline
\end{tabular}

All farms on the shallow soil above the chalk suffered greatly from drought, and there was scarcely any hay, and corn was very short in stalk. As regards the effects on forest growth, there was an enormous crop of acorns and sweet-chestnuts. All the lime blossom fell without maturing fruit, and isolated beech, elm and lime-trees lost most of their foliage in August. The heavy fall of rain in February and the first few days of March soaked the ground so thoroughly, that a plantation of twenty acres of three-year-old Scots pine transplants on the Bagshot sands, in Windsor Forest, was a complete success, in spite of the drought.

\section{Protective Rules.}

\section{a. During the Formation of Woods.}

i. Natural reproduction is preferable to artificial sowing, or if it cannot be carried out, choose deep-rooted strong transplants and cover the planting spots with sods or large stones. Nursery transplants, when planted out in the forest, stand 
drought better than seedlings taken directly from the seed-beds. Coniferous plants taken from the nursery with balls of earth round their roots, stand drought less well than strong wellrooted transplants; mound-planting also gives bad results in very dry years, and it may then be necessary to plant out spruce only under shelter of birch or Scots pine nurses.

ii. The soil should be deeply trenched, and sowing, or planting of yearlings, should be carried out simultaneously with the growth of a crop of oats, or buckwheat, which will shelter the young plants till the autumn; the deeply trenched soil enables Scots pine seedlings to form deep roots, and soil which has been well worked parts with moisture less freely, and is more hygroscopic than a compact soil. In years of drought and on poor dry soils, moss should be placed between the lines of sowings; this costs about $£ 1$ an acre.

iii. In hot countries, planting should be done at the very commencement of the monsoon, and sowing is of ten preferable, as many plants, such as teak, form very long tap-roots immediately after germination. Planting may also be done by means of plants grown in small bamboo-baskets, which soon rot and allow the roots to spread in the soil.

\section{b. Rules for Nurseries.}

i. Subdivide the area of the nursery by narrow evergreen hedges, or provide temporary side shelter by mats; these precautions are especially necessary for spruce.

ii. Trench the nursery-beds deeply in autumn, and manure with compost, or burned sods; this not only keeps the beds free from weeds, but also promotes the development of strong fibrous roots.

iii. Transplant yearling plants, especially of spruce, into nursery-lines.

iv. Nursery-beds of seedlings may be temporarily protected by sticking branches into the ground on the south side of the beds or all round them, or by covering them with mats, supported by a framework, 4 to 6 feet high, as in protecting plants against frost. The mats may be removed during showers, and only placed over the beds at the hottest time of day, from 11 A.м. to 3 P.м. Such shelter should also be 
withdrawn in the autumn in order to harden the plants. Where branches are used to protect plants from the sun, Scots or Weymouth pines are preferable, as broadleaved branches soon have their foliage shrivelled, and spruce needles fall off, while silver-fir foliage is too dense.

(v.) Keep the beds free from weeds, as weeding prevents the soil from caking, and renders it hygroscopic ; for this purpose the spaces between the plants should be hoed in hot summers, even if there are no weeds. Soft earth may be placed on either side of the rows of plants, when the beds are weeded.

vi. The plants may be watered, or irrigated; it is best to water in the evening, and when watering has been commenced it must be repeated from time to time till rain falls, as it encourages the formation of superficial rootlets, which would soon die should the beds become too dry. On this account the beds should be watered only when absolutely necessary. The crust of earth on the surface of the beds, due to watering, must from time to time be broken up with the hoe. An account of nursery-irrigation is given in Schlich's Silviculture.*

\section{c. Rules for T'ending Woods.}

All epicormic branches must be pruned from standards reserved in high forest, or over coppice, as they keep rain and dew from the young plants, and render the standards stagheaded. The standing-crop should be kept as dense as possible, and the natural soil-covering preserved. Trees along the boundaries of a forest, or along roads, should be kept dense, and the outer row be allowed to branch down to the ground, so as to exclude dry hot winds from the forest. A series of horizontal trenches may be dug along dry slopes, in order to retain the rain-water.

\section{d. Rules during Utilisation of Woods.}

The seeding-cuttings on poor dry soils should be kept dark, but at the same time, after a good crop of seedlings has sprung up, the plants should be rapidly or gradually exposed according to their demands on light so that they may get the full benefit of rain and dew, and develop rapidly. All isolated smooth barked mother-trees should be felled, and the bare patches

* "Manual of Forestry" (3rd edition), Vol. II., p. 137. 
round their stumps planted up. Small narrow felling-areas should be established, running from north-west to south-east, as far as this can be done without danger from storms, so that the young crops may get lateral shelter from the old wood to the south-west of them.

\section{Section II.-Bark-Scorching.}

\section{External Appearance.}

The name bark-scorching* denotes a well-known malady of trees, which generally occurs on the western or south-western

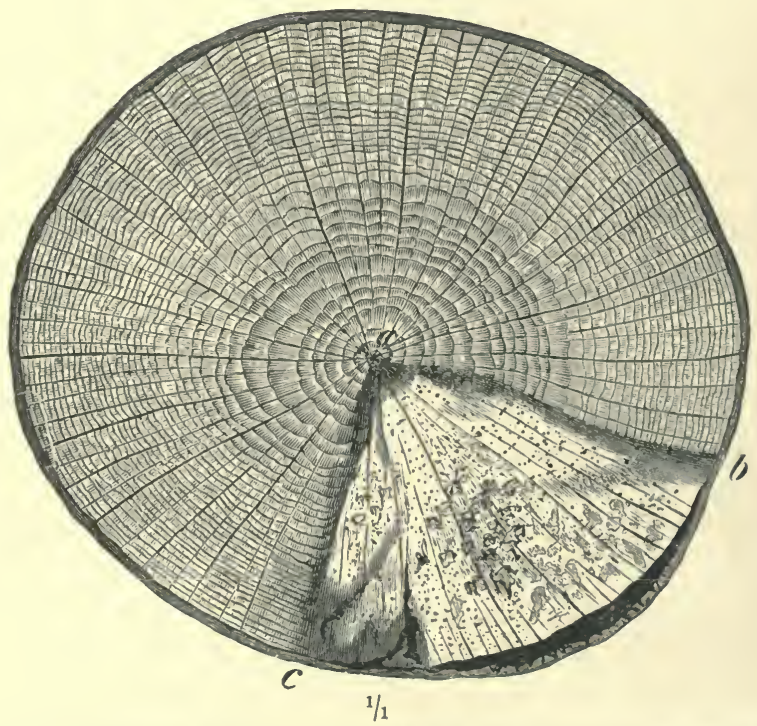

Fig. 243.-Transverse section of a beech affected by bark-scorching, cut 12 feet above the ground. The damage is limited to the sector $a b c$.

sides of stems and in directions intermediate to them, the W.S.W. side being the commonest seat of injury, while it only exceptionally happens on the southern side of a tree. This injury is first rendered visible by the drying up of the bark of affected trees, which assumes a reddish colour, and then

* The term bark-scorcling is used in Somerville's translation of Hartig's Diseases of Trees, ant is a better term than burk-blister, which has already been applied to diseases caused by fungi. 
gradually splits lengthwise and horizontally from the stem, and falls off in pieces. The injured sapwood turns brown, the brown colour fading gradually towards the still sound wood.

The exposed wood becomes rotten owing to the admission and germination of spores of various species of Polyporus. By strong and repeated insolation, the rot spreads in a wedgeshaped manner down into the heart of the tree in the direction of the medullary rays (Fig. 243).

The destructiveness of the fungi is frequently hastened by the fact that a strong growth of grass and herbage dries up the surface moisture of the soil.

\section{Explanation.}

Bark-scorching is the result of powerful insolation. If the sun beats directly on a stem, its west and south-west sides become considerably heated. The southern side of a tree is less heated owing to the frequent easterly winds, which blow during hot anticyclones when the sky is clear, and skim past the southern side of trees, and reduce the temperature of their bark and sapwood on that side, whilst the W.S.W. side of the tree is not affected by the east wind. This explanation is confirmed by the fact, that when the southern side of a tree is scorched, it has been found to be sheltered from easterly winds by an adjoining dense wood. The greater effects of the sun's rays on the W.S.W. side of a tree are also due to the fact that the maximum daily temperature is in the afternoon, when the sun has passed the meridian, and that the lower the sun is, the more direct are its rays in the radial direction of the stem, and the more intense are their effects.

Vonhausen found that the maximum temperature on the W.S.W. side of a tree, between its bark and sapwood, was $120^{\circ} \mathrm{F}$. when the air-temperature was $91^{\circ} \mathrm{F}$., while in Bavaria, on the 18th August, 1892, with an air-temperature of $96.8^{\circ} \mathrm{F}$., Hartig observed a temperature of $131^{\circ} \mathrm{F}$. between the bark and sapwood of some isolated 80 -year-old spruce trees. Cambium cells of European trees cannot withstand temperatures between $104^{\circ}-130^{\circ} \mathrm{F}$. any better than leaves and herbaceous shoots, which are speedily killed by such temperatures. 


\section{Damage done.}

(a) In general.-This malady reduces the technical value of the stems and frequently kills a tree. 'The forest-owner thus suffers a loss of timber and increment, to which may be added danger of breakage and of insect-attacks, and exposure of young growth requiring shelter.

(b) Species.-Bark-scorching affects chiefly trees with thin and persistent smooth cortext, free from cracks.

Species of trees that produce thick bark, and the bark of which is rough and fissured, do not suffer. Their dead coarse bark is a bad conductor of heat, and never becomes heated to the same extent as smooth bark.* The bast under coarse bark offers a further protection to the cambium against insolation.

Beech suffers most, then spruce and Weymouth pine. Next come hornbeam, ash and sycamore; next, Norway maple, lime, horse-chestnut, sweet-chestnut, cherry, rowan and appletree, sometimes silver-fir.

Oaks, elms, field-maple, birch, most species of Pyrus, Scots pine, black pine and larch never suffer from bark-scorching.

(c) Part of the 'Tree.-Bark-scorching affects only the clear bole of a tree, and generally its lower part from the base upwards. The portion of the stem which is immediately above the root-stock suffers most where there is no underwood, owing to the heat reflected from the ground, while the fact that sap is earliest in motion near the base of trees may contribute. The taller the stem and the ligher the crown above the ground, the more exposed is a tree to scorching. Large knots or. low branches localise the injury to the part of the stem which is below them. Stems covered with moss or lichens resist insolation, and so do trees that are branched down to the ground.

An example of the bad effects of pruning trees exposed to insolation may be seen in the Mirwart Estate in the Belgian Ardennes, where a number of spruce trees planted to give shelter along the eastern side of a meadow have been pruned of all their lower branches, and are all badly scorched.

* Hartig states that in September, at 10 a.m., with an air-temperature of $69.8^{\circ} \mathrm{F}$., the temperatures on the S.E. side of thin-barked beech and spruce were $98.6^{\circ} \mathrm{F}$. and $82.4^{\circ} \mathrm{F}$, while that of Scots pine was $68^{\circ} \mathrm{F}$. 
(d) Age of Tree.-The trees mentioned above are exposed to injuries by bark-scorching from the age of poles upwards, but large trees suffer more than smaller ones; the latter, owing to the greater curvature of their stems, do not receive so much direct heat as the former, and they radiate heat more freely than large trees. In beech woods, where bark-scorching is frequent, 60- to 70- year-old beech trees suffer most.

(e) Position of Trees.-Bark-scorching attacks trees standing in the open only, and especially those which have been recently exposed, after standing in a dense wood; also trees along the westerly and south-westerly boundaries of a forest. Trees forming a dense leaf-canopy are never attacked, as their bark cannot become heated like that of exposed trees. Exposed trees do not always suffer. in the first year after exposure; sometimes four years pass before bark-scorching occurs, but this depends on the state of the weather.

( $f$ ) Locality.-The locality and its surroundings, and the nature of the soil-covering, may be here considered. As westerly and south-westerly aspects are most exposed to danger, any woods forming.protective zones in these directions prevent or reduce the effects of insolation. Undergrowth and soil-covering of dead leaves and humus are also useful, as the reflection of the sun's heat from the ground is much greater when the soil, and especially calcareous or sandy soil, is fully exposed. The malady is most frequent during the hot months in beech forests.

\section{Protective Rules.}

(a) Avoid fellings by which beech- or spruce- woods may become exposed to the west, south-west, or south.

(b) Do not leave beech-standards near the threatened boundaries of a wood. In France it has been usual to lop the side branches of trees in woods bordering on roads, in order to prevent injury to the roads by drip and shade. This predisposes beech and other smooth-barked trees to scorching. It is better to fell such trees and encourage advance growth, which shelters the wood, without endangering the roads.

(c) Mix oak, elm, birch or conifers with beech.

(d) Allow the trees on the western and south-western 
borders of a beech or spruce forest to branch freely down to the ground; this may be secured by making timely thinnings in young woods.

(e) Avoid high prunings in the case of beech standard-trees, or any pruning of beech or spruce trees growing in hedgerows.

(f) Protect the soil-covering of dead leaves, moss, etc., and preserve the undergrowth along the borders of a forest.

$(g)$ For the protection of specially valuable avenue trees, their bark may be smeared with a mixture of whitervash, clay and water, cow-dung and water, etc.

Trees that have been scorched should not be removed, as they shelter trees behind them which would otherwise be attacked; it is better to form a protective belt of some shadebearing species, and not to remove the injured trees till this has attained a sufficient height.

\section{Section III.-Heat-crack.}

Beling states that cracks in trees have been caused by insolation; this happens in the spring (April and May), when there are considerable differences between the day- and nighttemperatures, and the ground being still cold, the centre of the tree does not expand so much as the bark. Cracks are thus formed on trees standing on southerly or south-westerly slopes, chiefly on beech 30 to 70 years old, but also on sycamore, hornbeam, oak and ash. The splits extend up the stem from near the level of the ground to 20 and more feet in height. Owing to the drying and loosening of the bark, local decay may be introduced into the wood, but small cracks usually close up again without any permanent injury resulting.

Schlich observed in the early part of 1895 , during severe frost, that the bark of beech-standards cracked or split when the sun rose in the morning. All such cracks or splits occurred in the south-east or south side of the trees, the cracking being followed by an outflow of sap. Trees which had thus been injured in previous years showed a considerable amount of decay in the wood, having the appearance of barkscorched trees.

As the resulting injuries are usually unimportant, no special measures need be taken to prevent heat-crack. 


\section{CHAPTER III. \\ PROTECTION AGAINST WINDS.}

Winds may be classified in various ways, by their speed, as winds and storms; their origin-land- or sea- winds; their direction according to the point of the compass from which they blow; the damage they inflict on forests, by drying up the soil, impeding height-growth and the formation of a regularly-shaped crown in trees, or by breaking and overthrowing individual stems or whole woods, the last injury being caused only by storms.

Wind, by blowing caterpillars from older trees on to young growth, may also increase the damage done by insects; this has been observed frequently in the case of attacks by the nun moth. Winds also spread the spores of fungi.

\section{Section I.-Prevalent Winds.}

South-westerly winds are most prevalent in Central Europe, especially during autumn and early winter. They blow as cool winds during summer, and are comparatively warm in winter, and bring much moisture and rain-clouds from the ocean. Dry winds from the north-east and east prevail generally during the spring, the cutting north-east wind on the coasts of the Adriatic being termed bora. The well-known cold north-east wind, named mistral, blows down the Rhone Valley, in France, and in Switzerland a hot dry wind from the south frequently prevails during the summer months and is termed föhn. Cold winds from mountains down on to valleys and plains blow generally at night, forming air-cataracts.

\section{Damage done.}

\section{A. General Account.}

Prevalent winds dry up and disperse the soil-covering, blowing dead leaves from slopes and ridges, and heaping them uselessly in hollows; they hinder the formation of dew, 
and spread the spores of fungi, and the seeds of forest-weeds. Easterly and north-easterly winds dry up the soil and young plants, and injure the foliage and fructification of trees. Strong south-westerly winds cause a misshapen growth of the crowns of trees, especially near the sea-coast and on the south-westerly borders of forests, where the trees are stunted in height and have their crowns bent over towards the east (Fig. 241, p. 513); they also break off blossoms and tender shoots, whilst damp winds near the sea-coast also injure trees by the salt they carry, which the rain washes from their leaves into the soil, rendering it salt and unsuitable for certain kinds of vegetation. This influence may be felt to a distance of five miles from the sea.

The results of these injurious influences are:-impoverishment of the soil, a rank growth of weeds, failure of reproduction, languishing of young growth, loss of increment and forking of old trees, spread of fungi, etc.

\section{B. Damage under Special Conditions.}

(a) Species.-Broadleaved trees suffer more than conifer's from dry winds.

The tender young foliage and inflorescence of beech and hornbeam are frequently so dried up by the north-east wind that they appear to have been frozen or scorched by summer heat.

The elm, oak, lime and birch are less liable to damage.

Where the larch is exposed to south-westerly gales, especially on shallow soils, it becomes sabre-shaped, curving outwards and upwards from its base; this is due to the wind from its seedling stage continually blowing the tree out of the vertical direction, which it strives to regain by continued upward growth. Orchard trees are similarly affected, whilst poplars and willows grow with their stems bending towards the east.

As regards winds blowing from the sea, experience gained near the Baltic and North Seas shows, that silver-fir, elms, aspen, black poplar and birch withstand their action well. The shrub-like mountain-pine (Pinus montana var. uncinata Rand.) also withstands the action of winds along the sea-coast better than Scots pine, and is extensively planted in Denmark and along the Baltic coast. In Britain, black pine, the 
Corsican variety of Pinus Laricio, the cluster or maritime pine, and of broadleaved species, sycamore, Norway maple and white poplar are very resistant. Oak suffers somewhat from saline spray, beech still more, and the spruce most of all.

(b) Age of 'Trees.--Seedlings and little plants, especially in sowings and plantations, and young coppice-shoots suffer most severely from cutting winds, until the ground is completely covered by their interlacing branches. Coppice suffers more than high forest, especially when the rotation is short, and high forest suffers the less, the closer is the leaf-canopy.

(c) Locality. - The most exposed localities are coast forests, cultivated plains with hedgerow trees, ridges and tops of mountains and hills, valleys running east and west, easterly aspects unprotected by higher hills, unsheltered plateaux, etc.

The amount of soil-desiccation by wind varies with the nature of the soil and wind. The faster the wind blows, the more moisture is removed from the soil. The damper the soil, the more water it loses, but deep soils suffer much less than shallow soils. Soil covered with low vegetation loses the most water, that covered with dead leaves and humus least. Bare soil is intermediate. Dry winds, under otherwise similar conditions, remove more water than moist winds, and warm winds more than cold winds. Wind also reduces the quantity of carbon dioxide in the air contained in the soil, and reduces the soil-temperature, the greater the velocity of the wind, and the greater the angle at which it meets the surface of the ground. Late spring and early summer are the most dangerous seasons.

\section{Protective Rules.}

The chief rules consist in the maintenance of a good leafcanopy, especially in localities exposed to prevailing winds. Along sea-coasts, therefore, and in high mountainous regions and other exposed places, natural regeneration, selection fellings and the formation of protective belts are advisable.

Wherever clear-cuttings are preferable, after a consideration of all local conditions, the following special rules should also be observed :-

(a) After leaving a protective belt as far as the destructive F.P. 
action of the wind precludes clear-cutting, establish narrow cutting-areas.

(b) Planting with balls of earth is advisable; if planting is being done during a dry east

N.
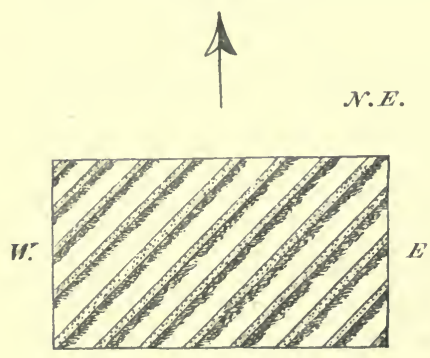

S.W. wind, the plants' roots should not be exposed even for ten minutes, unless they are N.E. covered by damp moss.

(c) Sowings should run from north-east to south-west, and soil should be heaped up on the south-east side of the lines, as shown in Fig. 244 ; this secures the young plants against frost and heat and is also the best protection against dry winds from the east and south. It can, however, be employed only on flat ground, for sowings on slopes must always be horizontal, in order to prevent the soil and seeds from being washed away by rain.

(d) Mix conifers with broadleaved trees.

(e) Belts of conifers 20 to 30 feet wide as in Fig. 245 should intervene between broadleaved woods and cultivated land, and should be established along forest roads. Corsican pine, spruce and silver-fir are the best species for the purpose, but if the soil is too dry for them, Scots or Black pines may be used. These protective belts are extremely useful in sheltering woods from drought and prevent the removal of dead leaves by the wind,

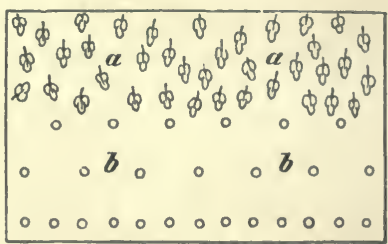

Fig. 245.

$a$ Broadleaved wood.

$b$ Coniferous wood. damage by frost, etc.; the external trees should be allowed to branch down to the ground, and along forest roads there should be a strip of land free from trees beyond the belt, to prevent the roads from being 
kept moist by the drip from overhanging trees. - This is greatly preferable to lopping the border trees along a roadside, which, besides its unsightly appearance, admits the wind into the forest, and exposes the bark to sun-scorching.

$(f)$ All undergrowth which springs up along easterly and north-easterly forest boundaries affords a natural protection belt and should be carefully preserved.

(g) Coppice should be cut from the west, south-west or north-west towards the opposite bearings. In high forests this is only permissible on plains which are exposed to the east and for storm-firm trees such as the oak.

\section{Section II.-Storms.}

\section{Origin of Storms.}

All winds are caused by differences in atmospheric pressure resulting from unequal temperatures of the air in different localities. Whenever the equilibrium of the atmosphere is thus disturbed, a current of wind sets in to restore it.

A storm is a wind with a velocity of at least 20 to 25 meters in a second. Its approach is accompanied by a barometric minimum. A hurricane has at least a velocity of 35 meters per second.

A line joining all places having the same atmospheric pressure, as indicated by the height of the barometric column of mercury, after compensation for the elevation of the place above sea-level and for temperature, is termed an isobar.

If maps are drawn, as in the Times' weather reports, showing the different isobars for every tenth of an inch, it will be noticed that they surround tracts from which either the pressure decreases in all directions, termed barometric maxima or anticyclones; or, from which the pressure similarly increases, which are termed centres of depression, barometric minima or cyclones.

The wind always blows from the regions of high pressure towards the depressions, i.e., from an anticyclonic region towards a centre of depression; it does not, however, blow in a direction normal or perpendicular to the isobars, but greatly inclined to this, owing to the effects of the earth's rotation, 
which gives it a twist to the right in the northerly hemisphere. The strength of the wind varies with the barometric gradient, or difference in atmospheric pressure at places distant one geographical mile normal to the isobars. The closer, therefore, the isobars are for any difference in the height of mercurial column, the greater is the gradient and the stronger the wind.

The isobars become crowded together wherever the pressure is lowest, and this fact, combined with the twist to the right of the winds rushing in from all directions to fill a depression, causes the revolving storms also termed cyclones, the absolute axes of which are more or less calm. Thus on the southern side of a depression, the wind blows from the S.W., on its western side from N.W., on its northern side from N.E., and on its eastern side from S.E.

The isobars are closest together on the western sides of depressions, so that the strongest storms come from a westerly direction (S.W. to N.W.). The depressions usually pass to the north of Central Europe, and traverse the continent from west to east, so that storms usually begin blowing from S.E. and gradually change to S., S.W., W., and N.W. Most of these storms travel across the British Isles, having originated in the Atlantic ocean or Gulf of Mexico, but the south-easterly direction of the wind hefore a cyclone is not very noticeable here.

Powerful storms therefore depend on the existence of barometric depressions, which may be only partial or irregular interruptions of an isobar, in which case the storm extends over a limited area only. Violent storms of limited extent but withs teep gradients that do considerable damage over a narrow zone of country, are termed tornados.

The direction of winds may be considerably modified in mountainous countries, by the spurs of the mountains as well as the directions of the valleys. Thus, a west wind may be converted into a north or south wind during its progress through a valley.

It is a still more frequent case for a south-west wind to become a south wind, and a north-west wind, west.

These local wind-directions must be considered whenever a working-plan is prepared. 
The rates of storms are given as follows by Rouse :-

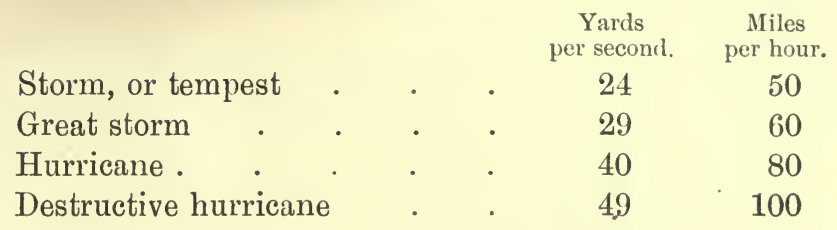

2. Damage done.

A. General Account.

Storms shake the roots of trees up and down in the ground and may either give a tree a decided leaning in a particular direction, or tear it out of the ground by its roots and with the earth adhering to them, or break its stem or branches. Such uprooted or broken trees are termed windfalls.

Whether the tree is blown down or broken depends partly on the intensity of the storm and partly on the relative power of resistance of its roots or stem. Breakage happens when the roots resist better than the stem, windfall when the roots are the weaker. Breakage may also be due to one tree falling on others. The amount of resistance to storms which the roots or stem of a tree offers, equal conditions being presupposed, depends on the nature of the soil (its compacity and degree of moisture, e.g., whether its resistance has been weakened by heavy rain before a storm), and that of the locality (plains, or hillsides, aspect, gradient, etc.).

Independently of the above, the storm-firmness of our trees varies according to species, length of bole, nature of crown, soundness of the wood, density of crop, mode of formation, and tending, as well as on other local circumstances. Each of these factors will be considered separately.

The roots of the trees that are stretched by the wind are termed anchor-roots, those on the lee side of the tree proproots. The prevailing opinion is that the anchor-roots hold up the tree against a storm, as the anchor holds a ship. Hesse, however, agrees with Nördlinger in attaching more importance to the prop-roots. In support of this he states that in a roadside avenue running $\mathrm{N}$. and $\mathrm{S}$., the trees on the W., having their prop-roots in the firm road, hold better against 
storms than those on the E. side of the avenue, that have their prop-roots in softer soil.

Storms not only overthrow single trees, but also whole woods. A wood may have narrow clearings cut into it by storms corresponding to their direction, or large blanks may be made.

Breakage may be of stem, fork, crown, or branches; the stem may be broken off close to the ground, or at some distance above it, and whirlwinds frequently twist the entire crown off trees.

The damage done by storms may be divect or indirect.

To the former class belong:-Loss of increment and breakage of timber, which may become only fit for firewood; damage to young growth owing to the breakage of underwood by trees standing over it which have been blown down; increased cost of exploitation or of reproduction of woods; reduced prices, owing to an excess of material being suddenly thrown on the market; irregularities in age-classes and in carrying out working-plans, also disorder in thinnings and in preparatory fellings. The disturbance of a forest workingplan may be so great, that it may become necessary- to recalculate the annual yield of a forest, and to prepare a new table of annual felling-areas.

Indirect damage done by storms is chiefly confined to invasions of weeds in the blanks and regeneration-areas where the trees have been blown down, and to attacks of barkbeetles.

\section{B. Damage under Special Conditions.}

(a) Species of Tree.-Conifers are far more exposed to damage than broadleaved species. Extensive destruction of broadleaved woods by storms is comparatively rare.

It would be difficult to draw up a comparative table of trees of different species according to their capacity to withstand storms, as the amount of damage done is greatly modified by local circumstances; but evergreen foliage and shallow root-systems render trees liable to be broken or blown over. As these two qualities are united in the spruce, this species is specially liable to damage by storms, as experience has proved. If, at any time, other trees suffer more than the spruce, this is due to the nature of the soil, to the extraordinary violence of the storm, or some other special circumstance. 
When species such as silver-fir, or Scots pine, with strong root-systems, are hindered from developing them normally, owing to the nature of the subsoil, they are exposed to danger equally with the spruce, and even more so; for in such cases they are compelled to have shallow root-systems which, unlike the spruce, they rarely develop evenly in all directions. Danger is also increased in the case of the Scots pine by the higher centre of gravity it possesses than the spruce.

A list of species arranged in ascending order of stormfirmness can therefore be drawn up only after allowing for the effects of local circumstances on each species, and presupposing a rational treatment in accordance with sylvicultural requirements.

From this point of view, conifers are arranged in the following order :-Spruce, silver-fir, pines and larch. Of the pines, the mountain and Cembran pines are most storm-firm, then the Corsican pine, the Black pine, and the cluster, Weymouth and Scots pines.

As regards broadleaved species, those which are shallowrooted, such as aspen, birch, beech, and hornbeam, are least storm-firm. The beech is more frequently blown down than any of these species, because it is most abundantly grown. In the woods above Gérardmer, in the Vosges, the porportion of beech increases under natural regeneration with the altitude, in the mixed forest of silver-fir, spruce, and beech ; and at the crest of the mountains, 4,000 feet, beech alone remains, the conifers being unable to resist the prevailing westerly gales. The following trees are fairly storm-firm :-ash, sycamore, Norway maple, elm, alder, lime and walnut; the deep-rooted oaks withstand storms best of all.

(b) Age of Tree.-Storms chiefly damage woods of advanced age, the second half or last third of a rotation being most endangered.

Extensive damage is rare in woods under sixty years of age, and occurs only under exceptional conditions, such as shallow-rootedness of young woods, soil without much consistency owing to saturation by rain, woods in very exposed localities or when assailed by exceptionally violent storms.

Damage to young trees consists more in causing them to 
deviate from the vertical position, less by uprooting, and less still in breakage.

In the storm on the Baltic coast in 1872, in the Greifswald, 25 -years-old Scots pines were affected. In 1876, 15 to 20 years-old spruce and Scots pines were seriously damaged. In some pole-woods 25 to 30 per cent. of the stems were bent an angle of 30 degrees towards the east and north-east.

(c) System of Management.-High forests are most exposed to danger from storms. The shelterwood compartment system leaving mother trees evenly distributed over the felling-area, is most endangered. In localities exposed to storms (mountain sides, etc.) this system is inapplicable, as the mother trees are inevitably blown down.

Whether uneven-aged and irregular Selection forests suffer more from storms than the even-aged woods of the Clearcutting system, is still an open question, which can only be answered after thoroughly considering the modifying influence of localities, and the degree of skill with which the woods have been treated. Hesse believes that the Selection and Group systems give more security against storms than the Clear-cutting system, as the trees in the latter are more crowded and have weaker roots, but under the former systems the trees to be felled must be very carefully selected.

Among the coppice systems, that of lopping side branches is the worst, as trees so treated have long narrow crowns, on which the wind can exert leverage. Pollards suffer less, and ordinary coppice least of all. Coppice-with-standards is also stormfirm, as only the standards can suffer, and damage to these is inconsiderable, owing to their strong root development and the uniformity of their crowns, due to their growth in the open.

(d) Nature of Stem.-Long, cylindrical stems with elevated and expanded crowns, having high centres of gravity, and affording strong leverage to the winds, are greatly exposed to damage by storms. Thus standards in high forest above young growth are peculiarly liable to be thrown or broken. Damaged or sickly trees, such as forked trees, those with decayed roots; trees injured by game, insects, cankers, fungi, cup-shake, bark-scorching, etc., are very liable to windbreak; this, as a rule, occurs at the damaged place. 
Uprooting of the tree with the soil attached to its roots is most frequent in the case of spruce or beech.

Breakage of crown or branches is most common in the case of Scots pine, alder, ash and robinia. The forked branches and crown of the two latter species are frequently broken by storms. In the case of oaks it is chiefly the dry branches of stag-headed crowns which are blown off by storms. In the Vosges, a distinction is made between silver-fir trees with a $\mathrm{U}$ fork and those with a $\mathrm{V}$ fork, the latter being more liable to breakage. Cankered silver-fir are very liable to breakage.

(e) Locality.-In Germany, forests on hills and low mountain-chains are more affected by storms than those in higher mountainous regions. During the ten years, $1870-80$, in the Thüringer-Wald and the Harz, damage by storms was chiefly at altitudes of between 800 and 1,800 feet ; but in 1876 , extended to 2,300 feet. This is because at higher altitudes spruce trees are shorter in the stem than those growing lower down, are also grown less crowded with low crowns in Selection forests, and have thus greater powers of resistance against storms than the crowded lanky stems of lower altitudes.

The configuration of the ground has a marked influence on the amount of damage done to forests by storms.

Gentle westerly slopes bordering on extensive plains or plateaux suffer greatly, and so do outlying hills and mountain ridges; also, narrow valleys running from the west or southwest towards the east or north-east. The damage is then done on the north and south slopes of these valleys, which the wind attacks in flank. Every bend in the valley reduces the violence of the wind. To endangered localities also belong: hills at the end of narrow valleys or outliers that project into them and steep slopes directly in the way of the storm.

A storm that descends a hillside is much more dangerous than one blowing up-hill. Whenever south-westerly winds prevail, a storm, after crossing a mountain ridge, must descend its north-easterly slope. If the west or south-west slopes of the hill are denuded of trees, or if the wind has to find its way across the ridge through narrow felling-areas between high woods, or by funnel-shaped ravines, the damage done on the north-easterly slope will be increased, as the air 
becomes condensed owing to the confined space in which it moves, and this increases the violence of the storm.

It is found that storms do more damage down-hill than up-hill, and for the following reasons :-

i. The root-system of individual trees is usually weaker down-hill than up-hill. Not only the anchor-roots, but also the prop-roots are more oblique in the soil to the wind-

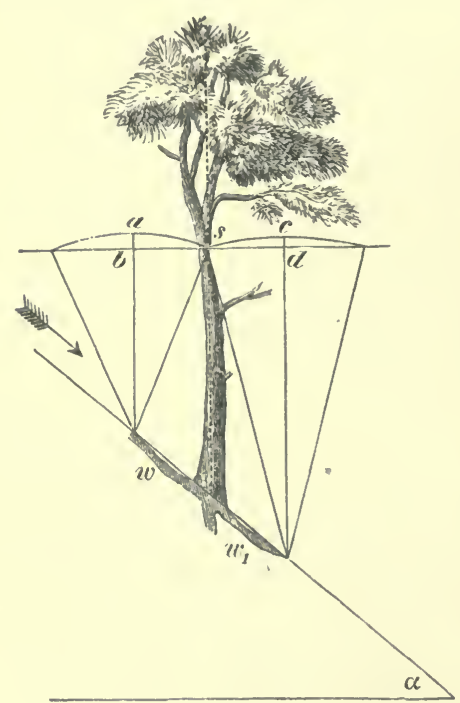

Fig. 246. direction on the easterly aspects, i.e., away from the wind. The descending storm therefore finds only a feeble resistance in the roots; the wind blowing up-hill has to overcome not only the resistance of the anchor-roots, but also those of the prop-roots.

ii. An ascending wind has to contend with the friction of the tree-crowns, as well. as of the soil, which reduces its force. Moreover, the prop-roots of the trees on the western slopes, exposed to the wind-direction, are more vertically inclined to the latter, and therefore offer a stronger resistance, than on the easterly slopes.

iii. The centre of gravity of a tree has to be raised less when blown over from above than from below, as the annexed diagram shows:-

Here $s$ is the centre of gravity of the tree, and $w, w_{1}$, two roots, and if the tree is to be thrown up-hill by the wind, $s$ must be raised through $a b$; if down-hill, through $c d$, which is less than $a b$. The greater the gradient of the slope, the more endangered is the tree.

The nature of the soil exercises an unmistakeable influence on the extent of the damage done by storms.

Shallow, loose, spongy soil affords a bad root-hold; this explains the great amount of windfall which occurs on moors 
and sandy soils; soils above a subsoil of stiff clay, into which the trees' roots do not penetrate, are also very subject to windfall. It has been observed that windfall in the Schwarzwald is more frequent on the red sandstone formation than on gneiss, granite, basalt or porphyry. In woods that have been planted on the sites of old fields, windfall is frequent, owing to the looseness and comparative poverty of the soil in mineral matter. Soils in which root-rot frequently occurs, such as calcareous soil, or land with a wet subsoil, are liable to windfall.

A high soil-covering, such as heather, broom, thorny or shrubby undergrowth, is beneficial, as these plants bind together the particles of soil, and also exercise considerable friction on the air in motion.

The state of the weather before and at the commencement of the storm also exercises considerable influence on the damage done.

Heavy rainfall accompanying a storm greatly diminishes the coherence of the soil, and increases the danger of uprooting, its effects vary of course with the nature of the soil. This was the case on the occasion of the terrible storms in 1872 and 1874. Frost, on the contrary, greatly increases the coherence of the soil, especially when the ground is covered with snow.

(f) Density of Crop.-Trees grown in the open, owing to their well-developed root-systems, and low pyramidal crowns, withstand storms much better than stems which have been drawn up in dense woods. Trees recently exposed in thinnings and regeneration fellings suffer most. The latter improve in their powers of resistance, as they get accustomed to their open position. Their root-systems become enlarged; in crowded woods, however, the stems afford one another mutual protection against the wind.

Damage is considerably greater in isolated woodlands than in extensive forests, as the various crops in the latter afford one another mutual support.

(g) Season.-Storms may occur at any season of the year, but the most destructive storms are during the six months between the autumnal and vernal equinoxes. Storms in spring are more dangerous than in autumn, as the soil is then generally less 
firm. Since 1870, damage to Prussian forests by storm, snow and rime have been recorded in all the Royal Forest districts, and the results published by the directors of the Forest experimental stations. 'I'his praiseworthy undertaking should be followed by all State Forest Administrations.

\section{Register of Storms.}

During the past century, the following are the dates of the most widespread and disastrous storms :-

1800 (3rd and 9th November, especially in the Harz).

1801 (29th and 30th January).

1833 (17th and 18th December).

1834 (4th January).

1836 (29th November and 24th-26th December, from the E.).

1839 (30th-31st October, especially in the Harz, from the E.).

1842 (3rd May).

1853 (14th and 15th December, from S.E.).

1866 (16th November).

1867 (8th April).

1868 (7th, 11th, and 29th. December).

1869 (17th December).

1870 (26th and 27th October).

1872 (12th and 13th November, especially near the Baltic, from the N.E.).

1875 (8th and 13th November).

1876 (12th and 13th March). In this storm, about thirty million cubic feet of timber were blown down in the State and Communal forests of Hesse, or 84 cubic feet per acre, being 125 per cent. of the total annual yield of the forests. 'The same storm cleared 24 cubic feet per acre in the Saxon forests, or 40 per cent. of their fixed annual yield. During the same year, 350,000 cubic feet of broadleaved trees were blown down in the Forest of Compiégne.

1877 (30th and 31st January, and 10th and 12th February).

1879 (20th and 21st February, 25th June, 20th November, and 5 th December). 
1880 (21st October).

1881 (14th and 15th October).

1883 (17th-19th October).

1884 (20th and 28th January).

1885 (15th October).

1888 (24th-26th November).

1890 (23rd, 24th and 27th January).

1892 (29th-30th March, in the Vosges; from E.).

1893 (16th and 17th November). Terrific storms over the north of England and Scotland accompanied by violent rain, the wind blowing at 90 miles an hour in the Orkneys; $1,850,000$ trees, valued at $£ 282,263$, were blown down in Perthshire and Forfarshire, the only conifers resisting the gale being Corsican and maritime pines.

1894 (12th February and 22nd December). The December storm was similar to that of 1893 , and only did less damage to the Highland woods because there were fewer trees left to be blown down. Great numbers of rooks, starlings, and other birds were entangled in the branches of trees and killed, or blown into the sea.

1895 (5th-7th and 12th-13th December; chiefly in S. Germany, but also in Schleswig-Holstein and the Harz).

1895 (5th-7th October, from N.E.).

1898 (4th-7th December).

1899 (12th-13th January).

1900 (14th February; 28,000 trees, including 15,000 oaks, blown down in the Forest of Bercé, Sarthe).

1902 (13th February; 292,500 cubic feet of timber, chiefly spruce, blown down in Forest of Gérardmer, Vosges; from N.E.).

Taking a general view of the storms in Central Europe, during the past century, the years 1801, 1833, 1868, 1876, 1893 , and 1894, have been the worst, and there has been, on the average, one destructive storm-year every three years.

Whirlwinds are of rare occurrence in Central Europe, and are usually only of limited extent and short duration. On the 1st August, 1877, a whirlwind fifty miles to the north of Berlin destroyed three-and-a-half million cubic feet of standing timber over a breadth of two-and-a-half miles. 
The coast districts between the mouths of the Mississippi river and Charleston are subject to terrific hurricanes, and in August, 1893, scarcely a tree was left standing in the islands there, nearly 2,000 people were killed, and $£ 1,000,000$ worth of property destroyed, the wind having blown at the rate of 125 miles per hour.*

\section{Protective Rules.}

a. During the Formation of Woods.

i. Favour the cultivation of broadleaved species wherever this is possible. The damage done by storms during the last ten years is a warning to foresters who are so ready to convert broadleaved into coniferous forests; this should be done only in cases of extreme urgency.

ii. Drain damp localities before making regenerationfellings.

iii. Use strong transplants 4 to 6 feet apart, so as to ensure the growth of sturdy trees. Planting spruce gives better results than sowing it.

iv. Mix deep-rooted species with shallow-rooted ones; for instance, mix oak, ash, sycamore, larch, or Scots pine with beech and silver-fir, and silver-fir, beech and larch with spruce.

Von Wiehl (Olmütz) placed rows of storm-firm trees in spruce woods every 150 metres, five or six rows of oak, sycamore, Scots, Weymouth, and Cembran pines, according to the soil and locality, transversely to the storm-direction, in flat land from N. to S., elsewhere parallel to the sides.

v. Maintain protective belts along the boundaries of a forest, where prevailing winds are to be feared, especially along farms and neighbouring woodlands. Boundary ditches should not be dug along these boundaries, as they cut through the roots of the nearest trees.

\section{b. During T'ending.}

i. Early, frequent and moderate thinnings should be made, so as to ensure normal root-systems, sturdy stems, and regularly shaped crowns. During the thinnings, as far as is possible without interfering with the proper density of the crop, all trees should be removed which have suffered injury to their

* “Scribner's Magazine," February, 1894. 
bark, or which are forked, diseased or affected with fungi. If the proper density of the crop would be impaired by wholesale removal of bad trees, begin with the worst and remove the others in future thinnings. It is better in thinning sprucewoods not to dig up stumps, as in so doing the roots of neighbouring trees may be cut through. Heavy thinnings in lanky and hitherto densely growing woods are dangerous.

ii. Trees along the borders of a forest should be allowed to branch low down the stem.

iii. Endangered border trees standing over young growth may be temporarily preserved by thinning out their crowns, and cutting those branches which extend at right angles to the direction of the prevailing wind. This has been successfully carried out with spruce at Stammheim, in Württemberg.

iv. Carefully avoid all causes leading to defects in trees; thus, resin-tapping should be stopped in spruce forests, deer which peel trees should be shot, and careful forest protection secured.

\section{c. During Fellings.}

i. Avoid very long rotations, as the area of a forest exposed to danger from storms increases in proportion to the length of the rotation. Thus, considering that danger from storm commences when the trees are fifty years old, we have:-

With 120 years' rotation $\frac{7}{12}$ ths of the area endangered.

$\begin{array}{lllllll}" & 90 & , & , & \frac{4}{9} \text { ths } & , & " \\ " & 60 & , & , & \frac{1}{6} \text { th } & , & \text { ", }\end{array}$

ii. All greatly exposed places in mountainous regions should be regenerated by the Selection system, and the slopes should not be touched till the summit has been regenerated.

iii. Regeneration in narrow strips commencing in the direction opposed to the prevailing wind, should be substituted for regeneration extending at once over a whole compartment, especially in spruce forest.

In the Black Forest, where silver-fir predominates, the group system of felling in patches, gives excellent results, as plentiful natural regeneration results. 
iv. Woods should always be regenerated in the direction opposed to the prevailing winds, that is, generally, from east or north-east to west or south-west, so as to secure a constantly

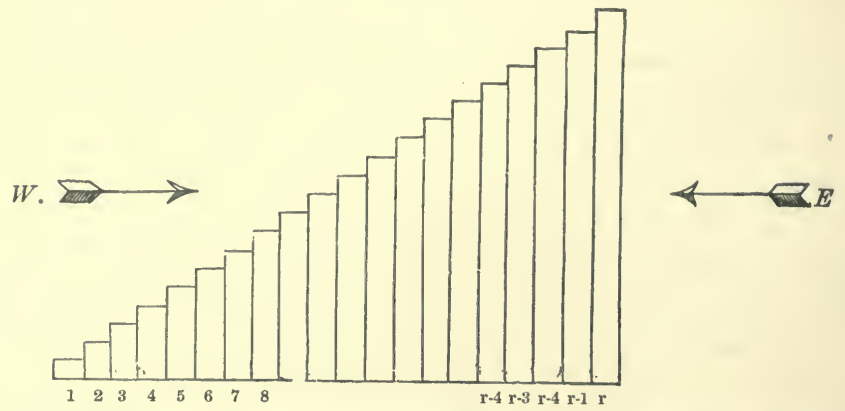

Fig. 247.-Normal arrangement of age-classes in a wood; $r$, length of rotation.

graduated succession of young woods on the windy side of the older woods. Nothing can ward off storms better than such a slope of trees as is shown in Fig. 247.

As such a succession of felling-areas may encourage insect attacks and would not be practicable over the whole area of a forest, it is usual to arrange the age-classes in a number of cutting-series, running more or less parallel to one another through the forest from east or north-east to west and southwest. Age-classes are, however, seldom so arranged that an old wood will not occasionally be found directly opposed to the force of the wind, after it has been exposed by felling another mature wood to the west of it, and in such cases, a severancefelling is required.

This is a narrow clearing made through a wood, to strengthen the border trees on its weather side, so that by the extension of their crowns and root-systems, they may protect the dense wood beyond them from storms. Severancefellings should be forty to fifty feet broad, and as nearly as possible at right-angles to the direction of the prevailing wind; they must be made before the trees are too old to respond to the increased exposure to light. Spruce woods, in which a severance-felling is to be made, should not be more than 20-30 years old. The cleared space should be at once 
planted up, and thus itself form a protective zone when the woods beyond it have been felled.

The young wood must be $10-20$ years old, before the felling of the old wood in front of it begins. Severance-fellings should not be risked in woods more than 50 years old.

Severance-fellings favour the system of small felling-areas, which have many great advantages. We must not, however, go too far in this matter. There is certainly a loss of yield in making a severance-felling, as part of an immature crop is sacrificed. The financial aspect of the question must therefore be considered, and whether the danger from storms justifies the sacrifice.

Severance-fellings are very extensively used in the Thüringian forest, and in the Saxon State forests.

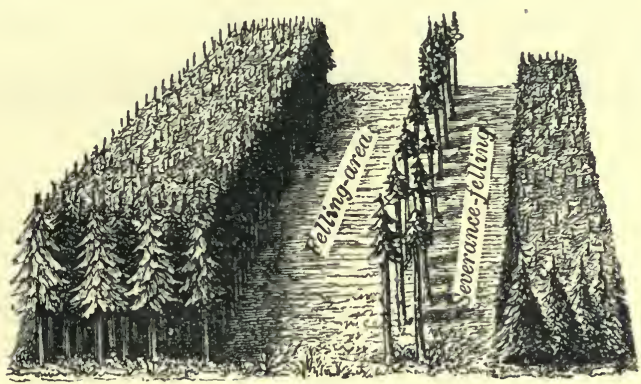

Fig. 248 .

When felling actually commences in a crop protected by a severance felling, a protective belt should be left along its eastern border, consisting of a double or treble row of trees, the crowns of which have been thinned by lopping away some of their branches, as shown in Fig. 248.

v. Felling-areas should have long straight boundaries, as fellings in outlying corners of a forest may easily admit storms.

vi. A system of rides with storm-firm borders should be laid out, which affords protection against storms.

The principal rides should be parallel to the storm-direction, and the secondary rides at right angles to it, so as to face the storms.

F.P. 


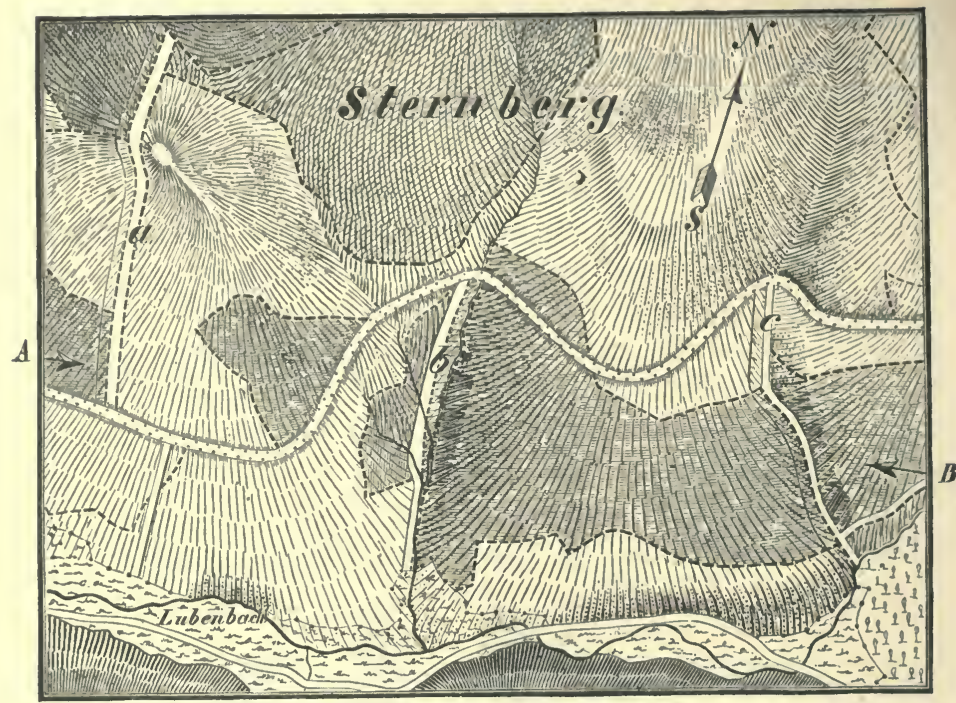

Scale $\frac{12}{12800^{\circ}}$

IV.

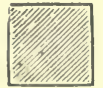

10 years old.
III.

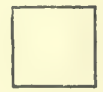

30 years.
II.

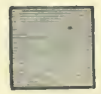

50 years.
I.

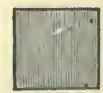

70 years.

Fig. 249.-Plan of part of the Zellaer Forest, with 3 severance-fellings, $a b c$.

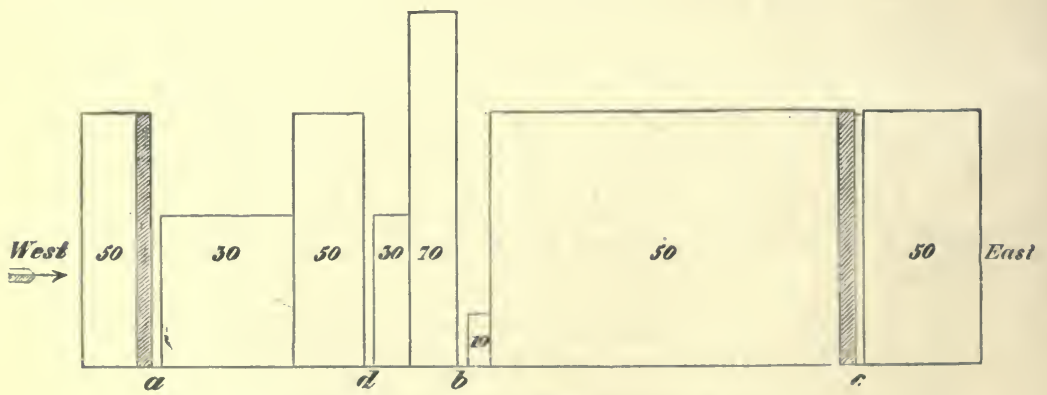

Fig. 250. - Section of the wood along A B.

The numbers refer to the average age of the wood. $a b c$ Severance-fellings. $d$ Road. The 10-year-old wood is a protective plantation. 
Fellings in high forest follow one another from east or north-east to west or south-west, according as a compartment is cleared in several years, or in one year.

Figs. 249 and 250 show the arrangement of the age-classes in a forest at Sternberg, in Thüringia. If it is wished to fell the 70-year-old wood without endangering that 50 years old, which it at present shelters from the west wind, it becomes necessary to separate the two woods by a severance-felling. This, as the diagrams show, has been already done six years ago, when the strip was planted with 4-years-old spruce transplants, which now form a 10-year-old protection belt to the 50-year-old trees. The westerly border-trees of the latter, have now become so wind-firm that the severance-felling $(b)$ might be widened. Another severance-felling $(a)$ has also been made between the 30 and 50-years-old woods, because the latter is to the west of the former and will first be mature. The proposed widening of $(a)$ is marked in Fig. 249 by a line, and in Fig. 250 by shading, but it cannot be carried out until the younger wood has become more wind-firm.

There is no apparent necessity for the severance-felling $(c)$, as the woods on both sides of it are of the same age, but it has been cut, in order that the large 50-years-old wood may be divided into two cutting series, both beginning from the east in order to aroid the necessity of having too large felling-areas.

Indispensable severance-fellings, such as $a$ and $b$, are termed protective, whilst those like $c$, made for administrative reasons, are termed silvicultural.

Fig. 251 represents a normal arrangement of age-classes in a forest, * the periodic blocks being variously shaded, and the compartments drawn square instead of oblong, so as to take up less room. The white compartments are the youngest, forming the woods of the fifth period, and the darkest compartments are those of the first period, where fellings will be at once commenced. The intermediate shades represent the second, third, and fourth periodic blocks.

* A period is an integral part of a rotation, and a periodic block is the area of forest which will be felled during any period. Thus a rotation of 100 years may be divided into 5 periods of 20 years each, and a working-section of a forest into five periodic blocks, the trees in which are aged respectively $0-20$, $21-40,41-60,61-80$, and $81-100$ years. 


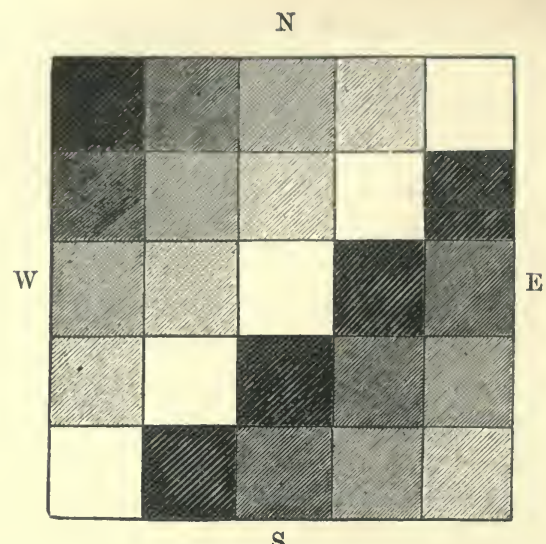

Fig. 251.

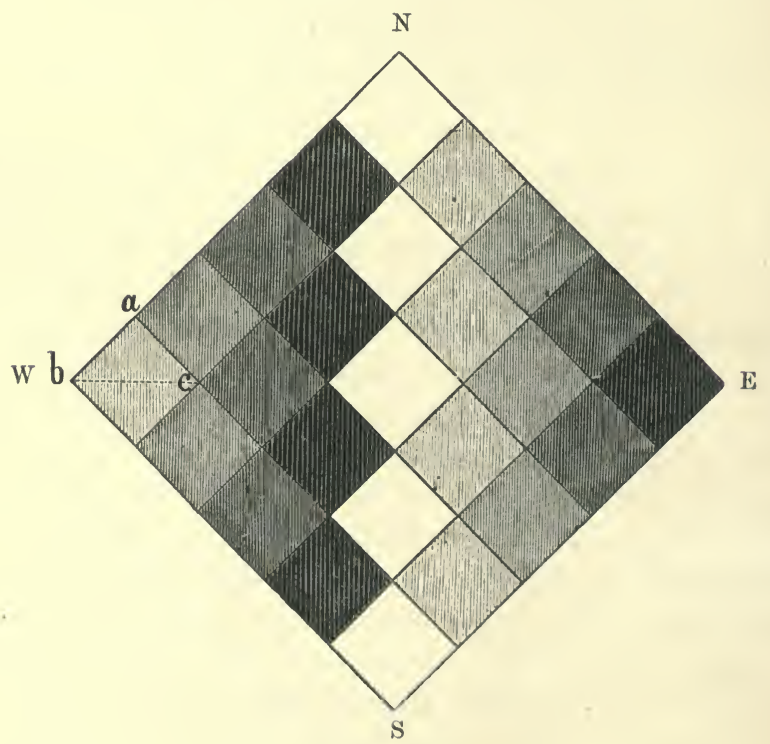

Fig. 252 .

$a b c=45$ degrees.

Denzin has, however, proposed that this arrangement of rides parallel and perpendicular to the storm-direction, which is the one usually employed, should make way for one at an angle of 
45 degrees $(a b c)$ to these directions, as shown in Fig. 252. This he considers to afford better protection to woods of second period against south-west, west-south-west, and south-southwest winds. Borggreve is also in favour of this system of rides.

The objection to this arrangement is that, although, after the dark areas have been felled, the woods of the second period are better protected against west and south-west winds, yet they are completely exposed to the cutting north-east with the accompanying danger from rime.

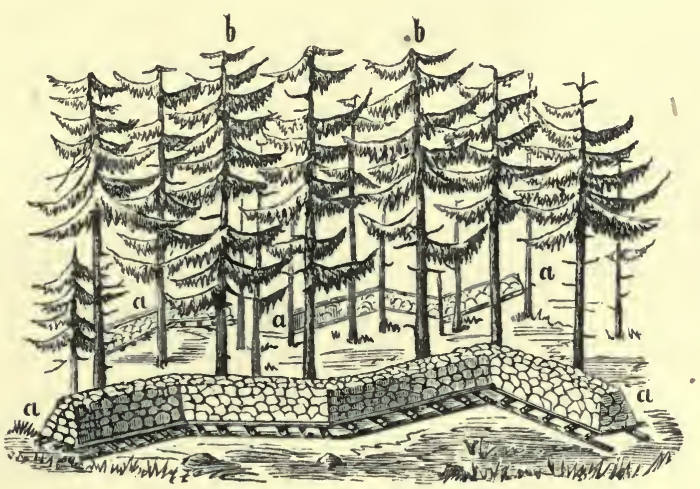

Fig. 253.

$a$ Heaps of stones. $\quad b$ Pruned and topped spruce trees.

It is also not prudent to adopt such a system universally, as storms are not always in the same direction.

Hess thinks that further experience is necessary before deciding between these two arrangements, and also as regards the shape of compartments, whether square,* rectangular, parallelograms, or trapeziums, as this may also affect the amount of damage done by storms.

vii. It is useless leaving standards of shallow-rooted species, such as spruce, in exposed places.

viii. Stumps should not be dug up in preparatory and seeding fellings, where storms are to be feared. After storms have damaged valuable middle-aged woods, further damage may be

* The question of the direction of fellings in mountainous districts, and of the proper shape of compartments, is discussed in detail by Karl Heyer, in " Der Waldbau," 1878, pp. 52 et seq. 
prevented by thinning out the crowns of trees left standing on the exposed sides of woods, and lading their roots with stones if they are easily procurable (Fig. 253).

\section{Treatment of Windfalls and Wood-breakage.}

On account of danger from bark-beetles, which follow extensive breakage in a wood, prompt measures must be taken after damage lias been done by a storm.

(a) As soon as possible, using all available labour, and mechanical means (transportable steam-saws, etc.), convert the broken material and remove it from the wood, after stripping the bark from all stems and broken pieces, at any rate of conifers. Trees that are still standing obliquely, or resting against other trees, can be left till the following season.

(b) All wood unfit for timber should be split and the stacks of fuel should be set up in well-aërated places. All rubbish may be made into charcoal or even burned, if necessary.

(c) Stems that cannot at once be sold, should be barked, to prevent insect-attacks. Whether they should be completely, or partially barked in strips depends on circumstances, chiefly on the species of tree. Complete barking is the best protection against insects, but it favours cracks and fungoidal attacks. For Scots pine, strip-barking in 1894 gave excellent results. For spruce it is best to bark completely, except that narrow rings of bark may be left at the ends and in the middle of each log.

(d) Stumps and roots of coniferous trees should be grubbed out and split up, even if a pecuniary loss is involved. In broadleaved woods, on the contrary, uprooted stumps should be replaced in the ground, or at any rate, the earth knocked from the roots and the holes filled up. Ordinary cart-jacks may be used to replace the stumps; they cost about 45 s. each, and two jacks are required for each stump. In a beech-wood, fifty-one men at two shillings a day replaced 422 stumps in this way at a cost of fourpence a stump.

(e) Wherever labour is insufficient to deal with all the fallen and broken wood, the trees uprooted with balls of earth may be left for a year.

Such trees, if broadleaved, obtain much moisture from 
their roots and may even put out foliage for two years in succession, and have even borne mast. Conifers only may be attacked by beetles and the wood become unsound when left in this way.

When the stumps are sawn off, the wood above the saw-cut should be firmly encircled with a chain, in order to prevent splitting of the log.

$(f)$ Favourable conditions of sale should be offered so that all broken wood may be sold as soon as possible. All intended fellings should be postponed until the volume of the broken wood has been calculated, and deducted from the annual yield. If there is more wood broken than the fixed annual yield, all principal fellings should be postponed for a year or more.

Some idea of the large quantity of wood which is blown down may be gained from the fact that in the spruce and silver-fir State forests in Württemberg, about one-third of the fixed annual yield comes from windfalls and breakage.

\section{Treatment of Woods which have been Damaged by} Storms.

When we consider the great variety of local circumstances which influence the degree of damage done by storms, it is impossible to draw up special rules for the treatment of injured woods which will meet all cases that may occur.

A few general rules will, however, be given which are applicable to the commoner cases for trees and poles, no damage being done by storms to thickets of saplings or to coppice-shoots. Further information on this subject should be obtained from books on silviculture.

\section{A. Injured Trees.}

All mature or nearly mature woods that have been badly invaded by storms should be felled earlier than was otherwise intended; this is especially true for woods which have thus become full of blanks. If, however, the storm has caused only a few blanks, the date fixed for fellings need not be anticipated.

Small blanks due to the fall of single trees, or small groups of trees, cannot well be planted up, as plantations succeed 
badly in such places, and within ten or fifteen years the crowns of the surrounding trees will close them again. Larger blanks, however, should be at once planted, before they become covered with weeds, unless natural regeneration can be secured. In planting blanks, about 20 to 25 feet should be left unplanted round them, as plants within this strip would suffer from the shade of the surrounding trees.

In filling blanks in injured spruce and silver-fir woods, beech, hornbeam, sycamore, or silver-fir are preferable; but if the forest contains red deer, silver-fir plants will require fencing with hurdles. Woods of Scots pine and larch, when damaged by storms, may be filled up with spruce, Weymouth or Corsican pines. Beech woods that have been invaded, where the soil is deep, should be planted with oak, and on good but stony soil, with sycamore; in wet places, with ash, or alder. When the next felling takes place, these groups of young trees will be carried on for another rotation, but will be thinned and pruned where they endanger the future young beech. They will eventually yield fine timber trees.

\section{B. Injured Poles.}

It is very difficult to decide on the proper treatment of polewoods when broken into by storms. Premature fellings would be undertaken only when the damage done is on a large scale, or when these woods interrupt the normal cutting-series, or when they would not expose neighbouring woods to the west.

In most cases the felling of broken poles will be considered in connection with the volume of broken timber from older compartments.

In general, the treatment of damaged pole-woods will vary according to species, locality, area of blanks, etc.

Small blanks could be left unplanted for the same reason as that given for older woods. Larger blanks could be planted with tall transplants of beech, hornbeam, or sycamore. Lime and white alder are also suitable species. Larch and Weymouth pine owing to their rapid growth would soon fill up the blanks, but the larch does not thrive everywhere, and the 
Weymouth pine does badly in mountainous districts. Here also 12 to 18 feet interval should be left between the plantation and the still standing poles.

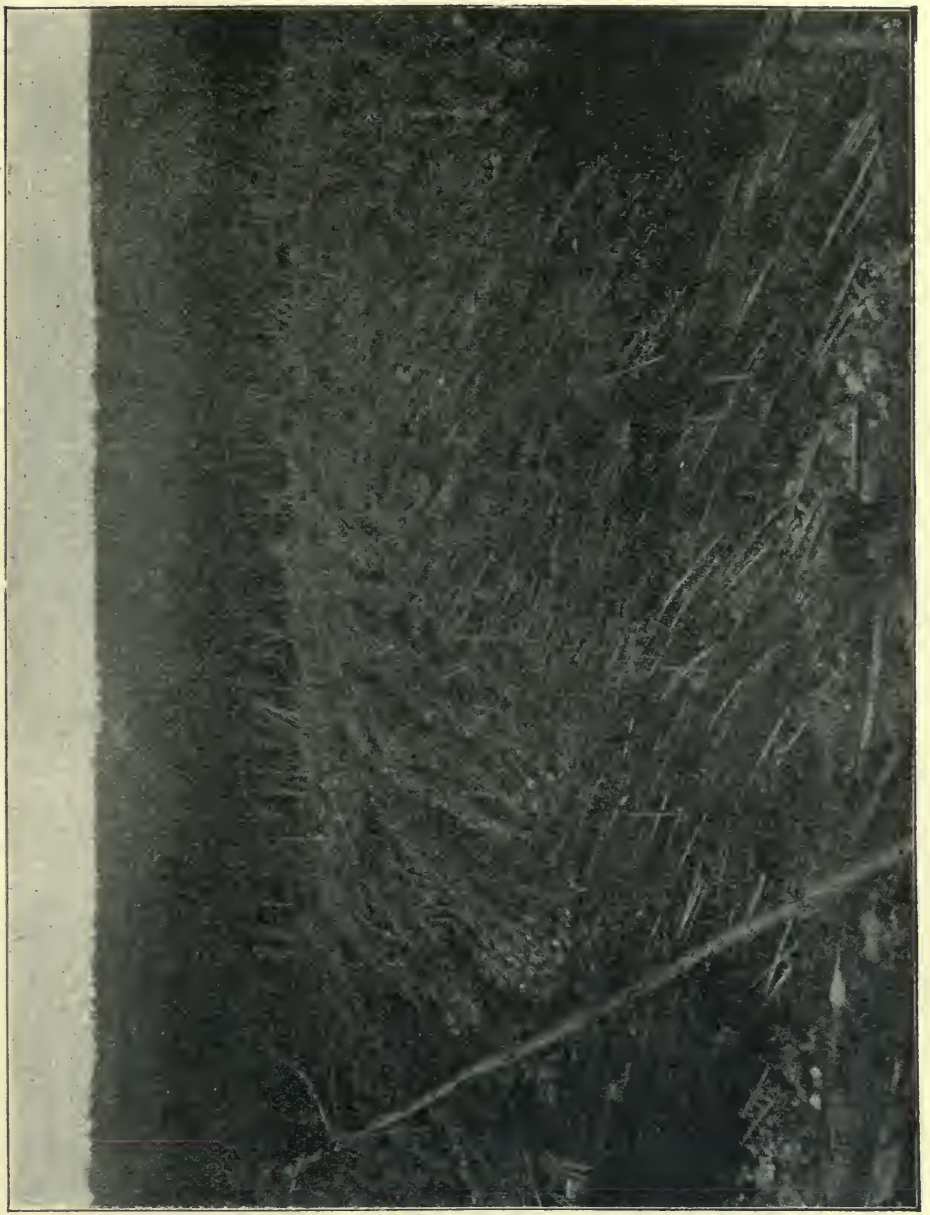

Woods intended for natural regeneration may be trained up by means of heavy thinnings to produce seed earlier than usual. 


\section{CHAPTER IV.}

\section{PROTECTION AGAINST HEAVY RAIN.}

\section{Damage done.}

\section{A. General Account.}

HeAvy and prolonged rainfall and occasionally water-spouts damage forests by carrying away the dead leaves, the soil, and seeds; by uprooting young plants, the roots of which are not sufficiently developed, such as seedlings and nursery transplants recently put out; by causing local swamps, destroying roads and ditches, loosening the roots of trees, preventing fruit from ripening, and breaking it off.

The results are impoverishment of the soil, failure of sowings, blanks in plantations, inundations, liability to windfall, loss of seed, etc.

\section{B. Damage under Special Conditions.}

The conditions on which the extent of the damage depends, independently of the force and volume of the rainfall, are chiefly the age of the crop, and the nature of the locality.

Only young plants the roots of which are insufficiently developed run the risk of being uprooted. These are chiefly young germinating seedlings, and transplants just lined out in nurseries, or planted in a felling-area.

As regards the locality, steep slopes with loose light soil, which are neither covered with woody growth, nor with herbage, moss or dead leaves, are most liable to damage. Loose soil when saturated with rain renders the roots of trees 
less secure against windfall. Clay soils are also injuriously affected by heavy rains, as a crust forms on their surface excluding air from the roots of plants.

\section{Protective Rules.}

(a) Maintain the forest growth and natural soil-covering of herbage, moss, and dead leaves on all steep slopes exposed to denudation.

In high forest, it is best to have natural regeneration under a shelterwood, but on slopes, coppice is less heavy than high forest, and protects the soil as well. In planting up such localities, the slopes may be terraced with advantage, and planting, which is preferable to sowing, should be in horizontal lines commencing at the top of the slope. For dry calcareous slopes the Austrian pine is most suitable.

(b) Establish a system of horizontal leaf-catching trenches, or protective trenches on dry slopes.

These trenches differ from one another by their dimensions.

The protective trenches are from 10 to 12 inches deep and 25 to 33 feet apart; they should be in lengths of 12 to 30 feet, to prevent the formation of drains. These trenches retain the excess water after heavy rain, and part with it gradually to the soil, the permanent moisture of which is increased. Leaves are washed and blown into them and the soil is thus enriched with humus and rendered more porous and deeper. In oak and beech forests, they catch the acorns and beech-nuts which are rolling downhill, and thus natural regeneration may be secured. Even the spoil-heaps from the trenches afford suitable sites for the germination of seeds.

If, however, the trenches are intended merely as leaf-catchers, they are shallower and closer to one another than the protective trenches. Excellent results have been obtained in the Hessian district, Lindenfels, by the use of leaf-catching trenches. They cost about $9 d$. to $1 s$. per running meter.

(c) All measures which cause or favour loosening of the soil should be abandoned in steep places; these are:- 
extraction of stumps, pasturing cattle, trenching the soil, removal of litter, etc.

(d) In order to protect forest roads from the effects of violent rainfall, ditches and culverts should be constantly kept free from weeds, silt and dead leaves. Where the road

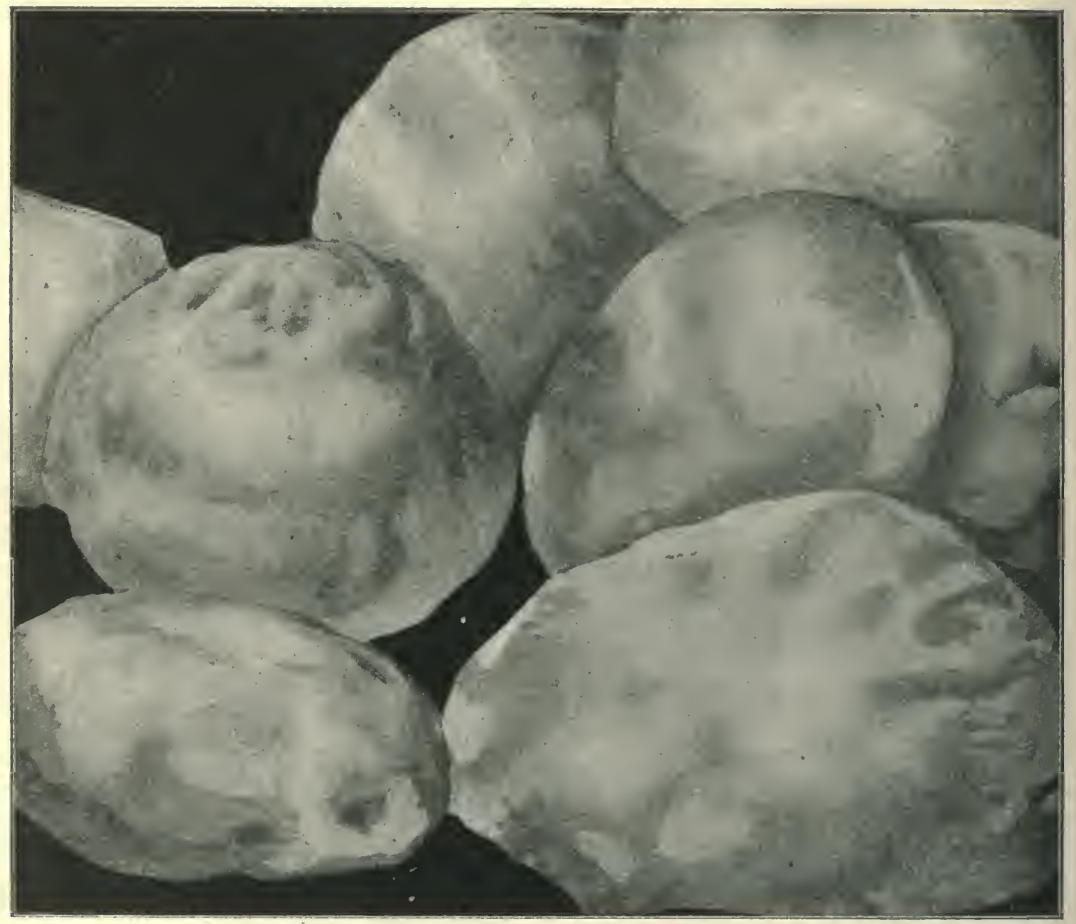

Fig. 255.- Iailstones (natural size) that fell at Seaford on May 30th, 1897. From a photo by Wynter, Seaford.

passes through a sandy cutting, the banks on either side may be terraced and fixed by wattle-work fencing, stakes of living willows being used, and sand-fixing species planted between the fences. 


\section{CHAPTER V. \\ PROTECTION AGAINST HAIL.*}

\section{Damage done.}

\section{A. General Account.}

HAIL completely beats down young plants, and injures saplings, poles and young trees by breaking off leaves, blossom, fruits, young twigs, and leading shoots, and by stripping off flakes of bark, either in little patches or short strips, and thus exposing the cambium-zone. The marks of the wounds made by hail in the bark of trees are often noticeable for a long time, the amount of damage done depending on the size of the hailstones.

Birds, and game such as hares and roes, may be killed by large hailstones. The greater the size of the latter the greater the damage done.

The direct consequences of damage by hail are: loss of increment, disease, deformed growth, decreased production of seed, and even death of young plants and poles.

The indirect damage consists in insect attack and the admission through the wounds made by hail of spores of species of Nectria and other fungi.

\section{B. Damage under Special Conditions.}

Conifers suffer most from hail, especially the Scots, Austrian and Weymouth pines, the spruce and silver-fir somewhat less; the larch soon recovers from injuries to its shoots or bark.

Among broadleaved species, those with less power of occluding wounds, and with thin bark, such as the beech, suffer most, but the oak, robinia and other trees when young

* Riniker, Hans: "Die Hageschläge in Kanton Aargau." Berlin, 1881. "Mittheilungen des Vernischen Statistischen Bureaux." Bern, 1885, 1886. "Die hagelschläge seit," 1878. 
may be seriously injured; the birch owing to its elastic shoots and leathery bark does not suffer much from hail.

Young plants 1 to 15 years old are most endangered, yearlings being often destroyed by a hailstorm; and sowings, especially when on a large scale, suffer more than plantations. Poles 15 to 30 years old suffer less than younger plants, while serious damage is rarely done to trees over 30 years old. 'The later in the spring the hail occurs, the greater is the damage, especially to smooth-barlied, weakly plants.

Oak-coppice for bark and osier-beds may suffer severely from hail. The damaged oak shoots are difficult to peel; and the osier wands break at the injured points. Even coppicewith-standards may often suffer severely. In high forest, open woods suffer more than dense woods, and isolated trees and those along the borders of the forest suffer most. Westerly, south-westerly and north-westerly aspects are chiefly threatened, as hail usually falls with a west or south-west wind. The stronger the wind, the greater the damage.

\section{Prevalence of Hailstorms.}

Hailstorms are not very common in Europe, they occur only in late spring or summer and generally during the daytime. 'They are very severe in Northern India, occurring generally during April and May, and the stones are then frequently as large as walnuts, and batter stucco buildings as if they had been subjected to a volley of musketry and even penetrate corrugated iron roofs. Such hailstorms may completely strip the young shoots from trees and tea-bushes, in the latter case causing damage which may be estimated at thousands of pounds for a tea district.

In Germany there are, on the average, only about five hailstorms a year, but on the west coast of Europe there are about fifteen. These are sometimes very local, extending only over small areas. Thus, in Cambridgeshire, within fifteen miles round Chatteris, one shilling per acre insurance for agricultural crops against hail is charged; outside this zone, sixpence per acre.

Hailstorms are very prevalent in Württemberg, where thousands of acres of cultivated land are annually laid waste 
by hail; a record of them has been kept since 1828. The chief results of the statistics there recorded may be summarised as follows :-

Communes with fields on hill-sides with south-westerly, westerly and north-westerly aspects suffer most. East, southeast and north-east aspects suffer much less.

Hailstorms generally come with the S.S.W., W. and W.S.W. winds. They follow the course of large river-valleys, when these run N.E., but leave the valleys when they run in other directions.

No connection between systems of forest-management, nor species of trees grown is discernible, either on the severity or frequency of the hailstorms.

Observations have also been made at the Meteorological Office at Zurich in Switzerland, between 1883 and 1893, and in discussing these, Dr. C. Hess* states that hail is more frequent in valleys than on mountains, where it is often transformed into sleet or rain. Near marshes and lakes, hail is more frequent than over woods. On passing over cultivated lands or hill forests, there is a tendency to a decrease in the intensity and at times an entire cessation of the hailstorms. Hailstorms follow a regular line and maps could be constructed showing where the crests of the hills should be protected by forests.

A hailstorm most destructive to woodlands occurred on the 2nd of August, 1888 at Chybi, in Austrian Silesia. On 1,917 acres of forest, belonging to the Archduke Albrecht, three confluent hailstorms almost completely destroyed 500 acres of young woods and plantations, and injured 800 acres of poles, middle-aged and old woods to such an extent that they had to be felled.

Mr. Rebmann, forstmeister at Strassburg, describes the great damage done by a hailstorm on the 30th June, 1898, which crossed Alsace from Avricourt in France, past Wörth to Karlsruhe into Bavaria. The storm travelled at 34 miles an hour over a distance of 437 miles, lightning being almost continuous. The stones were sometimes as large as the fist and killed much game and birds, one man and two horses.

* Extract from "Nature," January 3, 1895. Translated from "Naturwissenschaftlich Wochenschrift" for December 9, 1894. 
About 3,500,000 cubic feet of old timber was broken and thrown down, besides great damage done to young wood and to the agricultural crops. The falling of such masses of hail caused the air to rush in all directions, and trees were consequently blown down from all points of the compass.

According to Claudot ("Rev. des E. et F.," 10th March, 1896) French official statistics give 27,000,000 francs as the average value of the annual damage done by hail to French crops in 1825-36, whilst in 1884-88, this damage averaged $105,000,000$ francs, so that insurance rates against hail have increased so as to become sometimes prohibitive.

Owing to the disastrous effects of hail on agriculture, the question whether the maintenance of woods on mountains and hills affects the prevalence and severity of hailstorms is highly important. It is found that in Canton Aargau, in Switzerland, districts with much woodland suffer less from hail than less wooded districts.

\begin{tabular}{|c|c|c|c|c|c|c|}
\hline District. & & & & $\begin{array}{l}\text { Woodland } \\
\text { per cent. }\end{array}$ & & $\begin{array}{c}\text { Hailstorms } \\
\text { annually. }\end{array}$ \\
\hline Zosingen & - & - & & 40 & - & -2 \\
\hline nzburg & - & - & - & 32 & - & 6 \\
\hline Muri & - & - & - & 19 & - & 10 \\
\hline
\end{tabular}

In the northern part of this canton, the hailstorms prevail in the badly wooded tracts, and are scarcely known in the well wooded ones. In Bohemia, however, observation has not supported any connection between woodland and hail.

\section{Protective Measures.}

i. All hill-tops and ridges should be wooded and all blanks in forests should be filled with strong transplants.

ii. Adopt selection fellings in districts subject to hailstorms.

iii. Mix broadleaved trees with conifers, so that if the latter are seriously injured there may still be left material to restock the woods.

iv. Seriously injured spruce and Scots pine are ruined and must be felled. With larch and silver-fir recovery is possible. Young broadleaved plants should be cut back and allowed to shoot up again. 


\section{CHAPTER VI. \\ PROTECTION AGAINST SNOW.}

\section{Damage done.}

\section{A. General Account.}

SNow injures forest plants by its downward pressure when lying on their branches.

The resulting damage consists either in snow-pressure or snowbreak.

The action of snow-pressure consists in the bending or uprooting of entire stems, often with the ball of earth round their roots, or branches may be torn out of the stem.

Snoutreak is said to occur when the stem or branches yield to the weight of snow accumulated on them and break, either across the bole, the crown, or branches. When the ground is soft, bending chiefly occurs, when it is frozen breakage.

A special form of injury arises when a mass of snow sliding down a hill-side falls on undergrowth and crushes it; this resembles an avalanche, and is not uncommon on cold aspects.

\section{B. Damage under Special Conditions.}

The direct results of excessive snowfall resemble those occasioned by storms (p. 533). Much game is also destroyed. Fortunately rabbits cannot thrive in snowy mountains, as in the higher Ardennes.

The indirect damage done by snow is the softening of the soil and predisposition to denudation and landslips; swelling of mountain torrents, owing to rapid melting of snow, causes disastrous floods.

\section{a. Species of Tree.}

Trees with pendulous or flexible leaders or branches, such as birch, larch, deodar, and others with a tendency to a squat shrub-like habit and to form side-shoots into leaders, such as the mountain-pine, green alder, and most rhododendrons, are

F.P. 
adapted to grow in regions where much snow falls annually. On the contrary, trees with brittle attachment of the branches to the stem, such as Pinus rigida, Mill, and some Eucalypti, may withstand frost, but are broken to pieces by the snow.

Most European trees withstand snow fairly well, but evergreen conifer's suffer most from it, in the following order:Austrian and Scots pines and spruce; less-silver-fir.

Weymouth pine resists snow well, owing to the elasticity of its branches, and the larch suffers much less from snow than other conifers owing to its having no needles in winter for snow to rest on, but it may be injured when snow falls in autumn before it has lost its needles. Cembran pine is another tree found at high altitudes; though growing slowly, it attains a great age, and resists the snow owing to its tufted foliage and tendency to form new leaders, which the silver-fir also possesses.

The Austrian pine does not resist snow well owing to its dense crop of long needles, which allow much snow to rest on its crown. 'L'he spruce generally suffers more than Scots pine, as it grows at altitudes and on aspects where snow is most frequent and least liable to thaw; the Scots pine, on the other hand, is chiefly grown in plains where snow is less frequent and thaws sooner and cannot therefore accumulate in masses on the crowns of the trees. Wherever the spruce and Scots pine grow together in mixed woods, it is found that the latter is less resisting owing to the brittle nature of its wood; the branches of the spruce, being more elastic and splitting less readily, can support a greater weight of snow than pines. The silver-fir is more resisting than the spruce, owing to the greater depth of its root-system and the more upward insertion of its branches. In Windsor Forest, after a heavy snowfall, the position of any cluster pine can be at once recognised by the heap of broken branches under the tree.

Among broadleaved trees, the beech suffers most from snow, not on account of its possessing less powers of resistance, but because it ascends higher in mountains than other important broadleaved species.

Alder, robinia, aspen, and crack-willow suffer on account of their brittle branches, and even the birch is broken badly if 
snow should fall before it has lost its leaves. Hornbeam stands the danger better, and so do ash, maples and oak. It is, however, more difficult to draw up a scale of broadleaved trees according to their powers of resisting snow, as so few broadleaved trees form woods in mountainous districts.

The lower part of stems growing on mountain slopes exposed to heavy snowfall curves outwards before becoming vertical owing to the pressure of the snow which accumulates behind it, especially during the youth of the tree. In hollow depressions on steep slopes, the weight of the descending snow is so great, that masses of it slide down every year and crush all the seedlings they meet. Such places in the Himalayas are bordered by species of maple and horse-chestnut which apparently withstand the sliding action of the snow better than conifers or evergreen oaks, which are the chief components of the Himalayan forests between 7,000 and 9,000 feet altitude.

\section{Part of Tree.}

Young trees may be bent down, by snow, individually or in masses, inclusive or exclusive of the ball of earth around their roots.

Tearing out of branches by wet snow from the stem, as shown in Fig. 256, is a less common form of damage, by which the stem becomes almost worthless for timber, and more liable to fresh breakage. If all the branches of a verticil are thus torn out, the leading shoot invariably dies. This form of

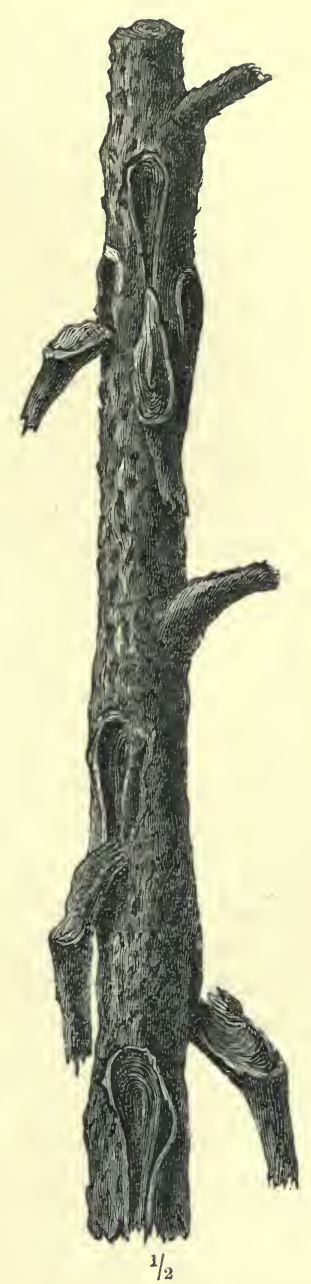

Fig. 256. - Portion of the leading shoot of a spruce, six branches of which have been torn off by snow. 
injury is common with pines, and branches up to $2 \frac{1}{2}$ inches thick are thus torn out, the holes becoming filled with resin, and the torn branches eventually falling off, so that the damage done to the tree may escape notice. In the case of spruce, the branches thus torn out are not generally more than $1 \frac{1}{2}$ inches thick.

Amongst broadleaved species, softwoods, including birch, suffer most in this way, then ash and maples; beech and oaks suffer less, though much similar damage was done by snow to oaks in Windsor Forest in October, 1878, when they were in full leaf.

According to the age of woods so affected, sometimes the leaders and branches, at others the stem at different heights above the ground, are more subject to snowbreak.

The former mode of injury is commonest in seed-years among older conifers, as the cones increase the weight on the crown of the tree.

Stem-breakage usually occurs in the case of trees injured by resin-tapping, game, or by other causes, or trees which are forked or cankered at or above the seat of injury. The exuding resin and the usual local decay at the wound reduces more or less the elasticity and strength of the stems. Observations in the Harz show the influence of wounds on snowbreak most clearly up to an age of about 45 years. Even thinnings have an influence, as most stem breakage at wounds occurred in heavily thinned woods. Thus the percentage of broken stems in the Harz, as counted by von Hague (1859-60), in 32-year-old spruce poles injured by game and resin-tappers, is as follows :-

BREAKAGE OF STEMS.

\begin{tabular}{|c|c|c|}
\hline $\begin{array}{c}\text { At the } \\
\text { point of injury. }\end{array}$ & $\begin{array}{c}\text { A bove the } \\
\text { seat of injury. }\end{array}$ & Remarks. \\
\hline 73 & 27 & Unthinned wood. \\
75 & 25 & $\begin{array}{l}\text { Slightly thinned a year before. } \\
\text { Heavily thinned a year before. }\end{array}$ \\
\hline 88 & 12 & Hen \\
\hline
\end{tabular}


The following table gives von Seelen's observations on damage by snow in December, 1883, in the Hasselfeld forest range.

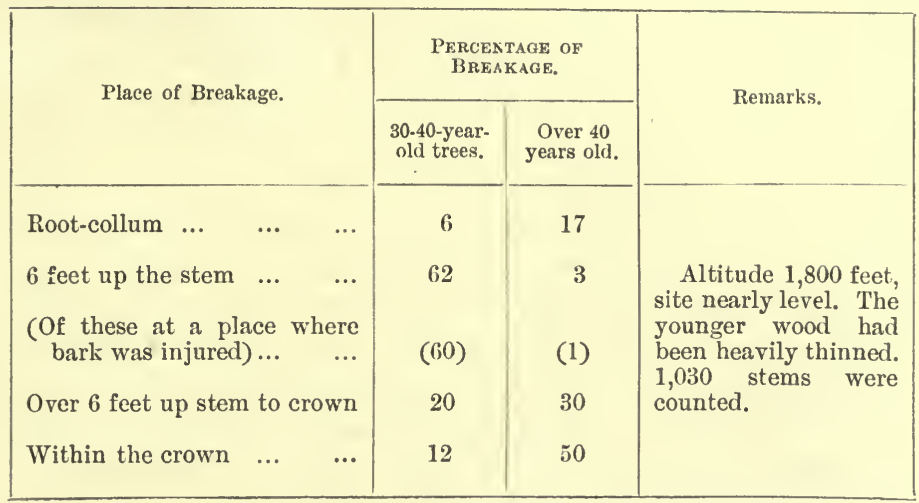

\section{c. System of Management.}

As the species which suffer most from snow are grown in high forest, that system is most liable to snowbreak.

Woods, where the trees in each compartment are of even age and height, suffer more than uneven-aged woods, such as those grown under the selection system; in the former case, snow may lie in masses like a flat roof over the crowns of the trees, especially when the wood is densely stocked, whilst in uneven-aged woods the snow has a greater surface to cover, the tree-tops being irregular in height, and more snow reaches the ground by falling between the crowns of the trees. In the second case, the wind also enters the wood more freely and shakes the snow from the crowns of the trees.

Hence, in localities liable to snowbreak, the selection and group systems are more suitable than other high forest systems. In coppice-with-standards, the lanky tellers occasionally suffer soon after a felling. Pure coppice is rarely injured by snow.

\section{d. Age of Wood.}

Slowly growing species such as silver-fir, spruce and beech are most endangered by snow between the ages of 20 and 60 years, quickly growing species such as Scots pine and larch 
between the ages of 15 and 30 years. Thickets 1 to 20 years old withstand snow better owing to their elasticity, and woods over 60 years old suffer less, on account of the greater size of the trees, although in Thuringia 60 to 100-year-old woods have suffered severely. A distinction must, however, be made between bending and breakage. Bending owing to snow is most frequent in woods 20 to 40 years old, and occurs generally in patches.

Snowbreal, on the contrary, is most frequent in woods 40 to 60 years old and even in older woods. The crown and leading shoots of the trees are chiefly broken in woods up to 60 years old, whilst in older woods branches are broken off the stem. In otherwise uninjured woods, stem-breakage is generally near the base of the crown and occurs here and there to individual trees. Younger drawn-up stems are often broken in groups, and sometimes in strips, owing to the action of wind during or after the fall of snow.

In the extensive snowbreak which happened in the Harz forests in December, 1883, trees of the following categories were injured in following proportion for the whole area affected :-

Age of Woods

in Years.

$20-30$

$30-40$

$40-50$

$50-60$

$60-70$

$70-80$

80 and over
Percentage of Breakage.

10

25

25

20

12

5

3

\section{e. Localily.}

Mountain-forests are more affected by snowbreak than forests of the plains and lowlands. The localities in Germany most exposed to snowbreak lie between altitudes of 1,300 and 2,400 feet; the snow falls more abundantly at higher elevations, but then the flakes are smaller and drier, and do not become so readily attached to the trees; lower down, on the other hand, the fall of snow frequently changes into rain. In 
Switzerland, in 1885 damage by snow extended to an altitude of 6,560 feet above sea-level.

No aspect is absolutely safe against snowbreak; most snow in Central Europe comes from a westerly direction, from which quarter also the strongest winds blow. The southeasterly, easterly and north-easterly aspects, especially just below the crest of the hills, suffer most; the snow falling most abundantly in such places and being less easily shaken from the trees by the wind, accumulates on their crowns. Since, also, freezing winds blow chiefly from the east, a frozen crust is then formed over the snow, on which more snow lodges when there is a subsequent snow-storm. North and north-westerly aspects suffer less, and westerly, south-westerly and southerly aspects least of all. Depressions and sheltered spots in valleys are much exposed to snowbreak, as the wind cannot free the crowns of the trees from snow in such places.

Fertile, deep, moist soil (above granite, basalt, porphyry) favours growth in height, produces brittle coniferous wood, and disposes the trees to breakage. Slowly grown short trees, that occur in unfavourable localities, are much less endangered. Too much moisture in the soil is also unfavourable, as the roots have a bad hold on the ground.

A strong growth of grass and herbage is bad in plantations, as the snow presses the weeds on the young plants.

\section{f. Mode of Formation.}

Under otherwise equal conditions young pole-woods which have grown up in dense thickets suffer most from snow, their scanty root-systems and slender drawn-up stems exposing them to danger. Poles resulting from sowings suffer more than plantations where from the first each individual plant has had sufficient room for its development. Planting two or more plants in each planting spot, termed multiple-planting, is also less favourable where snow is to be feared than planting single plants.

The distance between the planting-spots is also important, as plants with stronger roots, and crowns, capable of resisting the pressure of the snow, result from wide planting. Such 
plants may, however, be uprooted, at least at high altitudes, owing to the large surface of their crowns, so that wherever this danger is to be feared planting-spots must not be too far apart.

Observations made in the Harz forests in December, 1883, after the disastrous snow-storm already referred to, gave the following percentages in 100 acres of spruce woods which were bent down and broken by the snow :

Single planting, 18,

Multiple planting, 26,

so that the single planting suffered about one-third less than multiple plànting.

Mixed woods consisting of broadleaved trees and conifers suffer less than pure coniferous woods, as less snow rests on the trees, and the broadleaved species are less liable to injury. Beech, sycamore and hornbeam should therefore be mixed with spruce or silver-fir. The larch has not succeeded in German mountain-forests, but it grows admirably in the British Isles when mixed with beech and other conifers, provided the soil is suitable, and such mixtures are well adapted to withstand heavy falls of snow.

\section{g. Effect of Thinnings.}

Woods which have been properly thinned are generally less liable to damage than unthinned woods, not only on account of the sturdier forms of the trees and their more regular crowns, but also because more snow reaches the ground in thinned woods, and the weight of the snow which rests on the crowns of the trees is less than when the woods are very dense. The wind is also more effective in thinned woods in shaking the trees free from snow.

Extensive snowbreak has indeed been observed at times in thinned woods, but this does not invalidate the above reasoning, for sometimes thinnings are put off too long, and if excessive snow should fall on weakly stems just set free by a strong thinning, it is evident that much damage may be done. It is therefore to a certain extent an affair of chance, as regards the first thinning in a dense thicket, whether damage by snow occurs or not, but the longer the wood 
escapes damage after the thinning has been effected, the better it will resist should a severe snow-storm occur.

In thinned.woods, individual stems are more liable to breakage, whilst in unthinned woods whole patches of poles may be crushed. Bühler* has undertaken some very interesting experiments to investigate the effects of thinning on snowbreak. They show that heavy thinnings are less affected by snow than light thinnings; it is not the dominant poles with regularly shaped crowns that are so much endangered by the snow as the badly grown poles with lop-sided crowns, and these are removed in heavy thinnings as well as dead, dying and dominated poles. A heavy thinning somewhat interrupts the leaf-canopy, and thus allows more snow to reach the ground than in a dense pole-wood.

\section{h. State of the Weather.}

The snow is the more destructive the wetter and larger the flakes and the more quietly it has fallen. Small flakes pass more easily between the branches of the trees, and dry snow is more easily shaken off them by the wind than damp snow. During a frost, however, wood is more brittle, and consequently breakage is easier.

The greatest damage is done when a thaw sets in after a fall of snow, and is followed by a frost, a fresh fall of snow and a strong breeze. Such a combination of circumstances will cause extensive snow-breakage in woods of all ages, whether sown or planted, thinned or unthinned, forming a sad picture of devastation for the forester, who sees the results of his care at once nullified.

\section{Record of Damage done by Snow.}

Snowbreak being of a local nature only, the occurrence of serious damage in the Harz mountains may be cited. During the sixty-six years ending with 1897, there have been nineteen disastrous years of snowbreak, or one year in every four, the worst of which were as follows :-

In January and February, 1844, in Hanover, two million

* "Schneedrück u. Durchforstungsgrad," "Practischer Forstwirth," 1890. Nos. $3-6$. 
stems were broken by snow, over 95 per cent. of which were under 7 inches in diameter. In November and December, 1875, in Brunswick, 6,734,000 cubic feet of timber were broken by snow on 85,635 acres, being at the rate of 78 cubic feet per acre, about half the fixed annual yield of the forests. The chief damage was done on the northern side of the mountains. From the 10 th to the 13 th December, 1883, and from the 11th to the 27th January, 1884, 22,500,000 cubic feet of timber were broken in the Hanoverian Harz, and about $7,000,000$ cubic feet in the Brunswick State forests.

In the winter of 189495 , owing to the very heavy snowfall, much game was killed in Obersteirmark. On an area of 1,793 square miles, 5,642 head of red-deer, chamois, and roes perished, being about 15 per cent. of the stand of game, estimated at 21 head per square mile.

\section{Protective Rules.}

Protective rules against damage to forests by snow should be drawn up, either on the principle of reducing the power of attachment of the snow to the trees, or of strengthening the latter. The question will be discussed under the heads of formation, tending, and utilisation of the woods.

\section{a. Formation of Woods.}

i. Species endangered by snow should not be planted in snow localities, especially in pure forests. Scots pine is absolutely out of place in regions where snow lies deep in winter. The chief species here should be the spruce, silverfir, or larch.

ii. In planting spruce, introduce a mixture of silver-fir, larch and broadleaved trees, such as beech and sycamore.

iii. Natural regeneration, especially for silver-fir and beech, and also for spruce, will give better results than regular plantations; it produces the trees in groups and with a mixture of broadleaved species, which should be encouraged.

iv. Where the clear-cutting system is followed, strong nursery-trained transplants should be used to restock the felling-areas, the plantations being made in lines parallel to the direction of the prevailing wind, so that the snow may 
fall between the plants. The plants should be somewhat closely planted wherever heavy snow is to be feared, so that they may afford one another mutual support against the snow.

v. Avoid sowings in the open, planting with strong transplants (no multiple planting) and that have not been too closely lined out in nurseries, so as to produce strong, resisting plants.

It is better to plant in lines, which should be parallel to the direction of the prevailing wind, so that snow can be driven between the rows of plants. At lower elevations the rows should be $3 \frac{1}{2}$ to 5 feet apart, at higher elevations $2 \frac{1}{2}$ to $3 \frac{1}{2}$ feet, to prevent the branches being torn out. The plants may be $2 \frac{1}{2}$ to $3 \frac{1}{2}$ feet apart in the rows. Wider planting has given bad results in the Harz.

vi. An excessive growth of grass, bracken or other weeds should be removed from young growth, as it may be pressed down by the snow over the plants and kill them.

\section{b. Protection during Thinnings.}

i. The most efficient measure to protect woods against snowbreak is to make timely thinnings, in accordance with sylvicultural rules, and suitable to the circumstances of each case. In woods endangered by snowbreak, thinnings should commence early, be frequently repeated, and increase in intensity with the age of the trees. At the same time great care must be taken in the first thinning of densely stocked pole-woods.

ii. All injuries to the bark of trees, including resin-tapping, must be avoided.

iii. In specially valuable young pole-woods, the snow may be shaken from the trees; this measure was successfully applied to 10 to 20-year-old Scots pines in Württemberg and Silesia in 1868, but can evidently be carried out only on a small scale.

\section{c. During the Principal Fellings.}

i. Felling by the selection or group methods should be followed in high mountain regions, on peaks and ridges, as this favours uneven heights in the trees. Uniform covering of the crop with snow is thus prevented. 
ii. Wherever clear cuttings are practised, the felling-areas should be of small extent, so that areas 'of even-aged wood should not be too extensive; several series of felling-areas should therefore be established.

iii. In coppice-with-standards, only strong tellers should be reserved.

\section{Treatment of Injured Woods.}

The treatment of injured woods will depend on their age and the species of which they are composed, and the kind of damage they have experienced.

If extensive damage has been done by snow, the first duty of the forester is to remedy matters as soon as possible; in coniferous woods especially, all bent and broken wood should be at once worked up and sold. Trees on which three or four verticils of living branches have been spared may be left standing, after carefully pruning off their broken branches. Stems which have been bent over from the ground may recover their erect position owing to their elasticity and striving towards the light, and in any case they assist in keeping the soil covered. The woodcutters, who are removing broken stems, may be directed to set the bent stems upright, and, if necessary, attach them by string or wire to stems which are still erect.

For the rest, the treatment depends chiefly on the species, the age of the injured crop and the extent and nature of the snowbreak.

Young coniferous woods which have been broken in patches and strips should be replanted with large transplants of beech, sycamore, larch; spruce, silver-fir, or Weymouth pine may also be used, in accordance with the suitability of the soil for each species. Breakage of leaders is often repaired naturally by formation of new leaders, by Scots pine and larch, even though it may for long be recognised by double leaders, bayonet leaders, etc.

Older coniferous woods, when greatly thinned by snowbreak, should be underplanted; spruce-woods with beech and silver-fir; Scots pine woods with spruce and sessile oak. The remarks (p. 551) already made regarding repairs of damage done by wind are also applicable here. 
Injured broadleaved woods, especially beech pole-woods, may be repaired by cutting back the bent stems at heights of 12 to 18 feet from the ground, the stems being bent straight. In case of very serious damage, however, the injured woods, if not too old for reproduction from the stool, must be cut back close to the ground, and the thinned wood underplanted with beech or silver-fir. In order to fill larger gaps between the trees, sessile oak, larch, Weymouth pine, white alder and robinia may be used, the two latter at low altitudes.

By means of a combination of all these plantings, woods like coppice-with-standards will result, which, owing to their unevenness in age, height and rate of growth, will be better able to withstand future falls of snow.

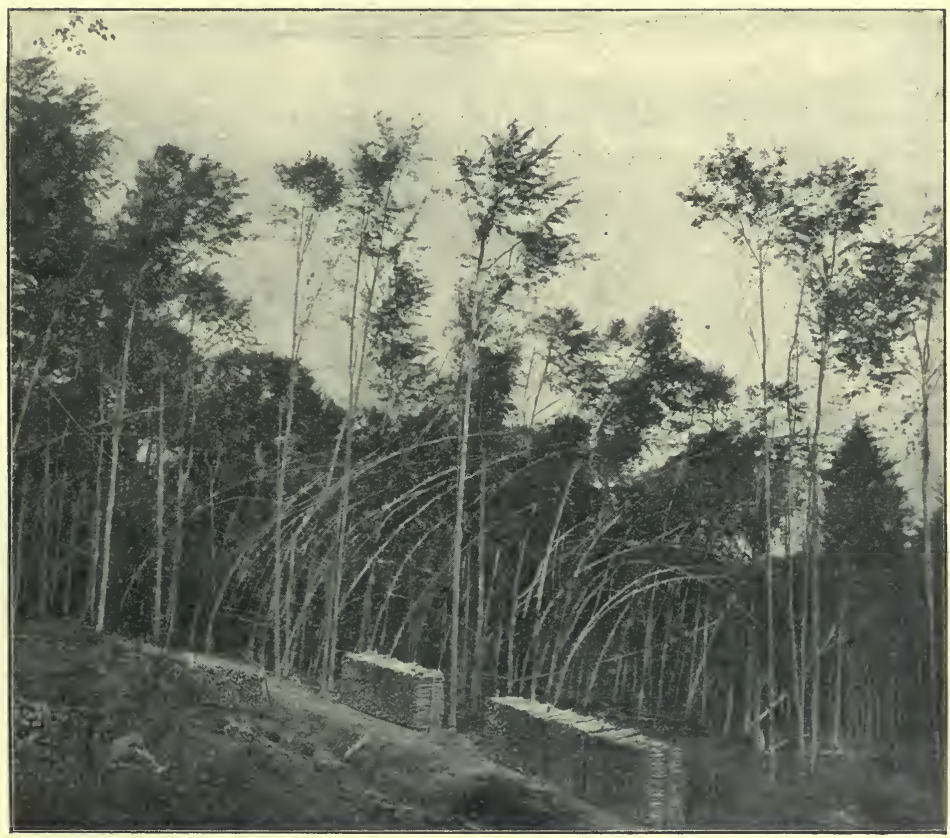

Fig. 257.-Beech bent by snow. Sihlwald, near Zurich. 


\section{CHAPTER VII. \\ PROTECTION AGAINST RIME.**}

\section{A. General Account of Damage.}

Rrme and ice may incrust and overlade stems, crowns and branches, and thus break or uproot trees. Rime, unless accompanied by snow, seldom seriously damages trees, but this is not the case with ice, and when this is followed by snow and a stiff gale, forests may suffer very considerably.

The damage done resembles that effected by storms and snow.

\section{B. Damage under Special Conditions.}

a. Species.

Coniferous woods suffer more than broadleaved woods. Scots pine and other pines suffer most, then spruce, silver-fir and larch. If larch be covered with needles, it may suffer more than spruce.

In broadleaved woods, poplars, willows, alder and robinia, on account of their brittle wood, are most endangered, but as these trees are not extensively grown, their damage is not very important. 'I'he beech, on account of its dense foliage, suffers considerably. Oaks and birch, in leaf, also suffer greatly.

$$
\text { b. Age of Crop. }
$$

Whilst damage by snow chiefly affects thickets and young pole-woods, ice and rime will do more damage to middle-aged and even mature woods. Scots pine and larch-woods thirty to sixty years old and beech-woods from forty to eighty years are most liable to injury. Pole-woods are generally bent, but may be sometimes crushed by the weight of ice they bear, as

* Vide "Notes on Hoar Frost" : C. B. Plowright, "Journal of R. Hort. Soc." March, 1891. 


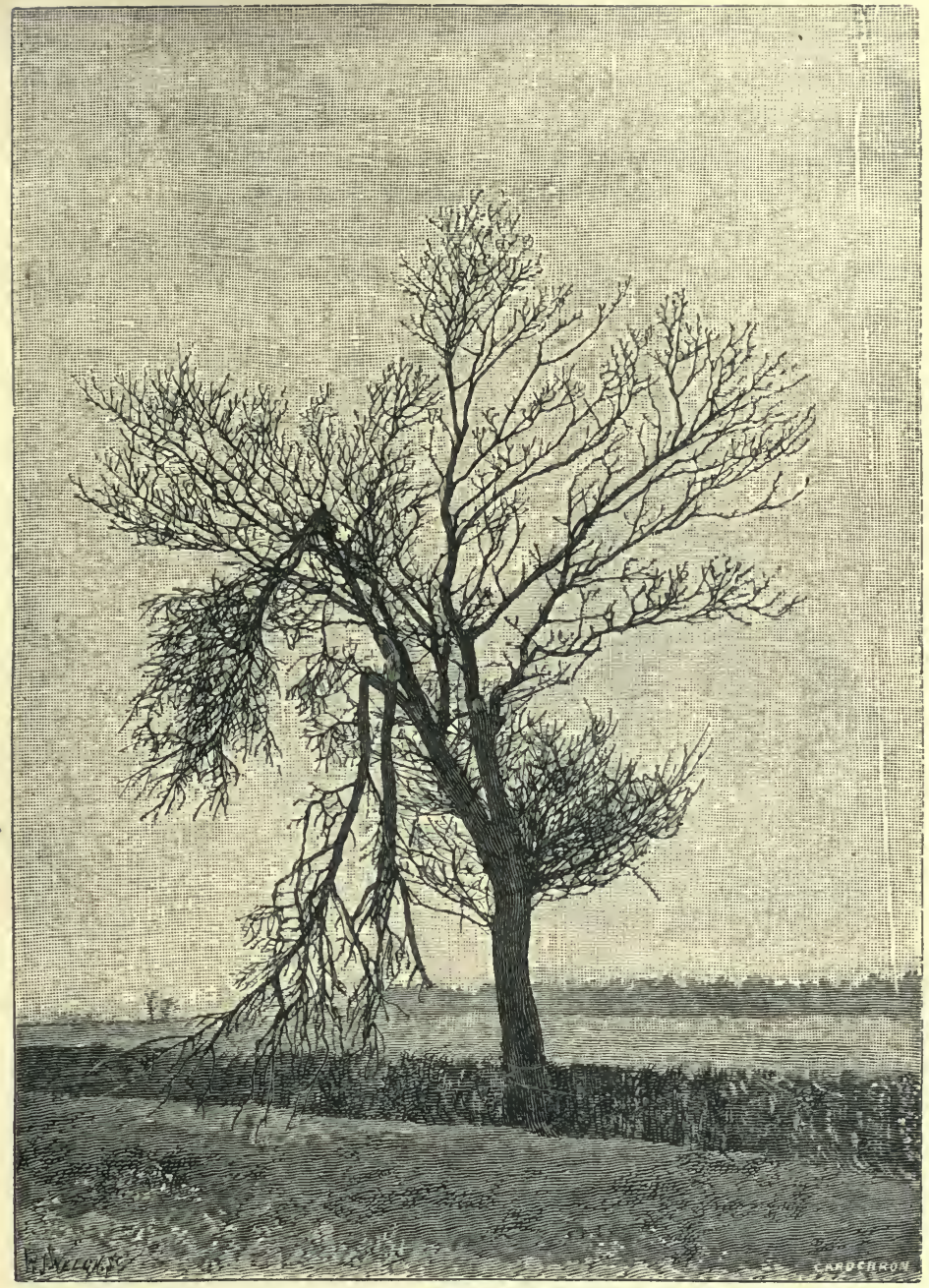

Fig. 258.-Oak tree, branches broken by rime. From vol. xiii. "Journal of R. Hort. Soc.," "Notes on Hoar Frost," Plowright.

if by a gigantic roller. Older trees are generally broken either in their boles, leaders or branches. Conifers laden with cones suffer most from breakage of leaders. Old oaks, especially when stag-headed, have their branches broken. 


\section{c. Locality.}

The damage done by rime and ice, in Central and Northern Germany, chiefly occurs at altitudes between 1,600 and 2,600 feet. In South Germany, up to 3,300 feet, crops suffer the more the faster their growth and the shorter the interval since the last thinning. The wetter the soil the more trees are uprooted. Northerly, north-easterly and easterly aspects suffer most, especially steep slopes and depressions exposed to the north-east wind. Woods suffer on both sides of valleys

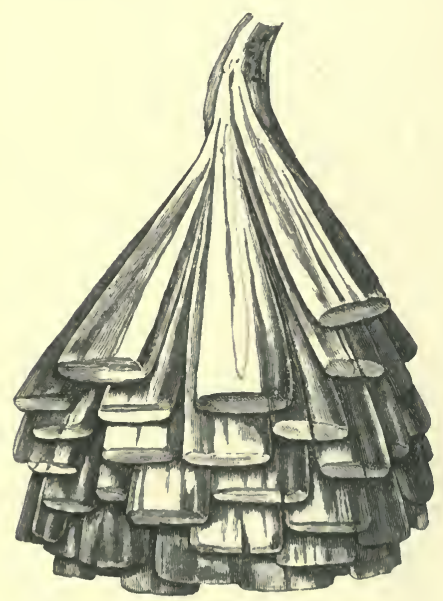

Fig. 259.-Needles of Scots pine encrusted with ice. running east and west, whilst in valleys running north and south only the east aspect suffers.

\section{d. Density of Crop.}

Isolated trees suffer more from rime and ice than trees growing in dense woods, as they have a larger surface exposed, and this applies to avenue trees, seed-bearers in regeneration - fellings and standards over coppice, and also to trees along the easterly and northerly borders of a wood, or of an exposed fellingarea. Trees afford one another mutual protection in a dense wood. At the same time, lofty poles just set free from a dense growth by a thinning may suffer considerably.

\section{e. Weather.}

Most damage by ice occurs in January and February; but trees may be endangered in November and December. North and east winds specially favour ice-formation.

\section{Record of Bad Years.}

The damage done by rime and ice as well as by snow is of a local nature, and in the Harz mountains there were thirteen 
bad years between 1821-1897, which were also the years $n$ which much snow-break occurred.

The weight of ice on the trees is sometimes considerable, as much as fifty pounds on six pounds of wood. A most destructive ice-break occurred between the 18th and 25th of November, 1858, in the Spessart, Odenwald, part of the Bavarian Palatinate and Rhenish Prussia, in which the icecrust was eighteen to twenty times the thickness of the wood on which it rested. In the Spessart, 2,750,000 cubic feet of wood was broken ; in the Odenwald, nearly $2,000,000$ cubic feet; in the State forests of the Palatinate, 11,000,000 cubic feet and

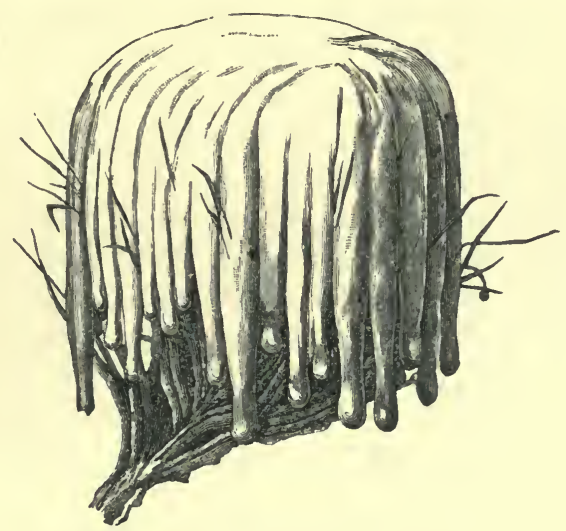

Fig. 260.-Shoot of Scots pine covered with ice.

about half as much, in the Communal forests. Observations showed that a spruce plant $3 \frac{1}{2}$ feet high had to support $165 \mathrm{lbs}$., and single Scots pine-needles, over half an ounce of ice. The picturesque forms of the ice-encrustations are shown in Figs. 259 and 260.

In France and Central Germany, from the 22nd to the 24th of January, 1879, there was most extensive breakage of woods by ice, which is described by Janin in the Revue des Deux Mondes. In certain broadleaved forests, about 50 per cent. of the stems were broken, and in carefully thinned Scots pinewoods, 70 per cent. In the forest of Fontainebleau, about $5,300,000$ stacked cubic feet of wood were broken, thin twigs of wood and telegraph wires being encrusted with ice to a 
thickness of 8 inches. Living larks were found frozen to the ground by their feet and tails, and in the Champagne district dead partridges were picked up covered with ice.

Great damage by rime to elm and other trees is described by Plowright as having occurred in Norfolk on Jan. 7th, 1889. (Fig. 258.)

\section{Protective Rules.}

(a) Formation of strong young growth. Where danger from rime and ice is feared, the Scots pine must be excluded or mixed with other species.

(b) Maintenance of the leaf-canopy even in old woods. Heavy thinnings should not be made in dense pole-woods.

(c) Isolated standards should not be reserved in high forests.

(d) A protective belt should be maintained on the northeastern and eastern borders of woods.

(e) Wherever danger from rime-frost is greater than from storms, cuttings should be made in woods from south-east to north-west; the south-westerly gales then blow along merely the face of the felling-areas, and endanger a few border-trees only. The correct direction for felling-series can be decided only after a thorough knowledge has been acquired of the configuration of the ground and of the local factors.

\section{E. Treatment of Injured Woods.}

Reference is here invited to Chapter III., p. 557, and Chapter VI., p. 570, dealing with woods damaged by storms and snow, as those which have been injured by ice will require similar treatment. 


\section{PART V.}

PROTECTION AGAINST NON-ATMOSPHERIC PHENOMENA. 



\section{PROTECTION AGAINST NON-ATMOSPHERIC} PHENOMENA.

'Тне chief non-atmospheric phenomena to which forests are exposed are suamps, floods and torrents, avalanches, shifting sands and forest fires. Damage to woods by these agencies will now be described. 


\section{CHAP'TER I.}

\section{PROTECTION AGAINST DAMAGE BY SWAMPS, FLOODS AND TORRENTS.*}

WATER acts either as a meteoric phenomenon, or as stagnant or flowing water on the surface of the ground, or in the soil ; its effects are partly mechanical and partly physiological.

'I'he chief mechanical effects consist in soil-denudation, landslips, or floods. Physiological damage is done to plantlife and to the soil by stagnant water causing bogs and marshes. Damage to forests by heavy rain has already been dealt with (p. 554).

\section{Section I.-Soil-Denudation.}

\section{Description.}

Soil-denudation on steep slopes may be due either to subsoilwater, surface-water, or to mountuin torrents.

Subsoil-water or surface-water on hill-sides may cause landslips, which bring down the soil with the vegetation growing on it, and expose the subjacent rock; this may occur either when the slope of the hill-side is excessive, or when there is an impermeable substratum which prevents the further descent of the water into the hill.

Excavations of pits or quarries at the base of a hill may have a similar effect.

Mountain torrents may cause soil-denudation, or form ravines, by deepening their beds and by wearing away their banks. The latter effect occurs chiefly at sharp turns in the course of the torrent, when one bank is formed of rock and the other of loose material. 'The force of the water increases with its

* Kraft, Gustav., "Beitrage zur forstl. Wasserbaukunde." Hannover, 1862. Demontzey; "Etude sur les Travaux de Reboisement et de Gazonnement des Montagnes." Paris, 1878. Id. Traité Pratique, 1882. Von Senkendorf, "Verbannung der Wildbäche." Vienna, 1884. Landolt, "Die Bäche, Schneelawinen und Steinschlïge." Zürich, 1886. 
velocity, and may be assumed to be proportional to the sixth power of the velocity of the stream.

To cite an example, a formidable landslip occurred on the 15th November, 1879, at Vitznau, on Lake Lucerne. Here, at the foot of the Rigi, a mass of earth exceeding 35,000 cubic feet, and covered with trees, fell down the mountain side and filled a depression, burying a chapel under mud to a depth of twenty feet.

Landslips occur frequently in all mountain chains, and in the Himalayas attain vast proportions; the Gohna landslip, in 1893, for instance, brought down enormous quantities of rock across a valley, damming up a tributary of the River Ganges. 'This led to the formation of a lake 10 miles long and 500 feet deep, which eventually burst the dam in. August, 1894, causing a flood 30 feet deep to rush down the Ganges valley and flood the town of Hardwar. Owing to the establishment of telegraphic communication, and to careful watching at the dam, all the inhabitants of the valley received timely warning of the probable bursting of the dam, and no lives were lost.

\section{Damage done.}

Soil-denudation reduces the forest area, buries plantations and young growth in mud, injures and destroys forest roads and other works, and fills up ditches. Ravines that become constantly enlarged by surface drainage are formed on hillsides, whilst the beds of watercourses are raised, interrupted and altered, by the material brought down by the water; inundations are thus caused. The amount of damage done increases, the steeper the slope and the more broken its contour, and the looser the soil and the greater the weight of the woody growth. Localities where landslips are likely to occur may be recognised beforehand in wet years by cracks forming in the soil.

\section{Protective Rules.}

The best protective rules to adopt against these dargers are:-

(a) Careful maintenance of a continuous woody growth on mountain-peaks, ridges and all dangerous slopes. Forests in 
such places are protection forests, and should be managed either by selection or as coppice. For mountain-tops and plateaux, the selection system is best, when accompanied by the timely planting up of all gaps that may occur in the wood; but on

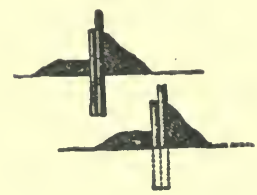

A

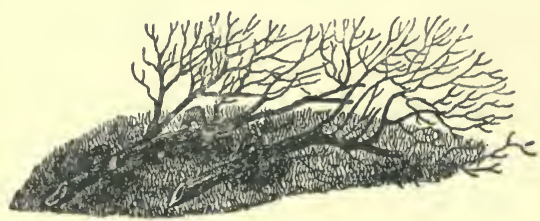

C

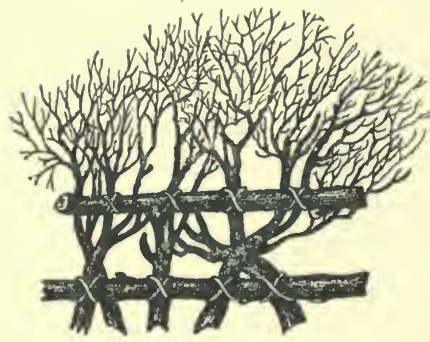

E

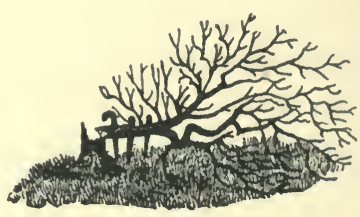

B

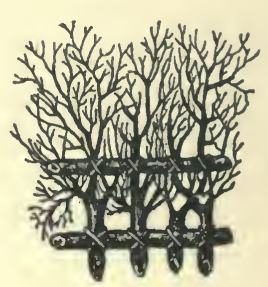

D

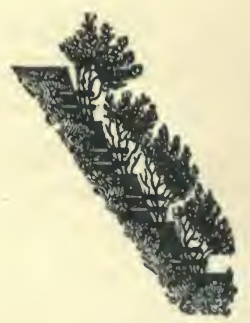

$\mathbf{F}$

Fig. 261.

steep slopes, high forest presses too heavily on the soil and should make way for coppice with short rotations.

(b) Wherever a landslip is to be feared, the bank should be kept up by wattle-fences, by protection of the soil-covering, and by not extracting the stumps of felled trees. The various protective measures which may be adopted, depend on the caluse of the danger and the circumstances of the locality. 
Surface-water, or subsoil-water, for instance, may be conducted away from above the endangered place by ditches or drains. All quarrying below the threatened hill-side must be stopped.

(c) The following measures provide against damage by a mountain torrent:-

i. Reafforesting the collecting-area of the stream; the methods to be adopted for this object are described further on.

ii. Securing the sides and bed of the torrent by revetments, from its collecting area, downwards.

iii. Reducing the force of the stream by terracing its bed, and constructing across the stream wattle-work fences or masonry works which keep stones and silt from accumulating in the lower parts of the stream.

iv. T'erracing the slopes of the valley on either side of the stream, and fixing them by means of sowings or plantations.

\section{Remedial Measures.}

When, in spite of every care, landslips or ravines have been caused by abnormally heavy rain, or by melting snow, protective works should at once be constructed. A revetment made of wattle-work, or of logs fixed in position by piles driven into the ground (Fig. 261, A), may prevent the occurrence of further damage. If, however, the landslip is extensive, several such constructions, one above the other, must be made, and the earth between thern be brought to a unifor'm slope and planted up. In certain cases, complicated masonry revetments are required.

In order to make natural revetments (Fig. 261, B and C) woody growth must be on the spot. The bush is partly cut through, splashed, and pegged down, with its crown uphill. Where there is no woody growth, trellis-work with living branches of willows or dead branches (Fig. 261, D and E) should be employed. Fig. 261, F, shows how these willow trellises may be planted along a slope. Wherever a landslip is feared, adjoining trees should be felled, as they would otherwise fall in and add to the damage. 


\section{Section II.-Inundations.}

\section{Causes of Inundations.}

Inundations originate in valleys and plains owing to the sudden thaw of masses of snow in the mountains or plateaux above them, or to prolonged or heavy rainfall, or to the interruption of watercourses by landslips.

The last of these causes is frequently due to clearing forests from mountain sides, and to bad management of protection forests. When, on hill-sides, the effects of rain and surfacedrainage are not reduced by a full leaf-canopy and by the binding effects of the roots of the trees on the soil, as well as the sponge-like action of the natural soil-covering of dead leaves and moss on the surface-water, the latter runs down unimpeded into the valleys, bringing with it quantities of boulders, gravel, silt and mud; this raises the beds of the watercourses, and causes them to overflow and spread destruction far and wide into the lower country, especially by leaving cultivated lands covered with gravel and silt after the floods have subsided.

Most inundations in Central Europe occur in April, when they are due to the general melting of the mountain snow, or in August or November, owing to heavy rainfall.

\section{Damage done.}

Inundations carry away the soil-covering and humus from forests, causing swamps and cold soil; they destroy young plants, hinder the formation of coppice-shoots, interrupt fellings and the export of forest produce, and often carry away timber to great distances. The floating wood endangers bridges, river-bank protection works, and works constructed to facilitate the floating of timber. In spring-floods, trees growing along the banks of streams may suffer from the friction of the ice which is carried down. Many game-animals, especially roe-deer, are drowned.

The mud brought down by the flood, however, richly compensates for the loss of soil-covering and humus. River mud contains not only nutritive mineral salts, but yields lime in a fine state of division, which is therefore readily absorbed by 
plants, and is an excellent manure for lands that are poor in lime. The higher the floods, the greater is the deposit of mud.

Dr. Schulze of Darmstadt gives the following percentages for the constituents of Rhine mud:-

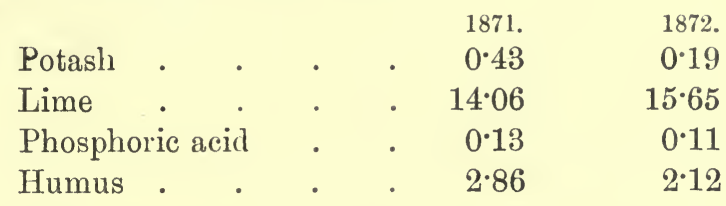

Professor Nessler of Carlsruhe found the following constituents in mud from the Upper Rhine.

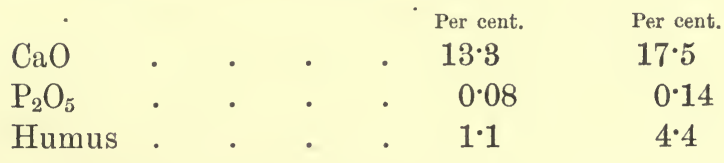

The average amount of calcium carbonate was 27.5 per cent. 'The percentages of potash and phosphoric acid are small, but always greater than in ordinary agricultural soil.

Besides the supply of large quantities of soil, the utility of floods also consists in the increase in subsoil-water, specially useful for forests in dry years, and the destruction of rabbits, mice, cookchafer-grubs, etc., that burrow in the ground.

The greatest recent floods in Central Europe in 1856, 1868, $1879,1882,1885,1888,1889,1890,1892,1896,1897$, and 1899, chiefly affected the Alpine districts of France and Switzerland, Hungary and Austria.

In 1856 the Rhone caused fearful floods, which drowned numbers of people and damaged property to the extent of $\mathfrak{£} 8,000,000$. One of the results of these floods was the enactment by the French Legislature of the laws for the reboisement of the denuded mountain-sides, of the 28th July, 1860, and of the 8th June, 1864, for regazonnement, or restocking them with grass.*

* "Forest Law," Baden-Powell, 1893, p. 248. Laws for the protection of mountain forests in Germany, Switzerland, and Italy are also referred to. 
Terrible floods occurred in Switzerland in 1868, and in Hungary in the valley of the River Theiss, in March, 1879. In September, 1882, damage estimated at $£ 1,000,000$ was caused by floods in Carinthia and the 'Tyrol, and there were serious floods in the Rhine valley in 1882, and in the regions of the Elbe and Oder in 1888. The great floods in Silesia and Brandenburg in the summer of 1897 , caused the promulgation of the law (1898-99) for protection of the tributaries of the left bank of the Elbe, in Silesia. Extensive floods occurred in the Thames and Severn valleys, and other districts in the South of Englind, in November, 1894.

Serious floods* occur in Northern India nearly every year between July and September, after the commencement of the summer monsoon, and owing to the great damage thus caused to irrigation canals fed by the Ganges and Jumna rivers, the forests on the southern slopes of the Siwalik Hills are now managed as protection forests. The Indian forest officials $†$ have for years recommended the adoption of similar measures to the lower hills between the Jumna and Sutlej rivers, as the first burst of the monsoon on the annually grazed and burned sandy hills above the Hoshiarpur district causes most disastrous inundations every year, besides bringing down quantities of sand, gravel, and boulders which have encroached considerably on the agricultural land below the hills, so that by 1891 , lands belonging to 914 villages were affected, and 30,000 acres of richly fertile and long cultivated land laid waste, besides immense damage being done annually to railway and road embankments, etc. The hills were formerly covered with forest growth, but during the last forty years, flocks of goats and herds of buffaloes belonging to about eighty hamlets of squatters have been allowed to browse down and destroy the forest growth which formerly fixed the soil on the hills, and would spring up again were the annual grazing and burning of the undergrowth restricted. A law, termed the Siwalik Act, was passed by the Punjab Legislative Assembly in 1900, which permits the Local

*Vide "Indian Forester," vol, xii., p. 418.

† Ibid., vol. v., p. 3. Baden-Powell's Report. Moir's Report, vol. x., p. 271 ; vol. xiii., p. 52.; ; vol, xvii., p. 216 
Government to make rules regulating the cultivation of land, the felling or firing of trees, quarrying and pasture on such areas.

\section{Protective Rules.}

Private agency can usually do little or nothing to prevent floods. The action of the State is indispensable, as the cost of the erection and maintenance of the works necessary to secure this object is quite out of proportion to the value of the property on which they must be erected, and the work of fixing the beds of mountain torrents and reafforesting hill-sides in process of denudation must be carried out over a large area.

The most effective measures depend on the careful management of mountain forests in the catchment-areas of dangerous watercourses, the main principle being to meet the danger at its source.

Although observant* people discovered these facts and wrote about them a century ago, a long time elapsed before improved forest management and the erection of the necessary works were undertaken in regions that were threatened in this way. Serious and successful action, however, is now being taken in France, in Austria-Hungary, and in Switzerland, to counteract the causes of floods.

The chief rules to be followed are:-

i. Regulation of Torrents and their Feeders.-The following account of torrents is taken from an address by Fankhauser, to the Berne Forestry Association, June 18th, 1897.

In every torrent there are three distinctly marked divisions :-

1. The catchment area.

2. The channel course.

3. The cone of débris.

The principal mass of water forming a torrent comes from the catchment area. Single drops of rain falling on the topmost ridges flow down their bare sides in fine, threadlike streams, and unite into larger and larger brooks. Mere

\footnotetext{
* Von Auẹssberg, Innspruck, 1779.
} 
drops wash away only earth and sand, and loosen the larger rocky masses, but the brooks carry down stones and gravel. The masses descending on all sides are received by the channel course. After heavy rain, the raging torrent rushes down its narrow bed, weighted with earth, sand and stones. It tears away and undermines fresh material from the bed and sides of the stream, and the projecting banks give way and add to the moving débris.

When the torrent emerges from its narrow bed into the level plain, its force diminishes. The rubbish is heaped up into a cone of débris, or may be washed away by a larger stream or river.

The most striking phenomenon in each torrent is the varying amount of water. The Rhine at Basel varies between its highest and lowest level, as $1: 20$. The torrent of Faucon, in the Lower Alps, once carried off 70 per cent. of the rainfall, or $60,000 \mathrm{cub}$. $\mathrm{m}$. of water, in twenty minutes, and at the same time, 180,000 cub. $m$. of rubbish.

By regulating torrents and their feeders the formation of the products of denudation is reduced, the velocity of the water is slackened, earth, gravel and boulders are retained in the mountains, while, if possible, a steady and continuous flow of water is maintained.

Works of the following nature should be designed in accordance with the nature of the locality, the characters of torrents, the area of the collecting ground, and the funds available:-

(a) Barricades of trees with their entire crowns thrown across torrents, or stones strongly joined together, with a tree in front of them. These protect the base of the torrent from deepening. Large masonry barricades are best made bowshaped, with the bend up-stream. The nearer they are to one another, the better protection they afford.

(b) Paving in masonry the bed of the torrent. This not only prevents deepening, but also obstructs the carrying down of silt, etc. These linings are made as in Fig. 262, A and B. . The bow-shaped form A is preferable, but the polygonal form is easier and cheaper to construct, and suffices when the débris is not composed of very large pieces, 
(c) Valley-revetments. (German, Thalsperren; French, Barages.) These are constructions that reduce the gradient of the torrent bed and the destructive power of the water.

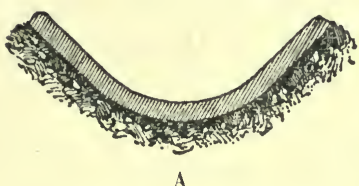

A

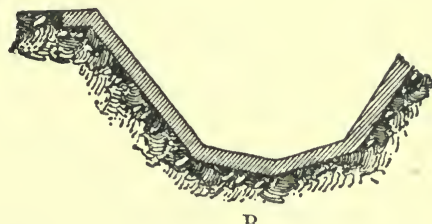

B

Fig. 262.

They protect not only the bed of the torrent below them, but raise its level behind them.

These revetments may be made of wood or of masonry, the latter owing to its superior durability is far preferable.

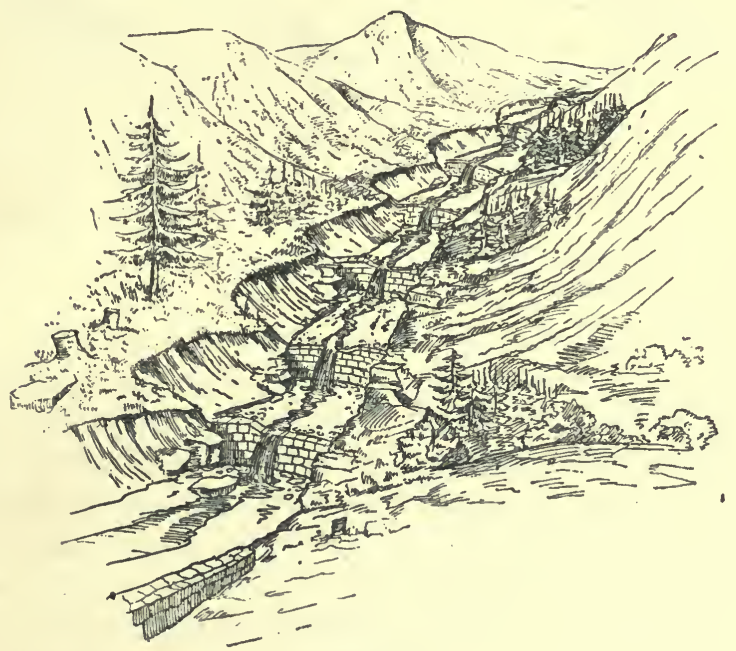

Fig. 263.

Their mode of construction varies, according to circumstances ; they are erected at regular intervals and collect silt and stones behind them. For small torrents and where rapid cheap work is required, mere wattle-fences may suffice. 
Fig. 263 shows how a valley is protected by a series of barrages.

(d) Wattle-fences. These consist in simple wattle-fences made in curves and almost horizontal, the central point being somewhat lower than the sides; they are afterwards raised as the bed of the torrent rises (Fig. 264, A and B). When further denudation is no longer feared, the middle of the ravine is paved with stones as shown in Fig. 264, C. The first fences are erected at distances apart of three meters; they are commenced from below and continued up-stream. Their erection is continued until the bed of the ravine is raised high enough for no more denudation to be feared.

This simple plan, devised in 1838 by Jenny, is advisable

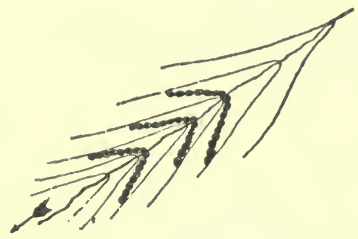

A

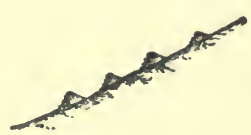

B

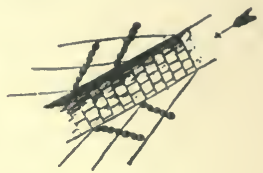

$\mathrm{C}$

Fig. 264.-Jenny's Wattle-Fences.

where only mud free from large stones comes down, and for lateral ravines leading into the main torrent.

(e) Addenda. All the above-mentioned works serve to secure the bed of the torrent. The question of maintaining its sides will be discussed further on.

Such works are useful in districts with granite or other rocks, other than limestone. Torrents coming from limestone districts or from glaciers cannot be properly regulated.

In connection with the above works, the slopes leading down to the torrent must be properly graded, and a system of horizontal protective trenches laid out, so as to cut off the soil-water and distribute it over a larger area. These trenches have proved extremely useful in preventing floods. They are beneficial to forest-vegetation, facilitate plantations, and also revi e the original springs of water.

The local forest-staff should carry out the above works and 
should possess the necessary technical and local knowledge to do so.

In France, up to 1898, the Government had acquired 375,000 acres in mountain districts for reboisement, and spent $£ 13,100$ in $1905-6$ on the necessary works, having by 1892 spent altogether $£ 1,820,000$ on the reboisement of 156,197 acres.

Extensive works have also been carried on in Austria since $1882, £ 180,000$ having been spent up to 1894 . In Switzerland, in the four years $1894-7$, about $£ 50,000$ has been spent for the rectification of torrents, in engineering works and planting.

ii. Wasteland in Monntain Regions, especially on sloping ground, should be planted up, and the forests in such regions carefully maintained.

Surell,* in 1841, published a paper on the subject, making the following assertions:-

(a) The covering of mountain soil with well-managed woods prevents the formation of destructive torrents, whilst the clearance of mountain woodlands favours them.

(b) The reboisement of mountain districts will rectify mountain torrents, while the clearance of forest and its soil-covering doubles the strength of the torrents, and causes new ones.

A treatise on forest protection cannot go very far into the sulject of the management of mountain forests. The following remarks, however, are useful :-

The forest should be under the selection system. Planting is better than sowing for wasteland and blank spaces. The species to be cultivated are chiefly Mountain and Cembran pines, larch and spruce. The lines of plants should be at an angle of $45^{\circ}$ to the course of the torrent. Grass seed, consisting of a mixture of Avena elatior, L., Bromus erectus, Huds., Holcus lanatus, L., should also be sown. Uprooting of trees and stumps in fellings must be abandoned. Pasture, usage of litter and other destructive forest usages must be absolutely forbidden.

F.P.

* "Etude sur les Torrents des Hautes Alpes." Paris, 1841. 
iii. Regulation of the Lourer Course of the Stream, in order that it may, as far as possible, be able to carry away high floods without danger to the surrounding country. A river is said to be regulated when the water is in the middle of the bed and flows away evenly, and the banks are firm.

In regulating watercourses the following points must be attended to :-

a. The profile of the watercourse must be normal. It must be deep enough to carry down small débris when there is an average quantity of water, and also wide enough to carry off floods without acquiring any great velocity. Too narrow beds must be widened, and too broad beds reduced in width.

$b$. The gradient of the bed of the watercourse must be so modified that its velocity will not be too great nor too slow. The former is effected by means of weirs, and the latter by shortening its course, as shown in Fig. 265.

c. Fixation of the River-banks. 'This can be done by plantations, or by special works.

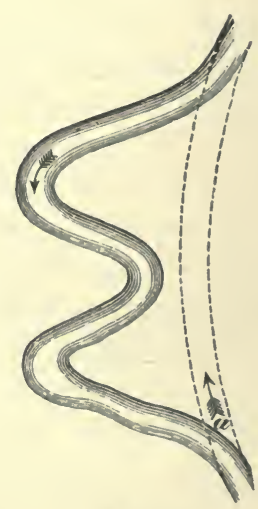

Fig. 265.

For a full account of the measures to be taken in the lower part of a stream, see Vol. V., "Forest Utilization," p. 374.

\section{Management of Forests on Iand liable to Inundations. *}

T'he management of forests on land liable to be flooded includes much that is special to the circumstances of the case. Species should be chosen that can withstand a good deal of moisture in the soil and occasional submersion; such are the pedunculate oak, elms, black alder, willows, black and white poplars, and the ash. In the wettest places the common alder and willows are found; ash is more sensitive to soil-moisture than poplars and the pedunculate oak.

Among exotics are, Iuglaus nigra, L., Carya alba, Nutt., C. amara, Nutt., Acer californicum, Torr., and Fraximus

* Rebmann, "Die Rheinwaldungen und deren Bewirthshaftung." Allgemine irorst. u. Jagd. Zeitung, 1896, pp. 360-381. 
americana, L.; the latter withstands water better than the common ash.

Pollarding, the Selection system, and Coppice-with-standards, rich in standards, are suitable systems of management. Treewillows may be poilarded, but poplars are best managed by cutting only their side branches, as pollarded poplars soon decay. Both poplars and willows speedily reproduce the bark, which has been rubbed off by ice; they are generally grown from strong cuttings. Oak, elm and ash may be grown in High Forest.

Reproduction is effected by planting saplings and slips, as natural regeneration is difficult to

A obtain on areas liable to floods.

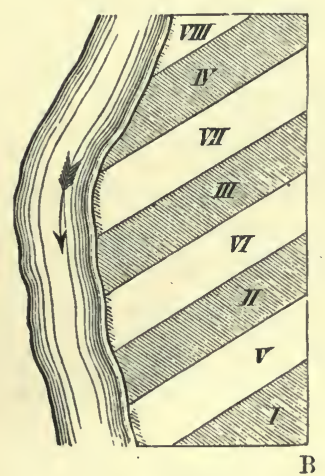

Fig. 266.

A large number of saplings must be planted, to replace those that are injured by floods and to kill blackthorn and other noxious weeds.

In the case of Coppice-with-standards, a much larger number of tellers is

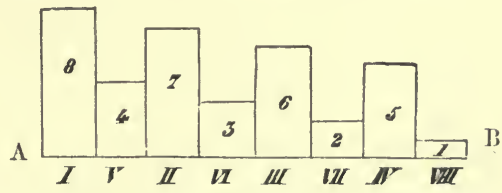

Fig. 267.- Section from $A$ to $B$, showing comparative heights of wood.

reserved at each felling than is usually the case under this system, in order to keep down inferior species such as blackthorn. Osier beds, chiefly of Salix viminalis, S. purpurea, etc., may be planted by means of cuttings, and cut over annually.

In the case of High Forest, or Coppice-with-standards, the felling-areas should be arranged at an oblique angle with the course of the stream as shown in Figs. 266 and 267, I. being the youngest and VIII. the oldest wood, and alternate compartments differing in age by half the rotation.

Such an arrangement. affords shelter to the young growth and prevents floods from carrying away beyond the next strip of wood the felled timber lying on any area. 
Fellings should take place when the water is lowest, or when it is frozen. Timber should be removed up to the advent of spring, and the commencement of the floods. Grass-cutting and removal of litter may be carried on freely in such forests, without danger of impoverishing the soil, which is enriched by the annual floods; pasture, however, should not be allowed.

\section{Section III.-Swamps.}

\section{Formation of Swamps.}

The soil of a locality becomes wet when the drainage-water has not a sufficient outlet. If there be no outlet for the water, swamps or peat-bogs may be formed. Either swamps or bogs may be caused by rain, snow- or spring-water, or water from rivers and ponds.

Drainage may be prevented either horizontally or vertically, the former if the water cannot escape superficially owing to an insufficient fall of the ground; the latter, if it cannot escape by penetration into the subsoil owing to an impermeable substratum of clay, turf, clayey or marly loam, soil encrusted with iron, or massive rock, especially in horizontal layers. Sometimes both these causes are at work, when the harm done is intensified. The local causes of swampiness may vary considerably.

(a) In lou-lying plains, swampiness is generally caused by flowing water, owing to a slight depression in the ground and a stiff soil.

(b) In basin-shaped valleys along watercourses ('T'alueg), swamps may be caused by surface-water, or by underground infiltration from the stream ; the former happens after floods, when the orerflow cannot find its way back into the stream, owing to the presence of high land along its bank. Part of the overflow must then remain on the low land, especially when the subsoil prevents the descent of the water. Lagoons along the sea-coast are formed in this way.

Water may spring through permeable soil from neighbouring watercourses, and when it thus appears in depressions, it 
denotes a high level of water in the stream and complete saturation of the soil.

(c) In high plateaux, swampiness is due to heavy rainfall, or to snowfall with subsequent thaw, or to saturation of the air combined with an impermeable subsoil accompanied by the growth of swamp-forming mosses or other plants.

(d) Swamps on a hillside are generally caused by springs, the water from which cannot penetrate into the ground on account of a subsoil of clay or of horizontal rocky strata. If the soil

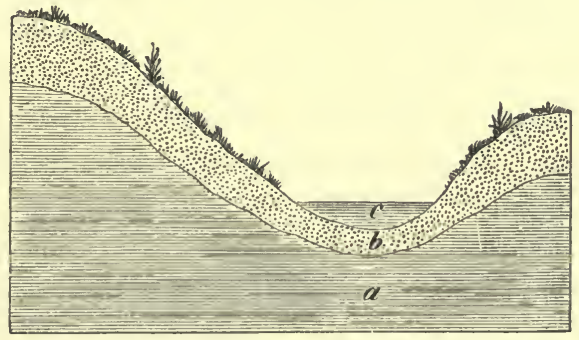

Fig. 268.

$a$. Impermeable stratum. $b$. Permeable stratum. $c$. Water.

on a hillside should be permeable above and impermeable below, all the water in it descends to the base of the hill, where it rises above the ground-surface and forms a swamp (Fig. 268). If, however, the permeable stratum terminates in the slope, drainage-water will spring out of the hillside, along the line where the two strata coalesce.

\section{Damage done by Swamps. \\ a. General Account.}

The damage done by swampy ground is as follows :-

i. Instability of the trees, which favours windfall, especially of the spruce.

ii. Stunted growth and liability to decay in the roots and stems of trees, and consequent loss of increment and sometimes death of the trees. The bad growth of trees on wet soil is due to the exclusion of oxygen from the roots and to the low temperatures of the soil and air, as wet soil may reduce air-temperature by $9^{\circ}$ to $14^{\circ} \mathrm{F}$., or to the formation of humic acid and 
carbohydrates instead of carbon-dioxide in the soil. Healthy growth and activity of roots is consequently much impaired.

iii. Increased damage by frost, sometimes lilling off young plants (p. 499).

iv. Difficulties in forest management in regeneration and harvesting, also in transport. The wetness of the soil increases the difficulty of cultivating it, and often renders spring-planting quite impossible; seeds do not germinate in too wet a soil, and young plants often perish.

$\mathrm{v}$. 'The tendency of a swamp to increase in area is another cause of danger to the forest.

\section{b. Accordiny to Specres.}

Hardly any forest species can withstand continuous stagnant wetness of the soil, but the degree of resistance to it shown by different species differs considerably. Experiments made in the Palatinate, where there is an impermeable subsoil, show that trees resisted a very wet soil in the following order:-

Pedunculate oak, elm, poplars, willows, hornbeam, common alder; ash, sessile oak; Scots pine, spruce; beech, silver-fir.

It is strange to find the alder so low in this scale, as other observations tend to prove that this species can withstand more moisture than the elm. 'I'he birch, and especially Betula pubescens, Ehr., will withstand much moisture in the soil, and so will the rowan (Pyrus Aucuparia, Gaertn.)

\section{c. Age of Wood.}

Young plants are frequently killed by inundations. Poles and trees on swampy ground suffer generally from root-decay, especially the spruce, larch, and Scots pine.

\section{d. Locality and Nature of Soil-Covering.}

Swamps are more frequent in lowlands than on hills and in mountain districts, on massive than on stratified rocks, and on heavy stiff soil than on loose soil. Local swamps may occur where the substrata are horizontal, as on the Buntersandstein in the Black Forest.

Certain forest weeds, such as sedges, reeds, peat-plints, and 
especially peat-moss, predispose to swampiness, whilst permanent pasture dries up the surface-soil, but will not thrive on very wet land.

\section{e. Density of Standing-Crop.}

Clearance of forests, especially in mountainous regions, favours the formation of swamps; it may be observed as a general rule, that swampy ground, when once stocked with young wood, becomes gradually drier as the wood grows older and covers the ground. This is especially true for coniferous forest, and the efficacy of the Scots pine for draining swamps is well known in Ireland, where many bogs have been formed on the former sites of forests, as is proved by the presence in them of bog-oak and other woods. The damp, cold London clay at Prince's Coverts near Esher, hardly ever dries up on the roads through the forest, but the ash, hazel, and aldercoppice will be found to have diried up the soil on both sides of an extremely wet road.

In the forest of S. Amand, near Valenciennes, in 1843, about 2,000 acres was ret heather land, the soil being sand with a slight mixture of clay. 'This was gradually planted with Scots pine, and these trees have drained the soil to a depth of 5 feet, so that coppice with oak standards is now being introduced in place of the pines. Snipe have almost disappeared.

The valley of the Upper Rhone affords a warning example of the effects of clearing forests on the formation of swamps; the high land above the river having been cleared of forest at the end of the eighteenth century, in order to afford land for agriculture. Field-crops, however, have made way for pasture, and the quantity of hay produced annually has decreased, till at last the formerly forest-clad areas have become covered with moss and converted into swamps. Reafforesting the area, as in the Dammersfeld, has been attempted, but is a difticult task.

In explanation it should be noted that in mountain regions with a cool, humid atmosphere, which is unfavourable to evaporation, the amount of water taken from the soil is proportional to the extent of leafy surface exposed to the air, and to the 
surface of the crowns of the trees standing on the area. The greater the amount of leaf-canopy, the more atmospheric precipitation falling on it is evaporated, and so much the less reaches the ground. Broadleaved trees act in this manner during the season of growth, but evergreen conifers throughout the year. In addition to this, the absorptive action of the roots, and the power of transpiration possessed by the foliage of trees must be reckoned, as well as the suppression of swamp moss by the cover of the trees.

Observations made between 1868 and 1871 at the double Bavarian meteorological stations, which are in pairs-in the forest and in the open-show that according to the season from 25 per cent. to 32 per cent. of atmospheric precipitation (rain, snow, \&c.), and averaging 26 per cent. for the whole year, did not reach the ground directly, but remained on the crowns of the trees. In 1882, Fautrat found that 20 to 27 per cent. of rainwater remained on the trees in Alsace-Lothringen. Much of this water, however, drops from the foliage or trickles down the stems of the trees to the ground.

There are certain localities-for instance, level land with an impermeable substratum and high atmospheric temperaturewhere swampiness of the soil is, on the contrary, increased by forests. In such cases, the rapidity of evaporation depends on the unimpeded action of the sun's rays and of dry winds, and clearing the ground of forests will increase the effects of these forces.

The action of forests, where the soil-covering of dead leaves, moss, and humus is carefully preserved, in main taining moisture near the surface of the ground and protecting the soil from the effects of insolation and drying wind, is very valuable on hot aspects and steep slopes, especially in hot countries, where water may be thus stored in the spongy soil-covering. A steady supply of water is thus maintained in springs on the hillside, while the absence of tree growth, on the other hand, allows rainwater to drain rapidly down and causes floods after heavy rainfall, and the watercourses may run nearly dry during the hotter months of the year.

Ebermeyer has proved by numerous observations that on a heavy clay soil, the root-zone of a spruce forest, from 16 to 32 
inches below the surface, is much drier than the corresponding zone on bare fallow land, the opposite being the case as regards the uppermost layers of soil, which are protected by the leafcanopy of the trees from insolation and the drying action of winds, while the moss and dead needles retain much moisture near the surface of the ground. Investigations in Russia by Ototzky, and in France by Henry, have confirmed this in the strongest possible manner, and for other trees besides spruce.

\section{f. Season.}

In countries with heavy snowfall, where the snow remains lying on the ground throughout the winter, the soil is wettest in the spring, after the snow has melted.

In the south-east of England, the soil is probably wettest from November till March, but dries up rapidly after the 1st of March till July, owing to the scanty rainfall and the prevalence of dry east winds.

\section{Protective Rules.}

(a) In mountain regions, and in very rainy districts, such as the boggy parts of Ireland, where the formation of swamps is to be feared, forests should be maintained and be completely stocked, and shadebearing conifers are best for the purpose.

The spruce probably exercises the greatest action in draining soil, the superficial roots of this species acting like drain-pipes; the Scots and Austrian pines are also very useful in suitable localities, and retain a large proportion of the atmospheric precipitations on their needles and branches.

(b) Marshy plants should be removed from the ground, and in damp, low-lying places the circulation of the air should be increased by clearings, thinnings, pruning and removal of undergrowth.

(c) All ditches and watercourses in forests should be kept open, and at least once a year should be cleared of waterplants, dead leaves and mud.

(d) Mountain torrents should be regulated.

Section IV.-Drainage.

A superfluity of water in the soil can be thoroughly rectified only by drainage. Before, however, undertaking such a work, 
a thorough inquiry should be made into all the bearings of the question, as extensive drainage-works, especially in mountainous districts, may damage a wide tract of country, and thus quite outweigh the advantages gained by affording a larger area for forest-growth and an increased yield of wood. Experience shows that by draining swamps and moorland at high altitudes, the supply of moisture to the soil and atmosphere may become so reduced that forestgrowth and agriculture suffer in districts lower down. This calamity is especially liable to affect older deep-rooted woody species, and woods accustomed to plenty of moisture in the soil. Drainage causes subsidence of the soil, and thus the roots of shallow-rooted trees such as spruce may become exposed, while pedunculate oak and ash may become stagheaded, owing to their roots being less supplied witl moisture than was formerly the case. Before, therefore, drainage is attempted, the demands on moisture of the species growing or to be grown on the drained area should be considered.

Neighbouring lands may also be affected by the lowering of the level of the underground water and drying up of the surface-soil, which may have bad effects on field-crops.

If the drainage of mountain forests be effected on a large scale, the distribution of atmospheric precipitation may be altered; the drier air may hinder the condensation of watery vapour, and the formation of dew and clouds may be lessened. Instead of frequent gentle showers, irregular storms of rain may come with disastrous results.

A further disadvantage is the reduction of the quantity of water in brooks and rivers, by which timber-floating, watercarriage and works for utilising water-power may suffer seriously.

Reuss states that the harm done by ill-advised drainage is most apparent in the Dobris mountain forests of the ColloredoMansfeld family; through the extensive drainage system, over 50 miles in length, effected there between 1858 and 1867, the growth in forest and field fell off to such an extent that it became necessary to fill up most of the drains. In the Harz mountains also, in 1840, much harm was done by too extensive drainage, whilst the attempts made since the middle of 
the present century to drain the peat-bogs in the Hannoverian Harz districts and to plant them with spruce have proved extremely costly, and given such poor results that they have now been abandoned.

On the above grounds-the danger of drying up sources of useful water-supply, and the fear that benefits resulting from forest drainage works may not repay the outlay involved-the construction of such works on a large scale is to be deprecated, and the forester should not as a rule venture beyond draining small local swamps, which may sometimes be rendered innocuous or even useful when converted into fish ponds, by excavating them or constructing a dam.

From a general view, therefore, of the matter, it follows

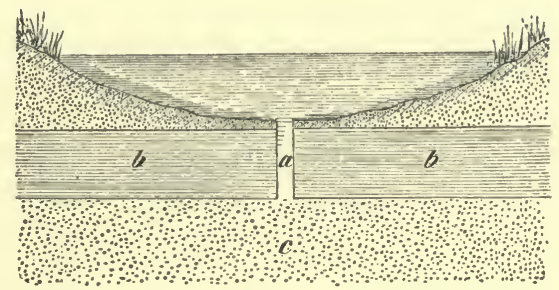

Fig. 269.

$a$. Vertical drain. b. Impermeable stratum. c. Permeable stratum.

that the advantages of drainage are greatest and the disadvantages least for forests on fairly level ground, whilst the reverse is true for mountain forests. 'The advantage of draining swamps as regards sanitation, circulation of the air and avoidance of malarial fever, need only be referred to here.

The following methods are employed in drainage:-

1. Vertical drainage.

2. Surface-drainage :-

(a) By open ditches.

(b) Kaiser's method of drainage.

3. Underground drainage by covered drains :-

(a) By trenches.

(b) By glazed pipes.

(c) By ordinary draining tiles. 


\section{Vertical Drainage.}

Vertical drainage is carried out by piercing an impermeable stratum and thus allowing the water to descend into a lower permeable stratum and be thus drained off. One or more borings of sufficient breadth should be made through the impermeable stratum at its lowest point, as shown in Fig. 269.

As an instance of the effects of vertical drainage, the planting of part of the Bagshot sand district, near Bagshot, by Schlich (1890-1900), may be cited. The land was mostly flat, with a pan 6 to 18 inches below the surface. It formed a swamp during winter, and was often very dry in summer. The pan was bored through at the planting holes with a pickaxe, and Scots and Weymouth pines planted. This communication between the upper and lower strata of the soil led to a complete drainage of the surface, and a fine crop of pine trees is now growing there.

\section{Surface Drainage.}

\section{a. By Open Ditches.}

i. Modf of Laying out a System of Drains.

The mode of laying out a system of drains depends on the nature of the locality. On level ground and in valleys, a complete network of drains is laid out after the land lias been carefully levelled, and consists of main drains, leaders and feeders.

The main drain should run along the lowest part of the area to be drained, necessary excavations being made to give it a uniform gradient between 0.5 and 1 per cent., and to conduct it into the nearest watercourse.

The leaders must carry off the water in the shortest direction from the feeders to the main drain, while the feeders have to collect water from the soil and conduct it to the leaders, the direction of which depends on the gradient of the ground. When the gradient is moderate, the main drains and leaders should run along lines of greatest fall; if it is too steep, their length must be increased by causing them to wind or bend so that the drainage water may not wash away the bed or sides of the drains, and cause the formation of ravines. The best 
fall for drains is from 0.5 to 1 per cent., but sometimes the lie of the ground may necessitate a certain length of drain of greater gradient.

The feeders should be obliquely inclined to the line of greatest fall in order to collect the maximum amount of water from the soil, and they should conduct the water into the leaders, to which they may be either at right angles or oblique.

The former system, as shown in Fig. 270, has the advantage of draining the largest area with the shortest length of drain. Fig. 271 shows oblique drainage, and the more acute the angle

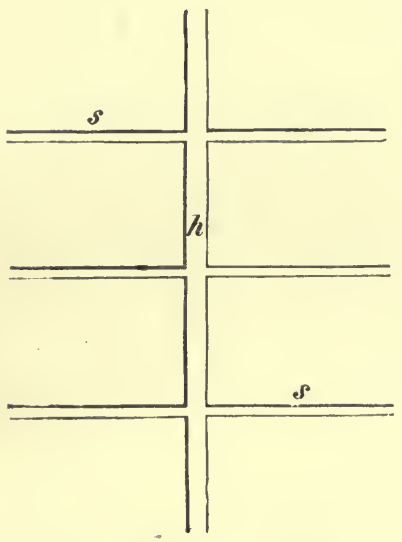

Fig. 270 .

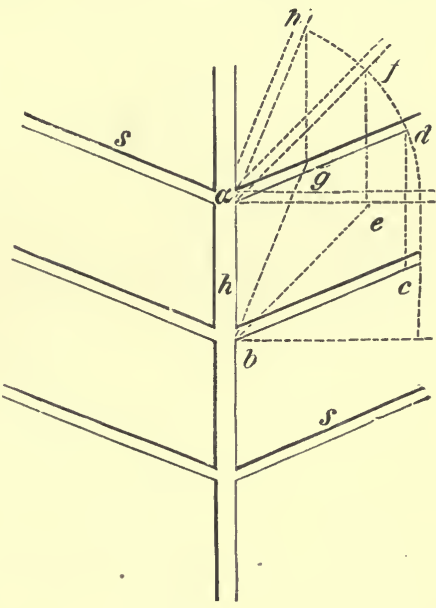

Fig. 271.

Plans of drainage. h. Main-drain. s. Feeders.

between the feeder and leader, the less will be the area drained by a given length of ditches.

$$
\text { Thus } a, b, c, d>a, b, e, f>a, b, g, h \text {. }
$$

The choice of the angle between the feeders and leaders depends chiefly on the gradient of the ground, the less the gradient the more acute the angle; feeders the bed of which gradually deepens as they approach the leader will be most effective.

Feeders can be laid out parallel to one another only whon the gradients are uniform. Figs. 272 to 274 show some interesting networks of drains by G. Koch. 
The proper interval between the feeders depends on the quantity of water to be drained away, the configuration of the ground and the nature of the soil. The interval between any two feeders will be inversely as the quantity of water in the soil. The looser the soil, the more easily is it drained. On the average, according to circumstances, intervals of 16 to

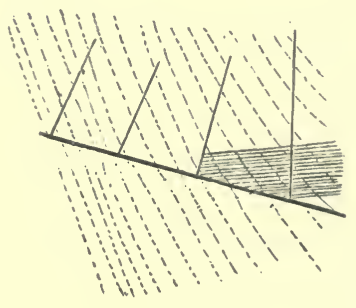

Fig. 272 .

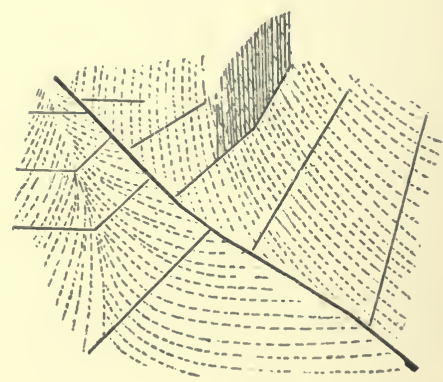

Fig. 273.

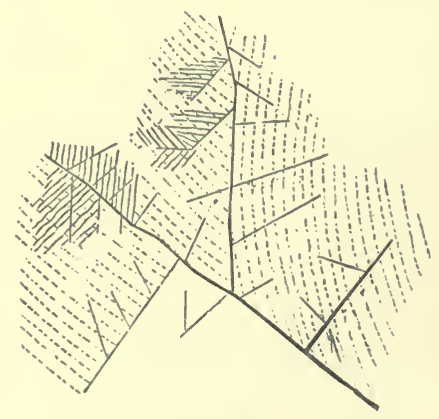

Fig. $2 \% 4$.

Plans of drainage.

22 yards may be chosen. In very wet land, the interval between the feeders may be reduced to 10 yards, whilst on drier land it may be extended to 30 yards.

A practical method of determining this interval is given by Heyer, as shown in Fig. 275. Cut a feeder A, and another B at different distances from $\mathrm{A}$ till the water in the soil at the middle point $\mathrm{C}$ between the two feeders falls to the depth $\mathrm{C} \mathrm{D}$, to which it is required to dirain. 
Water percolating from a river should be collected as near it as possible by deep drains running along the river-side, and leading back into the river lower down stream. Overflow from a stream can be kept back only by the construction of

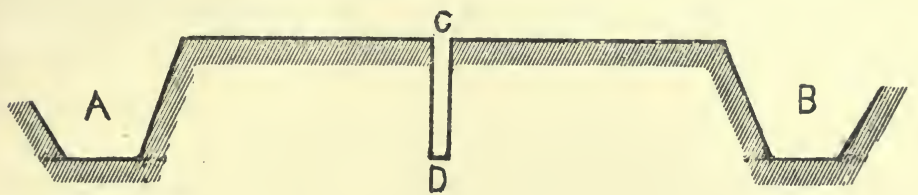

Fig. 275 .

embankments, as in the English fen districts, or along the river Severn.

On slopes, water should be collected at the points of issue from the water-bearing strata, before it can form a swamp. Thus the water should be collected in a drain $k k$ running along a contour-line on the hill-side (Fig. 276), and then conducted down-hill by a leader A along the line of greatest

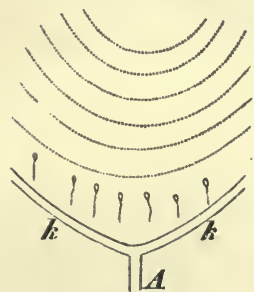

Fig. 276.

k. Feeder. a. Main drain at the base of a hill.

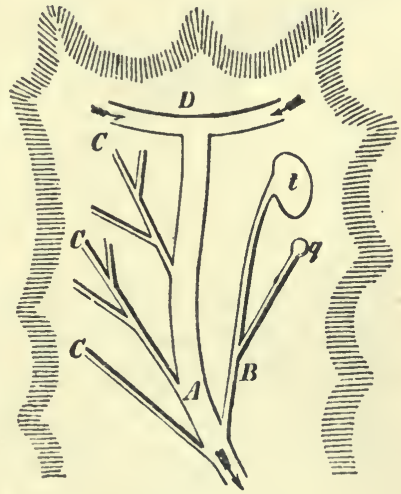

Fig. 277 .

$D$. Chief feeder. A. Main drain. $B$. Leader from a spring $q$, and a small swamp $t$. C. Feeders.

fall, any outlying swampy places in depressions being connected with the latter. Wherever the fall and the extent of the area to be drained are considerable, several such drains may be constructed, one above the other. 
When the gradient is slight and much water collects (Fig. 277) in a swamp, besides the main drain A, a few confluent drains should be cut, that lead into the main drain. They should join the main drain at a very acute angle, so that the passage of the water in it may not be interrupted, nor its walls undermined by water from the lateral drains.

\section{ii. Dimfensions of the Drains.}

The breadth of the drains depends on the amount of water in the soil; the gradient of the ground, and the purpose of the drains. The wetter the soil and the slighter the gradient, the broader must be the ditches; the leaders being broader than the feeders, and the main drain than the leaders. From 1 to $2 \frac{1}{2}$ feet is a sufficient width for the feeders, and 3 to 5 feet for the leaders and main drain.

The depth of the drains depends on the depth to which the land is to be drained, and on the physical nature of the soil

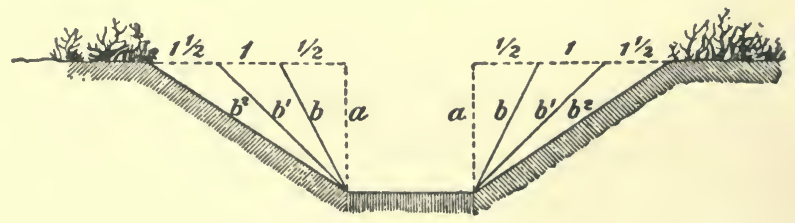

Fig. 278.

and subsoil. Clay requires a greater depth of drainage than loam, and this again than sandy loam. In peaty soils, the drains should go down to the mineral subsoil. In practice, the depth of drains is usually half their width, and draining to too great a depth is prejudicial, costing in excess of the requirements of the case, and depriving the subsoil of reserve water which will be required by the trees during dry weather. The amount of water on the land during summer, not in early spring, should be considered in fixing the depth of drains.

The slope of the sides of the drains depends on the degree of coherence of the soil, and on the gradient of the drain; the looser the soil and the steeper the gradient, the gentler must this slope be. In Fig. 278, $a$ is one meter, and the slope 
may be $\frac{1}{2}$ on peat, 1 on clay or stiff loam, $1 \frac{1}{2}$ on sandy loam, $2-3$ on sand.

The main drains may be provided with sluices at suitable places, so that they can be closed and the drainage stopped during dry seasons.

\section{iii. Time for Draining.}

Drainage should precede planting by a few years, so that the ground may become sufficiently dry and may settle down before the plants are put in ; a dry period of the year, e.g., late summer or autumn, should be chosen for the execution of the work.

\section{iv. Method of Digging tile Drains.}

Operations should be commenced with the main drain at the lowest part of the land, in other respects the system already described for digging boundary-trenches should be followed (p. 18). The earth removed from the drains should not be placed too close to them, as it may then be washed back again by the rain; it should be used for filling-up hollows or spread evenly over the surface of the ground, which is beneficial in wet places by raising their level. After the main drain has been dug the feeders and leaders should follow. It is most economical to give the work out to be done on contract.

\section{v. Advantages of the Method.}

The advantages of the method of draining by open ditches when compared with closed drains are :-

Cheap execution.

Ready discovery of places requiring repair, and cheapness of repairs.

Its disadvantages are:-

Loss to the forest growth of area occupied by the ditches. Difficulties in transport of produce.

Liability of the ditches to damage by men, cattle, etc. Too complete and rapid removal of water. This may cause temporary injuries for want of moisture in the soil, and may damage lands below the drained area. 
The loss of area taken up in open drains is not of any practical importance in forestry, and provided care be taken about the number and dimensions of the ditches, the other disadvantages of the method may to some extent be avoided. In mountain forests, where the snow is long in melting, and which are subject to unusually heavy rainfall, a system of open drains along the line of steepest gradient removes such a large volume of water from the forest, that this method, which is usually employed, especially on peaty ground, where the flowing water in the drains cuts into the land below, is of doubtful expediency. Under such circumstances the following method is preferable:-

\section{b. Kaiser's Method of Drainage.}

'The principle of Kaiser's* method of drainage consists in avoidance of the direct removal of the water from the forest and yet in a complete drainage of the wet land.

This is effected by the lowering of the water-level by means of a number of interrupted drains (collecting trenches) distributed uniformly over the area to be drained, combined with a system of small ditches widening out laterally.

The collecting trenches are 1 to 2 meters long, about 1 meter deep, and 1 meter wide, and are dug horizontally along contour lines. The lateral trenches, that unite these collecting trenches, and the dimensions of which correspond to the depth to which the water-level is to be reduced, are at right angles to the collecting trenches.

The following reasons are given in support of Kaiser's method of drainage :-

i. In every case too rapid and complete drainage, with its injurious consequences, is prevented.

ii. The degree of drainage required by the proposed plantation is completely under control, as the lateral drains are dug only deep enough to reduce the water-level sufficiently. The water removed from the soil and from the spoil-heaps that remain alongside the collecting trenches fills the latter

* Kaiser. "Beitrage sur Pflege der Bodenwirthsehaft mit besondere Ruicksicht auf die Wasserstandsfrage." With 24 plates. Berlin, 1883. 
and the lateral drains only to the same height as the latter has been reduced in the remainder of the area.

iii. In the first place, evaporation over the whole area is increased by the action of the sun and winds on the exposed water in the collecting trenches. In the second place, the surface having become drier and warmer by the drainage, increases the evaporation, and favours the capillary ascent of water from the subsoil; it also warms the air near the surface of the ground.

The results of this process must be favourable to the growth of plants. By the gradual drying up of the surface, peat-mosses and sour grasses disappear and the chemical and physical condition of the soil improve. The formation of peat ceases ; the decomposition of the humus becomes normal. Lichens

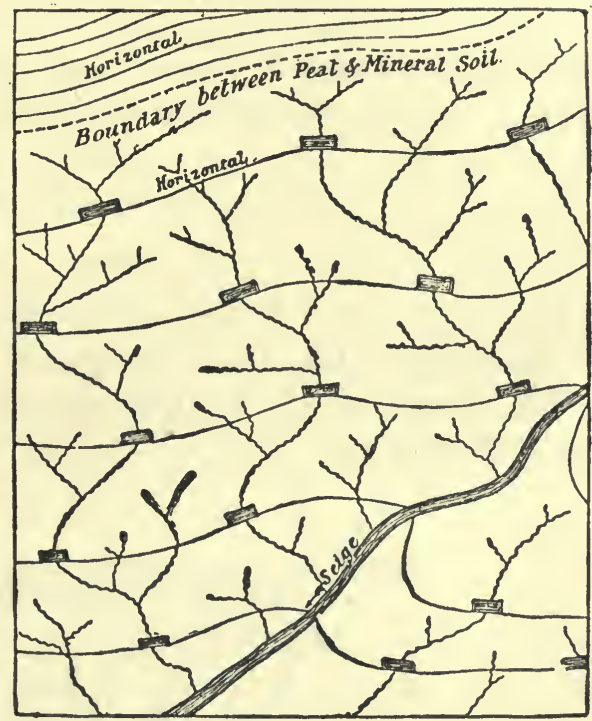

Fig. 279.-Kaiser's method of drainage. disappear from the stems. Danger from frost is diminished. Annual shoots, hitherto short, become longer. The water is thus utilised for the service of the forest.

The above method was tried in 1883 and subsequent years in the Bavarian Royal forest of St. Oswald on peaty areas, it is represented in Fig. 279. The collecting trenches were dug in depressions and other places where the peat was wettest. The lateral feeders were 30 to 45 centimeters wide and deep, quite deep enough for young spruce to become rooted above the subsoil water. The excess water was conducted from the collecting trenches by little trenches a few centimeters deep into a small watercourse named Seige, which 
conveyed it lower down. If such a watercourse does not exist a drain must be dug to receive and drain away the surplus water. The system of drains gave admirable results, and the cost was $12 s$. per acre, that of the upkeep per acre; $2 s$. annually.

'The cost of open drains in Germany, in 1883, was about $8 s$. per acre, but the extra cost of Kaiser's drainage is inconsiderable when compared with the superior benefits obtained.

The only objection to the method consists in the fact that the collecting trenches - at least in depressions-form so many little frost-holes, that increase local danger from frost.

\section{Covered Drains.}

a. Irenches.

i. Method of Construction.

Underground drains are usually made as in Fig. 280.

The trenches should be about one foot broad at their base, $1 \frac{1}{2}$ to $2 \frac{1}{2}$ feet deep, and with a slope as steep as the nature of

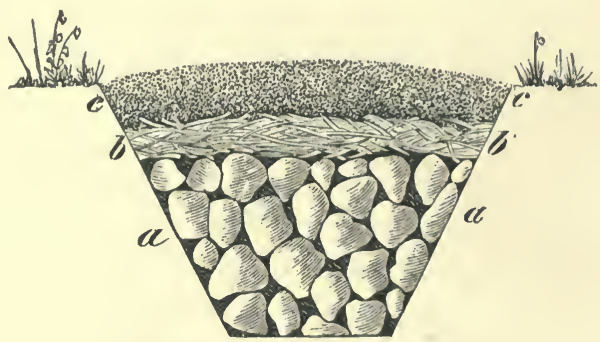

Fig. 280 - Section of a drain.

$a$. Layer of stones. $b$. Layer of branches. $c$. Layer of earth.

the soil will allow. The trench is then half filled with stones, which are covered with brushwood, reeds or sods, and the top is filled in with earth.

Another method is to cover the base of the trench with fascines or tied bundles of green osiers, branches of alder, poplar or shrubs, which are used immediately after they have been cut. The vacant spaces between the fascines along the sides of the trenches are filled up with moss, and the whole 
covered with earth, as before. This mode of drainage, known to the Romans, was introduced into England by Elkington, and was much practised until 1820 . It has the advantage of preventing excessive drainage, and may serve its purpose in places to be planted up, until the roots of the plants can themselves drain the soil.

\section{ii. Durability.}

Brushwood-drains when the fascines are of alder branches will last from 8 to 10 years; they rot sooner on calcareous soil and last longer on clay. As, however, the plants once forming a thicket themselves drain the soil, and by the use of fascines too much water is not removed, this method is highly advantageous.

Drains made with stones may last for 50 years, and are therefore preferable, unless temporary drains are sufficient for the purpose.

\section{iii. Value of the Method.}

Owing to the high cost of this method of drainage, it is used only for permanently wet ground. It is also largely employed for culverts to lead water across roads.

\section{b. Glazed or Cement Drain-pipes.}

Drain-pipes made of glazed burned clay or cement and of various dimensions are now generally used for culverts; they unite the advantages of rapid drainage and facility for being cleaned, with that of great durability.

\section{c. Draining Tiles.}

\section{i. Description.}

Draining tiles are cylindrical tubes of burned clay with a circular section. They are generally 1 to $1 \frac{1}{2}$ feet long, $\frac{1}{2}$ to $\frac{3}{4}$ inch thick, and their apertures $1 \frac{1}{2}$ to $4 \frac{1}{2}$ inches across. A good draining tile should be well-burned and smooth within, it should ring when struck, show a clean uniform fracture, and stand sudden changes of temperature without cracking, for which it may be tested by plunging it alternately into hot and 
cold water. The clay used for these tiles should be fairly pure, and contain no lime nor coarse grains of sand. The larger tiles are used for main drains and the smaller ones for collecting drains.

\section{ii. Laying the Tiles.}

Trenches for the tiles are similar to those in use for open drains, their dimensions depending on the nature of the soil ; their sides, however, should be vertical ; the main drains have a fall of 2 in 1,000, and the collecting drains a greater fall, and should be from 30 to 80 feet apart according to the nature of the soil. The shortest distance for collecting-drains is chosen when there is much subsoil-water in stiff clay or in very fine grained soil with great capillarity; in fact, the looser the soil, the further apart the drains should be.

The depth of the collecting-trenches should be from 3 to $4 \frac{1}{2}$ feet, and at least $3 \frac{1}{2}$ feet is necessary in cold climates, to prevent damage to the tiles by frost; the main drains should be somewhat deeper.

After the trenches have been dug, which for very wet soils should be in fine weather and with as little delay as possible, the tiles should be laid carefully, beginning at the upper end of the drains, and placed end to end at the bottom of the trenches; or, if the soil be loose, on a layer of clay or on flat roofing tiles, which will give the bed of the drain an even gradient, to which much attention should be paid. Brown* recommends placing a layer of stones under the tiles, in which ordinary drainage-water may rum, while its level will rise to that of the pipes only when the soil happens to be exceptionally wet. This is because the rootlets of trees are attracted towards wet substances in the soil, and will therefore branch freely among the stones and yet not block up the pipes, which are usually dry. Brown also advocates placing a layer of clay over the pipes, so as to keep the upper rootlets from getting into them.

The size of the aperture of the tiles depends on the degree of wetness and capacity of the soil ; the more water there is to be removed and the greater the danger of the tiles becoming

\footnotetext{
* "The Forester." Brown and Nisbet. Blackwood \& Co., 1894, Vol. I., 551.
} 
choked with soil, the larger the aperture of the tiles, and in sandy soil it should be at least two inches.

After laying the tiles, which should be done in dry weather, and as rapidly as possible, the trenches are filled in with earth, and the greatest care should be taken, especially when the soil is stony, that the pipes are neither broken nor displaced.

iii. Durability.

The durability of the drains depends on the nature of the soil, the quality of the tiles and the care taken in executing the work. Well-burned tiles at depths of $3 \frac{1}{2}$ to $4 \frac{1}{2}$ feet should last for 25 years and more; for instance, draining-tiles laid in 1850, in the Prussian Crown Estates, were in good order in 1880.

The cost of draining with tiles is about $£ 8$ per acre, and this is, of course, prohibitive for purely forest work.

\section{d. Comparison of Draining-Tiles with Open Drains.}

Drainage improves soils by lowering the level of subsoil water, and exposing a larger area of the soil to the influence of atmospheric air, thus rendering it warmer and accelerating the decomposition of humus. As compared with open drains, draining-tiles waste no productive area, are less subject to damage and drain the soil better, and their use is highly advisable in agricultural lands, but in forests they are much more costly to lay out than open drains, and they easily become choled by the rootlets of trees and of weeds such as Equisetum, Arundo, etc., and also by frogs' spawn. Deposits of iron-ochre may also be formed in the pipes, and they may become filled with sand.

Experience has shown that in forests all the disadvantages of draining-tiles occur more frequently than in agricultural lands, and they can be profitably used only in forest nurseries, or for bad forest meadows. The production of hay in meadows may be increased 25 per cent. by good drainage, and the quality of the hay is also improved. 


\section{CHAPTER II. \\ PROTECTION AGAINST AVALANCHES.*}

\section{Origin.}

Avalanches are caused by the loosening and fall of masses of snow or ice on steep smooth slopes in mountainous regions; they may consist of loose or massive snow, or both combined, or of ice from broken glaciers.

\section{a. Avalanches of Loose Snow.}

These are locally termed Staublawinen, and occur in November, when fine dust-like snow is falling; they are due to great steepness of the mountain sides, or to overhanging masses of snow falling on to rocks, the snow being separated into dust during its fall. They are of rarer occurrence than other avalanches and seldom cause any damage.

\section{b. Avalanches of Massive Snow.}

Movements of the upper layer of massive snow, termed Oberlawinen, occur chiefly from December to February, when thick layers of fresh snow have fallen on to old frozen snow, and become so weighty that they can no longer rest on the smooth base beneath them.

\section{c. Ground Avalanches.}

When masses of snow which extend down to the surface of the ground, roll or slide down a mountain side, they are termed Grundlawinen, and are extremely dangerous. They generally fall towards the end of winter at midday, during the melting of the snow, and when a Föhn, or south wind, is

* Landolt, El., "Die Bache, Schneelawinen u. Steinschläge." Zuirich, 1886. Pollack, Vincenz, "Dic Lawinen Oesterreichs und der Schweitz und deren Verbauungen." Vienna, 1891. 
blowing, and frequently during a storm. These are the commonest and most dangerous avalanches, and leave tracks which can be readily observed, as they occur over and over again at the same places.

\section{d. Glacier-Avalanches}

Consist of broken fragments of glaciers.

The following remarks apply only to avalanches of massive snow and ground avalanches.

\section{Damage done.}

The damage done to forests by avalanches consists in the breakage of all woods lying in their way, and in the obstruction of streams and roads which they cause. The rush of air that accompanies an avalanche is so great that it breaks many trees up to a distance of several hundred yards from the avalanche. Many ibex are also killed by avalanches. No forest can withstand the rush of a large mass of snow down the mountain side, and the higher, smoother and steeper, and freer from wood a mountain-side is, the greater the danger of avalanches, and the greater the rapidity with which they fall.

A high soil-covering of hill grass affords considerable protection.

In the winter of $1875-76$, in the district of Ragaz, of the Swiss canton Graubünden, 500 avalanches occurred, and in the district Schuls of the same canton, 381 avalanches. The winter of 1887-88 was also distinguished by the number of avalanches which fell $-1,094$ avalanches, chiefly between February and April, of which 871 (80 per cent.) extended to forests. On an area of 3,300 acres, $2,870,000$ cubic feet of timber was broken and uprooted. The damage done by the avalanches was valued at $\mathfrak{£} 17,220$.

In Austria, during the winter 1887-88, damage by avalanches was done to the extent of $\mathfrak{E} 28,000$.

\section{Protective Cultural Measures.}

(a) The surface above the tree-limit should be fixed by sowing grass. In order to afford a sufficient obstacle to the 
sliding down of the snow, the grass should be mown so as to leave a high stubble.

(b) All shrubs, such as rhododendrons, green alder, dwarf birch, etc., should be preserved carefully on steep slopes.

(c) The forest must be maintained up to the tree-limit, and this is the most important rule. Forests which serve to protect the country from avalanches are commonly found in Switzerland the 'Iyrol, and the Austrian Alps, and must be properly managed so as to secure the object in view.

The best species for such forests are Pinus Cembra, P. montana, green alder, larch and spruce. The mountainpine and alder resist the snow action splendidly. Spruce grows up to an altitude of 6,000 feet. Beech and sycamore form useful mixtures up to 4,600 feet. The Selection system must be adopted, and all gaps should be at once planted up. When a new forest is being formed, sometimes sowing and sometimes planting should be preferred. In stony, shallow calcareous soils, pit-sowings are made under the shelter of stones, rocks, dead branches stuck into the ground, or of logs fixed by stakes, all of which protect against the sliding of the snow. In places where there is deeper soil, in depressions, etc., multipleplanting with three and four plants should be tried. The cost varies from $£ 5$ to $£ 8$ per acre. Production of wood is of secondary importance in such forests, and, as a rule, only dead and broken wood should be utilised, and the stumps should then be left in the soil, the felling being high above the ground. Thickets of young wood must be carefully thinned. Neither removal of litter nor pasture, more especially that of the destructive goat, should be allowed, but, unfortunately, in such places browsing by goats is only too common, and the tree-limit is being continually lowered.

\section{Protective Works.}

Protective works consisting either of ditches, rows of wattlefences or walls should be made above and below the line where avalanches begin, which is easily recognised by a sudden change in the gradient of the slope.

(a) Ditches.-Interrupted horizontạl ditches, 6 to 16 feet 
apart, are dug all over the area, being arranged like the wattle-fences in Fig. 281; their construction on very steep slopes is evidently not unattended with danger.

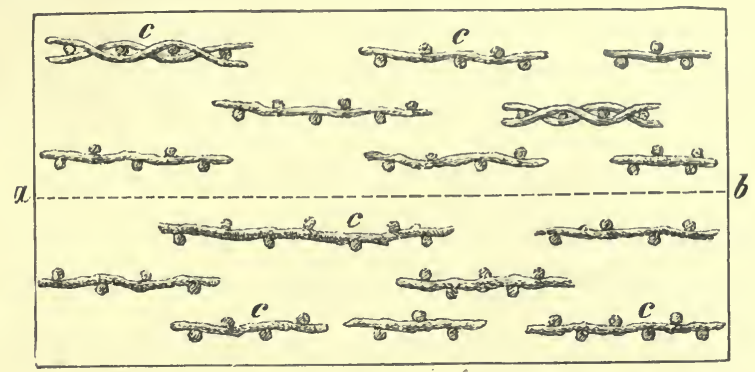

Fig. 281.-Plan of fences for protection against avalanches.

$a b$. Line where the avalanches commence. $c$. Fences.

(b) Rons of Wattle-Fences.-The stakes used may be either of wood or iron. These are set up at intervals of from 20 to 50 feet, their central points being at those of a series of

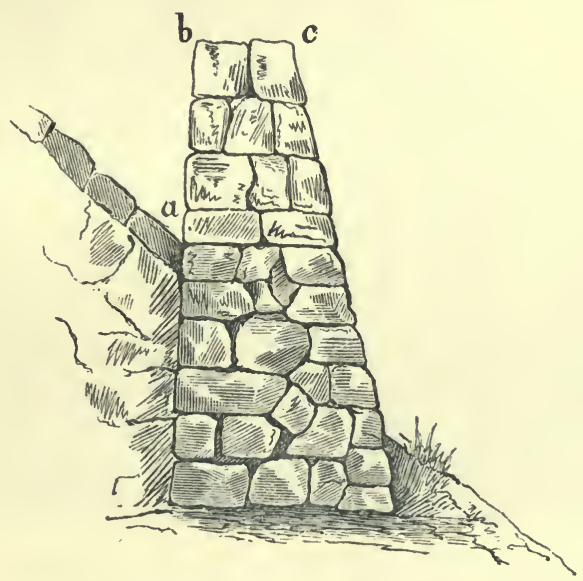

Fig. 282.-Dry masonry wall for protection against avalanches.

equilateral triangles; they should be 15 to 30 feet long, and of wattle-work with branches plaited between stakes firmly driven into the ground.

Such a system of wattle-fences allows soil to be formed on a 
rocky slope, which may afterwards be sown with grass, or planted with trees or shrubs.

(c) Walls.-On stony ground, walls of dry masonry may be erected instead of wattle-fences; their mode of construction is shown in Fig. 282. On steep rocky slopes, the rock must be cut to admit the foundation of these walls, but this need only be deep enough to prevent the walls from falling, owing to their own weight. Such walls have proved effective in the Swiss cantons, Uri, Graubünden and Wallis, and cost $3 s$. to $6 s$. per cubic meter. Confidence in them was greatly disturbed by the damage since 1867, done in 1887-88.

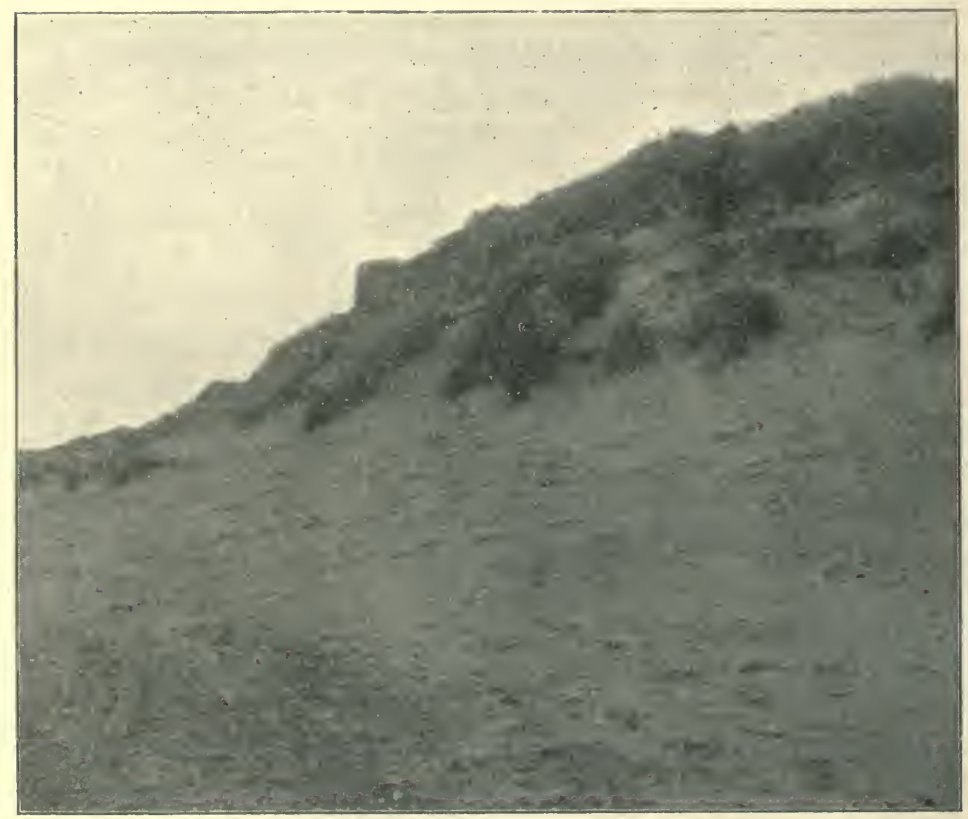

Fig. 283.-Sandhill with murram grass. Holkham. 


\section{CHAPTER III.}

\section{PROTECTION AGAINST SHIFTING SAND.**}

UNDER the term shifting sand is meant a fine-grained sand containing so little clay or humus that when dry and the soil is badly covered with vegetation, it is set in motion by the wind and blown from place to place. Shifting sand is generally found on the sea-coast, but also in the interior of countries. As the productive forest area becomes rapidly reduced by the spread of the sand, the evil must be promptly and vigorously met.

\section{Section I.-Sand Dunes.}

\section{Description.}

Sand is thrown up by the waves along the sea-coast at high tide, and becomes under certain circumstances heaped up into hillocks, or dunes, and is then carried further into the interior of the country. Vasselot de Régné states that the grains of sand on the Gascon coast are too large to be carried like dust before the wind, but are rolled up the slope of a dune and fall over its ridges, so that the dune naturally attains a slope of about $25^{\circ}$ towards the sea, whilst its slope inland is generally steeper, and may attain $60^{\circ}$. The sand is blown away from the ridges or from any eminences in the dune, however slight they may be, and is also carried through depressions made in a ridge to the further side of the dune. Two forces are at work on the sand-the sea-breeze which prevails during daytime and drives the sand inland, and the land-breeze by night, which finds the sand firmer owing to the dew, and is not so effectual in blowing it back as the sea-breeze is in blowing it forward.

*Wessely, Josef, “Der Europäische Flugsand u. seine Cultur.” Wien, 1873. "Notice sur les Dunes de la Coubre," par Vasselot de Régné. Paris, Imp. Nat., 1878. "La Dune Littorale," par C. Grandjean. "Revue des Eaux et Forêts." July-December, 1887. Lehnpfuhl, "Dünenwanderung und Diinenwald" ("Mündener Forstliche Heft," 2 Heft, 1892, p. 53). 
On the coasts of the North Sea and of the Baltic, in Holstein, Schleswig, Jutland, and in the Baltic islands, and along the western coast of France, from the Ile d'Oléron to the mouth of the Adour river, sand-dunes cover extensive areas, and until effective measures were taken to fix them, large tracts of cultivated land were buried in sand. Along the coasts of West and East Prussia, for a distance of 150 miles, dunes extend to a breadth never less than one-sixth of a mile, and unless they are fixed they encroach inland yearly by 50 feet. The area of European dunes is estimated at 21,000 square miles.

The coasts of the British Isles consist chiefly of rocky cliffs, but sand-dunes are found in Norfolk, Somersetshire, Lancashire, Elgin and other places along the coasts of Great Britain.

The dunes along the Bay of Biscay in the French Départements des Landes et de la Gironde extend over a total length of 140 miles, forming a series of parallel ranges about 160 feet high and 4 miles broad. During the constant political troubles of the middle ages, the natural forests of maritime or cluster pine (P. Pinaster, Soland.), which formerly covered this area, were burned and destroyed, and the sand invaded the country at the rate of 60 to 70 feet annually, covering whole towns and villages, cultivated fields, and vineyards. The passage of watercourses to the sea was interrupted by the accumulated sand ; a desolate malarious region, called Les Landes, resulted. Swamps and lagoons of brackish water alternated with vast tracts of arid sandhills, where a few sheep pastured, tended by shepherds on stilts.

In 1787, the engineer Brémontier published a treastise showing that the dunes could be fixed by sowing sand-grasses and pines, and the work of fixing the dunes of Gascony was commenced in 1788, and has been continued with complete success up to the present day. In 1810, the French Legislature passed an Act enabling the State to fix dunes belonging to municipalities and private owners, by means of plantations, the owners only recovering their property after paying the cost of fixing the sand. This they have only rarely been able to do, owing to the great cost of the operation compared with the value of the reclaimed land.

About 800,000 acres have thus been dealt with, the annual 
charge for new work and for maintaining the dunes which have been already fixed having been $£ 8,400$ in 1893 . In this way vast areas have been saved for agriculture, and enormous tracts of pine-forests created, which afford work to a large number of people in the extraction of resin and turpentine from the trees, and in timber-works, the pine-forests of the Landes now exporting about 600,000 tons of pit-timber to Great Britain annually, besides large supplies of timber and firewood for local use.

\section{Construction of a Littoral Dune.}

As an embankment along the coast prevents the wind from driving the sand inland, the chief point to be secured is to fix

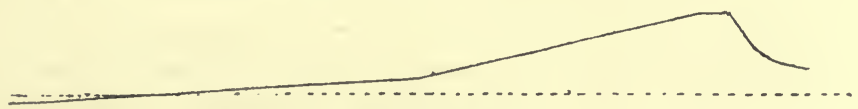

a. The Lion Dune.

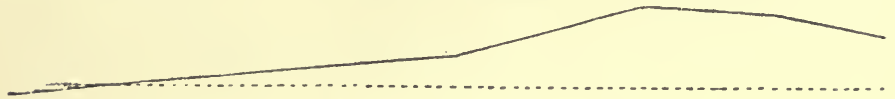

b. The Porge Dune.

c. The Ferret Dune.

Fig. 284.

the sand, so as to form what is termed the littoral dune, the mode of construction of which is as follows:-

Two parallel fences are erected along the coast, between and on both sides of which the sand accumulates, the fences being gradually raised till the dune has attained such a height that only inappreciable quantities of sand are blown over it.

The fence facing the sea is a continuous line of paling, from 300 to 600 feet distant from high-water mark; it is made of inch planks $6 \frac{1}{4}$ feet long, 6 to 8 inches wide, which are pointed below. They are inserted to $\frac{3}{8}$ ths of their length into the sand, and 1 inch apart, to allow sand to blow through. When the sand has nearly covered the planks, they are raised three feet 
by means of levers worked by one man against the next unraised plank, or by a stout rod passed through a chain fastened round the plank and lifted by two men. This operation is repeated until the proper height of the dune is attained, which Grandjean places at 10 metres, or about 33 feet.

The back fence is usually made of wattle-work and prevents the sand which has passed through the front fence from being carried inland, and gives a proper contour to the dune. This fence is replaced by a new one when it has become covered with sand.

The preceding diagrams (Fig. 284) taken from Grandjeans' work represent the ordinary sections of the littoral dune, and he considers $b$ and $c$ preferable to $a$, as being much easier to maintain. They have slopes of $26^{\circ}$ or $27^{\circ}$ facing the sea, which corresponds with De Régnés natural slope of the dunes. Grandjean, in the work already referred to, gives full and satisfactory reasons for the height and gradient he prefers for the littoral dune.

\section{Material for Fixing the Sand.}

The littoral dune can never be planted with trees, on account of the salt spray of the waves and the strong sea-wind. In certain places in Holland, masonry works and piles have been erected to protect the dune, but as a rule flexible plants are much more effective than rigid and costly works. Attention is therefore directed to sand-grasses and sedges, and the best of these for the purpose are:-

Sea marram, or matweed (Psamma arenaria, R. \& S.) ;

Baltic matweed (P. baltica, Schrad.) ;

Sand lyme-grass (Elymus arenarius, L.) ;

Sand sedge (Carex arenaria, L.).

All these plants are characterised by very long, much-divided rhizomes, and can withstand being covered over and buried in sand. The sea marram will grow only where it is continually covered with fresh sand, and dies inland in the shelter of the littoral dune, when no fresh sand covers it. It is termed gourbet in France, and is exclusively used for fixing the littoral dune along the Bay of Biscay. Next to the marram in repute 
for fixing the sand comes the lyme-grass, and these two species are chiefly used for the purpose in Holland.

Other plants grow in gradually among them; at first lichens and algae, then grasses, as for instance Arenaria peploides, L., Aira canescens, L., couch-grass (Agropyrum repens, Beauv.), and other plants, such as the sea-poppy, Glaucium luteum, Scop. ; Lathyrus maritimus, Bigel ; and Hieracium umbellatum, L., etc. Vasselot de Régné gives a very complete botanical list of dune plants.

Several shrubs then appear on the land side of the dune, as Salix repens, L. ; 'sea-buckthorn (Hippophae rhamnoides, L.) ; Lycium barbarum, L. ; Tamarix, etc.

\section{Maintenance of the Littoral Dune.}

When once the littoral dune has been raised to a proper height and profile and fixed by means of sea marram, it is necessary to maintain it constantly in the same state; any undue accumulation of sand in any part of the sea side of the dune at once causes an inland draught of sand on both sides of it, which if not at once attended to will breach the dune.

Men termed gardes cantonniers are therefore stationed along the littoral dune in Gascony, who cut away all vegetation except the marram from its surface facing the sea, in order to prevent undue accumulation of sand. As the marram grows readily from cuttings during the colder six months in the year, the workmen who cut it away from ridges plant it in depressions, or if the season be too hot or dry for the cuttings to take root, the pieces cut from ridges are merely placed on depressions. In this way, by cutting away the marram where it is too dense, and planting or placing it in depressions, the proper contour of the dune is maintained, as the sand accumulates behind the marram, and is blown away wherever the latter is cut.

In cases where the dune has been neglected and large depressions have been formed, it may be necessary to use wattle fencing to cause an accumulation of sand, but if ordinary care be taken, the marram grass will suffice to keep the littoral dune in good condition, and Grandjean believes that new littoral dunes may be formed by means of it, without using the fences described in section 3.

F.P. 


\section{Protective Coast Forest Zore, under the Shelter of the Littoral Dune.}

\section{a. Description.}

Under the shelter of the littoral dune, a protective zone of various woody species mixed with gorse, species of genista, heather, Tamarix, etc., is then allowed to spring up, but is generally planted or sown artificially.

The species chiefly grown near the Baltic coast is the Scots pine, over 8,000 acres of this species having been planted near Dantzig between 1795 and 1850.

In Zealand, the uncinata variety of the mountain-pine (Pinus montana, Mill.) has been used, and its great success is due to its indifference to soil and climate, and its habit of retaining its lower branches green for long periods. In France the cluster pine is chiefly used, but it is liable to be frozen when grown too far to the north.

Spruce, birch, or white alder may be mixed with the pines, and in South-west France pedunculate oaks and Q. Tozza, D.C. In depressions, the common alder, poplars, and willows may be grown.

The different varieties of Pinus Laricio, Poir., and especially the Corsican variety, maples and the silver poplar, are well able to withstand the force of the strong sea-winds.

As a rule, the growth of protective forests near the sea coast is poor, on account of the strength of the sea breeze and the poor nature of the sand in which the trees grow, and which is being constantly heaped over their roots, but protection and not timber is required in a zone extending from 600 to 2,000 feet beyond the littoral dune, and which if left unplanted would be a bare sandy tract tending to spread inland and ruin existing forests.

In a coast-protection forest, short terminal shoots, procumbent stems, one-sided crowns and a leaf-canopy sloping down seawards, are evidences of the struggle these woods carry on with the wind, but it is a forest all the same.

The conditions of growth greatly improve as the distance from the sea becomes.greater, so that further inland, especially if the sand contains little flakes of mica, even superior species such as beech or silver-fir may be grown, as in Alsensund 
in Schleswig. If, in any part of the protected zone, a shelving cliff of sand unprotected by vegetation is exposed to the wind; it should be covered with branches of pine, gorse, broom, etc., placed like slates on a roof, and some sand-fixing grass sown to prevent the sand from being carried inland.

\section{b. Method of Formation.}

The inequalities of the ground should first be levelled in order to afford the wind as few points of attack as possible. Sandfixing grasses should then be sown or planted, the former method being followed in France and the latter in Germany. Pieces of the grasses should be planted in rows at right angles to the direction of the prevalent wind, holes being made with a spade 1 foot to 2 feet apart, and three or four pieces of rhizome planted in each hole so deeply that only about 6 inches of them appear above the sand. They soon sprout and send out suckers in all directions through the sand, which they fix most effectually.

The cost of fixing sand with grass is that of 70 to 140 days' work at $3 s$. a day, averaging $£ 15$ an acre. In Prussia, longrooted yearling pines are then planted 1 foot apart in rows distant 3 feet from one another. The work is done with an iron dibble, so as not to loosen the sand unnecessarily. Mountain-pine is the best species in the north for fixing the sand, other trees being eventually planted between the pines. Cuttings of poplars or willows may be also planted.

In fixing dunes along the Baltic coast, Prussia spent $£ 3,100$ a year between 1884 and 1887, during which time 230 acres were fixed with grass and 608 acres stocked with trees. This is now being continued at an annual cost of $£ 5,000$.

The planting is usually effected under the protection of the littoral dune, and pine forests in the protective zone are then managed under the Selection system, and broadleaved species are coppiced.

In the Danish island of Zealand, up to 1866, sowing was preferred to planting, the sand being previously covered with a thin coating of loam which was placed on the ground in heaps in the autumn, and somewhat weathered by the winter's frost before being spread over the area in the spring. 
In France the cluster pine is sown with other seeds in the following proportion for an acre :-

Cluster pine seed. $\quad . \quad .26 \mathrm{lbs}$.

Furze or gorse . . . . $2 \frac{1}{2}$,

Genista . . . . $2 \frac{1}{2}$,

Marram grass . . . . $2 \frac{1}{2}$,

Seeds to attract insectivorous birds $2 \frac{1}{2}$,

As the seed is sown, it is covered with 1,000 faggots, 3 feet in girth and 5 feet long per acre of furze, broom, heather or

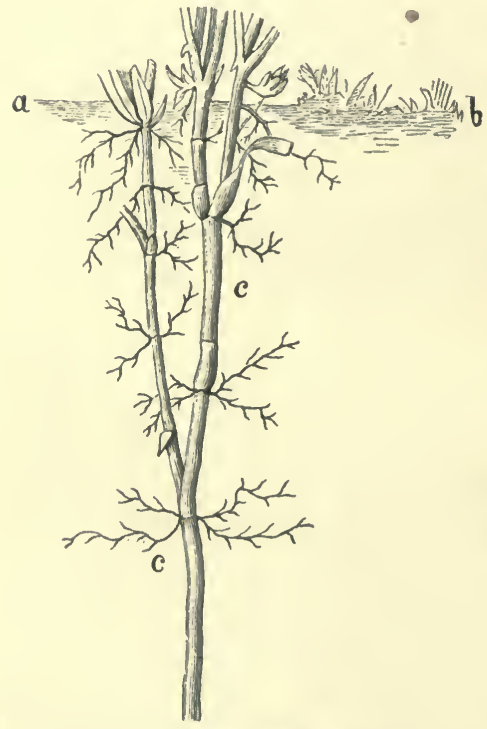

Fig. 285.-Psamma arenaria, Beauv. $a b$ Surface level of ground. $c$ Rhizomes.

pine branches, furze being preferred wherever it is available. The faggots are evenly distributed over the area and opened out, and the sowing is then commenced on the land side towards the littoral dune under protection of a wattle - fence intended to keep off the sand blown back by the land breeze. Each row of seed is covered by the branches, which are placed in rows with their lower ends towards the sea, so that each succeeding row of branches partly covers the preceding one, being arranged like slates on a roof and kept steady by spadefuls of sand thrown on them at intervals of 2 feet.

Areas of about 300 feet long by 60 feet broad are thus sown at one time. Between 1862 and $1874,5,200$ acres were thus sown in the Gironde at a cost of $£ 30,646$.

\section{c. Tending the Woods.}

The sand grasses used in fixing the dunes must not be cut or pastured. 'The water rat and the larvae of Polyphylla fullo, L., are the most dangerous enemies to the grass rhizomes. 
Dune forests must be strictly protected against grazing, removal of litter and trespass. Article $366_{\mathrm{A}}$ of the German Criminal Code punishes contravention of police regulations regarding dune forests with fines up to $\mathfrak{\&} 710$ s., or imprison-

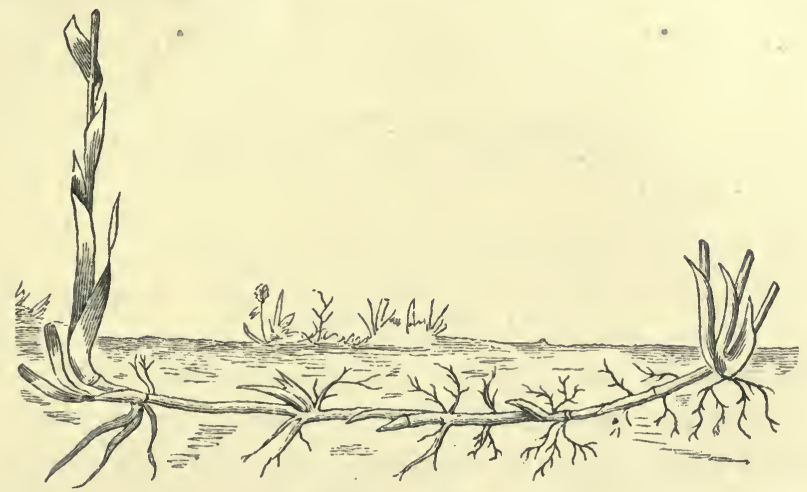

Fig. 286. - Elymus arenarius, I.

ment, and in Holland, four weeks' imprisonment is inflicted for cutting grass on dunes.

Only dead or dying wood should be removed from the dune forests.

\section{d. Addenda.}

The best English example of the fixing of shifting sands is on the Holkham sand-hills, on the Norfolk coast, belonging to the Earl of Leicester, where, since 1850, sea lime-grass and marram have been used to fix the sands, and several species of pine planted, of which the Scots and Austrian pines have proved most successful. The trees are planted widely, as thinnings would be injurious, unless lop and top were removed, owing to danger from fire. Now that the grass is kept down by the trees, fires are rare. Extensive planting of sand-hills has also been done in South-west Lancashire, Scots, Austrian and Corsican pines, as well as alder, birch, tamarisk and other plants, being used. Rabbits are the chief danger to these plantations, being very common on sand-hills along the coasts of Great Britain. Unless they are exterminated, there is little hope of fixing the sand. 
In India, along the Madras coast, extensive plantations of Casuarina equisetifolia, Forster, have been made, and grow with extraordinary rapidity, yielding excellent fuel.

In the Cape Colony, shifting sands are sown with cluster pine and Acacia Pycnantha and decurrens, the seed being mixed with rye seed; as the rye protects the seedlings. A layer of town refuse is first spread over the sand to assist in fixing it and serve as manure, ten tons to three acres of sand. Cupressus macrocarpa, Gord., and Pinus Halepensis, Mill., do well, also robinia.

\section{Section II.-Inland Sand.*}

\section{Description.}

Inland sandy tracts generally originate from sandy hills, and are due chiefly to the clearance or careless management of forests, and especially to removal of litter. Extensive sheep pasture on heather-land also readily sets sand in motion. Large tracts of shifting sands are found in Hannover, Oldenburg, Pommerania, etc. The greatest areas in Europe of inland shifting sand are, however, in Hungary and South Russia.

\section{Protective Rules.}

Maintenance of forests, especially on sandy hills, is the chief protective measure to be adopted. Not only must clearances of forests be prevented, but all destructive practices leading to their impoverishment must be stopped.

I'he following measures should be adopted in forests which serve as a protection against shifting sand :-

(a) The Selection system should be adopted, or only very small areas under a short rotation be cleared. Extensive clearings must be avoided in any case, but the shelter-wood systems with natural regeneration would be suitable were it always possible to obtain natural regeneration on dry, sandy areas. In the Gascon cluster-pine forests, clear-cutting is adopted, as the trees that form the final crop, being tapped for resin, do not produce seed. The pine seed is, however,

* Burkhardt, Dr. H., "Zur Kultur des Flugsandes," "Aus dem Walde," 1877, p. 167 . 
produced so abundantly by trees adjoining the cleared area and germinates so freely, that good results follow.

(b) In the case of artificial regeneration, and for filling up natural regeneration, planting is preferable to sowing, but the planting-holes should be small, and young plants used.

(c) The borders of the forest to windward must be kept densely stocked and all underwood protected, while the soilcovering is strictly preserved.

(d) Stumps should be left in the ground after fellings, and cultivation of cereal crops in combination with sowings of forest trees must not be undertaken.

(e) No pasturage should be allowed, and all servitudes for pasturage, passage of cattle, usage of grass or litter should be legally annulled.

\section{Fixation of the Sand.}

The supply of sand must be stopped at its origin by planting up the sandy hills from which it comes. Loose sand may be fixed by means of fences, or by covering it with branches or sods, and both these methods may be combined. Planting sandgrasses is not advisable, as it only increases the difficulty of restoring forest growth to the denuded area.

\section{a. Fences.}

Fences are generally made by driving into the ground pine stakes 6 to 8 feet long and $2 \frac{1}{2}$ to 4 inches in diameter. They should be driven 2 to 3 feet deep and supported alternately on either side by means of oblique stakes, as shown in Fig. 287.

Between the stakes, branches of Scots pine or of broom should be intertwined, leaving sufficiently large interstices for the sand to pass through, or else the fence would be broken by its pressure. Poplar- or willow-cuttings may be used instead of pine-stakes; they take root, and their side-shoots may eventually be twined into a fence.

The fences should run at right angles to the direction of the shifting sands, on both sides of roads, or other endangered places, their ends being turned round to serve as a protection 
against the winds blowing at right angles to the fences. Several of these horseshoe-shaped fences may be made, at suitable distances, parallel to one another, the distance between them depending on the locality; on level ground a fence will afford shelter for 200 to 230 feet, but on hilly ground for not more than half these distances, and on steep hill-sides not more than 60 feet.

One man can make from 60 to 66 feet of fencing in a day, non-inclusive of the labour of transporting the material. Fence-construction is therefore costly, and fences are not used at present so much as formerly, as they do not thoroughly

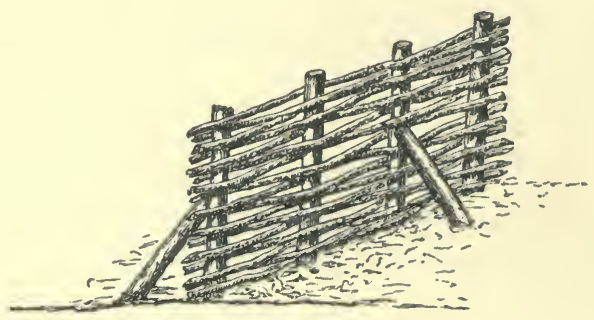

Fig. 287.

fulfil their object. In general, the formation of protective fences is now not followed, as they are expensive to erect, and the results are not considered sufficiently good.

\section{b. Covering the Sand.}

Before covering the sand, all unevennesses on the area should be smoothed down. The wind acts with more force on rough projections in the sand; and the steeper the hillocks, the more readily does the sand roll down them. Small depressions should be filled up with brushwood or wattle-work.

Branches, weeds, grass, seaweed, and sods or straw are the materials used, and, for the sake of economy, the nearest available material should be chosen. Branchy stems of Scots pine, juniper-bushes, heather, broom, reeds or rushes form useful material, and sods are cut from grass or heather land.

Covering the ground with sods is the best method, and is much followed in Hannover and Oldenburg, whilst straw is used 
in Flanders. The covering is chiefly employed for the most endangered places, such as ridges, the windward side of hills, depressions and roads; other places may be readily stocked with forest growth, provided fresh sand is not blown on to them.

The covering should then be applied from $\mathrm{W}$. or S.W. to E. or N.E., the ground being either entirely or partially covered. Roads are generally covered completely, but, in other cases, partial covering is adopted on account of the high cost of complete covering. The looser the sand the more complete
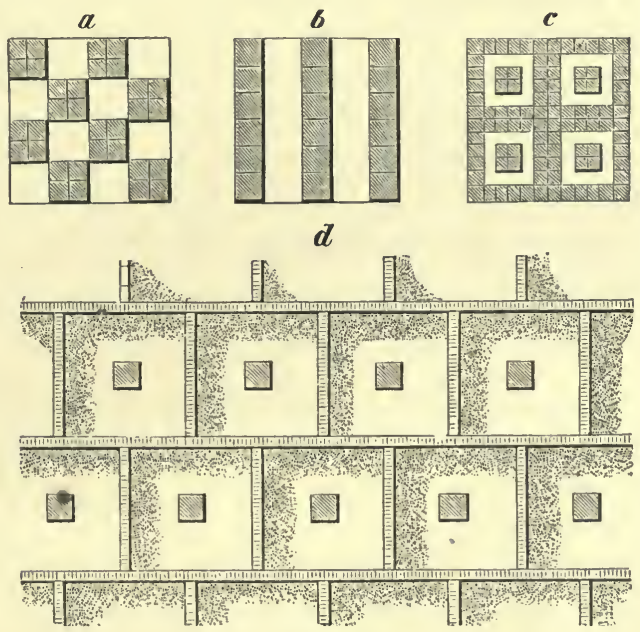

Fig. 288.

should be the covering, and it is always more prudent to do too much than too little in this respect.

Branches are either placed on the surface of the ground, or stuck into the sand, with the bushy end inclined away from the wind, the rows partially covering one another, but their use is not recommended on account of the difficulty in stocking an area which has been completely covered with branches, whilst if they are isolated, they are liable to be blown away.

Heather sods can be used only on level ground in pieces $1 \frac{1}{2}$ to $\cdot 2 \frac{1}{2}$ feet long, and should be tossed equably over the area by means of hay-forks, after it has been sown up with Scots 
pine seed. In the Osnaburg heath, about twelve waggon-loads, with two horses, of heather per acre, are required, and the cost is $\mathfrak{\&} 12 s$. per acre. Sowings thus carried out will generally prove successful if the spring be moderately wet.

Sods are always laid with the earthy side downwards, and should be firmly pressed down.

The diagrams on the previous page show how the sods may be arranged. Where a sod is laid in the middle of each patch, it should be larger than the others, and that form of sodding is preferable, as the loose sand within the patches cannot get out. The lines of sods should be at right angles to the direction of the prevailing wind. The work of sodding should be done during autumn, after the sand has been well soaked by rain, or in the spring, and the ground should be at once sown or planted.

In Germany, partial sodding of the ground costs from $£ 1$ to $£ 3$ an acre, with daily labour at $1 s .10 \%$. Covering with branches takes about forty or fifty cartloads per acre, and costs somewhat less than sodding.

\section{Stocking the Area.}

Fixing the sand should be followed by stocking the area, unless the two operations have been done simultaneously, or the stocking precede the covering, as is the case when branches or heather are used.

The most suitable species are Scots or mountain pines. These species are very hardy, and yield plenty of humus. The mountain pine, owing to its creeping habit, covers the ground admirably. Among exotics in West Prussia, Pinus rigida, Mill., and 1 . Banksiana, Ll., either pure or mixed with Weymouth pine, have given excellent results.

Of broadleaved trees, the robinia, owing to its faculty of producing suckers rapidly, fixes the sand, and has proved successful in Hungary. For damp places, poplars and willows should be used, the Canadian, white and black poplars being most usual. Salix arenaria, L., the Caspian willow (S. acutifolia, Willd.), S. longifolia, Host., or S. cinerea, L., may also be planted, the latter rapidly covering the soil with its creeping lateral branches, and it easily grows through any sand which may be blown over it. 
In South Russia, near Odessa, Ailanthus glandulosa, Desf., is used on sand-dunes, and also in the south of France. This very accommodating species grows rapidly and sends out numerous suckers, and thrives on the hot southern slopes of the Siwalik Hills in India, as well as in smoky London. The cluster pine may also be used, as in Gascony, but it is not very frost-hardy. Sowing is still employed in restocking bare sandy tracts in France, 15 to $20 \mathrm{lbs}$. of seed being used per acre; but in Germany, 3 to 4-year-old transplants with balls of earth are now planted in rows at right angles to the prevailing wind. The plants are put in deeply to prevent exposure of the roots, and because they suffer in summer from the heating of the sand. Scots pines do not suffer at all from this deep planting. In order to get the area stocked as soon as possible, intervals of only $2 \frac{1}{2}$ to 3 feet are left between the rows, and the plants are 1 to $1 \frac{1}{2}$ feet apart in the rows. In Hannover, they are planted with a heavy planting iron, termed Buttlar's iron,* and a mixture of $\frac{2}{3}$ peat with 2 per cent. unslaked lime and $\frac{1}{3}$ sand is used to fill the holes round the roots. The peat is hygroscopic and retains moisture near the plants' roots.

Robinias, poplars and willows are put in as cuttings in little clumps, or in furrows. Sometimes the ground is cultivated before the cuttings are put in, and Scots pine seed sown in the depressions. Hubert recommends that grass seed should be strewn over the plantations. In Austria, Jerusalem artichokes (Helianthus tuberosus) are frequently planted to shelter the woody plants against heat and cold.

In case the sandy tract is so extensive that it cannot be conveniently planted up in one year, a plan of operations extending over a series of years should be drawn up. A commencement should then be made on the windy side of the area, and the cultivation carried on in strips under shelter of the first year's work. In the Landes of Gascony, shelter-fences are erected to the leeward of each year's strip to protect the plants from sand blown back by land breezes. Whenever the work is thus gradually done, great care must be taken to fill up all gaps in the areas to windward before commencing the work beyond it.

*Vide Schlich's “Manual of Forestry," Vol. II., p. 124. 
At Lingen, in Hannover, work has been carried out gradually since 1818 , when there were 3,327 acres to be stocked, of which 75 per cent. was shifting sand, and the balance cultivated land. Between 1818 and 1832, 2,279 acres had been planted successfully, and the balance of 1,048 acres was fairly well stocked by 1837, the total cost, up to 1832 , being $£ 118 s$. an acre.

Forests on shifting sand must be managed most carefully. Pines are regenerated under the Selection or Strip systems, and broadleaved species by coppice. No pasture or removal of litter can be allowed.

An interesting account of the planting of shifting sands near Dresden, in Saxony, written in 1894 by Mr. A. M. Reuther, Conservator of Forests, India, is here appended.

"A considerable area situated within the Dresden Forest Circle has for many years been leased by the Military Department with the object of providing parade-grounds for the cavalry and infantry regiments stationed there. In 1867, it was decided to extend the parade-grounds, for which purpose a further area of $\mathbf{1 0 0}$ hectares was included in the lease; and, in order to obviate payment of compensation, the Military Department allowed the tree-stumps to be extracted, and the litter to be removed from this area after the forest on it had been clear-felled.

"The surface configuration of this area is undulating, and the soil consists mostly of pure sand, containing here and there an admixture of clay, up to 18 or 19 per cent. Very soon after the complete exposure of the soil, the sandy surface began to grow unstable, and already in 1870 the shifting sand, moved by the wind, covered not only the adjacent cavalry paradeground, but also blocked the more distant Königsbruicker Chaussée to such an extent as to interrupt all traffic on it. In the next few years the evil assumed such large proportions that it was found absolutely necessary to reafforest the area with the least possible delay.

"Operations were commenced in 1874 by covering the whole area with a network of wattled fencing. Strong stakes, 3 to 4 inches in diameter, were driven in to the ground 2 feet apart, in rows 1 chain apart running south to north, and interwoven with branches of Scots pine, the wattled fencing thus formed 
being $2 \frac{3}{4}$ feet high. At right angles to these lines of fencing similar fences were made, about 50 yards apart, and 2 feet high. Towards the west, where the general surface elevation is higher and exposed mounds and ridges exist, the fences were placed closer together than on the more sheltered east side, so that the average area of each rectangle enclosed by the fences was about 1 rood on the west, and about 2 roods on the east side. The shifting of the sand was thus greatly reduced, and restricted within the enclosures; and already in 1875 it became possible to begin planting. In that year birch and alder were planted in rows along the fences (on the sheltered side), the planting holes being filled with good soil brought from a distance; and in the following year planting up of the interior of each rectangle was begun with Scots pine plants 1 to 2 years old, which were put out in squares with the aid of Buttlar's planting tool, 3,200 plants being used per acre, and each plant supplied with a handful of good humus soil. The compost was prepared in autumn, and left lying in heaps during the winter, and conveyed to the site of the plantation just before the planting season in spring.

"The results are quite satisfactory in so far as the ground is now fully stocked, and the surface soil completely consolidated. But owing to the dryness and poverty of the soil, the growth of the plants is in many places very miserable, many of the Scots pines being only 1 yard high, though already 15 to 18 years old. The average height is, however, about 16 feet, and for the most part the plants have closed overhead. The entire area has been most carefully protected; cattle have been strictly excluded, and grass cutting disallowed, and all unauthorised persons have been prohibited from walking across it. These precautions were absolutely necessary to prevent disturbance of the unstable surface soil, and to give the plants a chance of establishing themselves.

"The cost of the cultural operations was 18s. per acre. .The wattled fencing.was constructed by a local battalion of Pioneers, and therefore involved no direct outlay; had the work been done by paid labourers, the cost would have been about $2 \frac{1}{2} d$. per running yard of fencing." 


\section{CHAPTER IV.}

\section{PROTECTION AGAINST FOREST FIRES.*}

Fiorest fires are nearly always caused by human agency, generally owing to carelessness, but are sometimes intentional ; they are also occasionally due to lightning.

It is intended to treat the subject according to thesse causes, taken in order.

Section I.-Forest lires caused by Human Agency.

\section{Causes.}

The following acts, omissions, or occupations may cause forest fires :-

Kindling a fire without permission in a forest, or by the side of a forest road, in order to warm themselves or to cook their food, by travellers, or men engaged in felling trees, roadmaking, etc.

Leaving a fire, which has been lighted by permission of the forest manager, without completely extinguishing it.

Carelessness of charcoal-burners whilst burning their kiln, or extracting charcoal from it.

Burning branches or weeds whilst cultivating crops on forest-land or on fields adjoining forests, also burning moor-, heather-, or grass-land.

Burning bark to destroy beetles, etc.

Night-fires by poachers after fish or game; burning out wild bees. The collection of wild honey and wax is common in East Prussia and in Russia and India, and frequently gives rise to forest fires.

Shooting in forests with rag or paper wads.

* Gerding, "Fires in the Lüneberger Haide," "Frstl. Blttr.," 1886, p. 241 ; Fernandez, "Notes on Indian Sylviculture" (2nd edition), 1893. This book gives a very detailed account of the measures for combating forest fires. 
Smoking in forests; throwing down burning cigar.ends or matches.

Carrying on dangerous industries in or near forests, such as the manufacture of pitch or turpentine, and also iron-smelting furnaces, or foundries.

Sparks from locomotive engines, especially when burning turf or lignite, and unprovided with spark-extinguishing apparatus.

Intentional firing of forests, for selfish motives, as when shepherds or farmers burn extensive forest areas to obtain fresh grass for their flocks and herds, for it grows up luxuriantly after a forest fire.

Motives of revenge, or superstition, as in India, where a deodar forest was burned to propitiate the goddess of small-pox.

It follows from a consideration of the numerous causes. of forest fires that the forester must be wide awake to prevent such calamities. Private resources are here quite insufficient, and the State must assist by framing suitable laws, and by instructing officials to be active in enforcing them.

\section{Kinds of Forest Fires.}

Forest fires may be in the ground, in the soil-covering, or in the crowns or stems of the trees.

\section{a. Ground-fires.}

These occur in peat, lignite, or.coal; they proceed slowly unless they come to the surface, when they partake of the character of fires in the soil-covering. Ground-fires rarely occur in forests.

\section{b. Surface-fires.}

These are the commonest and most important fires the forester has to contend against, burning the dead leaves, heather, grass, and other soil-covering of a forest.

\section{c. Fires in the Crowns of Forest Trees.}

These are less frequent in Central Europe, though common in North America and not unfrequent in India. They - generally arise from surface-fires, which spread to the crowns 
of the trees. A dense coating of lichens on the trees increases the danger of the occurrence of crown-fires.

\section{d. Fires in Stems.}

Green trees seldom catch fire even from lightning,* and when a whole stem is burned, there is generally some decay present, and the trunk or branches of the tree are hollow.

\section{Damage done. \\ a. General Account.}

Forest fires do direct damage by destroying whole woods, and especially young growth. Reproduction may be stopped for the year by the destruction of blossom or fruit, while, owing to repeated fires, broadleaved trees which are not killed become misshapen and weakly. Game may be killed in extensive fires. By heath fires in Hannover many hives of bees are burned.

Indirect damage consists in the burning of the dead leaves or needles on the ground, which prevents the accumulation of humus and the improvement of the soil, and renders it poor, hard and unsuitable for reproduction. Henry states ("Rev. d. E. et F.,"June 1st, 1902) that high forest produces the following quantity of dead leaves in 6 years per acre :-

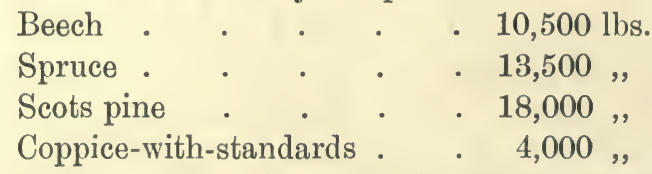

There is about $1 \frac{3}{4} \mathrm{lbs}$. of nitrogen in $100 \mathrm{lbs}$. of dead leaves, worth about $7 d$. a pound. The value of the nitrogen destroye 1 in the dead leaves is $14 s$. per acre for coppice-with-standards, and three to four times as much for high forest.

A proper sequence of age-classes may be interrupted. The annual burning of the soil-covering on hill-sides may cause

* Von Tubeuf, in 1892, observed that lightning had set fire to a growing spruce tree, and the fire spread to neighbouring trees.

In the years $1877-1883$, there were 509 fires in the Bavarian State forests, which arose as follows: 2 from ground-fires; 416 (82 per cent.), surface-fires; 70 (40 per cent.), combined surface and crown-fires ; 15 ( 3 per cent.), combined surface and stem-fires ; 6 ( 1 per eent.), stem-fires. 
soil-denudation when it is followed by heavy rain; this was the case in the Siwalik hill-range, extending over fifty miles between the rivers Ganges and Jumna, and its protection from fire was demanded in 1882 by the Indian Irrigation Department to prevent their canals from silting up. Some American forests are so seriously injured by fire, that rainwater passes over the soil, as over a roof. Observations have shown that up to 90 per cent. of the rainfall runs over the surface of burned forests and fills the watercourses with silt and other debris.

There is an increased tendency to breakage and to damage by insects, also to growth of weeds and consequent increased cost of sowing and planting. Fires are extremely injurious in forests on shifting sands.

After fires in Scots pine woods, the following insects may become extremely abundant and destructive: Myelophilus piniperda, L., in Fngland and Germany, in Germany only, Pissodes notatus, Fabr., T'omicus bidens, Fabr., T. Laricis, Fabr., Hylastes palliatus, Gyll., and Hylurgus minor, Hrtg., Myelophilus minor, Hrtg., etc.

\section{b. According to Species.}

In Central Europe, conifers suffer much more than broadleaved species from fire, owing to their resinous nature, and to the inflammable evergreen needles, which favour the spread of the fires. The Scots pine and the Austrian pine are the most exposed to danger. Other pines, such as Weymouth pine, are grown only to a limited extent, or, as in the case of Cembran and Mountain pine, they grow on high mountains, where fires are less dangerous. The greater danger the Scots pine experiences from fire is due to the early drying up of its lower branches and to the dry nature of the soil-covering, owing to the imperfect leaf-canopy of this tree and to the nature of the localities (heather lands) on which extensive pine forests occur. In France, the forests of maritine and Aleppo pines are specially liable to fires.

After pines, come in point of danger, first, the spruce, then silver-fir, and lastly, larch, owing to its being a deciduous tree.

F.P. 
Pinus rigida, Mill., in the Cotten forest near Bonn, in March, 1893, produced shoots from dormant buds, after a fire, but not a complete crop. The plants, 7-10 years old, were cut back, after the fire, and produced 9 or 10 shoots each, 38 c.m. high.

Amongst broadleaved species, rough-barked trees, such as oak and elm, withstand fires better than smooth-barked trees, such as the beech, ash or sycamore.

Fires are evidently more frequent and dangerous in High Forests than in coppices.

\section{c. Age of Trees.}

Young woods up to thirty years old are most exposed to fire, at first owing to the presence of weeds, later on, as the struggle for existence is strongest, and there is usually most dead wood at this period.

Well-stocked woods between $30-60$ years of age withstand fires best of all, as middle-aged coniferous woods after the earlier thinnings contain least combustible material, such as dead wood, grass or heather undergrowth.

Woods over 60 years of age, where grasses and other weeds spring up, again become more endangered.

The following average figures, taken from a list of forest fires in Hanover between 1864-84, support the above conclusions. Out of 1,000 acres of forest, there were burned annually during these twenty years:-

Broadleaved woods

Age. Acres.

Coniferous woods.$\quad \cdot \begin{cases}1-30 \text { yrs. } & 1 \cdot 107 \\ 30-60 & 0 \cdot 262 \\ \text { over } 60 & 0.354\end{cases}$

Mixed coniferous and broadleaved forest \{ $0 \cdot 464$

\section{d. Locality.}

Forests in plains, on account of the greater dryness of the air, and frequently of the soil, suffer more than mountainforests. On sunny aspects fires spread much more rapidly than on cool northerly slopes. A dry sandy soil increases the 
danger. Fire burns more slowly down-hill than up-hill, and the more so the steeper the slope and the stiller the air. As a slow fire is more easily regulated than a fast one, in jhums, or cultivations on forest clearings where the branches and undergrowth are burned, it is better to burn down-hill.

\section{e. Soil-Covering.}

A tall growth of heather, genista, broom, or grass, etc., increases the danger of fire, and so does an undergrowth of juniper or of sundry conifers. A mossy covering is prejudicial only in seasons of drought, and a covering of dead leaves or needles is usually a bad combustible, though fire in it may smoulder on for days. Whenever much branchwood, refuse of fellings and dead fallen wood, lie on the ground, the danger is increased.

Above all, Scots pine woods on heathland with dry soil and soil-covering and combustible foliage are most exposed to forest fires. In a pine wood, where all the soil-covering has been removed, a fire would find nothing to feed on.

In badly stocked Indian forests, the grass is frequently 6-8 feet in height, and in the open in Assam, the flowering stems of reeds may attain a height of 24 feet. The fierceness with which a fire passes through tall grass during the dry season must be seen to be believed, the sparks and flames sometimes crossing rivers one hundred yards broad.

The leaves of many of the Indian forest trees, such as the teak ('T'ectoria grandis, L. fil.) and the Sál (Shorea robusta, Gaertn.) fall in March and April during the dry season and when dead are very inflammable.

\section{f. Density of Growth and Extent of Forest Area.}

In so far as density of growth kills down heather, grass and other inflammable undergrowth, and provided all dead wood is removed in the thinnings, a densely stocked wood is less liable to be ignited than a thin wood with inflammable undergrowth. Once, however, that a dense forest is ignited, and especially if the fire is in the crowns of the trees, it can generally be extinguished only by a fall of rain, or a sufficiently wide gap in 
the wood caused by a road, river, fields, etc., or by purposely counter-firing or felling trees across its path.

If a forest is liable to be burned, it is better to subdivide it into small areas by fairly numerous rides and roads.

\section{g. Season.}

Most fires in Central Europe occur in dry springs from March to May when east winds prevail and the dry grass, leaves, and weeds under the trees and the presence of numerous workmen in the woods increase the danger.

The 509 fires in the Bavarian State forests (p. 640), during the years $1877-83$, which extended over 1,160 acres, occurred in the following months: January, 4; February, 4; March, 118; April, 114 ; May, 140 ; June, 51; July, 43 ; August, 20; September, 12 ; October, 2; November, 0; December, 1. Thus 73 per cent. of the fires occurred in March, April and May, and only 27 per cent. in the remaining months. Similar results follow from statistics in Hesse.

Forest-fires also occur in hot and windy summers, as in the years 1892 and 1893. Winter fires may occur on southerly aspects with dry grass. Two hundred and fifty acres of forest was thus burned at Oberammergau on the 14th January, 1898. In the case of some fires, it has been remarked that they generally fall off in violence during the night, but recover force again after sunrise, this being due to the daily variation in the strength of the wind, and sometimes to the nightly dew, which may extinguish a fire.

In tropical and semi-tropical countries forest-fires occur during the dry or hot seasons, and are very rare during the more or less prolonged summer monsoon. Thus in the NorthWest Himalayan coniferous forests, there may be fires in November and December, until snow has fallen, and then again from April till the monsoon breaks early in July, after the melting of the snow.

In the extensive Sál forests at the foot of the Himalaya mountains, extending from the Jumna river to the Borelli river in Assam, there is danger from fire from February till July, and this danger is increased by the fall of the dead Sál leaves in March and April. In the western part of these 
forests the danger from fire is probably greatest in May and June, whilst in the eastern parts in Bengal and Assam, where spring rains occur, the forests are fairly safe from fire in May, owing to the growth of fresh grass, which is incombustible.

\section{Register of Fires.}

Forest fires are of frequent occurrence in the heathlands of Berkshire, Surrey and Hampshire. They are not unfrequent in Germany in spite of the great care taken to prevent them, but their extent and frequency are inconsiderable when compared with Austria, the South of France, Sweden, Norway, Russia, Greece, India and North America. In this last country, forest fires frequently extend over hundreds of square miles of forest, and little or no trouble is taken to extinguish or prevent them. The most disastrous forest fires which have occurred in Germany during the present century are given below :-

1800, 4th to 21st August, 5,675 acres in the Black Forest near the Katzenkopf in Württemberg.

1863, 28th to 30th August, 3,300 acres near Königsbruch in W. Prussia.

1880, 1st to 3rd May, 3,250 acres on the Luineburg heath.

In the Prussian State forests, during the interval 18921898, the following damage by fires was done:-

\begin{tabular}{|c|c|c|c|c|c|}
\hline Year. & High Forest. & $\begin{array}{c}\text { Coppice } \\
\text { and C. with } \\
\text { standards. }\end{array}$ & $\begin{array}{l}\text { Wasteland } \\
\text { Heather, etc. }\end{array}$ & Total. & $\begin{array}{c}\text { Area stocked } \\
\text { with scots } \\
\text { Pine. }\end{array}$ \\
\hline $1892-93$ & $\begin{array}{l}\text { acres. } \\
8,436\end{array}$ & $\begin{array}{l}\text { acres. } \\
117\end{array}$ & $\begin{array}{l}\text { acres. } \\
1,623\end{array}$ & $\begin{array}{r}\text { acres: } \\
1(1,176\end{array}$ & $\begin{array}{l}\text { acres. } \\
6,285\end{array}$ \\
\hline $1893-94$ & 576 & 14 & 225 & 815 & 410 \\
\hline $1894-95$ & 539 & - & - & 539 & 427 \\
\hline $1895-96$ & 2,495 & - & 28 & 2,523 & 1,178 \\
\hline $1896-97$ & 102 & - & 4 & 106 & 101 \\
\hline $1897-98$ & 77 & - & - & 77 & 46 \\
\hline
\end{tabular}

It may be stated that, in Germany, on the average, out of 2,500 acres of forest half an acre is burned annually, or 0.02 per cent. of the forest area.

In Austria, in $1881-85$, there were 1,717 fires over 16,378 acres, the amount of damage done being $£ 10,367$. 
In France, between 1865 and 1870, about 25,000 acres of cluster-pine forest was burned in Gascony, and a large area was burned in 1893, including 1,200 acres near Arcachon in the forest de la Teste. There was also a large conflagration in these forests in 1898, extending over 63 miles, and causing damage valued at $£ 80,000$. The worst districts in France, however, for forest fires are the Départements of the Maures and Esterel, north of Marseilles, where large areas of forest, chiefly consisting of Quercus Ilex, L. and Pinus Halepensis, Mill. are burned every year, and a special law has been enacted for their protection from fire.

Extensive forest fires occur every year in Russia. In Canada, in 1868, it was estimated that $400,000,000$ dollars worth of standing timber was destroyed by fire. One of these fires extended 160 miles in ten hours.

The forest fires in September, 1881, and again in 1894 in the States Minnesota, Wisconsin and Michigan of the United States of North America were of enormous extent, hundreds of human beings being burned with their houses and cattle. Statistics are wanting to give some idea of the enormous annual destruction of forests in N. America by fire, and especially of the Southern pine (Pinus palustris, Mill.) which yields the best coniferous timber known in the whole world.*

Protection from fire of the State forests in British India has been seriously undertaken during the last forty years, and measures with this object in view are carried out on a large scale and at considerable cost to the State. Thus, in 18991904, measures were taken to protect from fire 35,236 square miles of State forest, the failures in this area amounting to 8 per cent. The cost of protection in 1891-92, averaged 10 rupees a square mile, or at $1 s$. $2 d$. per rupee $11 s$. $8 d$., being as low as $2 s .4 d$. in the Bombay Presidency. Besides the above, there are 66,196 square miles of State forest, in which either the forest is of such a character as to demand no special protective measures against fire, or its protection has not yet been undertaken. 'This takes no account of protection against fire in the forests of Native States, some of which are admirably managed.

* Cf. A Primer of Forestry, Gifford Pinchot. Washington, 1903. 
5. Prolective Measures.

From what has been already said, it is clear that for Central Europe, protective measures against fire have chiefly to be carried out in coniferous forests. The following rules will serve for private forests :-

(a) Mixture of broadleaved species in coniferous forests, either by single trees, groups, or in whole compartments, or as protective belts round the coniferous woods. Such protection is specially needed along the borders and roads through Scots pine forests.

Birch, oak, beech, black poplar, and robinia are suitable species, and the belts should be 25 to 35 feet broad, and may be either High Forest or Coppice. Such belts are largely used in the Landes of Gascony to protect the cluster pine from fire, and should be kept free from heather, ferns, dead leaves, and underwood, which are readily sold for litter. In the Tucheler Heide, ditches 2-3 metres broad are dug round endangered woods, and the spoil heaps formed into a mound inside the ditch. These mounds are planted with birch one metre apart, and have proved efficient. A similar plan is adopted in the sandy parts of Windsor forest.

Except in coniferous mountain forests, belts of broadleaved trees are practically useless in most parts of India, as trees that retain their foliage during the dangerous months will grow well only in moist places. In Assam, however, belts of evergreen forest growing in low ground on either side of watercourses frequently act as protective belts to the drier deciduous Sál forest on either side of them.

\section{b. Fire-Traces.}

Wherever forests are surrounded by inflammable undergrowth such as heather, grass, etc., fire-traces of sufficient breadth should be made along their boundaries, and internal fire-traces are also required for all extensive inflammable forest areas, to limit the extent of the damage done, in case a fire should cross the boundary, or break out within it. The number of internal fire-traces required for a forest must be left to local experience, but the forest manager should remember 
that a considerable area of forest is rendered unproductive when the length or breadth of the internal fire-traces are excessive, and that the cost of protection is thus greatly enhanced, so that he will limit the number and breadth of the fire-traces to the minima compatible with efficiency.

Fire-traces in Europe are broadest for coniferous forest, but rarely exceed 100 feet in breadth, while in India they are sometimes 400 feet broad.

Whenever the soil-covering on the traces can be utilised for thatching material, litter or fodder, it should be cut and removed. This may often be done by concessioners at no cost to the owner of the forest, or even on payment to him of a certain sum. It frequently happens, however, that the soil-covering has no local value, and must then be carefully burned to avoid the greater expense of cutting it.

Before burning fire-traces, the soil-covering is usually cut on guide-lines on either side of the trace, their breadth being about three feet more than the height of the covering. For greater safety, cross lines as broad as the guide-line are sometimes cut at intervals across the trace itself, so as to divide it into segments, each of which may be burned separately.

The guide-lines should be cut some time before the fire-trace is to be burned, and the cut material thrown on the trace, where it will dry, and facilitate the burning. A broad short scythe or a sickle may be used to cut the grass, heather, etc., from the guide-lines.

In burning the traces, it is a golden rule to remember that grass and heather in the open become dry sooner than under cover of the forest, so that border fire-traces may be burned before the internal ones. In firing a trace, a still afternoon should be chosen and men placed on either' side of it, two of whom fire the edges of the traces up to a cross line, if one has been cleared, or if not, to a sufficient distance for the other men to be able to beat out the return fire which runs along the ground in the stubble towards the forest. The other men, armed with evergreen boughs, which they can use to protect their faces from the heat of the fire, keep back on the guidelines, or even in the forest beyond them, until they see the return fire approaching too near the edge of the forest, when 
they rush forward and beat it out, leaving the flames from either side to meet in the trace, and burn all the standing grass or heather within it.

It should be noted that however still the air may be, before firing a trace has commenced, the ascent of hot air due to the fire will draw in colder air from all sides to fill up the vacuum thus produced, and if the wind be blowing in the faces of the men on one side of a fire-trace, lighting in the middle of the trace, as well as along its sides, will draw in the flame away from the men on the dangerous side, in spite of the wind, and will thus greatly facilitate their work.

On hill-sides, fire-traces should run along ridges, and they may be made zigzag when the hill-sides are steep, and are burned downhill. In forests where numerous fire-traces are cleared annually, it is often advisable to mark off the limits of the guide-lines by a simple trench of the breadth and depth of a plantation-hoe.

Where the soil-covering is very dense and tall, it is better to burn the traces twice, at first before they are completely dry, and again whenever dead leaves fall on the traces after the grass has been burned; dead leaves should be swept away or burned, in order to render the trace impassable by fire. This leaf-burning is, however, a simple operation which may be carried out by three or four men, whilst the first burning in dense tall grass may require 20 men, or more.

If by accident, during the burning of a fire-trace, the fire should get into the forest on either side of it, the further burning of the trace must be suspended until the fire in the forest has been extinguished; to do this it must be attacked on both sides by the gang of men and driven into the shape of a wedge.

One or two trustworthy men should follow the firing gang on either side of the trace, and should carefully extinguish all smouldering embers on the guide-lines, and throw all burning twigs and pieces of wood from the latter on to the middle of the trace, so that there may be no possibility of the forest catching fire from the very means which are taken to protect it.

Very full details as regards the practice of burning firetraces are given in Fernandez' Indian Sylviculture, and need 
not be repeated here, as in Europe the work of burning firelines is much simpler than in hot countries.

\section{c. Watching the Forests.}

During the dry season, after all the fire-traces have been

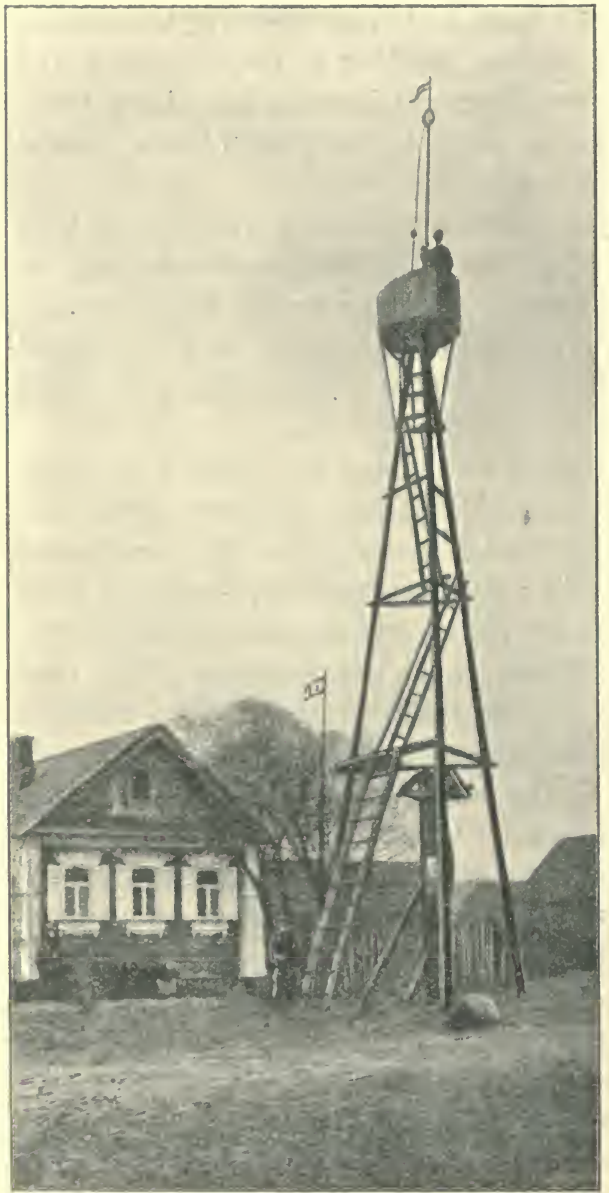

Fig. 289.-Russian watch tower for fire-guard. cleared, and until sufficient rain has fallen to render the forest safe from fire, it is often necessary to appoint special patrols to watch the forest, in addition to the ordinary protective establishment. 'These men warn all passengers along the roads of the danger from fire, sweep off or burn dead leaves on the fire-traces, relieve one another in night - watching, and instantly report all cases of fire to the forester and forest guards, when organised measures can be taken to extinguish it. In some cases, seats are made for the fire - watchers in trees, with ladders for ascending them, in order that any outbreak of fire may at once be detected. In Russia, special watch-towers are erected (Fig. 289). 


\section{d. Trenches round Peat Deposits.}

Wherever peat occurs in the forest soil, deep trenches should be dug round the peat deposits to isolate them from possible forest fires.

\section{e. Conduct of Thinnings.}

Early and careful thinnings should be made in young coniferous woods, and all dead branches should be pruned off and removed. The least that should be done is to clear the boundaries of all compartments of dead wood to a breadth of 30 to 45 feet.

\section{f. Along Railway-Lines.}

Fire-traces must be kept clear of woody growth, and of dead leaves, heather, and other inflammable material along all railway lines passing through forests. Most forest fires due to sparks from locomotives break out within 30 feet of a railway line, but to render the fire-traces quite effective, they should be 60 feet broad. The French law regarding forest-fires in the Maures and Esterel, makes such fire-traces compulsory along all railway-lines running through the forests of those Départements.

A short act, for the United Kingdom, named the Railway Fires Act, became law on the 4th August, 1905, making railway companies liable for damage done to crops, to the extent of $£ 100$. This limit to the value of the damage does not meet the necessities of the case, as regards extensive woods on dry sandy soil.

\section{g. Roads and Rides in the Forest.}

The network of forest-roads and rides may afford considerable assistance against fires. In order to protect the forest on either side of roads from any risk of fire from sparlss from pipes, etc., of travellers, or cartmen, all inflammable undergrowth and dead leaves should be cleared from the roads, and from a strip 10 to 15 feet broad on either side of them.

Some of the rides may be cleared as fire-traces, and where the prevalent winds are from the west, it is better that rides to be cleared as fire-traces should be at an angle of about 75 
degrees to the wind direction, as it is easier to burn them, and they afford a broader barrier to a fire coming from the west than if they were simply at right angles to the direction of the wind.

Besides roads and rides, watercourses often form effective fire-traces when the undergrowth is cleared away and burned on only one side of the watercourse at a time, but crossing the watercourse at its bends, so as to form a uniformly broad trace.

\section{h. Size of Working Sections.}

Where forest fires are to be feared, the working-sections should be comparatively small, so that there may not be extensive tracts of young woods, in which the danger from fire is greatest over large areas.

\section{$i$. Clearance of Felling-Areas.}

The felling-areas should be rapidly cleared of all refuse, and the produce of the thinnings also removed quickly, especially in the case of faggots from coniferous trees.

When workmen sleep on the felling-areas, great care must be taken as regards smoking, and fires should be allowed only inside their huts, which should be surrounded by broad firetraces, as the wind might otherwise blow sparks into the forest. In parts of Northern India, during the hot dry months of May and June, it has been customary to suspend all timber works owing to the risk of fire from the woodmen and carters, but these men can easily be taught to guard the forest from fire, and it is doubtful whether this restriction is necessary.

\section{j. Other Measures of Protection.}

Regulations restricting fires and smoking in forests in dry seasons, and also regarding the use of fire-arms, should be made by the State. The most complete State-regulations regarding forest fires are those enacted in $\mathbf{1 8 9 3}$ by the French Legislature. Somewhat similar rules are enforced in British India, except as regards railways, but they apply only to certain State forests. The private forest-manager must see that all State regulations regarding forest fires are observed, and should 
instruct the workmen engaged in occupations endangering the forest, such as charcoal or lime burning, what protective measures they must adopt, and should see that his instructions are followed.

In the British Isles, in addition to the law regarding fires caused by locomotives already referred to (p. 651), there is a Scotch law (13 Geo. III., cap. 54), making it illegal to burn muir or heath land in Scotland from 11th April.till 1st of November, under penalties of $40 s$., $£ 5$, and $£ 10$ for first, second and third offences, with alternative of imprisonment for six weeks, two or three months respectively.

During the dangerous season, the forest guards must be constantly on the watch against fires, as well as the fire-patrols, if it has been found necessary to engage additional men. All contraventions of the State regulations regarding forest fires should be at once reported to the police, or to a magistrate.

In order to prevent intentional firing of a forest, no privileges to cut grass, or to graze, should be conceded on an area which has been burned.

In India difficulties arise with sportsmen, when from fear of fires the forests are closed to shooting during a season which would be otherwise open. Special permission is sometimes given by Government to forest officers to open the forest temporarily to shooting after a heavy shower of rain, during the dry season, or in order to shoot tigers, or other destructive beasts. The shelter afforded to game or noxious animals by high grass near villages may become a great nuisance to the villagers, and the forest officers should not carry the practice of protection from fire too far in such cases, and it may even be advisable to burn off worthless tracts of scrub forest or grassland for pasturage, so as to keep public opinion on the side of the forester. On the other hand, Indian State forest officers have direct power to arrest offenders, and to call on all forest right-holders and workmen to assist in extinguishing a fire, and in certain cases, privileges and rights to forest produce may be temporarily suspended by the Government, in cases of wilful firing of a forest by villagers, or their refusing assistance when once a fire has broken out. 
A system of telephones in endangered forests is extremely useful, enabling the managers to mass men at points where a fire has broken out. In the Count of Frankenberg's forests, at Tillowitz in Silesia, such a system exists, connecting the forest guards with the manager's office.

\section{Rules for Extinguishing Forest Fires. \\ a. General Rules}

If a fire should break out in a forest, the manager must call on all available labourers from the nearest villages, as well as the forest workmen, to hurry to the site of the fire, and carry out the necessary measures for extinguishing it. The workmen should bring bill-hooks, hoes, iron-rakes, and axes, and provide themselves with saplings or branches to beat out the fire. The chief object should be to limit the progress of the fire at the smallest possible sacrifice of still unburnt woods. 'This is best done by attacking the fire on both sides nearly parallel to the direction of the wind, and gradually beating it out in the shape of a wedge. The burned area must be abandoned to the flames. The result depends on the presence of mind, courage, energy, decision of character and practical directions of the head forester present, and on the obedience, zeal and skill of the men. The chief forester present must be thoroughly acquainted with the locality, as it may be necessary to sacrifice an area of unburned forest by counterfiring. In order to detect at once any fires arising from sparks which may cross fire-traces, men must be posted at all threatened points around the actual fire. As it may talse several days to extinguish an extensive forest fire, arrangements may be required to work the available labour force by relays, and to supply the men at work with food and drink.

In countries like India, where forest fires are common, wherever the villagers willingly come forward to help in extinguishing fires, concessions may be made to them of dead firewood or thatching grass, and in case of the fire burning the houses of a village, situated near the forest, the manager should be ready to help with building and thatching material, either free or at cheap rates. 
In such localities more than half the battle against forest fires is won, when the protection of the forest from fire meets with sympathy from the neighbouring villagers.

In France and Germany, it is usual to call out the soldiers of a regiment quartered near the forest to assist in extinguishing extensive forest fires.

The cost of extinguishing fires varies between 20 and 50 per cent. of the damage done; in Saxony, 1889-93, it was 23 per cent.

\section{b. Ground Fires.}

The burning area must be isolated by digging trenches, which must be deep enough to prevent the fire from finding its way below them. Water should be poured on the burning turf, or soil from the trenches heaped on to it.

\section{c. Surface Fires.}

The fire should be beaten out with green branches as already explained. Wherever there is a dense undergrowth,

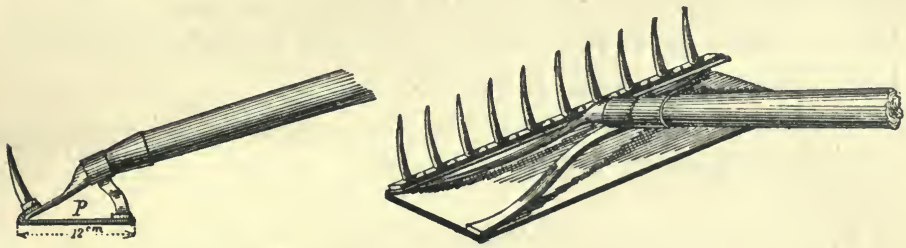

Fig. 290.-Rake used.in protection against fire.

as in the case of heather, it is better to beat down the fire vertically, but where the soil-covering is low, the branches should be used backwards and forwards like brooms to sweep it out.

At the spot where the fire commenced, workmen should clear away a strip of the soil-covering in order to isolate the fire. Iron rakes, Fig. 290, of a special kind can be used for this purpose with advantage, and unburned litter may thus be drawn by the teeth of the rakes towards the. workmen, or burning litter be pushed away by using the rake reversed.

Freshly dug up earth may be thrown on the fire.

A clearance, or fire-trace, may be made in front of the fire to stop its further progress. The distance of this from the 
fire should be so chosen that the fire-trace may be completed before the fire reaches it. In making this fire-trace, all the soil-covering should be cut and removed, and if there is time, a trench may be dug, and the earth from it piled up towards the fire.

It may be necessary to counterfire from a road, stream, ride or fire-trace; the soil-covering is then burned, and this fire directed so as to meet the advancing forest fire, when the two fires meet and become extinguished for want of fuel. This is a very efficacious remedy, but demands great care, and can be carried out only when the air is fairly still, and the undergrowth not too high, or fire may ignite the crowns of the trees; it will evidently be resorted to only in extreme cases.

\section{d. Crown Fires.}

The wooded area must be interrupted by felling a strip of trees in front of the fire, which is best done along a road or ride. The smaller trees should be dragged away, if there is time to do so, taller trees should be felled towards the fire and their crowns lopped off, if possible.

Counterfiring is of little use against crown-fires, but may be tried, if only young growth is burning.

\section{e. Stems on Fire.}

When a solitary hollow tree is burning, the hole may be stopped with sods or earth. If, however, the hollow extends to the top of the tree or through one of its main branches, the tree must be felled, after clearing away the undergrowth and soil-covering all round it, and the fire should then be extinguished with water or soil.

\section{Watching the Site of the Fire.}

In order to guard against a fresh outbreak of a forest fire, its site should be carefully watched by trustworthy persons until all further danger is over. In a coniferous forest, where the soil is deeply covered with dead needles, danger of rekindling may be incurred for a week or more after the fire has been extinguished, unless rain falls. The manager 
should go completely round the burned area and see that it is properly isolated from the surrounding forest by clearings of the soil-covering and trenches. All burning pieces of fallen wood on the site of the fire should be covered with earth, and wherever any fire reappears, it should be at once beaten out.

\section{Treatment of Woods Injured by Fire.}

The treatment of burned woods depends on their age, the extent of the fire and the amount of injury done to the trees.

Burned young coniferous woods should almost always be dug up and the area at once restocked. Occasionally young Scots pines may put out fresh needles and recover.

Older coniferous woods with uninjured crowns and with merely their bark singed may be left standing. If, however, the bast and sapwood should be seriously affected, it will be necessary to fell the trees, and especially if it is subsequently found that they have been attacked by beetles, as, for instance, Myelophilus piniperda, L., which will breed in the summer in pine woods that have been burned in the spring, and proceed in the autumn to thin out the crowns of all the trees around the site of the fire. Where this is to be feared, it is better to fell all trees that are apparently so weakened by the fire as to encourage the breeding of these destructive insects.

We should not, however, be very ready to fell broadleaved trees, as oak-woods, for instance, sometimes recover after being burned, especially the dominating trees, but beech are more susceptible to damage by fire. It is better in doubtful cases to await the next season of vegetation before deciding what is to be done. Young broadleaved woods may be cut back if seriously injured, but even this operation may be put off till the ensuing spring, as it may then prove unnecessary.

More information is necessary as to whether it is advisable, in particular cases, to fell, cut back or leave trees that have been injured by fire.

\section{Insurance against Forest Fires.}

After several fruitless attempts to found a society for assuring forests against fire, in 1895 the Munich Gladbacher 
Fire Insurance Company agreed to insure against damage by forest fires throughout Germany, and appointed a forest expert as manager of this branch of their business.

The company insures standing crops of trees up to the age of 60 years, and felled timber as long as it is the property of the insurer. Damage in burned forests is assured at its costvalue whenever this exceeds its actual value. The premia vary according to the greater or less danger of particular crops from 45 pfennigs to 4 marks per 1,000 marks of their insured value. For ordinary crops $1-60$ years old-

Pure broadleaved woods . . 0.85 marks.

Mixed coniferous , . . $1 \cdot 20$ "

Pure coniferous " . . $2 \cdot 00$,

In Switzerland, insurance against fire has been effected (1906) at 10 per cent. of the endangered capital.

In Belgium, insurance can be effected against forest fires at the following rates of premium per 1,000 francs value :-

Broadleaved woods . . 60 centimes.

Conifers under 20 years old . 6 francs.

" over " , . 5 francs.

\section{Section II.-Effects of Lightning on Trees.**}

Much has recently been written about lightning and its effects on trees, but the causes of thunder-storms are not yet clearly known. The action of lightning on trees also requires further study.

\section{Mode of Striking.}

When lightning strikes a terrestrial object it is termed a " direct stroke."

It is termed hot when it sets fire to the object, it is otherwise cold.

A back-stroke occurs when the accumulated positive or negative electricity at the top of an object, such as a tree,

* Klein, "Das Gewitter und die dasselbe begleitenden Erscheinungen." Graz, 1871.

Baur, "Der Blitz als Waldverderber," "Monatschrift fiur das Forst. u. Jagdwesen," 1873, p. 97.

Rippold. "Die Enstehung der Gewitter." Frankfurt-a.-M., 1897. 
strikes downwards, the inducing electricity in the cloud having struck in another direction, another tree for instance. One theory of the action of lightning, that of $\mathrm{F}$. Cohn, of

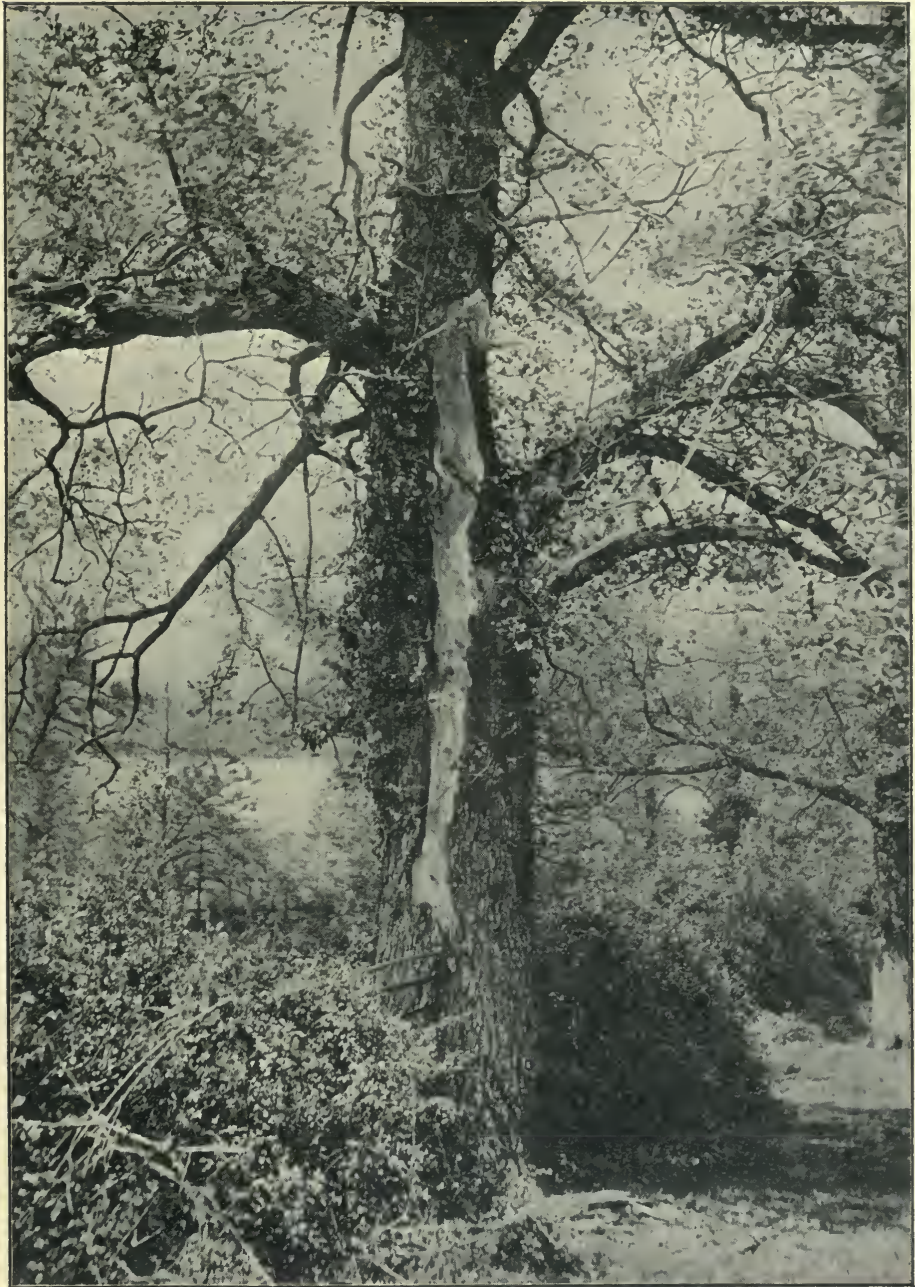

Fig. 291.--Elm tree struck by lightning, Cooper's Hill grounds, 27th Sept., 1897.

Breslau, is that when lightning strikes a tree the wet cambiumzone conducts the electrical discharge, and the contained 
water is suddenly converted into vapour. The expansion thus caused strips off the bark at the points of least resistance, and if the bark be smooth and thin, large pieces of it may be removed (Fig. 291). The wood may also be split from the top of the tree downwards, the lightning entering at the fine twigs on the top of the tree and running down the stem straight or spirally according to the direction of the fibres.

\section{Damage done. \\ a. General Account.}

The effects of lightning on a tree are very various; if the tree be split, the bark is usually removed only in a narrow

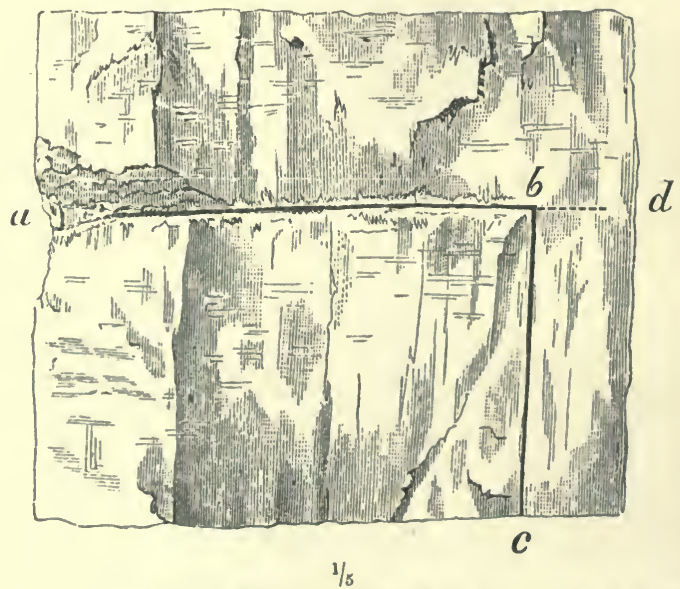

Fig. 292.-Horizontal lightning-stroke along $a b c$ on a beech tree.

$a$ Four meters above the ground. $b d$ A short dark line.

strip on either side of the tree, otherwise, occasionally in large flakes. Even in the former case the tree generally dies, it may be after a few years.

In other cases, pieces of wood are split off the stem, of all sizes up to several yards in length (Fig. 293). The lightning has even been known to enter a beech tree 100 years old, in Hesse, on the 11th July, 1886, horizontally and then strike down through its axis, as shown in Fig. 292. Sometimes large arms of a tree, or its whole crown, have been broken off by lightning. As a rule, the lightning runs down the tree into 
the ground, but in 3 per cent. of the cases observed it passed off to other trees before doing so.

Neither carbonisation nor tearing open of cells have been observed on trees struck by lightning.

'The injured parts observed on the stem or main branches of a tree are never the first point attacked. The lightning almost always strikes the fine topmost twigs (the best conductors), and proceeds thence along the main boughs and stem. It then generally follows the direction of the fibres, the path of least resistance. If the fibres are twisted, it follows a spiral path. The cambium, wood, and pith of a tree struck by lightning become discoloured, and often the topmost leaves turn brown, those below remaining green.

Very little is known regarding the effect of lightning on the inner structure and technical quality of timber. It is assumed that wood struck by lightning has its hardness and strength reduced. Wood and bark-beetles, wood-wasps and fungi, attack the tree, which soon dies. It should therefore be felled and converted as soon as possible.

When an unsound tree is struck by lightning it is sometimes set on fire, and the fire may then spread to the surrounding forest.

It has also been repeatedly observed in coniferous forests, that sometimes a whole group of trees may die from the effects of lightning, the marks of which may only be visible on one of the trees. This takes place some time after the occurrence, and leaves an ugly gap in a fine wood. This has been hitherto observed only in crops of Scots pine, spruce, silver-fir and larch. It may be the effect of back-stroke (p. 658). In such cases the dead trees should be carefully examined, as bark-beetles have been afterwards proved to have caused the death of the unstruck trees in certain cases.

'I'he soil may be the cause (p. 664), or small lightning strokes accompanying the principal stroke. Such a stroke is termed group-stroke.

\section{According to Species.}

All species of trees are liable to be struck by lightning, but oaks and other species with deep roots appear to be most 
exposed to this danger, perhaps on account of their roots forming better conductors to the moist subsoil than those of shallow-rooted species.

According to the valuable observations made annually by Dr. Hess from 1874 to 1890 in the forests of Lippe-Detmold,* among broadleaved trees the oak suffers most, among conifers the Scots pine. Then follow spruce and beech. The birch, poplars, ash, alder, willows, larch, and other trees suffer only exceptionally.

T'rees Strreck in Lippe-Detmold, 1874-1890.

\begin{tabular}{|c|c|c|c|c|c|c|}
\hline \multicolumn{4}{|c|}{ Broadleaved trees. } & \multicolumn{3}{|c|}{ Conifers. } \\
\hline Oaks & & . & . 310 & Scots pine. & . & . 108 \\
\hline Beech & . & . & . 33 & Spruce & . & 39 \\
\hline Birch & . & . & 10 & Larch & . & 11 \\
\hline Poplars & . & . & 6 & Austrian pine & . & 1 \\
\hline Ash. & . & . & 4 & Weymouth pine & . & . \\
\hline Willows & . & . & 2 & Others & . & . \\
\hline Other trees & & . & 8 & & & \\
\hline 'lotal & & & . 373 & Total & . & . 165 \\
\hline
\end{tabular}

The forest was stocked as follows:-

\begin{tabular}{|c|c|c|c|}
\hline Oak . & . 11 & per & ent. \\
\hline Beech . & 70 &, & , \\
\hline Spruce. & 13 & , & "я \\
\hline Scots pine & . & ", & , \\
\hline & 100 & & \\
\hline
\end{tabular}

The danger therefore, considering the beech as 1 , was 6 for a spruce, 37 for a Scots pine, and 60 for an oak.

Other observations by Collodon, $\uparrow$ Hellmann, $\ddagger$ Cohn, and Caspary give somewhat different results.

\footnotetext{
" “Ztschrft. fr. Frst. u. Jgdw.," 1879-1889.

† "Allg. Frst. u. Jgdztg.," 1875, p. 440.

$\ddagger$ "Frstl. Blttrn.," 1889, p. 26.
} 
Thus Hellmann, considering danger for the beech from lightning as 1 , gives-

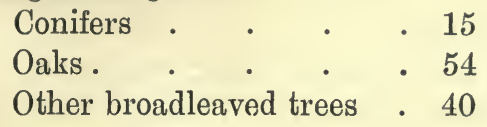

Cohn-Oaks

Poplars . . . . $12 j$ struck.

Caspary-Oaks . . . . 15 out of 93 trees

Poplars . . . . 34\} struck.

C. Hess (1896) found that pyramidal poplar is often struck, and that in eight out of the ten cases he observed lightning passed from the tree to a neighbouring building. Poplars should, therefore, not be too near to buildings.

According to Collodon, near the lake of Geneva, poplars rarely suffer from lightning.

In the "Revue des Eaux et Forêts,"* the results are given of 15 years' experience in a forest composed as follows :-

- Oak. Beech. Spruce. Pine. Others.

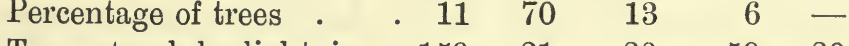

Trees struck by lightning . $\begin{array}{lllll}159 & 21 & 20 & 59 & 20\end{array}$

Relative frequency . $\quad \begin{array}{cccccc}48 & 1 & 5 & 33 & -\end{array}$

This agrees generally with the results obtained in Detmold.

Similar observations were made in the Bavarian State forests, $1887-1890$.

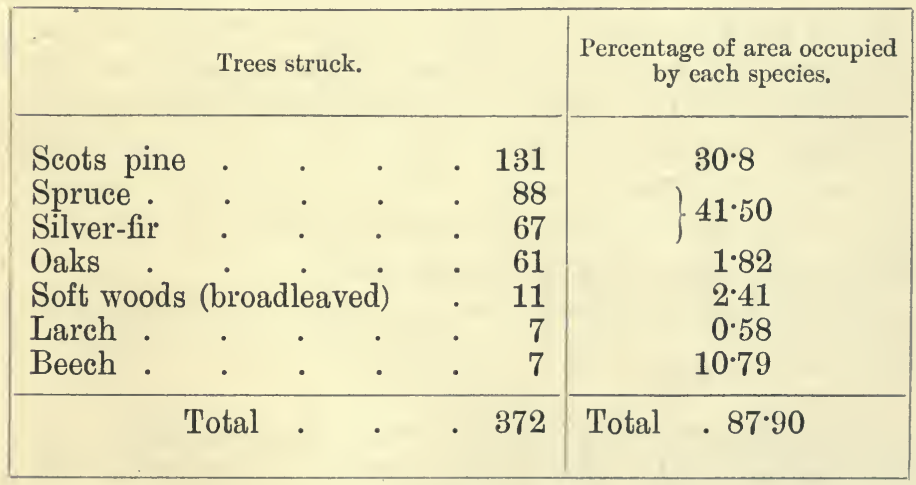

* February, 1894, p. 78. 
In the Saxon State forests, in 1897, the first year that such observations were made, it was found that the danger for oak was six times that for conifers.

On the whole, from these observations it is evident that local circumstances such as proximity of lakes, dampness of soil, density of growth, healthy or unhealthy condition of trees, affect the question whether one species will be more liable to attack than another in any particular locality.

Some experiments as regards the conductivity of electricity by wood have been recently made by Jonesco, of the Württemberg Society of Natural Science. In these experiments Holz's electric machine was used.

1 turn passed the spark through oakwood,

12 to 20 turns through beech,

5 turns through poplars and willows.

The use of heartwood or sapwood and state of dryness of the wood made no difference in the results, but the richness of beech in oil prevents its being a good conductor.

Fischer ("Biologie der Holz Gewächse"*) distinguishes between oily trees and starchy trees. In oily trees, the elaborated starch, during winter and spring, becomes converted into oil and passes into the pith, wood, and bark. Part of the starch in the bark also becomes converted into glucose. In the starchy trees, the reserve starch remains unaltered between autumn and May.

The green wood of the oily trees (beech, walnut, birch, lime), especially wood very rich in oil, is a bad conductor of electricity. The starchy trees (oak, poplar, maples, ash, elm, sorbus) are good conductors. Conifers are intermediate, the Scots pine in summer being as poor in oil as the starch trees, but rich in oil during winter. After the oil had been extracted from wood of fatty trees by means of ether they became as good conductors as typical starchy trees.

Starchy trees are therefore more in danger from lightning than oily trees.

\section{c. Locality.}

Damp soils conduct electricity well, but in dry places when the lightning has reached the ground, it may spread from

" Pringsheim's "Jahrbuch für wissenschaftliche Botanik," Band xxii., p. 73. 
root to root of neighbouring trees and cause them to die in groups.

It is probable that when sound well-conducting trees growing on damp soil are struck the lightning passes rapidly down to the earth without causing much breakage, but that when rotten wood is met with, which is a bad conductor, the crown or branches may be broken, or even the tree set on fire.

The relative frequency with which trees are struck on different soils in Lippe-Detmold is given below :-

\begin{tabular}{|c|c|}
\hline Loam & \\
\hline Sand & \\
\hline Clay . . & • \\
\hline Keuper marl & . \\
\hline Calcareous soil & . \\
\hline Flooded land & \\
\hline
\end{tabular}

This may explain the greater danger to trees from lightning in North Germany as compared with South Germany and Austria. It is also possible that loam and sand, producing most oaks and Scots pine, have high figures, while on calcareous soil the beech predominates.

Trees are said to be more frequently struck by lightning in badly wooded plains than in well-wooded mountain districts. This is true for the bare middle Rhine valley and its adjoining wood-stocked hills.

It is supposed that dense forests act as conductors and allow electricity to pass gradually from the earth to the clouds, whilst clearing the land of forests increases the heat of summer and hinders the neutralisation of the electricity of the clouds.

\section{d. Density of Crop and Condition of Trees.}

Lightning, according to Hess, strikes in preference trees standing free from their neighbours, those in avenues and on the border of a wood and also trees dominating over the rest of a wood.

Sound trees are more frequently injured than unsound trees, but dry trees may be struck, and stag-headed oaks are frequently smashed to pieces by lightning. Thus, a 
positively electrified cloud induces the separation of the electricity in a tree, driving the positive electricity into its roots and the earth, whilst the tree becomes charged with negative electricity. The strength of this charge becomes weakened by gradual discharge into the atmosphere from the numerous twigs and leaves in the crown of a vigorous tree. On the contrary, a tree with many dry branches and scanty foliage becomes thoroughly charged with negative electricity, and when struck by lightning receives a more violent shock than a sound tree.

\section{e. Season.}

In Central and Western Europe the most frequent thunderstorms are in June and July, between 3 and 5 p.m. or 1 and 2 a.m. These storms usually pass from S.W. to N.E. or from W. to E.

In the case of heavy rain before the lightning-stroke, the trees become better conductors, and are more liable to be struck.

The average rate at which thunder-storms travel in South Germany is given by C. Lang, the result of five years' observation, as $25 \frac{1}{2}$ miles an hour, which agrees with French observations. In 1886, the greatest rate was 49 miles, the least $6 \frac{1}{4}$ miles, an hour.

\section{Register of Damage by Lightning.}

The frequency of thunder-storms in Central Europe decreases as the latitude increases and in proximity to the Atlantic Ocean, as the following average figures show :-

Name of Country.

Italy .

Austria

Hungary, Baden, Württemberg .

Silesia, Bavaria, and Belgium

Holland

Saxony and Brandenburg .

France and South Russia .

Spain and Portugal .
Number of Thunder-storms per annum. 
Number of Thunder-storms

Name of Country.

per annum.

Schleswig-Holstein, Mecklenburg, Hannover,

West Prussia . . . . . . 13

North Russia . . . . . . 10

Little Russia . . $\quad$ • $\quad$. $\quad$. $\quad$. 9

Sweden and Finland . $\quad . \quad$. $\quad . \quad 8$

England and Swiss Alps . . . . 7

Norway . . . . . . . . 4

There has been no increase in the last thirty years in the number of thunder-storms in Germany, Austria and Switzerland, but in most other European countries their frequency has increased almost threefold, and this is considered to be due to increase of railways, metallic roofs and pipes for gas, water, etc., inside houses. The increased smoke from factories also favours thunder-storms.

Some interesting facts regarding trees killed by lightning are given below.

1848 (early in July): Fifty-two Scots pines about 125 year's old were killed by lightning at Sprillgehörge, in Hannover, only one of them being directly struck.

1865 (spring): Seventy 60-year-old spruce trees, only one of which was struck, were killed by lightning in the Harz Mountains.

1868 (11th May) : A green spruce tree struck and burned in Kothenwald, in Reuss.

1876 (17th July) : After a long drought, a dried-up moor stocked with a thicket of 11-year-old Scots pines and spruce was fired by lightning at Aurich, near Neuenwalde.

1887 (summer): Two lightning strokes about 70 feet apart killed all the trees on about one-fifth of an acre stocked with Scots pines and a few beech near Neustadt.

1887 (15th July): Seventy-two large spruce trees were killed by one stroke of lightning at Brückenberg. It was clearly seen from marks on the branches that the lightning had passed from tree to tree.

1891 (summer): On a road in Ober Hesse lightning struck twelve wooden posts (spruce poles 8 feet high and 2 inches in diameter) that were supporting plants of sycamore and oak 
planted along 100 metres of roadway. No injury was done to the living plants, but all the supports were struck and split, the lightning passing through the ground from one post to the other.

1895 (10th June): At Bockling, in Graf Schulenburg's forest, lightning set fire to a crcp of 15-year-old silver-fir, the fire extending over about sixty acres.

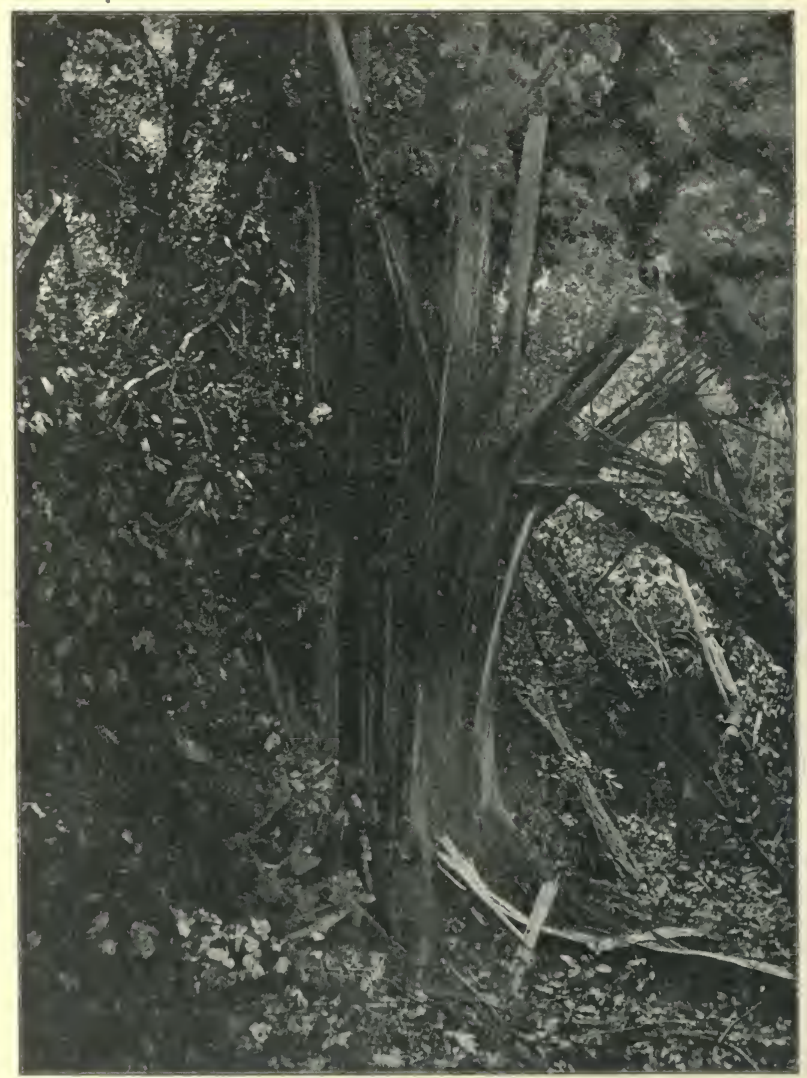

Fig. 293.-Oak tree struck by lightning, St. Amand, near Valenciennes, 23rd July, 1896. 


\section{PART VI.}

PROTECTION AGAINST CERTAIN DISEASES OF FOREST TREES. 



\section{CHAPTER I.}

\section{GENERAL ACCOUNT OF THE DISEASES OF PLANTS.}

\section{Definition.}

A Forest plant is said to be diseased when, owing to disturbances in the functions of its organs and in the chemical or physical processes going on within them, it assumes such a condition that it is hindered from further useful development and may consequently die, either wholly or in part. Disease therefore causes blanks in woods of all ages, and also loss of wood-increment and consequent reduction in their value.

\section{Causes of Disease.}

Many different causes of disease in forest trees may occur, for instance, old age, injuries by men and animals, injuries by parasitic plants (weeds and fungi), by atmospheric agencies. Disease is also due to certain local circumstances, such as soils too poor in the chemical compounds necessary for plant-life, soils too dry or very wet, too compact or too loose, etc.

Although much progress has been made during the last twenty years in the study of the diseases of forest trees, a wide field is still open for discovery in this respect.

\section{Classification of Diseases.}

The diseases of forest plants may be grouped according to their origin, the nature of the organs which are attacked, the

* A capital account of the conditions of environment which encourage disease in a plant is given in the Proceedings of the Royal Soc., vol. 47, "The Croonian Lecture," by H. Marshall Ward.

Hartig, Dr. Robert, "Lehrbuch der Baumkrankheiten." Berlin, 1889.

Frank, Dr. B., "Die Krankheiten der Pflanzen," 3 vols., 1896.

Soraner, Dr. Paul, "Zeitschrift fur Pflanzerkrankheiten." S uttgart. This periodical commenced in 1891 
progress of the disease and its importance in forestry. T'hese four headings have been considered in the following list :-

1. Diseases arising from plyysical agency (frost-crack, bark blister, etc.) and those from physiological causes, such as red and white rot.

2. Local diseases, such as of the roots, or of the stem, bark, buds, leaves or shoots, or of the inflorescence and fruits of the trees.

3. Acute or rapidly developing diseases, or chronic diseases which develop slowly.

4. Diseases which merely cause loss of increment, and others which affect the economic value of the wood, the latter consisting either in an abnormal growth of otherwise healthy woody tissue, such as burrs, twisted fibre, etc., or in an unhealthy state of the tissues, as in red or white rot.

The worst kinds of damage to forest plants by men, animals, plants, and atmospheric agencies have been already dealt with in the preceding chapters of this book. For the study of abnormal growth in healthy wood-tissues, the reader is referred to treatises on Forest Utilisation. In the following pages will be described certain diseased conditions which could not well be classified under any of the foregoing heads and are limited to the following:-red rot, white rot, stagheadedness, abnormal needle-shedding, and damage by factory fumes. 


\section{CHAPTER II.}

RED ROT.*

\section{Description.}

RED Rot is a decomposition of wood, by which its elementary organs are gradually detached from one another, and it becomes eventually converted into a loose-textured mass, at

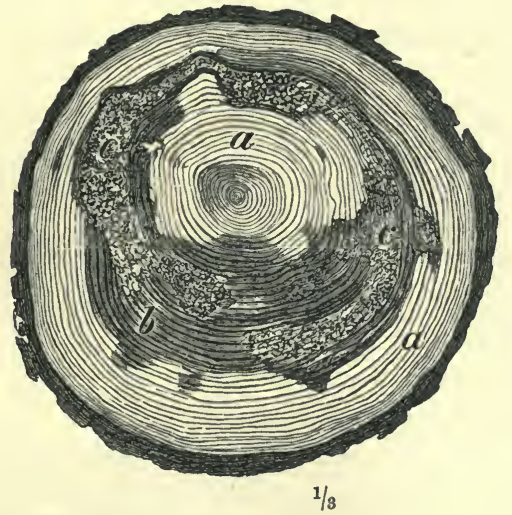

Fig. 294.-Section of a spruce suffering from red rot.

$a$ Sound wood. $b$ Discoloured wood where decay has commenced.

c Rotten wood.

first reddish-brown and passing through a dark brown condition into a peaty substance resembling humus. Frequently whitish mycelia may be noticed traversing the wood longitudinally.

Red rot (Fig. 294) occurs, according to its position, as root, stump, stem, or branch-rot. A transverse section through the rotting wood shows a great variety in the phenomena and course of this disease, often in the same tree. Either certain

*Willkomm, Dr. Moritz, "Die Mikrospischen Feinde des Waldes." Dresden, 1866, pp. 31 and 219. Hartig, Dr. R., "Die Rotfäule der Fichte," "Monatschrift fr. das Forst und Jagdwesen," 1877, p. 97, an excellent and comprehensive work.

F.P. 
annual zones or groups of annual zones of wood between the heart and sapwood are attacked,* or the disease occurs in patches, or attacks merely the central zones of the tree or branch. The sapwood is never attacked by red rot. The rotten wood may eventually be completely decomposed, when it disappears, leaving a hollow cylinder, in place of the heartwood, and this frequently without involving the death of the tree. Sometimes the innermost portion of the stem remains, forming a thin columnal, hard strand of wood united with the sapwood here and there by similar strands where branches have been enclosed in the wood.

The commencement of the disease may be recognised by a light violet or reddish colour of the wood, and by the porous spring zones being attacked before the harder autumn zones.

\section{Modifying Factors.}

a. Species.

Red rot occurs in almost every species of forest tree. Among broadleaved species oaks and elms suffer most, and among conifers the spruce and Scots pine. The disease usually commences at the roots of spruce trees.

Root rot usually spreads upwards through the heartwood to the branches. It may, however, on the contrary, gradually descend from the branches through the stem to the roots.

\section{b. Age of Tree.}

Red rot is a normal condition of very old trees, but a disease in the case of young trees. It has been observed in the spruce from the age of 10 years and upwards.

\section{c. Locality.}

Wood may become rotten in all kinds of localities, but certain conditions of the soil predispose trees to this disease. Such are - soils very rich in humus, calcareous soils, soils very compact or wet and cold, such as clays and peats which are not

* Termed Mondring in German and lunure in French. 
properly aerated, or where an impermeable substratum occurs at an inconsiderable depth below the surface of the ground. Wood also readily rots in places where cattle rest at midday, owing to the excrement.

\section{d. Treatment of Woods.}

A dense condition of a wood, especially in moist or wet localities, favours the evil. Tapping for turpentine, barking by game, and other injuries, such as pruning living branches without tarring, frequently give rise to the first symptoms of red rot in wood, especially when the trees are growing in localities predisposing them to disease.

\section{Causes.}

Widely differing and frequently contradictory hypotheses have been started to explain the origin of red rot. Usually it is attributed to external circumstances, such as unfavourable localities, injuries, etc., without further inquiry into its possible causes.

The first scientific inquiry into the cause of red rot is found in the works of Willkomm (1866), who designated a microscopic fungus as the sole origin of the disease. He named this fungus Xenedochus ligniperda, and another allied form which springs from it Rhynchomyces violaceus, which causes the bluish colour in rotting wood.

The question as to the origin of red rot was not by any means solved by Willkomm's researches, as he merely proved the presence of the above fungi in rotten wood, but did not make experiments to infect sound wood by means of their spores, so that it remained doubtful whether the fungi were the causes or merely the consequences of red rot.

Robert Hartig, in 1874, solved this question by proving that red rot in the case of spruce, Scots pine, oaks, etc., really arose from infection by parasitic fungi. Later on, in 1877, he further proved that, at least for the spruce, unfavourable soils and external injuries also induced the disease. As we have already in chapter III., part' II., discussed the infection of trees by fungi, we have now only to deal with the two latter cases. 


\section{a. Unsuitable Soils.}

The kinds of soil which induce red rot in the roots of trees, and chiefly in their deeper-lying roots, are generally peaty humus, calcareous soils, soils containing pans or impenetrable substrata of ochrous iron ore, lignite, clay or loam, also very fine sand, not infrequently found in the lias formations in Germany. Such subsoils interfere with aëration of the surface soil, the oxygen so necessary for the roots of trees being unable to reach them in sufficient quantity. This is due to the fact that the air in soils too compact or waterlogged is gradually deprived of its oxygen by the roots of the plants 'growing on it, and by the decomposition of the litter; this loss of oxygen is not sufficiently replaced by the admission of fresh air to the soil. The denser the wood, the faster the evil progresses ; fungi also accelerate the disease.

In the North-west German loamy heather tract, where pan is very prevalent, more than 75 per cent. of the Scots pine woods suffer terribly from red rot. Spruce, however, thrives there.

This form of red rot is more prevalent with larch and sometimes with Scots pine than with spruce, for the roots of the larch as well as those of Scots pine penetrate more deeply into the soil, and therefore rot more readily than those of spruce that spread in all directions in the upper layers of the soil.

Scots pine, however, when grown on shallow soils, can produce superficial roots like those of spruce, whilst experience in Windsor Forest shows that larch growing on a gravelly soil above a pan always gets red rot, and this is confirmed by A. D. Webster, ${ }^{*}$ who states that larch always gets red rot when grown on gravelly soils.

\section{b. External Injuries.}

Trees are frequently wounded during the felling, conversion, and transport of timber. Wounds also arise owing to forest pasture, game, mice, insects, from pruning green branches, or from meteoric influences, frost-crack, bark-scorching, windbreak

" "Practical Forestry." William Rider \& Son, London, 2nd edition, 1895. 
or snowbreak, hail, etc. Wherever the living tissues of the wood are exposed, especially where the wounds are not cleancut, moisture penetrates into them, unless they are protected by antiseptic substances, such as a natural flow of turpentine, or by tar. With the entrance of water into the tissues, certain chemical changes take place in their contents, and local disease may arise. Spores of fungi also penetrate the tissues, such as the spores of species of Polyporus in the upper parts of the tree, or of Armillarea mellea, etc., in its roots.

\section{Damage done.}

Red rot affects the technical value of wood in proportion to its extent and degree of development, and to the innate value of the tree which is attacked. Wood affected by red rot cannot be used as timber, and is only of slight value as fuel. The worst form of this disease is when it attacks a tree's roots, as it then generally affects the whole stem; the least dangerous form is in the branches.

It is not rare in spruce woods $60-70$ years old to find that 10 per cent. of the trees are rotten, whilst the liability of rotten trees to windbreak and snowbreak is another cause of disaster.

\section{Treatment of the Disease.}

The rules for combating red rot depend on the cause of the disease.

\section{a. When due to Unsuitable Soils.}

Great care should be taken in planting to allot the species of trees to soils suitable for their welfare.

Remove densely growing mosses and other unfavourable vegetation from damp mountain soils.

Drain and work up the superficial layers of compact soils.

In wet soils which cannot be drained, plantations should be made on mounds or ridges.

On calcareous soils broadleaved species should be intermixed with Scots pine and spruce; low rotations of $60-70$ years should be adopted for spruce. 


\section{b. When due to Injuries.}

Great care should be taken during timber-fellings and transport.

Pruning of green branches should, if possible, be avoided, or restricted to branches under 4 inches in diameter; all wounds made by pruning should be smeared with tar.

All rotten trees and stumps should be speedily removed from the forest.

All measures dictated by forest protection should be strictly followed in order to prevent injuries to the trees.

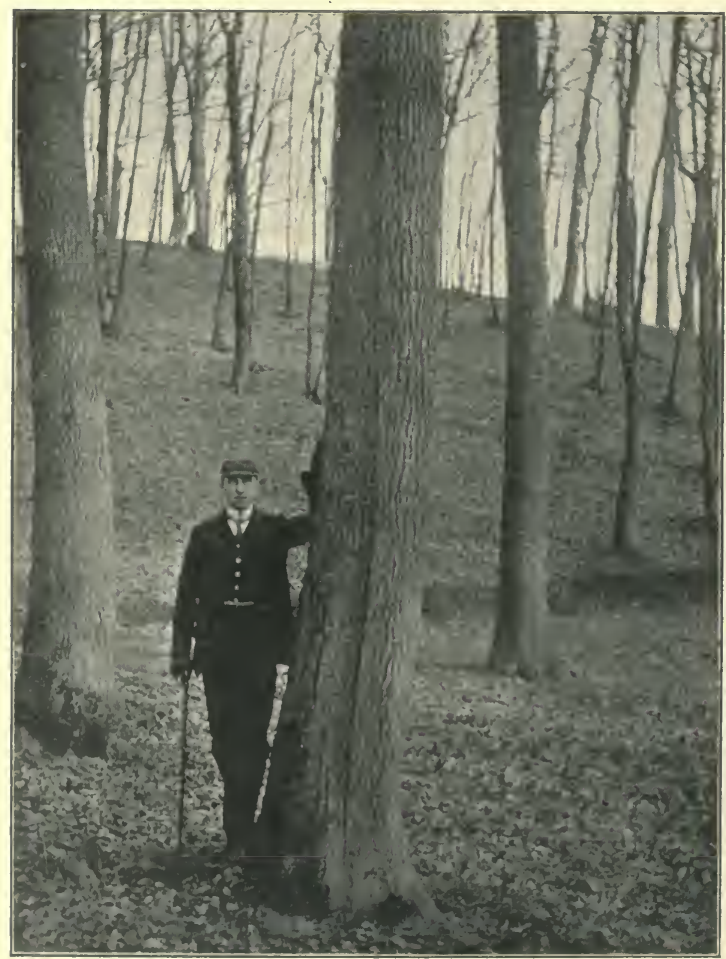

Fig. 295.-Frost-crack in an oak tree. Dillcnburg. Photo. by R. E. Marsden. 


\section{CHAPTER III.}

\section{WHITE ROT.*}

WhIte Rot is distinguished from red rot by the colour of the decomposing wood, which is of a whitish instead of a reddish hue. It is commoner among broadleaved species (beech, hornbeam, maple, oak, chestnut, poplars, and willows) than among conifers; it is probably due to several causes combined, but appears to be chiefly caused by fungi. White rot is rarer than red rot, and its course less rapid. The protective measures to be taken are similar to those against red rot.

* Books referred to under " Red rot." Also see p. 440 of the present work. 


\section{CHAPTER IV.}

\section{STAG-HEADEDNESS.}

\section{Description and Causes.}

IT has been already stated that red rot frequently attacks very old trees, rendering their stems hollow, but another sign of excessive old age is the death of some of the topmost branches of a tree, which has no longer súfficient vigour to pump water so far. The death of these branches causes them eventually to break off, and atmospheric moisture is then admitted into the trunk, and rot commences and penetrates downwards towards the roots. Stag-headedness may, however, occur in immature trees, and is then due to one of the following causes:-

(a) When trees which have been growing in a dense wood are suddenly exposed as standards, as in natural regeneration in high forest, or after the felling of the underwood in coppice-with-standards, the surface moisture of the soil may be reduced and the trees consequently become stag-headed. In some cases such trees, and especially oaks, having comparatively soft bark, owing to their formerly protected state in a dense wood, put out numerous epicormic branches from the dormant buds along their stems, which absorb the sap that would otherwise reach their crowns. This tends to cause stag-headedness, which may, however, be obviated by one or two prunings of the epicormic branches, until the bark becomes too hard for them to form.

(b) In forests of lightdemanders such as oak, larch, ash, Scots pine, the soil may be completely sheltered by the crop up to a certain age, but after $40-60$ years the leaf-canopy ceases to be sufficiently close to protect the soil from the sun, which gradually dries it up, and thus causes stag-headedness in the trees, unless the soil be protected by an underwood of shadebearers. This result follows more rapidly on hot 
aspects, and the more superficial the soil, and the more porous the subjacent rock, such as chalk or coarse gravel, and the less the rainfall and relative humidity of the air in the locality.

(c) Any interruption of the leaf-canopy in forests of all

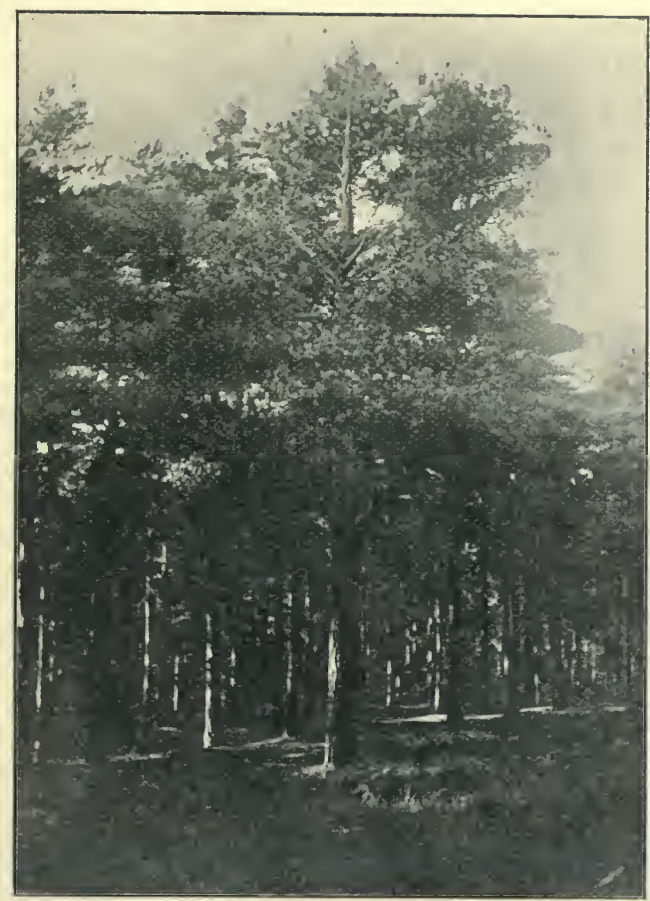

Fig. 296. - "Foxy" Scots pine, Windsor Forest.

kinds may cause deterioration of the soil and consequent stag-headedness.

(d) Drainage also, by lowering the level of water in the soil of a forest, may deprive formerly thriving trees of sufficient moisture, which their roots, adapted to reach water near the surface, can no longer absorb in sufficient quantity. Trees thus affected may become stag-headed. This happened on a large scale with oaks growing in the Wild Park at Carlsruhe, owing to the rectification of the course of the 
Rhine, and consequent lowering of the water-level in the soil. A similar result followed drainage in Windsor Park with regard to some of the elms in the Long Walk avenue, and it is not uncommon with alder-woods after drainage. Continual and excessive removal of litter from a forest may cause stag-headedness in immature beech forest.* It has been noticed in certain two-storied coniferous forests in North America after the upper stage of trees had been felled, and the sun allowed to dry up the soil-covering, that the lower stage, the roots of which had spread superficially in the layer of dead leaves and humus, became liable to stagheadedness and death.

(e) Stag-headedness in the Scots pine may be caused, as stated on p. 441, by the fungus Peridermium Pini, such trees being termed "foxy" (Fig. 293).

It is found that though, in the case of conifers, stagheadedness is speedily followed by the death of the tree, and beech also speedily succumbs when similarly affected, yet that some other broadleaved species, and especially oak, may remain stag-headed for many decades without dying, although the technical value of their timber rapidly deteriorates, and their trunks may become completely hollow.

One of the worst instances of stag-headedness, on a large scale, may be seen in the State forest of Compiegne. Between 1775 and 1790, an area in that forest of about 6,000 acres was clear-cut and planted by a contractor named Panellier with pure pedunculate oaks. The soil was either very sandy, or a stiffish clay, but wherever on adjacent land oak is mixed with beech and hornbeam, excellent oaks are produced. In the Panellier plantations, however, now 100 to 130 years old, the ground is generally bare of underwood under the oaks. The bark of the oak trees is yellow with lichens and they are nearly all stag-headed and have ceased to grow, presenting a deplorable picture. There are magnificent sessile oak trees more than twice the age of the Panellier oaks on sandy hills, called Les Hauts Monts, close to these pure pedunculate plantations, but these sessile oaks are mixed with beech.

*Fürst's "Waldschutz," translated by J. Nisbet, p. 59. Edinburgh, 1893 


\section{Treatment.}

a. Preventive.

i. Maintain the soil-covering of dead leaves, moss, etc., in order that the soil may not lose its moisture.

ii. Keep up a dense leaf-canopy, especially where the soil is shallow and liable to dry up, and where the subjacent rock is of a porous nature (chalk, gravel, etc.).

iii. Underplant all high forests of lightdemanders with a shadebearer, such as beech or silver-fir, as soon as grass or other herbage appears on the soil, and fill up with shadebearers any gaps which may have occurred in a forest owing to windfall, or other injurious causes. Underplanting oak forest with spruce may cause stag-headedness, on account of the quantity of moisture the spruce absorbs.

iv. Do not plant spruce, alder, ash or pedunculate oak in dry localities. The sessile oak will thrive on well-drained hillsides, where it is hopeless to plant the pedunculate oak.

v. Avoid draining, unless it is absolutely necessary.

vi. High forest is more suitable than coppice-with-standards in dry localities and those with superficial soil or above a porous rock.

vii. When epicormic branches appear on oaks and other standards in coppice-with-standards, or on standards left after regeneration in high forest, they should be pruned off before the next spring. It may be necessary to repeat the operation, but after two seasons in the open the bark of the standards becomes hardened, and the epicormic branches do not generally reappear. In any case the stems of the standards will be gradually sheltered again by the rising underwood, which will effectually kill any epicormic branches still on the tree.

The appearance of epicormic branches on oak trees growing in a dense wood is a sign of disease, and such trees should be gradually removed in the fellings, as they will certainly become stag-headed.

\section{b. Remedial.}

As a rule no remedy can be adopted when forest trees become badly stag-headed, the only measure to be followed being to fell them and utilise their timber before it becomes further 
deteriorated. Slightly stag-headed ornamental trees in parks or avenues may, however, be given a fresh start in life by trenching the ground under their crowns, breaking up any impermeable stratum under their roots, and manuring them with rich leaf-mould. Stag-headed trees may also be pollarded; the reduced length of stem may then enable the roots to nourish the pollard shoots sufficiently to prolong the life of the tree for several decades.

\section{Addendum.}

The death of trees by "bleeding to death," a popular phrase, is not uncommon with elms. The bark splits off in the spring in flakes from a tree which appears to be quite healthy. Sap exudes in frothy masses, and forms a deposit on the exposed wood. This continues throughout summer, and if the summer be a dry one the foliage eventually fades and falls off, and the tree dies. In a case that occurred in the very dry summer of 1906, the roots of the tree had been cut through by new drainage works, the tree standing between two cross-roads. Not a leaf was left on the tree by September, although it was quite flourishing in April, and not more than 100 years old.

Bleeding and peeling of the bark has also been observed on oaks in Cumberland (Brayton Hall). New bark was, however, formed under the flakes of bark that peeled off. 


\section{CHAPTER V.}

\section{NEEDLE - CAST.*}

\section{Description.}

Since the end of the eighteenth century, a disease, termed needle-cast (in German, Schuitte), has been remarked on young pines, the external signs of which consist in the gradual reddish or reddish-brown discoloration of their 1- or 2-year-old needles, which eventually die and fall off the plants. As a rule these symptoms appear first in the spring (Vor-winter Schiitte), but not unfrequently also in the autumn and early winter (Nach-uinter Schiutte), and in South Germany the latter often happens in years when the ground is free from snow. A steel-blue or violet colour of the 1-year-old pineneedles in autumn is no sign of disease, provided yellow or reddish-coloured spots do not also occur; this is an instance of the normal winter-colour of masy evergreen plants, which disappears as the thermometer rises in the spring, and gives place to the ordinary green colouring of the needles. The reddish discoloration and death of the needles proceeds from their tips downwards, and chiefly affects the lower parts of the plant near the ground. Pines thus affected resemble those injured by drought, but at the commencement of the disease more or less regularly distributed dark spots and stripes appear, and later, in May, small black sporangia of the fungus Lophodermium Pinastri, Schrad. $t$ Also resin collects on the sickly needles. The worst form of the disease may be recognised when the buds become encrusted with resin and dry-up, and then no recovery is possible for the diseased plants.

* Freiherr von Löffelholz, "Beitrag zu einer kritischen Nachweisung über die Schütte-krankheit der Kiefer." Berlin, 1865. Holzner, Dr. Georg, "Die Beobachtungen über die Schütte der Kiefer und die Winterfärbung immergrüner Gewächse." Freising, 1877.

+ See p. 465 . 


\section{Modifying Factors.}

\section{a. Species}

The Scots pine suffers most from needle-cast, also the black, cluster and mountain pines. The disease does not appear to have been as yet observed on Weymouth pine, nor on Pinus rigida, Mill., that is now extensively used for planting waste land.

\section{b. Age of Plants.}

Two-year-old plants suffer most from this disease, but 3 to 4- year-old plants may also be attacked, though the danger becomes less every year. In years when the disease is very prevalent, weakly plants may suffer up to the age of 15 years, but only up to about 6 feet from the ground.

\section{c. Locality.}

Pines growing in all kinds of localities are subject to this disease, but it is chiefly prevalent in damp or wet places exposed to frequent fogs. Thus valleys and plains suffer more than hills and mountains, where the snow protects the plants during winter. In depressions and in cold valleys, the disease is often very destructive. As regards aspect, southern and western slopes are most endangered; eastern slopes also suffer, but northern slopes either not at all or only exceptionally.

The soil appears to have some influence on the disease, but its effects have not yet been clearly explained. Stein* states that Scots pine suffers most on pure sandy soils, but after all it is on such soils that most indigenous Scots pine-woods are found. Von Löffelholz + has observed that plants suffer less on thoroughly cultivated soil than when the land has not been previously broken up, and this may be due to the better rootsystems and superior hardiness of the plants in such cases. It also appears that on peaty soil needle-cast is little to be feared, which fact may be due rather to the treatment of the pine-forests on such localities than to the nature of the soil.

* "Ueber die Schütte," Dr. F. Stein, "Tharandter Jahrbuch," vol. viii., 1852, pp. 208-225.

t The same, p. 41. 
Emmerling* states that sowings of 1-year-old pines in the North German heather-land suffer severely every year from needle-cast, whilst those on the more favourable, sandy loam are not affected by it.

It is clear that Scots pine is affected by needle-cast on all kinds of soil, but that on loam the plants are stronger and escape the danger better than on poor sand.

\section{d. Soil-covering.}

It is not yet decided what influence the nature of the soilcovering has on the disease. It may, however, be laid down as a general rule that ground covered with grass or weeds is less liable to it than bare localities, but the favourable influence of the soil-covering may be counterbalanced by other causes.

\section{e. System of Management.}

Under a shelterwood, the young pines may entirely escape the disease, or suffer only slightly, and lateral shelter from old pine-woods acts favourably by reducing insolation and radiation of heat from the ground. On large clearings, pines are almost always subject to needle-cast. Areas densely sown late in the year suffer most of all, when the individual plants have very small root-systems and thin elongated stems.

\section{f. Weather.}

The disease is most frequent in March, April and May, and a wide range of temperature, such as warm sunny days and cold nights with rime, favours it. Cold, dry easterly or north-easterly winds increase the evil. During cloudy, rainy weather in spring, the disease may not appear at all, or only slightly. It is also more frequent after damp winters with light snowfall than after the ground has been well covered with snow.

\section{Geographical Range.}

The disease occurs wherever the Scots pine is cultivated, but is less common in colder countries, such as Russia. It

* "Untersuchung uber die Ursache der Kiefernschuitte in Schleswig-Holstein," by Dr. A. Emmerling and Dr. G. Loges, "Allg. Frst. u. Jgdztg." 1882, p. 135. 
is not prevalent in the British Isles. In Germany it appears to be connected with the extension of clear-cutting and planting, which, since the end of the eighteenth century, has so largely replaced the system of natural regeneration of the Scots pine. In the damp, cold years 1850 to 1852 needle-cast wąs widespread and very destructive in North Germany, and again in 1881 to 1884 . Pine-plants which have once suffered from it are liable to be again attacked, as they are greatly weakened by the disease.

\section{Causes.}

Numerous reasons have been given for the needle-shedding disease, as quoted by both Von Löffelholz and Holzner. The nature of the soil, the state of the weather, and combinations of these have been cited. Some think that Lophodermium Pinastri is the sole cause of the evil, whilst others hold it to be due to a more rapid transpiration of water by the needles than the roots of the plants can supply. It is therefore probable that we have here to deal with many causes acting in combination, one with another, but these may be reduced to the three following :-

Needle-cast fungus, Lophodermium Pinastri, Schrad.

Frosts, and especially early frosts in autumn.

Insufficient absorption of water to supply that transpired by the plants.

We have therefore to deal with three forms of the disease:-

(a) Fungoidal needle-cast.

(b) Frost needle-cast.

(c) Dry needle-cast.

It is difficult to distinguish these causes from one another, as the fungus is always present, though frequently it may be only secondary.

\section{a. Fungoidal Needle-cast.}

The necessary account of this disease has been given above on p. 465. Hartig, * Prantl, and Tursley have supported the fungus theory, but many phenomena appear which contradict it, for example, from the disease beginning at the points

"Vide Hartig, "Lehrbuch der Baumkrankheiten." Berlin, 2nd edition, 1889, p. 103. 
of the needles, and the lower parts of plants suffering most, and above all, from the fact that the disease frequently appears in a single night, and is much commoner in broadcast sowings than in natural regeneration-areas. Hess has frequently observed the needles to have been attacked in every plant on a nursery-bed, after one night's hoar-frost succeeded by a sunny day, and this altogether excludes the action of the fungus as cause of the disease. Moreover, infection by the fungus, which is favoured by heat and damp, would be easier under a shelterwood than in the open, which is not the case. The Lophodermium is, however, widely spread as a saprophyte on dead needles of pines, as well as on those of the spruce and juniper.

\section{b. Frost Needle-cast.}

G. Alers* and Nördlingert have proved that the disease is frequently due to refrigeration of the plants on unprotected soil free from snow, by radiation from the soil-covering, and this opinion has been adopted by most practical men. Generally autumnal frost is the cause, and late frost is not injurious, except when there is a great difference between the nightand day-temperatures. The fact that on older plants only the lower branches lose their needles points to frost as the cause.

Frost needle-cast is common after wet, cold summers, during which the young shoots of the plants have not been properly lignified. Only late frosts can account for the needles turning red in the spring, but experience has shown that they are not nearly so destructive as early frosts. The fact that needlecast is so prevalent on clearings, in depressions and valleys, and on uncovered ground where there is no obstacle to radiation, renders it probable that in many cases frost is the cause of the disease.

\section{c. Dry Needle-cast.}

The drying-up theory of the origin of needle-cast was first published by Ebermayer, $\ddagger$ who, during the progress of his observations of soil-temperatures in the Bavarian forest

* Alers, "Centrlbl. fr. das ges. Frstw.," 1878, p. 132 ; 1893, p. 81. Also 1880, p. $156 ; 1882$, p. $159 ; 1883$, p. 259.

† Nördlinger, "Krit. Blttr. fr. Frst. u. Jgdw.", vol. xlvi., 1863, p. 185.

‡ "Die Physikalischen Einwirkungen des Waldes in der Abhandlung," "Thar. Frstl. Jhrbch.," vol. xxxiv., 1884, p. 158.

F.P. 
meteorological stations, was led to adopt this view of the matter. His theory is, shortly, as follows:-The young Scots pine plants, owing to the frequently high atmospheric temperature in March and April $\left(66^{\circ}\right.$ to $77^{\circ} \mathrm{F}$. in the shade), are on sunny days compelled to transpire freely. Although the soil is wet enough to replace the loss of water by transpiration, the action of the roots is restricted by the cold soil, the temperature of which may be only $40^{\circ} \mathrm{F}$., or less, down to a depth of 4 feet. Hence the little plants wilt and the needles dry up and die. This is not due, as in dry summers, to the absence of moisture in the soil, but to the inability of the roots to absorb water in the cold ground, and therefore an abnormal drying-up of the needles ensues.

This theory will not explain needle-cast in autumn, when the soil is warmer than the air, but when the needles are cast in the spring, it is in complete accordance with the observations recorded on pp. 686-7, under the headings "Locality" and "Weather." Sandy soils cool down at night to lower temperatures, under similar conditions, than clays, and wet soils become colder than dry soils. Insolation is greatest on bare southern aspects.

\section{Damage done.}

As a rule, needle-cast is not fatal to the plants, and those which have been attacked may recover, provided their terminal buds are still uninjured. Naturally, however, the injured plants languish for some time and are very liable to be attacked by insects. If, however, the disease recurs, and the terminal buds of the plants suffer, they have no chance of recovering.

\section{Treatment.}

As proper treatment of the disease will depend on its origin, the present section will be divided into headings according as the disease is due to a fungus, frost or the drying up of the plants. The method of contending with the attacks of the fungus has been already described on p. 465, and only the two latter causes will be dealt with here.

\section{a. Frost.}

i. Regenerate Scots pine woods under a shelterwood. Avoid large felling-areas in clearing Scots pine woods, and 
wherever, owing to circumstances, natural regeneration is impracticable, narrow strip-fellings should be effected, in order to afford the young plants lateral shelter against the sun.

ii. Avoid sowings, and especially broadcast sowings, in artificial reproduction of Scots pine. When transplants are scarce it is preferable to sow early in the year, in drills 10 to 12 inches apart. Densely growing seedlings should be thinned, and a mixture of spruce with Scots pine-seeds acts favourably, the spruce protecting the pines.

iii. Yearling pines are best planted out with balls of earth, by means of Heyer's circular spade, so that all injuries to the roots are avoided.

iv. Sowings of Scots pine should be abandoned in narrow deep valleys and in depressions.

v. As regards forest-nurseries, the following rules hold good:-

(a) The nursery should be in an exposed situation and not too small in area. It should, if possible, be higher than the surrounding land, never in a depression, or nearer than 50 yards to a wood to the west.

A wood to the west of the nursery reflects the rays of the sun on to it, which, heating the soil, cause early germination and shooting of the plants. This also favours stagnation of the air and late frost.

(b) Beds of seedlings should be covered with dead leaves or moss, leaving only the tops of the plants free.

(c) The beds may be protected by coverings, which should not be too dense. They should be placed at about a yard from the ground, towards the end of September, and before the first early frosts, and may be removed as soon as late frosts in spring are no longer to be feared. 'Throughout the winter, the coverings may be partially removed during bright days, but should be replaced before sunset. If the coverings are placed lower down, the plants suffer from insufficient aëration, but coverings such as are here described have proved very efficacious in different parts of North Germany.

(d) Seedlings may be sprinkled with fine dry soil at the beginning of September, so that only the needles remain 
uncovered. In case the earth should be washed away by rain, it must be replaced.

(e) Nursery-beds should be manured with decomposed beech leaf-mould. This has been strongly recommended by several foresters, and a coating of about 1 to $1 \frac{1}{2}$ inches appears to be sufficient. This prevents sudden wide ranges of temperature in the surface soil, though it is not clear on this account why beech leaf-mould is preferable to other similar manure. It is stated, however, that heather-humus when used instead of beech leaf-mould does not prevent needle-cast.

(f) When 2-year-old plants are used, the yearlings should be lined out in nursery-lines.

\section{b. Dry Needle-cast.}

The principles to be followed in the case of this variety of the disease should consist in plans for raising the temperature of the soil, and reducing the intensity of the light, in order to increase the activity of the roots and reduce transpiration. Attempts should also be made to increase the powers of resistance of the plants.

Soil-temperature is increased by the following measures:-

i. Draining wet soils.

ii. Deep cultivation and manuring, for instance with burned turf, but these measures can be undertaken only in permanent nurseries.

iii. Raising the level of the soil about 1 foot in places prepared for sowing or planting. 'This method is useful for other reasons, and especially in the case of compact or wet soils.

iv. Covering the intervals between rows of plants in the beds with substances that are bad conductors of heat, such as moss, dead leaves, etc.

Intensity of light is reduced as follows:-

v. Reproduction of Scots pine under shelterwoods, or with lateral shelter.

vi. Sowing Scots pine with leguminous fodder-crops, such as lucerne or saintfoin. This has given splendid results in Brandenburg and Mecklenburg.

vii. The hardiness of the plants is increased by giving them plenty of space from the first, by carefully preserving the 
fibrous rootlets during transplanting, and by using transplants with balls of earth round their roots.

\section{Conclusion.}

From the above, it is evident that the two varieties of the needle-cast disease may be treated similarly. Needle-cast, owing to the fungus, would indeed be favoured by some of the rules given under $(a)$ and $(b)$; for instance, reproduction under shelter, and manuring and covering with Scots pine-branches.

Two other methods of protection have recently been suggested, but Hess has no experience of his own regarding their efficacy. They are as follows:-

i. One or 2-year-old plants may be carefully dug up at the end of September or beginning of October, when they have assumed their normal winter colour, and placed in rows in a bed of loose earth raised 27 to 30 inches from the ground, and then covered loosely with a few dead leaves. The plants will be green and in good order for planting in the spring, when other plants left in the nursery-beds have become quite red.

ii. According to the other method, trenches are dug 24 to 27 inches broad, and 30 to 40 inches deep, and the plants placed in rows at the bottom of the trench with earth between the rows, either in autumn or in early spring. Sticks are placed across the top of the trench at distances of 6 to 8 inches, which are then covered with branches of Scots pine, or of silver-fir. Spruce branches will not do, as the needles drop off too readily. The density of the covering must be regulated according to the state of the weather, and it should be denser when there is a considerable range of temperature between the day and night in the spring. In case of prolonged drought the plants should be lightly sprinkled with water.

This method has been followed with advantage in certain forest ranges in Prussia. A trench 10 feet long will contain about 5,0001 to 2 -year-old pine-seedlings. It has not, however, always proved successful, and it is doubtful whether trenching plants in autumn may not be prejudicial. More experience is necessary before it can be confidently recommended. 
PROTECTION AGAINST DISEASES.

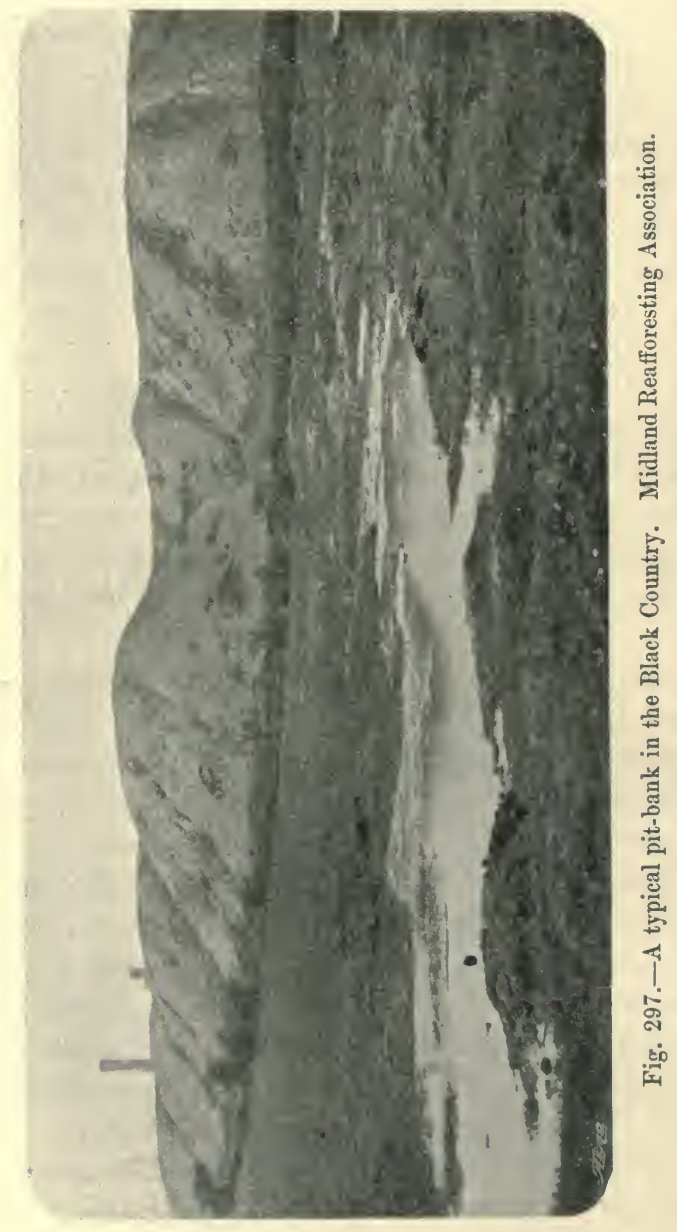




\section{CHAPTER VI.}

\section{DAMAGE TO TREES BY ACID FUMES FROM FURNACES, etc.}

\section{Description of Injury.*}

Woops long exposed to acid fumes from iron-smelting furnaces, alkali and other chemical works and brickfields, or to excessive coal-smoke in crowded cities, become continually more and more sickly, and may eventually die.

The needles of coniferous trees become discoloured at first on the side from which the fumes come, turning yellowish, then reddish, and finally falling off, probably owing to the action of the acids on the chlorophyll. The buds at first escape injury, but the twigs of the trees gradually die from the summit of the trees downwards. In this way the crowns of the trees get continually thinner, as if they had been attacked by the pine beetle, and they eventually die.

Broadleaved trees suffer in a similar way, the damage to the leaves showing itself by larger or smaller reddish blotches, which gradually spread over the leaf till it dies and falls off the tree. The fact that most broadleaved trees are leafless during winter, when there is most smoke, accounts for their comparative immunity in London, whilst in Lancashire large coal-fires go on burning all the year round. Then, in proportion to the area, there is ten times as much coal burned at St. Helen's as in London, and consequently vegetation suffers much more in the former place. .

*Vide "Journal of the Society of Chenical Industry,"pp. 202-206 and pp. 342 -345. Lunge's "Manufacture of Sulphuric Acid Alkali," vol. i., p. 110 ; vol. ii., pp. 182-190. "Air and Rain," by Dr. R. Angus Smith, 1872. Hasenclever, "Chemische Industrie," 1879. Von Schröder, Dr. Julius, and Reuss, Carl, "Beschädigung der Vegetation durch Rauch und die Oberharzer Huttenranchschäden." Berlin, 1883. The best monograph on the subject.-Journal of Royal Hort. Soc., March, 1891, "Trees and Shrubs for Large Towns," Maxwell T. Masters ; also "Effects of Urban Fog on Cultivated Plants," F. W. Oliver. 
Fruit-trees exposed to acid fumes cease bearing fruit before the foliage is seriously injured, and St. Helen's was formerly famed for its fruit; but since 1867, owing to the chemical works in its neighbourhood, no fruit has been produced there. Crops of wheat exposed to acid fumes may to all appearance be ripe and full when scarcely a grain is to be found in the ears. Root-crops, such as potatoes and turnips, suffer less, and on the whole trees suffer much more than grass or agricultural crops.

In the Tavistock woods, large areas of oak coppice were seriously injured by sulphurous fumes from arsenic mining works. Owing to the diminished working of these mines, it is now possible to replant the injured area with oak and larch.

In 1861, extensive damage was found to have been done to coniferous woods by the fumes from the works at Freiburg, in Saxony, in some of which sulphuric acid is made from iron pyrites. Stöckhardt* and Schröder, $\uparrow$ at the Tharandt laboratory, investigated the chemical components of the smoke which cause the damage, and Hamburger $\ddagger$ has done the same more recently. Subsequent notices§ have appeared about damage in the Oberharz owing to acid fumes, and the area of forest damaged by three iron-works, in 1881, was about 11,250 acres. In the Altenau forest-range this damage has become noticeable since American ores have been smelted, which contain more sulphur than the native ores.

Even by smoke from charcoal kilns Scots pine needles have been reddened at a distance of 50 yards, but this is due to the heat of the smoke.

\section{Injurious Components of Smoke.}

It has been proved by observations made at Tharandt, that, of the components of the fumes from the Saxon Works, lead, arsenic, and sulphur compounds, soot, etc., only sulphur dioxide is hurtful to woody growth, and a similar result has

* "Tharandter Jhrbch.," vol. ix., 1853, p. 169; also vol. xxi., 1871, p. 218.

† Id., vol. xxii., p. 185 ; vol. xxiii., p. 217.

$\ddagger$ Id., 1888 , p. 144

§ Reuss, "Ztschrft. fr. Frst. u. Jgdwsn., 1881," p. 65. Also "Cntrlbltt.fr. d. ges Frstw.," 1881, p. 267 ; id., 1882, p. 443. 
been arrived at in the case of coal-smoke. In order to ascertain the fact, various species of woody plants have been subjected to frequent and prolonged exposure to artificially produced fumes of each of the separate components of the smoke. Sulphur dioxide in the soil has no prejudicial effects on plants, as has been proved by watering them with diluted sulphur dioxide solution, for the gas speedily becomes converted into sulphuric acid, and forms harmless compounds with alkalies in the soil.

The action of the sulphur dioxide when the air is moist, or the leaves moistened with dew or rain, is rapid and decisive; it is probably absorbed by plants in the form of sulphuric acid, being taken up in variable quantities by the leaves or needles of different species of trees. It then proceeds from the leaves into the twigs. The leaves or needles gradually turn brown, owing to the decomposition of the chlorophyll and tissues of the leaf.

Sulphur dioxide finds its way into the atmosphere by the roasting of minerals containing sulphur, and from coal-fires, coal containing about 2 per cent. of sulphur, chiefly in the form of iron-pyrites. What minute quantities of this gas suffice to kill plants was proved in 1864 by experiments with spruce plants which were exposed to air containing only onemillionth part of sulphur dioxide. After 335 puffs of the air, the points of the needles began to turn brown, and eventually turned completely brown.

It has also been supposed that the soot in smolke might injure forest trees by blocking up their stomata, but this mode of injury is not admitted by Stöckhardt.

As injurious compounds of the smoke of other works may be reckoned : vapours of mercury, ${ }^{*}$ hydrochloric acid gas, oxides of nitrogen, and chlorine, also steam containing soda particles from cellulose-factories. The influence of hydrochloric acid from alkali-works is shown whenever the air contains $0 \cdot 1$ per cent. by a considerable increase in the chlorine in the leaves. Leaves get brown or red edges, and eventually dry-up and fall. Chlorine acts similarly, but more energetically. Hydrochloric acid is very destructive to vegetation, sometimes

* Wagner's “Jhrbch.," 1874, p. 277. 
forming dense clouds which, after escaping from alkali-works, settle on fields and kill whole patches of the crops in them; it is, however, on the whole less hurtful to woods and crops on a large scale than sulphur dioxide, and the same may be said of the similar action of the oxides of nitrogen, and chlorine. Dr. Angus Smith gives the following comparative statement of acidity of air at different places in England :-

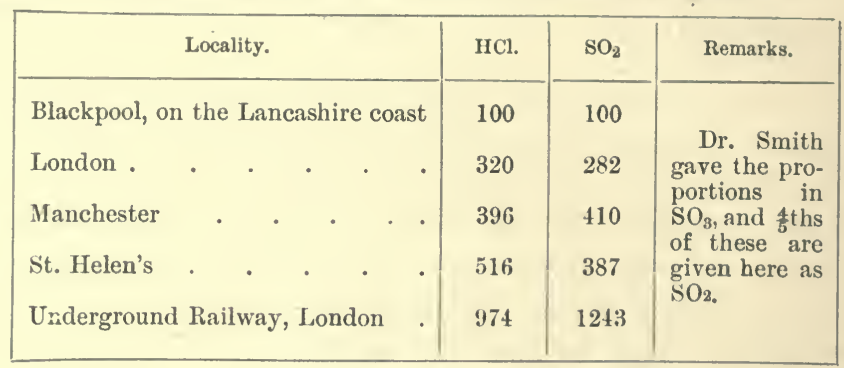

In a field near Blackpool he found 20.27 grains of hydrochloric acid and $155^{\circ} 30$ grains of sulphur dioxide in $1,000,000$ cubic feet of air, and the quantities in the other places may be calculated from these figures.

Dr. Hamburger* states that he exposed leaves to the action of $n, \frac{n}{10}, \frac{n}{100}, \frac{n}{1,000}$, and $\frac{n}{2,000}$ of sulphuric and hydrochloric acids of equivalent strength, $n$ being a normal solution of 49 grammes of sulphuric acid, or $36 \frac{1}{2}$ grammes of hydrochloric acid in one litre of water.

'The normal solution produced discoloration in about half an hour, yellowish-brown spots appearing in the middle of theleaves and extending gradually over the whole surface. The $\frac{n}{10}$ took 3 hours before signs of destruction appeared. The $\frac{n}{100}$ acted in about a day, but the action of the sulphuric acid was stronger than that of hydrochloric acid. The $\frac{n}{1,000}$ sulphuric acid produced discoloration in about a week, while the $\frac{n}{1,000}$ hydrochloric acid required 10 days to do so.

\footnotetext{
* "Journal of the Society of Chemical Industry," 1884, p. 205.
} 
The $\frac{n}{2,000}$ acid, equivalent to $24 \frac{1}{2}$ grammes of sulphuric acid or 181 grammes of hydrochloric acid in 1,000,000 parts of water, seemed to have no action. Two greenhouse plants were submitted to a daily spray of the $\frac{n}{2,000}$ acid for a month, but showed no corrosion.

\section{Damage done. \\ a. General Account.}

Among the direct kinds of damage done by acid fumes to trees are:-loss of increment, thinning out of woods and formation of blanks, injury to fruit, especially in the case of orchard-trees, loss of fodder by destruction of grass in a forest. Damage is done indirectly by rendering the woods liable to insect-attacks, to fire and other dangers.

\section{b. According to Species.}

Conifers suffer more than broadleaved species from smoke, even although the needles under similar conditions absorb less sulphur dioxide and are in themselves less sensitive and hardier than other leaves. This is due to the longer duration of the needles and their consequently increased exposure to the bad influence of the gas, and to the greater powers of recovery possessed by broadleaved species.

Thus evergreen conifers are not only longer exposed each year, but the evil accumulates from year to year as long as the needles remain on the tree, whilst broadleaved trees annually throw off their leaves.

Schröder* found that 1,000 square centimeters of leafsurface, containing double that quantity above and below, will, within 36 hours, absorb sulphuric dioxide as follows :-

C. $\mathrm{cm}$.

Silver-fir needles, young . . . . . . 18

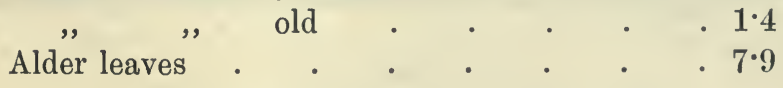

* "Thar. Frstl. Jhrbch.," vol. xxii., 1872, p. 193. 


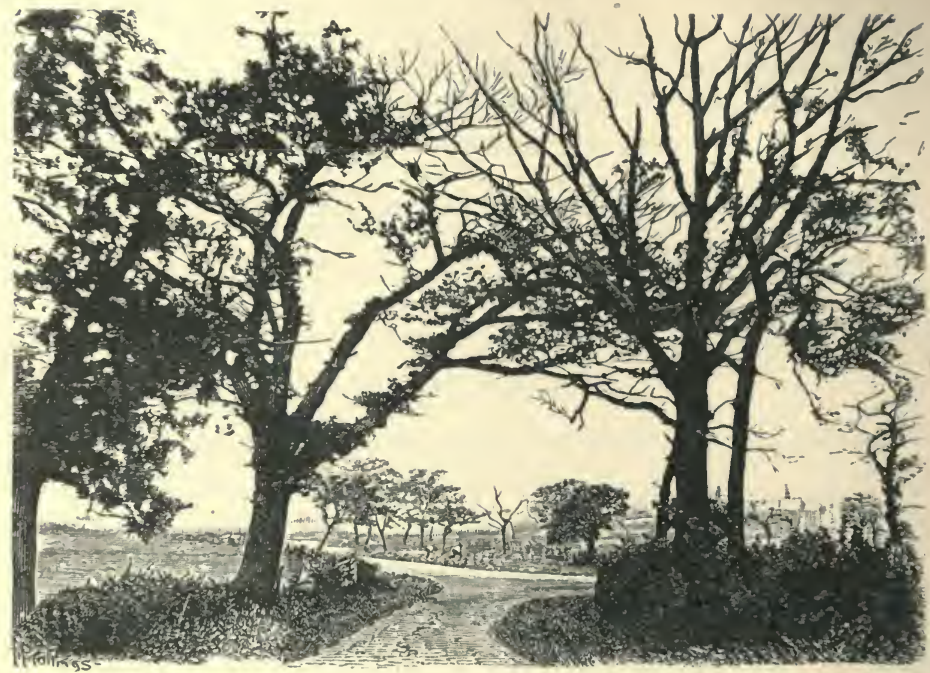

Fig. 298. - Oaks near a manufacturing town, the foliage damaged by acid fumes, photographed August, 1882,*

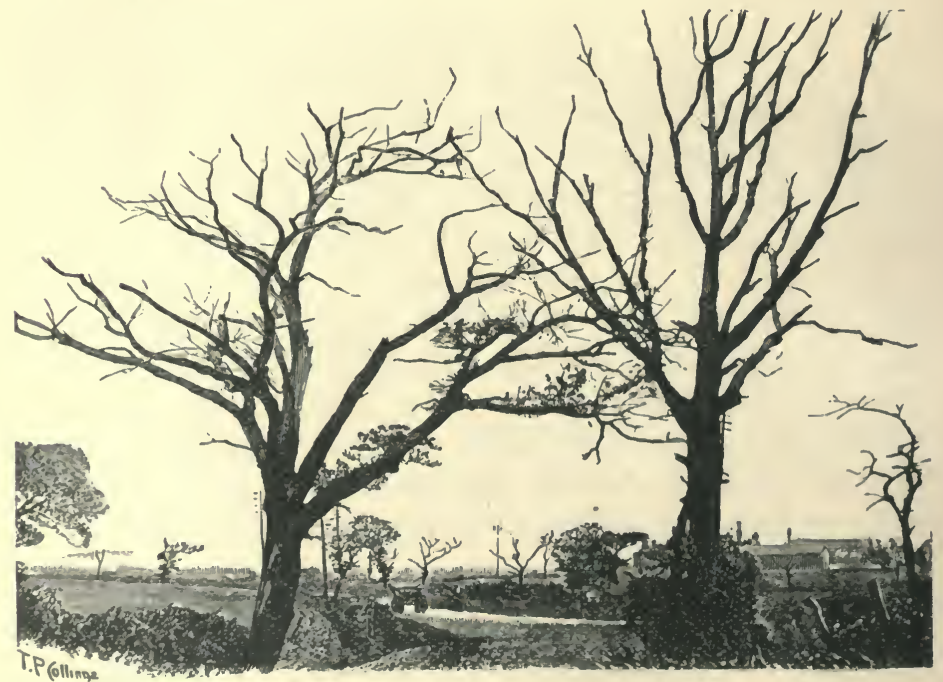

Fig. 299. - Same oaks photographed July, 1888, several years' cumulative injury having killed the trees.*

* From Croonian lecture by Marshall Ward (vide p. 671). 
When exposed a second time for 20 hours, the silver-fir needles absorbed $1.6 \mathrm{c} . \mathrm{cm}$., beech leaves $3 \cdot 1 \mathrm{c} . \mathrm{cm}$.

Webster* gives a list of trees and shrubs suitable for townplanting, but among conifers only mentions the deciduous Ginkgo biloba, or maidenhair tree, as flourishing in the worst smoke-infected parts of London, and Retinospora plumosa aurea, which has stood for seven years in one of the most smoky districts of Glasgow, and looks almost as well as when brought from the country.

Masters also recommends Ginkgo biloba, and Pinus excelsa.

J. W. Sowerby, the Secretary to the Royal Botanic Society of London, who has resided in the Botanic Gardens, Regent's Park, since 1842, states that when the gardens .were first laid out (1839-45) special mounds were made and planted with nearly all hardy species of conifers, and although the natural soil of the gardens is a stiff yellow clay, suitable soil was furnished for the different trees; but in 1895 , only a few miserable plants remained, including five or six deodars, and some yews, which last longest, but were then looking very bad.

The amount of damage done to broadleaved trees depends not only on the susceptibility of the leaves, but also on the powers of recovery of each species, so that trees which unite least susceptibility to greatest powers of recovery will suffer least.

Schröder has drawn up the following list:-

1. Conifers: Silver-fir, spruce, Scots pine least susceptible.

2. Broadleaved plants: Beech, lime, poplars, alder, maples, ash, hornbeam, aspen, oak.

The immunity of oak is not, however, confirmed by English experience, and Marshall Ward states that oaks suffer greatly from acid fumes. Perhaps the German authorities refer to sessile oak, which is rare in England, where the pedunculate oak abounds.

A Belgian $\dagger$ official report also considers the hornbeam

* "Practical Forestry," by Angus D. Webster. Rider \& Son. 2nd edition. London, 1895.

† "Rapport par la Commission d'Enquête relative à l'influence des Emanations Acides sur la Végétation," quoted by Dr. Angus Smith in an appendix to "Air and Rain." 
and oak as suffering most of all broadleaved species from acid fumes and even places them above the larch in this respect.

Borggreve at Münden drew up a similar table to that of Schröder, in the following order:-

1. Silver-fir, spruce, Scots pine.

2. Beech, lime, poplar, alder, maples, and ash.

3. Hornbeam, aspen.

4. Oak (least susceptible).

According to Hess' $\mathrm{s}^{*}$ own experiments elms (Ulmus montana and campestris) must be reckoned among resisting species.

The above grouping cannot always be relied on, as there are too many modifying factors in particular cases. London, with its constant coal-smoke and numerous factories and frequent dense sulphurous fogs, should give better practical results as to the comparative powers of resistance of trees than any merely artificial laboratory experiments.

There are fine large flourishing plane-trees (Platanus orientalis, $\dagger$ L.) in Cheapside and on Ludgate Hill, which are entirely surrounded by tall buildings, and the plane is growing well on the Thames Embankment and in many parts of London. The plane-tree sheds large flakes of its bark annually, and its buds are sheltered by its sheathing petioles; these facts probably contribute to its immunity.

The following account of the trees and shrubs which flourish in the Botanic Garden in Regent's Park, London, has been kindly supplied by J. W. Sowerby.

"Of the plane there are many very large trees. Maples of several species and varieties. Horse-chestnuts flower and fruit as well as in the country. Poplars of many species. $\downarrow$ Elms, of which a belt surrounds the gardens, and one old elm which was on the ground in 1838 is still healthy.

* "Frstl. Blttr.," 1874, p. 31 .

+ Masters and Webster recommend for town planting $P$. orientalis acerifolia, which has less deeply divided leaves than the normal plant, and may be distinguished from $P$. occidentalis, L., by the many fruit-balls attached to its peduncles.

¥ Populus canadensis, Desf., has a reputation in the Black Country for immunity from the effects of fumes. P. balsamifera, L., is growing well in St. James' Park. 
"Lime withstands smoke, but suffers from green aphis and other pests, and looks shabby in early autumn, as the leaves fall early. Robinia thrives for $30-40$ years, but then dies gradually, perhaps owing to the cold clay soil of the gardens. Two oaks remain small and scarcely grow, but have kept alive for over 50 years. Laburnum does well, and so do white and red thorns.

"Of shrubs, Aucuba japonica is best, and fruits freely, and so do several varieties of privet. Lilacs and box do well, and Mahonias fairly."

Webster adds the following to this list: species of Rhus and Cotoneaster, Virginia-creeper, ivy and the vine, besides Daphne Laureola, L., Skimmea japonica, Ribes sanguineus, and Jasminum nudiflorum. He also gives a list of trees suitable for town-planting, that generally agrees with Sowerby's list, but also contains the following: Ailanthus glandulosa, Desf., Magnolia acuminata, L., Liriodendron tulipifera, L., Catalpa speciosa, Engelm, Morus nigra, L. He states, however, that horse-chestnuts, limes, and elms soon show signs of distress when grown in smoky localities.

According to the Belgian official report, the black alder (Alnus glutinosa, Gaertn.) may be seen growing close to chemical works, and in situations very much exposed to acid fumes, but apparently suffering very little from them.

In planting avenues, or parks, in a crowded city, however, not only immunity from fumes has to be considered, but also the nature of the soil, the desirability of the tree, and the amount of shade it gives, and whether it bears radiation of heat from the houses and streets. The poplar, having a straggling crown and its branches being very brittle, is not suitable, while limes, except Tilia heterophylla, Vent., are liable to lose their foliage prematurely in hot dry summers. Probably the plane and sycamore are the best trees for the purpose. Of oaks, probably the Turkey oak (Quercus Cerris, L.) is the only deciduou species which can at all resist the smoke of a large city. Quercus Ilex is termed by Masters a good town tree.

In the Black Country, near Wolverhampton, Dudley and Bilston, the air is at present not nearly so impure as was 
formerly the case when the shafts of the smelting furnaces were open, and the furnaces themselves much more numerous than at present. Dudley Park is exposed on the east to the acid fumes of smelting furnaces, and yet ash, poplar, and sycamore trees are growing there fairly well with elder, hawthorn and hazel undergrowth, while beech appears on the western slopes of the park, that are exposed to open country where there are no furnaces. Grass grows well enough in the Black Country, and there can be no reason why the large extent of uneven grassy land near Bilston (about 14,000 acres), where the coalfields have been worked out, the soil being weathered shale, should not be planted with trees, instead of remaining, as it is at present, a dreary waste. It is said that to level this land would cost $£ 100$ per acre, but no levelling would be necessary, if it were to be planted up with trees, which grow well enough on similar - land in Belgium.

There are works at Bilston for galvanising iron, and the molten zinc in which the sheets of iron are plunged is covered with chloride of ammonium to prevent its oxidising. The fumes given off during the process are said to kill all leaves of trees near the works by June every year, but these fumes probably extend only for a short distance from the works.

Since 1903 planting has been undertaken in the Black Country under the auspices of the Midland Reafforesting Association. (Vide Figs. 297, 298).

$$
\text { c. Age of Trees. }
$$

Woods suffer from acid fumes at all ages, but poles $15-30$ years old appear to suffer most.

\section{d. Locality.}

The influence of the locality makes itself felt chiefly by the direction of the prevailing winds which bring the fumes towards the trees.

The Belgian Commission mentions 2,000 meters as the greatest distance from chemical works, in the direction of the prevailing winds, at which damage was observed. In certain cases, however, woods have been injured at distances of 
$4 \frac{1}{2}$ miles from the works, but naturally the amount of injury done varies inversely with the distance. Trees bordering on the wood, and especially on woods to the east and north-east of the works, will suffer most. In narrow valleys even the smoke of locomotives has proved prejudicial to trees on either side of a railway. Oliver states that the effects of London fog extend to 35 miles westward, and that seedlings of Cucurbitaceae and tomatoes are thus killed at even that distance from London.

It has been observed, chiefly in the Oberharz, that woods growing on fertile soil resist acid fumes better than those on poor soils.

\section{e. Climate.}

Exposure to light and moisture are not without influence on the action of acid fumes. Leaves suffer more when dew is resting on them than when they are dry. Thus the damage will be at its maximum after rain at midday, and at its minimum with cool nights and dry days. The damage during rainy weather, though more severe than in dry weather, does not extend far from the works, as the rain speedily dissolves the fumes.

\section{f. Sundry Circumstances.}

When older woods overshade an underwood, the former may protect the latter from damage by fumes, and trees standing above the general leaf-canopy of the wood, such as standards in high forest or above coppice, suffer most. The shelter afforded to crops and orchards by walls and hedges is also considerable.

Damage is not so soon marked in young woods under 30 years old as in older woods. In old woods, especially coniferous, damage is soon recognisable. Their foliage soon becomes thinner; the shoots dry up, and death soon occurs, often in two or three years.

\section{Methods of Recognising Damage.}

The question regarding external or internal signs for recognising damage by fumes is of great scientific interest. It is also of practical importance, as in the disputes or lawsuits between owners of woodlands and of smelting furnaces, the

F.P. 
first ground for determination is whether the damage to exposed woods is caused solely by the fumes or is due to other causes (frost, heat, dry winds, infection, or fungi).

There are only two methods for determining the cause of the damage :-

(a) Chemical analysis of the injured tree-parts (leaves, flowers, etc.).

(b) Microscopic examination of the marks on the injured needles or leaves.

On this subject there has been since 1895 a keen literary dispute, in which Borggreve, Schröder, Hartig, Ramann, Vater and Wieler have contended. Most of these disputants prefer chemical analysis, to determine the amount of sulphuric acid in the ashes of the leaves. This must obviously be done by a chemical expert. The excess of sulphuric acid in affected leaves over the amount in leaves from woods unexposed to fumes decides the question. As, however, the quantity of $\mathrm{SO}_{3}$ in perfectly healthy leaves varies much, Vater considers the following conditions necessary to prove damage by fumes :-

1. All injured and sound trees experimented on must have been growing on similar soil and at various distances from the smelting furnaces.

2. As a comparison, the average quantity of $\mathrm{SO}_{3}$ in sound trees must not be taken, but sound trees must be found and the quantity in them measured.

3. A sufficient number of sample trees must be chosen in order that reliable results may be obtained.

R. Hartig prefers the microscopic method, at any rate for spruce. He considers the foxy red colour of the contents and walls of the cells bounding stomata, and, when the fumes are very strong, the red colour of the prosenchymatous bundles, as sufficient proof of the poisoning. Such needles cannot assimilate $\mathrm{CO}_{2}$. They remain apparently healthy for several years on the trees, and die when the woody bundles become affected.

Ramann and Soraner both disagree with Hartig's statement that the change in the contents of the cells points exclusively to damage by fumes, as it may be due to damage by other factors. 
Hess therefore considers the chemical analysis as the best proof of damage done by fumes.

The presence of sulphur dioxide in the air near the furnaces is also an important factor in this question, and the air and the rain and snow that fall through it should therefore be analysed.

\section{Protective Measures.}

No thoroughly efficient measures have been devised against this evil. Tall chimneys, sometimes 500 feet high, carry the fumes into the higher strata of the atmosphere, but it has been found that hydrochloric acid descends from them to the ground in dense clouds, and lays waste the vegetation at greater distances from the works than before.

The best protective measure against hydrochloric acid is to get it condensed, as is now done in the British Isles under the Alkali Acts of 1863 and 1870, so that less than 1 per cent. of the acid generated in the works escapes into the air.

There is more difficulty in dealing with the sulphur dioxide, and even the most perfect smoke-combustion cannot free the air of it. Attempts have been made in Germany to convert it into sulphuric acid, but this removes only one-third of the injurious gas, and at Clausthal, in Germany, 1,250 tons of sulphur are annually sent into the air, greatly damaging the coniferous woods in the neighbourhood.

The forester in districts where hurtful fumes exist can therefore act only by planting protective belts of strong transplants of the most resisting trees in the direction of the factories, and managing them entirely by the selection system. Under the shelter of these belts it will be better, if possible, to grow coppice or coppice-with-standards, which do not attain the height of high forest. Conifers should not be grown near smelting furnaces.

\section{Estimation of Damage.}

As owners of woods injured by factory fumes can claim compensation in the courts of law, the question of estimating the damage done is of great importance.

In 1864 the Freiburg works had to pay $£ 2,750$ compensation 
for damage done to vegetation. Estimates of the value of the damage must be made in accordance with the principles of forest valuation, and involve much difficulty. More will not be said on this subject here, but references are given below* to German books specially dealing with it.

* Kraft, "Ueber die Berechnung der durch Hüttenrauch veranlassten Schädigung von Holzbeständen," "Ztschrft. fr. Frst. u. Jgdw.," 1887, p. 270 ; Rudnick, Id., 1889 , p. 417.

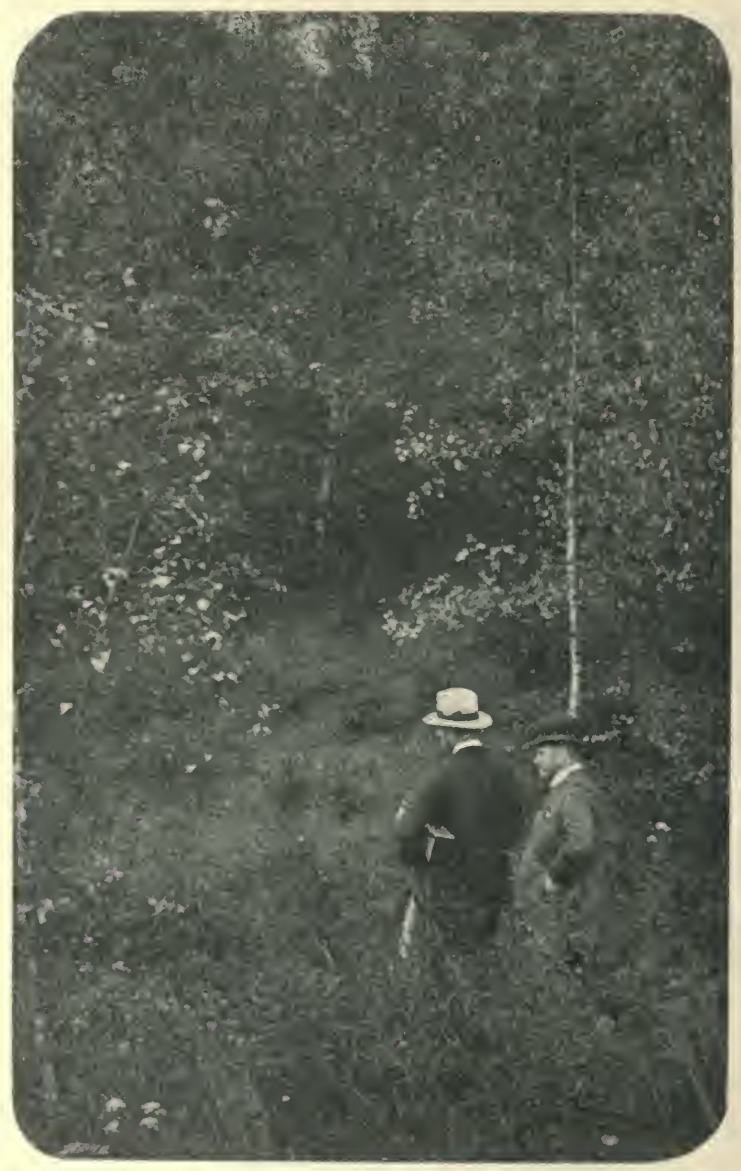

Fig. 300.-Woodland Glade near Cradley, in the Black Country. (Midland Reafforesting Association.) 


\section{INDEX.}

Adders, 172

A.

Aecidium Abietinum, 462

columnare, 462

Conorum Piceae, 472

$\begin{array}{ll}, \quad & \text { elatinum, } 448 \\ , \quad & \text { strobilinum, } 472\end{array}$

Aglaospora taleola, 481

Animals, injuries by, 95

Ants, 190

Aphididae, 361

Ash-twig moth, 344

Atmospheric influences, 489

Avalanches, 616

Bacteria, 421

\section{B.}

Badger, 129, 167

Bark, utilisation of, 27

," rights to, 84

Bark-beetles, 148, 235, 434, 534, 641

Bark-blister, oak, 481 .

, larch, 454

Bark-scorching, 522

Bears, 135

Beavers, 135

Beech canker, 477

," seedling mildew, 482

, woolly aphis, 366

Bees, 193

Birch, 402

Birds, damage by, 136

," useful, 167

, protection by law, 172

Black-game, 138

Blackthorn, 403

Bordeaux mixture, 466

Bordered-white moth, 326

Botritis Douglassii, 461

Boundaries, 10

Bracken, 407

Brambles, 403
Branchwood, dead, 51

Broom, 399

C.

Caeoma pinitorquum, 444

Camels, 40, 47

Canker, beech, 477

, silver-fir, 449

Capercailzie, 138

Cattle, 40

Centipedes, 173

Cerambycidae, 148, 279

Charcoal, 91

Chermes, 361, 457

Chrysomyxa Abietis, 462

Cinipidae, 358

Click-beetles, 214

Cockchafers, 200

Coccidae, 366

Colbert's Reform of French forests, 2

Coleophora laricella, 346, 456

Coleoptera, injurious, 199

,, useful, 180

Communal forests, firewood, 61

Compiègne, forest of, 3,107

Coral-spot disease, 479

Corticium amorphum, 454, 471, 682

Cossus, 148, 282, 291

Crickets, 368

Crows, 130

Cuckoo, 165

Cuscuta, 417

D.

Dasyscypha calycina, 454

Dean forest, 2

", " plague of voles, $12 \tau$

Death watch beetle, 217

Diptera, useful, 194

,$\quad$ injurious, 367

Diseases of insects, $186,302,317,322$

,, of plants, 671

Dodder, 417 
Dormice, 122

Dragonflies, 197

Drainage, 601

Drought, 514

E.

Easements, forest, 67

Elephants, 40, 47

Elm bark-beetle, 277

Epping forest, 89

Exoascus, 448

Exosporium, 455

F.

Factory fumes, 695

Fallow deer, 109

Ferrets, 118

Finches, injurious, 140 , utility of, 168

Fires in forests, 638

Fisheries, 53, 89

Flies, 195

Fomes annosus, 435

Foxes, 117, 130, 167

Frost, 491

Frostcrack, 50 j

Frostlifting of seedlings, 510

Fungi, 418, 421

G.

Gall-flies, 360

,, -wasps, 358

Game, 53, 89

Gastropacha pini, 294

Geometridae, 326

Goat moth, 148, 282, 291

Goldcrests, 167, 244

Grease bands, 176, 300, 318, 331

Greased barriers, 176

Gulls, 168

Gypsey moth, 319

H.

Hail, 557

Hares, 40, 47, 115

Heatcrack, 526

Heather, 400

Hedgehog, 129, 167
Hemiptera, injurious, 361

useful, 197

Herdsmen, 48

Heron, utility of, 130

Herpotrichia nigra, 472

Honey fungus, 429

,, wild, 53

Hydnum diversidens, 476

Hydrochloric acid, effect on trees, 697

Hylobius abietis, 225

Hylurgus piniperda, 265

Hymenoptera, injurious, 349

Hypnum, 50, 408

$$
\text { useful, } 184
$$

Hysterium Pinastri, 465

I.

Ichneumon wasps, $173,184,244$

Insect diseases, 186, 302, 317, 322

Insects, classification, 149

,, index of destructive, 374

, injurious, 199

, useful, 180

Insolation, 514

Inundations, 586

Jays, 139, 168

Juniper, 409, 419

K.

Kestrel, utility of, 130, 168

Ladybirds, 183

I.

Lapwing, 168

Larch blister, 348, 454

,. miner moth, 346,456

Leaf-beetles, 283

Leaf-roller moths, 331

Leaves, utilisation of, 29

, rights to, 84

,, injured by fumes, 695

Lepidoptera, 288

Lianes, 410

Lightning, 658

Litter, utilisation of, 49 
Litter, rights to, 88

Locusts, 371

Longicorn beetles, 279

Iooper moths, 326

Lophodermium macrosporum, 467 nervisequium, 468

Loranthus, 415 Pinastri, 465, 688

M.

Martens, 117, 122

Melamporella caryophyllacearum, 448

Melampsora Hartigii, 485

$$
\text { ,, pinitorqua, } 444
$$$$
\text { , } \quad \text { sp., } 486
$$

Mice, 123

Minor produce, 27, 53

Mistletoe, 412

Mole, 129

Mole-cricket, 368

Mouse typhus, 134

Musk beetle, 283

N.

Nectria cinnabarina, 479

,, Cucurbitula, 452

, ditissima, 477

Needle-cast, larch, 469

$$
\begin{array}{ll}
, & \text { pine, } 465,685 \\
, & \text { silver-fir, } 468 \\
, & \text { spruce, } 467
\end{array}
$$

Needle fungi, 461

Nesting boxes for birds, 169

Neuroptera, useful, 195, 199

New Forest, 2

Noctuidae, 319

Nun moth, 310

Nurseries, protection of, 396

O.

Oak bark-blister, 481

,, leaf-roller moth, 333

Occlusion of wounds, 104

Offences in forests, 55

Orchestes fagi, 221

Orthoptera, 368
Owls, utility of, 130, 168

Ownership defined, 66

P.

Pannage, 31, 87, 171

Pasture, forest, 35, 86

Peridermium Pini, 441

(acicola), 461

Pestalozzia Hartigii, 460, 481

Peziza Willkommii, 454

Pheasants, 138

Phytophthora Fagi, 482

, omnivora, 482

Pig, wild, 111, 167

Pigeons, 139

Pine beauty, 320

,, beetle, 265

,, blister, 441

", branch-twist, 444

,, looper moth, 326

,, moth, 294

, needle-cast, 465

,, shoot tortrix, 335

Plant lice, 361

Poison for mice, 134

Polecats, 117, 129, 167

Polytrichum, 50, 407, 409

Polyporus fulvus, 451

,, sp., 440,476

, $\quad$ sulphureus, 440,475

Porcupines, 135

Property defined, 64

R.

Rabbits, 3, 116

Rain, 554

Rats, 124

Red deer, 97, 99

,, rot, 439, 673

Resin, 28

Retinia sp., 235

Rhizina, 437

Rhytisma acerinum, 483

Rights of common, 69

,, to water, 90

, of way, 90

Rime frost, 574 
Rodents, 114

Roe deer, 110

Rooks, 130, 335

Root fungi, 429, 473

Rosellinia quercina, 473

Rove beetles, 181

S.

Sand dunes, 621

, inland, 630

Sawflies, 349

Scale insects, 366

Septoria parasitica, 460

Servitudes, 67

Sheep, 40, 167

Shrews, 129

Shrikes, 168

Silver-fir canker, 448

Sirex, 148

Snowbreak, 561

Softwoods, 81, 98

Soil denudation, 582

Sphaerella laricina, 469

Sphagnum, 50, 409

Spiders, 173

Spraying plants, 177

Spruce canker, 452,477

, cone fungus, 472

,, needle rust, 463

Squirrels, 118

Stagheadedness, 680

Starlings, 167

Stereum hirsutum, 477

Stoats, 117, 129, 167

Stones in forests, 52

Storms, 531

Sulphurous acid fumes, 696

Swamps, 596

Sycamore leaf-blotch, 483

$\mathrm{T}$.

Tachinae, 173, 195, 316

Template, 18
Termites, 199

Tiger beetles, 180

Tineidae, 343

Tomicus typographus, 238

Tomtits, 167, 244

Tortricidae, 331, 454

Tree traps, 176

Trametes radiciperda, 435

Pini, 438

Trichosphaeria parasitica, 470

Turnip dart moth, 325

Turpentine, 28, 84

U.

Uprooting by frost, 510

Utilisation of forests, 23

V.

Voles, 124

W.

Wasps, 188

Wax, collection of, 53

Weasels, 117, 129, 167

Weeds, 386

," hosts of fungi, 418

Weevils, 217

White rot, 439, 679

Willow beetle, 285

, leaf-blister, 485

Windbreak, 113, 550, 553

Windfalls, rights to, 83

Winds, 513, 527

Windsor forest, 3, 334

Winter moth, 329

Witches' broom, 447

Woodpecker, 76, 142, 244

Wood-wasps, $35 j$

Woolly aphis, 366

Wrens, 167, 24t

END OF VOLUME IV. 

SD

371

S33.

1906

v. 4

Forestr SCHLICH

Schlich, (Sir) William

A manual of forestry
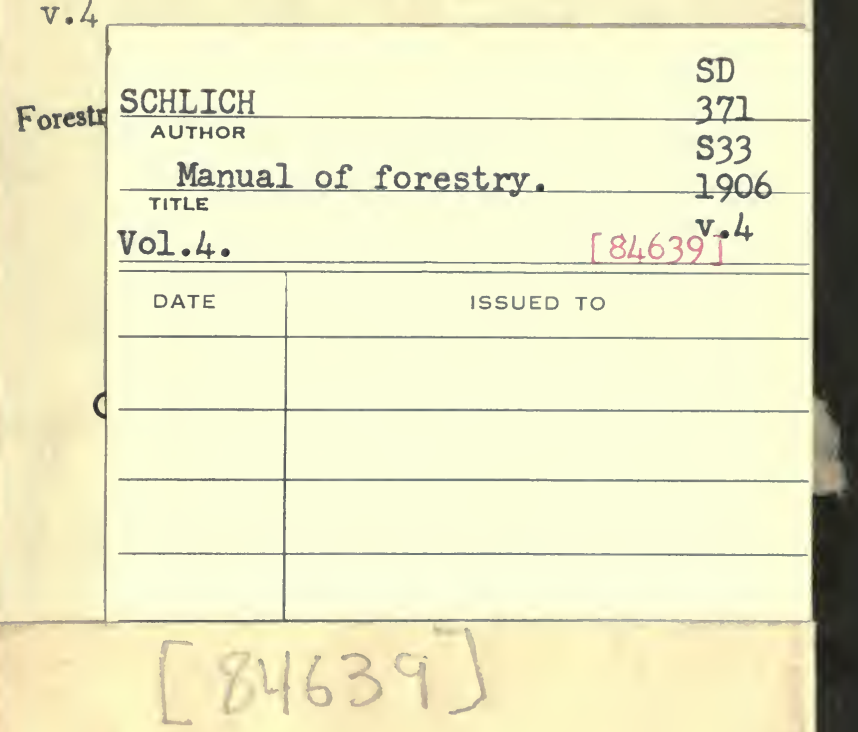

\author{
LIBRARY \\ FACULTY OF FORESTRY \\ UNIVERSITY OF EORONTO
}


